„A média valójában saját jogán társadalmi erö, és nemcsak más erök visszatükrözödése.” Robert W. McChesney

\title{
STRATÉGIÁK ÉS JOGALKOTÁS
}

A hazai média- és a kapcsolódó szerzői jogi szabályozás elmúlt tíz éve

PHD ÉRTEKEZÉS

DR. SARKADY ILDIKÓ

Szegedi Tudományegyetem

Állam- és Jogtudományi Kar Doktori Iskola

Szeged 2016

Témavezető: Dr. Blazovichné Dr. habil. Gellén Klára PhD

Kézirat lezárva: 2016. április 30. 


\section{TARTALOMJEGYZÉK}

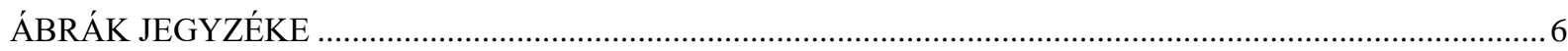

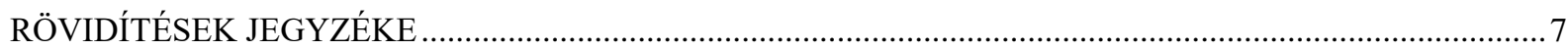

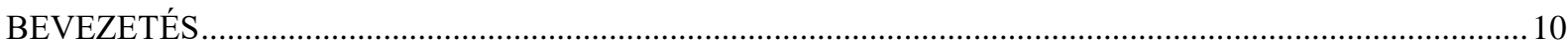

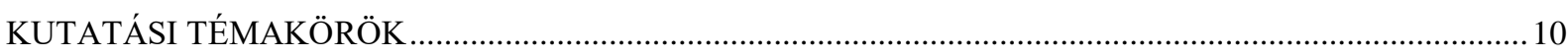

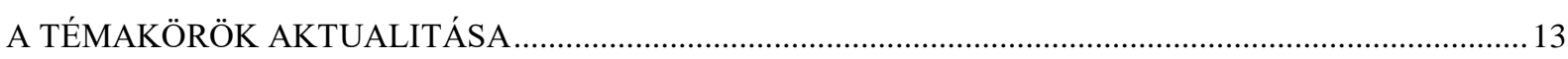

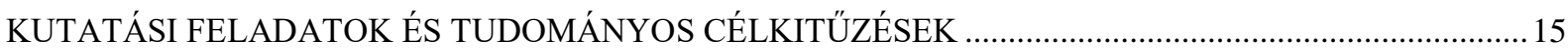

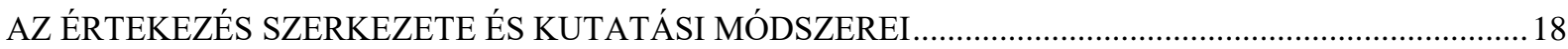

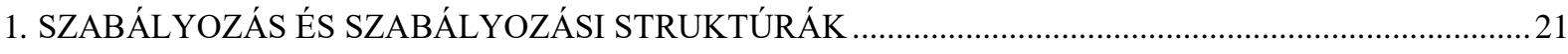

1.1. Szabályozási kezdetek: sajtó-, szerzői- és távközlésjogi előzmények …………………………........ 21

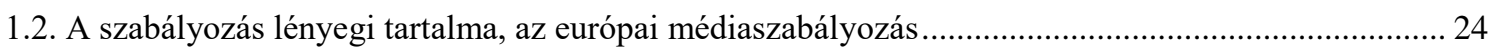

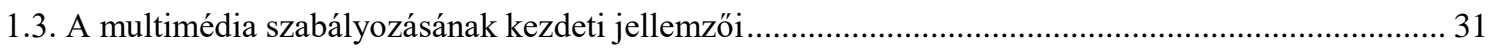

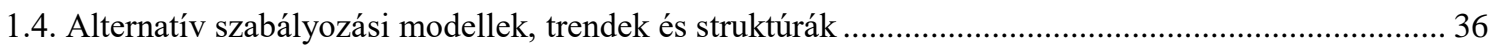

1.4.1. Az alternatív szabályozási eszközrendszer kialakulása, jelentései................................................. 36

1.4.2. Alternatív szabályozási modellek a nemzetközi és az Európai Uniós dokumentumokban ............ 42

1.4.3. Better regulation és a best of practice eszközrendszere .............................................................. 45

2. A HAZAI MÉDIASZABÁLYOZÁSI REFORM 2006 - 2008 KÖZÖTT ..........................................................47

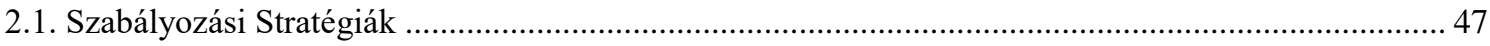

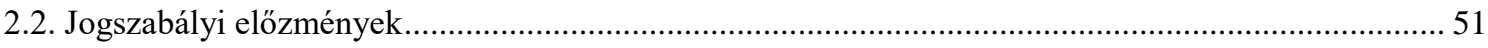

2.3. Egység és „pillérek” a Jogalkotási Koncepcióban, a médiareform „hardver”-e: a digitális átállás jogi

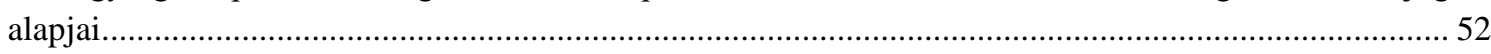

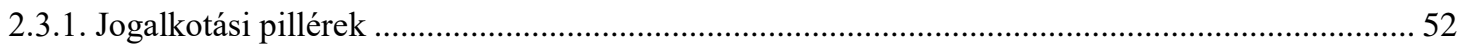

2.3.2. Szabályozási kölcsönhatás a pillérek között uniós szinten............................................................ 55

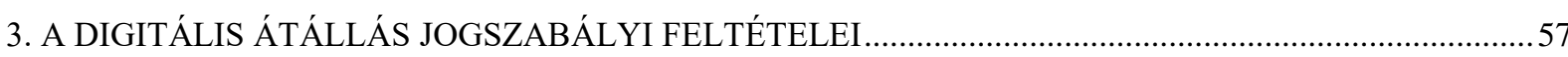

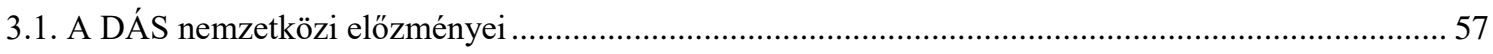

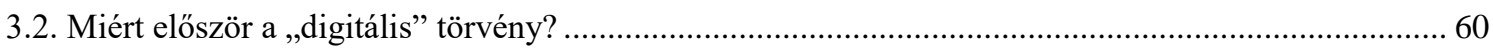

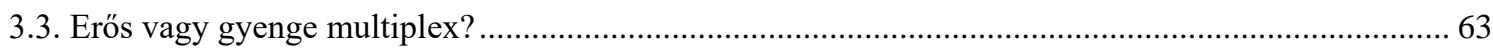

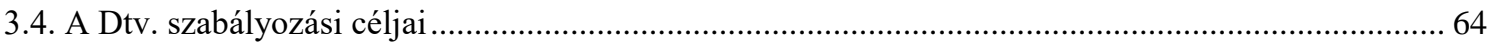

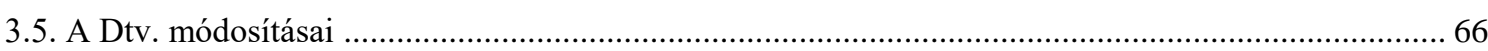

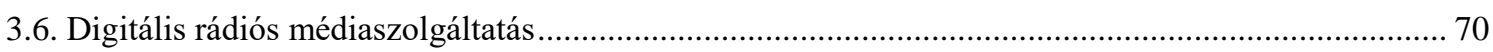

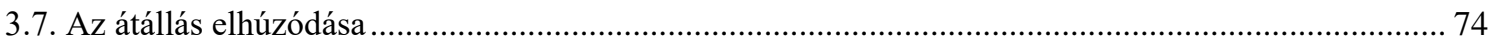

4. NAMS JOGALKOTÁSI KONCEPCIÓ: A MÉDIASZABÁLYOZÁS „SZOFTVERE” ...................................79

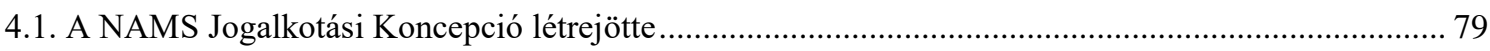

4.2. A NAMS Jogalkotási Koncepció elvei, megközelítési módjai és célrendszere ................................... 81

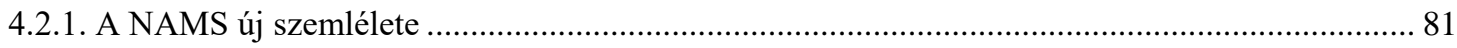

4.2.2. Az Országos Rádió és Televízió Testület funkcióinak alkotmányossági kérdései......................... 82

4.2.3. A NAMS Jogalkotási Koncepció célrendszere ............................................................................. 87 
5. SZABÁLYOZÁSI PILLÉREK ÉS A JOGALKOTÁS TERÜLETEI A NAMS JOGALKOTÁSI KONCEPCIÓBAN

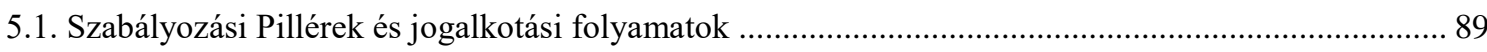

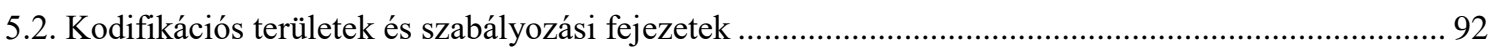

6. SZABÁLYOZÁSI ELVEK ÉS CÉLOK A TARTALOM SZEGMENSBEN ………......................................94

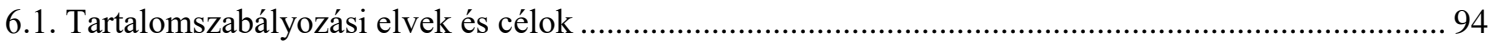

6.2. A tartalomra irányadó $N A M S J K$ tételek a médiaszabályozásban, szabályozási tárgykörök ................ 98

6.2.1. Rádiós műsorszolgáltatás, háromosztatú médiarendszer és közösségi médiaszolgáltatás ............. 98

6.2.2. Általános médiajogi szabályozás, speciális közszolgálati műsorszolgáltatás és a lekérhető tartalmak médiaszabályozáson kívüli elhelyezése ........................................................................... 102

6.2.3. Ön- és társszabályozás a médiaigazgatásban ……………………………………………........ 103

6.2.4. Új médiajogi terminológia és a szolgáltatások elhatárolási dilemmái. „Szenzitív”lekérhető

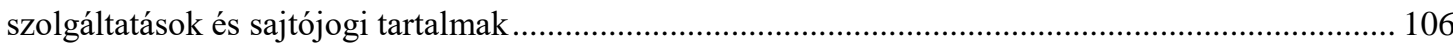

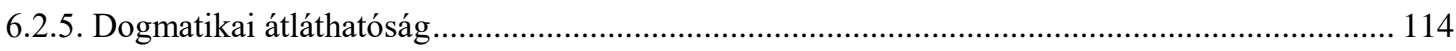

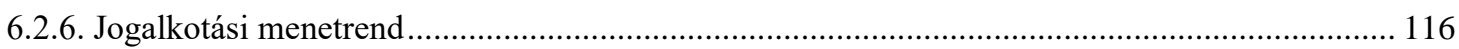

6.2.7. A lineáris és lekérhető médiatartalom, az információs társadalmi szolgáltatások szabályozásának

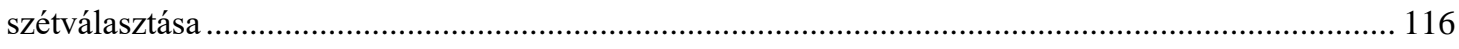

6.2.8. A származási ország elve és annak szükséges áttörése ……………………………………..... 118

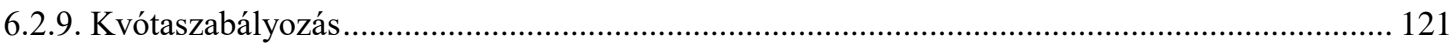

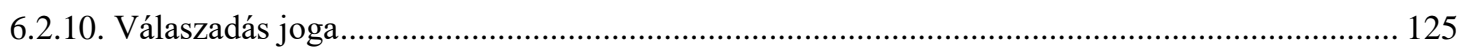

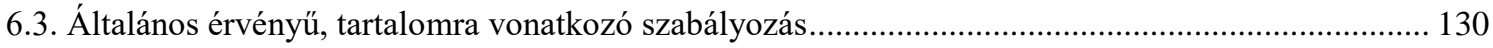

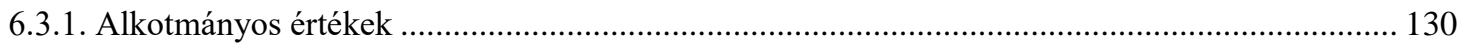

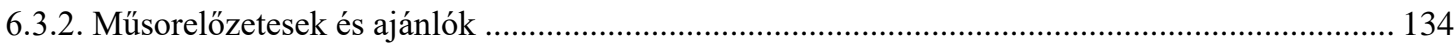

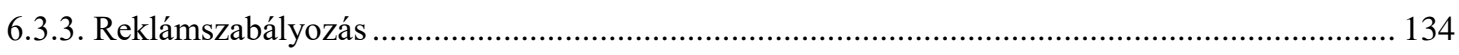

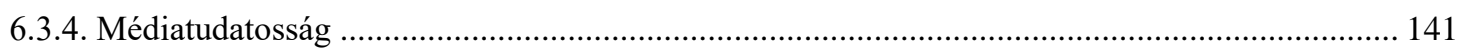

6.4. A müsordíj jogi „természete” és helye a médiaszabályozásban......................................................... 143

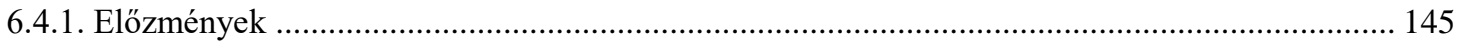

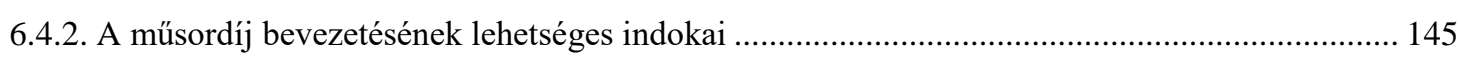

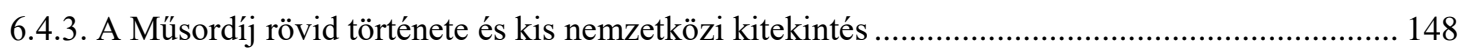

6.4.4. A müsordíj lényegi tartalma, konvergenciája ……………………………………………….... 151

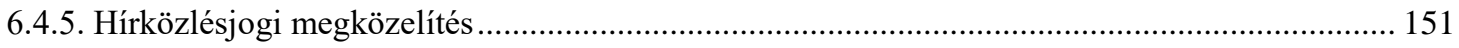

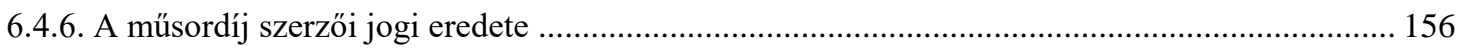

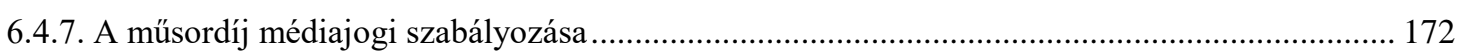

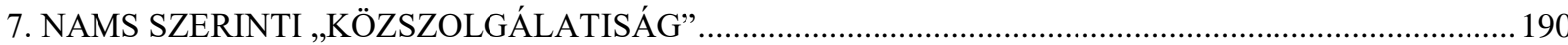

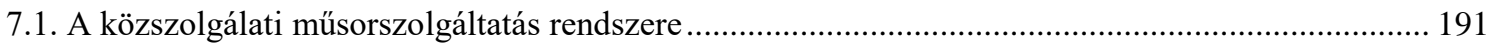

7.1.1. A közszolgálati müsorszolgáltatás kitüntetett jelentősége ............................................................. 191

7.1.2. Intézmény-centrikus szabályozás kontra feladatközpontú, funkcionális szemlélet ..................... 192

7.1.3. A müsorszolgáltatói szerepek tiszta elválasztása .................................................................. 192

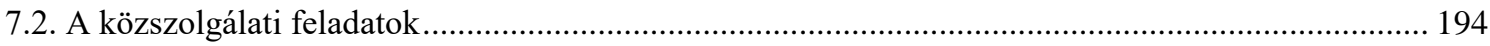


7.2.1. A közszolgálati feladatok meghatározása ………................................................................... 194

7.2.2. A közszolgálati feladatok jellege és meghatározásuk szabályozási szintje .................................. 195

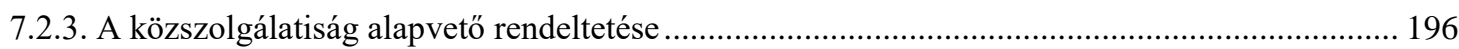

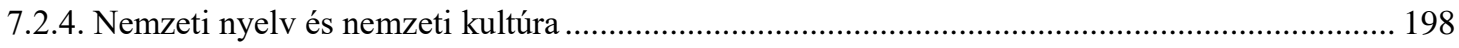

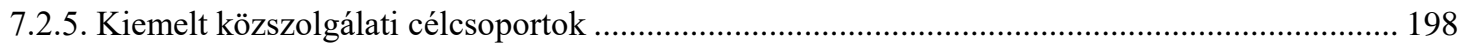

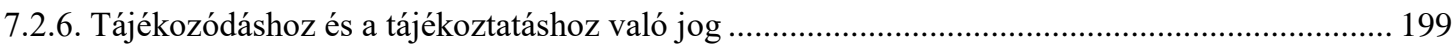

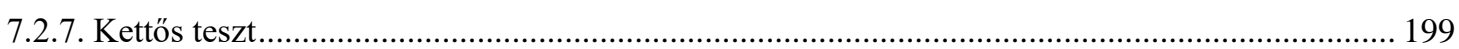

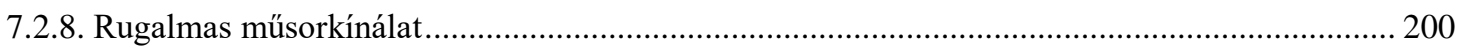

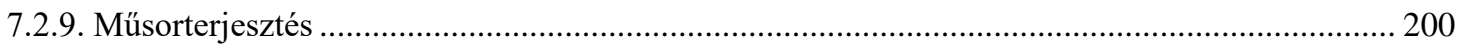

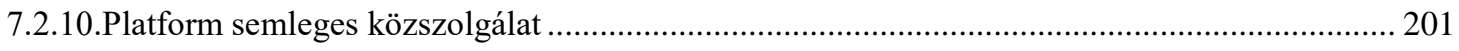

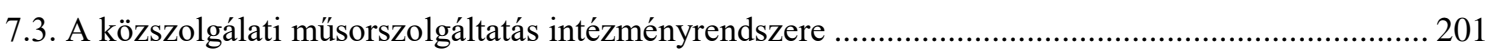

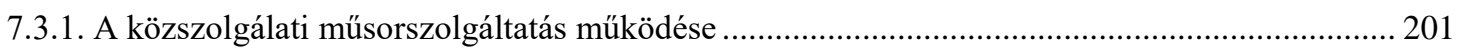

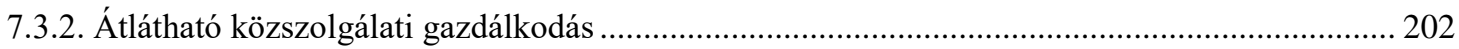

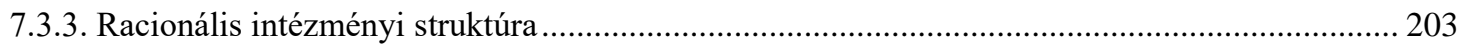

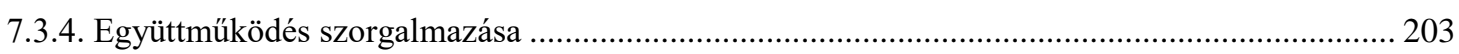

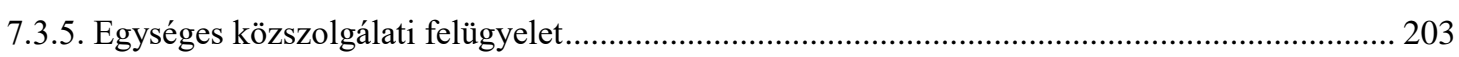

7.3.6. A közszolgálati intézmények szervezeti formája …………………………………………..... 204

7.3.7. A tulajdonosi jogok gyakorlása és a tulajdonosi jogok gyakorlója ............................................... 204

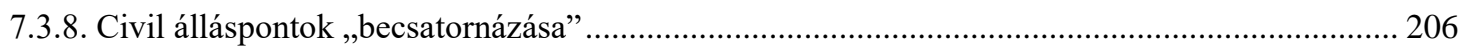

7.4. A közszolgálati feladatok teljesítésének ellenőrzése, a hatékony feladatellátás értékelése ................ 206

7.4.1. Ellenőrző mechanizmusok és az Állami Számvevőszék hatásköre............................................ 206

7.4.2. A médiahatóság hatásköre a közszolgálati müsorszolgáltatásban................................................. 207

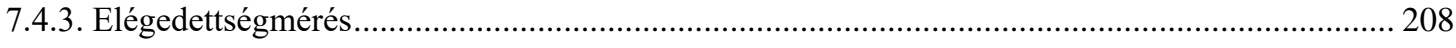

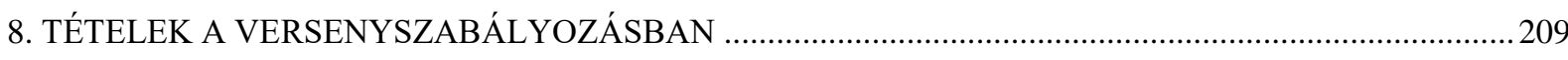

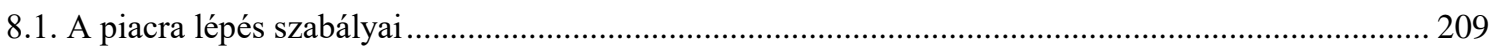

8.1.1. Engedélyezési eljárás helyett nyilvántartásba vétel ....................................................................... 209

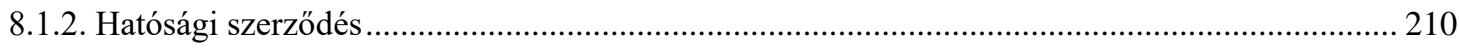

8.1.3. A müsorszolgáltatói magatartás hatósági kontrollja ................................................................ 211

8.1.4. Vállalkozási formák és magyar tulajdonosi kör ..................................................................... 213

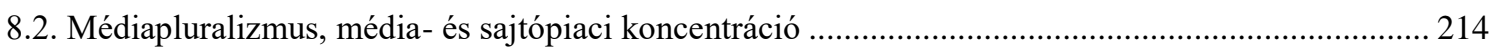

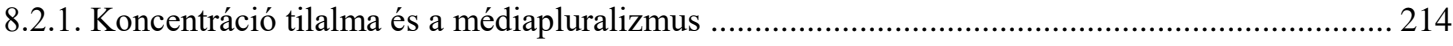

8.2.2. Meghatározó véleménybefolyásoló képesség versus jelentős befolyásoló erő ............................. 216

8.2.3. VBK kategóriák, valamint az MVK és JVK kötelezettségek küszöbértéke................................. 218

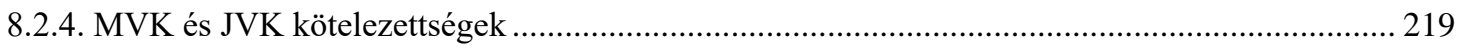

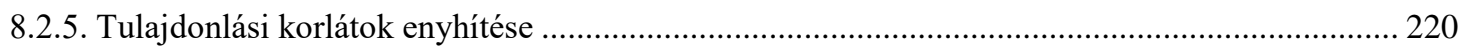

8.2.6. Nézettség, hallgatottság és közönségarány; verseny a nézettség 'piacán' ................................... 222

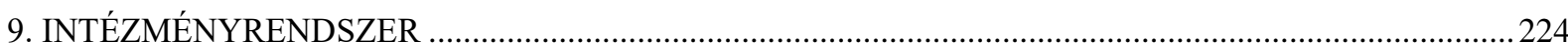

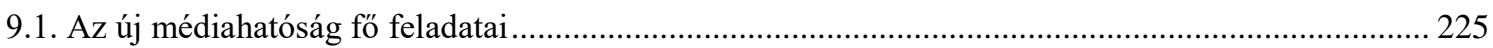




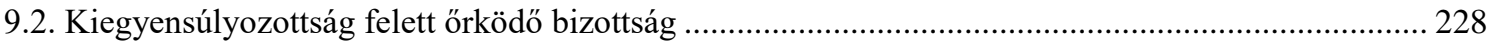

9.3. Média Fogyasztási Jogok Képviselője versus Média- és Hírközlési Biztos ...................................229

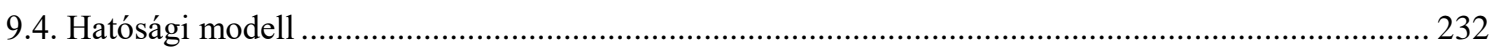

9.5. Szabályozási elvárások az új médiahatósággal szemben ......................................................... 233

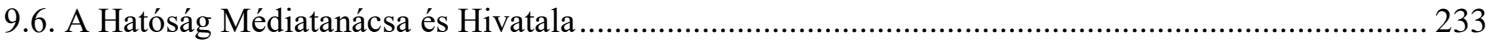

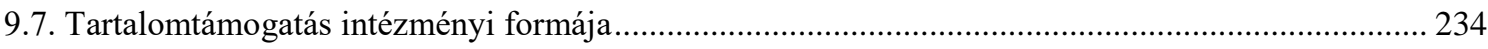

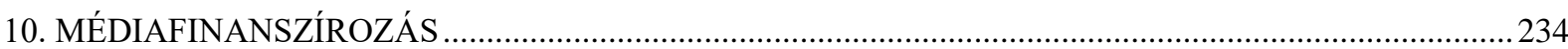

10.1. A felügyeleti rendszer finanszírozása ............................................................................. 235

10.2 Közszolgálati müsorszolgáltatás finanszírozása ................................................................. 236

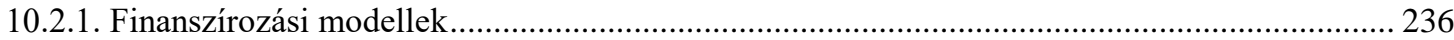

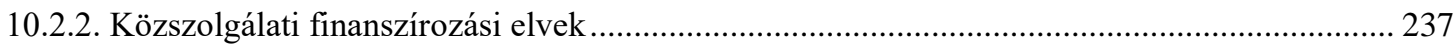

10.2.3. A közszolgálati média fokozatos mentesítése a reklámoktól .............................................. 237

10.2.4. Finanszírozási megoldások egységesítése ........................................................................ 239

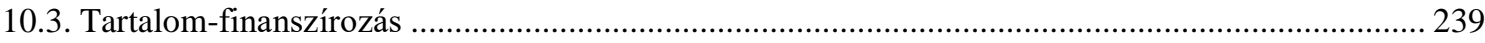

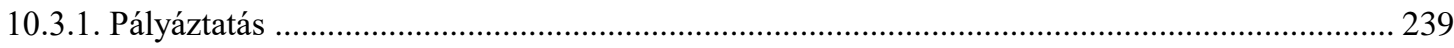

10.3.2. Összhang más célrendszerekkel ..................................................................................... 240

10.3.3. Összehangolt, stratégiai célokhoz kötött tartalom-támogatási rendszer................................ 240

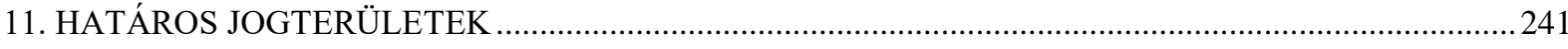

11.1. Médiaszabályozás és a határos jogterületek általános elvi összefüggései.................................. 241

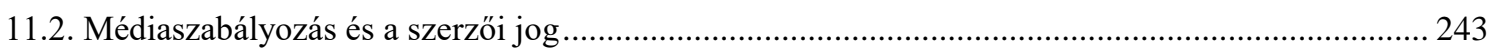

11.3. A NAMS-hoz kapcsolódó és azon túli szerzői jogi intézmények ..............................................245

11.3.1. A közös jogkezelés kérdésköre a NAMS alapján ............................................................. 247

11.3.2. A hazai közös jogkezelést érintő legfőbb szabályozási változások ........................................ 266

11.3.3. Az audiovizuális médiával kapcsolatos jogdíjrendszerek nemzetközi és hazai összefüggései . 272

11.3.4. Magyar díjszabási eljárás az Szjt. alapján ...................................................................... 275

11.4. Közszolgálati médiavagyon és az archívumok szerzői jogi kérdései ........................................ 277

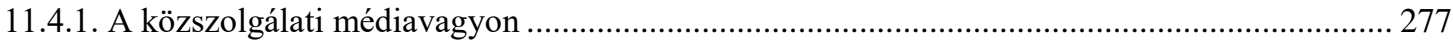

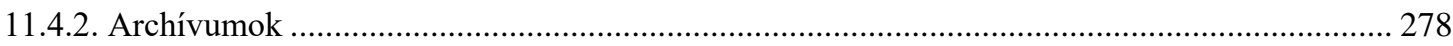

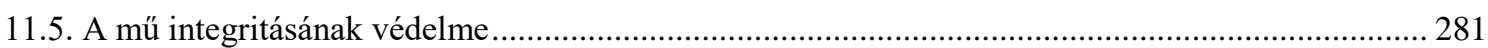

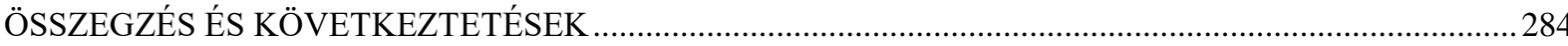

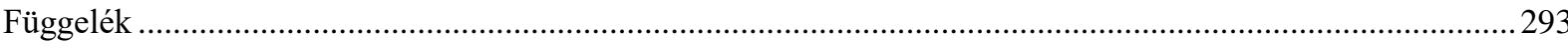

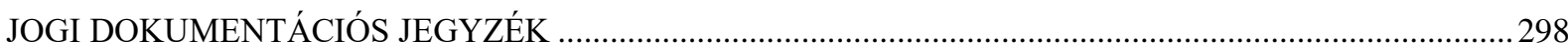

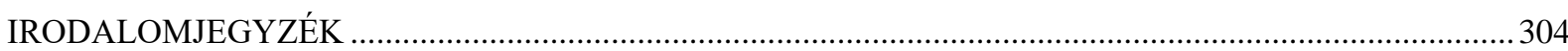

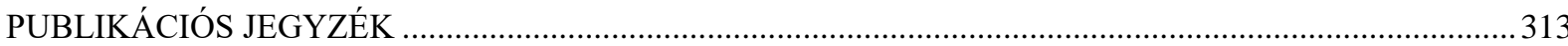




\begin{abstract}
ÁBRÁK JEGYZÉKE
1. ábra Horizontálisan és vertikálisan is összefüggő témakörök.......................................................................11

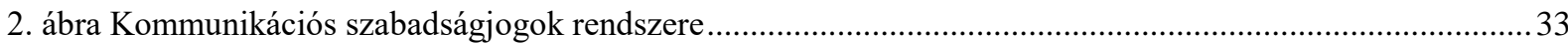

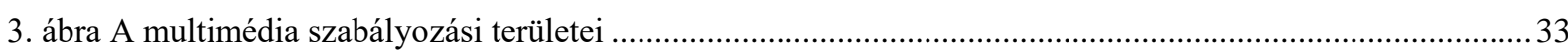

4. ábra Szabályozási lánc az állami jogi szabályozáshoz való viszonyulás alapján...............................................39

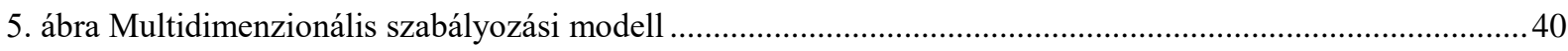

6. ábra A médiaszabályozási reform NAMS által azonosított pillérei ..................................................................54

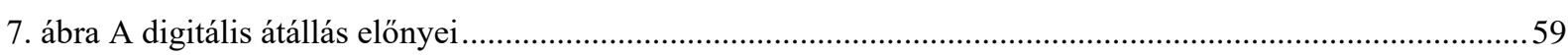

8. ábra A digitális átállás hazai helyzete 2006 novemberében - nemzetközi összehasonlításban ...........................62

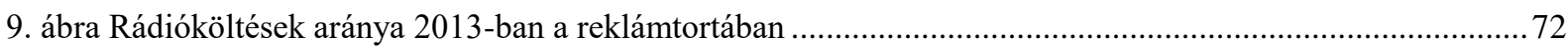

10. ábra Rádióköltések aránya 2014-ben a reklámtortában ................................................................................. 72

11. ábra AGB Nielsen adatok a digitális televíziózásról 2014 öszén .................................................................. 77

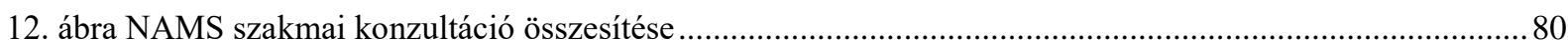

13. ábra a lineáris audiovizuális szolgáltatásokra értelmezhető egyszerüsített média-értéklánc ............................90

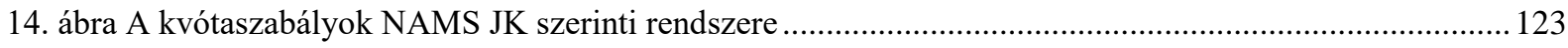

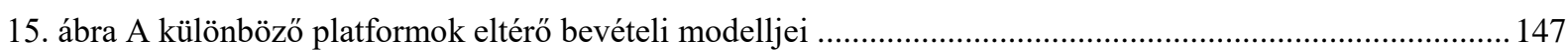

16. ábra Műsordíj-elem az előfizetési díjban............................................................................................ 154

17. ábra A médiajoggal határos jogterületek és a szerzői joggal való átfedések ................................................244

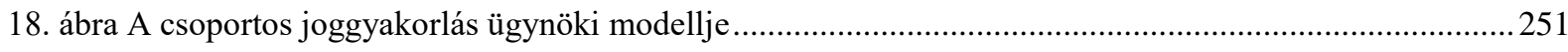

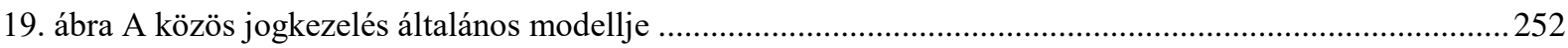




\section{RÖVIDÍTÉSEK JEGYZÉKE}

ASCAP The American Society of Composers, Authors and Publishers (Zeneszerzök, Szerzők és Kiadók Amerikai Egyesülete)

BBC British Broadcasting Corporation (Brit Közszolgálati Músorszolgáltató)

BDT Búrósági Döntések Tára, "Döntvénytár"

BMI Broadcast Music, Inc. (Dalszövegírók, Zeneszerzők és Zenei előadó müvészek Amerikai Előadói Jogvédő Szervezete, az ASCAP keretében)

BRTF Better Regulation Task Force (A brit Jobb Szabályozás Munkacsoport)

BUE Berni Uniós Egyezmény

CATV Community Access Television (Kábeltelevíziós müsorelosztás)

CBS Columbia Broadcasting System (A Columbia amerikai televíziós társaság műsorszolgáltatási rendszere)

CISAC International Confederation of Societies of Authors and Composers (A Szerzők és Zeneszerzők Társaságának Nemzetközi Szövetsége)

DAB Digital Audio Broadcasting (Digitális hang müsorszórás)

DAMA Derechos de Autor de Medios Audiovisuales (Az audiovizuális média szerzői jogainak spanyol szervezete)

DÁS Digitális Átállás Stratégiája

DTH Direct to Home service (Közvetlenül a háztartásokba irányuló szolgáltatás)

DRM Digital Right Management (Digitális jogkezelés)

DVB - T Digital Video Broadcasting — Terrestrial (Digitális földfelszíni video adás)

DVR Digital video recorder (Digitális Video Rögzítö)

EASA European Advertising Standards Alliance (Európai Reklám Szabvány Szövetség)

EBU European Broadcasting Union (Európai Müsorszolgáltatási Unió)

EUB Európai Unió Bírósága

EPG Electronic Program Guide Elektronikus müsorfüzet a digitális televíziózásban

FTA Free to air (Szabadon fogható müsorszolgáltatás)

GEMA Gesellschaft für musikalische Aufführungs- und mechanische Vervielfältigungsrechte (Zenei Előadói és Mechanikus Többszörözési Jogok Társasága)

GVL Gesellschaft zur Verwertung von Leistungsschutzrechten (Teljesítményvédelmi jogok Társasága)

GSM Global System for Mobile

Communication (Európai fejlesztésủ digitális mobilszolgáltatási szabvány)

ICC International Chamber of Commerce Nemzetközi Kereskedelmi Kamara

IPTV Internet Protocol Television(Internet kapcsolaton keresztüli televíziózás)

ITU International Telecommunication Union (Nemzetközi Távközlési Egyesület)

JBE Jelentős befolyásoló erővel rendelkező médiaszolgáltató 


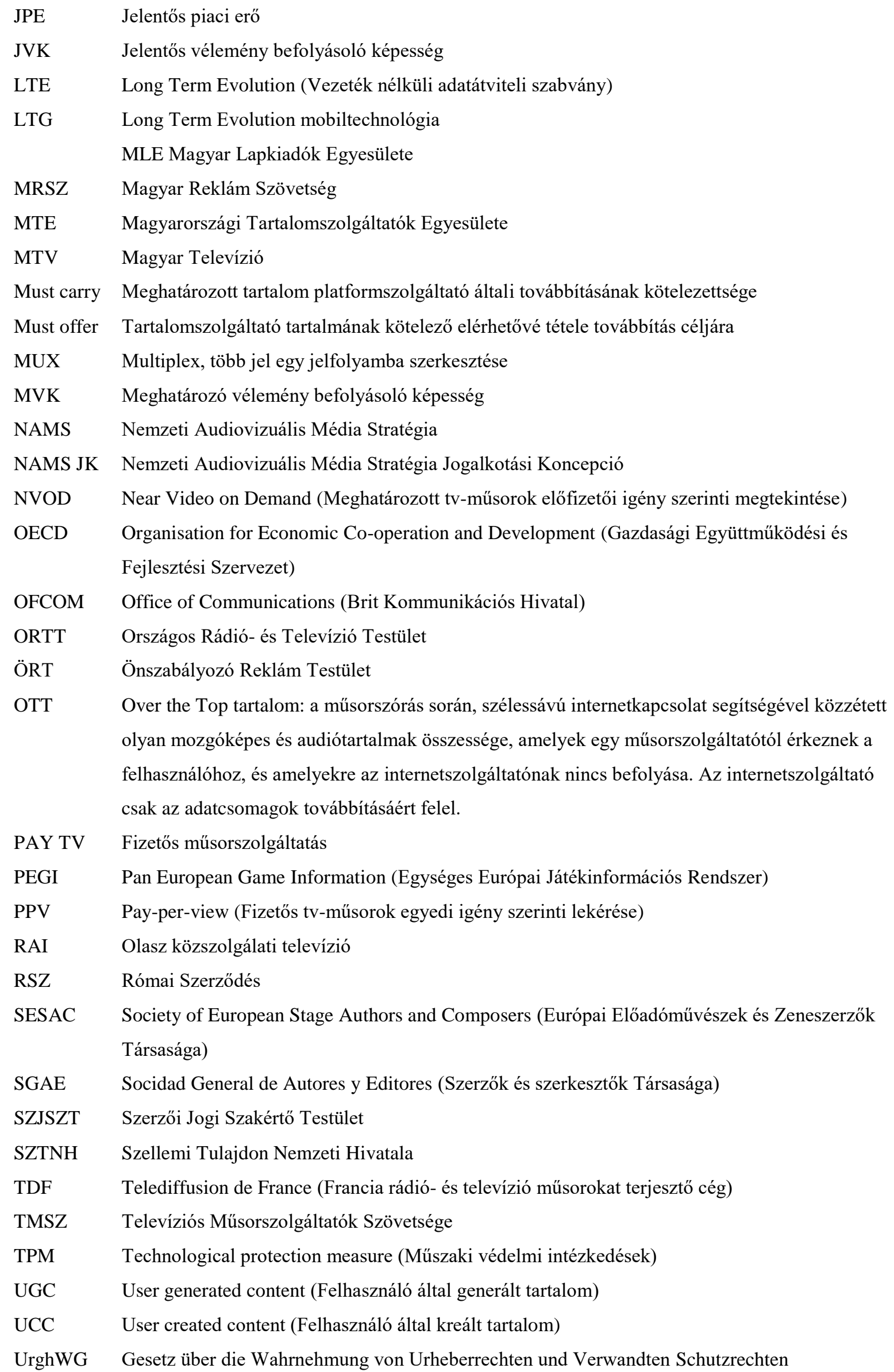


(Urheberrechtswahrnehmungsgesetz) (Német szerzői jogi törvény)

VerwGesG Bundesgesetz über Verwertungsgesellschaften (Verwertungsgesellschaftengesetz) (Német közigazgatási törvény)

VOD Video on demand (Müsortartalom igény szerinti megtekintése)

WCT 2004. évi XLIX. törvénnyel kihirdetett WIPO Szerzői Jogi Szerződés (1996)

WIPO World Intellectual Property Organization (Szellemi Tulajdon Világszervezete)

WPPT WIPO Szerződés az előadásokról és a hangfelvételekről

WRC World Radiocommunication Conference (Rádió-távközlési Világszervezet)

WSIS World Summit on the Information Society (Információs Társadalom Világtalálkozója) 


\section{BEVEZETÉS}

Az Egyesült Államok 21. századi médiapolitikáját vizsgálva McChesney ${ }^{1}$ a média problematikájának elsődleges tényezőjét a médiatartalomban látja, de ennél is nagyobb problémának tartja azt a struktúrát, ami a tartalmat generálja. A dolgozat e megállapítással egyetértve -, a hazai médiaszabályozás elmúlt évtizedének legfontosabb állomásait a 2006 kora őszén indult médiaszabályozási reformtól napjainkig kíséri, és a média-jogalkotás folyamatait alapvetően a tartalomszabályozás szemszögéből veszi górcső alá. A témaválasztás rendhagyó; dolgozat - amint azt az igen tágan megfogalmazott címe is érzékelteti -, több, egymással horizontálisan és vertikálisan is összefüggő témakört dolgoz fel és - ebből eredően - a témakörök aktualitása, a dolgozat szerkezete és kutatási módszere, valamint - természetszerüen - a megállapítások és következtetések is sokrétüek.

\section{KUTATÁSI TÉMAKÖRÖK}

Az értekezés az elmúlt tíz év hazai média jogalkotását fogja át; vizsgálódásának alapvetően három horizontális témakörét tíz év hazai médiaszabályozása, és az ahhoz kapcsolódó szerzői jog kodifikációjának legfőbb állomásai képezik. A dolgozat sorrendben első horizontális témakörét, az általános médiaszabályozási bevezetőt és a modern szabályozási struktúrákat elemző részét, a kutatás középpontjában álló, 2006-2008 között zajlott hazai médiaszabályozási reform elemzése és megállapításai követik; harmadik főbb témakörét pedig a médiajoggal határos jogterületek vizsgálata, elsősorban a szerzői jog audiovizuális médiával összefüggő egyes jogintézményeinek elemzése adja.

A kutatás horizontális témakörei egyes jogalkotási folyamatok és bizonyos fázisaik tekintetében, illetőleg jogintézmények vonatkozásában vertikálisan is „mélyre” ásnak, e tekintetben a kutatás teljes feltérképezésre törekszik.

Az értekezés az első, általános médiaszabályozás horizontális témakörben részletesen is elemzi a modern szabályozási struktúrákat, az ön- és társszabályozás alternatív szabályozási modelljeit, és e szabályozási modellek állami-jogi szabályozáshoz való viszonyát, valamint a „,better regulation” uniós módszereit és legújabb elképzeléseit.

\footnotetext{
${ }^{1}$ Robert W. McCHESNEY: Mi a baj a médiával? Az Egyesült Államok médiapolitikája a 21. században (Sorozatszerk.: KOLTAY András - NYAKAS Levente) Complex, Budapest, 2012. 15.
} 


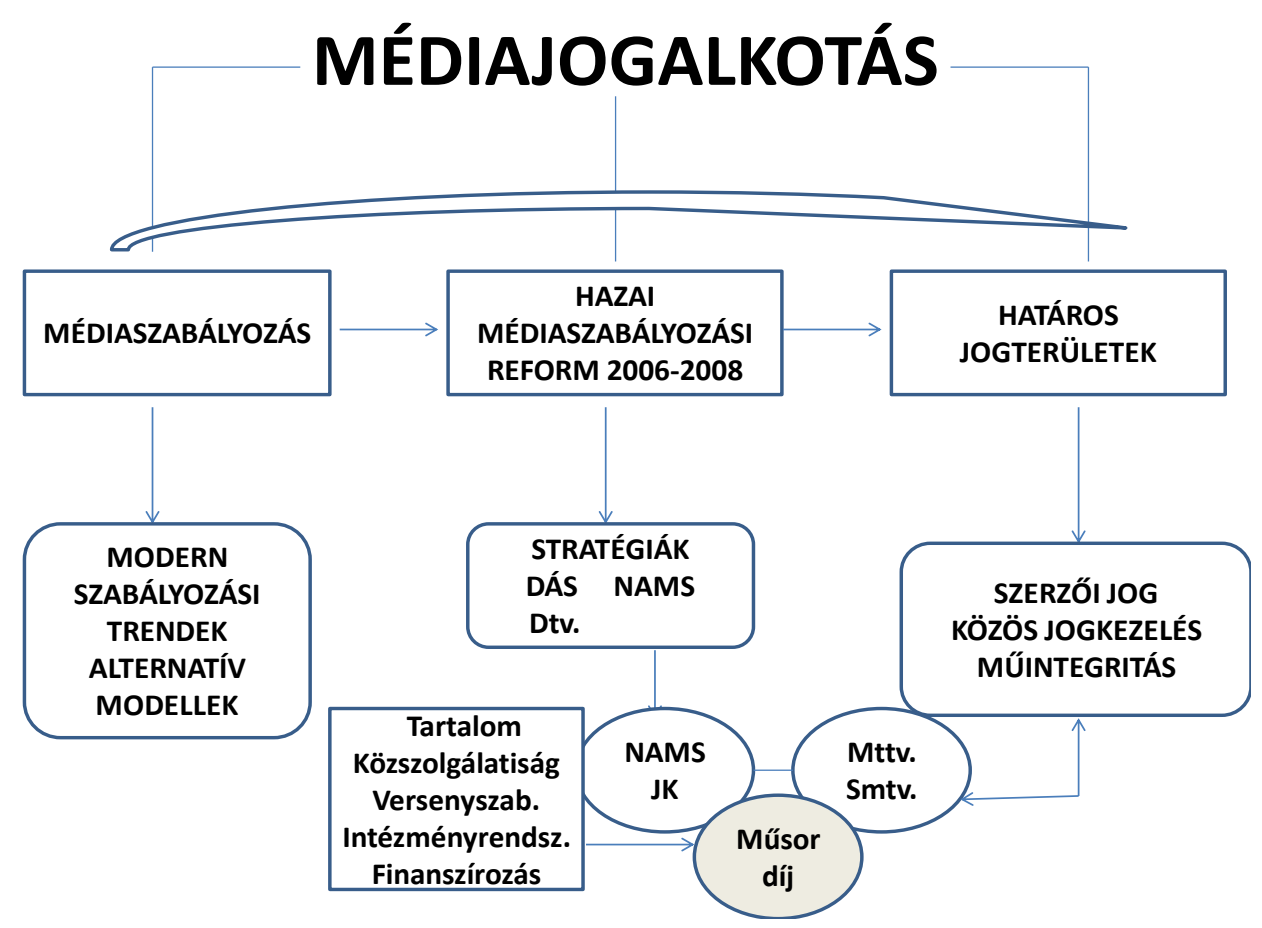

\section{1. ábra Horizontálisan és vertikálisan is összefüggő témakörök}

Az értekezés centrumában álló ,átfogó médiaszabályozási reform”² horizontális téma keretében a dolgozat részletesen bemutatja a szabályozási reform folyamatát, elemzi a jogi szabályozást megalapozó Stratégiák, a Digitális Átállás Stratégiája (DÁS), valamint a Nemzeti Audiovizuális Média Stratégia $(N A M S)^{3}$ létrejöttének megszokottól eltérő jogalkotási eszközeit és módszereit, a Stratégiák lényegét, egymáshoz való viszonyát. A dolgozat e része önálló fejezetet szentel a digitális átállás jogi előkészítési folyamatának, a „digitális” törvény szabályozási céljainak és főbb rendelkezéseinek. Az értekezés teret enged a rádiós médiaszolgáltatás digitális átállásával kapcsolatos szakmai polémiák ismertetésének, állást foglalva az átállás szükségessége mellett.

A média-jogalkotási reform másik, a dolgozat szempontjából meghatározó szabályozási pillére bemutatja a NAMS Jogalkotási Koncepció (NAMS JK, Koncepció) célrendszerét, elveit és szabályozási fejezeteit (tartalomszabályozás, „közszolgálatiság”,

\footnotetext{
${ }^{2}$ A „,médiaszabályozási reform” és a tág értelemben vett médiaszabályozás a digitális átviteli rendszerek, illetőleg a müsorterjesztési piac, valamint a médiatartalom szabályozására vonatkozó stratégiai előkészítést és jogalkotási feladatokat együttesen jelenti a dolgozatban.

${ }^{3}$ A Miniszterelnöki Hivatal által kiírt pályázatra készített (Réczicza White \& Case LLP KPMG konzorcium), a MeH által átdolgozott és a szakmai-társadalmi vita eredményeként véglegesített Stratégia 2007. június.
} 
versenyszabályozás, intézményrendszer és finanszírozás), majd mindezeket összeveti a 2010-től létrejött többszintű hazai médiaszabályozás rendszerével, jogintézményeivel.

A komparatív elemzés rámutat a Jogalkotási Koncepcióban megfogalmazott szabályozási szándék, célok és tételek médiatörvényekben ${ }^{4}$ való megjelenésére, időközi korrekciójára, vagy éppen a jogi szabályozásból való kimaradásra és annak okaira; e kutatási eredményeket a függelék táblázata foglalja össze.

Az értekezés alaptémája historikus jellegünek is mondható, hiszen a 2006 nyár végén indult átfogó médiaszabályozási reform folyamatát és jogi dokumentumait - médiatörténeti szempontból is -, immár tíz év távlatából szemléli és vizsgálja az annak idején megfogalmazott médiaszabályozási elvek és tételek időt állóságát.

Nyilvánvaló, hogy az elvi jellegü, 2006 és 2008 között kidolgozott Stratégiák és NAMS Jogalkotási Koncepció (NAMS JK, JK Koncepció), valamint a konkrét - mintegy három évvel későbbi - normaszövegek funkciója eltérő. Összevetésük, komparatív elemzésük mégis - tudományos és jogtörténeti megközelítésben is - rendkívül izgalmas feladat, jelentős szakmai kihívás.

A dolgozat e részében a müsordíj jogi természetének komplex vizsgálatán keresztül kirajzolódik az jogintézményen belüli konvergencia léte, a műsordíj lényegéhez tartozó különböző - polgári-, média-, hírközlési-, verseny- és szerzői jogi -, szempontok egymást kiegészítő összhangja, és e jogterületek eltérő szemléletéből eredő, egymással párhuzamosan létező értelmezésének megnyilvánulása, a jogterületek integritása is.

A dolgozat harmadik, horizontális részét képező kutatási témakör a médiaszabályozáshoz kapcsolódó szerzői jogterület egyes jogintézményeit (szerzői közös jogkezelés, archívumok, müintegritás) vertikálisan is vizsgálja. A szerzői jog a digitális technológia elterjedésével különös jelentőségre tett szert az elmúlt években, sorra látnak napvilágot vagy kerülnek felülvizsgálatra az audiovizuális médiát is érintő szerzői jog tartalmú irányelvek, illetőleg találkozunk az Európai Unió Bírósága által hozott döntésekkel, amelyek a nyilvánossághoz közvetítés szerzői jogi szempontjait a médiajogi megítéléshez ${ }^{5}$ közelítik.

\footnotetext{
${ }^{4}$ A médiatörvények alatt szűk értelemben az Smtv.-t és az Mttv.-t, legszükebb értelemben az Mttv.-t kell érteni.

${ }^{5}$ Az értekezés terjedelmi okokból sem dolgozta fel a magyar szerzői jogi kodifikáció legújabb, az értekezés kéziratának lezárását követően elfogadott hazai közös jogkezelési törvényt és annak végrehajtása tárgyában megjelent kormányrendeletet, (e hazai jogforrásokat a kodifikációs és szakmai elképzelések ismertetésével készíti elö), továbbá csak utalást tartalmaz a 2016 szeptemberében napvilágot látott uniós irányelvi javaslatra és rendeletre.
} 


\section{A TÉMAKÖRÖK AKTUALITÁSA}

A média szabályozásával kapcsolatos kérdések, a múlt szabályozási hibáiból való okulás, valamint az új trendek vizsgálata szinte állandó kutatási területe a médiaszabályozással foglalkozó szakmai köröknek. E téma kapcsán a dolgozat elöre vetíti az alternatív szabályozási modellek, és modern szabályozási struktúrák várható hatását és befolyásoló szerepét a jövő média jogalkotására.

A központi témakör elemzésének aktualitását a hazai médiaszabályozási reform tíz éves és a jelenlegi médiaszabályozási rezsim ${ }^{6}$ alkalmazásának mintegy fél évtizedes időszaka adja. Ez az időtávlat már elegendő ahhoz, hogy visszanyúljunk a gyökerekhez ${ }^{7}$ és az értekezés legfőbb témájaként elemezzük a jelenlegi médiatörvények alapját képező $N A M S$, valamint az ennek esszenciáját képező Jogalkotási Koncepció ${ }^{8}$ médiaszabályozással kapcsolatos elveit és azok megjelenését vagy éppen hiányának indokát a hazai médiatörvények szövegében.

Az értekezés legföbb témájának aktualitását - az említetteken túl, mindenekelőtt - az a már közhelynek számító, de tényként elkönyvelt rendkívül gyors, szinte forradalmi technikai és technológiai fejlődés adja, amely a múlt század második felétől a média- és hírközlési eszközrendszert folyamatos átalakulásra késztették, és amely az ezredforduló környékén megalapozta a tág értelemben vett médiaszabályozás „hardver”- jének, a digitális terjesztési platformok és müszaki megoldások európai uniós szabályrendszerének kialakulását. E témakör kutatása és feldolgozása másrészről azért is időszerü, mert az eszközrendszer rendkívül változatos és gyors fejlődése indukálta a tartalmi szabályok európai uniós újragondolását és eredményezte a tartalomszabályozás „szoftver”- jének megalkotását, az audiovizuális médiaszolgáltatási irányelv, az AVMS létrejöttét.

\footnotetext{
6 Médiaszabályozási rezsim alatt az Alaptörvény (Szabadság és felelősség IX. Cikk) sajtóra és az audiovizuális médiára irányadó rendelkezéseit, valamint azon sarkalatos és nem sarkalatos törvényeket értem, amelyek tárgya közvetlenül a médiával kapcsolatos jogviszonyok rendezése. E körbe tartoznak: a 2010. évi LXXXII. törvény a médiát és a hírközlést szabályozó egyes törvények módosításáról, a 2010. évi CIV. törvény a sajtószabadságról és a médiatartalmak alapvető szabályairól (Smtv.), a 2010. évi CLXXXV. törvény a médiaszolgáltatásokról és a tömegkommunikációról (Mttv.), a 2003. évi C. törvény az elektronikus hírközlésről (Eht.), valamint a 2007. évi LXXIV. törvény a müsorterjesztés és a digitális átállás szabályairól (Dtv.).

${ }^{7}$ A dolgozat tartalmi és terjedelmi okok miatt a rádiózásról és televíziózásról szóló 1996. évi I. törvény (Rttv.) rendelkezéseire csak egyes vonatkozásokban tér ki.

${ }^{8}$ Nemzeti Audiovizuális Média Stratégia Jogalkotási Koncepció a NAMS szakmai véleményezését követő lényegi tartalma, az Audiovizuális Média Kormánybiztosa (AMK) által véglegesített szöveg 2007. december.
} 
A digitális átállásra vonatkozó uniós irányelvek és az $A V M S$ irányelv ${ }^{9}$ uniós előkészületei meghatározó hatással voltak a hazai átfogó médiaszabályozási reform mintegy tíz évvel ezelőtti, 2006 nyár végi elindítására, továbbá a DÁS, a NAMS és a Jogalkotási Koncepció kidolgozására, majd pedig a hatályos többszintű médiaszabályozási rendszer kialakítására. $\mathrm{Az}$ értekezés ennek megfelelően a jelenlegi hazai médiaszabályozás alapjait történetiségében mutatja be, hogy lássuk: a 2010. évi kormányváltást követő pár hónapon belül létrejött új szabályozási rendszer ${ }^{10}$ nem néhány hetes munka teljesítménye, hanem egy több éven keresztül formálódó, eredetileg politikai konszenzussal támogatott, szakmailag pedig médiapiaci kutatásokkal, stratégiákkal megalapozott, a médiajoggal határos jogterületeket átvilágító tanulmányokkal ${ }^{11}$ is alátámasztott átfogó médiaszabályozási reform és kodifikációs folyamat eredménye.

A müsordíjra vonatkozó 2014. évi médiatörvény módosítás - joggal -, előtérbe helyezte a jogintézménnyel kapcsolatos köz- és szakmai érdeklődést. Jogi természetének vizsgálata bár a jogintézmény először a $D A ́ S$-ban, illetőleg a Dtv-ben szerepelt ${ }^{12}$-, azért képezi a komparatív elemzésen túl a dolgozat fontos részét, mert a már kialakult üzleti modellek megváltozásában jelentős szerepe van, továbbá jellegzetes példája a médiával határos jogterületek különböző megközelítési szempontjainak, eltérő vizsgálati szemléletének, egyben pedig tárgya valamennyi határos jogterület elemzésének (6.4. alfejezet).

A szerzői jog a digitális technológia elterjedésével különös jelentőséghez jutott az elmúlt években. Az értekezés harmadik részét képező kutatási témakör a médiaszabályozáshoz kapcsolódó szerzői jogi terület egyes jogintézményeit vizsgálja. Az Európai Unió szerzői

\footnotetext{
${ }^{9}$ Az Európai Parlament és a Tanács 2010/13/EU irányelve (2010. március 10.) a tagállamok audiovizuális médiaszolgáltatások nyújtására vonatkozó egyes törvényi, rendeleti vagy közigazgatási rendelkezéseinek összehangolásáról (Audiovizuális médiaszolgáltatásokról szóló irányelv, AVMS). A NAMS és a JK is az irányelvet még „AMSZ” rövidítéssel illeti.

${ }^{10} \mathrm{Az}$ új kormány megalakulása: 2010. 05. 25. (2010. évi XLII. törvény a Magyar Köztársaság minisztériumainak felsorolásáról, kihirdetve: 2010. 05. 25. A médiatörvények megalkotása: 2010. évi LXXXII. törvény (elfogadva: 2010. 07. 22.) Smtv. kihirdetve: 2010. 11. 9. Mttv. kihirdetve: 2010. 12. 31.

${ }^{11}$ A NAMS-hoz a Miniszterelnöki Hivatal megbízásából készült tanulmányok: 1. A közös jogkezelök által alkalmazott szerzői jogdijak szerepe az audiovizuális szektorban MSZH (szerk.: KISS Marietta) szerzők: CSERBA Veronika, FICSOR Mihály, HEPP Nóra, KISS Zoltán, MUNKÁCSI Péter, PENYIGEI Krisztina. Budapest, 2007. (Szerzői Jogi Tanulmány). 2. A kereskedelmi müsorszolgáltatás versenyjogi alapú szabályozása MTA Jogtudományi Intézet Infokommunikációs Jogi Centrum, 2007 Szerzök: TÓTH András, POLYÁK Gábor, Közremüködők: KOPPÁNYI Szabolcs, TÉNYI Géza (Versenyjogi Tanulmány). 3. A nemzeti tartalmak elöállitásával, szerkesztésével és átvitelével összefüggö tartalmi és pénzügyi feltételrendszer kialakitása - a közszolgálati müsorszolgáltatás szabályozási kérdései PTE ÁJK Informatikai és Kommunikációs Kutató Intézet, szerzők: LENGYEL Márk, POLYÁK Gábor, SZŐKE Gergely László 2007. (Közszolgálati Tanulmány).

${ }^{12}$ Dtv. 37. §
} 
jogi szabályozása felébredt „csipkerózsika álmából” és sorra látnak napvilágot vagy kerülnek felülvizsgálatra az audiovizuális médiát érintő szerzői jogi tartalmú irányelvek, illetőleg találkozunk az Európai Unió Bírósága által hozott döntésekkel, amelyek a nyilvánossághoz közvetítés szerzői jogi szempontjait a médiajogi megítéléshez közelítik. Előre kell bocsátani, hogy az értekezés terjedelmi okokból sem dolgozta fel a magyar szerzői jogi kodifikáció legújabb, az értekezés kéziratának lezárását követően elfogadott hazai közös jogkezelési törvényt és annak végrehajtása tárgyában megjelent kormányrendeletet (e hazai jogforrásokat a kodifikációs és szakmai elképzelések ismertetésével készíti elö), továbbá csak utalást tartalmaz a 2016 szeptemberében napvilágot látott uniós irányelvi javaslatra és rendeletre.

A dolgozat a hazai médiaszabályozásból és a kapcsolódó jogterületek jogalkotásából, joggyakorlatából - terjedelmi okok miatt is - legfeljebb tíz évet foghat át, azonban meghatározó szabályozási korszak lényegi ismertetésére és elemzésére vállalkozik.

\section{KUTATÁSI FELADATOK ÉS TUDOMÁNYOS CÉLKITÜZÉSEK}

A dolgozat az alternatív szabályozási módszerek és modellek, így az ön-, és társszabályozás, valamint a ,jobb szabályozás" és a 'best practice' eszközeinek részletes elemzésével kíván rávilágítani e szabályozási rendszerek jogi szabályozás melletti kiegészitö jellegére és egyre növekvö jelentöségére. Az 1. fejezet a NAMS JK és a hazai médiaszabályozás komparatív összehasonlítását egy médiaszabályozási bevezetôvel indítja és elsődlegesen az alternatív szabályozási trendek szerepkörét az állami-jogi szabályozáshoz való viszonyulásukban vizsgálja. Az értekezés a legújabb kutatási eredmények feldolgozásával külön is figyelmet szentel az önszabályozási rendszerek és módszerek elemzésének, bemutatva a 'self-regulation' jogi szabályozással összevetett előnyeit és hátrányait, továbbá hatás-mechanizmusát. A 'better regulation' kapcsán a dolgozat rámutat az Európai Unió 2014 őszétől megújult jogalkotási módszereire, ismertetve a „minőségi jogalkotás”, valamint az „intelligens jogi szabályozás” elveit megfogalmazó uniós jogi dokumentumok lényegi tartalmát.

A dolgozat legfóbb célja és vállalása az átfogó médiaszabályozási reform keretében, a 2006 és 2008 között született médiajogi dokumentumokban megfogalmazott elvek és tételek megjelenésének vizsgálata, a több éves szakma-szemléleti és elvi folytonosság elemzése és kimutatása a jelenlegi magyar médiaszabályozásban. A kutatás alapján joggal tehetők fel a dolgozatot leginkább foglalkoztató következő kérdések: 
1) Kimutatható-e összefüggés a 2006-2008 közötti átfogó médiaszabályozási reform során létrejött jogi dokumentumokban megfogalmazott szabályozási szándék és a jelenlegi magyar médiaszabályozási rendszer között? 2) Amennyiben igen, úgy a 2006 és 2008 között készült jogi dokumentumok mely szabályozási célkitűzései, elvei és tételei azonosíthatóak a 2010-ben létrejött magyar médiaszabályozásban? 3) Mely médiajogi rendelkezésekben élnek tovább a 2006 és 2008 között született szabályozási célok és elvek? Végül pedig 4) melyek azok a tíz évvel ezelőtti Stratégiákban és a Jogalkotási Koncepcióban rögzített szabályozási célkitüzések és elvek, amelyek a 2010-től felállt médiaszabályozási rendszerben már aktualitásukat veszítették, átalakultak vagy nem élnek tovább?

Az értekezés ennél fogva, nem egyszerüen a $N A M S$ és a $J K^{13}$ létrejöttének körülményeit, szemléletét és módszereit mutatja be, illetőleg főbb szabályozási elveinek ismertetését tekinti elsődleges feladatának, hanem az elemzett jogi dokumentumokban megfogalmazott szabályozási célok, elvek, tételek és összefüggések továbbélésének összegző dokumentumaként kíván szolgálni a tíz évvel ezelőtti médiapolitikai célkitüzések mentén, a 2010-ben felállított hazai médiaszabályozási rendszerben. A dolgozat ennek megfelelően, egyfelöl bemutatja a $N A M S$ és a $J K$ kidolgozásának történeti folyamatát, módszertani menetét, a szabályozási elvek és tételek kialakulását (2., 4., 5. fejezetek és részben a 6. fejezet). A NAMS Jogalkotási Koncepció egyes fejezetei alapján pedig másfelöl elemzi - a szük értelemben vett - tartalomszabályozásra, ${ }^{14}$ a közszolgálati médiaszolgáltatásra, ${ }^{15}$ a médiapiac összefüggéseire, az intézményrendszerre és a finanszírozásra irányadó koncepciós princípiumokat, illetőleg kimutatja azok megjelenését vagy éppen hiányát a magyar médiaszabályozásban (6., 7., 8., 9. és 10. fejezetek).

Az értekezés több esetben a Jogalkotási Koncepció „mögé” is tekint és a NAMS eredeti, társadalmi vitára bocsátott szövegéhez nyúlik vissza, kiegészítve ezzel a Jogalkotási Koncepció végleges elgondolásait különösen a 2. 4. és 5. fejezetekben.

$\mathrm{Az}$ átfogó médiaszabályozási reform két pillérének konvergenciájára, nevezetesen a tartalom- és a hírközlésjogi-szabályozás szimbiózisára figyelemmel, a kutatás során nem lehetett eltekinteni a digitális müszaki átállással kapcsolatos szabályozási előzmények

\footnotetext{
${ }^{13}$ A dolgozat a NAMS JK szövegéböl kiindulva végzi el a kutatást, de több esetben hivatkozik a NAMS eredeti szövegére. Ebben az esetben egyértelmüen megjelöli az elemzett szövegrész forrását.

${ }^{14}$ Az értekezés szük értelemben vett tartalomszabályozás alatt kizárólag a médiatartalommal kapcsolatos szabályozási kérdéseket érti.

${ }^{15}$ A NAMS és a JK is a közszolgálati médiaszolgáltatást összefoglaló néven „közszolgálatiság” elnevezéssel illette. A szöveghủ idézés érdekében ezt a kifejezést is használom a dolgozatban NAMS JK 32.
} 
lényegi, önálló fejezetben való ismertetésétől sem. Az átfogó médiareform szabályozási pilléreken nyugvó rendszerének, a konvergáló jogterületek egymásra hatásának bemutatása, valamint a digitális átállás máig ható vizsgálata - beleértve a rádiós digitális átállás szükségességét is (3.7.) -, a dolgozat másik jelentős feladata és célkitüzése. ${ }^{16}$ (3. fejezet).

A már jelzett szabályozási konvergencia jegyében indokolt ismertetni az audiovizuális média és a határos jogterületek egymással átfedésben lévő jogintézményeit, így bizonyos hírközlési- és versenyjogi vonatkozásokat is, elsősorban a versenyszabályozási fejezetben (8.), valamint az audiovizuális szektorban a digitális technológiával különös jelentőségre szert tett szerzői jogi kérdések körében (11. fejezet).

A NAMS JK által a tartalomszabályozás részeként megfogalmazott, az audiovizuális médiával határos szerzői jogi szabályozási tárgykörök és jogintézmények a digitalizációval megnövekedett jelentőségüknél és terjedelmüknél fogva önálló fejezetben kerülnek kifejtésre. Az audiovizuális média szerzői közös jogkezelésének vizsgálata, a NAMS-hoz készült Szerzői Jogi Tanulmány eredményeinek és a dolgozat által továbbfejlesztett kutatási megállapításainak elemzése, a hazai és egyes tagállami közös jogkezelési rendszerek sajátosságainak bemutatása az értekezésben kiemelt szerepet kapott. Az értekezés e fejezete a NAMS Jogalkotási Koncepcióban is szereplő szerzői jogi célrendszert, elveket és szemléletet veti össze az audiovizuális médiaszabályozás eltérő célkitüzéseivel, szabályozási szempontjaival és terminológiájával, mintegy bevezetve a hazai szerzői jogi törvény 2011. évi módosításának, valamint a közös jogkezelés 2014. évi irányelvének és hazai implementálásának ismertetésére vonatkozó részét. (11. fejezet 11.2. 11.3.) A közszolgálati médiavagyon és az archívumok szerzői jogi kérdései (11.4.) kapcsán a dolgozat azt vizsgálja, hogy a közszolgálati tartalomfinanszírozás NAMS JK-ban megfogalmazott elvei, úgymint közszolgálati és az egyéb értékteremtő tartalom-fejlesztés pályázati alapú támogatása, a digitalizált közszolgálati archívumokra megfogalmazott szabályozási célok $^{17}$ és az egységes nemzeti archívum létrehozatalának szándéka mennyiben öltenek testet az új médiaszabályozásban.

A mü integritásának szerzői védelme (11. fejezet 11.5.) kifejezetten az új médiaszabályozás következtében került a dolgozat látókörébe; a jogintézmény audiovizuális médiával kapcsolatos megközelítése a gyakorlati szempontok ismertetésével

\footnotetext{
16 NAMS is a $D A ́ S-t$, valamint az Rttv. jogharmonizációs célú módosítását tekintette legfontosabb előzményének NAMS 5.

${ }^{17}$ NAMS 49.
} 
új megvilágításba kerül. E kérdéskörben a dolgozat azt elemzi, hogy a müsorszám indokolt mértékü megszakítása mennyiben feleltethető meg a műegység szerzői jogi védelmének, illetőleg azt, hogy a média és a szerzői jogi szabályozási kollízió feloldható-e a joggyakorlatban.

\section{AZ ÉRTEKEZÉS SZERKEZETE ÉS KUTATÁSI MÓDSZEREI}

Az értekezés bevezető gondolatait követően 11 fejezetre tagolódik és a kutatási eredményeket összegző megállapításokkal, következtetésekkel zárul.

A dolgozat munkamódszere az egyes szerkezeti egységek, fejezetek tartalmától függően változik. Az értekezés a médiajogi reform jogi dokumentumainak bemutatása tekintetében - alapvetően a jogtörténeti jellegből adódóan is - jelentős részben leíró és összehasonlító elemzés. Az írás több esetben kitér a NAMS elveit meghaladóan a Jogalkotási Koncepcióban megfogalmazott, adott esetben konkrétabb célkitüzések bemutatására (önés társszabályozás) is. A leíró és összehasonlító elemzésen túl - különösen a médiaszabályozással kapcsolatban (alternatív szabályozási modellek), valamint a médiajoggal összefüggő egyes határos jogterületek jövőbe mutató jogintézményei tekintetében (müsordíj jogi természete, a közös jogkezelés kérdésköre) - a dolgozat „mélyre ás”, részletes dogmatikai elemzésbe bocsátkozik, ebből következően e fejezetek szerkezete, stílusa, jellege is eltér a komparatív részekétől.

$\mathrm{Az}$ 1. fejezet a médiaszabályozás elvi megalapozását és az új szabályozási trendek vizsgálatát végzi el a hazai és nemzetközi szakirodalom kutatási eredményeinek felhasználásával és egyedi következtetések levonásával. A megállapítások alapját az uniós és egyes tagállami, valamint hazai szabályozások képezik. Ez a fejezet az audiovizuális médiával összefüggő szerzői jogi kérdésekkel foglalkozó, valamint a műsordíj vizsgálatára vonatkozó alfejezettel együtt dogmatikai elemzést végez.

A dolgozat több esetben gyakorlati szempontból is megvilágítja az adott jogintézményt (pld. médiaszolgáltatói - müsorterjesztői megállapodás létrehozatali folyamata a műsordíj kérdéskörében), azaz a leíró és komparatív módszer mellett az adott jogintézmény teljes feltérképezésére törekszik. A kutatás kiterjed a magyar és külföldi szakirodalom feldolgozására, a közösségi és tagállami jogforrások, adott esetben az Európai Bíróság joggyakorlatának ismertetésére, valamint a hazai jogszabályok, az Alkotmánybíróság vonatkozó határozatainak és a bírói gyakorlat, továbbá versenytanácsi és szakértői testületi dokumentumok elemzésére is. 
A dolgozat fő gerincét adó $N A M S$ és $J K$, illetőleg a 2010-ben létrejött médiaszabályozás „összehasonlítása” hangsúlyozottan nem a korábbi, 1996-os médiatörvény és a Stratégia szabályozási elképzeléseit veti össze. A dolgozatnak ezért nem is tárgya a NAMS korábbi médiatörvényt meghaladó elveinek kifejtése, hanem kifejezetten a digitális technológia eredményeként kialakult új szabályozási szemlélet, célok és tételek ismertetése egy olyan időszakban, amikor még nem látszottak világosan az új technológia alkalmazásának lehetőségei és - ebből következően - a szabályozási szükség irányai sem.

A dolgozat 2. és 3. fejezete leíró jelleggel betekintést enged a 2006 és 2008 közötti médiareform „kulisszatitkaiba”, a Stratégiák és más jogi dokumentumok létrejöttének folyamatába, a reform munkamódszereibe. E fejezetek hangvétele, megfogalmazása a tudományos munkától talán szokatlan módon közvetlen, mondhatni néhol bensőséges jellegü, de nem lehetett eltekinteni a személyes tapasztalatok feldolgozásától. ${ }^{18}$

Az értekezés 4. és 5. fejezetei kifejezetten a NAMS és a $J K$ létrejöttével, új szemléletével, a kialakított cél- és eszközrendszerrel, valamint a szabályozási pillérek bemutatásával foglalkozik. A médiahatóság funkcióinak alkotmányos kérdései körében különös hangsúlyt kapnak az Alkotmánybíróság határozatai, amelyek - többek között - egyfelől az új médiahatóság hatáskörének és feladatainak egyértelmű meghatározásához és a funkciók elhatárolásához adtak iránymutatást a jogszabály-előkészítők és a jogalkotók számára, másfelől pedig a már létrejött médiaszabályozási rendszer átfogó vizsgálatát végzik el.

A dolgozat a $N A M S J K$ szerkezetét követve leíró és összehasonlító módszerrel tárgyalja a tartalom (6. fejezet), a „közszolgálatiság” (7. fejezet) a versenyszabályozás (8. fejezet), az intézményrendszer (9. fejezet), valamint a médiafinanszírozás (10. fejezet) elveit. A dolgozat e fejezeteinek kutatási módszere alapján először bemutatásra kerülnek a vonatkozó $N A M S J K$ elvek és tételek, szabályozási szándék, célok, majd az adott fejezeten belül, annak végén a megvalósult szabályozás rendelkezései, a jogszabályhelyekre történő hivatkozással. Az új médiaszabályozás ${ }^{19}$ rendelkezéseinek részletes kifejtése, elemzése alapvetően nem tárgya az értekezésnek; emiatt a dolgozat a kialakult szabályozás ismertetését, adott esetben kritikáját csak azon rendelkezések, illetve jogintézmények tekintetében rögzíti, (vagy adott esetben a szabály hiányára utal), amelyekben a Stratégiákban lefektetett szabályozási szándék, cél, valamint a létrejött normaszöveg

\footnotetext{
${ }^{18}$ A szerzö 2006. augusztus 1-töl a Miniszterelnöki Hivatal médiajogi főtanácsadója, majd 2007. október 1tỏl az Audiovizuális Média Kormánybiztosa (AMK).

${ }^{19}$ A dolgozat az Smtv. hatályos, az Mttv. 2014. évi CVII. törvénnyel módosított 2015. január 1-töl hatályos szövegét veszi alapul; az Smtv. és az Mttv. ettől eltérő hivatkozásait pedig - a megfelelő részeknél - jelöli.
} 
között jelentős eltérés mutatkozik. Ilyenek - többek között - az írott sajtót is magában foglaló egységes médiatörvény kérdése, a médiaszolgáltatások elhatárolása és a szabályozás tárgyi hatálya, a közszolgálati média feladatainak meghatározása, a közszolgálati média „reklámtalanítása”, illetőleg a véleménybefolyásoló képesség elvének módosult megvalósulása. Az értekezés egyes jogintézmények, szabályozási megoldások esetében véleményt formál a hatályos médiaszabályozásról, de nem bocsátkozik a médiatörvények hatályba lépését követö, elsősorban politikai jellegü hazai és külföldi bírálatok elemzésébe, megítélésébe.

A müsordíj jogintézménye ugyan szerzői jogi eredetü, és a $D A ́ S$-ban, valamint a Dtv. szabályai között jelent meg először a tág értelemben vett hazai média jogalkotásban, jelenleg alapvetően mégis a médiajogi tartalomszabályozás részét képezi, ezért a jogintézménnyel kapcsolatos kutatási rész a tartalomszabályozási fejezetben (6.4. alfejezet) kerül tárgyalásra.

A dolgozat harmadik, határos jogterületekkel kapcsolatos horizontális témaköre az egyes jogintézményeket elsősorban szerzői jogi megközelítésben vizsgálja (közös jogkezelés, közszolgálati médiavagyon, archívumok, müintegritás védelme). A szerzői közös jogkezelés nemzetközi és hazai szabályozásának, illetőleg jogfejlődésének kutatásához egyfelől a jogintézmény $N A M S$-hoz készült háttértanulmánya szolgáltatott kiinduló alapot, beható elemzésére és a kutatás tovább vitelére pedig másfelől az önálló közös jogkezelési irányelv létrejötte és hazai implementálása alapján került sor. ${ }^{20}$

Az értekezést összefoglaló megállapításokkal és következtetésekkel zárom, illetőleg a korszerü szabályozás jövőjéről egyfajta víziót vázolok fel. A dolgozat 19 ábrát illeszt az adott szövegrészekhez, mintegy illusztrálva a szöveg képi megjelenítését; a megvalósulási táblázat pedig a függelékben kapott elhelyezést az értekezésben.

\footnotetext{
${ }^{20}$ A szerző 2011-ben a szerzői jogi törvény - többek között - a közös jogkezelőket érintő módosításának előkészítője, a Szellemi Tulajdon Nemzeti Hivatalának szerzői jogi igazgatója.
} 


\section{SZABÁLYOZÁS ÉS SZABÁLYOZÁSI STRUKTÚRÁK}

\subsection{Szabályozási kezdetek: sajtó-, szerzői- és távközlésjogi előzmények}

A szabályozás kialakulásával és kezdeti lépéseivel kapcsolatos rövid történeti bevezető igazolja a médiajoghoz kötődő, azzal határos jogterületek több esetben azonos, egymáshoz közeli gyökereit, valamint azt, hogy e jogterületek közös eredete nyilvánvalóan hozzájárult az önállósodott szerzői-, sajtó-, média-, hírközlési-, és versenyjog egymáshoz közelítéséhez, egymásra való hatásához és a szabályozásban is megjelentő konvergenciájához. $^{21}$

Az üzenetek, hírek, információk lehető leggyorsabb célba juttatása a történelem minden korszakában stratégiai jelentőséggel bírt; csaták, háborúk kimenetelét, emberi sorsok alakulását befolyásolta. A szerzői-, a sajtó-, ${ }^{22}$ majd a médiajog ${ }^{23}$ létrejöttének és fejlődésének a gépesített munkafolyamat útján történő sokszorosítás adott lendületet, általa a nyomtatott formában rögzített gondolattartalom tömegek részére vált elérhetővé. A könyvnyomtatás előtti történelmi korszakokban önálló, elkülönült jogterületekről nem beszélhetünk. Az egymással határos jogterületek kialakulásában és változásában alapvetően három műszaki találmány játszott fő szerepet, amelyekhez az általuk elindított jogfejlődési szakasz is köthető: ${ }^{24}$ a 15 . században a nyomdagép európai feltalálása, a 20. században az analóg másoló gépek és a rádiózás megjelenése, végül pedig a digitális korszak vívmányainak elterjedése. A legfiatalabb jogterület, az egymástól távollévők közötti információáramlás szabályozása, a távközlés jogának létrejötte, az elektromos jelek

\footnotetext{
${ }^{21}$ Az EU Bizottságának értelmezésében a konvergencia egyfelöl a szolgáltatások egymáshoz való közelítését, nevezetesen a különböző hálózati platformok azonos vagy hasonló szolgáltatási képességét (szolgáltatási konvergencia), másfelől pedig az elkülönült berendezések, fogyasztói, végfelhasználói eszközök egyetlen rendszerbe való integrálását, a fogyasztói konvergenciát jelenti. Technológiai oldalról a konvergencia jelensége a kommunikációs eszközök egységesülése, így a televíziós műsorszolgáltatás, az internet és a hálózati kommunikáció egymásba integrálása. [A távközlési, média és információtechnológiai szektorok konvergenciájáról és ennek szabályozási kihatásairól az információs társadalom felé haladás szempontjából, az Európai Unió Bizottsága, Brüsszel 1997. december 3.] (Zöld Könyv 1997)

${ }^{22}$ Sajtójog alatt kifejezetten a nyomtatott sajtóra vonatkozó szabályozást értem.

${ }^{23}$ A médiajog magában foglalja a hagyományos rádiós és televíziós müsorszolgáltatatás mellett a lekérhető médiaszolgáltatásokat is. Ld.: KOLTAY András: Bevezetés: a média és a médiajog 31-35, (KOLTAY I.) 31. In: Magyar és európai médiajog KOLTAY András - NYAKAS Levente (szerk.) [KOLTAY-NYAKAS I.] Complex 2012., valamint KOLTAY András - MAYER Annamária - NYAKAS Levente - POGÁCSÁS Anett: A médiaszolgáltatás és a sajtótermék fogalma az új magyar médiaszabályozásban. Iustum Aequum Salutare VII.2011/4. 71-101. [KOLTAY - MAYER - NYAKAS- POGÁCSÁS]

${ }^{24}$ YosHIYUKI Tamura: Rethinking Copyright Institution for the Digital Age. WIPO Journal, 2009/1. 66-68. In: MEZEI Péter: A szerzői jog jövöje (is) a tét - gondolatok a Google books könyvdigitalizálási projektröl. Iparjogvédelmi és Szerzői Jogi Szemle 6. évf. 5. szám, 2011. október 5-47. (MEZEI I.)
} 
felfedezésével veszi kezdetét. A nyomtatás ${ }^{25}$ kezdetben „helyi üzlet” és - ennek megfelelően -, a nemzeti jog ellenőrzése alatt állt, majd pedig jelentős iparág lett, amely egyre inkább igényelte a közérdeklődésre számot tartó, nyilvános információk feletti jogszerü állami korlátozás kialakítását. A sajtószabadság eszméje összeforrt a könyv-, majd a lapnyomtatással és a gondolatok tömeges terjesztésének lehetősége megnyitotta az utat annak korlátozásához is. ${ }^{26} \mathrm{~A}$ nyomtatott sajtó szabályozásának sokszínűsége Európában és másutt megerősítette a szoros kapcsolódást a területileg szuverén állam, a joghatóság elvei és a nemzeti média között.",27

A felvilágosodás korában, a libertárius média-modell ${ }^{28}$ érvényesülésének idején az egyén szólásszabadsága és gondolatainak nyomtatásban való megjelenése, illetőleg az ehhez kapcsolódó alapjogok létrejötte és biztosítása vált döntő jelentőségüvé. A sajtó az általános nyelvhasználatban a nyomtatás vagy hasonló eljárások útján sokszorosított iratok összességét jelöli, és magában foglalja a napi irodalmat (napi sajtót) csakúgy, mint mindenféle időszaki sajtóterméket és a könyvkiadást. A sajtó fogalma a tömegkommunikáció tárgyai és eszközei mellett kiterjed a sajtóban tevékenykedő vállalatokra (kiadókra) és a nyomdatermékek előkészítése, előállítása és legalább részbeni terjesztése területén dolgozó személyekre." 29 Jogi értelemben a 'sajtó' a sajtóra vonatkozó előírásokat egyesíti; a sajtójog pedig felöleli a sajtóra vonatkozó sajtójogi jogviszonyok szabályozott előírásait, amelyek a sajtószabadság alkotmányos garanciáit jelentik. ${ }^{30}$

Bár a 19. században a sajtószabadságot az alkotmány fontos biztosítékaként kezelték, a kezdeti szabályok elsődleges feladata mégis a gondolatközlés, a véleményszabadság államhatalmi eszközökkel való korlátozása volt. ${ }^{31}$ A sajtó cenzúrázása ${ }^{32}$ még a 19. században is teljesen legális intézmény volt például Franciaországban és Ausztriában.

\footnotetext{
${ }^{25}$ A nyomtatott sajtó első termékei a 16. században „pamfletek és plakátok formájában ${ }^{, 25}$ jelentek meg. Perry KELLER: Európai és nemzetközi médiajog, liberális demokrácia, kereskedelem és az új média, Complex Wolters Kluwer 2014. KOLTAY-NYAKAS (szerk.) (KELLER) 1.

${ }^{26}$ SARKADY Ildikó: A sajtó európai szabályozása Magyarország az ezredfordulón, Stratégiai Tanulmányok a Magyar Tudományos Akadémián, Mủhelytanulmányok GLATZ Ferenc (szerk.) „Az információs társadalom és a jog átalakulása" 2. Átdolgozott változat, MTA Társadalomkutató Központ 2002. (GLATZ) BKÁE Aula. 2002. Médiagazdaságtan, Médiaszabályozás Szöveggyüjtemény 2002.12.9. (GÁLIK IV.) In: SARKADY Ildikó: Médiajogi írások ÚMK 2005. (SARKADY I.) 36-85.

${ }^{27}$ KELLER 276-280.

${ }^{28}$ GÁLIK Mihály - POLYÁK Gábor: Médiaszabályozás KJK-KERSZÖV 2005. (GÁLIK-POLYÁK) 21.

${ }^{29}$ Heinz STÖCKEL: Presserecht München Verlag C.H. Beck, 1994. (STÖCKEL) 9.

${ }^{30}$ Frank FECHNER: Medienrecht UTB Für Wissenschaft Mohr Siebeck, 2001. (FECHNER) 9.

${ }^{31}$ Ilyen eszköz a kaució és a cenzúra intézménye, bizonyos témájú írások nyomtatásának megakadályozása vagy terjesztésének tiltása, valamint rendkívüli szankciók alkalmazása, illetőleg a sajtótermékek rendőri elkobzása, megsemmisítése, stb. Ld.: 985. lbj.
} 
„A sajtószabadság kiteljesülésére akkor kerülhet sor, ha egyetlen ilyen eszköz alkalmazása nem szükséges, illetőleg megengedett.",33

A sajtóval, illetve a médiával kapcsolatos jogi szabályozás követi a kontinentális, illetőleg az angolszász jogrendszerek sajátosságait. A szabályozási modellek is lényegileg két fajta struktúrába sorolhatók: i) az egymásra épülő jogi szabályozás teljes vertikumát megvalósító, minden jogforrási szintet felölelő vertikális sajtójogi szabályozás (német, francia, svéd és görög szabályozási struktúrák), ii) a média rendszer egészét átfogó, az írott sajtót, az elektronikus médiát és a telekommunikációt is magában foglaló horizontális szabályozás (angol, német, francia, osztrák, svéd, görög). ${ }^{34} \mathrm{Az}$ angolszász rendszerre jellemző, hogy „alkotmány hiányában a szólásszabadságot a jogállami tradíciók védelmezik." ${ }^{35}$ A szabályozási modellek egymást kiegészíthetik, illetőleg adott esetben együttesen is érvényesülhetnek. Az összesítetett médiaszabályozási modell egyik példája ${ }^{36}$ Németország, ahol az 1990-es évek második felére létrejött törvényi szabályozás háromszintű - alaptörvényi, szövetségi és tartományi ${ }^{37}$-, és amely kiterjed a print- és elektronikus médiára, valamint a távközlés jogi szabályozására is. ${ }^{38} \mathrm{Az}$ audiovizuális média kialakulásának alapja a mintegy 90 éves médiaplatform, a rádiózás létrejötte a 20. század küszöbén, sok feltaláló, természettudós különböző korokban és földrajzilag is távol eső országokban végzett munkájának eredménye. A drótnélküli telegráf, illetőleg a rádió

\footnotetext{
${ }^{32}$ SARKADY I. 41-46. Az internet 20. századi megjelenésével a cenzúra intézménye újjáéledt, a cenzúrázás modern formái is megjelentek. „A cenzúra kifejezés az információ interneten történő közzétételének, vagy az ahhoz való hozzáférésnek az ellenőrzését vagy megakadályozását jelenti. Az államok gyakran élnek ezzel a lehetőséggel a nem kívánt információk kiszürése és az információ internetes elterjedésének megakadályozása érdekében.” Rolf H. WEBER - Ulrike I. HEINRICH Az új médiakörnyezet szabályozási kérdései In: Medias Res III. évfolyam, 2. szám NYAKAS Levente (szerk.) [WEBER- HEINRICH] 284. 55.lj. A cikk eredeti angol nyelvü címe és megjelenése: Governance issues of the new media environment In: KOLTAY András (szerk.) Media Freedom and Regulation in the New Media World Wolters Kluwer 2014. 85-101. A tanulmány részben Rolf H. WEBER: International Governance in a New Media Environment címü munkáján alapszik. In: Monroe E. PRICE - Stefan G. VERHULST - Libby MORGAN (szerk.) Routledge Handbook of Media Law. Abingdon, Routledge, 2013. In: WEBER (WEBER) 275.

„Mert a cenzúra kétségkívül halhatatlan” PRUZSINSZKY Sándor: Halhatatlan cenzúra Médiatudományi Könyvtár KOLTAY-NYAKAS (szerk.) MTMI 2014. Bevezetés 12. Ld.: 985. lbj.

33 BÓDINÉ DR. BELIZNAY Kinga: Sajtórendészeti igazgatás a XIX. századi Európában Magyar Közigazgatás, 1998/1. 34-43.

${ }^{34}$ SARKADY I. 39-40.

${ }^{35}$ KOVÁCS Krisztina - CSEH Gabriella: A lapalapítás és a sajtószabadság magyar és nemzetközi szabályozása COLPI 1996.

${ }^{36}$ Szintén komplex a médiaszabályozás Svédországban (1991 sajtótörvény, 1991 rádiótovábbításról és átvitelröl szóló törvény, 1991 telekommunikációról,1994 müholdakról, 1996 rádió-, és televízió törvény) SARKADY I. 75.

${ }^{37} \mathrm{http}: / /$ mediatorveny.hu/dokumentum/105/EU_tagallamokbol_szarmazo_peldak.pdf

${ }^{38}$ POLYÁK Gábor - SZÖKE Gergely: Médiaszabályozás Németországban 2007. január AKTI 7-8. SARKADY I. 62-70.
} 
távközlés rohamos, világméretü elterjedése új lehetőségeket nyitott meg a kommunikáció egyre fejlődő korszaka előtt és szükségessé tette a rádiózás, a sajtó-, és a távközlési jog nemzeti és nemzetközi szabályozásának kialakítását. Az akkorra már létrejött nemzeti szerzői jogi törvények és nemzetközi szerzői jogi egyezmények többnyire az új technikai vívmányokat a szerzői müvek szempontjából új felhasználási módnak ismerték el és általános felhatalmazás hiányában - csak azokban az országokban igényelték a szerzői jogi törvények aktualizálását, ahol a szerzők jogosítási, engedélyezési joga nem terjedt ki ezeken az új felhasználási módokon történő müértékesítésekre. A rádióközlés szerzői jogával - az 1928-ban megtartott római nemzetközi konferenciára készített javaslat alapján - revideálták az 1886. évi Berni Uniós Egyezményt $(B U E) .{ }^{39}$ A rádiós sugárzás hazai szerzői jogi megítélése - a BUE 1928-as módosítása nyomán - a bírói gyakorlat alapján, az 1921-es szerzői jogi törvényünk ${ }^{40}$ kiterjesztő értelmezésével formálódott. Az ítélkezési gyakorlat a rádiót mechanikai elöadást szolgáló készüléknek minősítette és tiltotta az engedély nélküli átvitelt a rádiós sugárzáshoz való jog tekintetében.

\subsection{A szabályozás lényegi tartalma, az európai médiaszabályozás}

A szabályozás fogalma az állami cselekvés, az állami szerepvállalás minden formáját felöleli, ${ }^{41}$ a leginkább elfogadott elméletek szerint az állam és a gazdaság „,harcmezeje,”42 illetőleg a hatóságok által a társadalmilag értékes tevékenységek feletti tartós és célzott felügyelet, ${ }^{43}$ amely alapos hozzáértést és a szabályozott tevékenységgel való egyfajta együttélést feltételez. ${ }^{44}$ A média feletti ellenőrzés és a társadalom feletti kontroll közötti kapcsolat evidens; a média valamennyi társadalmi berendezkedésben a hatalomért és annak felügyeletéért folytatott küzdelem. A média elsődlegesen a demokrácia köztere,

\footnotetext{
${ }^{39} \mathrm{Az}$ irodalmi és művészeti művek védelméről szóló 1886. szeptember 9-i Berni Uniós Egyezmény Párizsban, az 1971. július 24-én felülvizsgált szövege. Magyarországon kihirdette az 1975. évi 4. számú törvényerejü rendelet. (BUE)

${ }^{40} 1921$. évi LIV. törvénycikk a szerzői jogról.

${ }^{41}$ SARKADY Ildikó: Közös jogkezelés és médiaszabályozás, In: Emlékkönyv Ficsor Mihály 70. születésnapja alkalmából barátaitól Szent István Társulat 2009. (SARKADY II.) 280.

${ }^{42}$ Cento VELJANOVSKI: Regulators and the Market Institute of Economic Affairs, London 1991, In: TÓTH András: Az elektronikus hírközlés és média gazdasági szabályozásának alapjai és versenyjogi vonatkozásai HVGORAC 2008. 21. (TÓTH I.)

${ }^{43}$ Philip SELZNICK: Focusing operational research on regulation, in R. Noll, ed., Regulatory Policy and the Social Science, Berkeley California, 1985. In: TÓTH I. 21.

${ }^{44}$ Giandomenico MAJONE - Alexander SURDEJ: Regulatory Agencies in Economic Governance, The Polish Case in a Comperativ Perspective, KICES Working Papaers, June 2006 In: TÓTH I.) 21.
} 
ugyanakkor egyfelől piac, másfelől a kulturális értékek teremtője és hordozója is. Ez az elsődleges szerepkör és kettős megközelítés jellemzi a médiát kezdetektől fogva.

A szólásszabadságot a demokrácia szolgálatába helyező elméletek közül e jog értelmét és legfőbb célját az állampolgárok közügyekben és az azokról való döntésekben való részvételben fogalmazzák meg, illetőleg a sajtószabadságot a demokratikus önkormányzateszközének tekintik. ${ }^{45}$ A média megosztott, kettős természete alakította ki meghatározásának alapvetően két szempontú szemléletét is, a „piaci modellt”, valamint a „nyilvános szféra” modellt. ${ }^{46}$ A piaci modell szerint a média úgy viselkedik, mint bármely más termék, viszonyait a kereslet-kínálat szabályai határozzák meg és az üzleti siker mércéjét a profit orientálja. A nyilvános szféra modellje, a „társadalmi nyilvánosság” elmélete $^{47}$ ezzel szemben, a médiát a közérdek szolgálatába helyezi, amelyben a média célja nem pusztán a fogyasztó „,kegyeinek” elnyerése és a profitszerzés, hanem az állampolgárok kulturális, társadalmi és információs igényeinek kielégítése, értékek közvetítése. A média évszázados változásait és fejlődését leképezik a média definíciójára kidolgozott meghatározások, nevezetesen, hogy milyen médiaipar képes leginkább a „köz” érdekét szolgálni. A média szabályozása tehát elsősorban a közösség, a „köz” érdekében kialakított szabályrendszert, illetőleg azoknak a védelmi szabályoknak az összességét jelenti, amelyek a kereskedelmi média működését a magánérdek felől a közérdek felé tereli. Ebből következően nem a kormányzati beavatkozás szükségessége a kérdéses, hanem annak mikéntje. „A médiaipar jogszabályok és szabályozások bonyolult rendszerétől függ, amelyek mind a játéktér kialakításában, mind a játékszabályok definiálásában segédkeznek." 48

A médiajog önálló jogági, még inkább különálló jogterületi létének kérdése - talán éppen „negyedik hatalmi ág” mivoltából eredően - szinte állandó témája a médiával, kommunikációval és jogi szabályozásával foglalkozó szakirodalomnak. Leginkább azzal az állásponttal lehet egyetérteni, miszerint: „Önmagában attól, hogy alkotmányjogi, alapjogi szempontból ismerünk olyan csoportosítást, amely a társadalmi (!) kommunikációval kapcsolatos jogokat egy csoportba foglalja, még nem következik az,

${ }^{45}$ KOLTAY András: A médiaszabályozás elméleti alapvetései In: Magyar és európai médiajog Wolters Kluwer 2015. 93-96.

${ }^{46}$ David CROTEAU - William HOYNES: A média mint üzlet, Nagyvállalati média és közérdek Complex Wolters Kluwer 2013. KOLTAY-NYAKAS (szerk.) (CROTEAU-HOYNES) 35-56.

${ }^{47}$ Jürgen HABERMAS: A társadalmi nyilvánosság szerkezetváltozása: Vizsgálódások a polgári társadalom egy kategóriájával kapcsolatban Századvég Budapest, 1993. Eredeti megjelenés: 1962. (HABERMAS habilitációja)

${ }^{48}$ CROTEAU-HOYNES 84. 
hogy ezzel a kommunikációs jelenség valamennyi lényeges területét lefedtük volna, s ezáltal bátran használhatnánk a „kommunikációs”, vagy „tömegkommunikációs jog” általános értelmű kifejezést." ${ }^{49}$ Véleményem szerint a médiajog továbbra sem önálló jogág, hanem gyüjtőterülete azon törvényeknek és alacsonyabb rendü jogszabályoknak, amelyek a médiához direkt vagy indirekt módon kapcsolódnak. ${ }^{50}$

Az európai kontinens médiaszabályozása - más iparági szektorok szabályozásához hasonlóan - hagyományosan a nemzeti államok piaci folyamatokba beavatkozó, sokszor túlzott szabályozó jellegü funkcióján alapult. A sajtó- és a médiatartalmak közzétételét az információk és a szórakozás iránti fogyasztói igény határozta meg évszázadokon keresztül. A rádiózás megjelenése, a frekvenciák határokat nem ismerő természete, illetőleg a múlt század közepére elterjedt televíziózás kezdetben nem változtatott a szabályozó állam monopolisztikus, a kialakuló médiapiac folyamatait meghatározni akaró és képes szerepfelfogásán. A kezdeti állami szabályozó monopólium több tényező együttes létén alapult, nevezetesen a frekvenciák szükösségén, az adók kiépítésének és üzemeltetésének jelentős költségigényén, valamint az államnak már említett alkotmányos tájékoztatási feladatán-, illetőleg azon az alapjogokból eredő kötelezettségén, miszerint a csekély számú, (többnyire közszolgálati) csatornákon belül is biztosítania kell a kiegyensúlyozott tájékoztatás feltételeit. $^{51} \mathrm{Az}$ állami tulajdonú, az államigazgatásba vagy az állami szolgáltató szektorba betagolt, jellemzően monopolszervezetủ rádió- és televíziószervezetek küldetése volt, hogy az állam szócsöveként a nemzeti értékek és hagyományok megjelenítőjeként, a kulturális normák őrzőjeként és teremtőjeként müködjön. ${ }^{52}$ Az állam szabályozói monopóliumát megalapozó tényezők alkotta rendszer a múlt század '70'-es éveinek közepére bomlásnak indult; egyes, korábban fontos tényezők jelentősége eliminálódott. A technikai fejlődéssel, majd különösen az 1990-es években, a digitális technika televíziós műsorszolgáltatásban való megjelenésével a frekvenciaszükösség a korábbiakhoz képest már nem volt értelmezhető. Egyes álláspontok szerint ugyanakkor: „[...] a frekvenciaszükösség nem szűnt meg, sőt ugyanarra a kapacitásra (értsd: az optimális terjedési jellemzőkkel bíró müsorszórási célú frekvenciasávokra) sokkal több

\footnotetext{
${ }^{49}$ Donald E. LIVELY Kommunikációs jog lényeges elvei In: UDVARY Sándor: Alkotmányos médiajog KRE 2008. (UDVARY I.) 27.

${ }^{50}$ SARKADY Ildikó: A sajtójog aktuális kérdései 2002, Átdolgozott változat megjelent: Bírák Lapja XII. évf. 2002.1. In: Médiajogi írások 11-35. (SARKADY III.) 12.

${ }^{51}$ 1/2007. (I. 18.) AB határozat - A kiegyensúlyozottság követelménye, a „belső pluralizmus”.

${ }^{52}$ GÁLIK-POLYÁK 39.
} 
igény mutatkozik, amit a digitális átvitel nem ellensúlyoz."53 Más megfogalmazások értelmében pedig a fizikai szükösség átmenetileg megszünt, azonban várhatóan rövid időn belül újra jelentkezhet. ${ }^{54}$

A médiaszolgáltatást nyújtó csatornák száma is szinte korlátlan lett, ezzel az állam tájékoztatási kötelezettsége, illetőleg az egyes csatornákon belüli kiegyensúlyozott médiakínálat, a belső pluralitás biztosítása súlytalanná vált, azt a külső pluralizmus ${ }^{55}$ váltotta fel. A reklámpiaci bevételeken megerősödött kereskedelmi médiapiac szereplői számára sem jelentett már különösebb nehézséget az új müszaki vívmányokba való befektetés, sőt több esetben a jelentős reklámbevételekre szert tett magántőke kényszerítette ki az állami monopóliumról való lemondást. ${ }^{56}$

A kezdetben természetesnek vett, monopolhelyzetet élvező állami rádió és televízió intézményét több nyugat-európai nemzetállamban az 1970-es évek közepétől alkotmányellenesnek nyilvánították, azonban ez a tény sem szüntette meg a média és a vele konvergáló piacok állami szabályozásának szükségességét. A gondolatszabadság és a szabad információáramlás számos állami feladat megvalósításához nélkülözhetetlen feltétel, ugyanakkor pedig - a hatalom megszerzése és fenntartása érdekében - egyben a mindenkori állami kontroll és korlátozás tárgya. Az államnak a médiaszabályozás során olyan speciális közpolitikai és fiskális természetü feladatokat is teljesítenie kell, mint amilyen a közszolgálati médiaszolgáltatás intézményrendszerének kialakítása és müködtetése vagy a médiafinanszírozás, illetőleg a reklámszabályok kialakítása. Az állam a közpolitikai célok megvalósításához szükséges információk közlése és azok korlátozása közötti egyensúly megteremtése mellett gyakran a szabályozás eszközeivel beavatkozik bizonyos média megjelenési folyamatokba; a reklámipar megadóztatásával - többek között - befolyásolja a kereskedelmi média finanszírozhatóságát, ez által pedig kontrollálja a média-, reklám- és hírközlési piac természetes folyamatait. A hírközlést és a médiát átszövő folyamatos technológiai megújulás az állam és a média viszonyát permanensen változóvá teszi, a jogi szabályozás „követő jellege” folytán azonban állandó lemaradásban

\footnotetext{
${ }^{53}$ NYAKAS Levente: A magyar médiaszabályozás lehetőségei az európai audiovizuális politika fényében Médiakutató 2008 nyár (NYAKAS I.)

${ }^{54}$ BAYER Judit: A közszolgálati televiziózás újragondolása a digitális korszakban Médiakutató 2008 nyár (BAYER I.)

${ }^{55}$ The activity report of the Committee of Experts on Media Concentrations and Pluralism. Submitted to the 4th European Ministerial Conference on Mass Media Policy. Prague, December 7-8., 1994. Idézi Karol JAKUBOWICZ: Médiapluralizmus és koncentráció. In: GÁLIK Mihály (szerk.): A médiakoncentráció szabályozása - szöveggyüjtemény Gondolat 2011. 263. (GÁLIK I.)

${ }^{56}$ KERTÉSZ Krisztina: A média szabályozása az Európai Unióban és Magyarországon. A jogharmonizáció folyamata az audiovizuális szektorban, Médiakutató 2001 tavasz (KERTÉSZ) 1.
} 
van a müszaki fejlődéssel szemben. Míg a technológiai fejlődés folyamatos impulzusokat ad a médiaszabályozás változásainak, addig a médiaelmélet müvelői körében a szabályozásra szintén meghatározó jelentőségü kultúra, valamint a társadalomban uralkodó eszmék és nézetek szabad megjelenítésének éppen a médiaszabályozás ad teret. A digitális világgal együtt járó konvergencia, az új típusú szolgáltatások megjelenése a sajtószabadság és a média fogalmának újragondolását is szükségessé tették. ${ }^{57} \mathrm{Az}$ audiovizuális szektor rohamos technológiai fejlődése és egyre jelentősebb gazdasági szerepe ellenére sem került azonnal az Európai Unió szabályozási látókörébe. Ennek egyrészt az audiovizuális média kettős, egyfelől kulturális, másfelől pedig gazdasági természete volt az oka, amely napjainkig is meghatározza az audiovizuális média uniós és nemzetállami szabályozásának jellegét. Mivel a rádiózást és a televíziózást sokáig kulturális tevékenységnek tekintették és az Európai Közösséget létrehozó Római Szerződés ${ }^{58}$ (RSZ) a kulturális szolgáltatásokra vonatkozó szabályozást nemzetállami hatáskörben hagyta, ezáltal nem volt alapja a szektorra vonatkozó egységes uniós szabályozás kialakításának. Az Európai Unió Bírósága 1974-ben az ún. Sacchi ügyben fö kérdésként azt vizsgálta, hogy az olasz államnak joga van-e fenntartani monopóliumát a kábeltelevíziózásban, illetőleg a kereskedelmi reklámozás terén vagy pedig ezek olyan szolgáltatásnak minősülnek, amelyek szabad áramlását az államnak a RSZ értelmében biztosítania kell. ${ }^{59}$ A Bíróság határozatában kimondta, hogy a rádió és televízió müsorok sugárzása önmagában, vagyis tartalmuktól függetlenül is „mások javára végzett tevékenységek összessége”, s mint ilyen a RSZ hatálya alá tartozó szolgáltatásnak minősül. Az EU Bíróságának 1991-ben megerősített e döntésével megnyílt az audiovizuális médiaszektorra vonatkozó egységes uniós szabályozás jelentősége. Az egységes audiovizuális szabályozást késleltető másik tényező az uniós szabályozási hatáskör bizonytalansága volt, nevezetesen annak a kérdésnek az eldöntése, hogy az audiovizuális médiapolitika egyes tartalmi és formai elemei, különösen a médiaszabályozás intézményi rendszerének felügyelete uniós hatáskörbe tartozik-e. ${ }^{60} \mathrm{Az}$ egységes audiovizuális médiapolitika megteremtését és a szabályozás kidolgozását - végül is a múlt század '80'-as éveinek második felére - a közös európai gazdasági piac, (később térség) létrehozásának sürgető szükségessége, valamint az

\footnotetext{
${ }^{57}$ KOLTAY András: Átalakuló sajtószabadság - az állam jövőbeni feladatai a demokratikus nyilvánosság erősitése érdekében című előadása, HTE konferencia 2015.

58 1957. március 25.

${ }^{59}$ Der Europäische Gerichtshof (EUGH) Urteil vom 30.4. 1974. Rs. (Sacchi) Slg 1974, 409-428. C 155/73 1975. április 30.

${ }^{60}$ A média és politika viszonyát vagy a médiafelügyelet részletszabályait illetően jelenleg sincs kötelező uniós elöírás, azt az EU a tagállamok „belügyének” tekinti. KERTÉSZ.
} 
amerikai kultúrával, elsősorban az amerikai filmek dömpingjével szemben megfogalmazott „egységes európai kulturális identitás” követelménye indokolta.

A tömegkommunikáció terén az egységes fellépés legeredményesebb fejleménye az 1979es MacBride jelentés, amely az „új világ információs és kommunikációs rend” megteremtésének lényegét folyamatként aposztrofálta. Az 1980-as évek elejétől több nemzetközi és uniós dokumentum született a nyílt információs versenypiac létrehozásáról, illetőleg az azonos szemléletü kulturális célok megfogalmazásáról és az európai audiovizuális médiapolitika kialakításának szándékáról. ${ }^{61} \mathrm{Az}$ EU egységes gazdasági piacának létrejöttét támogatni képes európai „kommunikációs tér” gondolata először az Európai Bizottság „televízió határok nélkül” címü, 1984-ben megjelent Zöld Könyvében fogalmazódott meg, ${ }^{62}$ illetőleg ezt megelőzően az Európai Bíróság a már említett Sacchi ügyben kimondta az audiovizuális szektor szolgáltatási jellegét. A Zöld Könyv a médiaszolgáltatásokat alapvetően olyan kulturális jellegü szolgáltatásként értelmezi, amelyhez ellenszolgáltatás kapcsolódik, ennél fogva piaci értéke van, tehát egyben gazdasági jellegű szolgáltatás is. A médiaszolgáltatás kettős természete jelenik meg a Zöld Könyv által megalapozott, a médiatartalmak szabályozását irányelvi szinten megvalósító első direktíva, a Határok Nélküli Televiziózásról szóló irányelvben (TWVF). ${ }^{63}$ TVWF irányelv célja különösen a kábeles és müholdas müsorszórás technológiák alkalmazásával az egységes televíziós müsorszolgáltatási piac kialakulásának elősegítése volt. Az első Televíziós irányelv ugyan közösségi szinten szabályozta az audiovizuális ágazat kereskedelmi jellegét, az audiovizuális szektort, mint kulturális tevékenységet azonban továbbra is tagállami hatáskörben hagyta. ${ }^{64} \mathrm{~A}$ TVWF irányelvet felváltó, a digitális környezethez igazított $A V M S^{65}$ irányelv tovább hordozza a szolgáltatás kettős jellegét, amikor kimondja: „Az audiovizuális médiaszolgáltatások ugyanúgy kulturális, mint gazdasági szolgáltatások. E szolgáltatások külön szabályozását indokolja, hogy növekszik

\footnotetext{
${ }^{61}$ EU Parlament által megrendelt tanulmány és az annak nyomán készült Schall jelentés (1981), a Hahn jelentés (1982), Arfé határozat (1983), továbbá a Bizottság 1983-ban kiadott „Realitások és tendenciák az európai televíziózásban" címü jelentése. KERTÉSZ.

${ }^{62}$ Az Európai Unió Bizottságának Zöld Könyve „A müsorszolgáltatási közös piac létrehozásáról, különös tekintettel a kábeles és müholdas szolgáltatásra.” [COM (84) 300], (Zöld Könyv 1984)

${ }^{63}$ Az Európai Parlament és a Tanács a tagállamok törvényi, rendeleti vagy közigazgatási intézkedésekben megállapított, televíziós müsorszolgáltatási tevékenységre vonatkozó, a határok nélküli televíziózásról szóló, 97/36/EK irányelvvel módosított 89/552/EGK irányelve,1989. október [Televíziós irányelv, TWVF]

${ }^{64}$ NYAKAS I. 2.

${ }^{65}$ AVMS irányelv jelenleg ismét felülvizsgálat alatt áll: 2014. október 23-24-én tartott ülésén az olasz EU elnökség, Rómában elindította az AVMS irányelv megfelelöségi felülvizsgálatát, mely egy átfogó módosításban gondolkodik, mintsem az irányelv kismértékű kozmetikázásában. Ld.: 114. és 979. lbj.
} 
jelentőségük a társadalom és a demokrácia számára - különösen azáltal, hogy biztosítják a tájékozódás szabadságát, a vélemények sokszínűségét, és a médiapluralizmust -, valamint az oktatás és a kultúra számára." ${ }^{\circ 6}$ A TWVF irányelvet az egységes belső piac létrehozását célzó dokumentumok között az 1990-ben született „,Nyillt hálózati hozzáférés” irányelve ${ }^{67}$ követte, a médiaszolgáltatások kettős jellege pedig a 2006-os Szolgáltatási irányelv ${ }^{68}$ létrejötte során is előtérbe került. A kulturális természetü érvek azonban nem bizonyultak elegendőek ahhoz, hogy az audiovizuális szolgáltatások a Szolgáltatási irányelv hatálya alá kerüljenek. ${ }^{69}$

Az állami monopóliumon alapuló ún. normatív/kulturális műsorszolgáltatási modellből ${ }^{70} \mathrm{a}$ kereskedelmi szolgáltatások térnyerésével, a '80-as évekre duálissá bővült audiovizuális médiapiac kereskedelmi ága - éppen a médiaszolgáltatás gazdasági jellegének felerősödésével - a '90-es évek végétől kétségessé tette a közszolgálat létjogosultságát, intézményi közfinanszírozásának létét a különböző uniós fórumokon. ${ }^{71}$ Az audiovizuális médiaszolgáltatások egyszerre kulturális és gazdasági természete, illetőleg az abból adódó eltérő szemlélet, a gyakorlatban leginkább tehát a kereskedelmi médiaszolgáltatók és a közszolgálati médiumok közötti konfliktusban, nevezetesen a közfinanszírozás kritikájában mutatkozott meg. A bírálatok alapját az képezte, hogy a közszolgálati médiák jelentős állami támogatása versenyhátrányt eredményez az ilyen támogatást nem élvező kereskedelmi médiák számára, amelyek ez által elveszíthetik megszerzett médiapiaci pozícióikat. $^{72}$ A kritikákat összegző Fehér Könyv a közszolgálati média uniós megerősítését követően, az Amszterdami Jegyzőkönyv (1997), illetőleg a közszolgálati müsorszolgáltatás állami támogatásáról szóló bizottsági közlemény megjelenése

\footnotetext{
${ }^{66}$ AVMS (5)

${ }^{67}$ A Tanács 1990. június 28-i 90/387/EGK irányelve a belső piac létrehozásáról hírközlési szolgáltatások vonatkozásában a nyílt hálózat elvének megvalósításával (Nyílt Hálózat-hozzáférési Irányelv). Ld.: TÓTH András: A hozzáférési kötelezettség versenyjogi és szabályozási alkalmazása a távközlésben In: A versenyjog aktuális kérdései TÓTH Tihamér (szerk.) Gazdasági Versenyhivatal 2005. (TÓTH II.) 208.

68 Az Európai Parlament és a Tanács 2006. december 2-i 2006/123/EK irányelve a belsőpiaci szolgáltatásokról (Szolgáltatási Irányelv) Ld.: 172. lbj.

69 Szolgáltatási irányelv 2. cikk (2) g) Megjegyzem, a médiaszolgáltatások megosztott természete szintén állandó témája a frekvenciagazdálkodásnak is. Ld.: NYAKAS I. 4-6.

70 Jan van CULIENBURG \& Denis McQUAIL Media Policy Paradigm Shifts: Towards a New Communications Policy Paradigm. European Journal of Communication, 2003 No. 18. In: NYAKAS I. 181207.

${ }^{71}$ NYAKAS I. 1.

${ }^{72}$ Az Európai Unió Bizottságának Közleménye az Európai Parlamentnek, a Tanácsnak, az Európai Gazdasági és Szociális Bizottságnak és a Régiók Bizottságának (2004. május 12.) - Fehér Könyv az általános érdekü szolgáltatásokról [COM (2004) 374]
} 
(Közlemény 2001) ${ }^{73}$ után került elfogadásra. A Közlemény 2009-es, átdolgozott változata részletes követelményrendszert dolgozott ki a közszolgálati média müködtetésére. Rögzítette a tagállamok számára, hogy a közszolgálati médiarendszert i) hivatalos aktussal kell létrehozni, ii) feladatkörét jól körülhatároltan, a lehető legpontosabban kell meghatározni, iii) újabb, digitális szolgáltatások nyújtása esetén pedig konzultációs kötelezettséget írt elő a kereskedelmi médiaszektor védelme érdekében. A Közlemény alapelvként határozta meg a közszolgálati média ingyenes jellegét azzal, hogy az ellenszolgáltatás fejében nyújtott szolgáltatás önmagában nem teszi kereskedelmivé a szolgáltatást. A nem kifejezetten közszolgálati feladatok ellátása nem vezethet a piaci verseny torzulásához, illetőleg a közszolgálati médiarendszer támogatásához nyújtott anyagi ráfordításnak arányban kell állnia a közszolgálati feladatok elvégzéséhez szükséges mértékkel. A Közlemény nem tiltotta a közszolgálati médiumok számára a kereskedelmi szolgáltatások nyújtását, azonban a kereskedelmi és közszolgálati feladatokat egyértelműen el kell választani egymástól. Az Európa Tanács a közszolgálati tevékenység jelentőségét elismerve, 2007-es ajánlásában megfogalmazta, hogy a közszolgálat számára is biztosítani kell a digitális technika előnyeit a közszolgálati kötelezettségek teljesítéshez. Az Európai Parlament 2010. november 25-i állásfoglalása kiemeli a közszolgálati műsorszolgáltatás digitális korszakban vállalt küldetését, miszerint a jó minőségü közérdekű tartalmat egyetemesen hozzáférhetővé tegye minden érdemleges felületen. ${ }^{74}$

Szükségesnek tartom még megjegyezni, hogy az EU Bizottsága az Altmark-csomagként is ismert, az általános gazdasági érdekủ szolgáltatásokra vonatkozó állami támogatási csomag felülvizsgálatát 2011 végéig, a revízió befejezéséig szinte folyamatosan napirendjén tartotta. $^{75}$

\subsection{A multimédia szabályozásának kezdeti jellemzői}

A demokráciákban a média meghatározó tényezője a politikai akaratnyilvánításnak, ugyanakkor egyben az államhatalom kontrollja is. A média „küldő - befogadó” szereplői közötti közvetítő, információátviteli funkciója megközelíthető egyrészt társasági,

\footnotetext{
${ }^{73}$ Communication from the Commission on the application of State aid rules to public service broadcasting (2001/C 320/04) felülvizsgálva: 2009/C 257/01.

${ }^{74}$ Az Európai Parlament 2010. november 25-i állásfoglalása a közszolgálati müsorszolgáltatás a digitális korszakban: a kettős rendszer jövőjéről (2010/2028 (INI))

${ }^{75}$ Az Európai Unió Bizottságának Közleménye az Európai Parlamentnek, a Tanácsnak, az Európai Gazdasági és Szociális Bizottságnak és a Régiók Bizottságának Az általános gazdasági érdekủ szolgáltatásokra vonatkozó uniós állami támogatási szabályok reformjáról, Brüsszel, 2011.3.23. COM (2011)
} 
vállalkozás-szervezeti, másrészt pedig gazdasági szempontból. A média szabályozási funkciója azonban mindenekelőtt a modern demokrácia alapelveinek letételében nyilvánul meg. A médiajog lényegi struktúrája is ebből a meghatározó funkcióból vezethető le, alapját pedig az alkotmányos médiaszabadság, a kommunikációs jogok összessége adja. A kommunikációs jogok az „európai jogi örökség” egyik legfontosabb részét képezik és körébe tartoznak „mindazon alapvető (emberi) jogok, amelyeknek központi eleme, magja a kommunikációs folyamat maga, vagy azzal szoros összefüggésben van.”76

A média ugyanakkor nem elhanyagolható, értéket előállító gazdasági tényező is, amely a különböző média-vállalkozásokon keresztül versenyhelyzetnek van kitéve; emiatt a versenyjognak is tárgya. A média fontos funkciója a kulturális értékek közvetítése, a képzés, az ismeretterjesztés, a szórakoztatás, valamint az információ közvetítése; ebböl következően a médiával kapcsolatos kommunikációs alapjogok körébe tartoznak: a véleményszabadság, az információszabadság, illetőleg a tömegmédia szabadsága. A fentiekben körülírt médiafogalmat illetően a német alkotmánybíróság már 1990-ben megállapította, hogy „az elektronikus média fogalma nem határozható meg teljes pontossággal és a sajtószabadság fogalma, alkalmazási köre semmiképpen sem köthetö konkrét technikához."77

Habermas a média fogalmát a „nyilvános szféra” kifejezéssel illeti, amely értelmezésében „egy olyan technika, amely a demokratikus társadalom kiépítése szempontjából képes értékelni a beszéddel kapcsolatos gyakorlatokat és a médiastruktúrákat."

A német Fechner a kommunikációs szabadságjogok alatt azoknak a különböző alapjogoknak az összefoglaló rendszerét értette, amelyeknek központi jelentősége van a médiában. Meghatározásában a véleményszabadság a vélemény szabad kinyilvánításához és terjesztéséhez való jog, az információs szabadság a valamennyi elérhető forrás hozzáféréséhez való jog, a tömegmédia szabadsága pedig a sajtó-, a rádió- és a film szabadságának joga. ${ }^{79}$ A kommunikációs szabadságjogok összefüggéseit Fechner a következő ábrával jelölte: ${ }^{80}$

\footnotetext{
${ }^{76}$ UDVARY Sándor: A médiaszabályozás alkotmányos alapjai, a kommunikációs alapjogok In: KOLTAYNYAKAS I. (UDVARY II.) 131-132.

${ }^{77}$ BVerfGE 83, 238. In: KOLTAY I. 31.

${ }^{78}$ HABERMAS habilitációja, In: Monroe E. PRICE: A televizió, a nyilvános szféra és a nemzeti identitás Magvetö 1998. (PRICE) 51.

${ }^{79}$ FECHNER 15.

${ }^{80}$ FECHNER 16.
} 


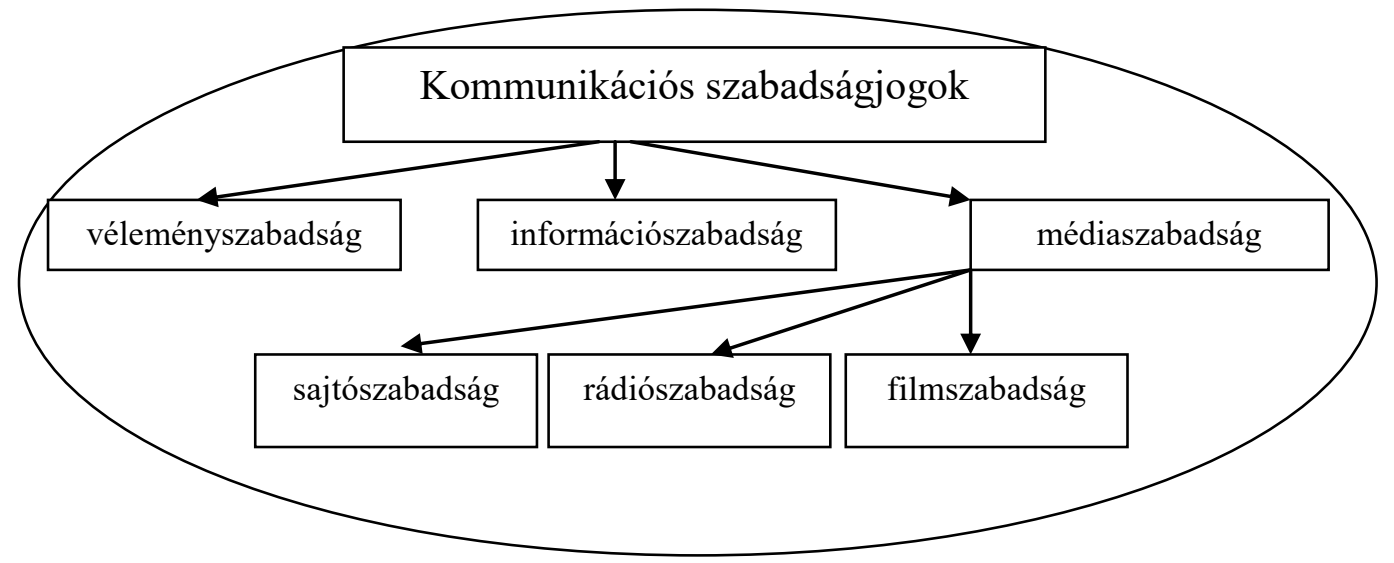

2. ábra Kommunikációs szabadságjogok rendszere

Fechner álláspontja szerint annak ellenére, hogy ezekről a szabadságjogokról a német Alaptörvény ${ }^{81}$ azonos normában, egy helyen rendelkezik, a szabályozás célja mégis különböző. Míg a véleményszabadság és az információszabadság mindenekelött az egyént védik, a médiaszabadság, amelynek a rádió és a film szabadsága mellett a sajtószabadság is részét képezi, elsősorban a vélemények kifejezésének szabadságát szolgálja.

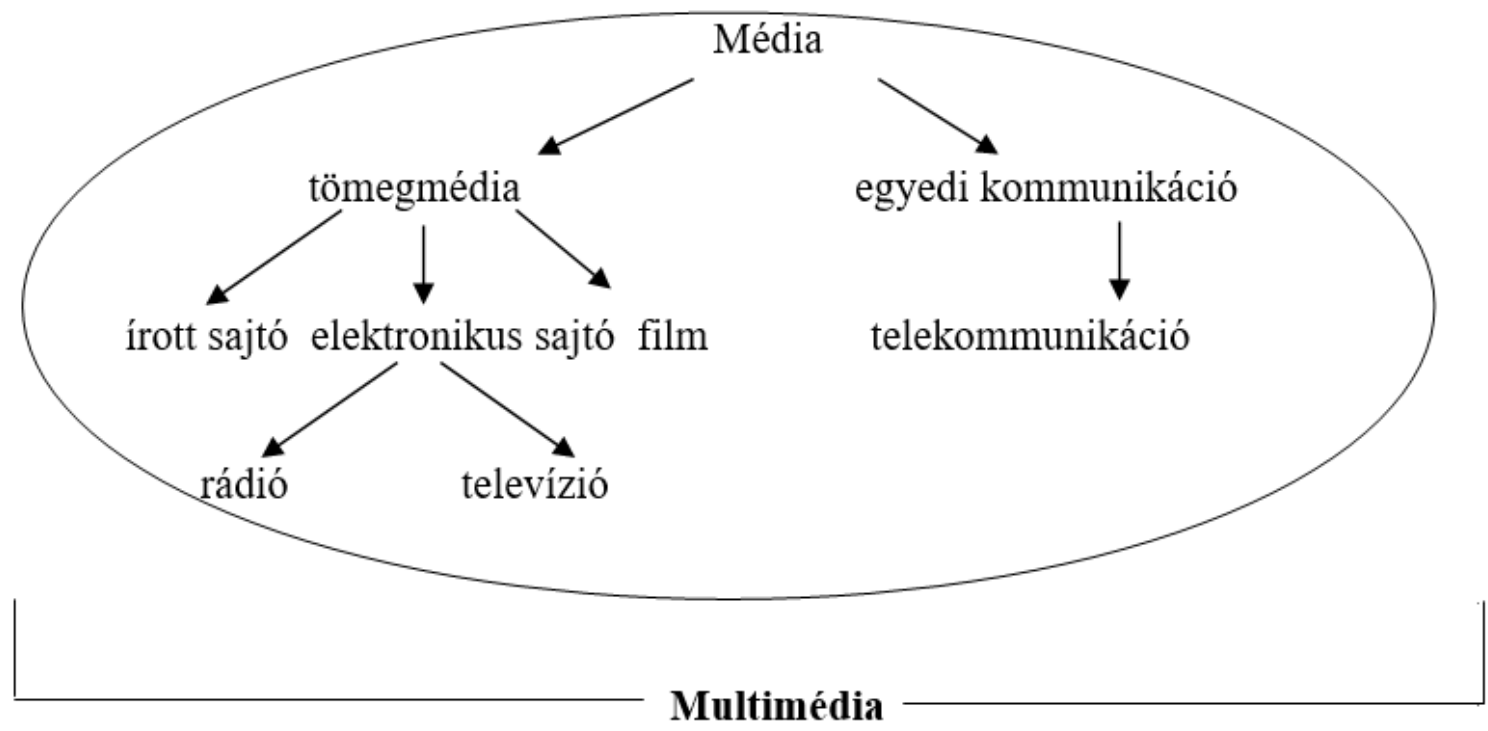

\section{3. ábra A multimédia szabályozási területei}

${ }^{81}$ Art. 5 Abs.1Grundgesetz für die Bundesrepublik Deutschland (Verfassung Deutschland) 
Fechner új médiák vagy multimédia alatt a '90-es évek óta létrejött elektronikus kommunikációs technikákat értette, amelyek - álláspontja szerint - összefüggenek mindenfajta információ digitalizálásával. Az általa a '90-es évek végén kidolgozott médiastruktúrában önálló szabályozási terület a sajtójog, a rádiózás/televíziózás, illetőleg a műsorszórás joga, valamint a multimédia-jog. A „multimédiához” tartozó szabályozási területeket pedig a 3. ábra szerint határozta meg: ${ }^{82}$

A személyi számítógépek megjelenése, majd egyre fejlettebb változatainak elterjedése gyökeresen hatott a kezdetleges kommunikációra. Az egy küldö és egy vagy több, de meghatározható számú befogadót jelölő kommunikációs séma, amely a nyomtatott sajtó, valamint a hagyományos rádió, televízió, illetőleg film és olvasója, nézője, hallgatója közti információáramlást képezte le, az internet megjelenésével sok, mondhatni tömeges küldő és kontrollálhatatlan számú befogadó közötti kommunikációvá vált. Mivel az internetes platformok és „üzenő falak” valamennyi érdeklődő számára egyidejűleg adnak lehetőséget az interaktív kapcsolat-teremtésre, az így kialakult kommunikációs modellben a küldői és befogadói szerepek váltogatják egymást, illetőleg egyszerre is megvalósulhatnak. ${ }^{83}$

A technológiai haladás eredményeként a hagyományos értelemben vett rádiózást és televíziózást, azaz a lineáris szolgáltatást jelentő korábbi műsorszolgáltatás elnevezése a lekérhető tartalmak szolgáltatását is magában foglaló médiaszolgáltatássá változott. A jövő médiaszabályozásában nem egyedül a hatalmi eszközökkel való korlátozás, hanem az vált elsődleges kérdéssé, hogy a médiaszabályozás mennyire akarja és mennyire képes „kordában tartani” a megállíthatatlan technológiai fejlődés által állandóan indukált, változó médiát, illetőleg mennyiben tud érvényt szerezni az örök érvényủ szabadságjogoknak. A médiarendszer kialakítása a digitalizált világban - a korábban szinte „kizárólagos” ágazati médiatörvény csökkenő jelentősége mellett - sokkal inkább összetett szabályozási eszközökön keresztül valósul meg. ${ }^{84}$ A jelen médiaszabályozóit - álláspontom szerint joggal elsősorban az foglalkoztatja, miképpen lehet a már meglévő szabályokat az új technológiákra alkalmazni, a lehető legjobban megőrizve a jelenlegi jogi és szabályozási környezetet. ${ }^{85}$

\footnotetext{
${ }^{82}$ FECHNER 9.

${ }^{83}$ WEBER-HEINRICH 275.

${ }^{84}$ POLYÁK Gábor: Megjegyzések a digitális kor médiapolitikájához Médiakutató 2002 ősz (POLYÁK II.)

${ }^{85}$ Katrin Nyman METCALF: A digitalizáción túl: médiaszabadság az új valóságban In Medias Res 2014/2. 255.
} 
Az új technológiák, az ,információs szupersztrádák” ${ }^{\nexists 86}$ ugyanis új módon rombolják le a határokat és ez a kommunikáció közösségi természetére és határaira is befolyással van. Az új média a globalizáció motorjává vált, jelentős szerepet vállalva a szabályozás és a demokrácia kapcsolatában. ${ }^{87}$ Weber és Heinrich különbséget tesznek a médián keresztüli befolyás és irányítás, valamint a médiaszabályozás között; ez utóbbi tekintetében pedig szintén hangsúlyozzák az új médiakörnyezetre való adaptálhatóságuk felülvizsgálatának szükségességét. ${ }^{88}$ A média szabályozásának eszközeit elsősorban tehát a szabályozás céljai határozzák meg, ugyanakkor az eszközök az értéklánc elemeire vonatkoztatva is rendszerezhetők. Ez utóbbi csoportosítás az adott szabályozási eszköz média értéklánc elemeire való hatását jelzi. Az értéklánc mentén történő szabályozás - amit a NAMS és a Jogalkotási koncepció is követett -, vonatkozhat a médiatartalomra, a médiaszolgáltatók piaci müködésére, valamint a müsorterjesztés infrastrukturális vonatkozásaira. ${ }^{89}$

A 19. század közepére kialakult elektronikus kommunikáció és vizuális média kiegészítették és részben átalakították a printmédia környezetét, majd az internet 20. századi megjelenése további alapvető változásokat eredményezett a média kultúrában. A technológia forradalma a reklámpiacot sem hagyta érzéketlenül, ,az ezredfordulót követő évtizedekben a reklám 'kereskedelmi gyakorlattá', a média szempontú normatív alrendszerekben pedig 'kereskedelmi kommunikációvá' szélesedett."90

A jelenleg még párhuzamos eszközrendszerek léte előre vetíti a médiaszabályozási struktúrák átformálódásának további igényét, a korábbi offline, print és helyi tömegkommunikáció helyébe lépő online, globális, audiovizuális és egyedi kommunikáció mentén. A médiaszabályozás személyi köre - emiatt is -, egyrészről felöleli az utóbbi időszakban jelentős médiabefolyást szerző magánfeleket és gazdasági érdekeltségeiket, valamint az államot, másrészről pedig a saját belső szabályzataikat kialakító médiavállalatokat és civil-szakmai szerveződéseket is. A médiaszabályozás lehetséges palettáján az állami kontrolltól a társszabályozáson keresztül a gazdasági szektorok szakmai szervezeteinek önszabályozása is megtalálható. ${ }^{91}$

\footnotetext{
${ }^{86}$ PRICE 347-348.

${ }^{87}$ WEBER-HEINRICH 273.

${ }^{88}$ WEBER-HEINRICH 273.

${ }^{89}$ POLYÁK Gábor: A médiarendszer kialakitása HVG - ORAC 2008 (POLYÁK I.) 78.

${ }^{90}$ PÁZMÁNDI Kinga: A kereskedelmi kommunikáció és a médiapiac 'Tények' és normativ 'ellensúlyok' In Medias Res 2012/1 69.

${ }^{91}$ Önszabályozás jelentőségéröl: Industry self-regulation: Role and use in supporting Consumer interests OECD 23-Mar-2015., APEC Action Agenda on Advertising Standards and Practice Development
} 


\subsection{Alternatív szabályozási modellek, trendek és struktúrák}

Az alternatív szabályozási modellek bemutatása, az új szabályozási trendek és létrejött struktúrák bővebb elemzése az értekezés elején azért kap teret, mert egyfelől a 2006-os médiaszabályozási reform idején, a NAMS kidolgozásának folyamatában az Európai Unió jogalkotásában és a nemzetközi szervezetek egyezményeiben megjelentek, sőt egyre nagyobb jelentőségre tettek szert az állami-jogi szabályozáson kívüli szabályozási módszerek, másfelől pedig a jövő médiaszabályozásának eredményességét ezek az új szabályozási módszerek - álláspontom szerint - lényegileg is meghatározhatják.

\subsubsection{Az alternatív szabályozási eszközrendszer kialakulása, jelentései}

Az állami szabályozáson kívüli szabályozási módszerek, majd rendszerek először önszabályozás formájában - a sajtó feletti kontroll eszközeként jelentek meg. Már a múlt század elejétől találkozunk Európában az újságírók önszerveződéséhez kötődő, önkéntes jogkövetésen alapuló egyfajta regulációval. Svédországban a sajtó müködését az 1916-ban felállított Sajtó Panaszügyi Bizottság kontrollálta, 1969-től pedig sajtó ombudsman is bekapcsolódott a bizottság munkájába. ${ }^{92}$ A francia újságírók országos szervezete 1918-ban elfogadta a szakmai kötelezettségeket megállapító chartát, majd 1935-ben meghatározták az újságírók jogi státuszát. A II. Világháborút követően a bajor demokratikus sajtó újjászervezését végző amerikai megszálló tisztek 1947-ben kiadták a „Tisztességes újságírás útmutatóját" (Fair Practice Guide), amely több kódex és kézikönyv tartalmát egyesítve jelentős hatást gyakorolt a későbbi etikai kódexekre. A Német Sajtótanács 1973ban, a kiadókkal és az újságírók különböző szakmai szervezeteivel folytatott egyeztetések eredményeként elfogadta a „Publicisztikai Alapelvek” néven a sajtókódexet, amelyet a „Szerkesztői irányelvek” egészítenek $\mathrm{ki}^{93}$ A briteknél az önszabályozás hosszú történetének kezdeteit a 19. századra vagy még korábbra teszik, minden esetre az önszabályozás kialakulása szempontjából a 20. század volt a meghatározó, amikor is az önszabályozás az állami szabályozás egyik változatává válik. A folyamat gyökerei a 19.

2014/SOM3/045anx10, F. CAFAGGI: Constutional Foundations of Transnational Private Regulation ix, HiiL Project, European University Institute Florence, Italy 2011. (CAFAGGI tanulmány)

${ }^{92}$ Jesper FALKHEIMER: Swedish Press Ethics in a Changing Media Landscape 1, Paper for the 23rd Conference and General Assembly, IAMCR, Intercultural Communication, Barcelona, 21-26 July 2002.

${ }^{93}$ SARKADY I. 70, 74. 
századi 'laissez faire ${ }^{94}$ gazdaságirányítási és kormányzati elvhez nyúlnak vissza, amikor is az állam a lehető legkevésbé avatkozott be a gazdasági folyamatokba és hagyta, hogy a piacot a kereslet és kínálat viszonyai alakítsák. Adam Smith megfogalmazásában a kormányzat szerepe korlátozódjék a törvény és a rend fenntartására, az ország védelmére, valamint azon közjavak nyújtására, amelyek termelésére a magánvállalatok nem vállalkoznak (pl. közegészségügy, köztisztaság). ${ }^{95}$

A megengedő, „hagyni” gazdaságpolitika a 20. század második felére a „gondoskodó” vagy más néven ,jóléti állam” létrejöttéhez, majd fokozatosan a „szabályozó állam” kialakulásához vezetett. A folyamat reflexiójaként fogalmazódott meg a túlzott szabályozást megvalósító, a gazdasági és társadalmi rendszerekbe aktívan beavatkozó állammal szemben a jogszabályok leépítésének, a deregulációnak az igénye, és a hagyományos jogi szabályozás mellett megjelentek azok az új „önkéntes” és/vagy „párhuzamos” szabályozási lehetőségek, amelyek a hagyományos jogi szabályozási struktúrákat kiegészítve, azok mellett biztosítják a követendő iparági magatartási normák betartását.

Az iparági önszabályozás sokkal inkább belső késztetés, önkorlátozás, mint jogi értelemben vett tényleges, a kikényszerítés lehetőségével, azaz szankciórendszerrel megtámogatott, a szó jogi értelmében vett „,szabályozás”. Az önszabályozás a jogi, állami szabályozáson túlmutató intézmény, amely a piac szereplőinek önkéntes, jogkövető magatartása, valamint a saját maguk által folytatott szakmai-üzleti gyakorlatuk, magatartásuk alávetése a szakma értékrendjének, etikai elvárásainak. ${ }^{96}$ A hagyományos állami szabályozási rendszerek megváltozására, kiegészülésére az internet berobbanása meghatározó hatással volt. Elsősorban az állami szabályozás késlekedése miatt és elkerülése végett az internetes szakmai körök kezdték kidolgozni a saját magukra irányadó szabályozási elveket, ${ }^{97}$ majd több állam is közzétette az online médiára vonatkozó alapvető

\footnotetext{
94 A laissez-faire gazdaságirányítási elmélet lényege szerint a kormányzatnak csak a lehető legkisebb mértékben szabad befolyásolnia a gazdasági tevékenységeket, a döntéseket a piacra kell hagynia. A laissezfaire tisztán soha nem létezett, bár a 19. századi Anglia közel állt megvalósításához. Mivel a 19. században sok nemzeti kormányzat vallotta 'a gazdasági döntéseket a piacon a kínálat és a kereslet határozza meg' elvét, a 19. század a laissez-faire évszázada lett Európában és Észak-Amerika jelentős részén.

95 Adam SMITH: Nemzetek gazdagsága A gazdagság természetének és okainak vizsgálata 1776. Közgazdasági és Jogi Könyvkiadó Budapest, 1992.

${ }^{96} \mathrm{Az}$ önszabályozás és a társszabályozás rendszeréről ld: GÁLIK - POLYÁK 40-45., valamint SARKADY Ildikó: Az önszabályozás szerepe a modern szabályozási struktúrákban ÖRT 2015. (SARKADY IX) http://www.ort.hu/images/Pdf/\%C3\%96RT_Tanulm\%C3\%A1ny_FINAL_SARKADY.pdf

${ }^{97}$ A hazai internetes tartalomszolgáltatók 2001-ben érdekvédelmi és önszabályozó testületként alapították meg a Magyarországi Tartalomszolgáltatók Egyesületét. (MTE)
} 
szabályozást. ${ }^{98}$ Az Európa Tanács Miniszteri Bizottsága, valamint az OECD 2011-ben jelentette meg az internet szabályozásának elveiről szóló nyilatkozatait. ${ }^{99}$ Az állami-jogi szabályozási rendszer a történetileg vázolt, elsősorban a technológiai fejlődés által indukált folyamat eredményeként fokozatosan egyre több, új elemmel egészült ki és létrehozta azt a szabályozási láncot, „többes szabályozási struktúrákat”, amelyek között az ön- és társszabályozás egyfajta alternatív mechanizmusként funkcionál.

Az önszabályozás legtágabb jelentésében a jogi, állami szabályozáson túlmutató jogintézmény. Magában foglalja: i) általában egy adott iparágban több évtizedes tapasztalat alapján kialakult és folytatott szakmai-üzleti gyakorlatra, szakmai értékrendre, etikai normákra és magatartási előírásokra vonatkozó, a fennálló jogrendszerrel nem ellentétes, sokszor annál szigorúbb szabályokat, ii) az iparág szereplőinek önkéntes, követő magatartását és alávetését a szakma értékrendjének, etikai elvárásainak és az általuk kialakított szabályoknak, valamint iii) a viták elrendezésének önkéntes eljáráson alapuló, békés módját. Az önszabályozás lényegi jellemzője, hogy rendszerének létrejöttét és müködését az abban résztvevő szereplők maguk finanszírozzák és a szabályok negligálása nem jár a jogi szabályok megsértésének szankcióihoz hasonló jogkövetkezményekkel. ${ }^{100}$ Az önszabályozásnak a szakirodalomban is többféle meghatározásával találkozunk, így például a definíció lényege szerint az önszabályozás ,,az államtól függetlenül müködik, a piaci szereplők önkéntes vállalása útján, sajátos eljárási renddel, a résztvevők finanszírozása mellett és nem füződik hozzá közvetlen jogkövetkezmény. Az állami elem azonban ebben a rendszerben is megjelenhet." 101

A szabályozási lánc elemei - a fentiekből következően is - elsősorban az állami, közhatalmi szabályozáshoz való viszonyulásukat illetően értelmezhetők:

\footnotetext{
${ }^{98}$ M.I. FRANKLIN: Digital Dilemmas Power, Resistance and the Internet OXFORD University Press 2013.

${ }^{99}$ OECD Internet Szabályozási Elvek: Council Recommendation on Principles for Internet Policy Making. Elfogadva 2011. december 13. [OECD Szabályozási Elvek 2011.]

${ }^{100}$ Megjegyzem, vannak olyan szakmai vélemények is, miszerint az önszabályozási normák megsértéséhez szintén füződnek szankciók. BAYER Judit: Az internet tartalomszabályozása Magyarországon (Önszabályozás versus állami szabályozás) (BAYER II.) 451. In: ENYEDI NAGY Mihály - SARKADY Ildikó - POLYÁK Gábor (szerk.) Magyarország médiakönyve 2002. Enamiké. Nyilvánvalóan itt bizonyos más jellegü, üzleti, az adott vállalkozás image-ével összefüggő, hátrányos következményekre lehet gondolni, de semmi esetre sem a jogi értelemben vett közhatalmilag kikényszeríthetö szankcióra.

101 Angela CAMPBELL: Self-Regulation and the Media. Federal Communications Law Journal 711, 06/15/99 (CAMBEL 1999) In: CSINK Lóránt - MAYER Annamária: Variációk a szabályozásra Önszabályozás, társszabályozás és szabályozó hatóság a médiajogban MTMI 2012. KOLTAY-NYAKAS (szerk.) 36.
} 


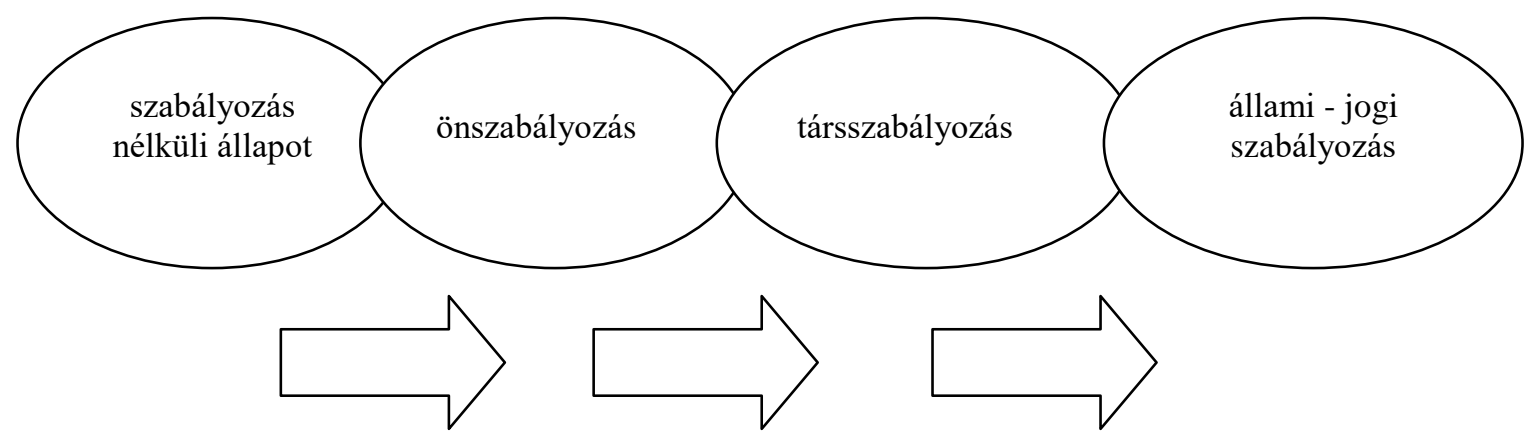

\section{4. ábra Szabályozási lánc az állami jogi szabályozáshoz való viszonyulás alapján ${ }^{102}$}

A szabályozás nélküli állapotban sem az állami, sem pedig a magánszabályozás nem érvényesül. A már említett „tiszta önszabályozás” (pure self-regulation) ${ }^{103}$ rendszere mindenféle állami beavatkozás nélküli állapotot jelent, a szabályokat kizárólag az önszabályozó szervezetek alkotják és a szabályok betartását is az azt létrehozó magánszervezetek ellenőrzik. A társszabályozásban kombinált szabályalkotás és ellenőrzés érvényesül az állami szervek és az önszabályozó szervezetek részéről; végül pedig az állami-jogi szabályozás megalkotása és érvényesítése kizárólag az állami kontroll rendszerén keresztül valósul meg. A fenti, az Európai Bizottság által is elfogadott legegyszerübb szabályozási séma - az önszabályozást létrehozó, azt müködtető nemzetközi szervezetek, illetőleg államok által képviselt modellek szerint még további elemekkel, láncszemekkel bővülhetnek, egészülhetnek ki. Az ausztrál modell az önszabályozás és a társszabályozás közé illeszt egy további elemet, a „kvázi szabályozást”, melynek lényege, - mintegy átmenetet képezve a két szabályozási láncszem között -, hogy az iparági magatartási szabályokat az állami jogalkotó szervek alkotják meg, de a szabályok érvényesítése, betartásának ellenőrzése továbbra is az önszabályozó szervek feladata. A kvázi szabályozási elem lehetővé teszi, hogy a magatartási kódex be nem tartása, megszegése esetén a kódex jogi szabállyá erősödik, és más jogszabályokhoz hasonlóan állami eszközök útján kikényszeríthetővé válik. A brit $B R T F$ az alapmodelltől eltérő rendszert alakított ki 2003-ban. Az önszabályozás az öt elem centrumában helyezkedik el, a „,Tájékoztatás és oktatás”, valamint az „Ösztönzésen alapuló struktúra” között. Az első és az utolsó elem megegyezik az alapmodell kezdő és végső láncszemével. A BRTF

\footnotetext{
${ }^{102}$ Ian BARTLE - VASS Péter: Self-Regulation and the Regulatory State. A Survey of Policy and Practice. 1-73. Overview 1 szövege alapján a szerző által készített ábra. The Universty of Bath Research Report 17. 2005. (BARTLE-VASS)

${ }^{103}$ BARTLE-VASS 17.
} 
meghatározásában az önszabályozás önkéntes szabályok összessége, amelyet azok alkottak meg, akik azt be is tartják. Az $O E C D$ önszabályozás fogalmát az önkéntes eszközök körében helyezi el, a szabályozási eszközök palettáját pedig a kormányzati beavatkozás szintjéhez méri. Az Egyesült Királyság Fogyasztóvédelmi Tanácsa a sikeres önszabályozás feltételeit: a) az önszabályozási célok pontos kijelölésében, valamint b) az iparági kódex lényeges tartalmi elemeinek meghatározásában látja. Az államhoz való viszonyát tekintve az önszabályozás Hyuyse és Parmentier ${ }^{104}$ értelmezésében felöleli az i) alvállalkozói (az állam által megadott szabályozói keretet az önszabályozó tölt meg tartalommal) ii) összehangolt akció (közös szabályalkotás az állam és az önszabályozó által) iii) beépítés (az önszabályozási normákat beépítik a jogi szabályozásba) iv) tiszta önszabályozás (az iparági kollektív cselekvés megvalósulása, amely kizárja a szakma hitelét rontó szektorális szereplőket) kategóriáit.

Az önszabályozással foglalkozó elméletek közül meg kell még említeni a multidimenzionális megközelítést, amely lényege szerint az állami szabályozás és az önszabályozás két területen a) az államilag elismert önszabályozás, valamint b) a kötelezö önszabályozás keretében átfedésben van egymással. Az a) esetben az önszabályozással rendezett norma ex post jogi szabállyá válhat, a b) esetben pedig az állami szabályozás elöre, ex ante meghatározza az önszabályozás keretébe tartozó szabályozási tárgykört.

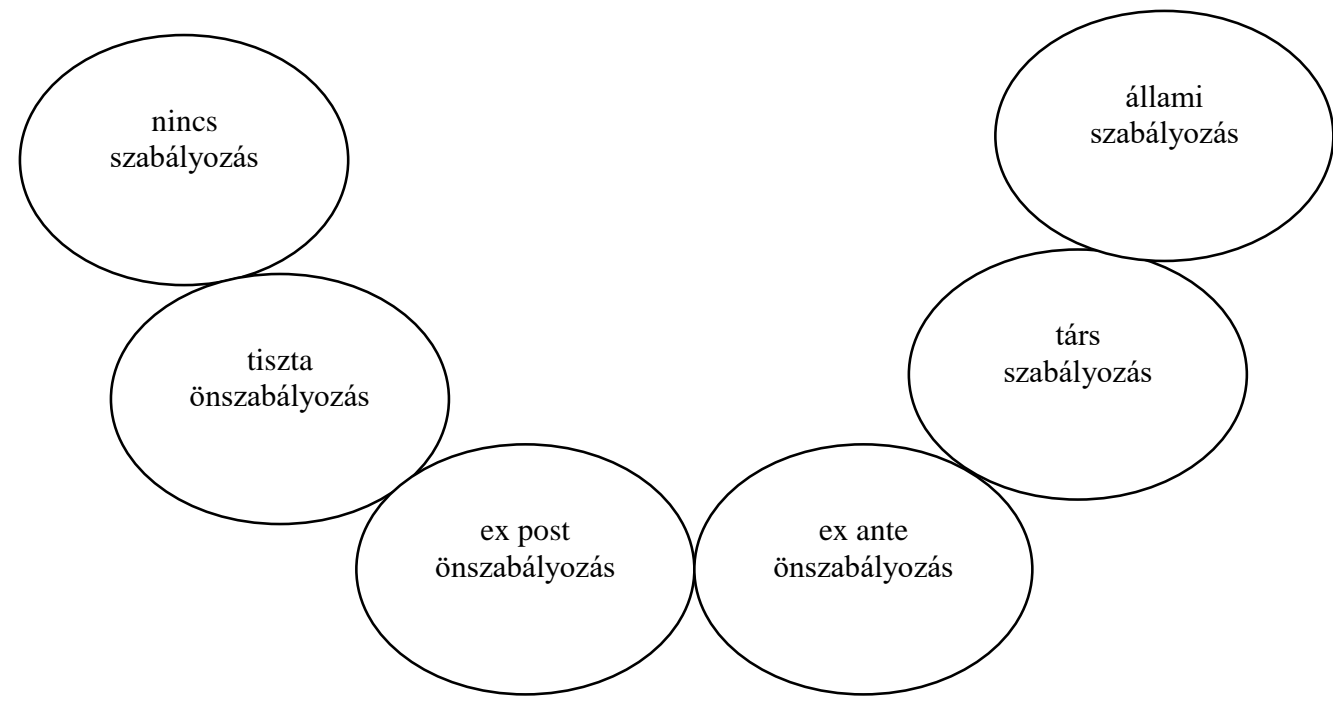

\section{5. ábra Multidimenzionális szabályozási modell}

${ }^{104}$ HYUYSE-PARMENTIER elmélete SEGAL nyomán In: CSINK-MAYER 45. 
Cafaggi $^{105}$ szerint a reklám önszabályozásában a szabályozási lánc a különböző és egymással kölcsönös függésben lévő szintek közötti kapcsolatban valósul meg, leginkább egy egymással vertikálisan összefüggő szervezeti rendszert alkotva. A különböző nemzetközi és nemzetállami önszabályozó szervetek által alkotott vertikális lánc „láncszemei” között nem érvényesül a szó jogi értelmében vett hierarchikus viszony, mert sem az ICC, sem pedig az EASA, továbbá más nemzetközi önszabályozó szervezetek által kiadott ajánlásoknak, normáknak nincs kötelező ereje a nemzeti önszabályozásokra. Az önérdek érvényesítésén és önkéntes szabálykövetésen alapuló „magánszabályozás” előnyös tulajdonságai mellett negatív hatásként jelentkezik a gazdasági szereplők között a „,nagyok összefogása a kicsik ellen” elv, valamint az ún. „chilling effect”, ${ }^{106}$ amely az állami szabályozás „,hütő hatásaként” funkcionál. Az iparági önszabályozás egyik kudarca volt az amerikai rádió-iparág összefogásának hiánya az 1920-as években. Az iparág szereplői nem tudtak megegyezni a frekvenciák elosztásában és felhasználásában; a privát szabályozás szándékát a frekvencia állami szabályozása pótolta.

Az alternatív szabályozási rendszereket az abban résztvevők oldaláról megközelítő szemlélet szerint az ún. „többszereplös” szabályozási modell figyelmen kívül hagyja a hagyományos közjogi és magánjogi szabályozás több évszázados rendszereit, legitimálja a hatósági intézkedéseket és erősíti a jogi dokumentumokba, határozatokba vetett közbizalmat. Mivel a médiaszabályozás lehetséges változatai között az állami szabályozástól és kontrolltól a társszabályozáson keresztül a gazdasági szektorok szakmai szervezeteinek önszabályozása is megtalálható, a médiaszabályozás személyi köre - emiatt is - egyrészt felöleli az állam mellett az utóbbi időszakban jelentős médiabefolyást szerző magántulajdonosokat és gazdasági érdekeltségeiket, másrészt pedig a saját belső szabályzataikat kialakító médiavállalatokat és civil-szakmai szerveződéseket. Míg a médiapiacon a 20. század folyamán létrejött médiakoncentrációk tulajdonosai a lehető legszélesebb közönséget kiszolgáló müsoraikkal jelentős befolyásra tettek szert, addig a médiafogyasztók és civilszervezeteik lényegében alig rendelkeznek beleszólással a médiában. Az állam figyelme az új szabályozási módszerek iránt változatlanul fennáll; az alternatív szabályozási módok elterjedése és egyre gyakorlottabb alkalmazása szoros

\footnotetext{
105 CAFAGGI xi.

${ }^{106}$ Dr. Gabor BENKE: Constitutional Issues of European Advertising Self-Regulation Outsourcing Chilling Effect? PHD. Értekezés Budapest, 2013.

https://sierra.ceu.edu/search?/aBenke+G $\{$ u00E1 $\}$ bor/abenke+gabor/1\%2C1\%2C2\%2CB/frameset\&FF=aben ke+gabor\& $1 \% 2 \mathrm{C} \% 2 \mathrm{C} 2$
} 
együttmüködést tesz szükségessé az állami szervek, a hatóságok és az önszabályozó szervezetek transznacionális, nemzetközi és nemzeti testületei között. Az együttmüködés iránya - vélhetően - a közös szabályozási gondolkodás, célmeghatározás és a tényleges együttes szabályozás felé tart. Hangsúlyozni kell, hogy az etikai szabályok kereteit, az önés társszabályozási rendszerek mozgásterét az állami, jogi szabályozás határolja le; ennél fogva e szabályok soha nem lehetnek ellentétesek a fennálló jogi normákkal, azokat részletezik, kiegészítik.

A jogi szabályozás és az önszabályozás jellege, tulajdonságai és hatása között jelentős különbségek azonosíthatók. Míg az állami szabályozás a lehető legszélesebb közérdek érvényesítésének talaján hozza létre a közpolitikai célok megvalósítása érdekében szabályrendszerét, addig az önszabályozás kisebb közösségi érdekek érvényesítése céljából, iparági szinten fogalmazza meg magatartási szabályait, etikai normáit. Az állami és az önszabályozás között további lényeges eltérés, hogy az állami jogszabályok végrehajtását minden esetben a közhatalom kényszerítő ereje, önálló szankciórendszer erősíti. Az „önszabályok” betartása - ilyen szankciók híján - az üzleti érdekekkel való összhang létén múlik. A ,self-interest” hiánya mutatkozott meg abban, hogy az Egyesült Királyság legnagyobb médiavállalatai 1980-ig nem csatlakoztak a sajtótanácshoz, illetőleg Rupert Murdoch médiamágnás több éves kihagyás után csak 1987-ben lépett újra vissza a tanácsba, amikor is médiabirodalmát újabb nagy kiadó megvásárlásával növelte. ${ }^{107}$

\subsubsection{Alternatív szabályozási modellek a nemzetközi és az Európai Uniós dokumentumokban}

Az Európai Unió a '90-es évek végén több, a jövőbeni médiaszabályozás és a konvergencia alapjait meghatározó dokumentumot jelentetett meg. Kiadta a távközlési, média és információtechnológiai szektorok konvergenciájáról és ennek szabályozási kihatásairól szóló Zöld könyvet, ${ }^{108}$ majd közleményeit a közösség jövőbeni audiovizuális politikájáról, az audiovizuális politika alapelveiről és irányelveiről a digitális korban, valamint az elektronikus kommunikációs infrastruktúra és a kapcsolódó szolgáltatások új keretfeltételeinek fejlődése címmel. ${ }^{109}$ Az Európai Bizottság felismerve az önszabályozás

\footnotetext{
${ }^{107}$ CSINK-MAYER 36.

${ }^{108}$ Green Paper on the convergence of the telecommunications, media and information technology sectors, and the implications for Regulation - Towards an information society approach COM/97/0623 (Zöld Könyv 1997)

${ }^{109}$ COM (1998) 446, COM (1999) 657, COM (1999) 539.
} 
jelentőségét, közleményében ${ }^{110}$ kiemelte, hogy az EU jobb szabályozási politikájának célja a szabályozás minőségének javítása, a szabályozás alaposabb megtervezése. Az alternatív szabályozási modelleket támogató rendelkezések már 2002-ben az Elektronikus Kereskedelemről szóló irányelvben ${ }^{111}$ megjelennek, itt még elsősorban az önszabályozás nemzetállami szabályozásokban való ösztönzésének formájában. Az AVMS szövege hivatkozva a „Better Regulation” eszközére, javasolja a szabályozási megközelítés gondos elemzés eredményeként történő kiválasztását. ${ }^{112}$ Az irányelv Preambulumában rögzíti az önszabályozás és a társszabályozás szükségességét, és - tapasztalatokra hivatkozva megállapítja mindkét szabályozási eszközrendszer jelentőségét a magas szintü fogyasztóvédelem terén, továbbá ösztönzi mindkét szabályozási mód nemzetállami alkalmazását anélkül, hogy a már meglévő ön- és társszabályozási kezdeményezéseket veszélyeztetné. Az irányelv az önszabályozást olyan „önkéntes kezdeményezési típusként” határozza meg, amely lehetővé teszi a gazdasági szereplők, a szociális partnerek, a nem kormányzati szervek vagy a szövetségek számára, hogy saját maguknak fogadjanak el közös iránymutatásokat. Az eredményes önszabályozás - az AVMS értelmében - hasznos kiegészítője lehet a jogszabályok és a bírósági, illetőleg közigazgatási mechanizmusoknak, ugyanakkor a jogi szabályozást nem helyettesítheti. A társszabályozás minimális formájában kapcsolatot teremt az önszabályozás és a nemzeti jogalkotó között; amennyiben céljai nem teljesülnek, úgy lehetővé kell tenni az állami beavatkozást. ${ }^{113}$

Az olasz elnökség által a Digitális Egységes Piac program keretében 2014. október 23-24én elindított $A V M S$ irányelv megfelelőségi felülvizsgálat a direktíva átfogó módosításában gondolkodik. ${ }^{114} \mathrm{Az}$ ön- és társszabályozás tekintetében a Bizottság az Európai Parlamentnek és a Tanácsnak címzett „Minőségi jogalkotással javítani az eredményeken uniós program” címü közleményében hangsúlyozta, hogy a szakpolitikai megoldások

\footnotetext{
${ }^{110}$ A Bizottság közleménye a Tanácsnak, az Európai Parlamentnek, az Európai Gazdasági és Szociális Bizottságnak és a Régiók Bizottságának. Az Európai Unión belüli jobb szabályozás stratégiai felülvizsgálata \{COM (2006) 690 végleges\}

${ }^{111}$ Az Európai Parlament és a Tanács 2000/31/EK irányelve (2000. június 8.) a belső piacon az információs társadalommal összefüggő szolgáltatások, különösen az elektronikus kereskedelem, egyes jogi vonatkozásairól (Elektronikus kereskedelemről szóló irányelv) Ld.: 172. lbj.

112 AVMS (44) hivatkozza a Bizottság közleményét a Tanácsnak és az Európai Parlamentnek - Jobb szabályozás a növekedés és a munkahelyteremtés területén az Európai Unióban \{SEC(2005)175\} $\mathrm{COM} / 2005 / 0097$.

${ }^{113}$ AVMS (44)

${ }^{114}$ Javaslat Az Európai Parlament és a Tanács irányelve a tagállamok audiovizuális médiaszolgáltatások nyújtására vonatkozó egyes törvényi, rendeleti vagy közigazgatási rendelkezéseinek összehangolásáról szóló 2010/13/EU irányelvnek a változó piaci körülményekre tekintettel való módosításáról.

COM/2016/0287 final - 2016/0151 (COD). [AVMS Felülvizsgálati Javaslat] Ld.: 65. lbj. és 979. lbj.
} 
mérlegelése során mind a hatósági eszközöket, mind pedig a jobb ön- és társszabályozás elveit, valamint a közösségi gyakorlatok alapján jól kialakított nem hatósági eszközöket figyelembe fogja venni. A megfelelöségi javaslat leszögezi, hogy az AVMS irányelv által összehangolt területeken kidolgozott több kódex összhangban áll a jobb ön- és társszabályozás javításának elveivel. A jogalkotási védőháló léte pedig szintén jelentős sikertényezőnek tekinthető az ön- vagy társszabályozás révén kialakított kódexek betartásának népszerüsítésében. ${ }^{115}$ A Javaslat legalább ilyen fontos tényezőek tekinti azt is, hogy a kódexek konkrét célokat és célkitüzéseket határoznak meg, így lehetőséget kínálnak azok rendszeres, átlátható és független nyomon követésre és értékelésére. Az arányosság fenntartására tekintettel alkalmazott fokozatos szankciókat általában a rendszer kikényszerítésének eredményes eszközeiként tartják nyilván. Az irányelv által összehangolt területeken elfogadott ön- és társszabályozó kódexekben ezen elvek követését irányozza elő a Javaslat. A Javaslat konkrét ön-, illetőleg társszabályozási iránymutatásokat is megfogalmaz - többek között - a kiskorúak egészséges táplálkozása, valamint az alkoholos italok felelős forgalmazása érdekében. ${ }^{116}$ A Bizottságnak és a tagállamoknak ösztönözniük kell az ön- és társszabályozási magatartási kódexek kidolgozását a gyermekmüsorokat kísérő vagy azokban foglalt nem megfelelö kereskedelmi közleményeket illetően, amelyek olyan élelmiszerekre és italokra vonatkoznak, amelyek túlzott bevitele nem ajánlott (alkoholtartalmú italok, cukor, zsír, transz-zsírsavak, só/ nátrium). ${ }^{117}$ A Javaslat szintén ön- és társszabályozási magatartási kódexek keretében javasolja rendezni az alkoholtartalmú italok kereskedelmi közleményeire vonatkozó szabályozást. ${ }^{118} \mathrm{Az}$ ön- és társszabályozási rendszerek bevált gyakorlatainak cseréjét a Bizottságnak, valamint az Audiovizuális Médiaszolgáltatásokat Szabályozó Hatóságok Európai Csoportjának (ERGA) a teljes Unióban ösztönöznie kell, sőt a Bizottságnak - indokolt esetben - elő kell segítenie az uniós magatartási kódexek kidolgozását is.

Az UNESCO 2011. évi jelentésének megfogalmazásában az önszabályozás - a média területén - magatartási kódexekbe foglalt, a szólásszabadságot védő minőségi előírásoknak és annak a folyamatnak a kombinációja, amely az előírások megtartására és a felelösségre

\footnotetext{
115 Javaslat (7)

${ }^{116}$ Javaslat (10) - (12)

${ }^{117}$ Javaslat 11. a) a 9. cikk (2) bekezdésének javasolt módosítása.

118 Javaslat 11. a) a 9. cikk (3) bekezdésének javasolt módosítása.
} 
vonásra irányul. ${ }^{119} \mathrm{Az} \quad O E C D$ elsősorban a fogyasztóvédelemmel kapcsolatos összefüggésekben elemzi az önszabályozás szerepét és jelentőségét. ${ }^{120} \mathrm{Az}$ OECD Fogyasztópolitikai Bizottságának 2010-ben kiadott „Fogyasztópolitikai eszköztár” (Consumer Policy Toolkit) című jelentése - figyelemmel az OECD korábbi (2002, 2006), hasonló tárgyú riportjaira -, kijelöli a fogyasztóvédelmi politika fejlesztésének és alkalmazásának kereteit (Jelentés 2010). A Jelentés 2010 leszögezi, hogy a fogyasztóvédelmi témakörök meghatározásában az iparági önszabályozásnak (industry self-regulation - ISR) különösen akkor lehet jelentősége, ha ezek a kijelölt tárgykörök az üzleti világ normáira és viselkedési elöírásaira is kiterjednek. A Fogyasztópolitikai Bizottság „Az önszabályozás szerepe és jelentősége a fogyasztói érdekek szolgálatában” címü 2015. évi jelentése (a továbbiakban: Jelentés 2015) az ISR szerepét elsősorban azokban a fogyasztóvédelmi kérdésekben tanulmányozza, amelyekben az iparági önszabályozás hasznos lehet, illetőleg azt elemzi, hogy milyen lépéseket kell tenni annak érdekében, hogy az iparági önszabályozás - ezen a téren - a jövőben is sikeres legyen.

\subsubsection{Better regulation és a best of practice eszközrendszere}

Az Európai Unió 2014 óta alelnöki szinten, önálló bizottságban kezeli a megfelelő, jobb szabályozás (Better Regulation - BR) kérdését. A BR mechanizmusát a Bizottság az egyik legfontosabb prioritásnak tekinti az EU politikai célkitüzéseinek minél eredményesebb megvalósítása érdekében; 2015. május 19-én fogadta el a Jobb Szabályozásért Agenda ${ }^{121}$ reformcsomagot, amely a lehető leghatékonyabb döntéshozatali mechanizmus kialakítása céljából az Unió jogalkotási folyamatait nyitottabbá és átláthatóbbá kívánja tenni. A Bizottság által kezdeményezett témakörökben ${ }^{122}$ az - EU szakpolitikák meghatározási és jogalkotási folyamatait teljesen lefedő - intézkedési tervcsomag a döntéshozatalt előkészítő eljárásokat, valamint a jogi dokumentumok és módosítások tervezeteit a Bizottság honlapján nyilvánosságra hozza, hogy az érdekeltek véleményezhessék azokat. A véleményezési eljárás során lehetősége van az önszabályozó és más civilszervezeteknek

\footnotetext{
${ }^{119}$ UNESCO Jelentés 2011 Zlatev, Ognian; Lani, Remzi; Baydar, Yavuz; Mollerup, Jacob; Vilović, Gordana; Turtia, Tarja; Hulin, Adeline Professional Journalism Self-Regulation and New Media, Old Dilemmas in South East Europe and Turkey (UNESCO Jelentés 2011)

${ }^{120}$ Ld.: OECD Fogyasztópolitikai Bizottság jelentései 2002, 2006, 2010, 2015.

${ }^{121}$ Better Regulation Agenda: Enhancing transparency and scrutiny for better EU law-making Strasbourg. 2015. május 19., http://europa.eu/rapid/press-release_IP-15-4988_en.htm.

122 List of planned Commission initiatives. 2015. június 11. http://ec.europa.eu/atwork/pdf/planned_commission_initiatives_2015.pdf.
} 
is szakmai álláspontjuk kifejtésére, amelyek - megalapozottságuk esetén - a végleges dokumentum részévé válhatnak. Az Agenda kiemelt jelentőséget tulajdonít 1) a jogalkotást és döntéseket alátámasztó hatáselemzéseknek; 2) a jogszabályok és döntések tényekkel való alátámasztásának; 3) a hatályos jogforrások felülvizsgálatának és a jogi dokumentumok aktualizálásának; 4) a nyilvános konzultációknak, valamint 5) az EUpolitikába és a jogalkotásba vetett állampolgári bizalom erősítésének. A Bizottság Agendával azonos napon kiadott közleménye a „Jobb szabályozás a jobb teljesítményért”"123 című dokumentum a BR-t az EU szabályozás „szolgálatába” helyezi az átlátható, nyitott, érthető, hatékony és hatásos uniós jogalkotás érdekében. A közlemény REFIT $^{124}$ programja a 'minőségi jogalkotás' megteremtése érdekében az EU jogrendszer racionalizálását, költségtakarékos és kiszámítható szabályozási keretrendszer kialakítását tüzi ki célul, mindezt pedig az EU intézmények, a tagállamok és minden érdekelt bevonásával.

A nyilvánosság bevonásával zajló, transzparens folyamat eredményeként a Bizottság által előkészített intézményközi megállapodás ${ }^{125}$ az uniós intézmények együttműködését, a költségtakarékos és az adminisztrációt minimalizáló intelligens szabályozás eszközeit (hatásvizsgálat, érdekeltek bevonása a döntés előkészítés folyamatába, vélemények figyelembe vétele, jogszabályok utólagos értékelése stb.) fekteti le a jobb jogalkotás érdekében.

Az Európai Unió a fentieken és a BR eszközein túl bizottságokon átívelő platformot hozott létre, amely 'Community of Practice for Better Self- and Co-Regulation' néven fogja össze az alternatív szabályozással kapcsolatos témaköröket és határozza meg a best practice eszközeit. ${ }^{126}$ Az EU Pledge ${ }^{127}$ keretében az élelmiszeripari cégek vállalták, hogy bizonyos,

\footnotetext{
${ }^{123}$ Communication from the Commission to the European Parliament, the Council, the European Economic and Social Commitee and the Committee the Regions Strasbourg, 19. 5. 2015 COM (2015) 215 final Better regulation for better results - an EU agenda.

${ }^{124}$ Regulatory Fitness and Performance Programme 'REFIT'.

${ }^{125}$ Intézményközi megállapodás az Európai Parlament, az Európai Unió Tanácsa és az Európai Bizottság között a jogalkotás minőségének javításáról Strasbourg 13.4. 2016.

${ }^{126} \mathrm{http} / / / \mathrm{ec}$.europa.eu/digital-agenda/en/news/join-our-community-practice-better-self-co-regulation.

${ }^{127} \mathrm{Az}$ EU Pledge ebben az értelemben a piaci szereplők önkéntes vállalásait jelenti elsősorban a gyermekeknek szóló élelmiszeripari reklámok terén. A 2005-ben indult nemzetközi kezdeményezés magyar változatát 2014-ben már 12 piacvezető élelmiszeripari szereplő írta alá; önként vállalták, hogy nem hirdetik termékeiket 12 év alatti gyermekeknek, valamint nem reklámozzák azokat tévében, nyomtatott sajtóban és interneten olyan médiaközönség számára, amelynek legalább 35 százaléka 12 évesnél fiatalabb. A 2014-ben publikált jelentés szerint a cégek 98,4 százalékban teljesítették vállalásaikat, a gyerekcsatornákon sugárzott élelmiszerreklámok száma pedig a kezdeményezés 9 éve alatt közel harmadára csökkent. www.danone.hu/hir/2015-05-19/eu-pledge-magyarorszagon
} 
az egészséges táplálkozási kritériumoknak megfelelő élelmiszerek kivételével a 12 éven aluli gyermekeknek nem hirdetik termékeiket. ${ }^{128} \mathrm{Az}$ alkoholreklámok terén még jelentősebb volt az iparág önszabályozási vállalása: a 18 éven aluli korosztály számára nemcsak az alkohol tartalmú italok reklámozásától tartózkodtak a hirdetők, hanem azt is vállalták, hogy nem mutatnak 25 éven aluli fiatalokat a hirdetésekben, és nem készítenek olyan reklámokat, amelyek elsődlegesen a fiatalkorúak számára tartalmaznak vonzó elemeket. $^{129}$

\section{A HAZAI MÉDIASZABÁLYOZÁSI ${ }^{130}$ REFORM 2006 - 2008 KÖZÖTT}

\subsection{Szabályozási Stratégiák}

A jelenlegi hazai média- és hírközlési szabályozási rezsim alapját a 2006-ban kezdődő reform eredményeként elfogadott két Stratégia, a $D A ́ S$ és a NAMS képezi. Már a $D A ́ S$ is megfogalmazta, hogy a két Stratégia nem váltja ki egymást, hanem egymásra épülve az egyik kiegészíti a másikat. ${ }^{131}$ A 2006 augusztusában kormányprogram alapján indult átfogó médiaszabályozási reform, ${ }^{132}$ illetőleg a digitális átállás jogszabályi hátterének megteremtése és a folyamat gyorsítása a részletesen kidolgozott, a miniszterelnök által még augusztusban jóváhagyott Alapvetés ${ }^{133}$ szerint kezdődött el. Fontos kiemelni, hogy a kormányzati feladatként 2006. augusztus 1-töl a Miniszterelnöki Hivatalból $(\mathrm{MeH})^{134}$

\footnotetext{
${ }^{128}$ A Nestlé az EU Pledge első aláirói között volt. Ennek keretében nem reklámozzák a táplálkozási profilba nem illeszkedő termékeiket 12 éven aluli gyermekeknek tévében, sajtóban és a honlapjaikon, 2016 januárjától pedig mozira, rádióra, a mobilmarketingre és a direkt marketingre is kiterjesztetik a vállalást. http://brandtrend.hu/hir/2015/07/09/az-ort-treningezte-a-nestle-munkatarsait, 2015. július 9.

${ }^{129}$ www.mediapiac.com/mediapiac/Kiemelt-szerepet-kapott-az-onszabalyozas-a-Bizottsagban/111745.

${ }^{130}$ Médiaszabályozás alatt ebben a fejezetben kifejezetten a legszükebb értelemben vett médiaszabályozást, a tartalomszabályozást kell érteni.

${ }^{131}$ A DÁS-ban a kormány elkötelezte magát arra, hogy a NAMS alaptézisei a DÁS-hoz hasonlóan széles körben ismertté váljanak és 2007 folyamán véglegesítésre és elfogadásra kerüljenek DÁS 31. 13.

${ }^{132} \mathrm{Az}$ „Átfogó médiaszabályozási reform” fogalma a digitális átviteli rendszerek, illetőleg a műsorterjesztési piac, valamint a médiatartalom szabályozására vonatkozó stratégiai előkészítést és jogalkotási feladatokat együttesen jelenti az értekezésben.

${ }^{133}$ A médiaszabályozási reform folyamatának alapjait lefektető, a médiaszabályozási fötanácsadó által kidolgozott és a miniszterelnök által 2006. augusztus 18-án jóváhagyott Alapvetés.

${ }^{134}$ Az audiovizuális média, valamint a digitális átállás szabályozási hatásköre egy kormányrendelet, valamint a kancellária miniszter és a szabályozással érintett gazdasági és közlekedési miniszter megállapodása alapján 2006 öszétől a MeH hatáskörébe került. [160/2006. (VII.28.) Korm. rendelet a Miniszterelnöki Hivatalról, valamint a Miniszterelnöki Hivatalt vezető miniszter feladat- és hatásköréről Magyar Közlöny 2006. évi 93. szám]
} 
vezérelt szabályozási folyamat, különösen annak szervezeti „,formája” és módszerei, ${ }^{135}$ a jogalkotás közigazgatási eszközrendszerétől többnyire idegen, de mégis rendkívül célravezető megoldásoknak bizonyultak. Ilyen, nem a jogalkotási menetrendbe illesztett, de „eredményorientált” módszerek voltak - többek között - a $M e H$ szakmai előkészítése alapján a parlamenti pártok rendszeres „ötpárti” egyeztetései, szintén a $\mathrm{MeH}$ által rendszeresített ún. Szolgáltatási fórumok, illetőleg a civil szervezetekkel való egyeztetések és találkozók. A jogalkotás törvényileg szabályozott rendjétől eltérő, és a korábbi médiakodifikációs gyakorlat folyamatába sem illeszthető, de mégis a leginkább sikeresnek az a „hallgatólagos” szervezeti forma ${ }^{136}$ bizonyult, amely a kormányzati jogalkotást előkészítő Kormányirodát lényegében mentesítette a médiaszabályozással kapcsolatos feladatok alól és a médiareform valamennyi szakmai előkészítő tevékenységét közvetlenül a kancellária miniszter tanácsadói köréhez tartozó médiaszabályozási főtanácsadóhoz, illetőleg 2007 októberétől az Audiovizuális Média Kormánybiztosához telepítette. A média és hírközlési piac felmérése, a Stratégiák és a $D A ́ S$ kormányhatározat tervezet kidolgozása, ${ }^{137}$ a törvényjavaslatok szakmai előkészítése, e jogi dokumentumok nyilvános vitája, ${ }^{138}$ továbbá megannyi más egyeztetési forma - beleértve a rendszeres „ötpárti" ${ }^{139}$ megbeszéléseket is -, 2006 és 2008 között jelentős mértékben hozzájárultak a jogi dokumentumok széleskörü szakmai megalapozásához, valamint társadalmi és politikai elfogadásához. Mindezen egyeztetési eszközök és módszerek pedig végeredményben a „digitális” törvény több mint

${ }^{135}$ A médiaszabályozással kapcsolatos szakmai előkészítést a MeH-ben kezdetben a kancellária-miniszter felügyelete alatt álló - a jogalkotás előkészítéséért felelös kormányirodán kívüli egységként - a médiaszabályozási főtanácsadó vezetésével két fő végezte; munkájukat két közgazdászból és két jogászból álló külső tanácsadó-team segítette (Telkes Tanácsadó Kft. és a Colosseum Kft. által alkotott konzorcium). 2007. október 1-től az átfogó médiaszabályozási reformot a fötanácsadó az Audiovizuális Média Kormánybiztosaként irányította. A kormánybiztos 2008. április 1-jei lemondását követően nem volt a médiaszabályozási reformnak és a digitális átállás folyamatának felelős kormányzati irányítója a 2010. évi országgyülési választásokat követő kormányváltásig.

${ }^{136}$ A médiaszabályozást irányító szervezetek $\mathrm{MeH}$, illetőleg az AMK. A NAMS kommunikációja során használt „kormánybiztosság” elnevezés a szabályozásban közvetlenül résztvevők kollektív felelősségét kívánta érzékeltetni, de ez nem mentesítette a kormánybiztost egyéni felelőssége alól.

137 1014/2007.(III.13.) Korm. határozat a televíziózás és a rádiózás digitális átállásának kormányzati feladatairól [Magyar Közlöny 2007. évi 29. szám]

${ }^{138}$ A jogi dokumentum tervezeteinek a MeH honlapján való közzététele és nyilvános véleményeztetése, továbbá az érintett piaci és nem piaci szereplök közötti formális és informális találkozók, valamint konferenciák.

139 2006-2010 közötti parlamenti pártok: MSZP, SZDSZ, FIDESZ-KDNP, MDF. A főtanácsadó által kezdeményezett „ötpárti” tárgyalásokon valamennyi parlamenti párt frakcióvezetője által kijelölt, megbízó levéllel megerösített egy fő szakpolitikus és egy fö médiajogi szakértő, azaz pártonként két fö képviselte az egyes pártokat. Az „ötpárti” médiaszabályozási egyeztetések a médiajogi fötanácsadó, majd kormánybiztos szakmai előkészítésével és koordinációjával zajlottak 2006 öszétől folyamatosan; kezdetben kéthetente, majd a jogalkotási feladatok bővülésével arányosan, heti két alkalommal. 
90 százalékos elfogadásához, valamint az első médiatörvényünk ${ }^{140}$ jogharmonizációs célú módosításának egyhangú parlamenti megszavazásához vezettek. Ez a média jogalkotást előkészítő, koncentrált szervezeti megoldás és szabályozási munkamódszer azért is érdemel néhány mondatot az értekezésben, mert a negyedszázados média-jogalkotási kísérletek 2007-es sikere, valamint a jelenleg hatályos médiaszabályozási rezsim hosszabb távra szóló szakmai megalapozása döntő részben ezeknek az eszközöknek és módszereknek, illetőleg a jogalkotás szervezeti megoldásának köszönhető; eredményessége pedig ezen eszközök és módszerek teljes nyilvánosság elötti következetes alkalmazásában rejlik. ${ }^{141}$

A parlamenti pártok egyetértése és az eredményes jogalkotás érdekében a tartalom és a forma egységét, a véleményszabadság garanciáit és a hírközlési típusú normák összhangját már a Dtv-ben biztosítani kellett. Így kerültek be a „digitális” törvény hírközlési jellegü rendelkezései közé tartalom-szabályozási elemek, a külön fejezetet alkotó, a vélemények sokszínűségét szolgáló rendelkezések. ${ }^{142}$ E rendelkezések kiforratlanságát, a Dtv. szabályai közötti elhelyezését utólag több kritika érte. ${ }^{143}$ A szabályozásban ezek a kérdések megfelelö helyükre, az Mttv-be kerültek, de 2007-ben a Dtv. megszavazása érdekében meg kellett hozni ezeket a szakmai kompromisszumos döntéseket. Míg a reform első része, a $D A ́ S$ és a digitális törvény megalkotása, illetőleg az Rttv. jogharmonizációs módosítása a szakmaiság talaján, a társadalmi és politikai egyeztetések mentén zajlott, addig a médiaszabályozási reform másik pillére, a szük értelemben vett médiaszabályozás 2008 őszétől átmenetileg megrekedt. ${ }^{144}$ A pártok által összeállított „kísérleti” dokumentumok, amelyek a „Szakmai javaslat egy médiatörvény lehetséges tervezetére” címet viselték, „a lehető legtávolabb álltak minden alkotmányos alapelvtől és a szakmaiság

\footnotetext{
${ }^{140}$ Az Rttv.(régi médiatörvény) jogharmonizációs célú módosításának elfogadása 2007. VI. 18., kihirdetése VI. 26. a Dtv-vel együtt-

${ }^{141}$ „Akárhogy is van, valami kis sikert az analóg-digitális átállás előkészítésében fel tud az ország mutatni...” GÁLIK Mihály: A hozzáférés és a médiakoncentráció túlszabályozása a digitális átállás hazai folyamatában Médiakutató 2008 nyár (GÁLIK II.)

${ }^{142}$ Dtv. IV. fejezet A vélemények sokszínüségét szolgáló rendelkezések.

${ }^{143}$ KOLTAY András: A müsorterjesztés és a digitális átállás szabályairól szóló 2007. évi LXXIV. törvény 26.

$\S$ (1) bekezdésének értelmezéséről Jogi Fórum 2008 nyár (KOLTAY VIII.) http://www.jogiforum.hu/files/mediajog/dtv_26_koltay.pdf 7. GÁLIK II. 2.

${ }^{144} \mathrm{Az}$,átmeneti” időszakban született törvényjavaslatnak nem nevezett dokumentumok: „Szakmai javaslat a médiaszolgáltatásokról szóló törvény egy lehetséges tervezetéhez" 2008. november 4, átdolgozott változatok: 2008 december 23., 2009. február 10. SARKADY VII. 128-133. Hivatkozza: A magyarországi médiaháború története Média és politika 1989-2010 (Szerk.: PAÁL Vince, sorozatszerk.: KOLTAY András - NYAKAS Levente) Complex Wolters Kluwer Budapest, 2013. 293. 206. lbj. (Magyarországi médiaháború)

Ld. még: GÁLIK Mihály: A médiapolitika két évtizede (GÁLIK III.) 11. SARKADY Ildikó: Karácsonyi meglepetés Lapkiadás és Médiapiac 2009.1-2.sz.február (SARKADY IV.).
} 
érvényesítésétől.” 2009 júniusában ugyan az MSZP képviseletében egyéni képviselői indítványként benyújtásra került az Országgyülésnek egy, a médiaszolgáltatásokra vonatkozó törvényjavaslat, ${ }^{145}$ azonban azt a Kulturális és sajtóbizottság még csak tárgysorozatba sem vette, azaz a vezető kormánypárti politikusok javaslatát maga az MSZP sem támogatta. ${ }^{146} \mathrm{~A}$ javaslat visszaállította volna a társadalmi véleményezés intézményét; a felállítani tervezett Közszolgálati Tanács nézői-hallgatói panelt müködtetett volna, amely véleményezőként közremüködne a közszolgálati stratégia kidolgozásában. A javaslatban már finomodott a korábban sok kritikával illetett "médiarendőrség" elképzelése, amely szerint a médiahatóság bármely helyszínt átkutathat, oda önhatalmúlag, a tulajdonos (birtokos), illetve az ott tartózkodó személyek akarata ellenére is beléphet, e célból lezárt területet, épületet, helyiséget felnyithat. Az újabb szöveg értelmében a feladatai ellátásához, a tényállás tisztázása céljából bármely személy vagy szervezet a kezelésében levő adatokat, illetve a birtokában levő iratok másolatát olvasható és másolható formában köteles a médiahatóság kérése esetén annak rendelkezésére bocsátani, továbbá az adatokat a médiahatóság által meghatározott, összehasonlításra alkalmas formátumban szolgáltatni, valamint felvilágosítást adni. A törvényjavaslatból kikerült a felelős szerkesztő tevékenysége vagy mulasztása miatt kiszabható háromhavi bér szankciója is. Bár a 2009-es törvényjavaslat szövegében viszonylag kidolgozottnak tekinthető, azonban - többek között - nincs kellő figyelemmel az AVMS irányelv rendelkezéseinek pontos, de a magyar médiaés hírközlési piac sajátosságaihoz igazodó átültetésére; a NAMS által javasolt konvergens média- és hírközlési hatóságot különálló szervezetekként szabályozza, a testületek tagjait kizárólag pártpolitikai alapon jelöli, kizárva a szakmai álláspontok érvényesítésének lehetőségét, valamint közszolgálati intézményi rendszerében túlságosan követi az Rttv. megoldásait. A javaslat tehát politikai konszenzus hiányában „elhalt” és a hazai médiaszabályozás majd csak 2010-től vett ismét lendületet.

Visszatérve a NAMS-hoz: annak társadalmi-szakmai vitája 2007. szeptember 5-én kezdődött a Stratégia nyilvánosságra hozatalával a $M e H$ honlapján. A nyilvános vitán és az egyeztetéseken megfogalmazódott vélemények $\mathrm{MeH}$ honlapon történő közzétételére november 28-án került sor. ${ }^{147}$ A vitaanyaggal kapcsolatos belső egyeztetések 2007 decemberében befejeződtek. A véleményeket is összegző 116 oldalban véglegesített NAMS

\footnotetext{
${ }^{145}$ T/9954 törvényjavaslat a médiaszolgáltatásokról, jegyezte dr. Jánosi György, benyújtva: 2009. június 11. ${ }^{146}$ Magyarországi médiaháború 292-293. ld.: 144. lbj.

147 A NAMS tételeit az Audiovizuális Média Kormánybiztosa a 2007. október 2-án tartott szakmai konferencián, a Szolgáltatói Fórumon ismertette, ahol a MeH honlapján szeptember 5-töl nyilvános vitára bocsátott NAMS közzétételével egy időben a résztvevők további konzultációs lehetőséget kaptak.
} 
alapján az 52 oldalas Jogalkotási Koncepció végleges formájában 2008. január 7-én került fel a $M e H$ honlapjára és vált nyilvánossá. A NAMS egésze és a Jogalkotási Koncepció a későbbiekben a médiaszabályozással kapcsolatos társadalmi, politikai egyeztetéseken szakmai kiindulásként szolgált és meghatározó irányt mutatott a 2011-től hatályos médiatörvények szövegének kidolgozásához.

\subsection{Jogszabályi előzmények}

A hazai szabályozást illetően röviden utalni kívánok az 1990-es évek elejétől több jelentős módosítást is megélt, végül igazgatási jellegűvé ,zsugorodott,” 1986. évi II. sajtótörvényre (Stv.), amely különösebb szabályozási igény nélkül a '90-es évek elején „engedte” kialakulni és lényegében a 2010. évi új szabályozási rezsim létrejöttéig „hagyta” müködni a hazai sajtópiacot. „A médiatörvény százhatvankettő paragrafusával szemben a sajtótörvény többszöri módosítás után is csak huszonhárom szakasszal rendelkezik. Mégis ez az a jogszabály, amely éppen azért, mert nem esett a túlszabályozás hibájába, hagyja érvényesülni a lapkiadás elmúlt tíz évében lezajlott piaci változásait. Nem állít például a laptulajdonlás terén korlátokat, nem épít szerkezeti és szervezeti elöírásokat a lapkiadás és a lapterjesztés szabályozásába." 148

Az elektronikus médiát szabályozó hazai első, 1996-os médiatörvény érdemei gyerekbetegségei ellenére is -, vitathatatlanok. ${ }^{149}$ Elsö médiatörvényünk ${ }^{150}$ legnagyobb jelentősége ugyanis létében rejlik: megteremtette a duális média rendszerét, az elektronikus média szabályozásának önálló kereteit, kialakította annak terminológiáját, különválasztotta e szabályrendszert az írott sajtó szabályaitól, elkülönítette egymástól a közszolgálati és kereskedelmi müsorszolgáltatókra vonatkozó rendelkezéseket, illetőleg - az általános reklámszabályok törvényi megfogalmazását megelőzve - a hazai médiaszabályozásban létrehozta az elektronikus médiában megjelenő reklámokra vonatkozó speciális rendelkezéseket. $^{151}$ Az Rttv.-t egyes szakirodalmi megállapítások az Alkotmányhoz

\footnotetext{
${ }^{148}$ SARKADY Ildikó: Az önálló sajtótörvény problematikája és a kormányzati irányitás Acta Humana 2005. 1. szám, Infokommunikáció és Jog 2004/4, Médiajogi írások 2005. 147-148. (SARKADY V.)

${ }^{149}$ A Médiatörvény jelentőségéről ld: SARKADY Ildikó: Jogi intézményrendszer a médiában (SARKADY VI.) Acta Humana - Emberi jogi közlemények, 30. 1998, Médiajogi írások 181-182.

${ }^{150}$ RÉVÉSZ T. Mihály: A duális médiarendszer jogi megalapozása Magyarországon Jogtörténeti Szemle 2005. 2. 27-40. (RÉVÉSZ)

${ }^{151} \mathrm{Az}$ 1997. évi LVIII. törvény a gazdasági reklámtevékenységröl az Rttv. hatályba lépését követően született.
} 
hasonló funkcionális törvénynek, ${ }^{152}$ mások kis túlzással „mini-alkotmánynak”153 tekintették. Mindenesetre megállapítható, hogy az első médiatörvény a maga nemében és idején korszakalkotó volt, azonban a 21. század elejére betöltötte jogtörténeti küldetését. Időközben ugyanis a sajtó- és médiajog fejlődését alapvetően meghatározó müszakitechnikai fejlődés - a nemzetközi és uniós szabályozásnak megfelelően - szükségessé tette a hazai szabályozás újragondolását és teljesen megváltozott, korszerü alapokra helyezését. Itt kell utalni arra is, hogy a hazai törvényalkotást már az 1987-es jogalkotási törvény stratégiai megalapozáshoz és hatáselemzéshez kötötte. ${ }^{154}$ Később, a jogalkotás 2010. évi törvényei ${ }^{155}$ pedig kifejezetten előírták a jogalkotási koncepció elkészítését, a kötelező társadalmi és a közvetlen egyeztetés különböző formáit, így például a honlapon való közzétételt és véleményeztetés rendszerét, amelyeket a $D A ́ S$ és a NAMS kidolgozása, elfogadtatása során a $\mathrm{MeH}$, illetőleg az $A M K$ már alkalmazott.

\subsection{Egység és „pillérek” a Jogalkotási Koncepcióban, a médiareform „hardver”-e: a digitális átállás jogi alapjai}

\subsubsection{Jogalkotási pillérek}

A 2006-os hazai szabályozási Alapvetés átfogó reformot hirdetett és a jogalkotási feladatokat - az uniós közösségi jognak megfelelően - lényegében két, a gyakorlatban azonban három szabályozási pillér ${ }^{156}$ mentén azonosította. A szabályozási tárgyak elválasztásának közösségi jogi kívánalma, ${ }^{157}$ nevezetesen a tartalom és a tartalom átvitelére felhasznált hírközlö hálózatok szabályozásának külön választását elöíró uniós követelmény

\footnotetext{
${ }^{152}$ CSEH Gabriella - SÜKÖSD Miklós: Médiajog és médiapolitika Magyarországon I. Médiajog ÚMK 1999. 41-42. In: UDVARY I. 183.

${ }^{153}$ DR. SZELÉNYINÉ DR. ROSZIK Erzsébet A média lehetőségei és korlátai Bírák Lapja 2/2002.91. In: UDVARY I. 183., RÉVÉSZ 40.

154 1987. évi XI. törvény a jogalkotásról 18. §(1). „A jogszabály megalkotása előtt - a tudomány eredményeire támaszkodva - elemezni kell a szabályozni kívánt társadalmi-gazdasági viszonyokat, az állampolgári jogok és kötelességek érvényesülését, az érdek összeütközések feloldásának a lehetöségét, meg kell vizsgálni a szabályozás várható hatását és a végrehajtás feltételeit. Erről a jogalkotót tájékoztatni kell." ${ }^{155}$ 2010. évi CXXXI. törvény a jogszabályok előkészítésében való társadalmi részvételről 1.§ (1). „E törvény hatálya kiterjed a miniszterek által előkészített jogszabálytervezetek megalapozását szolgáló szabályozási koncepciókra is (a továbbiakban: koncepció).” Továbbá: 2. § (1), 4. §, 5. §, 7. § (1) a), 8. § (1)-(3), 9. § (4)

${ }^{156}$ A Kormányzati Stratégia-alkotási Követelményrendszer (KSaK) módszertana alapján „,a pillérek azok a legmagasabb szintü területek, amelyek együttesen meghatározzák az adott terület helyzetét, amelynek mentén leírhatók az adott területet jellemző legfontosabb összefüggések és célok, és megfogalmazhatók a célok elérésére szolgáló eszközök" NAMS 6.

${ }^{157}$ Keretirányelv (5) Ld.: 172. lbj.
} 
azt eredményezte a magyar stratégia és média-jogalkotásban, hogy a tartalomszolgáltatásra és a műsorjelek hírközlö hálózatokon történő továbbítására vonatkozó szabályozás kidolgozása két különböző szabályozási rezsim alá került. ${ }^{158} \mathrm{~A}$ Keretirányelv leszögezte továbbá azt is, hogy a televízió-müsorok tartalmára a TWVF irányelv (5) vonatkozik, továbbá, hogy az átvitel, valamint a tartalom szabályozásának egymástól való elválasztása nem sérti az ezek között meglévő kapcsolatok figyelembevételét, különösen a médiapluralizmus, a kulturális sokszínüség és a fogyasztóvédelem biztosítása érdekében.

Mindezek alapján hangsúlyozni kell, hogy az átviteli rendszerek és a müsorterjesztési piac, illetve a tartalom szabályozása tisztán szakmai alapon, az uniós irányelvi rendelkezéseknek megfelelően és nem politikai konszenzus hiányában ${ }^{159}$ különültek el a Stratégiákban, illetőleg a jogalkotási pillérekben. Az audiovizuális média tartalomszabályozásának, illetőleg az átvitelrendszerek önálló szabályrendszerének kialakítását a 2006-os Szolgáltatási irányelv is megerősítette, ugyanis kivonta hatálya alól a rádiós müsorszórást és az audiovizuális médiaszolgáltatásokat, ez utóbbiba beleértve a mozgófényképészeti szolgáltatásokat, függetlenül elöállításuk, elosztásuk és továbbításuk módjától. ${ }^{160} \mathrm{Az}$ AVMS irányelv szintén hangsúlyozza az elkülönített átvitel és tartalomszabályozás szükségességét. ${ }^{161}$

A hazai reform - az uniós irányelvek figyelembevételével - először az egyik pillér, a technikai oldal, az földi analóg müsorszórási átviteli rendszer jogszabályi hátterének megteremtését tűzte ki célul. Ennek megfelelően a digitális átállás stratégiai megalapozását, azaz a $D A ́ S$ jelentős átdolgozását, ${ }^{162}$ majd kormányhatározattal történő elfogadását, a digitális átállás törvényi feltételeinek kialakítását, valamint az akkor még szabályozás nélküli müsorterjesztési piac szabályozását elsőként kellett elvégezni.

\footnotetext{
${ }^{158}$ Dtv. Indokolás.

${ }^{159}$ Ezzel ellentétes megállapítást tesz: „Eldőlt az a vita, hogy vajon szabad-e csak a müsorterjesztést külön szabályozni, függetlenül a rádiózás és a televíziózás egészének szabályozásától, [...] ugyan a kettőt valóban jobb lett volna együtt csinálni, de a politikai feltételek, a törvénykezés kétharmados támogatásának normatív követelménye, illetve e támogatás valószínüsíthetö hiánya ennyit tettek lehetővé.” GÁLIK III. 11.

${ }^{160}$ Szolgáltatási irányelv (24), 2. cikk (2). Ld.: 172. lbj.

${ }^{161}$ AVMS (5) (18)

${ }^{162}$ A Digitális Átállás Stratégiájának első változata még 2004-2005 években az Informatikai- és Hírközlési Minisztérium megrendelésére készült. Az IHM által „(A) DÁS” alapján kidolgozott törvényjavaslat nem került elfogadásra a 2006 tavaszi parlamenti ülésszakban. A DÁS 2006 őszi nyilvánosságra bocsátását megelözően a fötanácsadó és munkatársai által jelentős mértékben átdolgozott, több mint 300 oldalas Stratégiát a MeH a honlapján közzétette, meghirdette a DÁS nyilvános vitáját és lefolytatta a szükséges szakmai és közigazgatási egyeztetéseket.
} 
A másik, a tartalomszabályozási pillér ${ }^{163}$ kettős tartalmat hordozott: egyrészt régi adósságunk törlesztését, az akkor még hatályos Rttv. jogharmonizációs célú módosítását, ${ }^{164}$ másrészt pedig az új médiaszabályozást megalapozó NAMS kidolgozását, valamint az új médiatörvény megalkotását. Az Rttv. jogharmonizációs célú módosítása ${ }^{165}$ a Magyarországgal szemben kezdeményezett kötelezettségszegési eljárás ${ }^{166}$ alóli mentesülés céljából, az új tartalomra vonatkozó „médiatörvény” megalkotásáig képezte a jogalkotási pillérek egyikét.

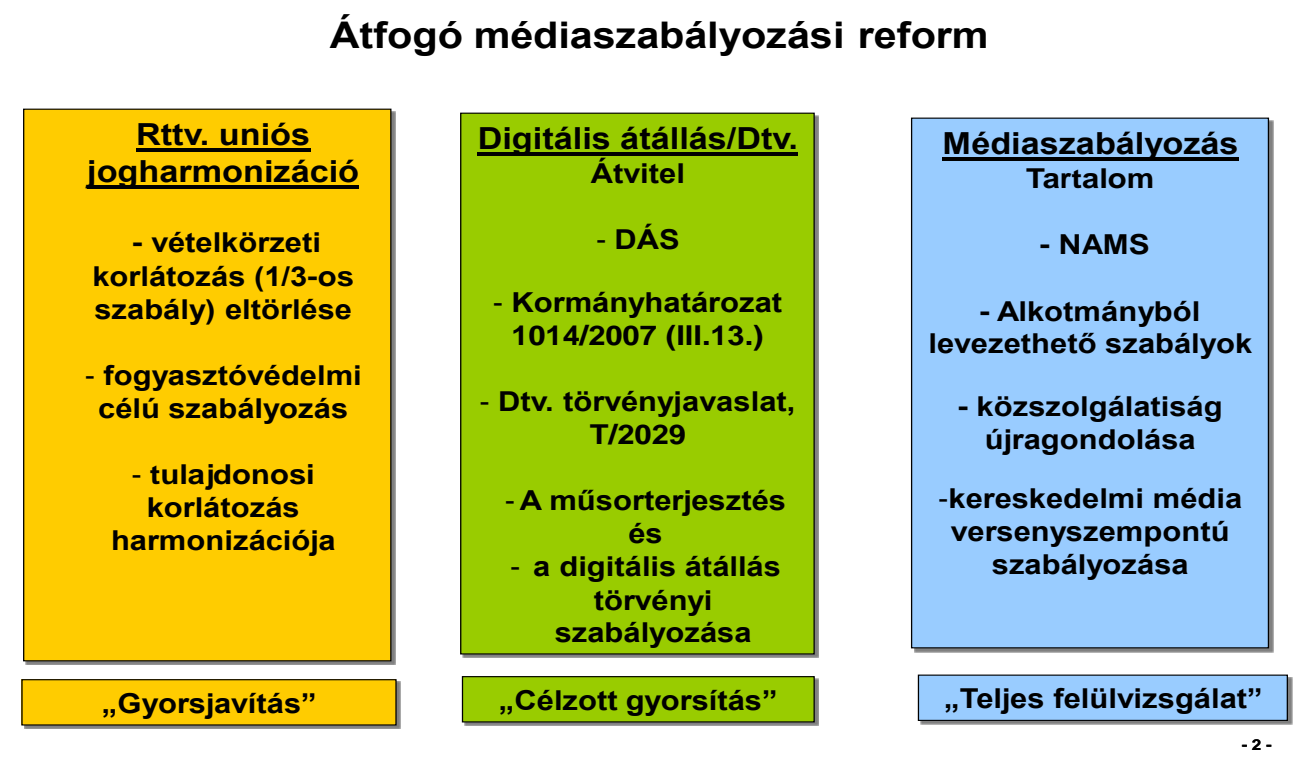

6. ábra A médiaszabályozási reform NAMS által azonosított pillérei ${ }^{167}$

\footnotetext{
${ }^{163}$ Tartalomszabályozási pillér alatt - az átviteli rendszer és műsorterjesztés pillérével szemben - a média teljes szabályozási tartalmát értem. A „hogyan jut el a jel a fogyasztóhoz” kérdéssel szemben a „mit juttatunk el a médiafogyasztóhoz" kérdés szabályozási válaszai kerülnek itt megfogalmazásra.

1642007 elött az Országgyülés elé kerülő Rttv. módosítási javaslatok két ízben sem szerezték meg a jelenlévő országgyülési képviselők szavazatának kétharmados többségét.

${ }^{165}$ 2004. április 30-ig kellett volna az Rttv-t megfeleltetni az uniós jognak.

${ }^{166}$ Az Rttv. 115. § (4) bekezdésében foglalt vételkörzet korlátozás hatályban tartása miatt az EU Bizottsága 2007. március 16-án kötelezettségszegési eljárást kezdeményezett Magyarország ellen az Európai Unió Bíróságánál. Magyarország ugyanis nem teljesítette az elektronikus hírközlő hálózatok és elektronikus hírközlési szolgáltatások piacain belüli versenyröl szóló, 2002. szeptember 16-i 2002/77/EK bizottsági irányelv 2. cikkének (3) bekezdésében foglalt kötelezettségeit. Az Rttv. 2007. évi jogharmonizációs célú módosításának eredményeként a Bizottság az infringement eljárást megszüntette Magyarországgal szemben.

167 A szerző „DÁS-tól a NAMS-ig” című prezentációjának egyik slide-ja, az előadás elhangzott a Média Hungary 2007. május 15-i konferenciáján.
} 
A NAMS Jogalkotási Koncepció a KSak módszertana alapján a stratégiai pillérek mentén átfogóan elemezte a szabályozás előtt álló kérdéseket, elkülönítve a közszolgálati és kereskedelmi, valamint a rádiós és televíziós tartalmakat. A $N A M S J K$ a $S W O T^{168}$ analízis szerint bemutatta a szabályozással kapcsolatos erősségeket, gyengeségeket, valamint lehetőségeket, továbbá vázolt egy egységes jövőképet, amelynek eléréséhez szükséges eszközöket és a stratégiai változatokat is ismertette. Hangsúlyozni kell, hogy a fötanácsadó által kezdeményezett „ötpárti” tanácskozás viszonylag korán egységre jutott egy teljesen új, korszerü médiatörvény megalkotását illetően és egyöntetüen elvetette egy újabb „toldozgatás-foltozgatás” gondolatát, a meglévő Rttv. módosítását. A NAMS a kormány médiapolitikájának stratégiai alapdokumentumaként született, olyan tematikus szakstratégia, amelynek fő célja - az iparági fejlődés követelményeinek, valamint az Európai Uniós irányelveknek megfelelően - az állami szerepvállalás újragondolása. „A stratégia (NAMS) térben elsősorban a Digitális Átállás (DÁS) stratégiájához illeszkedik figyelembe veszi annak megállapításait és várható eredményeit."169

A NAMS a digitális átállás akkori céldátumán ${ }^{170}$ túlmutató, a földfelszíni digitális átállást követö öt-nyolc évre fogalmazott meg irányadó elveket és célokat úgy, hogy a célok és a megvalósításhoz felhasznált eszközök a digitális korszakban is érvényesek maradjanak. Az 1997-től folytatott médiaszabályozás hiányaként emlegetett közszolgálati média súlyának aránytalansága, csekély jelentősége ${ }^{171}$ is orvoslást nyert azáltal, hogy a NAMS és - ennek alapján - a $J K$ megkülönböztetett figyelemmel kezelte a közszolgálati média területét és a „Közszolgálatiság” a NAMS Jogalkotási Koncepció önálló szabályozási fejezete lett.

\subsubsection{Szabályozási kölcsönhatás a pillérek között uniós szinten}

A hazai médiaszabályozási reform szabályozási pillérei közötti kölcsönhatás mindenekelőtt uniós szinten jelentkezett. A tartalomszabályozásra irányadó korábbi uniós Televíziós irányelv újragondolását és az új irányelv, az $A V M S$ megszületését alapvetően ugyanis a digitális technológiák elterjedése, valamint az átvitel-technikai rendszerekre, az

\footnotetext{
${ }^{168}$ SWOT elemzés a stratégiaalkotás folyamatának egyik lépése: Strengths Weaknesses Opportunities Threats. A SWOT analízisröl ld. bővebben: NAMS 10.

${ }^{169}$ NAMS 5.

170 2011. december 31.

${ }^{171}$ GÁLIK III.12.
} 
elektronikus hírközlési hálózatokra és a digitális átállásra vonatkozó, a döntően 2002-ben elfogadott irányelvcsomag ${ }^{172}$ sürgette.

A digitális irányelvcsomag jelentős impulzust adott a médiatartalmak új technológiákkal kompatibilis szabályozásához, és az új uniós tartalomszabályozási irányelv megalkotásához. A Bizottság 2005 decemberében látta elérkezettnek az időt, hogy hozzálásson a határokon átnyúló televíziós müsorszolgáltatás, a tartalom újraszabályozásához. A magyar külügyminisztérium 2007. év áprilisi jelentéstervezete (Külügyminiszteri Jelentéstervezet) a készülő audiovizuális médiaszolgáltatási irányelvvel kapcsolatban megállapítja, hogy a javaslat figyelembe veszi a nézők audiovizuális tartalmak közötti választási lehetőségeinek bővülését, a lineáris és a nemlineáris szolgáltatások sajátosságainak szabályozási szükségleteit. Az irányelvtervezet célja, hogy a lineáris szolgáltatásokra vonatkozó jogszabályi környezetet modernizálja és egyszerüsítse, valamint minimumszabályokat vezessen be a nem lineáris audiovizuális szolgáltatásokra. A Jelentéstervezet a javaslatot összhangban állónak minősítette a Bizottság analóg müsorszórásról digitális műsorszórásra átállást szorgalmazó törekvésével, amely törekvés hozzájárult a lisszaboni stratégia megvalósításához. „Az új szabályozás [...] elöreláthatólag jelentősen befolyásolni fogja a tagállamokban kialakított, eddig csak a hagyományos televíziózásra és rádiózásra vonatkozó médiaszabályozást."

Az Európai Unió a német elnökség alatt elfogadta az irányelv tervezetének politikai megállapodását és közel végleges szövegét. „A gyorsan változó információs és kommunikációs technológiák, illetve a müsorszolgáltatási piacoknak az európai

\footnotetext{
${ }^{172}$ Az Európai Parlament és a Tanács 2002. március 7-i 2002/19/EK irányelve az elektronikus hírközlő hálózatokhoz és kapcsolódó berendezésekhez való hozzáférésről és azok összekapcsolásáról (Hozzáférési irányelv), az Európai Parlament és a Tanács 2002. március 7-i 2002/20/EK irányelve az elektronikus hírközlő hálózatok és elektronikus hírközlési szolgáltatások engedélyezéséról (Engedélyezési irányelv), az Európai Parlament és a Tanács 2002. március 7-i 2002/21/EK irányelve az elektronikus hírközlő hálózatok és elektronikus hírközlési szolgáltatások közös keretszabályozásáról (Keretirányelv), az Európai Parlament és a Tanács 2002. március 7-i 2002/22/EK irányelve az egyetemes szolgáltatásról és az elektronikus hírközlő hálózatokhoz és elektronikus hírközlési szolgáltatásokhoz kapcsolódó felhasználói jogokról (Egyetemes szolgáltatási irányelv), az Európai Bizottság 2002. szeptember 16-i 2002/77/EK irányelve az elektronikus hírközlő hálózatok és elektronikus hírközlési szolgáltatások piacának versenyéről, az Európai Parlament és a Tanács 2000. június 8-i 2000/31/EK irányelve a belső piacon az információs társadalommal összefüggő szolgáltatások, különösen az elektronikus kereskedelem egyes jogi vonatkozásairól (Elektronikus kereskedelemröl szóló irányelv, 114. lbj.).

${ }^{173}$ MAGYAR KÖZTÁRSASÁG KORMÁNYA J/2007. számú jelentése a Magyar Köztársaság európai uniós tagságával összefüggő kérdésekről és az európai integráció helyzetéről Budapest, 2007. április (Külügyminiszteri Jelentéstervezet) 71-72. Ld.: 280. lbj. és 460. lbj.
} 
audiovizuális piacot átalakító új fejleményei tükrében" ${ }^{174}$ a Bizottság javaslatot tett a határok nélküli televíziózásról szóló irányelvet módosító, az audiovizuális médiaszolgáltatásokra vonatkozó irányelvre (COM (2005) 646). A 2007/56/EK irányelv módosította a határok nélküli televíziózásról szóló irányelvet, és annak az 'audiovizuális médiaszolgáltatásokról szóló irányelv' - $A V M S$ - elnevezést adta.”Az irányelv kodifikált változatát 2010. március 10-én fogadták el (2010/13/EU). Az AVMS irányelv a korszerü technológia megoldásait figyelembe véve, felismerve az audiovizuális szolgáltatások kulturális és egyben gazdasági jellegét, - a határok nélküli televíziózásról szóló irányelvhez viszonyítva - a tárgyi hatályát kiterjesztette a lekérhető szolgáltatásokra, azaz a nem lineáris audiovizuális médiaszolgáltatásokra is, amelyben a médiaszolgáltató által összeállított müsorkínálat alapján a felhasználó egyéni lekérés alapján, az általa kiválasztott időpontban tekintheti meg a müsorszámokat. Az irányelv céljai között szerepelt, hogy bővítse a lekérhető audiovizuális szolgáltatások belső piacát, valamint hogy modernizálja a müsorterjesztő szolgáltatásokra vonatkozó szabályokat, különösen a reklámozás, a kereskedelmi kommunikáció szabályait. Az irányelv jogtechnikaiszabályozási elvként fogalmazta meg a tartalom egységes és az átviteltechnikától független elbírását, az elkülönített tartalom és átvitel szabályozást, a plurális médiarendszert és a fogyasztói érdekek kiemelt védelmét. Az AVMS deklarálta az audiovizuális szektor önálló iparági jellegét, azt, hogy ez a szektor is piacként müködik és versenyviszonyok jellemzik. Ennek megfelelően az $A V M S$ rendelkezései támogatják e piaci viszonyok müködését, fő céljának pedig a verseny élénkítését tekinti, amelyet a versenytorzulás elkerülésével, az egységes belső piac, az egységes információs térség ${ }^{175}$ megteremtésével és a jogbiztonság javításával kíván megvalósítani.

\section{A DIGITÁLIS ÁTÁLLÁS JOGSZABÁLYI FELTÉTELEI}

\subsection{A DÁS nemzetközi előzményei}

Az 1990-es évek elején az új gyártási technológiáknak köszönhetően az egyre gyorsabb és olcsóbb integrált áramkörök révén a digitális technika a televíziózás területén is megjelent. Az 1993-ban megalakult DVB Project konzorcium vállalta a vonatkozó szabványok kidolgozását és elterjesztését az egész világon. Ennek eredményeként kialakult a digitális

174 Fabrizio PORRINO Az Európai Unió ismertetése az Audiovizuális iparágról 2013. http://www.europarl.europa.eu/ftu/pdf/hu/FTU_4.8.2.pdf

${ }^{175}$ AVMS (11) 
televíziós - az ún. DVB (Digital Video Broadcasting) ${ }^{176}$ - szabványcsalád, amely az akkor ismert platformokon (mühold, kábel, földi) szabványosította a digitális sugárzás kódolásiés átviteltechnikáját. A média és hírközlés világában - tág értelemben - digitális átállásról az egész média-értéklánc vonatkozásában beszélünk, amikor a müsorgyártáson keresztül a terjesztésen át a müsor vételéig, azaz a tartalom fogyasztóhoz való eljuttatásáig az egész folyamat digitális technológiával és eszközökkel valósul meg. A digitális átállás lényege szükebb értelemben - a különböző müsorterjesztési platformok (földfelszíni, kábel, mühold, IP alapú, mobil kézi készülékes) analóg rendszereinek és szolgáltatásainak digitális rendszerekre és szolgáltatásokra történő átállítása, a legszükebb értelemben pedig a digitális átállás kifejezetten a földi analóg müsorszórás digitális müsorterjesztéssé alakítása.

A digitális átállás révén minden müsorterjesztési platform kapacitása jelentősen nő, a földfelszíni televíziós müsorszórás esetében frekvenciasávonként - a jeltömörítési módtól függően - akár öt-tíz televíziós csatorna müsora és számos más kiegészítő szolgáltatás is terjeszthető, szemben az analóg rendszer egyetlen televíziós müsorfolyamával. Mindemellett a szolgáltatás minősége is jelentősen javul, új interaktív és értéknövelt szolgáltatások vezethetők be, és a médiafogyasztási szokások is megváltoznak.

\footnotetext{
${ }^{176}$ Digital Video Broadcasting - A digitális televíziózásra vonatkozó nemzetközileg is elfogadott, páneurópai platform, nyílt szabványok gyüjteménye, amelyet a több mint 270 tagból álló nemzetközi, ipari konzorcium, a DVB Projekt ajánlásai alapján dolgoztak ki. A szabványokat az Európai Távközlési Szabványosítási Intézet (ETSI), az Európai Elektrotechnikai Szabványügyi Bizottság (CENELEC) és az Európai Müsorszóró Unió (EBU) Közös Műszaki Bizottsága (JTC) adja közre.
} 
MELYEK LEHETNEK A DTV POLITIKA FORMÁLÁSÁNAK FŐ SZEMPONTJAI?

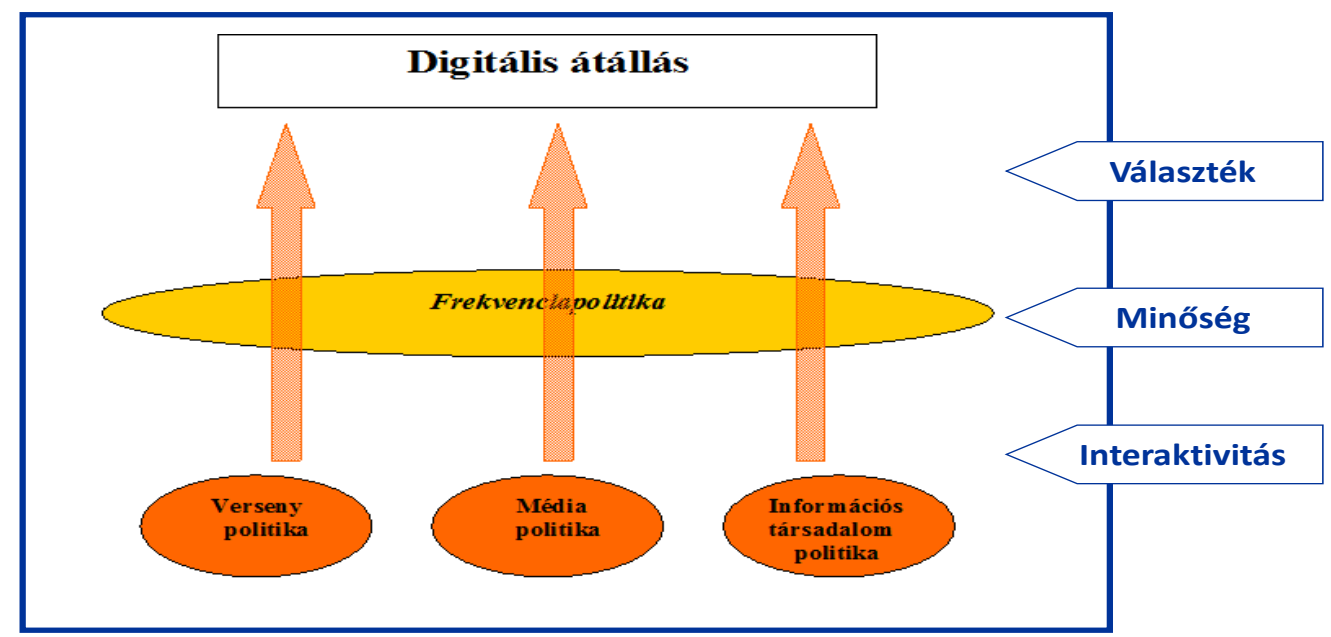

A digitalizáció gazdasági, kulturális és szociális nézőpontból egyaránt gyökeres változásokat hoz, ezért az államnak a digitális átállás során adódó kérdéseket mindig több szempont együttes mérlegelésével kell kezelnie.

\section{7. ábra A digitális átállás előnyei ${ }^{177}$}

„A digitalizáció jelentősen mérsékli az eddigi frekvencia szükösséget, hiszen a jelenlegi frekvenciatervek szerint is lehetővé válhat elvileg akár 30, később pedig akár 80 televízió csatorna digitális földfelszíni sugárzása szemben a jelenlegi hárommal (m1, RTL-Klub, Tv2). Emellett a felszabaduló frekvenciákon új elektronikus hírközlési szolgáltatások, valamint multimédia-alkalmazások, így a mobiltelefon és a földfelszíni műsorszórást ötvöző konvergens szolgáltatások (pl. mobil televízió) harmonizált bevezetését tervezi az EU."178

Az 1990-es évek első felében indultak be a müholdas és kábeles platformok, ( $D V B-S$ és $D V B-C)$ a digitális szolgáltatások. A rendszeres földi (DVB-T) sugárzást 1998-ban NagyBritanniában kezdték el, ezt több európai ország kereskedelmi szolgáltatása követte, így többek között - Belgiumban, Finnországban, Hollandiában, Németországban, Olaszországban, Svédországban és Spanyolországban. Az Európai Unió 2002-es, említett digitális irányelv csomagja előírta a földi analóg müsorszórásról a digitális

\footnotetext{
177 A szerző által „A Digitális Átállás Stratégiája a televíziózásban és a rádiózásban 2006-2012 (A)DÁS”, címmel tartott előadás Budapest, 2006. november. (DÁS prezentáció 2006)

${ }^{178}$ Dtv. Indokolás.
} 
műsorterjesztésre történő átállás müszaki-technológiai követelményeit és lefektette az átálláshoz kapcsolódó alapelveket. A jogi szabályozás elsősorban a müsorterjesztés piacát érintette leginkább. A hazai szabályozásban a digitális átállás állami jogalkotási kötelezettségét az Alkotmány ${ }^{179}$ rögzítette egyrészt az információhoz való jutás alapjogának deklarálásával: a jelet oda is el kell juttatni, ahova az üzleti alapon nem éri meg; másrészt pedig a véleményszabadság kifejezésével, nevezetesen azzal, hogy a sokszínü, kellően differenciált médiatartalom választási lehetöségével mindenki élhessen. ${ }^{180}$

Az állami szabályozási kötelezettség kizárólag a földfelszíni digitális müsorterjesztésre vonatkozott, hiszen a többi platform (mühold, kábel, IPTV, mobil) digitalizálását maguk a piaci szereplők oldották meg. A $D V B-T$ állami szabályozásának elindulása és eredményei óriási lendületet adtak a más platformokat üzemeltető hazai piaci szereplők digitális fejlesztéseihez, további jelentős beruházásaihoz. ${ }^{181}$

\subsection{Miért először a „digitális" törvény?}

Mivel a tartalom szabályozása szorosan összefügg a folyamatosan korszerüsödő átviteli rendszerek jogszabályi hátterének megteremtésével, a műszaki-technikai feltételek teljesítése és a tartalom-szabályozási folyamat lebonyolítása csak egységben, egymásra épülve és egymásra hatva képzelhető el. Az Európai Unió már említett digitális átállásra vonatkozó irányelv csomagja a '89-es Televiziós irányelv felülvizsgálatát is időszerüvé tette, sőt felgyorsította. A meghirdetett szabályozási reformot sok bírálat érte, amiért a jogalkotási folyamat nem az új médiatörvény megalkotásával kezdődött. A magyarázat pedig kézenfekvő volt: az átvitel-technikai pillér szabályozását nemzetközi kötelezettségvállalás sürgette, ugyanis Magyarország is csatlakozott azon uniós tagállamokhoz, amelyek az átállás kötelezettségét 2011. december 31-ig vállalták. A 2006. májusi $I T U^{182}$ genfi rádió-távközlési (frekvencia elosztó) konferencián ${ }^{183}$ az ehhez szükséges frekvenciákat hazánk megszerezte. Ahhoz, hogy a müszaki átállás a vállalt

\footnotetext{
179 1949. évi XX. törvény a Magyar Köztársaság Alkotmánya 61. § (1)

${ }^{180}$ SARKADY Ildikó - GRAD-GYENGE Anikó: A média-értéklánc szerzői jogi vonatkozásai MTMI 2012. (SARKADY-GRAD-GYENGE) 51.

${ }^{181} 2008$ tavaszán indult a UPC digitális és HD adása.

${ }^{182}$ KELLER 281.

${ }^{183}$ ITU RRC-06 (Regional Radiocommunication Conference Genf 2006. május 15-június 15.) értekezleten Magyarország összesen 8 digitális televíziós (DVB-T) és 3 digitális rádiós (T-DAB) multiplex (MUX) lehetőséget szerzett.
} 
határidőben megtörténhessen, az egyébként késésben lévő folyamat felgyorsítása érdekében először a jogszabályi kereteket kellett létrehozni. „Az Európai Unió tagállamainak nagy többségében a digitális müsorterjesztés jogszabályi háttere biztosított és a digitális földfelszíni műsorszórás elindult, vagy - mint például a Magyarországgal szomszédos országokban - a közeljövőben elindul. Magyarország azonban e téren jelentős lemaradásban van mind az Európai Unió régebbi 15 tagországával, mind az újonnan csatlakozott országokkal szemben: hazánkban - megfelelő stratégiai megalapozás és jogszabályi háttér hiányában - mind a mai napig nem indult el a digitális földfelszíni müsorszórás sem közszolgálati, sem kereskedelmi szolgáltatásként. Ez a lemaradás egyben azt is jelenti, hogy amennyiben a digitális átállással kapcsolatos jogalkotási lépések és kormányzati intézkedések nem történnek meg 2007 folyamán, nemcsak a szomszédos országokkal szemben maradunk le végérvényesen, hanem elértéktelenedik a genfi frekvencia-elosztási értekezleten megszerzett frekvenciavagyon is. Emellett késlekedésünk hátráltatja a környező országok digitális átállását is."

A digitális átállással összefüggő hatékony szabályozói fellépés, a digitális átállás jogi feltételeinek mielőbbi kialakítása azért is volt rendkívül fontos, mert az Európai Bizottság 2005. május 24-én, „az analógról a digitális müsorszórásra történő áttérés felgyorsitásáról" címmel kiadott közleményében 2012. január 1-jét jelölte meg az analóg földfelszíni müsorszórás beszüntetésére. Ennek értelmében Magyarországnak 2011. december 31-ig a digitális átállás folyamatát a földfelszíni platform esetében be kellett fejeznie. ${ }^{185}$ A másik ok, ami miatt a jogalkotást nem a tartalom kérdéseinek szabályozásával kellett kezdeni az volt, hogy ugyan akkor már két éve folytak az audiovizuális média tartalomszolgáltatására vonatkozó új uniós irányelv előkészítő munkálatai, de a vajúdás összesen öt évig tartott. Ésszerütlen lett volna a hazai jogalkotást ezzel a területtel indítani a tartalomszabályozásra vonatkozó új irányelv végleges szövegének ismerete nélkül.

\footnotetext{
${ }^{184}$ Dtv. Indokolás.

${ }^{185}$ SARKADY Ildikó: Digitális átállás - Meddig? Infokommunikáció és Jog 2012/3 (SARKADY VII.) 128133.
} 
HOL TARTUNK NEMZETKÖZI ÖSSZEHASONLÍTÁSBAN?

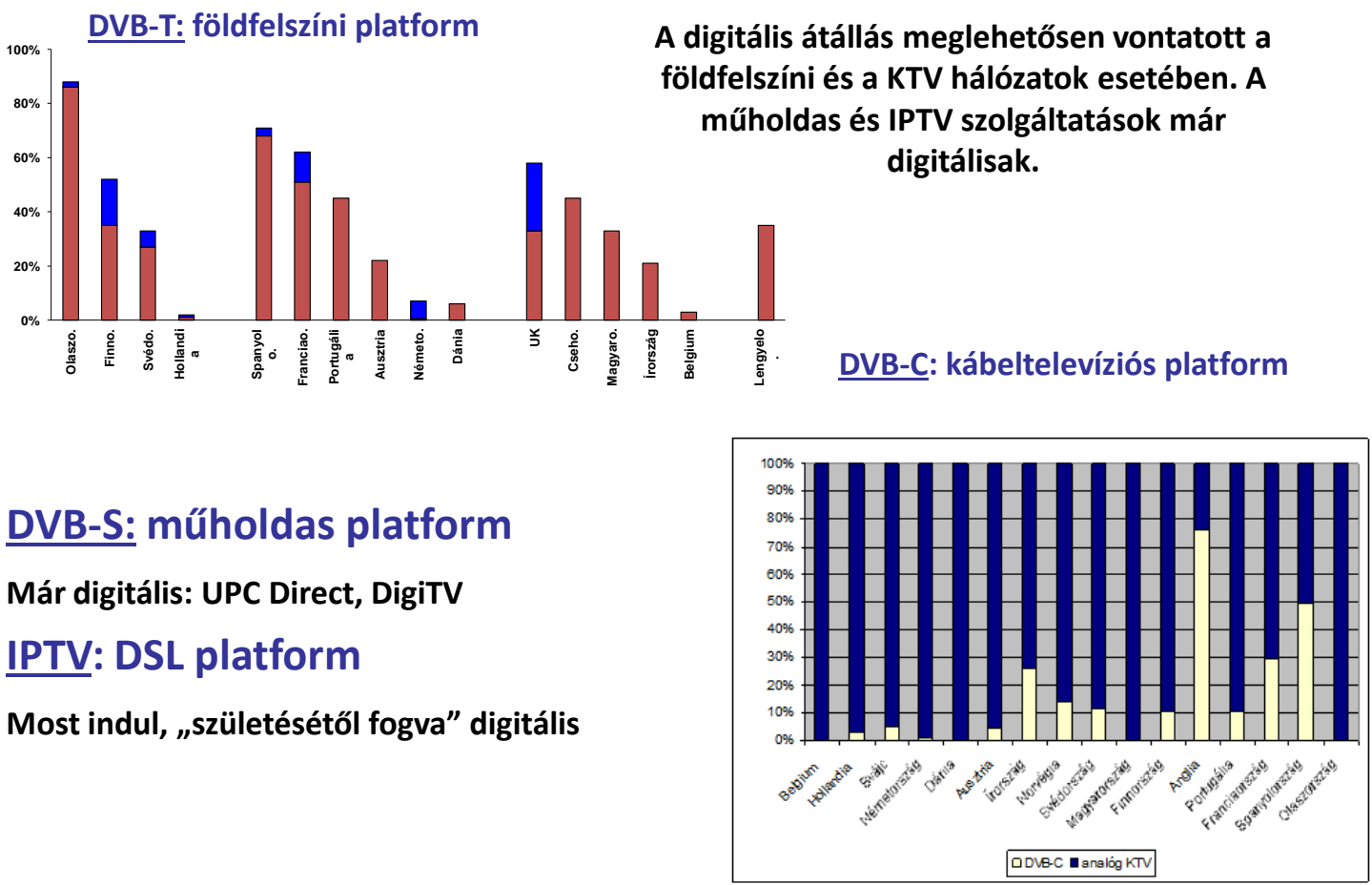

\section{8. ábra A digitális átállás hazai helyzete 2006 novemberében - nemzetközi összehasonlításban ${ }^{186}$}

Miközben a $M e H$-ben folytak az Rttv. jogharmonizációs célú munkálatai is, a tényleges szabályozási reform - az ismertetett okokból - a „hardverrel”, a müszaki-technikai feltételek kialakításával, az átvitel rendszerének szabályozásával kezdődött. Első lépésben a volt Informatikai és Hirközlési Minisztériumtól örökölt (A)DÁS lényeges tartalmi elemeit kellett átdolgozni és a médiaviszonyokra alkalmassá tenni. A digitális átállás feltételei mellett az akkor még szabályozatlan hazai müsorterjesztési piac rendezett müködési irányait - a jelentős hazai kábel-penetráció miatt - is szükséges volt kialakítani. A Dtv. szakmai előkészítő munkálatai kezdettől fogva a parlamenti pártok képviselőinek bevonásával folytak, a politikailag releváns kérdések tekintetében a pártok közvetlen egyeztetéseket is folytattak. E konzultációk eredményeként egyeztek meg a pártok például a pályázati eljárás elöírásai között a kiírási dokumentáció többlet feltételeiben, különös

${ }^{186}$ DÁS prezentáció 2006. 
tekintettel a hír-, illetve közéleti tartalmú müsorokat szolgáltató televíziós müsorszolgáltatókra. ${ }^{187}$

\subsection{Erős vagy gyenge multiplex?}

A digitális átállás jogszabályi feltételei kidolgozásának folyamatában az egyik leglényegesebb a multiplex $(M U X)^{188}$ szolgáltatói modell kérdésének eldöntése volt. A $D A ́ S$ is az egyik legfontosabb stratégiai döntési pontnak tekintette a földfelszíni multiplex pályáztatás során az 'erős' vagy 'gyenge' modell kérdésében való szabályozói döntést. ${ }^{189}$ Az erős multiplex modell esetében a szabályozói beavatkozás súlypontja a multiplex szolgáltató kiválasztása, illetőleg a szolgáltatói tevékenységre történő feljogosítása. A $M U X$-on helyet foglaló csatornákat, illetőleg szolgáltatásokat illetően a piaci döntések játszanak szerepet, ezért ez a modell üzleti szempontból vonzó. A gyenge multiplex modellben - ezzel szemben - a szabályozói beavatkozás közvetlenül a csatornákat és a szolgáltatásokat érinti, a multiplex szolgáltató kiválasztása és szolgáltatásra való feljogosítása nem alapvető fontosságú; emiatt a piaci szereplők e modellt a digitális földfelszíni platform üzleti akadályának is tekinthették. A $D A ́ S$ konzultáció során az álláspontok megoszlottak a $M U X$ modell tekintetében, a véleményezők egy része az üzleti hatásokat előre nem láthatónak minősítette, és emiatt nem formált véleményt a modell kérdésében. Az állami szabályozónak - a vázolt két egymással ellentétes hatás és következményei miatt - a modell tekintetében egyensúlyt kellett teremtenie. Az állami beavatkozás túlzott volta, a szükségesnél nagyobb adminisztratív és szabályozói hatáskörök telepítése a platformüzemeltetöre, (gyenge $M U X$ ) ugyanis a modell létét, müködését veszélyezteti, és a szükséges magánberuházások elmaradását eredményezheti. A kevés állami beavatkozás (erős $M U X$ ) ugyanakkor a közszolgálati müsorszolgáltatás háttérbe szorulásához, versenyjogi szempontból erőfölényes helyzetek kialakuláshoz és az azzal való visszaéléshez, ezáltal a média sokszínűségének csorbulásához vezethetett volna. Az erős vagy a gyenge multiplex-modell megválasztásának terén az erős

\footnotetext{
${ }^{187}$ Dtv. 39. § (2) b)

188 Dtv. 5. § 28. Multiplex: a digitális müsorterjesztés céljára szolgáló, audiovizuális és rádiós médiaszolgáltatásokat, kiegészítő médiaszolgáltatásokat, elektronikus hírközlési szolgáltatásokat, valamint ehhez kapcsolódó más azonosító jeleket és adatokat tartalmazó szabványosított jelfolyam.

${ }^{189}$ DÁS 33.
} 
modell biztosította a platform politikai kiszolgáltatottságának csökkentését, ezáltal nagyobb esélyt nyújtva az üzleti sikerre. ${ }^{190}$

Mindezen tényezők együttes mérlegelése alapján a multiplex modell tekintetében olyan stratégiai javaslat született, amely mindkét modell elönyeit szem elött tartotta, azonban alapvetően az erős modell mellett tette le a voksot. A szabályozásban meg kellett határozni az állami beavatkozásnak azt a mértékét, amely elengedhetetlenül szükséges a véleményszabadság és a média sokszínüségének fenntartásához, ugyanakkor - a multiplex üzemeltetői szerepkör vonzóvá tétele érdekében - biztosítja a platformüzemeltető üzleti szabadságát. Ennek megfelelően a legnagyobb lefedettségü $M U X$ l-en valamennyi, médiapolitikailag determinált televíziós és rádiós közszolgálati csatorna helyet kapott (gyenge modell), ${ }^{191}$ a $M U X 2$ és $M U X 3$ pedig a pályáztatás eredményeként nyertes platformüzemeltető által csatornákkal szabadon feltölthetővé vált (erős modell). ${ }^{192}$ A $D A ́ S$ javaslatait a Dtv. is átvette. Az erős $M U X$ modellt is támogató állami szabályozói döntés, miszerint a kereskedelmi $M U X$ üzemeltető saját maga, piaci alapon határozhatott a médiaszolgáltatók befogadásáról, jelentős hatással volt a médiaszolgáltatások liberalizációjára és a 2010. évi médiaszabályozásra is. Az erős MUX melletti szabályozói döntés - visszatekintve is - helyes választásnak bizonyult. A gyenge modell voks esetén ugyanis a földfelszíni platform időközbeni térvesztéséért elsődlegesen a „rugalmatlan szabályozást" tették volna felelőssé. ${ }^{193}$

\subsection{A Dtv. szabályozási céljai}

A Dtv. eredeti célja az akkor már igen előre haladott (országosan mintegy 70 százalékos) kábel és müholdas penetráció mellett a földi analóg müsorszórás számára megfelelö piaci esély és versenyhelyzet feltételeinek megteremtése, valamint egy ,egészséges” müsorterjesztési környezet kialakitása volt. Az átállás céljait és lényegét illetően a Dtv. indokolása a rögzíti, hogy „A digitális átállás levezénylése [...] bonyolult gazdasági és társadalmi hatású folyamat, amely a lakossági, szolgáltatói és kormányzati szektort egyaránt érinti, mivel

\footnotetext{
${ }^{190}$ ROZGONYI Krisztina: A digitális átállás folyamata és helyzete Magyarországon - régiós kitekintésben Médiakutató 2012 tél

191 „A kötelezendően továbbítandó közszolgálati csatornák számát a Nemzeti Audiovizuális Média Stratégia alapján legkésőbb a multiplex pályázat kírásáig kell meghatározni.” (A) DÁS 16. 42.

192 (A) DÁS 15.

${ }^{193}$ BOTH Vilmos - LUDÁNYI Arnold: Károm kérdés a digitális átállásról Médiakutató 2012 TÉL http://www.mediakutato.hu/cikk/2012_04_tel/05_digitalis_atallas (BOTH-LUDÁNYI)
} 
a) lényegében minden magyar háztartás a célcsoportja,

b) kibővíti az audiovizuális szolgáltatásválasztékot,

c) elősegítheti az információs társadalmi szolgáltatások terjedését,

d) jelentős szolgáltatói (adók, hálózat) és fogyasztói (dekóder, digitális vevőkészülék)

e) beruházásokat tesz szükségessé,

f) átrendezheti a piaci erőviszonyokat a hírközlési és a médiaszektorban,

g) gyorsítja az intézményi és szabályozási konvergencia-folyamatot.”

A digitális földfelszíni müsorszórás a frekvenciaszükösség és szabályozási hiátus miatt önmagában, piaci alapon nem indulhatott el. A különböző terjesztési platformok egyenlőtlen hazai eloszlása és a szabályozás teljes hiánya a versenyhelyzet torzulását eredményezte a műsorterjesztési piacon. A legszükebb értelemben vett digitális átállás, a földi analóg müsorszórás digitálissá alakításának szükségességét a technikai fejlődés és a piaci verseny követelte ki.

Az Európai Unió kezdetben a digitalizációt versenypolitikai kérdésként kezelte és hagyományos versenyjogi eszközökkel próbálta megakadályozni a digitális technikával rendelkező vállalkozások közötti integrációt. Az Európai Tanács már 1989-ben szabályozta a koncentrációk ellenőrzését; ${ }^{194}$ ennek alapján az Európai Bizottság több esetben is elutasította a digitális kódolási technikához kapcsolódó vállalkozások fúzióját. A müsorszolgáltatás és a hírközlés piacán jelentős erőt, piaci részesedést képviselö üzleti csoportok (Bertelsmann, Kirch Media Group és a Deutsche Telekom, illetve jogutód cégeik, a másik esetben a norvég Norsk Telekom, a dán Tele Danmark AS és a svéd Kinnevik cég) szövetkeztek volna feltételes hozzáférést engedő rendszerrel rendelkező társaságokkal. ${ }^{195}$ A koncentrációk korlátozásának versenyjogi alapja az volt, hogy a digitális müsorszolgáltatás technikai feltételeivel, azaz a feltételes hozzáférési technikával ${ }^{196}$ rendelkező szolgáltatók azáltal, hogy „kapuőrként” „gatekeepers”- ként korlátozhatják bizonyos csatornákhoz való hozzáférést és meghatározzák a kikódolás árszintjét, megakadályozhatják a müsorok eljutását a médiafogyasztókhoz. Ez a monopolhelyzet pedig megengedhetetlen a médiapiacon. A feltételes hozzáférés

\footnotetext{
194 A Tanács 4064/89/EGK rendelete (1989. december 21.) a vállalkozások közötti összefonódások ellenőrzéséről.

195 SARKADY Ildikó: A digitális müsorszolgáltatás jogi kérdései In: Médiajogi irások (SARKADY VIII.) 200-210.

196 Feltételes hozzáférési rendszer: minden olyan müszaki megoldás, intézkedés, illetve rendszer, amely lehetővé teszi, hogy valamely műszaki intézkedéssel védett rádió- vagy televízió műsorhoz előfizetés vagy más formában megjelenő előzetes egyedi feljogosítás alapján férjenek hozzá (Dtv. 5. § (1) 11.)
} 
(Conditional Acces) ugyanis olyan modullal működő technikai megoldás, amely a titkosított tartalmak visszafejtését biztosítja.

Jelentősebb változást a televíziójelek átvitelére szolgáló szabványok használatáról szóló irányelv ${ }^{197}$ hozott, amely egyértelművé tette, hogy a szolgáltatások és az azok közvetítését biztosító infrastruktúra kölcsönös hatással vannak egymásra, illetőleg rivalizálnak egymással. Ebből következően a digitális koncentrációk megelözésére a versenyjog hagyományos eszközei már nem bizonyultak elegendőnek. Az irányelv ugyan még versenyjogi alapon, de a digitális technikára vonatkoztatott speciális rendelkezésekkel szorgalmazta a szabad verseny élénkülését; így például a domináns piaci pozíció kialakulását gátló rendelkezéseket az irányelv együtt rendelte alkalmazni a tagállami, illetve európai szintű versenyjogi szabályozással. Az irányelv gyakorlatát elemző 1999-ben készült jelentés ugyan az irányelv sikeréről számol be, de a tényleges eredmény igen csekély: a feltételes hozzáféréssel rendelkező vállalkozások változatlanul prosperáltak, az ilyen technológiát nem alkalmazók pedig továbbra is kiszorultak erről a piacról. ${ }^{198} \mathrm{~A}$ közösségi érdekeket figyelembe vevő elvek több uniós jogforrásban is megjelentek, de ezek a kezdeményezések nem fogalmazódtak meg irányelvekben. A kezdeti uniós szabályozási elégtelenség azonban generálta azoknak a megoldásoknak a kidolgozását, amelyek a „,mindent szabad” szabályozási elv újra gondolását igényelték.

\subsection{A Dtv. módosításai}

A Dtv. és az Rttv. 2007. júniusi parlamenti megszavazását követően a kormánybiztos vezetésével tovább folytatódtak a NAMS szakmai egyeztető munkálatai, illetőleg a Stratégia eredeti szövegváltozatának átdolgozása és véglegesítése. A parlamenti pártok még áprilisban aláírt megállapodással kötelezték el magukat az új médiatörvény tervezetének 2008 végéig való kidolgozása mellett, a $M e H$ szakmai előkészítésével és koordinálásával. Időközben, 2007 tavaszán váltott tulajdonost a jelentős DVB-T pályázati eséllyel induló Antenna Hungária Zrt. ${ }^{199}$

\footnotetext{
${ }^{197}$ Az Európai Parlament és az Európai Bizottság 95/47/EC irányelve (1995. október 24.) a televíziójelek átvitelére szolgáló szabványok használatáról (Televíziós Szabvány Irányelv)

${ }^{198}$ A jelentés elemzését részletesen ld.: KOVÁCS András Péter: A digitális technológiák hatása az európai médiaversenyre 2001. május 9.

199 2007. május 9-én jelentette be a svájci Swisscom, hogy az Antenna Hungaria Zrt.-ben lévő 100\%-os tulajdonát 80,7 milliárd forintért eladja a francia Telediffusion de France részére. A versenyhivatali jóváhagyást követően 2007 júliusában megtörtént a tranzakció zárása, az Antenna Hungária Zrt. tulajdonosváltása.
} 
E tény - többek között - új megközelítésbe helyezte a Dtv. Országgyülés által már elfogadott szövegét. A politika és a szakmai elökészítés útjai elváltak. Míg az $A M K$ és a szakmai team az áprilisi megállapodás értelmében az új médiaszabályozás stratégiai megalapozásán, a politika a Dtv. első módosításán dolgozott. Ez utóbbi javaslat kialakítása szakmai előkészítés és társadalmi egyeztetés nélkül zajlott; a Dtv. első módosítási javaslatát - a médiaszabályozási reform mintegy két éves periódusa alatt először - a koalíció önálló képviselői indítványként nyújtotta be. ${ }^{200}$ A képviselői önálló indítvány útján történő törvénymódosítás 2007-ben egy fél évvel korábban szinte egyhangú parlamenti szavazással elfogadott, kifejezetten újszerü, elsősorban müszaki, technológiai szakmai kérdéseket taglaló, több rendelkezését illetően minősített többséget igénylö törvény esetében rendhagyó eljárásnak bizonyult. Anélkül, hogy az önálló képviselői indítvány jogintézményének létjogosultságát bármilyen szempontból és mértékben kétségbe vonnám, szükségesnek tartok rámutatni az Alkotmánybíróság (AB, Testület) évekkel későbbi, az új, 2010. évi médiaszabályozásra vonatkozó indítványok tárgyában hozott 165/2011.(XII. 20.) AB határozatára [1.2.], amely - többek között - foglalkozott a képviselői önálló indítvány jogintézményével is. A Testület tárgyi határozatát az új médiaszabályozás hatályba lépésekor még élő Alkotmány ${ }^{201}$ rendelkezései alapján hozta és deklarálta, hogy az Alkotmány 25. § (1) bekezdése alapján törvényt a köztársasági elnök, a Kormány, minden országgyülési bizottság és bármely országgyülési képviselő kezdeményezhet. Határozatában az Alkotmánybíróság megállapította, hogy a parlamentáris kormányzati rendszerekre jellemző hatalommegosztás rendjében a társadalmi viszonyokat átfogóan szabályozó törvényjavaslatokat jellemzően a Kormány terjeszti elő. Amennyiben nem a Kormány a törvényjavaslat előterjesztője, az előkészítőt nem köti a Kormány számára külön törvényben elöírt egyeztetési kötelezettség, ${ }^{202}$ azonban a törvényjavaslattal kapcsolatosan megfogalmazott kormányzati álláspont kialakítása során is indokolt a külön törvényben vélemény-nyilvánításra feljogosított szervek véleményének kikérése. Az $\mathrm{AB}$ 2011-es döntése kifejezte a társadalmi egyeztetés szükségességét még azon törvényjavaslatok esetében is, amelyeknél az előterjesztő nem a Kormány. A társadalmi, illetőleg az érintett civil- és szakmai szervezetekkel való egyeztetés hiánya ugyanis anélkül, hogy a törvény közjogi érvénytelenségét eredményezné -, az AB határozat

\footnotetext{
200 2007. évi CLIV. törvény a müsorterjesztés és digitális átállás szabályairól szóló 2007. évi LXXIV. törvény, valamint a rádiózásról és televíziózásról szóló 1996. évi I. törvény módosításáról (Dtv. első módosítása), az Országgyülés által elfogadva: 2007. december 3-i ülésnapon.

${ }^{201}$ Magyarország Alaptörvénye 2011. április 25.

202 2010. évi CXXX. törvény a jogalkotásról.
} 
értelmében - felveti a jogalkotó oldalán a politikai felelősség kérdését. Ennek az álláspontnak a Dtv. első módosítása tekintetében - $\mathrm{AB}$ határozat nélkül is - irányadónak kellett volna lennie, de az első módosítás sem szakmai, sem társadalmi egyeztetésen nem mérettetett meg. A Dtv. 2007. évi decemberi, első módosítása kardinális kérdésekben változtatta meg a júniusban elfogadott törvényt. Az akkor teljesen megalapozatlannak tűnő rádiós átállási céldátum meghatározásán túl - különösen a pályázati kiírási dokumentáció tekintetében - hozzáigazította az új piaci tulajdonos igényeihez és a politika ezzel kapcsolatos elvárásaihoz. ${ }^{203} \mathrm{Az}$ első módosítás korrekciót hajtott végre az országos kereskedelmi televíziók digitális átállási feltételei és az analóg földfelszíni müsorszórásuk leállítását illetően is. ${ }^{204}$ Ekkor változott meg a Nemzeti Hirközlési Hatóság (NHH) pályázat kiírási kötelezettségének határideje az átmeneti időszakban rendelkezésre álló négy digitális müsorszóró, valamint a digitális átállást követően rendelkezésre álló további egy digitális televízió műsorszóró hálózat üzemeltetési jogára, valamint e módosítással kerültek be a Dtv-be - nem vitatható módon - az új Médiahatóság és a Gazdasági Versenyhivatal együttműködésének szabályai is. ${ }^{205}$ A Dtv. első módosítása akkori szakmai indokolatlansága ellenére bizonyára hozzájárult a pályáztatás eredményességéhez, azonban már akkor látszottak a tényleges átállás késedelmének jelei és egyértelmüvé vált a tartalomszabályozási reform elhúzódása.

A 2010-ben létrejött médiaszabályozási rendszert megalapozó törvények a Dtv-t több ponton is érintették. ${ }^{206} \mathrm{~A}$ módosítások alapvetően az új médiastruktúra kialakításával kapcsolatban korrigálták a szervezeti elnevezéseket (Nemzeti Média-s Hírközlési Hatóság, Médiatanács stb.), aktualizálták a hatályba léptető és átmeneti rendelkezéseket, módosuló jogszabályokat. A digitális átállás forrásait az Mttv. telepítette a Müsorszolgáltatás Támogató és Vagyonkezelő Alaphoz és korrigálta a hatóságok közötti együttmüködés feltételeit, szervezeti kereteit. Az Smtv. hatályon kívül helyezte, illetőleg módosította a kiegészítő digitális szolgáltatások egyes szabályait, továbbá az Mttv-vel együtt beültette a Dtv-be az új médiarendszer érintett fogalmi meghatározásait (digitális szolgáltató/szolgáltatás helyett médiaszolgáltató/médiaszolgáltatás, vételkörzet fogalma, stb.). A vélemények sokszínűségét szolgáló rendelkezések, az alkotmányos

\footnotetext{
${ }^{203}$ Módosított Dtv. 39. § (2) b) c) l)

${ }^{204}$ Módosított Dtv. 39. § (2) c), (8)

${ }^{205}$ Módosított Dtv. 43. § (1), valamint 46. § (4)

${ }^{206} 2010$. évi LXXXII. törvény a médiát és a hírközlést szabályozó egyes törvények módosításáról, az Smtv., a 2011. évi CVII. törvény az Egyes elektronikus hírközlési tárgyú törvények módosításáról, valamint a 2011. évi CCI. törvény az Egyes törvények Alaptörvénnyel összefüggő módosításáról.
} 
kötelezettségek, valamint a továbbítási kötelezettségre vonatkozó rendelkezések hatályon kívül helyezésre kerültek, illetőleg aktualizálva illeszkednek az új médiaszabályozásba. A digitális átállás szempontjából e módosítások különösebb relevanciával nem bírnak. Jelentősége van azonban a Dtv. 38. § (1) bekezdésében foglalt televíziós átállási céldátum törvényi halasztásának, valamint a Dtv. első módosításakor már alkalmazott, a rádiós átállás vállalhatatlan feltételei miatt kétséges átállás esetére előírt „gumi szabály” televíziós átállásra történő adaptációjának. A 2011. január 1-vel hatályos rendelkezések szerint az átállásnak 2012. december 31-ig kellett volna megvalósulnia úgy, hogy a lakosság legalább 94 százalékát elérje a közszolgálati médiaszolgáltatás. „Amennyiben az előzőekben meghatározott feltételek a megjelölt időpontig nem biztosíthatóak, az audiovizuális médiaszolgáltatások terjesztése digitális átállásának határnapja az előzőekben meghatározott feltételek teljesülésével esik egybe, azzal, hogy a digitális átállás határnapja legkésőbb 2014. december 31.”

Ez a törvényi megfogalmazás a Dtv. rádiós átállásra vonatkozó első módosításától annyiban különbözik, hogy itt a végső céldátumot az Európai Unió által véghatáridőnek megjelölt időpont miatt mégis csak meg kellett határozni. A 2011. augusztus 3-tól hatályos módosítás törölte a digitális müsorterjesztési szolgáltatás vételére alkalmas „készülék rendelkezésre állását" előíró fordulatot a Dtv. 38. § (1) bekezdéséből és helyette konjunktív feltételként „,a lakosság számára kiskereskedelmi forgalomban elérhetőek legyenek a vételi eszközök" megoldást fogalmazta meg. E módosítás tartalma kétségtelenül a fogyasztó számára nagyobb biztonságot nyújt, de „kódolta” a digitális átállás elhúzódását.

A közszolgálati médiaszolgáltató analóg müsora leállításának csak a Nemzeti Média- és Hirközlési Hatóság (NMHH, Médiahatóság, Hatóság) elnöke által rendeletben meghatározott módon is időpontban volt helye. A leállást megelőzően legalább három hónapig, azt követően pedig egy hónapig volt lehetőség a digitális vevődekóderek versenysemleges állami támogatására. A 2012. január 1-től hatályos módosítás értelmében a Hatóság elnöke az államháztartásért felelős miniszter véleményének kikérésével rendeletben állapította meg a közszolgálati médiaszolgáltatások digitális vételének biztosítása érdekében a digitális vevődekóderek, illetve a vevődekóderek helyszínen történő beszerelésére, telepítésére, valamint az ehhez szükséges eszközök állami 
támogatására vonatkozó szabályokat és az állami támogatásra való jogosultsággal összefüggő adatszolgáltatás rendjét. ${ }^{207}$

\subsection{Digitális rádiós médiaszolgáltatás}

A Dtv. módosításai körében szükséges néhány gondolat erejéig kitérni a rádiós médiaszolgáltatás digitális földi terjesztésére, a rádiózás digitális átállására.

A rádióközlés, illetve a rádiós müsorszolgáltatás uniós médiajogi szabályozását illetően le kell szögezni, hogy az sem a 20. század végi, sem pedig az azt követő médiairányelvekben nem szerepel, sőt az AVMS kifejezett rendelkezéssel ki is veszi hatálya alól a rádiós szolgáltatásokat. ${ }^{208}$ „Ezen irányelv alkalmazásában az „audiovizuális” kifejezés a hangos vagy néma mozgóképre utal, így a némafilmeket is magában foglalja, de nem terjed ki a hangátviteli vagy rádiós szolgáltatásokra.[...]"

Mivel első médiatörvényünk a rádiós müsorszolgáltatást is a szabályozás tárgyává tette, így a magyar média jogtörténeti hagyományait követve, illetőleg a rádiós szakma jogos kérésének engedve a $D A ́ S$ és a $N A M S$ is külön teret szentelt a rádiózással kapcsolatos szabályozási kérdéseknek. A Dtv. eredetileg elfogadott változata - összhangban más nemzeti szabályozásokkal -, nem határozott meg céldátumot a rádiózás átállását illetően. A képviselői önálló indítványként előterjesztett első Dtv. módosítás azonban - a televíziós átállás 2011. december 31-i céldátumát nem érintve, - többek között - a világon akkor egyedüliként és különösebb szakmai indok nélkül meghatározta a rádiómüsorok földi terjesztésének digitális átállási céldátumát ${ }^{209}$ és a rádiós átállás egyéb feltételeit is. ${ }^{210} \mathrm{~A}$ digitális rádió műsorszórási szolgáltatáson keresztül történő közszolgálati műsorszolgáltatás 94 százalékos lakosság-elérési kötelezettsége és a lakosság 75 százalékos digitális készülékkel való ellátottságának törvényi elöírása a céldátumig a „jogalkotó” számára is kétséges lehetett, mert a módosított 38. § (2) bekezdésében a következő fordulattal élt: „Amennyiben az előzőekben meghatározott feltételek a megjelölt időpontig nem biztosíthatóak, a rádiómüsor terjesztés digitális átállásának határnapja az előzőekben meghatározott feltételek teljesítésével esik egybe.”

A megfogalmazás alapján a módosítási javaslatot tevők sem bíztak a feltételek megvalósulásában, ezért egy olyan „biztonsági szelepet” építettek a javaslat szövegébe,

\footnotetext{
${ }^{207}$ Dtv. módosított, 2012. január 1-től hatályos 53. § (2)

${ }^{208}$ AVMS (23)

209 2014. december 31.

${ }^{210}$ A Dtv. 2007. évi CLIV. törvény 3. §-ával megállapított 38. § (2)
} 
amely - lényegében - az egész rádiós lekapcsolás törvényi meghatározását kétségessé teszi. A Dtv. első módosítása tehát a világon elsőként és egyedül céldátumot határozott meg a rádiós médiaszolgáltatás földi terjesztésének digitálissá válásáról. Ez, az akkor még szakmailag megalapozatlannak tünő javaslat mára több országban is elfogadottá vált. ${ }^{211}$ Jelenleg a rádiózás fejlődésének egyik legfontosabb válaszútjához érkezett: marad az analóg terjesztési platformon és lassan, de biztosan megszünik önálló médiamüfaj lenni vagy halad a korral és digitálisan, bővített multimédiás szolgáltatásokkal továbbra is megtartja önálló platform jellegét. A digitális rendszerek $(D A B / D A B+)$ mindenekelött technológiai értelemben forradalmasítják a rádiózást, és számos előnyt jelentenek a médiafogyasztó hallgatók számára. A digitális technológiával egy frekvencián akár 10-20 rádiós csatorna müsora is továbbítható, valamint a hallgatók autózás közben, kedvezőtlen, változó terepviszonyok mellett is mindig egyenletes vételminőségben rádiózhatnak. A digitalizált jel sokkal jobb hangzást biztosít, valamint lehetővé teszi képi-szöveges kiegészítő információk átvitelét is. ${ }^{212} \mathrm{~A}$ digitális rádiózás gyors terjedését az segíti leginkább, hogy az autógyárak beépítik az új modellekbe a digitális vételre alkalmas készülékeket. Következtetésként rögzíthető, hogy a Dtv. első módosítása óta megváltozott hírközlési- és médiapiaci környezet, a terjesztési értéklánc rádiózáson kívüli teljes digitalizálódása szükségessé tették a korábbi stratégiák, a hagyományos üzleti modellek újragondolását és a digitális rádiózás melletti új érvrendszer kialakítását. Egyértelmüvé vált, hogy a rádiózás, mint önálló médiaműfaj nincs leáldozóban, sőt: bizonyos élethelyzetekben (autós rádiózás, háttér rádióhallgatás stb.), meghatározott célközönség számára preferált, illetőleg kizárólagos tartalom-hozzáférési lehetőség, és ez által jelentős, egyre nagyobb tért hódító reklámhordozó eszköz.

Az MRSZ, illetőleg az MLE által készített felmérések szerint 2012-ben a reklámtortán belül a rádiós költések aránya 3,9 százalék volt. Ez az arány 2013-ra 5 százalékra nőtt. A rádiós költések abszolút számokban 6.817 millió forintról 8.83 millió forintra, 29 százalékkal emelkedtek a két év viszonylatában. ${ }^{213}$ 2014-ben a rádiós költés adatai 0,1 százalékkal ugyan mérséklődtek, a rádió mégis jelentős tényező maradt a platformok versenyében.

${ }^{211}$ Európában elöször Norvégia fog átállni 2017-2019 táján. Elsöként állnak át a norvégok a digitális rádióra Origo 2015. 04. 22., Norvégia átállt a kristálytiszta digitális rádiózásra http://hu.euronews.com/2017/01/11/norvegia-atall-a-kristalytiszta-digitalis-radiozasra 2017. 01. 11.

${ }^{212}$ A digitális jel elönyei http://www.sat.hu/hirek/a-digitalis-tevek-utan-jonnek-a-digitalis-radiok/3160.html

${ }^{213}$ Rádiós költések 2012-2013 viszonylatában http://brandtrend.hu/2014/03/04/reklamtorta-2013-2/ 


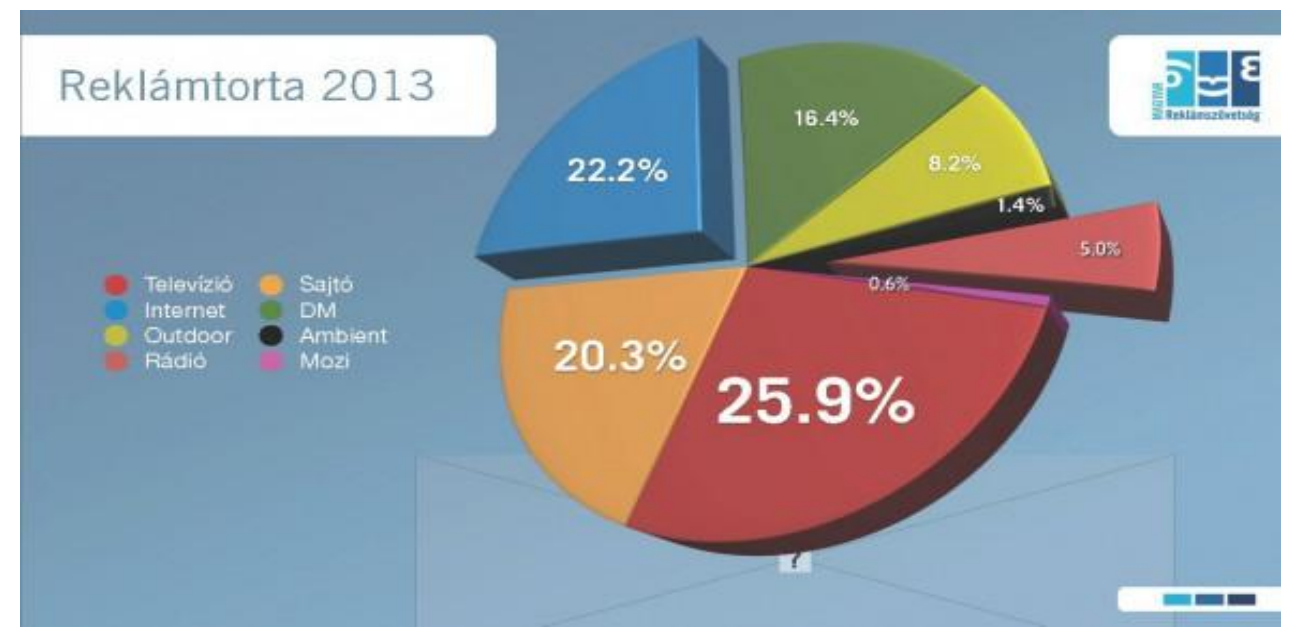

\section{9. ábra Rádióköltések aránya 2013-ban a reklámtortában}

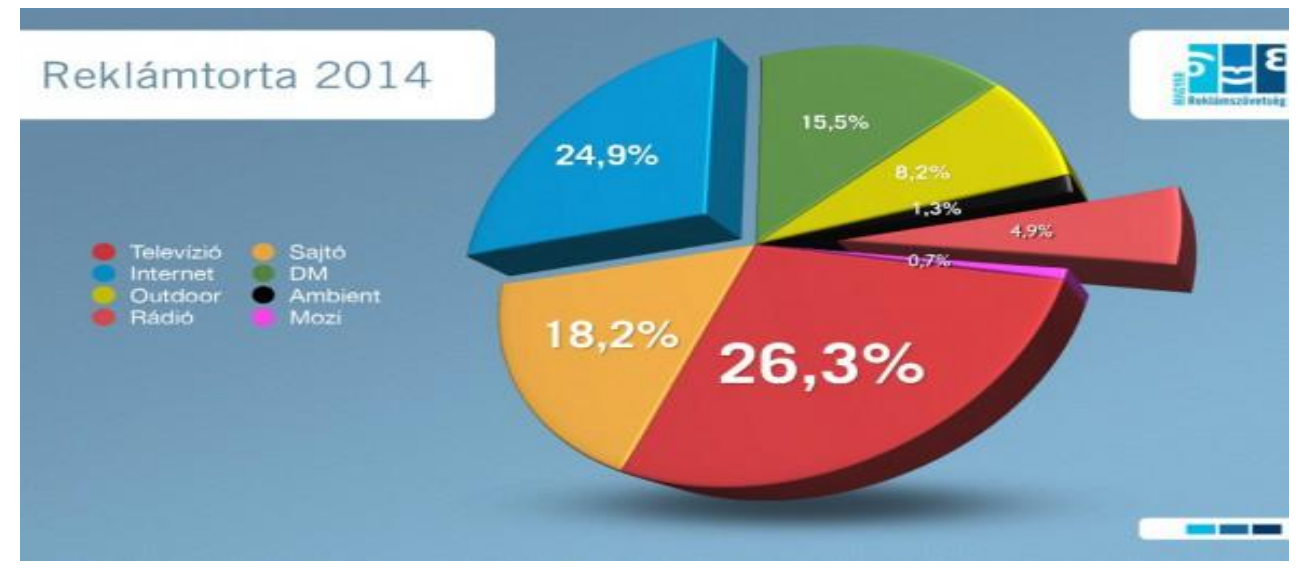

10. ábra Rádióköltések aránya 2014-ben a reklámtortában ${ }^{214}$

A feltett kérdésre tehát egyértelmü a válasz: A rádiózás digitálissá alakítása a terjesztés terén mindenekelőtt azért szükséges, mert - annak a hallgatók számára már vázolt előnyei mellett -, a rádió az egyetlen kommunikációs eszköz, amely lemaradt a digitális átállásban: müsorának terjesztése - annak ellenére, hogy a technológia mintegy húsz éve rendelkezésre áll -, nem valósult meg, csak a müsorgyártás környezetét korszerüsítette. Ennek megfelelően indokolt kívánalom, hogy a rádiózás is alkalmazkodjon a digitális multimédiás környezethez és megújuló platformként elsősorban azon fogyasztói szegmens

${ }^{214}$ Reklámtorta 2014 https://www.mediapiac.com/mediapiac/Reklamtorta-2014/112183/ 
számára nyújtson szolgáltatást, akik nem akarják vagy nem képesek önerőből más platformok szolgáltatásait igénybe venni. A multimédiás környezetben ugyanis minden médiafogyasztó megtalálja az adott élethelyzetben számára leginkább megfelelő médiaplatformot és ezek között a rádió az egyetlen, amelyik nem rendelkezik a legkorszerübb terjesztési technológiával. A hallgatottsági és reklámköltési adatok azt jelzik, hogy a rádiózás - különösen egyes napszakokban - igen jelentős tömegeket ér el, ugyanakkor az árbevételek nincsenek arányban az egyre növekvő hallgatottsági adatokkal, hiszen a rádió - éppen a korszerü technika hiánya miatt - nehezen kombinálható más médiaplatformokkal. A rádiózás digitális átállása a hazai rádiós szektor technológiai jövőképének kialakítása mellett tartalmi megújulását, kínált szolgáltatásainak és promóciós lehetőségeinek bővülését is eredményezné.

Ami a szabályozást illeti: A lineáris rádiós médiaszolgáltatók analóg adásaik sugárzására jelenleg a Médiatanács által lebonyolított pályázati eljárás keretében és hatósági szerződés feltételei szerint nyernek jogosultságot. ${ }^{215} \mathrm{~A}$ korlátos erőforrásokat igénybe vevő rádiós médiaszolgáltató hét évig érvényes, lejáratkor kérelmére pályázat nélkül egy ízben legfeljebb öt évre megújítható jogosultságot szerez. A megújításra irányuló igényt a jogosultság lejárta előtt - jogvesztő - tizennégy hónapos határidővel kell kezdeményezni. A Médiatanács a jogosultság megújításáról annak lejárta előtt legkorábban négy, legkésőbb hat hónappal dönt. A megújítást kizárja a szolgáltató szerződést vagy az Mttv. ismételt vagy súlyos megszegését megállapító jogerős médiatanácsi határozat, az Rttv. ${ }^{216}$ szerinti szerződés vagy törvénysértés, illetőleg büntetőjogi jogerős ítélet (a Btk. 329. §ában elkövetett büncselekmény miatt a médiaszolgáltatóval munkaviszonyban vagy munkavégzésre irányuló jogviszonyban álló személy által), valamint a médiaszolgáltató díjtartozása. Az Mttv. a pályázati eljárás rendjét, menetét, a jogosultság megszerzésének feltételeit részletesen szabályozza. E szabályokra kifejezetten a korlátos erőforrások igénybevétele, az analóg sugárzás miatt van szükség. A rádiózás digitális átállása feleslegessé tenné a rádiós médiaszolgáltatók számára e szabályok előírását és egyszerüsítené a rádiózás törvényi feltételeit. A szabályok - nyilván - a digitális televíziós médiaszolgáltatások egyszerübb, nyilvántartásba vételi szabályaihoz közelítenének, illetve hatályuk kiterjedne a digitális rádiós médiaszolgáltatások jogosítására is.

\footnotetext{
${ }^{215}$ Mttv. 48-63. § ld: NYAKAS Levente: Az audiovizuális és rádiós médiaszolgáltatások szabályozása In: KOLTAY-NYAKAS I. (NYAKAS II.) 517 - 530.

${ }^{216}$ Rttv. 112. § (1) b)
} 


\subsection{Az átállás elhúzódása}

A digitális átállás elhúzódása szakmai körökben értetlenséget váltott ki és jelentős sajtó visszhangot keltett. A 2010-ben napvilágot látott új dátum indokaként a javaslatot előterjesztők azt hozták fel, hogy az átállás a Dtv-ben eredetileg meghatározott céldátumáig a vevőkészüléket „nem vagy csak óriási pénzügyi és egyéb terhek útján” lehetne biztosítani az érintetteknek. Ezzel szemben több digitális átállással foglalkozó internetes híradás tényként rögzítette: „Jövő év közepére várhatóan már csak néhányszázezer (kb. 300-500 ezer) olyan háztartás lesz, amelyeket esetleg szociális alapú támogatással kéne ellátni valamilyen digitális vétellel.”

Újságírói javaslatként fogalmazódott meg, hogy az érintettek számára ki lehetne dolgozni egy más országokban már bevált kuponos rendszert, amivel platform-semlegesen kedvezményesen juthatnának hozzá a rászorulók vagy a földi digitális műsorsugárzás vételéhez szükséges vevőkészülékhez, illetve csatlakozhatnának kábeles vagy műholdas digitális szolgáltatáshoz. Az ehhez szükséges forrás kevesebb, mint az a költségvetést is érintő veszteség, amit a digitális átállás időpontjának elhalasztása okoz. Csak a közszolgálati m1-es adás éves analóg sugárzási díja több mint amennyiért a rászorulókat vevőkészülékkel lehetne ellátni. ${ }^{217}$

A digitális átállás időpontjának elhalasztásával Magyarország a korábban vállalt EU ajánlásoknak megfelelő időpontot nem tudta tartani és azt is akadályozta, hogy az analóg földfelszíni tévésugárzás leállításával felszabaduló frekvenciákat más célokra - többek között - a következő generációs LTE mobiltechnológiához ${ }^{218}$ lehessen hasznosítani. A késedelem következtében a pályázati győztes Antenna Hungária hiába nyerte el az öt televíziós multiplex üzemeltetését, abból kettőt csak az analóg lekapcsolás után indíthatott el, ami bevételkiesést eredményezett számára és az államnak is. Szintén kérdéses volt a két országos televíziós kereskedelmi csatorna digitális átállással kapcsolatos „sorsa”. Az átállás elhúzódása felvetette a két kereskedelmi csatorna analóg műsorszórásra vonatkozó koncessziójának megszünése utáni sugárzás mikéntjét is. ${ }^{219}$ Az RTL Klub és a TV2 csatornákat üzemeltető médiaszolgáltatók a terjesztési költségek csökkentése érdekében is a mielőbbi átállásban voltak érdekeltek, hiszen a simulcast időszakban éves szinten több

\footnotetext{
${ }^{217}$ Digitális átállás csak 2015-ben? 2010-12-22. http://www.hificity.hu/cikk.php?ident=7182

${ }^{218}$ Felszabaduló frekvenciák hasznosítása.

http://www.telekom.hu/rolunk/sajtoszoba/sajtokozlemenyek/2011/oktober_07

219, „[...] egyelöre a TV2 számára sem világos, hogy egy 2012. júliusi, halasztott analóg lekapcsolás után ’ milyen formában célszerü és lehetséges' a műsort a nézőkhöz eljuttatni. TORONTÁLI Zoltán: Digitális átállás teljes sötétségben Figyelő 2011. 01. 20. A koncesszió lejárta: 2012. július 9.
} 
milliárd forintos müsorszórási díjat párhuzamosan fizettek az analóg, és a digitális adásért az államnak. Az újabb dátummódosítás pedig az üzleti terveiket is befolyásolta. ${ }^{220}$

A Médiahatóság által a két kereskedelmi csatornával kötött hatósági szerződés 2012. július 9-ig szólt. A tárgyalások során a szolgáltatók jelezték, hogy a digitális átállás időpontjáig nem kapcsolják le az analóg adást és élni kívánnak az analóg müsorszolgáltatás, a szerződések ideiglenes meghosszabbításának lehetőségével, azaz továbbra is fizettek az analóg szolgáltatás után is az Antenna Hungáriának. Az elhúzódó simulcast időszak, a párhuzamos sugárzás a két kereskedelmi televízió számára milliárdos nagyságrendü, nem tervezett többletkiadással járt. Az országos kereskedelmi médiaszolgáltatók helyzetét nehezítette az a körülmény is, hogy az akkor hatályos médiaszabályozás szerint a digitális átállásig nem kérhettek programdíjat (müsordíjat) az analóg médiaszolgáltatásért a kábelszolgáltatóktól. ${ }^{221} \mathrm{Az}$ is megállapítást nyert, hogy „,a szabályozó hatóság nem sok erőfeszítést tett" ${ }^{\text {222 }}$ az átállás késedelméről szóló balsejtelmek eloszlatása, és a döntéshozatali folyamat átláthatósága érdekében. 2011-2012 idején egyértelmüvé vált: a digitális átállás elhúzódásának hatásai gazdaságiak, morálisak és politikaiak. ${ }^{223}$ „A digitális átállás Magyarországon már rég elkésett ahhoz, hogy a földi tévé müsorszórást megmentse. Ezért ideje lenne inkább a földi tévézés teljes lekapcsolásának határidejét kitűzni, hogy az erre a célra használt spektrum mihamarabb megnyíljon a vezeték nélküli szélessávú adatátvitel számára."224

Az átállás elhúzódásának következményei közül érdemes megemlíteni: 2012 februárjában a Radió Spectrum Policy (RSP) tekintetében az EU illetékes Bizottsága arról határozott, hogy a 892-960 MHz frekvencia sávot, a jelenlegi müsorszórási sáv felső részét, mint dividendet mobil szolgáltatásra kell fordítani. Az Európai Unió ezzel a döntésével felismerve, hogy a mobil technológiából származó szinte korlátlan eredeti lehetöségek rendkivül gyorsan és határtalanul bővithetök -, a frekvenciahozadék oda ítélésével további támogatást nyújtott a mobil platformnak. A 470 és a $790 \mathrm{MHz}$ közötti sávban ugyan még biztosítható volt az az öt televíziós multiplex, amit az Antenna Hungária a pályázaton

\footnotetext{
${ }^{220}$ „Politikai okai is lehetnek a TV2 és az RTL váratásának. Egy éven belül harmadszor módosította a digitális átállás határidejét az Országgyülés. Legutóbb tavaly december végén tolták ki az időpontot, 2014 végére. BEDNÁRIK Imre - NYUSZTAY Máté| Digitális tili-toli Népszabadság| 2012. január 19.

221 Mttv. Átmeneti rendelkezések 207. § (6) Az analóg földi terjesztésű, országos audiovizuális médiaszolgáltatás médiaszolgáltatója a Dtv. 38. (1) bekezdésében meghatározott időpontig médiaszolgáltatásáért programdíjat (müsordíjat) nem kérhet.

${ }^{222}$ BOTH-LUDÁNYI 1.

${ }^{223}$ SARKADY VII. 133

${ }^{224}$ PÁPAI Zoltán: Digitális átállás: utolsó pár előre fuss 2012. 03.14. http://infrapont.postr.hu/ (PÁPAI)
} 
elnyert, de a WRC 2012-es határozata elörevetítette, hogy 2015 és 2020 között az EU Bizottságának újabb döntése értelmében még jobban beszükülhetnek a lehetőségek: a 700 MHz-es sáv is szélessávú mobil szolgáltatásra kerül alkalmazásra. 2020 után pedig, amikor is lejár az Antenna Hungária hatósági szerződése, a már elnyert $M U X$-ok sem lesznek használhatók teljes bizonyossággal. Szükséges hangsúlyozni, hogy - amint azt az EU Bizottsága is belátta -, a mobil technológia a frekvenciát sokkal hatékonyabban használja fel, mint a földfelszíni müsorszórás, ${ }^{225}$ ráadásul - éppen e technológiai sajátosság miatt értékesebb, ezáltal versenyhelyzetben kereskedelmi szempontból is sikeresebb lehet. A hosszabb távú előnyök kiaknázása érdekében érdemes lenne megfontolni a további spektrumsávok felszabaditását, hiszen a földfelszíni műsorszórás jelentősége mind technológiai, mind pedig gazdasági szempontból egyre csökken. Az $N M H H$ digitális átállás monitoring 2011. első félévi kutatási eredményei szerint az analóg lekapcsolásban érintett háztartások aránya folyamatosan csökkenő tendenciát mutatott. Akkor a 3950 ezer tévéző magyarországi háztartás 21 százaléka, mintegy 853 ezer háztartás volt érintett az analóg lekapcsolásban; ebböl - az akkor mért adatok szerint - elsődlegesen érintett 650 ezer háztartás, másodlagosan érintett 203 ezer háztartás volt. A műholdas előfizetések terjedése a földfelszíni vételi módok visszaszorulásával járt együtt. Az országos televíziókat kizárólag földfelszíni analóg vétellel elérők aránya 2005 óta 38 százalékról 14 százalékra esett vissza. 2012-re a magyarországi tévéző háztartások 45 százaléka rendelkezett digitális tévévételi móddal. ${ }^{226} 2013$ végére, a teljes analóg lekapcsolás után a televíziózás nélkül maradt háztartások aránya csak 0,5 százalék volt, ami nemzetközi viszonylatban is kiemelkedően jó eredmény. A digitális átállás költségkeretéből két milliárd forintot is megspórolt az $N M H H .^{227}$

\footnotetext{
225 „A mobilhálózatok kis cellákból állnak, s így egy ország területén sokszor felhasználják ugyanazt a frekvenciát." PÁPAI.

${ }^{226} \mathrm{NMHH}$ adatok http://nmhh.hu/dokumentum/151795/dig_atallas_2012_tavasz_webre_vegleges.pdf

${ }^{227} \mathrm{NMHH}$ adatok http://nmhh.hu/tart/index/569/Hirek_a_digitalis_atallasrol\#sthash.bM3iZgn8.dpuf
} 


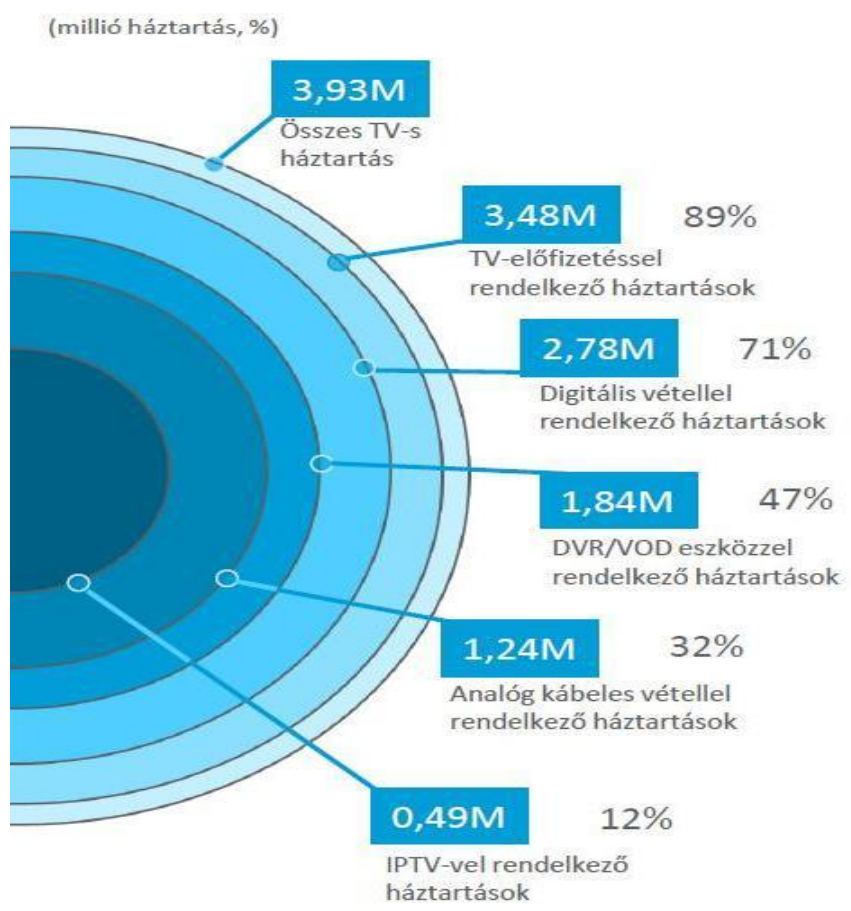

\section{1. ábra AGB Nielsen adatok a digitális televíziózásról 2014 őszén ${ }^{228}$}

A digitális átállást követően 2014 harmadik negyedévére az összes televízióval rendelkező magyar háztartás több mint 70 százaléka használ valamilyen digitális vevőkészüléket (a háztartások esetenként több vételi móddal is rendelkezhetnek); az IPTV elterjedtsége 10 százalék feletti. Az összes magyar tévés háztartás 89 százaléka, közel 3.5 millió háztartás rendelkezik TV-elöfizetéssel. Az analóg kábeles vétel 1.2 millió háztartásban elérhető, 2.8 millió háztartás pedig valamilyen digitális platformon keresztül fogja a televíziós adásokat, ezen belül az IPTV-vel rendelkező háztartások száma megközelíti a félmilliót. Az időeltolásos televíziózást lehetővé tevő $D V R / V O D$ eszközzel rendelkező háztartások aránya 47 százalék. ${ }^{229}$

A digitális átállással kapcsolatos folyamat értékelésének összegzéseként meg kell állapítani, hogy 1) a kezdeti szándék egyenes és egyértelmü volt: a digitális átállás jogszabályi és technikai feltételeinek megteremtése, a folyamat felgyorsítása. Az is leszögezhető, hogy 2) a szabályozási reform első szakasza mintegy „kegyelmi állapot”-ban

\footnotetext{
${ }^{228}$ Nielsen Közönségmérés, ES14 Alapozó Felmérés. http://nmhh.hu/tart/index/601/Televizio_havi_gyorsjelentes ${ }^{229}$ Nielsen Közönségmérés Alapozó Felmérés. http://nmhh.hu/tart/index/569/Hirek_a_digitalis_atallasrol\#sthash.bM3iZgn8.dpuf
} 
kifejezetten eredményes és sikeres volt. 3) „Ötpárti” tárgyalások eredményeként megszületett két kétharmados törvény, 4) Magyarország az utólag csatlakozott uniós államok közül a Dtv. megalkotásával elsőként teremtette meg a hazai digitális átállás jogszabályi feltételeit. 5) Az Rttv. jogharmonizációs módosításával, valamint a NAMS Jogalkotási Koncepciójával együtt „megágyazott” a tartalomszabályozásnak, az új tartalomszabályozási rezsim kialakításának. A Dtv. fentiekben idézett indokolásában megfogalmazott célok többsége örökérvényü igazság, másik része a folyamat során megvalósult, kisebb része pedig mára aktualitását vesztette. Összegezve: országos szinten a földfelszíni televíziós digitális átállás 2013. október 31-vel sikeresen befejeződött. ${ }^{230}$ Az átállás hazai folyamata kapcsán azonban - azt elsősorban a szabályozás oldaláról vizsgálva -, több megállapítást is meg kell fogalmazni.

1) A digitális átállás elhúzódása, a simulcast időszak kitolódása és a digitális hozadék hasznosításának késlekedése jelentős költségnövekedéssel járt, 2) a földi müsorterjesztés az átállás tényleges megvalósulásának idejére tovább vesztett eredeti platformpozíciójából, 3) az eredeti szabályozási szándék ebből következően, (a földi műsorterjesztési platform számára egyenlő versenyfeltételek biztosítása, valamint a közszolgálati műsorok földi platformon keresztüli minden háztartásba való eljuttatásának alkotmányos kötelezettsége) teljesen aktualitását veszítette. Ez utóbbi tény kapcsán pedig ma már joggal merülhet fel a kérdés: a hazai digitális átállás 2006-ban miért éppen a földi platform állami szabályozása útján volt elképzelhető? Az eredeti szabályozási szándék és a tényleges megvalósulás között ugyanis annyi idő telt el, amely a kezdeti célokat is kétségbe vonta. A válasz pedig nyilvánvaló: e kérdés annak idején fel sem merülhetett, hiszen az átállás szabályozási hátterének további késedelme eleve kétségessé tette volna a Dtv. létrejöttét és veszélyeztette volna a hazai átállás eredményességét. Szükséges megjegyezni azonban, hogy más tényezők, mint például a politikai támogatottság Dtv. elfogadását, különösen pedig a pályáztatást követő hiánya, az országos kereskedelmi műsorszolgáltatók analóg jogosultságának feltétel nélküli ORTT általi meghosszabbítása, részben elbizonytalanította a piaci szereplőket és érdektelenné tette a müsorszolgáltatókat is az átállásban.

A folyamat késedelmének eredményeképpen le kell szögezni azt is, hogy a digitális átállás pozitív hatásai elsősorban közvetett módon jelentkeztek. A digitális átállás szabályozási

\footnotetext{
${ }^{230}$ Nézőpont Intézet Médiamühely elemzése: Sikertörténet a digitális átállás 2013. november 20. http://nmhh.hu/cikk/161427/Nezopont_Intezet_Sikertortenet_a_digitalis_atallas\#sthash.BdnNbpbU.dpuf, http://nmhh.hu/tart/index/601/Televizio_havi_gyorsjelentes
} 
folyamatának kezdeti lendülete és a Dtv. viszonylag gyors, konszenzusos parlamenti elfogadása indított el olyan piaci folyamatokat, amelyek hozzájárultak a müholdas, kábeles és vezetékes piac fejlesztési döntéseihez, ${ }^{231}$ a müsorterjesztési piac élénküléséhez, a platformok egymás közti hasznos rivalizálásához, végeredményben pedig a terjesztési díjak csökkenéséhez.

\section{NAMS JOGALKOTÁSI KONCEPCIÓ: A MÉDIASZABÁLYOZÁS „SZOFTVERE”}

\subsection{A NAMS Jogalkotási Koncepció létrejötte}

A Dtv. 2007. évi képviselői indítvánnyal előterjesztett módosításával egy időben a tartalomszabályozás jogi kereteinek kialakítását, a $N A M S$ és az új médiatörvény kidolgozását a szakmai team végezte. A 2007. szeptember 5-én társadalmi vitára bocsátott $N A M S$ - koalíciós kezdeményezésre - nem osztotta a DÁS sorsát; nem lett a stratégiából kormányhatározat, amely konkrét határidőket és felelösöket nevezett volna meg a médiatörvény tervezetének összeállításával és előterjesztésével kapcsolatban. A NAMS elveire és tételeire figyelemmel ugyanakkor a kormánybiztos vezetésével véglegesítésre került a Jogalkotási Koncepció, amely a jelenleg hatályos médiaszabályozási rendszer alapjait lefektette és a főbb szabályozási elveket meghatározta. A Jogalkotási Koncepció a NAMS szakmai véleményezésének eredményét rögzítő 52 oldalas lényeget tartalmazó változata, amelynek célja a magyarországi - szük értelemben vett - médiaszabályozási reform elvi megalapozása volt. Míg a $D A ́ S$ kormányhatározattal történő elfogadása a dokumentumot az állami irányítás egyéb eszközei sorába emelte a konkrét feladatok, felelősök és határidők meghatározásával, addig a NAMS esetében a kormánykoalíció elzárkózott attól, hogy a Stratégia - a DÁS-hoz hasonló „utat fusson be”. A 2007. szeptember elején nyilvános vitára bocsátott $N A M S$ vitaanyagot és az ahhoz beérkezett szakmai véleményeket összegezve, olyan Jogalkotási Koncepció került kidolgozásra, amely a média-jogalkotás jövőbeni alapját képezte.

${ }^{231}$ BOTH-LUDÁNYI 3. 


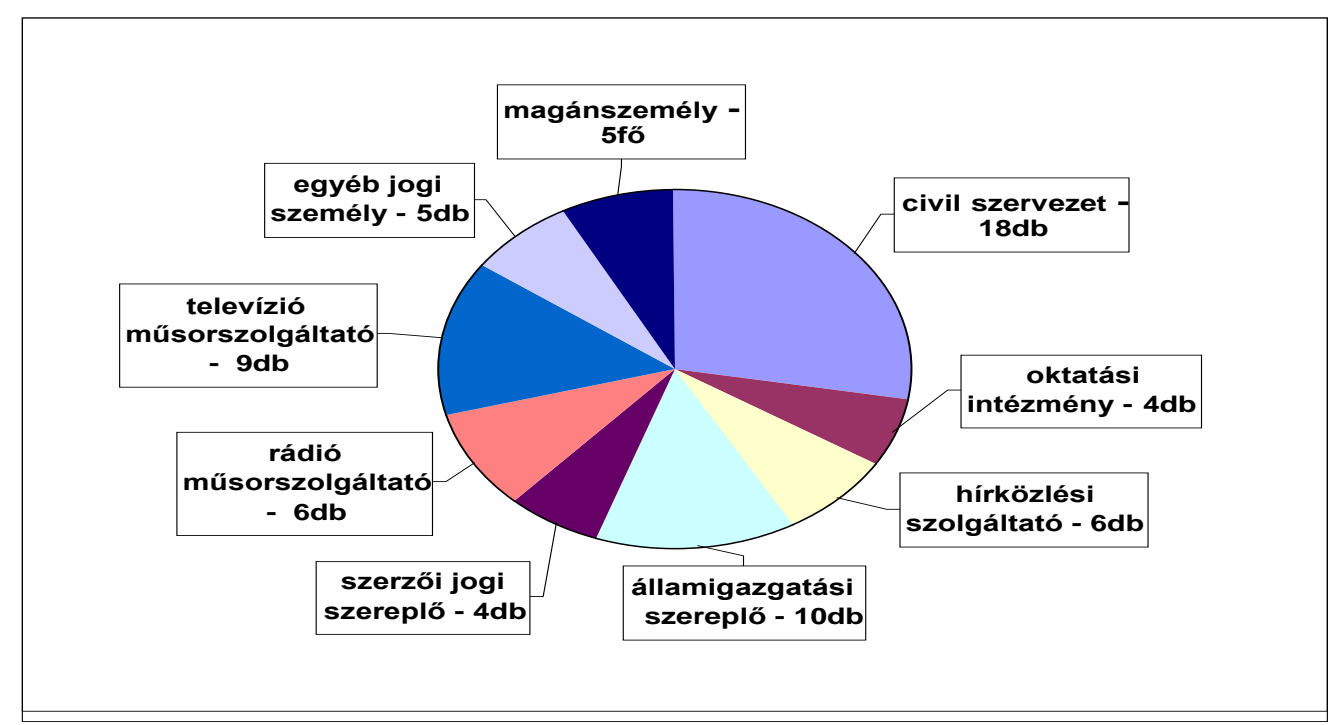

12. ábra NAMS szakmai konzultáció összesítése ${ }^{232}$

A 2007. október 5-én lezárult szakmai konzultáció keretében a $M e H$ honlapján elérhetővé tett NAMS vitaanyaghoz összesen 67 írásbeli hozzászólás érkezett, több mint 600 oldal terjedelemben. A projekt során a vitaanyag összeállítói több tucatnyi interjút készítettek a hazai hírközlési és médiapiaci szereplőkkel, közigazgatási szakemberekkel és a civilszervezetek képviselőivel. A beérkezett írásos véleményeket az $A M K$ feldolgozta és a $M e H$ honlapján összefoglaló dokumentumban is közzétette. A NAMS JK - számos szakmai észrevétellel megerősítve, - a médiaszabályozás középpontjába a médiapluralizmust, a vélemények sokszínüségét és a kulturális sokoldalúságot helyezte. A rádiós piac szereplői szinte egybehangzóan üdvözölték, hogy ugyan az audiovizuális irányelv nem tér ki a rádiós piac szabályozási kérdéseire, a hazai Médiastratégia - már csak a média jogalkotás magyar történeti hagyományaira is tekintettel - a rádiós tartalomszolgáltatókat az audiovizuális média szabályozási tárgykörében tartja. A hozzászólók kiemelték a szakmai vitaanyag minden korábbi hasonló tematikájú dokumentumnál átfogóbb jellegét, de egyegy témakör kapcsán bírálatok és építő kritikák is megfogalmazódtak. Az érintettek által képviselt eltérő érdekek miatt a sok esetben egymással ellentétes álláspontok közül a Jogalkotási Koncepció a vélemények közelítésével a társadalom, az állam és a piac szempontjából egyaránt legelőnyösebb megoldások feltárását szorgalmazta és építette be a szövegbe. A beérkezett szakmai álláspontok egyértelmüen konstruktív, építő-jellegü 
véleményt fogalmaztak meg, elismerve a médiaszabályozási reform átfogó jellegének szükségességét és a szabályozás teljes nyilvánosságot biztosító munkamódszerét;,,még a negatív észrevételek esetében is érzékelhető a véleményezőt átható szakmai felelősségérzet." 233 Összességében megállapítható, hogy valamennyi hozzászóló álláspontját a szakmaiság jegyében, és szakmai felelősségérzettől áthatva fejtette ki.

A Jogalkotási Koncepció MeH honlapon történő közzétételével egy időben, 2008 elejére egyértelmủvé vált, hogy a kormánykoalíció nem szorgalmazza a tartalomszabályozás, illetőleg az új médiatörvény olyan ütemben történő megalkotását, amint azt az Alapvetés, a NAMS, valamint a parlamenti pártok által 2007 áprilisában aláírt megállapodás célozta. ${ }^{234}$ Mivel a NAMS $J K$ nem lett kormányhatározat, az elkészült és nyilvánosságra hozott Koncepció a konzultációs folyamat során beérkezett, az audiovizuális média kormánybiztosának törekvéseivel és szemléletével összhangba hozható javaslatokat és felvetéseket tartalmazza, a kormánybiztos szakmai álláspontját tükrözi. A NAMS Jogalkotási Koncepció „,...] ilyen értelemben nem tekinthető sem a kormány, sem a koalíciós pártok szakpolitikusai által már elfogadott anyagnak."235

\subsection{A NAMS Jogalkotási Koncepció elvei, megközelítési módjai és célrendszere}

\subsubsection{A NAMS új szemlélete}

Az átfogó reformot a NAMS Jogalkotási Koncepció az új audiovizuális médiaszolgáltatási irányelv létrejöttével, a közszolgálati médiarendszer újragondolásának szükségességével, valamint a digitalizáció következtében megváltozott piaci környezettel, és a verseny élénkülésével is indokolta. A koherens audiovizuális stratégia, illetőleg az ezen alapuló és kiszámítható szabályozás kidolgozása már régi adóssága volt a média-jogalkotónak. ${ }^{236} \mathrm{~A}$ korszerü médiapolitika és médiaszabályozás - a NAMS szakmai előkészítők álláspontja szerint - egy olyan rugalmas keretrendszer, amely a technológiai változásokat, a konvergencia folyamatokat, valamint a hagyományos médiapiaci értékeket együttesen

\footnotetext{
${ }^{233}$ NAMS JK 5.

${ }^{234}$ A parlamenti pártok szakpolitikusai 2007. április 25-én megállapodást írtak alá - többek között - a digitális átállás pályáztatási folyamatáról, arról, hogy a tartalomszabályozási kérdések tekintetében - a NAMS koncepciója alapján - folytatják az „ötpárti” egyeztetéseket és a Dtv. „pályázati eljárás eredményének kihirdetéséig az Országgyülés kétharmados többséggel elfogadja az audiovizuális médiaszabályozás tartalmi kérdéseit rögzítő média „Alaptörvényt”.”

${ }^{235}$ NAMS JK 3.

${ }^{236}$ Az új médiatörvény megalkotásának szükségességéről, illetőleg a napvilágot látott tervezetekről ld.: UDVARY I. 12-13. 1-6. lbj. Ld.: 973. lbj.
} 
figyelembe veszi, de amely a gyorsan változó müszaki és piaci környezetben is képes igazodási pontként szolgálni a piaci szereplők és a felügyelő hatóság számára. Az első haza médiatörvény érdemi és jogtechnikai hibái, illetőleg az alkalmazása során egyértelművé vált visszásságokat kiváltó rendszere, valamint az ezeket kezelni próbáló ad hoc szabályozói lépések igazolták az Rttv. korszerütlenségét és alkalmatlanságát a megváltozott médiapiaci környezetben, valamint a digitalizációt illetően is. Az első médiatörvény ,[...] egy tranzitperiódusban, súlyos párt- és társadalmi viták közepette született Rttv. óhatatlanul magán hordozza e viták nyomait, sebeit; [...]”237

A Dtv. csak átmenetileg volt képes az ORTT kettős funkcióját ${ }^{238}$ kezelni, a közszolgálati média szabályozása, intézményrendszere pedig folyamatos megújítást igényelt. A médiaszolgáltatás egész folyamatát érintő digitalizáció és konvergencia hatásai, a frekvenciaszűkösség minimalizálódása, a fogyasztói szokások várható átalakulása, valamint a müsorterjesztési piacon már látszódó versenyélénkülés mind olyan tényezők voltak, amelyek a korábbi szabályozási szemlélet radikális megváltozását eredményezték a Médiastratégia kidolgozásánál és az alapvető elvek lefektetésénél. A NAMS JK az Európai Unió integrált szemléletmódja alapján, az audiovizuális médiaszolgáltatásokkal összefüggő gazdasági, társadalmi és kulturális szempontok egységes és átfogó figyelembevételével, a lineáris és lekérhető tartalmak szempontjából pedig a tartalomtovábbitási platformok egységes kezelése szerint készült. A médiapiac szereplöinek szempontjai, az érintett hatóságok, államigazgatási szervek és a fogyasztók érdekeinek kiegyensúlyozott megjelenitése, valamint a vélemény-nyilvánitás alapjogának érvényesülése szintén a föbb megközelítési módok és elvek között szerepeltek. ${ }^{239}$

\subsubsection{Az Országos Rádió és Televizió Testület funkcióinak alkotmányossági kérdései}

A NAMS $J K$ a hazai médiaszabályozás átfogó reformjának szükségességét egyrészt az Rttv. már említett nyilvánvaló alkalmatlanságával és hiányosságaival magyarázta, a stratégiai megalapozás nélküli, korábbi ad hoc szabályozói lépéseket elégtelennek tartotta, másrészt pedig hivatkozott az Országos Rádió- és Televízió Testület alkotmányellenes müködésére vonatkozó alkotmánybírósági megállapításokra, és az ORTT testületi tagjai mandátumának közelgő lejártára is. Itt röviden szükséges kitérni az Alkotmánybíróság

\footnotetext{
${ }^{237}$ UDVARY I. 16.

${ }^{238}$ 46/2007. (VI. 27.) AB határozat.

${ }^{239}$ NAMS JK 4.
} 
vonatkozó, 46/2007. (VI. 27.) AB határozatára, amelyet mintegy tíz évvel az indítványok beadását követően, az ORTT müködésének kellő tapasztalatai birtokában hozott meg. Az Alkotmánybíróság több, az Rttv-t érintő indítvány alapján vizsgálta az ORTT, a Panaszbizottság, továbbá a közalapítványok kuratóriumi tagjainak jelölésére, valamint a müsorszolgáltatási engedélyek kibocsátására és a müsorszolgáltatói tevékenység felügyeletére vonatkozó szabályok alkotmányosságát. A következőkben a Testület határozatának a 2010-es médiaszabályozásra közvetlenül kiható, a jogalkalmazás irányát meghatározó megállapításaival foglalkozom. Az $A B$ mindenekelött leszögezte, hogy a müsorszolgáltatók sajtószabadságának megfelelö, állami beavatkozástól mentes, független és szabad müködésének fontos garanciája a médiahatóság átlátható, kizárólag a törvényeknek alá vetett müködése. Az ORTT-t ,átvilágító” határozatában az Alkotmánybíróság - többek között - alkotmányellenesnek minősítette és alkotmányos mulasztást állapított meg az ORTT kettős jogi státuszát (szerződő fél és hatóság), ${ }^{240}$ valamint az általa lebonyolított pályázati eljárást illetően. Határozatában az $A B$ mások mellett megállapította, hogy ,[...] az Országgyülés mulasztásban megnyilvánuló alkotmányellenességet idézett elő, mert nem biztosította törvényben, hogy a müsorszolgáltatási jogosultságra vonatkozó pályáztatás során az Alkotmány 61. § (2) bekezdésének megfelelően érvényesüljön a sajtószabadság. Mulasztásban megnyilvánuló alkotmányellenesség áll fenn továbbá azért is, mert az Országgyülés nem szabályozta törvényben az Alkotmány 57.§ (1) bekezdésének megfelelő, a müsorszolgáltatási jogosultság elnyeréséről szóló jogalkalmazói döntések teljes körü, érdemi bírósági felülvizsgálatának lehetőségét."

Az ORTT „kettős” funkciójával, , kettős jogi státuszával” kapcsolatban, nevezetesen azzal, hogy egyfelől hatóságként felügyeli a müsorszolgáltatókat, másfelől pedig az általa felügyelt müsorszolgáltatókkal a frekvencia-pályáztatás eredményeként polgári jogi szerződéses jogviszonyba is kerül, az AB határozat megállapította, hogy a kettős jogi természet különösen élesen jelentkezik az Rttv. 112. § (1) bekezdés d) és f) pontjaiban.

Az Rttv. 136. $\S$ (1) bekezdés „12. és” szövegrészét az Alkotmánybiróság alkotmányellenesnek nyilvánította és a következöket deklarálta: „,...] azáltal, hogy az ORTT közhatalmi jogosítványait összemossa a polgári jogi jogviszonyból származó jogokkal -, lehetőséget ad a hatóság önkényes, szubjektív jogalkalmazói döntésére

${ }^{240}$ Az ORTT kettős jogi státuszáról ld.: UDVARY I. 181-182. 
[754/B/1999. AB határozat, 534/E/2001.AB határozat], ezért nem felel meg az Alkotmány 2. § (1) bekezdésében biztosított jogbiztonsági követelményeknek."

Az alkotmányellenesnek nyilvánított 136. $\S$ (1) bekezdés „,12. és” szövegrész - az AB határozat értelmében - lehetőséget ad az önkényes jogalkalmazói döntésnek, ami a sajtószabadság érvényesülésének korlátozásával járhat. Udvary szintén megállapítja, hogy a médiatestület kettős jogi státusza sértheti a jogbiztonság alkotmányos elvét. ${ }^{241}$ Álláspontja szerint ugyanakkor e kettős helyzet a Ket. ${ }^{242}$ hatályba lépésével, azaz 2005. november 1-vel megszünt, mivel a Ket. biztosítja a hatósági szerződés megkötésének lehetőségét a közigazgatási határozat meghozatala helyett. Az ORTT kettős jogi helyzete és annak következményei nem ítélhetők meg kizárólag közigazgatási jogi szempontok alapján. A Ket. ugyan formailag ténylegesen megszüntette a kettős szerepkörből eredő ellentmondásokat, ugyanakkor nem szüntette meg a kettős jogi státuszból származó visszaélés lehetőségét és az $A B$ által megállapított jogbizonytalanságot.

Az ORTT jogalkalmazói státuszát, illetőleg az Rttv. 115.§ (4) bekezdésének értelmezésével kapcsolatos 1294/2001. (IX. 28.) számú ORTT határozat alkotmányosságát a vételkörzet korlátozása tárgyában hozott 2/2005. (II.10.) AB határozat - egy előtte folyamatban lévő ügyben bírósági kezdeményezésére - is elemezte. Az Alkotmánybiróság elvi jellegü határozata egyértelmüen megerősítette az ORTT jogalkalmazói hatáskörét, megállapítva: „Ez a határozat [mármint az 1294/2001. (IX. 28.) számú ORTT határozat (szerzői betoldás)] nem tekinthető az állami irányítás egyéb jogi eszközének, a jogalkotásról szóló 1987. évi XI. törvény (a továbbiakban: Jat.) 46. § (1) bekezdése alapján ugyanis határozatot kizárólag az Országgyülés, a Kormány, a kormánybizottságok, az önkormányzatok és az önkormányzatok szervei hozhatnak. A Jat. 54. §-a alapján jogszabály értelmezésére jogi iránymutatásként elvi állásfoglalásban van mód, amelynek kiadására az Országgyülés és a Kormány jogosult. A Jat. 55. §-a szerint pedig a miniszter és az országos hatáskörü szerv vezetője adhat ki irányelvet és tájékoztatót."

Az $A B$ megállapítása szerint az 1294/2001. (IX. 28.) számú ORTT határozat nem minősül a médiatörvény alapján hozott közigazgatási határozatnak sem, mivel az ORTT a később hozott 1331/2002. (IX. 12.) számú ORTT határozatban döntött az államigazgatási ügyben és szólította fel a müsorelosztót a jogsértéstől való tartózkodásra. Következésképpen mondta ki taláros Testület -, az ORTT-nek nem volt jogszabályi felhatalmazása az 1294/2001. (IX. 28.) számú ORTT határozat meghozatalára.

${ }^{241}$ UDVARY I. 181.

${ }^{242} 2004$. évi CXL. törvény a közigazgatási hatósági eljárás és szolgáltatás általános szabályairól. 
Udvary az $\mathrm{AB}$ határozatban a médiatestület státuszára vonatkozó, általa rendkívül előre mutatónak tartott alábbi megállapítását ${ }^{243}$ csak üdvözölni lehet: „Ez a határozat azonban általános értelmező határozatnak minősül, amelyben a médiatestület az inkriminált szakasz általa elfogadott értelmezését tette közzé. Ez az Rttv. alapján hatáskörébe nem tartozik, hiszen az ORTT jogalkotásra nem jogosult, hanem csak a jogszabály végrehajtása körében annak értelmezésére."

Az Rttv. 112. § (1) bekezdésének érintett pontjai az ORTT hatáskörét szabályozták a műsorszolgáltatók törvénysértése vagy nem szerződésszerű teljesítése esetére. ${ }^{244}$

Az ORTT polgári jog szabályai szerinti kötbérérvényesítési jogával kapcsolatban az Alkotmánybíróság nem találta alkotmánysértőnek a kettős funkciót; elismerte, hogy az ORTT a műsorszolgáltató szerződésszegése esetén az Rttv. alapján közigazgatási szervként és szerződő félként is, azaz kétféleképpen is érvényesítheti a kötbérfizetési szankciót aszerint, hogy számára melyik a kedvezőbb és hogy melyik garantálja inkább a végrehajtás sikerességét.

A felmondási jogra vonatkozó 112. § (4) bekezdés, valamint a 136. § (1) bekezdés alapján az ORTT egyfelől közigazgatási határozatot hozhat a műsorszolgáltatási szerződés azonnali felmondásáról, másfelől pedig egy adott közigazgatási eljárás eredményeként juthat arra a következtetésre, hogy a szerződés felmondására van szükség. Ez utóbbi esetben az ORTT közigazgatási eljárásban hozott határozata nem szünteti meg a szerződést, hanem a felmondás jogát a másik félhez intézett nyilatkozattal, azaz a polgári jog szabályai szerint gyakorolja. A müsorszolgáltató szerződésszegése miatti ORTT eljárások közötti választás lehetősége az Rttv. szabályozási konstrukciójából ered, ugyanis önmagában az a tény, hogy egy jogszabályban különböző jogágakhoz kapcsolódó jogintézmények keverednek, nem alkotmánysértő.

A Testület a müsorszolgáltatási jogosultságokra előírt pályázati eljárással kapcsolatos ORTT hatáskörök kapcsán leszögezte, hogy i) a jogosultság elnyerésének feltételeit (nyílt, átlátható és pártatlan eljárás) jogszabálynak kell meghatároznia ii) a hatóság valamennyi határozatát indokolnia kell, a határozatoknak a nyilvánosság számára hozzáférhetőnek kell

\footnotetext{
${ }^{243}$ UDVARY I. 152.

${ }^{244}$ Rttv. 112. § (1) „Ha a műsorszolgáltató az e törvényben, illetve a szerzői jogról szóló törvényben, valamint a müsorszolgáltatási szerződésben és rádióengedélyben elöirt feltételeket és előírásokat nem teljesíti vagy megsérti, illetőleg ha müsorszolgáltatóval a cselekménye elkövetésekor munkaviszonyban, vagy munkavégzésre irányuló más jogviszonyban lévö személy bünösségét a Btk. 329. §-ában meghatározott büncselekmény miatt jogerös ítélet állapította meg, a Testület [...]

d) érvényesíti a szerződésben megállapított kötbért,

f) azonnali hatállyal felmondja a szerződést $[. .$.$] "$
} 
lenniük, valamint iii) valamennyi határozattal szemben biztosítani kell a bírói felülvizsgálat lehetőségét. E feltételeknek az Rttv. nem felelt meg; a törvényi hiányosság pedig alkotmányellenes helyzetet teremtett. További hiátusként állapította meg az Alkotmánybiróság azt, hogy az Rttv. nem rendelkezik a benyújtott pályázatok határidejéröl, valamint a határozatok indokolási kötelezettségéről sem. E hiányosságok az $A B$ értelmezésében kétséget ébreszthetnek a müsorszolgáltatók sajtószabadságnak megfelelö független müködését illetően. [IV.3.] Alkotmányos mulasztást állapított meg a Testület az Alkotmány 57. § (1) bekezdésében deklarált jogorvoslati jog szabályozásának médiatörvényi elmaradása miatt is, mivel az Rttv. nem biztosította a müsorszolgáltatást lezáró pályázati érdemi döntés elleni bírói út igénybevételének lehetőségét. A jogorvoslati jog törvényi lehetőségének megteremtése hiányában pedig nem érvényesül a műsorszolgáltatási jogosultság pályáztatása során a sajtószabadság. A „médiahatározat” mindezeken túl - az önrendelkezés jogából levezetve - deklarálta mindenki legszemélyesebb jogát a jogérvényesítés kérdéseiben való döntésre, nevezetesen arra, hogy polgári jogi igényeit a bíróság előtt szabadon érvényesíthesse, tartózkodjon attól, vagy éljen-e jogorvoslati lehetőséggel. Az Alkotmánybiróság 2007. évi „médiahatározata” meghatározó jelentőségű volt a jövő médiaszabályozásának szempontjából. Egyértelmủvé tette a médiahatóság jogalkalmazói hatáskörét, és több szempontú vizsgálata deklarálta az ORTT kettős jogi státuszának alkotmányellenes voltát. Az Alkotmánybíróság elöre mutató megállapításokat tett tovább az alkotmányos rend védelmének médiajogi szabályozását illetően is. Ez utóbbi körben az $A B$ leszögezte, hogy a müsorszolgáltatónak, mint minden jogalanynak tiszteletben kell tartania az alkotmányos rendet. Ennek - az Rttv-ben is rögzített alapelvi rendelkezésnek - az alapján az ORTT törvénysértés esetén szankcionálhat, amennyiben azt rendkívüli körülmények indokolják. Ilyen rendkívüli elvi példának hozta fel a határozat az alkotmányos rend alapját képező emberi méltóságot sértő ideológiát hirdető müsorszolgáltatói magatartást. A hatóság által alkalmazott joghátrányoknak ilyen esetekben fontos szerepe lehet az alkotmányos alapstruktúra tiszteletben tartása érdekében. A 2010-es új médiaszabályozási rendszer követte az Alkotmánybiróság határozatában foglaltakat az analóg lineáris médiaszolgáltatásra való jogosultság elnyerésére irányuló pályázati eljárás tekintetében, amikor is a Médiatanács határozatával szembeni bírósági felülvizsgálatot lehetővé teszi. ${ }^{245}$ Az új Médiahatóság jogalkalmazói státusza tekintetében, a hatályos médiatörvényi rendelkezések sem ruházzák

${ }^{245}$ Mttv. 62. § (5)-(6) és 63. § (4) 
fel a Médiahatóságot jogalkotói hatáskörrel a „kettős” jogi státusz tehát megszünt. A digitális technológia, a hírközlési hálózatokon megvalósuló müsorterjesztési digitális jelátvitel, a rádiófrekvenciák elosztásában és hasznosításában való hírközlési- és média hatásköröket gyakorló hatóságok együttmüködését, valamint a jogi szabályrendszer egymáshoz való közelítését és a felügyeleti intézményi keretek konvergenciáját is eredményezte. Az új, konvergens Hatóság jogi státuszát, feladatait és hatáskörét az értekezés Intézményrendszer címü fejezete tárgyalja.

\subsubsection{A NAMS Jogalkotási Koncepció célrendszere}

A NAMS rögzítette a Stratégia célállapotát és részletesen meghatározta a „,Tartalom”-, az „Átvitel” -, a „Fogyasztói” -, az „Intézmény” -, valamint a „,Finanszírozás” pillérek szabályozási céljait. ${ }^{246}$ A $J K$ a NAMS célrendszeréből kiindulva a szabályozás átfogó céljaként olyan versenyképes audiovizuális médiapiac létrejöttének előmozdítását határozta meg, amelynek keretei között az egymással versenyzö platformokon a szolgáltatások és tartalmak széles választéka biztosítja a kiegyensúlyozott müködést, érvényesül a véleménynyilvánítás szabadsága, a szólás- és sajtószabadság, valamint a tájékozódáshoz való jog. A Koncepció stratégiai célja a hazai audiovizuális médiapiac versenyképességi potenciáljának kihasználása, így különösen a hazai médiapiaci vállalkozások (tartalomelőállítók, műsorszolgáltatók) gazdasági súlyának és az európai piacon való jelenlétének növelése volt. A hazai médiavállalkozások az európai dimenzióban értelmezett versenyképességének növelése a szabályozás számára technikai szempontból is szükségszerüségként jelentkezett: a jogalkotó csak akkor számíthat alappal arra, hogy a szabályozás eszközrendszerével hatékony védelemben részesítheti a hazai fogyasztók érdekeit, ha a magyar médiapiacon bevételt elérő vállalkozások meghatározó része a hazai joghatóság alatt müködik. ${ }^{247}$

A Jogalkotási Koncepció a média-értéklánc alapján kijelölt pillérek mentén fogalmazta meg részletes céljait. ${ }^{248} \mathrm{~A}$ tartalom-elöállitás és az audiovizuális médiaszolgáltatások tekintetében a NAMS JK fontosnak tartotta a médiapluralizmus biztosítását, amelyet egyfelől az erős „közszolgálatiság” formájában, másfelől a kereskedelmi szegmens által szolgáltatott sokszínűségben látta megvalósulni. Szintén a szabályozás tartalom-

\footnotetext{
${ }^{246}$ NAMS 23-24.

${ }^{247}$ A joghatóság uniós és hazai szabályozása, valamint a joghatóság-váltás magyar tapasztalatai a származási ország elve és annak szükséges áttörése címü 6.2.8. számú alfejezetben kerül kifejtésre.

${ }^{248}$ Ld: 13. ábra.
} 
előállítással és az audiovizuális médiaszolgáltatásokkal összefüggő céljaként fogalmazódott meg a diverzifikált, minőségi, a vélemények sokszínüségének megjelenését biztosító országos és helyi médiaszolgáltatások létrejöttének elősegítése, a kulturális és nyelvi sokszínüség biztosítása, valamint az európai és magyar tartalom-elöállitás szorgalmazása. Ez utóbbi a közszolgálati médiaszolgáltatásban különös hangsúllyal szerepelt. Az emberi méltóság, a közrend, a gyermekek, a személyhez füzödö jogok és a kisebbségek védelme szintén a tartalom-elöállítással kapcsolatos célkitüzésként jelentek meg a Koncepcióban. Az átvitel tekintetében a NAMS a müsorterjesztő platformok hatékony, fenntartható és technológia-semleges versenyét, valamint a korlátos erőforrásokkal való hatékony gazdálkodást jelölte ki célként, a $J K$ pedig e célokat kiegészítette azzal, hogy a sokszínü, értékes tartalmak minél több müsorterjesztési platformon jelenjenek meg és jussanak el a médiafogyasztókhoz. A NAMS JK a szabályozással a fogyasztók védelmét szolgáló reklámszabályozás megalkotását, a tudatos médiafogyasztóvá nevelés ösztönzését, valamint a fogyatékkal élők médiafogyasztásának megkönnyítését kívánta elérni. Az intézményi pillér a felügyeletre vonatkozóan olyan, az audiovizuális médiapiacot irányító - felügyelő intézmény létrehozását irányozta elő, amely független és politikai befolyástól mentes, pénzügyileg és szakmailag autonóm szervezetként, világos, jogszabályban definiált struktúrában és müködési rendben, átlátható, ellenőrizhető és elszámoltatható módon müködik. ${ }^{249}$ A NAMS JK olyan finanszirozási rendszer kialakítását célozta, amelyben egyértelműen elhatárolható módon, a pontosan meghatározott feladatokhoz igazodva biztosítható a felügyeleti tevékenység, a közszolgálati médiaszolgáltatás, illetve a tartalom-előállítás támogatásának pénzügyi háttere. A rendszerben a finanszírozásnak a felügyelet tekintetében átláthatónak, normatívnak, költséghatékonynak, a közszolgálatiságra vonatkozóan feladatvezéreltnek, kiszámíthatónak és szintén normatívnak, végül pedig a tartalom-előállítás finanszírozásának átláthatónak és pályázati alapúnak kell lennie. ${ }^{250}$

${ }^{249}$ Az Európai Tanács Miniszteri Bizottságának ,a műsorszolgáltatási szektor szabályozó hatóságainak függetlenségéről és feladatairól” szóló Rec. (2000) 23. ajánlása [Recommandation REC (2000) 23.]

${ }^{250}$ NAMS 17. 


\section{SZABÁLYOZÁSI PILlÉREK ÉS A JOGALKOTÁS TERÜleTEI A NAMS JOGALKOTÁSI KONCEPCIÓBAN}

\subsection{Szabályozási Pillérek és jogalkotási folyamatok}

A NAMS önmagában is öt szabályozási pillért, legmagasabb szintü kodifikációs területet azonosított, amelyek a Stratégia önálló fejezeteinek bázisát is képezték. A három vertikális pillért a - szük értelemben vett - tartalom, az átvitel és a fogyasztó alkotta, míg a horizontális pilléreket az intézményrendszer és a finanszírozás adta. A NAMS JK a hírközlési és médiaszabályozási kérdéseket egymásra tekintettel kezelte. A vertikális pillérek az audiovizuális média értéklánc felépítéséhez igazodtak, a horizontális pillérek pedig a teljes értékláncot átfogó olyan jelentős területekként kerültek meghatározásra, amelyeknél az intézményrendszer tekintetében lényeges közpolitikai és szabályozási eszközök bevezetése volt szükséges. Itt kell megemlíteni, hogy a szabályozási eszközcsoportok tekintetében a NAMS megkülönböztette a szűken vett médiaszabályozáshoz kapcsolódó, a médiaszabályozáson belüli intézkedéscsoportokat azoktól a szabályozási intézkedésektől, amelyek a médiával határos, „szélesebb jogi környezetben lévő egyéb jogágak sajátos eszközrendszerén keresztül járulnak hozzá a $N A M S$-ban meghatározott média-specifikus célok eléréséhez."251

A NAMS leszögezte, hogy az egyes szabályozási területek nem határolhatóak el egyértelmü útmutató alapján, illetőleg e szabályozási területek rendkívül szoros kapcsolatban állnak egymással. A sajátos média-finanszírozási rendszer vonatkozásában horizontális szemléletre volt szükség; a pillérstruktúra értéklánc-alapú megközelítését a NAMS JK többek között azért tartotta szükségesnek, hogy a média- és hírközlési típusú szabályozási feladatokat - az uniós elvárásoknak megfelelően - el lehessen különíteni egymástól. A Koncepció az egyszerüsített értéklánc mentén haladva elemezte a médiapiacot és az ezzel kapcsolatos jogalkotási feladatokat, elkülönítve a hírközlés és az audiovizuális média szabályozási teendőit. Az audiovizuális szolgáltatások esetében a média-értéklánc már a NAMS megalkotásakor sokkal összetettebb és sokoldalúbb volt, új funkciók jelentek meg és az interaktív szolgáltatások következtében az értéklánc szereplöinek pozíciója adott esetben fel is cserélödött.

${ }^{251}$ NAMS 25. 


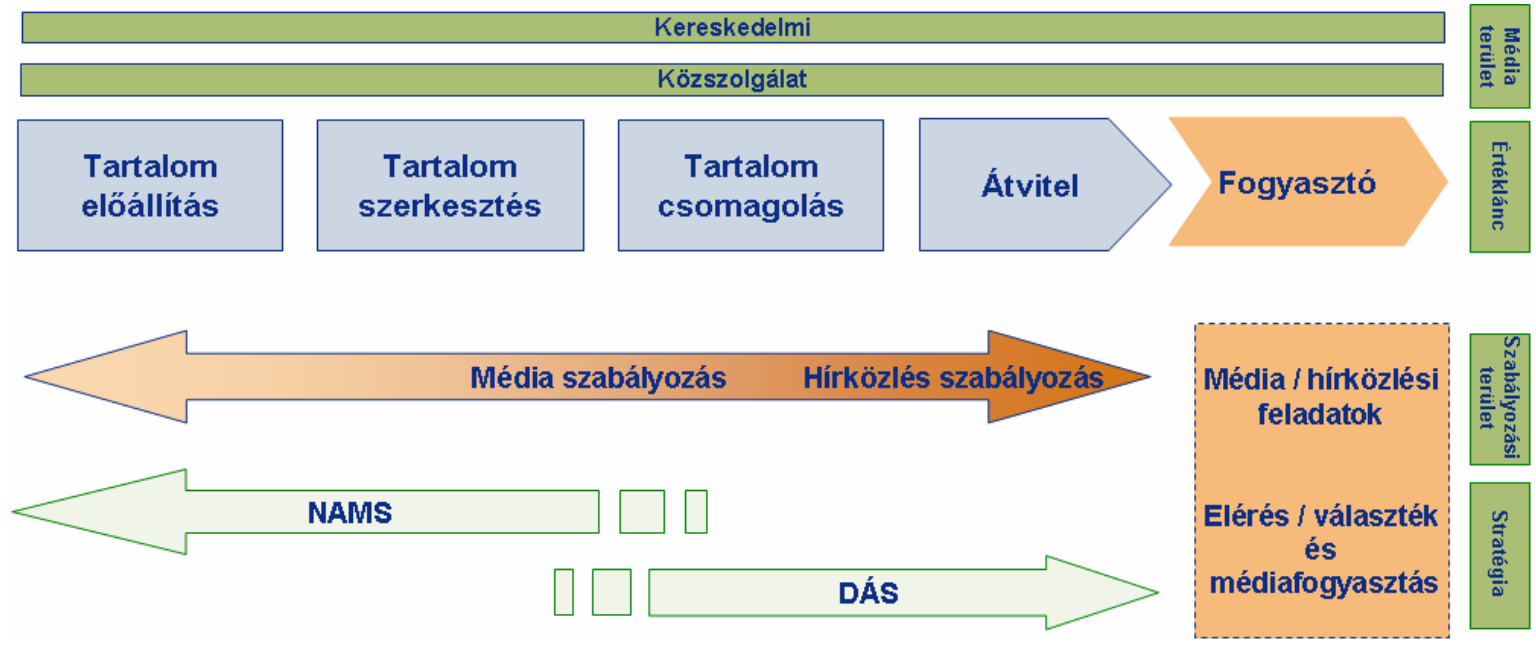

13. ábra a lineáris audiovizuális szolgáltatásokra értelmezhető egyszerüsített médiaértéklánc ${ }^{252}$

A digitalizációval az értéklánc ,,hálózatosodása ${ }^{, 253}$ új lendületet vett és már akkor látszott, hogy az értékláncon belül az egyes „láncszemek” közötti arányok eltolódhatnak. A kezdeti, leegyszerüsített értéklánchoz ${ }^{254}$ képest a médiaszolgáltatások előállítása és a médiafogyasztókhoz való eljuttatása egyre bonyolultabb, többszereplős rendszert alakított ki, amely rendszer alapvetően összefügg a médiakoncentrációs folyamatokkal és az audiovizuális szektor konvergencia jelenségeivel. ${ }^{255} \mathrm{Az}$ új típusú, speciális tartalom a felhasználó által elöállított, kreált tartalom (User Created Content,UCC) ${ }^{256}$; az így előállított tartalom a szerzői jogi szakirodalomban különbözik a felhasználó által generált tartalomtól, a User Generated Content,UGC fogalmától. Míg az UCC esetében kizárólag a felhasználó a szerzői jogi értelemben vett alkotó, a szerző, addig a más által előállított és hozzáférhetővé tett $U G C$ tartalmakat, szerzői müvet, szomszédos jogi teljesítményt úgy változtatja meg a fogyasztó vagy akár a felhasználó (hozzátesz, elvesz, átalakít stb.), hogy

\footnotetext{
252 NAMS JK 6.

${ }^{253}$ CSERMELY Péter: A rejtett hálózatok ereje: Hogyan stabilizálják a világot a gyenge kapcsolatok? Vince 2005. In: SARKADY-GRAD-GYENGE 48, 119. lbj.

${ }^{254}$ Ld.:13. ábra.

${ }^{255}$ GÁLIK-POLYÁK 321.

${ }^{256}$ A szakirodalom már használja a User Uploaded Content, a UUC fogalmát is, ami a felhasználó által letöltött tartalmakat jelenti.
} 
ez a változtatás szerzői jogi szempontból felveti az átdolgozás vagy a többszörözés jogának problematikáját, illetőleg érinti a mű integritásának kérdéseit. ${ }^{257}$

A NAMS a megvalósuló kodifikáció mikéntjére, az eltérő szavazati arányos szabályozási tárgykörök törvényi elhelyezésére is kereste a megoldást: „Az egyes szabályozási eszközcsoportok megvalósítása során az Alkotmány és a közösségi jog által kitüzött keretek között szükséges eljárni, ám törekedni kell arra, hogy a NAMS által kitüzött célokat - a számára biztosított mozgástéren belül- maximálisan figyelembe vegye a szabályozás." 258

A szabályozási területek egymással való szoros kapcsolata miatt a $N A M S$ a törvényalkotási folyamat során a kétharmados minősített-, illetve az egyszerü többséggel megszavazott kérdések szétválasztására két megoldást javasolt. ${ }^{259} \mathrm{Az}$ egyik változat a kétharmados többséget igénylö, illetőleg az egyszerü többséggel megszavazható tárgyköröket külön törvényben jelölte elhelyezni, amely ugyan egyértelmüvé teszi a jogalkotói akaratot, ám „koherencia zavarral járhat, amennyiben egymással szorosan összetartozó területeket kell külön jogszabályban kezelni." ${ }^{260}$ A másik kodifikációs alternatíva ${ }^{261}$ az egyetlen, egységes médiatörvény megalkotása volt, amely a médiaszektorral kapcsolatos valamennyi kérdést egy jogszabály keretein belül rendezi, és a szavazás során kerülnek elkülönítésre a kétharmados és az egyszerü többséges szabályozási kérdések. Mivel az Rttv. ez utóbbi módszer alapján került elfogadásra, a $N A M S$ a javaslatok megfogalmazása során felvetette az audiovizuális média jogfejlesztésének már korábban tapasztalt „,megbénulási” esélyét. ${ }^{262}$ Az Alkotmánybiróság 64/1991. (XII. 17.) AB határozatának indokolása ${ }^{263}$ értelmében alapjog tartalmának meghatározása és lényeges garanciáinak megállapítása csakis törvényben történhet, és törvényt kell alkotni az alapjog közvetlen és jelentős

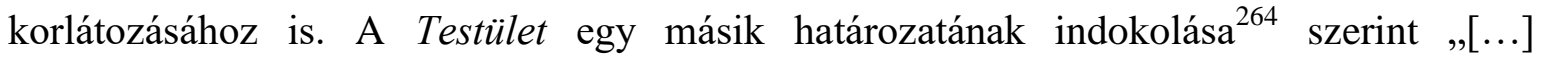
valamely, az Alkotmány által meghatározott törvény elfogadásához megkívánt minősített többség nem egyszerűen a törvényalkotási eljárás formai elöírása, hanem olyan alkotmányos garancia, amelyek lényeges tartalma az országgyülési képviselők közötti széleskörü egyetértés." A minősített többség követelménye - ebből következően -

\footnotetext{
${ }^{257}$ NAMS JK 7. SARKADY-GRAD-GYENGE 47-58.

${ }^{258}$ NAMS Javaslat 27.

${ }^{259}$ NAMS Javaslat 27.

${ }^{260}$ NAMS Javaslat (i) 27.

${ }^{261}$ NAMS Javaslat (ii) 27.

${ }^{262}$ NAMS Javaslat (ii) 27.

${ }^{263}$ 64/1991. (XII. 17.) AB határozat C) 2.

${ }^{264} 1 / 1999$. (II 24.) AB határozat 1.
} 
nemcsak az adott alkotmányi rendelkezés közvetlen végrehajtásaként kiadott törvény megalkotására vonatkozik, hanem a törvény módosítására (rendelkezéseinek megváltoztatására, kiegészítésére) és hatályon kívül helyezésére is. Mindezek alapján minősített többséggel elfogadott törvényt egyszerü többséggel elfogadott törvénnyel nem lehet módosítani vagy hatályon kívül helyezni. Az Alkotmánybíróság - ebből következően - csak a kétharmados minősített többségü törvény módosítása esetére zárta ki a kétharmados, illetve egyszerü szótöbbséges rendelkezések közötti különbségtételt, ezt egy minősített többségü új törvény megalkotása esetén nem írta elö. A Testület által a 64/1991. (XII. 17.) AB határozatban kidolgozott teszt analógiájára pedig az egyszerü és a minősített többségü rendelkezések elkülöníthetők. ${ }^{265}$ Mivel az új médiatörvény megalkotásának szükségességében szakmai és politikai konszenzus született, illetőleg egyértelművé vált, hogy az Rttv-t csak egy új médiatörvény válthatja fel, ez megnyitotta az utat a NAMS által javasolt második, (ii) verzió előtt. „Ha a jogalkotó teljes terjedelemben hatályon kívül helyezi az Rttv.-t (és adott esetben az Stv.-t), olyan tiszta lapra írhat, amelyen csak az Alkotmány rendelkezései, különösen a $61 . \S$ (2)-(4) bekezdései találhatók." ${ }^{266}$ Ezt az álláspontot támasztja alá a fentiekben már idézett 1/1999. (II. 24.) AB határozat indokolása $^{267}$ is. A 2010-es média-jogalkotás - vélhetően ezen alkotmányossági megfontolások és a korábbi médiatörvényi tradíciók alapján - az egyszerű és kétharmados szabályok egy törvényen belüli együttes elhelyezése, az „egységes szabályozás”268 mellett tette le a voksot.

\subsection{Kodifikációs területek és szabályozási fejezetek}

A NAMS JK a jogalkotás legfőbb területeit és szabályozási fejezeteit - a média-értéklánc folyamatában és a NAMS vitaanyag megközelítési módjai alapján - a következőkben határozta meg: i) tartalomra vonatkozó szabályozás ii) versenyszabályozás iii) közszolgálatiság iv) intézményrendszer v) finanszírozás.

A hatályos médiaszabályozás - lényegében a NAMS JK rendszerezése alapján - a szabályozási területek négy fő csoportját azonosította, a finanszírozási kérdéseket pedig nem önállóan, hanem minden szabályozási tárgyhoz rendelten kezeli:

i) a médiaszolgáltatások tartalmára vonatkozó előírások (tartalomszabályozás)

\footnotetext{
${ }^{265}$ ABH 1999. 41.

${ }^{266}$ UDVARY I. 205.

${ }^{267}$ 1/1999. (II. 24.) AB határozat Indokolás ABH 1999. 40.

268 165/2011. (XII. 20.) AB határozat. 1.3.
} 
ii) a piacra lépés szabályai (versenyszabályozás)

iii) a közszolgálati médiaszolgáltatás rendszere (közszolgálatiság)

iv) a médiaszolgáltatás felügyeleti rendszere, hatósági struktúra és eljárás szabályai (intézményrendszer).

A NAMS JK a szabályozásban nem kívánta együtt kezelni az audiovizuális médiaszolgáltatásokat és az írott sajtót, illetőleg annak termékeit. A sajtótörvényböl 2007re a módosítások eredményeként lényegében egy igazgatási jellegü, a sajtópiac müködésére érdemi hatást kifejteni nem képes jogszabály lett. Az első médiatörvény pedig tíz évvel a sajtótörvény után, már megalkotásakor magában hordozta az alkalmazása során előjött jogtechnikai és tartalmi hibák többségét. ${ }^{269}$ Az írott sajtó szabályozása „külön tartásának” indokai voltak még a korábban különálló, egymástól független, időben is távol eső és a szabályozás jogtechnikai színvonalában sem azonos szabályozási környezet, a lapkiadás elektronikus médiaszolgáltatásoktól eltérö, csak bejelentéshez kötött és szinte felügyelet nélküli rendszere, továbbá az $A V M S$ irányelv alanyi és tárgyi hatálya, amely az írott sajtóval egyáltalán nem foglalkozik. Egyesekben felmerült ugyan az egységes „kommunikációs törvény” megalkotásának gondolata, de az átfogó médiaszabályozási reform egyes pilléreinek felállítása és a stratégiák kidolgozása során - első körben - nem volt indokolt és időszerü a sajtójogi rendelkezések beemelése az elektronikus média törvényi szabályozásába. Ezt a feladatot a mintegy négy évvel későbbi jogalkotás elvégezte. Az Alkotmánybíróság már idézett 165/2011. (XII. 20.) AB határozata ${ }^{270}$ az új médiaszabályozási rezsimmel kapcsolatban megállapította, hogy az az eddigi hárompilléres szabályozási rendet (írott sajtó - elektronikus sajtó - telekommunikáció, hírközlés) átalakította, és egységes szabályozást alkotott. Az egységesen szabályozott és kezelt médiatartalom gyüjtőfogalmába beletartoznak a nyomtatott és az internetes sajtótermékek is, amelyeket egyéb médiaszolgáltatásoktól nem az előállítás technikája, hanem a tömegkommunikációban betöltött szerepük, befolyásoló képességük ${ }^{271}$ különböztet meg. A Testület e megállapításával kapcsolatban szükségesnek tartom hangsúlyozni, hogy a médiatartalom szabályozási kérdései korábban a sajtótörvényben, illetöleg a médiatörvényben kerültek megfogalmazásra. Az utóbbi törvény, az Rttv. a frekvencia állami monopóliuma miatt a müsorszolgáltatás jogának elnyerésére vonatkozó

\footnotetext{
${ }^{269}$ SARKADY Ildikó: A médiatörvény gyakorlati tapasztalatai (SARKADY IX.) 171-178. In: Médiajogi írások.

${ }^{270}$ 165/2011. (XII. 20.) AB határozat Indokolás 1.3.

${ }^{271}$ A véleménybefolyásoló képesség elméletéről és gyakorlatáról a Tételek a versenyszabályozásban című 8 . fejezet 8.2.1. és 8.2.3. alpontjaiban lesz részletesebben szó.
} 
pályáztatási feltételeket és ehhez kapcsolódó egyes távközlési kérdéseket is rendezte. ${ }^{272} \mathrm{Az}$ elektronikus hírközlési törvény megalkotásával azonban a média- és a hírközlési szektor szabályozása Magyarországon is elvált egymástól és a 2007-ben megalkotott Dtv. szintén ezt a folyamatot erősítette. Itt ismételten utalok arra, hogy a Dtv. átmeneti jelleggel, az új médiaszabályozás létrejöttéig bizonyos, az alkotmányos alapjogok érvényesülését is biztosító garanciális tartalomszabályozási kérdéseket is megfogalmazott. ${ }^{273} \mathrm{~A}$ Dtv. e rendelkezései utóbb átkerültek a médiatörvényekbe.

\section{SZABÁLYOZÁSI ELVEK ÉS CÉLOK A TARTALOM SZEGMENSBEN}

\subsection{Tartalomszabályozási elvek és célok}

A NAMS Jogalkotási Koncepció a tartalom-előállítás és az audiovizuális médiaszolgáltatások tekintetében meghatározott részletes célrendszer alapján, a célok megvalósítása érdekében a szabályozás számára a következő tételeket rögzítette:

\section{Az AVMS irányelv átültetése a hazai jogrendszerbe}

Az AVMS irányelvet 2009. év végéig ${ }^{274}$ kellett a tagállamoknak nemzeti jogrendszerükbe átültetniük. A $N A M S J K$ szerint az $A V M S$ a lineáris szolgáltatások tekintetében egyértelmü „harmonizációs kényszert” vezetett be, míg a lekérhető szolgáltatások tekintetében kijelölte az átültetéssel kapcsolatos nemzeti hatáskört. A Koncepció a hazai jogrendszernek és hagyományoknak megfelelően a szabályozás hatályát a televíziós müsorszolgáltatások mellett a rádiós müsorszolgáltatásokra vonatkozóan is fent kívánta tartani.

\section{Háromosztatú médiapiac}

A NAMS JK megállapította, hogy a magyar audiovizuális piac a közszolgálati, a kereskedelmi és közösségi müsorszolgáltatók „háromosztatú” rendszerén alapul és a médiarendszer szereplői eltérő célok érdekében, eltérö üzleti modellek szerint müködnek. A Koncepció ezért a három különböző müsorszolgáltató típusra eltérő szabályok

\footnotetext{
${ }^{272}$ Rttv. VI. fejezet Müsorszolgáltatási jogosultság 85-114. §, A Testület [ORTT] és a Hírközlési Főfelügyelet kapcsolata III. fejezet 2. cím 52. §

${ }^{273}$ Vélemények sokszínűségét biztosító rendelkezések Dtv. IV. fejezet.

${ }^{274}$ „A tagállamok hatályba léptetik azokat a törvényi, rendeleti és közigazgatási rendelkezéseket, amelyek szükségesek ahhoz, hogy ennek az irányelvnek [2007/65/EK irányelv] legkésőbb 2009. december 19-ig megfeleljenek." AVMS 2007/65/EK irányelv 3. cikk (1)
} 
megállapítását javasolta, ezen belül is eltérő szabályozást tartott szükségesnek az egyes szereplők lineáris és lekérhető szolgáltatásaira vonatkozóan.

\section{Piacfelügyeleti hatáskör}

A NAMS JK teret kívánt hagyni az új médiahatóság piacfelügyeleti hatáskörének, hogy biztosítani lehessen az átalakulóban lévő médiapiac rugalmas és hatékony felügyeleti kereteit.

\section{4. Ön-és társszabályozás}

Az ön- és a társszabályozást a $N A M S$ a tartalomszabályozás egyik jövőbeni lehetőségeként kezelte, a már müködő önszabályozó fórumokkal való együttmüködést, illetőleg a társszabályozás erősítését szorgalmazta. ${ }^{275}$ A NAMS értelmében az önszabályozás azokon a területeken (internet, újságírás) is biztosíthatja bizonyos társadalmi elvarások, értékek érvényesülését, amelyekre az állami szabályozás nem terjedhet ki. ${ }^{276} \mathrm{~A}$ Jogalkotási Koncepció a NAMS-ban megfogalmazott e célokon túl az ön- és társszabályozást - szintén a tartalomszabályozás keretében - a jogalkalmazó és a civil szféra közötti olyan együttmüködési formaként határozta meg, amely a megfelelő struktúrák kialakulása esetén kiegészíthetik az audiovizuális médiaszektor gyors változásaihoz kevésbé rugalmasan alkalmazkodni képes jogalkotást. A Koncepció ezért kereste azokat a kapcsolódási pontokat, ahol lehetőség nyílt a müködő ön-, illetve társszabályozás (alapelvek, kiskorúak védelme) tapasztalatainak hasznosítására. ${ }^{277}$

\section{Jogdogmatikai rendszerezettség}

A NAMS $J K$ a szabályozás jogdogmatikai rendszerezettsége érdekében a nem „médiaspecifikus" szabályokat az általános jogszabályokban, a televíziós és rádiós lineáris szolgáltatásokra, valamint a közszolgálati médiaszolgáltatás speciális szabályaira vonatkozó rendelkezéseket az audiovizuális médiaszolgáltatásokról szóló törvényben, a lekérhető szolgáltatások szabályait pedig az elektronikus kereskedelmi törvényben (Eker. tv. $)^{278}$ kívánta rendezni. A Koncepcióban - ennek megfelelően - már megjelent a

\footnotetext{
275 NAMS 13-14.

${ }^{276}$ NAMS 109.

277 NAMS JK 7.

278 2001. évi CVIII. törvény az elektronikus kereskedelmi szolgáltatások, valamint az információs társadalommal összefüggő szolgáltatások egyes kérdéseiről. (Elker. törvény)
} 
többszintü szabályozás igénye, valamint az azonos törvényi szinten is több médiaszabályozással kapcsolatos törvény megalkotásának szükségessége.

\section{Késleltetett hatálybaléptetés a lekérhetö szolgáltatásokra}

A fentiekben vázolt, hasonló szakmai érvek indokolták a lekérhető szolgáltatásokra vonatkozó szabályozás késleltetett hatályba léptetésének bevezetési szándékát a NAMS JKban. A stratégiai elgondolás szerint a lekérhető szolgáltatásokra irányadó szabályozás a müsorszolgáltatásokra vonatkozó törvény megalkotásával egyidejüleg elkészült volna, azonban hatályba léptetésére - versenyképességi megfontolások alapján -, a rádiós és televíziós müsorszolgáltatásokra vonatkozó szabályozás megalkotását követően, a többi európai tagállam szabályozási megoldásai ismeretében került volna sor. ${ }^{279}$

\section{7. Önkorlátozás a lekérhető szolgáltatások szabályozása során}

A NAMS JK tervei szerint a magyar szabályozásnak a lekérhető szolgáltatásokat zártan, az $A V M S$ adta fogalom-meghatározás keretein belül kell értelmeznie; a közösségi szabályok átültetése során pedig a Koncepció kevésbé beavatkozó magatartást szorgalmazott.

\section{Származási ország elve}

A tartalomra vonatkozó szabályozás terén lényeges volt, hogy - az akkor körvonalazandó közösségi joggal összhangban - a jogalkotó megteremtse a származási ország elvétől való eltérés lehetőségét, de kizárólag a közrend védelme érdekében. A származási ország elvével kapcsolatban a már idézett 2007 -es Külügyminiszteri Jelentés ${ }^{280}$ is leszögezi, hogy a joghatósági szabályok tekintetében Magyarország ragaszkodik a származási ország elve főszabályként való alkalmazásához, és ezen elv alól csak olyan kivételeket tart elfogadhatónak, amelyek esetén megfelelő garanciák állnak rendelkezésre.

\section{Alkotmányos értékek}

Az új médiaszabályozás szempontjából továbbra is elsődleges szempont volt az alkotmányos értékek megóvása, így különösen az emberi méltóság és a gyermekek védelme, a faji, nemi, vallási vagy nemzetiségi hovatartozáson alapuló gyülöletkeltés és negatív diszkrimináció tilalmának érvényesítése, valamint a vélemény-nyilvánítás szabadságának biztosítása, a tájékoztatás függetlenségének, a tárgyilagosságnak, a 
tájékozódás szabadságának, valamint a vélemények és a kultúra sokszínűségének alapelvei.

\section{Reklámszabályozás}

$\mathrm{Az}$ audiovizuális médiaszolgáltatásokban megjelenő reklámok $^{281}$ szabályozására vonatkozóan az $A V M S$ viszonylag tág mozgásteret kívánt biztosítani a nemzeti szabályozás számára. A NAMS JK a reklámszabályozás esetében is a jogdogmatikai szempontokat figyelembe véve, az általános reklámszabályokat a gazdasági reklámtevékenységről szóló törvényben, az audiovizuális média speciális reklámszabályait (kereskedelmi közlemények, a támogatás szabályai, a műsorok megszakíthatósága, közzétételi kötelezettség, stb.) az audiovizuális médiaszolgáltatásokról szóló törvényben tartotta célszerünek elhelyezni. Az AVMS irányelv által lehetővé tett újfajta reklámozási formákra tekintettel a $N A M S J K$ a vonatkozó szabályozásban differenciáltan kívánta kezelni a közszolgálati, a kereskedelmi és a közösségi müsorszolgáltatókat, illetve az általuk nyújtott lineáris és lekérhető szolgáltatásokat.

\section{Szerzői jog}

A NAMS JK a szerzői joggal kapcsolatos jogalkotási feladatokat nem a médiaszabályozásban, hanem a szerzői jogi szabályozás keretei között tartotta indokoltnak rendezni. A különböző film és audiovizuális archívumok felügyeletét ellátó intézményrendszer müködésének összehangolására, az indokolatlan párhuzamosságok felszámolására is javaslatot tett.

\section{Médiatudatosság}

Ahhoz, hogy a fogyasztók a sokszereplős médiatérben hatékonyan el tudjanak igazodni, a tudatos választás és fogyasztás a számukra biztosított legyen - a NAMS JK a médiatudatosságra való nevelésre és a médiaismeretek oktatására az eddiginél nagyobb hangsúlyt kívánt fektetni.

\footnotetext{
281 A NAMS JK a kereskedelmi közlemények szabályozását, illetőleg a kereskedelmi kommunikációra vonatkozó szabályozást a „reklámokra” vonatkozó szabályozás vagy a „reklámszabályozás” elnevezéssel is illeti.
} 


\subsection{A tartalomra irányadó $N A M S J K$ tételek a médiaszabályozásban, szabályozási tárgykörök}

\subsubsection{Rádiós müsorszolgáltatás, háromosztatú médiarendszer és közösségi médiaszolgáltatás}

1. Rádiós müsorszolgáltatás ${ }^{282}$

A Koncepció a hazai audiovizuális média szabályozás tárgyi hatályát a továbbiakban is fent kívánta tartani a televíziós müsorszolgáltatás mellett a rádiós müsorszolgáltatásokra is, megjelenítve a szabályozásban a rádiós és a televíziós médiaszolgáltatások társadalmi, kulturális, és finanszírozási különbségeit. Ennek érdekében a NAMS JK arányos és differenciált szabályozás kialakítását tüzte ki célul.

Az Smtv. és az Mttv. tárgyi hatályát továbbra is fenntartják a rádiós médiaszolgáltatásra is, a hazai médiatörvények hatálya pedig a Magyarországon letelepedett médiatartalomszolgáltató által nyújtott médiaszolgáltatásra és kiadott sajtótermékre vonatkozik. ${ }^{283} \mathrm{Az}$ audiovizuális médiaszolgáltatás Mttv-beli fogalma, a müsorszám ${ }^{284}$ Smtv-ben meghatározott definíciója egyértelmüvé teszik e törvények alanyi és tárgyi hatályának a rádiós médiaszolgáltatókra, illetőleg a rádiós tartalmakra való vonatkoztatását. ${ }^{285} \mathrm{Az} \mathrm{Mttv}$. tekintettel van a NAMS $J K$ differenciált és arányos szabályozási céljaira, a rádiós médiaszolgáltatás sajátosságaira, és érvényesíti a rádiós médiaszolgáltatás eltérő jellegéből eredő különbözőségeket - többek között - a lineáris rádiós médiaszolgáltatásban a zenei, illetőleg a magyar zenei kvóták megállapításánál, ${ }^{286}$ valamint a műsorszámok besorolásánál. $^{287}$

\footnotetext{
${ }^{282}$ A digitális rádiós médiaszolgáltatásról részletesebben ld.: 3.7. alfejezetet.

${ }^{283}$ Mttv. 2011. évi CCI. törvény 390. § b) pontjával módosított 1. § (1) hatályba lépés: 2012. január 1.

284 Mttv. 203. § 1. Audiovizuális médiaszolgáltatás: hangos vagy néma mozgóképeket, állóképeket tartalmazó műsorszámokat bemutató médiaszolgáltatás. Smtv. 1. § 3. Müsorszám: hangok, illetőleg hangos vagy néma mozgóképek sorozata, amely egy médiaszolgáltató által kialakított müsorrendben vagy müsorkínálatban önálló egységet alkot, és amelynek formája és tartalma a rádiós vagy televíziós médiaszolgáltatáséhoz hasonlítható.

${ }^{285}$ Az Mttv. 203. § 58. pontja értelmében rádiós médiaszolgáltatás az olyan médiaszolgáltatás, amely hangok sorozatából álló müsorszámokat mutat be.

${ }^{286}$ Mttv. 21. § (1) - (2)

${ }^{287}$ Mttv. 10. $§(3)$
} 
2. Triális magyar médiarendszer és a közösségi média ${ }^{288}$

A magyar médiarendszer „több lábon állása” már az Rttv-ben biztosított volt; helyi-, körzeti-, közmüsor-, közszolgálati, országos-, szakosított műsorszolgáltatás, illetőleg müsorszolgáltató fogalmát határozta meg a törvény. ${ }^{289} \mathrm{E}$ médiaszolgáltatási formák alapvetően követhetők az Mttv. rendszerében is: a vételkörzet szerinti kategóriák sztereo vétel esetén kiegészültek a kisközösségi médiaszolgáltatás típusával, de maradt: a helyi-, körzeti-, és az országos médiaszolgáltatás kategóriája. A médiaszolgáltatás jellege szerint a törvény közszolgálati és tematikus médiaszolgáltatást különböztet meg. ${ }^{290}$ A jelenlegi médiaszabályozás - sajátos módon - egyik médiatörvényben sem határozta meg a kereskedelmi médiaszolgáltató és médiaszolgáltatás definícióját és ilyen meghatározást az Rttv. sem tartalmazott. Az Mttv. ugyanakkor a korlátos erőforrásokat igénybe vevő analóg lineáris médiaszolgáltatások pályáztatási eljárására irányadó rendelkezései között a kisközösségi médiaszolgáltatások különös pályáztatási szabályainál kizárja a kisközösségi médiaszolgáltatás kereskedelmi jellegét, ${ }^{291}$ ezzel utalva a kereskedelmi jellegű szolgáltatás létére. Ez a „kisegítő” szakasz azonban nem pótolja azt az Mttv-beli hiátust, miszerint a kereskedelmi médiaszolgáltatás és a médiaszolgáltató fogalma nem szerepel a törvényben.

A közösségi műsorszolgáltató és a közösségi müsorszolgáltatás fogalma kifejezetten először a 2000. év végi médiatörvény tervezetekben ${ }^{292}$ jelent meg, majd „speciális lehetőségként az ORTT vezette be 2002-ben a közösségi jogosultsági formát, a kis, lokális közösségek rádiózásának megkönnyítésére. A kisközösségiek saját döntésük alapján vagy közmüsor-szolgáltatóként, vagy non-profitként müködtek; jellemzően inkább a non-profit státuszt választották."293

A NAMS nem kívánt szakítani a hazai médiaszabályozás hagyományaival, ennek értelmében fent kívánta tartani a közszolgálati, a kereskedelmi és a közösségi média triális rendszerét és e nevezett müsorszolgáltatókra vonatkozó differenciált szabályozást. A közösségi médiaszolgáltatás a NAMS háromosztatú médiarendszerének egyik önállósult szolgáltatási formájaként fogalmazódott meg, megállapítva, hogy a helyi

\footnotetext{
${ }^{288}$ A „közösségi média” kifejezés - nyilvánvalóan - jelen esetben az Mttv. Első Rész IV. fejezetében szabályozott szolgáltatást és nem az Európai Unió ún. „közösségi” médiaszabályozását jelenti.

${ }^{289}$ Rttv. Értelmező rendelkezések 2. §

${ }^{290}$ Mttv. Értelmező rendelkezések 203. § 15. 24. 25. 31. 52.

${ }^{291}$ Mttv. 2011. évi CVII. törvény 64. § (4) bekezdésével megállapított szöveg. Hatályos: 2011. VIII. 3-tól.

${ }^{292}$ GOSZTONYI Gergely: A közösségi médiaszolgáltatók a hatályos magyar jogi szabályozásban Médiakutató 2011 tél (GOSZTONYI I.)

293 NAGY Krisztina: Közösségi médiatérkép Mérték blog 2012. július 19. http://mertek.hvg.hu/2012/07/19/kozossegi-mediaterkep/ (NAGY I.)
} 
műsorszolgáltatók egy része jelentős közszolgálati szerepet tölt be, illetőleg a helyi rádiók sok esetben hallgatottság szempontjából népszerübbek, mint az országos rádiók. ${ }^{294} \mathrm{~A}$ Stratégia a háromosztatú médiarendszer különböző szolgáltatási elemeire, így a közösségi szolgáltatásra is eltérő szabályozási célok meghatározását és üzleti modellek kidolgozását, ezen belül is az egyes szolgáltatási típusok sajátosságainak megfelelően a lineáris és lekérhető tartalmak tekintetében is különbség tételt javasolt az új szabályozásban.

„A (NAMS) vitaanyag tehát a közösségi médiumok tekintetében kétarcúra sikerült. Voltak benne igen elöremutató és pozitív, a szektor jelentőségét hangsúlyozó elemek, de találhattunk benne a szektor számára elfogadhatatlan szabályozási terveket, ötleteket is."295 El kell ismerni, hogy a közösségi média szabályozási céljainak megfogalmazása, a Stratégia alkotóinak legjobb szándéka ellenére sem volt teljesen egyértelmü. A digitális átállás - a nemzetközi példák alapján - leginkább a közszolgálati médiát viselte meg. ${ }^{296}$ Kérdéses volt, hogy az alapvetően közszolgálati funkciót ellátó kis helyi, közösségi szolgáltatók hogyan, milyen többletforrásból tudnak átállni a digitális technológiára, illetőleg milyen állami vagy más támogatás szükséges talpon maradásukhoz. Tapasztalatok hiányában a NAMS legfeljebb stratégiai szinten jelölhette ki a közösségi médiával kapcsolatos szabályozási irányokat és csak nagyon óvatosan fogalmazhatott a szabályozási elképzeléseket illetően.

A közösségi médiaszolgáltatás részlet-szabályainak kidolgozása a 2010. évi jogalkotás feladata volt. A megvalósult szabályozás a közösségi médiaszolgáltató tekintetében csak a lineáris médiaszolgáltatásról, illetőleg a rádiós közösségi médiaszolgáltatásról rendelkezik, a lekérhető közösségi tartalmakat nem rendelte a szabályozás hatálya alá. E tekintetben tehát a differenciált szabályozás megvalósult, ugyanakkor a közösségi lekérhető tartalmak szabályozása - annak vélhető szabályozási szükségtelensége miatt, illetőleg a túlszabályozás elkerülése végett -, kimaradt a törvényből. ${ }^{297}$

A közösségi médiaszolgáltatás ugyanakkor az Mttv-ben - jelentőségét elismerve - önálló fejezetben került szabályozásra, új kategóriaként a „köz” érdekében ${ }^{298}$ egyesíti a régi médiatörvény közműsor-szolgáltatásra és a nem nyereségérdekelt műsorszolgáltatásra

\footnotetext{
${ }^{294}$ NAMS 22.

${ }^{295}$ GOSZTONYI Gergely: Alternativ (?) média. A közösségi média szabályozásának vetületei ELTE Eötvös Kiadó, 2014. (GOSZTONYI II.)

${ }^{296}$ Részletesebben ld.: 7. NAMS szerinti közszolgálatiság.

${ }^{297}$ Ennek okát az Mttv. indokolása nem adja meg és arra a Kommentár [A médiaszabályozás kommentárja Complex Wolters Kluwer 2011 KOLTAY András - LAPSÁNSZKY András (szerk.)] (KOLTAYLAPSÁNSZKY Kommentár) sem tér ki.

${ }^{298}$ NAGY I.
} 
vonatkozó fogalmi elemeket. A jogalkotó célja a korábbiakkal szembeni jóval pontosabb és korszerübb kritérium meghatározás volt, fenntartva a hasonló korlátozások és kedvezmények rendszerét a szabályozásban (kötelező továbbítási jogosultság, részvételi lehetőség a Müsorszolgáltatás Támogató és Vagyonkezelő Alap pályázatain). ${ }^{299}$

A szabályozásban lényegében megvalósult az e szolgáltatási formára vonatkozó sajátos szabályozás; a háromosztatú rendszer szolgáltatási formák szerint eltérő szabályozási megjelenését látjuk - mások mellett - az Mttv. értelmező rendelkezései között, a hálózatba kapcsolás, a vételkörzet-bővítés, a rádiós médiaszolgáltatás, a közösségi médiaszolgáltatásban közzétett reklámszabályozásban ${ }^{300}$ és a szerződésmódosítás rendelkezéseinél, ${ }^{301}$ továbbá a közösségi médiaszolgáltatásra vonatkozó teljes IV. fejezetben, valamint a törvény közszolgálati médiaszolgáltatás címet viselő harmadik részében. A közösségi médiaszolgáltatás után - beleértve az ideiglenes hatósági szerződéseket is - a korábbiakhoz hasonlóan, nem kell médiaszolgáltatási díjat fizetni, azonban az új szabályozás mégis felveti a tényleges közösségi credo eliminálódását. A szakirodalomban felvetett probléma, miszerint „,[...] országos médiaszolgáltatást nem lehet közösségi médiaszolgáltatásként elismerni, ezáltal a közösségi médiaszolgáltatók vételkörzete szükségszerűen kisebb vagy korlátozottabb lesz az országos mértéknél." ${ }^{\text {302 a }}$ korábbi szabályozás öröksége. Álláspontom szerint ezt a rendelkezést az Mttv. helyesen vette át az Rttv. szabályozásából, hiszen egyfelől a közösségi és az országos megkülönböztetés nem kizárólag vételkörzeti kérdés, hanem a szolgáltatások jellege is jelentős szempontja a két kategória közötti különbségtételnek, másfelől pedig az azonos vételkörzeti nagyság lehetővé tétele a szabályozásban éppen a közösségi jelleg értékének elvesztését eredményezhetné és megkérdőjelezné a közösségi szolgáltatás önállóságát.

A szigorúbb tartalmi előírások és a médiatanácsi kontroll lehetővé tétele ugyanakkor e szolgáltatási formának indokolatlanul a közszolgálati médiaszolgáltatáshoz való közelítését eredményezi és a létrejött szabályozás - az Mttv. indokolásában megfogalmazott céloktól eltérően - nem kellően differenciált, pontos és piac-érzékeny. ${ }^{303}$ Ez a megállapítás a közösségi szolgáltatás folyamatos megújulásából, szabályozásának még mindig átmeneti

\footnotetext{
${ }^{299}$ Mttv. Indokolás.

${ }^{300}$ Mttv. 36. §

${ }^{301}$ Mttv. 64. § (2) Közösségi médiaszolgáltató csak közösségi médiaszolgáltatóval kapcsolódhat hálózatba. Országos médiaszolgáltató nem lehet hálózatba kapcsolódó médiaszolgáltató.

${ }^{302}$ GOSZTONYI Gergely: Az alternativ média helye a médiadiskurzusban. Az alternativ média története és a közösségi médiaszolgáltatók a hatályos magyar szabályozásban. MTMI Budapest, 2014. (GOSZTONYI III.) http://mtmi.hu/dokumentum/499/gosztonyi_gergely_az_alternativ_media_helye_a_mediadiskurzusban.pdf ${ }^{303}$ A közösségi rádiós médiaszolgáltatók pályáztatásáról részletesen ld.: GOSZTONYI I., NAGY I.
} 
jellegéből eredhet és vélhetően nem a jogalkotói szándék kétségének tudható be. Az önálló közösségi média léte ugyanis a közszolgálati és kereskedelmi média mintegy „köztes válfaja"304 a médiapluralizmus és véleményszabadság egyik meghatározó tényezője.

\subsection{2. Általános médiajogi szabályozás, speciális közszolgálati müsorszolgáltatás és a lekérhető tartalmak médiaszabályozáson kívüli elhelyezése}

A NAMS JK szándéka szerint a kidolgozásra kerülő új, audiovizuális médiaszolgáltatásokról szóló törvény általános médiajogi szabályozást tartalmaz, amelynek hatálya kiterjed a televíziós és rádiós lineáris müsorszolgáltatásra, valamint meghatározza a közszolgálati müsorszolgáltatásra vonatkozó speciális normákat is. A Koncepció, amint az a tartalomszabályozási elvek és célok ismertetése során is említésre került, a lekérhető médiaszolgáltatásokat - tagállami szabályozási tapasztalatok hiányában - dogmatikailag az elektronikus kereskedelmi szolgáltatások körében, az információs társadalommal összefüggő szolgáltatások egyes kérdéseit rendező elektronikus kereskedelmi törvényben helyezte volna el. A lekérhető szolgáltatásokra irányadó szabályozás médiaszabályozáson kívüli, elektronikus kereskedelmi törvényben való rendezésének jogszabály-előkészítői szándékát egyfelől a szakmai óvatosság vezérelte, másfelöl pedig az AVMS irányelv lineáris és nonlineáris szolgáltatásokra irányadó eltérö kezelése indokolta. Ez utóbbi tekintetében az irányelv különböző szabályozási megoldásait a magyar jogalkotónak is célszerű volt követni. ${ }^{305}$ A szakmai megfontoltság továbbá pedig abból eredt, hogy 2007-ben a digitális átállást már megvalósító ${ }^{306}$ vagy ahhoz közelebb álló uniós tagállamokban sem volt kellő tapasztalat a digitális technológia által előhívott lekérhető tartalmak és kiegészítő szolgáltatások szabályozási kérdéseit illetően. Az AVMS irányelv más nemzeti tagállamok általi implementációja, a későbbiekben kialakuló tagállami szabályozási modellek megfelelő irányt mutattak volna a hazai szabályozáshoz is. A 2010. évi média-jogalkotás nyilván már ezen ismeretek és tapasztalatok birtokában döntött helyesen a lineáris és a nem lineáris szolgáltatások egy törvényben való szabályozása mellett. Az új médiaszabályozási rezsim - elfogadva a rádiós

\footnotetext{
${ }^{304}$ 37/1992. (VI. 10.) AB határozat, valamint 37/2008. (IV. 8.) AB határozatok

${ }^{305}$ NAMS JK 38.

${ }^{306}$ Európában elsőként Finnország állt át a digitális müsorszórásra 2007-ben, Hollandia 2004-töl fokozatosan állt át, Anglia tervezett átállási dátuma: 2006-2010, Spanyolország pedig 2008-ra valósította meg a földi analóg televíziós műsorszolgáltatásának digitális átállását. Forrás: CSEH Gabriella: A digitális müsorszolgáltatásra vonatkozó időszerü jogi kérdések Magyarországon Médiakutató 2004 ősz (CSEH I.)
} 
médiaszolgáltatásra vonatkozó $N A M S J K$ tételt, illetőleg a televíziós és rádiós lineáris szolgáltatás törvényi szabályozásának indokoltságát, továbbá a közszolgálati médiaszolgáltatásra irányadó speciális normák szabályozási önállóságát, a lekérhető médiaszolgáltatások tekintetében - véleményem szerint helyesen - nem követte a 2007ben készült $N A M S J K$ elképzeléseit. Az új médiaszabályozás létrejöttekor ugyanis már kellő tagállami tapasztalat ${ }^{307}$ állt a jogszabály előkészítők és a jogalkotó rendelkezésére a lekérhető tartalmak szakmailag is megfelelő implementálásához és annak egységes médiaszabályozásban történő elhelyezéséhez. A 2006-2007-es évek kezdeti szkepticizmusa alaptalannak bizonyult, az AVMS irányelv végleges szövege is együtt kezelte a lineáris és a lekérhető tartalmakat, valamint dogmatikai megfontolások sem indokolták a két tartalomfajtára vonatkozó rendelkezések külön jogszabályban való megjelenítését, illetőleg a lekérhető tartalmakra vonatkozó szabályozás késleltetését. Megjegyzem az AVMS irányelv átültetési kötelezettségének lejárt határideje sem engedett további késedelmet.

A közszolgálati média preferált helyzetével és sajátos szabályozási igényével kapcsolatos jogalkotói szándékokat a $N A M S J K$ önálló szabályozási fejezetben fogalmazta meg. Ezekre a közszolgálati médiaszolgáltatás fejezetének tárgyalásakor térek ki.

\subsection{3. Ön- és társszabályozás a médiaigazgatásban}

\section{1. Önszabályozás}

A szakmai önszabályozás, a „privát” szabályozás ${ }^{308}$ - amint az fentebb ismertetése került -, már a NAMS kidolgozásának idején világszerte elterjedt gyakorlat volt a médiában. Az Egyesült Királyságban a sajtóval kapcsolatos kérdések rendezését - elismerve és vitatottan 1990-től a Press Complaints Commission ${ }^{309}$ keretében, majd 2014 szeptemberétől az Independent Press Standards Organisation által - kizárólag az önszabályozás keretében törekszenek megoldani. A magatartási szabályok többnyire etikai kódexekben öltenek testet $^{310}$ és a megfogalmazott alapelvek lényegében ugyanazokat vagy legalábbis hasonló téziseket rögzítik: valós, hiteles információ léte, bármilyen diszkrimináció tilalma a nemek,

\footnotetext{
307 „Új médiatörvényt fogadtak el Észtországban, Svédországban és Spanyolországban is 2010 és 2011 folyamán.” DEZSÉRI Kálmán: A magyar médiatörvény a médiáról szóló európai uniós vitákban Médiakutató 2011 ösz (DEZSÉRI)

${ }^{308}$ CAFAGGI „Private Regulation” ix.

${ }^{309}$ KOLTAY András: A nyomtatott sajtó önszabályozása az Egyesült Királyságban: a Press Complaints Commission Infokommunikáció és Jog 129-134, 2010/39. augusztus. (KOLTAY II.)

${ }^{310}$ Tiina LAITILA: Journalistic codes of ethics in Europe 10; 526-544, European Journal of Comunication 1995. 1995-ben több mint 30 nemzeti újságírói etikai kódex létezett Európában (LAITILA) 527.
} 
fajok, etnikumok között, az információk megszerzésének tisztességes volta, az informátor személyiségi jogainak tiszteletben tartása, valamint a vélemények és a kritikák szabadságának érvényre juttatása. ${ }^{311} \mathrm{Az}$ önszabályozás szerepe a reklámiparban kezdettől fogva különösen jelentős volt; a rendszeres reklám-önszabályozás, az önszabályozási gyakorlat létrejötte megelőzte a jogi szabályozás kialakulását. ${ }^{312}$ Az első, 1937-ben született nemzetközi reklámkódex szabályai fontos iránymutatás adtak a későbbi nemzeti állami reklámszabályozások részére. ${ }^{313}$

\section{Társszabályozás a médiaigazgatásban}

Az Mttv. - teljesen új jogintézményként - bevezeti a társszabályozást. A médiatörvény alapelvei között fontos szerepet tulajdonít a szakmai önszabályozó testületeknek és a különböző ön- és társszabályozó eljárásoknak. ${ }^{314}$ Emellett pedig önálló fejezetben ${ }^{315}$ rendelkezik a szakmai önszabályozó szervezetekkel való együttműködés ${ }^{316}$ részletes szabályairól, ezáltal lehetővé téve e szervezetek közremüködését a jogalkalmazásban: „[...] a jogalkotás a társadalmi viszonyok alakításának nem kizárólagos módja. Egy másik, lehetséges út, ha a jogalkotó teret enged az ön- és társszabályozásnak; lehetővé teszi, hogy a szabályozás alanyai magukra nézve állapítsanak meg normákat, amelyekhez (állami) joghatás kapcsolódik."317

A társszabályozás fogalma több szempontból is meghatározható, egyfelől jelentheti a szakmai szervezetek és a hatóság együttmüködését a médiaszabályozás betartása érdekében," ${ }^{318}$ másfelől pedig - más megközelítésben - azt a mechanizmust definiálja, amelynek keretében valamely közösségi jogalkotási aktusnak, a jogalkotó által meghatározott célkitűzéseknek megfelelő megvalósítását, a területen elismert érintett szereplőkre (gazdasági szereplők, szociális partnerek, nem kormányzati szervezetek vagy

\footnotetext{
${ }^{311}$ LAITILA 527.

312 Magyarországon a Magyar Reklámszövetség 1975 januárjában, az Önszabályozó Reklámtestület a 1996 márciusában alakult meg; 2006-ban tizenhat szakmai szervezet segítette a reklámiparág müködését, 2009-ben pedig már huszonhat szakmai szervezet írta alá a megújult Reklámetikai Kódexet. (Reklámetikai Kódex)

${ }^{313}$ CAFAGGI ix.

${ }^{314}$ Mttv. 8. §

${ }^{315}$ Mttv. Negyedik Rész A médiaszolgáltatások és a sajtótermékek felügyelete VI. fejezet Társszabályozás a médiaigazgatásban.

${ }^{316}$ „A társszabályozás az ördöggel kötött paktum” - nyilatkozta Aiden WHITE a hazai médiatörvény a hatályba lépése nyomán kialakult helyzetet vizsgáló nemzetközi küldöttség vezetöje, az Ethnic Journailsm Network igazgatója, a londoni székhelyü Media Diversity Institute munkatársa. http://atlatszo.hu/2011/11/17/mediatorveny-a-tarsszabalyozasimegallapodas-az-ordoggel-kotott-paktum/

${ }^{317}$ CSINK-MAYER 72.

${ }^{318}$ KOLTAY-LAPSÁNSZKY Kommentár 375.
} 
egyesületek) bízza.”319 A társszabályozással az állami szabályozó a szabályozási célokat együttmüködés formájában kívánja megvalósítani, modellje az önszabályozás keretein belül értelmezhető, és két módon kapcsolódhat az állami hatósági szabályozáshoz: a) az önszabályozás folyamata az állam által lefektetett jogi alapokon indulhat el vagy b) a hatósági szabályozás egy már meglévő önszabályozási mechanizmust emel be a hatósági szabályozás rendszerébe." 320

Az ön- és a társszabályozást a NAMS JK idézett megfogalmazásával azonosan a jelenlegi médiaszabályozás is az audiovizuális média jogalkotását kiegészítő, a jogalkalmazó és a civil szféra közötti együttmüködési formának tekinti, ${ }^{321}$ az ön- és társszabályozó eljárások fontos szerepét az alapelvek között hangsúlyozza. ${ }^{322}$ Az Mttv. társszabályozási rendszere a Palzer által kidolgozott második változatot alkalmazza, azaz a meglévő önszabályozási mechanizmust - szabályozási garanciákkal - emeli be a hatósági szabályozásba. Az önigazgatási rendben, nem hatóságként ${ }^{323}$ eljáró és a törvény által felhatalmazott önszabályozó szervezetek Médiatanácstól származtatott hatáskörét az Mttv. részletesen körülírja. A megvalósult szabályozás szerint a Médiatanács azokat a hatásköröket adja át az önszabályozó szervezeteknek társszabályozásra, amelyeket egyedül nem kíván ellátni. A magyar modell sajátossága, hogy az átadott közfeladat tekintetében - kizárólag közigazgatási szerződés keretében - a civilszerveződés a Médiatanács hatáskörét nem kiegészíti, hanem helyettesíti. Az átadott hatásköröket a társszabályozó szervezet közfeladatként, de nem közhatalmi jogkört gyakorolva látja el. ${ }^{324}$ A társszabályozás, illetve a média jogalkotóval való együttes szabályozás a szubszidiaritás elvét alkalmazva lehetővé teszi, hogy a Médiatanács szakmai szervezeteknek adjon felügyeleti jogkört a jogszabály hatálya alá tartozó szektorokban, iparágakban, részterületeken müködő személyekkel, vállalkozásokkal szembeni eljárásra. Így a reklám szektorban az ÖRT a Médiatanáccsal kötött közigazgatási szerződés keretében ${ }^{325}$ a nem lineáris médiaszolgáltatásban megjelenő

319 A jogalkotás minőségének javításáról szóló 2003. december 16-i intézményközi megállapodás (2003/C/321/01) In: WEBER-HEINRICH 49. lbj.

${ }^{320}$ Carmen PALZER: Co-Regulation of the Media in Europe: European Provisions for the Establishment of Co-Regulation Framework Iris Plus, No.6 In: GÁLIK-POLYÁK 44 (PALZER) 2.

${ }^{321}$ KOLTAY-LAPSÁNSZKY Kommentár 375.

${ }^{322}$ Mttv. 8. $\S$

${ }^{323}$ SZIKORA Tamás: Társszabályozás a médiaigazgatásban In: KOLTAY Szerk. (SZIKORA) 251.

${ }^{324}$ LAPSÁNSZKY András: Társszabályozás a médiaigazgatásban In: KOLTAY-NYAKAS I. 835-850. (LAPSÁNSZKY) 841.

325 A Médiatanács és az Önszabályozó Reklám Testület 2011. július 6-án kötött közigazgatási szerződést. A Médiatanács ezt megelőzően közigazgatási szerződést kötött a Magyarországi Tartalomszolgáltatók 
kereskedelmi kommunikáció tekintetében olyan panaszok kivizsgálását végezheti, amelyek az emberi méltóságot, vallási vagy világnézeti meggyőződést sértő reklámra, a tudatosan nem észlelhető hirdetési technikák alkalmazására, dohányárut, fegyvert, lőszert, robbanóanyagot, továbbá csak orvosi vényre kapható gyógyszert népszerüsítő reklámokra vagy a kiskorúak káros, illetve tisztességtelen befolyásolásával kapcsolatos reklámtartalmakra vonatkoznak. A társszabályozás nem lép az autonóm önszabályozó szervezet tevékenységének helyébe. Az Mttv. a társszabályozásra vonatkozó rendelkezései mintegy funkcionális decentralizációt megvalósítva, lehetővé teszik a delegálható médiaigazgatási feladat- és hatáskörök tekintetében a nonprofit polgári jogi jogalany önszabályozó szervezetek, szövetségek, egyesületek stb. számára a közfeladatok ellátásában való részvételt. Az állami hatósági és az önszabályozás közötti „,középutat”326 jelentő társszabályozás előmozdíthatja a teljes hazai médiára vonatkozó egységes etikai kódex kidolgozását.

\subsection{4. Új médiajogi terminológia és a szolgáltatások elhatárolási dilemmái. „Szenzitív"lekérhető szolgáltatások és sajtójogi tartalmak}

1. Új médiajogi terminológia és a szolgáltatások elhatárolási dilemmái

A 2007-ben kirajzolódó új uniós normarendszer hazai jogrendszerbe való átültetése új terminológia és új fogalmak bevezetését, valamint az ezekre vonatkozó szabályozás kialakítását tette szükségessé. A Koncepció már használta az AVMS megújult terminológiai rendszerét és szövegében rögzítette a lineáris és lekérhető müsorszolgáltatás fogalmát. ${ }^{327}$ A lineáris és a lekérhető szolgáltatások különböző társadalmi, kulturális és gazdasági hatásaira tekintettel a NAMS $J K$ a két szolgáltatástípusra eltérő szabályozási megoldást tartott célszerünek. Megfogalmazta, hogy a magyar szabályozásnak nem lehet célja a szabályozási tárgykör indokolatlan kiterjesztése a médiajogi szempontból nem releváns, például információs társadalommal összefüggő szolgáltatásokra. Megállapítása szerint a magyar szabályozásnak a lekérhető szolgáltatásokat zártan, az irányelv adta fogalommeghatározás keretein belül kell értelmeznie. A $N A M S J K$ kiemelte a konzultáció során is

Egyesületével (2011. június 29.), majd a Magyar Lapkiadók Egyesületével (2011. július 8.), valamint a Magyar Elektronikus Müsorszolgáltatók Egyesületével (2011. július 20.) is.

${ }^{326}$ POGÁCSÁS Anett: A nyomtatott és az internetes sajtótermékek szabályozási kérdései 516. In: KOLTAYNYAKAS I. 509-516.

${ }^{327}$ NAMS JK 18. A NAMS JK alapvetően még a műsorszolgáltatás kifejezést alkalmazta, a dolgozatban azonban - az adott médiajogi rendelkezéseknek megfelelően - a médiaszolgáltatás fogalmat is használom. 
megerősítést nyert azon megállapítást, miszerint a szolgáltatók többsége egyetért a magyar jogalkotó kevésbé beavatkozó magatartásával a közösségi szabályok átültetése során. ${ }^{328}$ $\mathrm{Az}$ információs társadalommal összefüggő szolgáltatások egyértelmü gyakorlati besorolására és az audiovizuális médiaszolgáltatásoktól (lineáris és lekérhető szolgáltatások) való elkülönítésére a NAMS a német modell bevezetését javasolta. ${ }^{329} \mathrm{~A}$ digitális technológia gyors térhódítását, de annak nehézkesebb szabályozási átültetését és lassabb gyakorlati alkalmazását érzékelteti, hogy a nálunk előre haladottabb német jogi szabályozásban és joggyakorlatban is egyfelöl az új szolgáltatások megjelenése, másfelöl pedig a hagyományos televíziózásra és más médiaszolgáltatásokra (beleértve az ekereskedelmi szolgáltatásokat is), illetve a hírközlési szolgáltatásokra vonatkozó szabályozások átfedései több értelmezési problémát is felvetettek. A Szövetségi Államok Médiaintézeteinek Igazgatói Konferenciája ${ }^{330}$ a tartalom véleménybefolyásoló képességéből kiinduló egyedi iránymutatásokban azonosította az audiovizuális- és más médiaszolgáltatások tipikus jellemzőit, valamint határozta meg a követendő jogértelmezést. Az audiovizuális médiaszolgáltatások, valamint az információs társadalmi szolgáltatások elhatárolásánál lényeges szempont volt a tartalom vélemény szabadság gyakorlására alkalmas volta, illetőleg az, hogy a tartalmat tömeges nyilvános megtekintésre szánták. Ez utóbbi két konjunktív feltétel esetén indokolt volt az információs társadalommal összefüggő szolgáltatás médiaszabályozás körébe vonása. A szolgáltatások egyértelmű elhatárolására vonatkozó magyar megoldási javaslat a lineáris müsorszolgáltatások körébe kifejezetten a 'hagyományos' rádiózást és televíziózást sorolta, a lekérhető szolgáltatásokat pedig - már az AVMS irányelv 2007. évi változatának ismert tervezete ${ }^{331}$ alapján - az egyéni igény szerinti lekérés, egyéni felhasználás tényállási elemekkel illette. E szolgáltatásoktól elkülönítetten kezelte az információs társadalommal összefüggő szolgáltatásokat, amelyek a vonatkozó önálló törvény szerint „elektronikus úton, távollévők részére, rendszerint ellenszolgáltatás fejében nyújtott szolgáltatás, amelyhez a szolgáltatás igénybe vevője egyedileg fér hozzá." 332

\footnotetext{
${ }^{328}$ NAMS JK 19.

${ }^{329}$ NAMS 5. 48. $\mathrm{lbj}$.

${ }^{330}$ Direktorenkonferenz der Landesmedienanstalten (DLM)

331 AVMS 2007/65/EK irányelv (2007. december 11.) I. Fejezet 1. cikk g) „lekérhető audiovizuális médiaszolgáltatás" (azaz nem lineáris audiovizuális médiaszolgáltatás): olyan médiaszolgáltató által nyújtott audiovizuális médiaszolgáltatás, amelyben a médiaszolgáltató által összeállított műsorkínálat alapján a felhasználó egyéni kérés alapján, az általa kiválasztott időpontban tekintheti meg a műsorszámokat;"

${ }^{332}$ Elker. törvény 2003. évi XCVII. törvény 2. § (1) bekezdésével megállapított szöveg, hatályos: 2004. I. 1töl.
} 
A 2010. évi magyar médiaszabályozás konzekvensen követi az AVMS elöírásait és a NAMS $J K$ szabályozási elveit. Ennek megfelelően dolgozta ki és viszi végig a törvények szövegén az irányelv lineáris és lekérhető szolgáltatásokra vonatkozó szabályait. ${ }^{333}$ A szolgáltatások időközben egyértelművé vált azonosíthatósága és ennek a szabályozásban való megjelenése szükségtelenné tette a magyar joggyakorlatban a német modell alkalmazását.

2. Szenzitív lekérhető szolgáltatások és sajtójogi tartalmak

A lekérhető szolgáltatások kapcsán is szükséges rámutatni az Alkotmánybiróság 165/2011.(XII.20.) AB határozatára, amely az internetes szabályozást a sajtótermék fogalmának megfelelő körben, differenciált megközelítésben vizsgálta. A szabályozás a sajtótermék fogalmát meghatározza, ${ }^{334}$ és a fogalmat az 1986-os Stv. rendelkezéseihez képest bővíti az internetes szolgáltatással. A törvények sajtóterméknek minősítik a napilap és más időszaki lap egyes számait, valamint az internetes újságot vagy hírportált, amelyet olyan természetes vagy jogi személy, illetve jogi személyiséggel nem rendelkező gazdasági társaság gazdasági szolgáltatásként nyújt, és amelynek tartalmáért szerkesztői felelősséget vállal. E gazdasági szolgáltatás elsődleges célja szövegből, illetve képekből álló tartalmaknak a nyilvánossághoz való eljuttatása tájékoztatás, szórakoztatás vagy oktatás céljából, nyomtatott formátumban vagy valamely elektronikus hírközlö hálózaton keresztül. A szerkesztői felelősség a médiatartalom kiválasztása és összeállítása során megvalósuló tényleges ellenőrzésért való felelősséget jelenti, és nem eredményez szükségszerüen jogi felelősséget a sajtótermék tekintetében. Gazdasági szolgáltatásnak pedig a szabályozás konjunktív feltételei szerint az önálló, üzletszerűen ${ }^{335}$ - rendszeresen, nyereség elérése érdekében, gazdasági kockázatvállalás mellett - végzett szolgáltatás minősül. Az Smtv. és az Mttv. a sajtóterméknek tehát két típusát ismeri: a nyomtatott sajtóterméket (napilap és más időszaki lap), valamint az internetes sajtóterméket internetes újságok vagy hírportálok formájában. ${ }^{336}$ A sajtótermékek nyilvántartása és a lapnyilvántartás hatósági kezelése a mindenkori kulturális tárca „Lapnyilvántartásától” először - az Stv. alapján - a Kulturális Örökségvédelmi Hivatalhoz, majd 2012. január 1től - az Mttv. ${ }^{337}$ értelmében - az NMHH-hoz került. A sajtótermékek nyilvántartásba vételére irányadó rendelkezések átvették az Stv. korábbi vonatkozó szabályainak lényegét,

\footnotetext{
${ }^{333}$ Smtv. 1. § 4. 5., Mttv. Második Rész, I. fejezet a Médiaszolgáltatások tartalmára vonatkozó előírások stb.

${ }^{334}$ Smtv. 1. § 6., Mttv. 203. § 60.

${ }^{335}$ Az Smtv. 2011. évi XIX. törvény 1. § (1) bekezdésével megállapított szöveg, hatályos: 2012. IV. 6-tól.

${ }^{336}$ KOLTAY-LAPSÁNSZKY Kommentár 18.

${ }^{337}$ Mttv. 208. § (3)
} 
és a szabályozás magában foglalja az Stv. alkalmazása során kialakult bírói gyakorlatot is többek között - a védjegyjogi védelem alatt álló sajtótermékek megjelölése, illetőleg a hatósági sajtónyilvántartásba felvett termékek elnevezésének használatával kapcsolatos kollízió feloldása tekintetében. ${ }^{338}$

Az Smtv. értelmében az internetes sajtótermék olyan internetes újságokat, illetőleg hírportálokat foglal magában, amelyek szöveggel és képpel kommunikálnak. ${ }^{339} \mathrm{Az}$ Alkotmánybiróság rámutatott arra, hogy a sajtószabadság az internetes sajtó tevékenységére is kiterjed, alkotmányossági értelemben - a többi tömegkommunikációs formához hasonlóan - szabályozás alá vonható. Az internet, mint kommunikációs csatorna ugyanakkor az emberi kommunikáció egyre változatosabb formáit hozza létre, amelyek közül nyilvánvalóan nem mindegyik sorolható a tömegkommunikáció fogalmi körébe. A magáncélú közlésekre, honlapokra, blogokra, közösségi portálokra, ebböl következően nem irányadók a sajtó szabályozásánál meghatározó szempontok. A médiaszabályozás körébe vonható internetes újságok szabadsága pedig - az elektronikus technológiához való hasonló jellegük ellenére - nem korlátozhatók az audiovizuális médiaszabályozás indokai alapján, hiszen az internetes sajtótermékek létrehozatala, müködtetése a nyomtatott sajtó lapalapítási szabadságánál egyszerübb. A hírportálok, internetes újságok befolyásoló képessége, az emberi gondolkodásra gyakorolt hatása sem azonosítható az audiovizuális média más eszközeivel. A jogalkotó már 2011. április 6-tól kezdődő hatállyal, tehát az AB határozat megjelenése előtt módosította, az „önálló, üzletszerü tevékenység” fogalmi elem beiktatásával lényegében pontosította az Smtv. 1 . $\S 1$. és 6 . pontjaiban a médiaszolgáltatásra és a sajtótermékre meghatározott fogalmakat. E módosított definíciók egyértelművé tették, hogy a hatósági felügyelet, illetőleg a médiatörvények szabályai kizárólag a médiumként viselkedő, nevezetesen a tömegek tájékoztatását, szórakoztatását célzó, továbbá önálló, üzletszerü gazdasági tevékenységet folytató médiaszolgáltatókra, illetőleg szerkesztett portálokra terjed ki.

Az Alkotmánybiróság az Mttv. Negyedik Része I. Fejezetének 109. § (1) bekezdése körében vizsgálta az internetes sajtótermékek hatósági felügyeletét és megállapította, hogy az Mttv. vonatkozó rendelkezései alapján $a z N M H H$ hatósági felügyelete mind a nyomtatott, mind pedig az internetes sajtótermékek tekintetében, egyfelöl a közösség egészének érdekében, másfelől az egyéni jogokkal összefüggésben fennáll. Emiatt az Alkotmánybíróság a továbbiakban azt elemezte, hogy a nyomtatott és az internetes

\footnotetext{
${ }^{338}$ Mttv. 46. § (6) d)

${ }^{339}$ Smtv. 1. § 6 .
} 
sajtótermékek által előállított tartalom, illetőleg az e tartalmakkal szemben az Smtv. 14-20. §-iban megfogalmazott korlátozások - a sajtószabadság szempontjából - szükségesek és arányosak-e. Az Alkotmánybiróság a különböző médiumok hatásmechanizmusától függetlenül, valamennyi médiatartalom tekintetében indokolható, szükséges és arányos korlátozásnak tekinti a médiatartalom szolgáltatónak a Magyarország alkotmányos rendjének tiszteletben tartására vonatkozó kötelezettségét, ${ }^{340}$ továbbá a gyülöletkeltés, valamint a kirekesztő magatartás tiltására vonatkozó törvényi elöírást. ${ }^{341}$

E fejezetben szükséges röviden kitérni két olyan jogintézmény elemzésére, amelyek közül az emberi méltóság alkotmányos alapelv jogfejlődésének eredményeként kiforrtak a jogintézménnyel kapcsolatos médiajogi és más jogági megközelítések, továbbá egyértelművé váltak az egyéni és az intézményi jogérvényesítés lehetőségei. Az újságírói forrásvédelem szabályozási kérdéseinek külön vizsgálata pedig - annak ellenére, hogy a $N A M S$ nem tette tárgyává a nyomtatott sajtó szabályozásának újragondolását -, azért indokolt, mert a sajtószabályozással kapcsolatos tartalmi kérdések körében e jogintézményre vonatkozó normaszöveg-változás alapvető és lényegi.

A méltóságvédelem az új médiaszabályozásban az Alkotmánybíróság határozatai nyomán új megközelítésbe került, differenciált értelmezése pedig a Médiatanács határozataiban ${ }^{342}$ is megjelent. Az Alkotmánybíróság először a 47/2007. (VI. 27.) sz. határozatában vizsgálta az emberi méltóság Rttv.-ben meghatározott védelmének alapjogi kérdéseit. Az Rttv. értelmében „a müsorszolgáltató [...] tevékenysége nem sérthet emberi jogokat." ${ }^{343} \mathrm{~A}$ 2007-es AB határozat a szabályozás kapcsán kimondta, hogy az ORTT a régi Médiatörvény 3. § (1) bekezdése szerinti alapelvi rendelkezés alapján eljárva az adott közigazgatási eljárásban nem az egyes jogalanyokat ért jogsérelemről, hanem arról dönt, hogy az adott müsor témája, jellege, nézöpontja nem sérti-e az emberi jogokban megjelenö alapvető értékeket. ${ }^{344}$ A 2007-es AB határozat az alapvető értékek többféle értelmezési lehetősége kapcsán a médiajogi szabályozás intézményvédelmi feladatára kívánt utalni. ${ }^{345}$

\footnotetext{
${ }^{340}$ Smtv. 16. § első fordulat.

${ }^{341}$ Smtv. 17. §

${ }^{342}$ Nem teljes körủen: a Médiatanács 1044/2011. (VII.19.) számú és 1153/2011. (IX. 1.) számú határozatai, valamint 828/2011. (VI. 22.) számú és 169/2013.(I.30.) számú döntései. Ld. részletesen: SARKADY Ildikó: Emberi méltóság és a reklám. az ÖRT felkérésére 2016-ban készült tanulmány, megjelenés alatt. (SARKADY X.)

${ }^{343}$ Rttv. 3. § (2)

${ }^{344}$ 46/2007. (VI. 27.) AB határozat, ABH 2007. 592, 606.

${ }^{345}$ KOLTAY András: Az emberi méltóság védelmének kérdései a médiaszabályozásban és a joggyakorlatban In: Személy és személyiség a jogban szerk.: MENYHÁRD Attila - GÁRDOS-OROSZ Fruzsina (Wolters Kluwer Budapest, 2016) 196. KOLTAY IX.
} 
Az Alkotmánybiróság megállapítása értelmében az emberi jogok védelmének médiajogi és más jogági (polgári és büntetőjogi) megközelítése elválik egymástól. Míg a polgári jog és a büntetőjog feladata adott esetben az egyén jogsérelmének orvoslása, illetve az egyénnel szembeni szankció érvényesítése, addig a médiajogi megközelítés az emberi jogok és az emberi méltóság közösségi szempontú intézményét helyezi védelem alá és teszi lehetővé a médiahatósági fellépést.

A 2010-től megváltozott médiaszabályozás egyfelől továbbra is a médiaszolgáltató általános kötelezettségévé teszi az emberi méltóság tiszteletben tartását, ${ }^{346}$ másfelől konkrét tényállásban tiltja is annak megsértését. ${ }^{347}$ Szükséges itt megjegyezni, hogy az Smtv. eredeti szövege az ORTT korábbi határozatai alapján a müsorszámok készitése során is tiltotta a méltóságsértést, azonban e határozatokat a bíróság hatályon kívül helyezte. ${ }^{348} \mathrm{~A}$ 2010-es médiaszabályozás átfogó alapjogi vizsgálatában született, már hivatkozott 165/2011. (XII. 20.) AB határozat eredményeként módosított Mttv.-ből a „műsorszámok készítése során” fordulat kikerült; ${ }^{349}$ a határozat továbbá az egyéni és a közösségi védelem érdekében történő jogérvényesítés tekintetében egyértelműen elkülöníti a médiajogi fellépés jogalapját a polgári és büntetőjogi egyéni igényérvényesítés lehetőségétől: „indokolt, hogy a hatóság - e jogok intézményes tartalmát érintő körben - [...] a közösség érdekében felléphessen a jogsértővel szemben”. ${ }^{350}$ Míg 2007-es határozat „az alkotmányos alapstruktúra tiszteletben nem tartása" esetén, addig a 2011-es AB határozat a 'demokratikus alapértékek tagadása' okán tekinti lehetségesnek a médiahatósági fellépést, az utóbbi határozatban már valamennyi médiummal szemben. ${ }^{351}$

Az emberi méltóság több tekintetben is alapját képezi a sajtószabadság korlátozásának: egyfelől az alkotmányos rend tiszteletben tartásának kötelezettsége oldaláról, másfelől pedig abból a szempontból, hogy az egyéni jogok érvényesítéseként a méltóságában megsértett személy a polgári jog és a büntető jog szabályai szerint is felléphet jogai

\footnotetext{
${ }^{346}$ Smtv. eredeti 14. § (1) „A médiatartalom-szolgáltatónak az általa közzétett médiatartalmakban, illetve azok készítése során tiszteletben kell tartania az emberi méltóságot.” 16. § „a médiatartalom-szolgáltató [...] tevékenysége során nem sértheti az emberi jogokat."

${ }^{347}$ Smtv. 14. § (2) „Tilos a megalázó, kiszolgáltatott helyzetben lévő személyek médiatartalomban történő, öncélú és sérelmes bemutatása."

${ }^{348}$ A Mónika show című müsorszám szerződései kapcsán a bíróság megállapította, hogy a médiahatóság kizárólag a műsorszám alapján vizsgálhatja az emberi méltóság megsértését, a műsorkészítés folyamata és a müsorszám „utóélete” nem lehet a médiahatósági vizsgálat tárgya. Hivatkozza: KOLTAY IX. 197.

${ }^{349}$ Smtv. 2012. évi LXVI. törvény 18. §-ával megállapított 14. § (1) hatályos 2012. VI. 19-tól.

${ }^{350}$ 16/2011. (XII. 20.) AB határozat, ABH 2011, 478, 512.

${ }^{351}$ KOLTAY András: Az emberi jogok, az emberi méltóság és az alkotmányos rend védelme a magyar médiaszabályozásban 37-67. In Medias Res 2012/1 (KOLTAY IV.) 45.
} 
védelmében. Az emberi méltóság elleni médiahatósági fellépés - a 2011-es AB határozat értelmében - az emberi gondolkodásra, társadalmi folyamatokra különleges hatással bíró audiovizuális média tekintetében - ténylegesen - szükséges és arányos korlátozása a sajtószabadságnak, de ugyanez a korlátozás nem érvényes a hatásában eltérő nyomtatott és internetes sajtóra. Az utóbbi két médium vonatkozásában az emberi jogok közösségi szempontú védelme érdekében a hatóság generális jellegü fellépése a sajtószabadság aránytalan korlátozásának minősül, ezért alkotmányellenes. A megalázó, kiszolgáltatott helyzetben lévő személyek médiatartalomban való öncélú és sérelmes bemutatását tiltó rendelkezés pedig olyan sajátos tényállást tartalmaz, melynek esetében - valamennyi médiumot illetően - indokolt, arányos és szükségszerü a médiahatósági fellépés törvényi biztosítása.

Az Alkotmánybiróság döntése értelmében nem minősül aránytalan beavatkozásnak továbbá a kiskorúak fejlődésére súlyosan káros médiatartalmak közzétételének korlátozása valamennyi médiumban. A sajtószabadság korlátozása szempontjából a Testület által a nyilatkozatot tevő személy és a magánélet megsértésének tilalma vonatkozásában elvégzett szükségességi és arányossági teszt kimutatta, hogy az Smtv. 15., valamint18. §-ában megfogalmazott tényállások ${ }^{352}$ védelme érdekében a törvény a hatósági fellépésre olyan kiegészítő hatósági eljárást biztosít, amely alkotmányosan nem indokolható, ezért az a sajtószabadság aránytalan korlátozásának minősül. A kereskedelmi közlések tartalmi előírásait tartalmazó Smtv. 20. §-ával kapcsolatban - hivatkozva korábbi eseti döntéseire -, megerősítette a kereskedelmi és gazdasági célú közlések tekintetében a hatóság útján történő korlátozás indokoltságát. Megfogalmazta ugyanakkor a nyomtatott és internetes sajtótermékek befogadóra gyakorolt, az audiovizuális médiától eltérő hatásmechanizmusát, valamint erre tekintettel a két médium privilegizált kezelését a kereskedelmi közlések tartalma szempontjából: „Mivel a gazdasági közlések célja alapvetően vagy kizárólagosan gazdasági érdekek által motivált, ezért az ilyen kommunikáció védelme lényegesen alacsonyabb, azaz ebben a körben szélesebb körü beavatkozás lehet alkotmányosan indokolt, mint a véleményközlés egyéb eseteiben.” ${ }^{353}$

Az Alkotmánybiróság megállapításait összegezve: a nyomtatott és internetes sajtótermékek tekintetében az emberi méltóságra, a nyilatkozatot adó személy jogaira, az emberi jogokra, valamint a magánélet védelmére az Smtv. által alapított médiahatósági fellépés a

\footnotetext{
${ }^{352}$ A 2012. évi LXVI. törvény 22. §-ával módosította a 15. § rendelkezéseit, a 18. §-t pedig hatályon kívül helyezte 2012. VI. 19-töl.

${ }^{353}$ 1270/B/1997. AB határozat, ABH 2000. 718., továbbá ld.: 8. 2. 1. MVK versus JBE, 742. lbj.
} 
sajtószabadság szükségtelen és aránytalan korlátozásának minősül; ennél fogva a nyomtatott és internetes sajtótermékek a törvény személyi hatályának megváltoztatásával 2012. május 31-től kikerültek annak hatálya alól. Ezzel lényegében igazoltnak volt tekinthető a NAMS és a JK azon tétele, amely 2007-ben az elektronikus médiaszolgáltatásokkal nem kívánta egy törvényben kezelni a nyomtatott, valamint az internetes sajtó szabályozását. A 2012. június 4-én elfogadott 2012. évi LXVI. törvény ugyanakkor ismételten az Smtv. tárgyi hatálya alá helyezte a sajtótermékeket ${ }^{354}$ többek között az emberi méltóságot sértő általános és konkrét tiltó tényállás, ${ }^{355}$ a médiatartalom alkotmányos rendet sértő, ${ }^{356}$ illetőleg a gyülöletkeltés és kirekesztés tilalmára ${ }^{357}$ vonatkozó rendelkezések tekintetében. A sajtótermékek tárgyi hatályát revideáló 2012-es Smtv. módosítás e rendelkezések tekintetében nem áll ellentétben a jogalkotó mintegy hét-nyolc évvel korábbi, a nyomtatott sajtóra és az internetre vonatkozó önálló törvényi szabályozási szándékával. Az emberi méltóság értelmezésének polgárjogi és médiajogi jogfejlődése, az időközben kijegecesedett alkotmánybírósági jogértelmezés, valamint az emberi méltóság és az emberi jogok alapjogi jelentősége, továbbá a megváltozott piaci környezet mind olyan tényezők, amelyek 2012-re indokolttá tették a sajtótermékek egységes médiaszabályozásba illesztését.

A 2010-es médiaszabályozást megelőzően a forrásvédelem kérdéseit az Stv. ${ }^{358}$ szabályozta, jelenleg az Smtv. rendelkezik a jogintézményröl. Az Smtv. eredeti szövege szerint a sajtó jogosult volt titokban tartani az informátor személyét, azaz az információ forrását. A titokvédelem azonban a minősített adatot (államtitok, szolgálati titok) illetéktelenül átadó informátor személyére nem terjedt ki, és nem vonatkozott az információt tartalmazó, azok hitelességét bizonyító dokumentumokra, adatokra sem. A titoktartás joga érvényesült a bírósági és hatósági eljárásokban, és még a tanúzás alól is mentességet jelentett. Az újságírót a forrásvédelem csak abban az esetben illette meg, ha az információ közzététele a közrend védelme érdekében állt. A bíróság és a hatóság (majd nyomozóhatóság) az újságírót az informátor személyének felfedésére a nemzetbiztonság

\footnotetext{
354 2012. évi LXVI. törvény a médiaszolgáltatásokkal és a sajtótermékekkel összefüggő egyes törvények módosításáról (1a) E törvény hatálya - a 13. §, a 14. § (1) bekezdése, a 19. § (1), (2) és (4) bekezdése, valamint a 20. § (8) bekezdésének második mondata és (9) bekezdése kivételével - kiterjed a Magyarország területén letelepedett médiatartalom-szolgáltató által kiadott sajtótermékre is."

${ }^{355} \mathrm{Smtv}$. 14. § (1)-(2)

${ }^{356}$ Smtv. 16. §

${ }^{357}$ Smtv. 17. §

${ }^{358}$ Stv. 11. § „Az újságíró a felvilágosítást adó személy nevét jogosult - annak kérelmére köteles - titokban tartani; bűncselekményre vonatkozó felvilágosítás esetén a büntetőjogszabályok rendelkezései az irányadók."
} 
vagy a közrend védelme, valamint büncselekmény elkövetésének felderítése vagy megelőzése érdekében, kivételesen indokolt esetben kötelezhette. A szabályozást sok kritika érte a forrásvédelem sajtószabadságot szükségtelenül és aránytalanul korlátozó rendelkezései miatt, továbbá többek között a már említett dokumentumvédelem hiánya okán, valamint azért is, mert a szabályozásban nem volt egyértelmű az informátor felfedésére jogosult hatóság „kiléte”.

Az Smtv. 2012-es módosítása lényeges rendelkezéseket vezetett be a jogintézményt illetően. ${ }^{359}$ Egyértelművé vált, hogy a szabályozás nemcsak az informátort, hanem az információt is védelem alá helyezi ${ }^{360}$ továbbá, hogy az informátor felfedésére, ${ }^{361}$ illetőleg az információ azonosítására alkalmas dokumentumok, tárgyi bizonyítékok stb. átadására csak a bíróság, és kizárólag büncselekmény felderítése érdekében, kivételesen indokolt, törvényben meghatározott esetben kötelezheti a médiatartalom-szolgáltatót, vagy a vele jogviszonyban álló személyt, az újságírót. ${ }^{362}$ Az új szabályozással a jogalkotó meghajolt a szakmai érvek előtt és megfelelő jogi környezetet teremtett az intézmény számára. ${ }^{363}$

\subsubsection{Dogmatikai átláthatóság}

A NAMS Jogalkotási Koncepció szerint a jogkövetés megkönnyítése és a jogbiztonság céljából a szabályozás dogmatikai átláthatósága érdekében a nem média-specifikus szabályok az általános jogszabályokban, a televiziós és rádiós lineáris szolgáltatások, valamint a közszolgálati médiaszolgáltatás speciális szabályai az audiovizuális

\footnotetext{
${ }^{359}$ Smtv. 2012. évi 2012. évi LXVI. törvény 19. §-ával megállapított 15. §, hatályos: 2012. VI. 19-től.

${ }^{360}$ Smtv. 2012. évi LXVI. törvény 17. §-ával módosított „6. § (1) A médiatartalom-szolgáltató, valamint a vele munkaviszonyban vagy munkavégzésre irányuló egyéb jogviszonyban álló személy törvényben meghatározottak szerint jogosult a számára a médiatartalom-szolgáltatói tevékenységgel összefüggésben információt átadó személy (a továbbiakban: információforrás) kilétét a bírósági és hatósági eljárások során titokban tartani, továbbá bármely, az információforrás azonosítására esetlegesen alkalmas dokumentum, irat, tárgy vagy adathordozó átadását megtagadni.” Hatályos 2012. VII. 3-tól.

${ }^{361}$ A Fővárosi Törvényszék elsőfokú itélete értelmében a Figyelő újságírójának nem kell felfednie az MKB Bankról szóló cikkében publikált adatok információforrását. http://www.jogiforum.hu/hirek/36981 2016. 12. 09.

${ }^{362}$ Smtv. 2012. évi LXVI. törvény 17. §-ával módosított „6. § (2) A bíróság - bűncselekmény elkövetésének felderítése érdekében - törvényben meghatározott, kivételesen indokolt esetben az információforrás felfedésére, valamint az információforrás azonosítására esetlegesen alkalmas dokumentum, irat, tárgy vagy adathordozó átadására kötelezheti a médiatartalom-szolgáltatót, valamint a vele munkaviszonyban vagy munkavégzésre irányuló egyéb jogviszonyban álló személyt.” Hatályos 2012. VII. 3-tól.

363 "Azon pontok tekintetében pedig, melyek kapcsán valóban megfogalmazódott jogi ellenérv - így az újságírói forrásvédelem vagy az írott sajtóra vonatkozó egyes tartalmi követelmények kapcsán -, ott a jogalkotó lépett és változtatott" - vélte a központ. http:/hir.ma/belfold/alapjogokert-kozpontmegalapozatlanok-voltak-az-uj-mediaszabalyozast-ero-kritikak/510234
} 
médiaszolgáltatásokról szóló törvényben, a lekérhető szolgáltatásokra vonatkozó rendelkezések pedig a már nevesített elektronikus kereskedelmi törvényben kerültek volna elhelyezésre. A reklámra vonatkozó általános rendelkezéseket továbbra is a gazdasági reklámtevékenységről szóló törvény ${ }^{364}$ (Grtv.), a sajtó-helyreigazitás jogintézményét pedig a Polgári Törvénykönyv tartalmazta volna. A „reklámszabályozás”, a kereskedelmi kommunikáció tekintetében az - időközben bekövetkezett - uniós irányelvi „átrendeződés” ${ }^{365}$ és az ennek megfelelő hazai implementációs kötelezettség teljesen átformálta a médiaszolgáltatásban megjelenő kereskedelmi kommunikáció ${ }^{366}$ szabályozását. Az új rendszerben a jogsértő kereskedelmi közlemények - mint egy fajta tisztességtelen kereskedelmi gyakorlat - megítélésére legtágabb értelemben az Fttv. rendelkezései az irányadók. A korábbi szabályozási elveknek megfelelően a gazdasági reklámokra, valamint a kereskedelmi közlemények más formáira vonatkozó általános szabályok továbbra is a Grtv.-t felváltó Új Grtv.-ben maradtak, illetőleg kerültek újonnan szabályozásra. A versennyel összefüggő jogsértő kereskedelmi gyakorlatra irányadó szabályozás pedig a módosított versenytörvény rendelkezéseibe épült be. ${ }^{367} \mathrm{~A}$ médiaszolgáltatásban megjelenő kereskedelmi közleményekre vonatkozó rendelkezések ${ }^{368}$ az „ágazati” szabályozásban maradtak és az Smtv., illetőleg az Mttv. rendelkezései közé kerültek beépítésre. Az Új Grtv. és a médiatörvények viszonyában a lex generali - lex speciali elve érvényesül, és az általános - különös elv irányadó ${ }^{369}$ a kereskedelmi kommunikáció médiaszabályozására az Smtv. és az Mttv. kapcsolatában is.

\footnotetext{
${ }^{364}$ 1997. évi LVIII. törvény a gazdasági reklámtevékenységröl. (Grtv.)

365 A NAMS JK közzétételét követően lépett hatályba a UCP irányelv [az Európai Parlament és a Tanács 2005/29/EK irányelve (2005. május 11.) a belső piacon az üzleti vállalkozások fogyasztókkal szemben folytatott tisztességtelen kereskedelmi gyakorlatairól] átültetése tárgyában a 2008. évi XLVII. törvény a fogyasztókkal szembeni tisztességtelen kereskedelmi gyakorlat tilalmáról (Fttv.), valamint a gazdasági reklámtevékenység alapvető feltételeiről és egyes korlátairól szóló 2008. évi XLVIII. törvény (Új Grtv.) ${ }^{366}$ GELLÉN Klára: A kereskedelmi kommunikáció szabályozása a médiajogban (prof. dr. Homoki-Nagy Mária (szerk.) HVG-ORAC 2012. (GELLÉN I.) 21-26.

367 1996. évi LVII. törvény a tisztességtelen piaci magatartás és versenykorlátozás tilalmáról. (Tpvt.)

${ }^{368}$ Kereskedelmi közlemények, médiaszolgáltatások és a müsorszámok támogatása, termékmegjelenítés a müsorszámokban, politikai reklám, közérdekủ közlemény és társadalmi célú reklám, reklám és televíziós vásárlás a lineáris médiaszolgáltatásban, reklám és közérdekü közlemény a közszolgálati és a közösségi médiaszolgáltatásban, valamint a közzétételi kötelezettség szabályai Mttv. 23-37. §, Smtv. 20. § (1)-(7)

${ }^{369} \mathrm{Az}$ Új Grtv. eredeti szövege szerint [1. § (3)] A rádió és televízió müsorszolgáltatásában közzétett reklámra - ha e törvénytöl eltérö követelményeket állapít meg - az Rttv.-ben foglalt rendelkezéseket kell alkalmazni. Az Új Grtv. Mttv. 227.§ (1) bekezdésével módosított szövege szerint az audiovizuális és rádiós médiaszolgáltatásban közzétett reklámra az Smtv-t és az Mttv-t is alkalmazni kell. Hatályos: 2011. I. 1-töl.
} 


\subsubsection{Jogalkotási menetrend}

$\mathrm{A} z$ unió többi tagállamával összhangban álló szabályozás megalkotása érdekében a Koncepció eredetileg azt a jogalkotási metodikát és sorrendiséget állította fel, hogy a lineáris szolgáltatásokra vonatkozó szabályozás (audiovizuális médiaszolgáltatásokról és a közszolgálati médiaszolgáltatásokról szóló törvény) megalkotásával egyidejüleg készüljön el a lekérhető szolgáltatásokra vonatkozó jogszabály-tervezet is.

A lekérhetö szolgáltatásokra vonatkozó szabályok hatálybalépésére azonban csak később, az Elkertv. módositása keretében, a többi tagállam átültetési gyakorlatának ismeretében kerüljön sor. E jogalkotási „menetrend” szerint 2008. év végén felülvizsgálatra került volna a lekérhető szolgáltatásokra kialakított szabályrendszer, hatályba lépése 2009. év végére volt tervbe véve. Ezzel a megoldással a NAMS JK meg akarta állítani azt a már akkor elkezdődött, fentiekben jelzett folyamatot, hogy a müsorszolgáltatók ne elsősorban a bevezetésre kerülő szigorúbb hazai médiaszabályok miatt és elől „meneküljenek” más uniós országba.

\subsubsection{A lineáris és lekérhető médiatartalom, az információs társadalmi szolgáltatások szabályozásának szétválasztása}

A szabályozás tárgyi hatálya szempontjából a NAMS JK - az átlátható, egyértelmü szabályozás kialakítása céljából - fontos kérdésnek tartotta a lineáris, a lekérhető és az információs társadalmi szolgáltatások szétválasztását. A megfelelő elhatárolás mellett a hatósági nyilvántartás szabályait is eltérően kívánta a NAMS JK meghatározni úgy, hogy a lineáris médiaszolgáltatókat szolgáltatásuk tekintetében bejelentési kötelezettség terhelje, míg a lekérhető audiovizuális médiaszolgáltatók és szolgáltatásuk az AVMS irányelv alapján szintén a médiaszabályozás hatálya alá tartozzanak, azonban e szolgáltatások ne alapuljanak kötelező nyilvántartásba-vételen. A $N A M S J K$ számos érvet sorakoztatott fel a lekérhető szolgáltatások kötelező nyilvántartásba vétele ellen. A szolgáltatók viszonylag jelentős számának megsokszorozódásával lehetett számolni a piacra lépés gazdasági és technikai akadályainak csökkenése alapján, a szolgáltatás jellegéből adódóan pedig a nyilvántartásba vétel a szolgáltatások nem egyértelmü besorolása miatt csak egy előzetes hatósági vizsgálaton alapulhatott volna. Mindkét tényező indokolatlan terhet jelentett volna a hatóságra. A lekérhető audiovizuális médiaszolgáltatások még inkább határokon átnyúló jellege miatt továbbá a hazai regisztrációs elöírásokat a környező országok nyilvántartási 
gyakorlatára figyelemmel kellett volna kialakítani. Végül pedig a lekérhető szolgáltatások, illetőleg szolgáltatóik kötelező nyilvántartásba vétele ellen szóló legfontosabb érv, a jogkövetkezmény azonossága volt, nevezetesen, hogy a jogsértést elkövető szolgáltatókkal szemben az eljárás akkor is megindítható, ha nem kérték nyilvántartásba vételüket."370 Ennek alapján - a jogbiztonság fokozása érdekében - a NAMS eredeti javaslatában megfogalmazódott, hogy bármely szolgáltató nyilvántartásba vétel nélkül kérhesse a hatóságtól szolgáltatásának besorolását, nevezetesen annak megállapítását, hogy „tevékenysége a médiaszabályozás hatálya alá tartozó nem lineáris tartalomszerkesztési tevékenységnek minősül-e." ${ }^{371}$ A $N A M S$ - többek között - ezért sem állt ki a nem lineáris tartalomszerkesztési tevékenységek bejelentési és regisztrációs kötelezettsége mellett. Tekintettel továbbá arra, hogy a NAMS JK szerint a lekérhető szolgáltatást nyújtó szolgáltatók nyilvántartásának célja a szolgáltató önbesorolásának elősegítse volt, a Koncepció jogi és gazdasági ösztönzők alkalmazásával a lekérhető audiovizuális médiaszolgáltatók önkéntes nyilvántartásba vételét javasolta; az információs társadalmi szolgáltatókat illetően pedig a regisztrációt nem kívánta bevezetni a szabályozásba.

A jogalkotó az egységes szabályozás mellett tette le a voksot. Az Smtv. felhatalmazása alapján $^{372}$ törvény a médiaszolgáltatások megkezdésének vagy végzésének, illetve a sajtótermékek közzétételének feltételéül szabhatja a hatósági nyilvántartásba vételt. A nyilvántartásba vétel feltételei nem korlátozhatják a sajtó szabadságát. A létrejött szabályozás - a NAMS JK szabályozási céljaihoz képest - egységes bejelentési kötelezettséget ír elő a lineáris médiaszolgáltatási jogosultság megszerzése, a lekérhető és a kiegészítő médiaszolgáltatások, valamint a sajtótermékek tekintetében, de a szolgáltatások, illetőleg a kiadói tevékenység eltérő jellege miatt külön-külön feltételrendszer alapján. ${ }^{373} \mathrm{~A}$ lineáris médiaszolgáltatás csak bejelentést és hatósági nyilvántartásba vételt követően kezdhető meg, a lekérhető és a kiegészítő szolgáltatásokat, valamint a sajtótermékek kiadását azonban meg lehet kezdeni nyilvántartásba vétel nélkül is, tehát a regisztráció nem feltétele a szolgáltatás, a tevékenység megkezdésének, de gyakorlásának igen: a bejelentést a szolgáltatás, illetőleg a tevékenység megkezdését követő hatvan napon belül meg kell tenni az NMHH Hivatalánál. ${ }^{374}$ A hatvan napon túli regisztráció esetén vagy regisztráció hiányában a szolgáltatás vagy a kiadói tevékenység gyakorlása jogsértő. A

\footnotetext{
${ }^{370}$ NAMS JK 43.

371 NAMS 44.

${ }^{372}$ Smtv. 2011. évi CVII. törvény 65. § (5) bekezdésével megállapított 5. § (1), hatályos 2011. VIII. 3-tól.

${ }^{373}$ Mttv. 41. § (1) és (2), valamint 42-43. §

${ }^{374}$ Mttv. 41. § (1)-(2)
} 
médiaszabályozás a $N A M S J K$ vonatkozó céljait meghaladva kötelező bejelentéshez és regisztrációhoz köti a médiaszolgáltatások nyújtását és a kiadói tevékenységet, még ha a lekérhető, kiegészítő szolgáltatások, valamint a sajtótermékek esetében a bejelentés nem is feltétele az aktivitás megkezdésének. A nyilvántartásba vétel kialakult szabályai nem vehetők kritika alá, hiszen e rendelkezések szorosan összefüggenek a szolgáltatási formák egyértelmü és világos fogalom-meghatározásával és e fogalmak elkülönítésével. A NAMS kidolgozásának időszakában e fogalmak közötti átfedések, az új szolgáltatások besorolhatóságának dilemmái, a jövőbeni szabályozás értelmezési kérdései legfeljebb a stratégiai szintü javaslatok megfogalmazását tették lehetővé a már ismert vagy alakulóban lévő uniós szabályozás alapján.

\subsubsection{A származási ország elve és annak szükséges áttörése}

A származási ország princípiuma a közösségi audiovizuális szabályozás egyik alapköve, melyet a NAMS $J K$ is irányadónak tekintett a joghatósági kérdések szabályozásánál. A Koncepció a származási ország elve szempontjából elsődleges céljának tekintette, hogy a magyar médiaszabályozás előzze, de legalábbis akadályozza meg a magyar joghatóság alá tartozó müsorszolgáltatók „elvándorlását”. ${ }^{375}$ Itt kell rámutatni arra, hogy a hazai médiapiacon az eleve külföldről sugárzó, valamint 2006-tól egyre intenzívebbé váló szolgáltatói joghatóságváltás 2012-re mintegy tizenöt film-, tizenhat ismeretterjesztő- és öt sportcsatornát, továbbá hat gyermekmüsort, valamint nyolc egyéb müsort sugárzó magyar nyelvü csatornát érintett. ${ }^{376}$ A szolgáltatói áttelepülés" okai számosak. A médiaszolgáltató müködési körén kívüli tényezőként említhető a más tagállami kedvezőbb gazdasági (adóés pénzügyi) környezet [Csehország], az ellenérték nélküli médiaszolgáltatási lehetőség [Románia], vagy a magyar szolgáltatási díjaknál kedvezőbb díjak alkalmazása [Csehország]. A joghatóságváltást elősegítő további tényező a tartalomszolgáltatás rugalmasabb felügyeleti ellenőrzése [brit OFCOM, Csehország] és a müsorszámok kategóriába sorolásának a magyartól kedvezőbb volta, vagy éppen hiánya is [Csehország]. A kivándorlás médiaszolgáltatók tevékenységéből fakadó okai között a médiatörvények (Rttv. Mttv.) megszegésének hazai szigorúbb szankció rendszere, valamint az ORTT fokozatosságot és arányosságot több esetben nem ismerő felügyeleti gyakorlata említhető,

\footnotetext{
${ }^{375}$ Ld. még: 8.1.3. alfejezetet a műsorszolgáltatói magatartás kontrolljáról. 726. lbj.

${ }^{376}$ Forrás: NAGY Dóra: Magyarországra sugárzó, külföldi joghatóságú médiaszolgáltatók Hová és miért mentek el Magyarországról a televiziók? In Medias Res 2012/1. 137-138. (NAGY)
} 
amely adott esetben nagy összegű bírságok felhalmozását eredményezték egyes szolgáltatók oldalán [Minimax, HBO]. A 2009. május 1-től az OFCOM joghatósága alá került Viasat3 székhelyváltásához - mindezeken felül - a médiahatósággal való „,nem felhőtlen viszony” is hozzájárult. ${ }^{377}$ A Cool TV Romániába településének indokát pedig mások mellett az új román illetőségü tulajdonos, valamint a hazai magas műsorszolgáltatási alapdíj képezte. A 2010 után érvényesülő média-szabályozási környezet a joghatóság tekintetében megfelelő kereteket teremt a további elvándorlások megakadályozására, de a médiaszabályozáson kívüli egyéb tényezőknek is jelentős szerepe van a médiaszolgáltatók „itthon tartásában”. 378

A Koncepció lényegesnek tartotta továbbá, hogy a jogalkotó - a közösségi joggal összhangban - teremtse meg a származási ország elvétöl való eltérés lehetöségét a közrend védelme érdekében. Ennek megfelelően a NAMS JK azt javasolta, hogy a magyar szabályozás a közösségi norma átültetése során biztosítson konzultációs lehetöséget az Európai Bizottsággal, illetve annak a tagállamnak a hatóságával, amelynek joghatósága alá az érintett szolgáltatás tartozik. A $J K$ az EU Bizottságával és más tagállamok hatóságaival való együttmüködés mellett szorgalmazta, hogy a hazai szabályozás biztosítsa a más tagállamokból érkező sérelmes szolgáltatásokkal kapcsolatos megkeresések és válaszadás meghatározott eljárási rendjét. Abban az esetben, ha egy másik tagállamban müködő műsorszolgáltató a hazai jogszabályokat a közösségi jog által kijelölt körben nyilvánvalóan és súlyosan megsérti, akkor a származási ország elvétől való eltérést a NAMS JK indokoltnak tartotta. A Koncepció az audiovizuális médiaszolgáltatások tekintetében e korlátozó intézkedéseket kellően hatékonynak minősítette, ugyanis a Magyarországra irányuló műsorok döntő többsége esetében a hatóságok képessé válhatnak a joghatóság azonosítására és a megfelelő korlátozás előírására.

Az AVMS irányelv a származási ország elvét követve lehetővé teszi a tagállami médiaszolgáltatók számára, hogy székhelyüktől különböző tagállamba, tagállamokba sugározzák müsoraikat; továbbá biztosítja az uniós országok számára azt is, hogy meghatározott feltételek esetén - érvényesítsék felügyeleti hatáskörüket a joghatóságukon kívül álló médiaszolgáltatókkal szemben is. Az $A V M S$ irányelv 2. és 3. cikkei körülhatárolják azokat az eseteket, ahol a tagállamok korlátozhatják a származási ország elvének maradéktalan érvényesülését, illetve, hogy megfelelő lépéseket tehessenek a piaci

\footnotetext{
${ }^{377}$ NAGY 140.

${ }^{378}$ Ilyen kedvezőtlen jogszabályi, gazdasági környezet lehet a reklámadó bevezetése a 2014. évi XXII. törvény alapján.
} 
szereplők vagy a nézők érdekeit sértő szolgáltatókkal szemben. Az Unió gyakorlata szerint a tagállamok abban az esetben korlátozhatják a más tagállamokban gyártott termékekhez, szolgáltatásokhoz való szabad hozzáférést, ha ezeket a korlátozásokat a közrendhez kapcsolódó megfontolások indokolják, és akkor is csak abban az esetben, ha a korlátozás mértéke arányos az elérni kívánt céllal, valamint ha e célkitüzést más, kevésbé korlátozó rendelkezésekkel nem lehet elérni. E szabályozás kulturális jelentősége az egységes európai kulturális piac megőrzése és védelme, nevezetesen az, hogy az európai müvekhez és tartalmakhoz való hozzáférés lehetősége csak kivételesen és rendkívüli esetekben legyen korlátozható. Az irányelvnél esetenként szigorúbb tagállami joghatósági szabályoknak összhangban kell állniuk az uniós jog elveivel. ${ }^{379}$ Meg kell jegyezni azt is, hogy az AVMS irányelv a közösségi jog korszerüsített, nemzetközi együttmüködést elöirányzó eljárásrendszert vezetett be mind a lineáris, mind pedig a lekérhető szolgáltatásokra vonatkozóan.

Az Mttv. AVMS irányelvet implementáló joghatósági rendelkezései alapján a törvény tárgyi hatálya alapesetben a Magyarországon letelepedett médiatartalom-szolgáltató által nyújtott médiaszolgáltatásra és kiadott sajtótermékre terjed ki. ${ }^{380}$ Az új médiatörvény az $A V M S$ irányelv vonatkozó cikkeinek átvételével - a NAMS JK által meghatározott célok és tételek szerint érvényesíti - a származási ország elvét a más tagállamban letelepedett médiaszolgáltató által nyújtott jogsértő lineáris, valamint lekérhető audiovizuális, továbbá rádiós tartalomszolgáltatás vagy kiadott sajtótermék tekintetében. ${ }^{381}$ A szabályozó Hatóság ezekben az ügyekben együttmüködik más tagállamok médiahatóságaival, ${ }^{382}$ a szabályozás továbbá a Médiatanács részére biztosítja az Európai Bizottság értesítésének kötelezettségét, valamint a Bizottsággal való konzultáció lehetőségét. Az Mttv. a Médiatanács feladat- és hatáskörébe rendeli a más tagállamban letelepedett médiatartalomszolgáltatók által elkövetett jogsértésekkel kapcsolatos hatáskörök gyakorlását. ${ }^{383}$ Eltérő eljárást határoz meg a törvény az $A V M S$ irányelv hatálya alá tartozó, más tagállamban letelepedett szolgáltatók lineáris audiovizuális médiaszolgáltatása, illetőleg az AVMS hatályán kívüli, de Magyarország területére irányuló rádiós médiaszolgáltatása, valamint terjesztett, közzétett sajtótermékek által megvalósított jogsértés esetére. A származási

\footnotetext{
${ }^{379}$ AVMS 4. cikk (1)

380 2011. évi CCI. törvény 390. § b) pontjával módosított Mttv. 1. § (1). A Magyarországon letelepedett médiaszolgáltató kritériumait az Mttv. 1. § (2)-(3) bekezdései határozzák meg.

${ }^{381}$ Mttv. 176-180. §

${ }^{382}$ Mttv. 183. $\left.\S(1) \mathrm{n}\right)$

${ }^{383}$ Mttv. 182. § d)
} 
ország elvétől való eltérés érvényesül a normaszövegben a lineáris szolgáltatás esetében a kiskorúak védelmére, illetőleg a gyülöletbeszéd tilalmára vonatkozó rendelkezések megsértése esetén, a lekérhető szolgáltatások vonatkozásában pedig a közrend védelmén túl, a büncselekmények megelőzése, felderítése és üldözése, a közösségek elleni gyülöletkeltés tilalmának megsértése, vagy a kiskorúak, a közegészség, a közbiztonság, a nemzetbiztonság és a fogyasztók, befektetők védelme miatt szükséges okból. Ezekben az esetekben a médiatartalmakat fogadó állam a szolgáltatások szabad áramlásának uniós elvével szemben is jogosult a szabályozásra és a fellépésre. Az AVMS irányelv a jogsértés esetére alkalmazandó hatósági jogkövetkezmények körének meghatározását tagállami hatáskörben hagyta. Az Mttv. eredeti szövegében ilyen jogkövetkezményként szerepelt a bírságolás lehetősége is, amelyet az Európai Unió Bizottsága 2011 februárjában - a Magyar Kormánnyal folytatott levélváltás eredményeként - nem tartotta az irányelvben meghatározott intézkedések körébe tartozónak. Az Mttv. 178. §-a az uniós jogharmonizáció hatálya alá nem vont rádiós szolgáltatások és sajtótermékek tekintetében a más tagállamokkal való együttmüködési kötelezettség mellett nem írja elő a Bizottság értesítését. Mivel a rádiós szolgáltatások és a sajtótermékek nem tartoznak az AVMS hatálya alá, az Mttv. e rendelkezése sem írhatott elő a Bizottság számára feladatot és határozhatott meg többlet hatáskört. ${ }^{384}$

\subsubsection{Kvótaszabályozás}

\section{A kvótaszabályozás elvei és céljai}

Előre kell bocsátani, hogy a médiaszolgáltatások „kettős természete”, ${ }^{385}$ azaz egyszerre gazdasági és kulturális jellege miatt a kvótaszabályok viszonylag későn, a kulturális, illetve az egységes belső piaci irányzat megegyezésének eredményeként kerültek be az uniós irányelvi szabályozásba. A Jogalkotási Koncepció a kvótaszabályozás kialakításánál a hazai médiapiac sajátosságaiból indult ki. Az európai és magyar nyelven készített müvekkel kapcsolatos kvótaszabályozás - a NAMS JK szerint ugyanis - akkor alkalmas a médiapolitikai célok elérésére és egyben akkor arányos, ha figyelembe veszi a magyar piac sajátosságait. A magyar audiovizuális médiaszolgáltatási piac a közszolgálati, a kereskedelmi és (helyi) közösségi müsorszolgáltatók háromosztatú rendszerén alapult,

\footnotetext{
${ }^{384}$ Ezzel egyezö álláspontot képvisel KOLTAY-LAPSÁNSZKY Kommentár 348.

${ }^{385}$ NYAKAS Levente: A kvótaszabályozás az európai audiovizuális médiaszabályozásban - gazdasági és kulturális megfontolások határán Iustum Aequum Salutare X. 2014. 1. 129-147. (NYAKAS III.) 134.
} 
melynek szereplői a nyilvánvaló eltérő célok érdekében, eltérő üzleti modellek szerint müködtek. A Jogalkotási Koncepció - ennek megfelelően - a három különbözö müsorszolgáltató típusra eltérő kvótaszabályok megállapítását javasolta. A Koncepció egyik alapvetö célkitüzése volt a kvóták megállapítása során a tartalomra vonatkozó szabályozási területen az európai kultúra támogatásán túl a nemzeti és a magyarországi nemzeti kisebbségi anyanyelvi kultúra támogatása, amihez a NAMS JK értelmében meg kell teremteni az ezt elősegítő jogszabályi környezetet és jogintézményeket, valamint biztosítani kell a szükséges anyagi forrásokat. Specifikus célként jelölte meg a Koncepció a minöségi magyar tartalmak elöállitásának ösztönzését és e tartalmak fogyasztókhoz történő eljutásának támogatását.

A magyar médiaszabályozás hatálya alá tartozó audiovizuális médiaszolgáltatót terhelik egyrészt a közösségi jogban meghatározott európai, illetve ezen belül a független elóállítók által készített művek bemutatására vagy azok gyártásához való hozzájárulásra vonatkozó kvóták, másrészt a tagállami hatáskörben megállapított, nemzeti tartalom előállítási céljait szolgáló, eredetileg magyar nyelven, illetve a nemzeti és etnikai kisebbségek nyelvén készített müvekre, ezen belül is a független előállítású müvekre vonatkozó, szintén müsoridőhöz/ráfordításhoz kötődő kvóták.

\section{A kvótaszabályok rendszere a Jogalkotási Koncepcióban}

Sem a nemzeti nyelvi kvóták, sem a független előállítókkal kapcsolatban megállapított opcionális ráforditás/müsoridő alapú kvóták esetében nem alakult ki a közösségen belüli „legjobb gyakorlat”. Emiatt a NAMS Koncepció a piaci viszonyoknak megfelelő, egyben az európai/magyar kultúra támogatását hatékonyan előmozdító, differenciált kvótarendszer kialakítását tartotta szükségesnek, összhangban a filmtörvény ${ }^{386}$ rendelkezéseivel. A kvótarendszer kialakításánál a $N A M S J K$ alapvető volt a lineáris és lekérhető tartalmak megkülönböztetését, a közszolgálati, a kereskedelmi és a közösségi műsorszolgáltatók, a televíziók és rádiók, valamint az akkori piacfelmérésen alapuló meghatározó véleménybefolyásoló képességgel rendelkező $(M V K)$ és a jelentős véleménybefolyásoló képességgel rendelkező (JVK) szolgáltatók közötti differenciálást. A közszolgálati müsorszolgáltatók tekintetében a Koncepció minden egyes csatorna esetében indokoltnak látta a kvótarendszer fenntartását. A kereskedelmi televíziókra vonatkozó szabályozásban a Koncepció - a médiahatóság ellenőrzési jogosultsága mellett - a differenciált

${ }^{386} 2004$. évi II. törvény a mozgóképröl. 
kvótarendszer bevezetését tartotta kívánatosnak úgy, hogy az $M V K$ és a $J V K$ müsorszolgáltatók az európai és a magyar kvótát saját döntésük alapján akár müsorszámok előállítására/megvásárlására történő közvetlen ráfordítással, akár a független gyártók számára müsoridő biztosításával teljesíthetik, illetve azt a Tartalom-támogatási Alapba történő pénzbeli befizetéssel is megválthatják.

\begin{tabular}{||c|c|c|c|c||}
\hline $\begin{array}{c}\text { KVÓTA } \\
\text { SZABÁLYOK }\end{array}$ & $\begin{array}{c}\text { KÖZSZOLGÁLATI } \\
\text { TELEVÍZIÓ }\end{array}$ & $\begin{array}{c}\text { KERESKEDELMI/ } \\
\text { KÖZÖSSÉGI } \\
\text { TELEVÍZIÓ }\end{array}$ & $\begin{array}{c}\text { KÖZSZOLGÁLATI } \\
\text { RÁDIÓ }\end{array}$ & $\begin{array}{c}\text { KERESKEDELMI/ } \\
\text { KÖZÖSSÉGI } \\
\text { RÁDIÓ }\end{array}$ \\
\hline Lineáris & $\mathrm{X}$ & - & $\mathrm{X}$ & - \\
\hline Lekérhető & - & - & - & $\mathrm{X}$ \\
\hline $\mathrm{JVK}$ & $\mathrm{X}$ & $\mathrm{X}$ & $\mathrm{X}$ & $\mathrm{X}$ \\
\hline $\mathrm{MVK}$ & $\mathrm{X}$ & $\mathrm{X}$ & $\mathrm{X}$ & \\
\hline
\end{tabular}

\section{4. ábra A kvótaszabályok NAMS JK szerinti rendszere ${ }^{387}$}

A rádiók esetében hasonló differenciálást tartott szükségesnek a Koncepció. A magyar tartalom preferálásának általános médiapolitikai céljaként megfogalmazott rádiós kvótaszabályok elöírását azonban a $N A M S J K$ további hatásvizsgálattal és az érintettekkel folytatott konzultációkkal javasolta megalapozni. A kvótaszabályok korábbi, éves utólagos hatósági kontrollját pedig a valós médiapolitikai célt, a tartalom támogatását jobban szolgáló, év közbeni korrekcióra kényszerítő gyakoribb ellenőrzéssel és szankcionálással szándékolta felváltani.

Az Mttv. müsorkvótákra vonatkozó rendelkezései ${ }^{388}$ a törvény preambulumában megfogalmazott, a nemzeti és kulturális identitás megerősítését szolgáló célokkal, továbbá az AVMS irányelvvel és a határokat átlépö televiziózásról szóló európai egyezmény

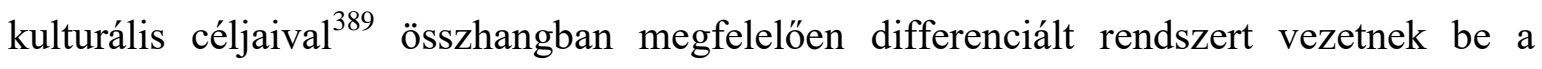

\footnotetext{
${ }^{387}$ NAMS JK 3. ábra 21-22.

${ }^{388}$ Mttv. 2014. évi CVII. törvény 2. §-ával megállapított 20-22. §-i, hatályos 2015. I. 1-től.

${ }^{389}$ A határokat átlépő televíziózásról szóló európai egyezmény, kihirdette:1998. évi XLIX. törvény.
} 
szabályozásba. A magyar kvótarendelkezések ${ }^{390}$ figyelemmel vannak a lineáris és lekérhető médiaszolgáltatások, az audiovizuális és rádiós tartalmak eltérő jellegére, valamint a közszolgálati médiaszolgáltatástól elvárt többlet teljesítményre, és - az ebből következő - speciális, szigorúbb rendelkezések szükségességére.

A kvótarendszer nem veszi át az Rttv. korábbi „ráfordítás alapú” kvóta-meghatározását, amely a NAMS $J K$-ban is csak egyik változatként szerepelt. Ennek oka az AVMS irányelv szerint a médiaszolgáltatóktól független producerek és müsorkészítők támogatása, ${ }^{391}$ nevezetesen az, hogy a független gyártók alkotásainak ösztönzése segíti az ilyen müveket létrehozó kis- és középvállalkozások létrejöttét is. Az Mttv. - ennek megfelelően meghatározza a független műsorkészítö ${ }^{392}$ fogalmát, továbbá a magyar mü ${ }^{393}$ és az európai mü ${ }^{394}$ definícióját. A hatályos kvótarendszer a független müsorkészítők alkotásai mellé - a magyar nyelvi kultúra megőrzése és a hazai gyártási kapacitás bővítése érdekében - kiépíti a magyar nyelvi kvótarendszert. A közszolgálati médiaszolgáltatásban a Koncepcióval összhangban érvényesülnek az egyedi kvótaelőírások. Itt utalok az Mttv. azon módosítására, amely a közszolgálati médiaszolgáltató lineáris audiovizuális médiaszolgáltatása tekintetében megváltoztatta a százalékos arányokat: az évi teljes müsoridő több mint hatvan százalékát európai müvek, több mint felét magyar mủvek, és több mint tizenöt százalékát tőle független müsorkészítővel készíttetett vagy független müsorkészítőtől beszerzett, öt évnél nem régebben készült európai művek tehetik ki. ${ }^{395} \mathrm{~A}$ kereskedelmi müsorszolgáltatók tekintetében az Mttv. megalkotásának idején - elsősorban a médiapiaci környezet változásai miatt - már nem volt szükség az $M V K$, illetőleg a $J V K$ kategóriák közötti differenciálásra, így azt az új szabályozás a kvóták tekintetében sem tartalmazza. A magyar zenei müvekre vonatkozó arányokat a jelenlegi szabályozás szintén a Koncepció magyar repertoár arányának növelésére vonatkozó tételével összhangban érvényesíti. ${ }^{396}$ Az Mttv-ben meghatározott műsorkvótáktól eltérő kvóták alkalmazására a Médiatanáccsal kötött hatósági szerződés alapján kerülhet sor; a kvótákra vonatkozó

\footnotetext{
390 A Médiatanács 248/2015. (III. 17.) számú döntése: A Magyar Televízió Nonprofit Zrt. M3 médiaszolgáltatása kvótakötelezettségeinek teljesítése 2014-ben a médiaszolgáltató havonta teljesített adatszolgáltatásai tükrében.

391 AVMS irányelv (68)

392 Mttv. 203. $§ 12$.

${ }^{393}$ Mttv. 203. § 37.

${ }^{394}$ Mttv. 203. § 9.

${ }^{395}$ Mttv. 20. § (3)

${ }^{396}$ Mttv. 22. § (6)
} 
adatszolgáltatási kötelezettség törvényi elöírásával pedig a szabályozásban teljesül a havi rendszeres hatósági kontroll lehetőségének NAMS JK-ban előírt követelménye. ${ }^{397}$

\subsubsection{Válaszadás joga}

A NAMS a magyar jogrendszer személyiségi jogvédelmi eszközeit a közösségi jogi szabályozással összhangban állónak látta és e téren - különös tekintettel arra, hogy a Stratégiának a sajtószabályozás nem volt tárgya - minimális szabályváltozásokat célzott.

A NAMS szétválasztotta a lineáris és nem lineáris tartalmak jogvédelmi eszközeinek szabályozására vonatkozó javaslatokat és azt összefoglaló néven - a francia jogrendszerből ismert $^{398}$ - válaszadás joga elnevezéssel illette. A klasszikus lineáris tartalmakkal kapcsolatban nem tünt indokoltnak az akkori szabályozás megváltoztatása, hiszen a sajtóhelyreigazítás jogintézménye mellett biztosított egyéb jogvédelmi eszközök, így a polgári jogi személyiségvédelmi jogérvényesítés és/vagy a Büntető Törvénykönyv reparációs rendszere elegendő fellépési lehetőséget biztosított a sérelmes közlésekkel szemben. A nem lineáris tartalmakra vonatkozó válaszadás jogának szabályozása során a NAMS egyrészt az érintett szolgáltatások technológia-semleges kijelölését, másrészt pedig a véleményszabadság aránytalan korlátozásának tiltását tartotta szem előtt. Mivel a nem lineáris tartalmakkal kapcsolatban maga a sértett is közzétehet valótlan tényállítást cáfoló közléseket, a NAMS megfontolandónak tartotta a válaszadás jogának lekérhető tartalmakra való vonatkoztatását. Az új Ptk. 2006. évi kodifikációs „Vitatervezete” ugyanis a sajtó fogalmát kiterjesztette az internet sajtószerủ felhasználására, ezáltal a sajtó-helyreigazítás hatálya alá eső médiumok köre is bővült. ${ }^{399} \mathrm{~A} N A M S$ végül azt az álláspontot képviselte, hogy - figyelemmel az új Ptk. kodifikációjára, illetőleg a polgári jog várható jogfejlődésére -, az audiovizuális médiaszabályozás hozza létre a sajtó-helyreigazításhoz hasonló jogintézményét válaszadási jog néven úgy, hogy a válaszadás joga a lineáris tartalmakon túl biztosítson alkalmas személyiségvédelmi eszközt a nem lineáris tartalmakra is.

A válaszadás joga a Ptk. 2001. évi módosítása tárgyában készült javaslatban $(\mathrm{PtkM})^{400}$ került ismét a személyhez füződő jogok sorába. ${ }^{401}$ A „Lex Répássy” néven ismertté vált

\footnotetext{
${ }^{397}$ A Médiatanács 580/2015. (V. 19.) számú döntése az Mttv. 22. § (8) bekezdése szerinti adatszolgáltatási kötelezettség nem teljesítése esetében hozott konkrét ügyben.

${ }^{398}$ A tág értelemben vett válaszadás joga a tényközléseken túl a véleményközlésekre vonatkozó reflektálás lehetőségét is magában foglalja az 5/2001. (XII.5.) AB határozat alapján.

${ }^{399}$ NAMS 17. 57. lbj.

${ }^{400}$ T/3797. törvényjavaslat (PtkM): "79. § (1) Ha valakiről napilap, folyóirat (időszaki lap), rádió vagy televízió valótlan tényt közöl vagy híresztel, illetöleg való tényeket hamis színben tüntet fel, - a törvényben
} 
törvénymódosítás a sajtóban közzétett, a személyhez füződő jogot sértő véleményre, vagy értékelésre adandó válasz közzétételének kötelezettségét kívánta megteremteni. A köztársasági elnök az Alkotmánybíróságtól kérte a törvény elözetes vizsgálatát, mivel álláspontja szerint a Ptk. módosításában a válaszadásra vonatkozó rendelkezések korlátozzák a sajtószabadságot, azon belül is a szerkesztés szabadságát, így a válaszadás jogintézménye az elérni kívánt célhoz képest aránytalanul, így alkotmányellenesen korlátozza a sajtószabadságot. Az Alkotmánybíróság 57/2001. (XII. 5.) AB határozatában egyfelöl összegezte korábbi határozatai alapján a vélemény- és sajtószabadság demokratikus rendszer szempontjából lényeges kérdéseit, amely körben e szabadságjogok politikai célú korlátozását vizsgálta. Másfelöl azonban szükségesnek látta a Testület a vélemény- és sajtószabadság korlátozásának elemzését az alapjogok, mások jogainak, különösen jó hírnevének, valamint emberi méltóságának védelme eseteiben is. E körben megállapította, hogy ,„...] a tág értelemben vett válaszadás joga a véleménynyilvánítás és a sajtó szabadságának nem alkotmányellenes korlátozása." ${ }^{402}$ A válaszadási jog ugyanakkor az időszaki lap, a rádió, a televízió tekintetében a válasz közlésének kötelezettségét jelenti, amely adott esetben a közlemény megjelentetésére való kényszerités lehetöségét hordozza magában. Mivel a törvényi kényszerítés befolyásolja a közlésre vonatkozó szabad döntést, a válaszadás jogának véleményekre és bírálatokra, illetőleg értékítéletre vonatkozó gyakorlása a sajtószabadságnak, ezen belül is a szerkesztési szabadságnak a korlátozását jelenti: „Ez egyúttal azt is maga után vonhatja, hogy nem tesznek közzé olyan véleményt, amelynél fennáll a veszélye a válaszközlési kötelezettségnek. Ilyen módon közvetetten jelentkezhet a sajtószabadság részeként is megjelenö véleményközlési szabadság korlátozása. „403

biztosított egyéb igényeken kívül - követelheti olyan közlemény közzétételét, amelyből kitűnik, hogy a közlemény mely tényállása valótlan, mely tényeket tüntet fel hamis színben, illetőleg melyek a való tények (helyreigazítás).

(2) Akinek személyhez füződő jogát napilapban, folyóiratban (időszaki lapban), rádióban vagy televízióban közölt valamely vélemény vagy értékelés sérti, - a törvényben biztosított egyéb igényeken kívül - követelheti saját véleményének vagy értékelésének közzétételét is (válaszadás)

(3) A helyreigazítást, illetve válaszadást napilap esetében az erre irányuló igény kézhezvételét követő nyolc napon belül, folyóirat (időszaki lap) esetében a legközelebbi számban azonos módon, rádió, illetőleg televízió esetében pedig - ugyancsak nyolc napon belül - a sérelmes közléssel azonos napszakban kell közölni."

${ }^{401}$ Ezt megelőzően több kísérlet is született a sajtó-helyreigazításnál szélesebb jogköröket magában foglaló válaszjog intézményének hazai bevezetésére, az első javaslat kidolgozója Pokol Béla jogász professzor, alkotmánybíró.

402 57/2001. (XII. 5.) AB határozat Indokolás II. 9-11.

${ }^{403}$ 57/2001. (XII. 5.) AB határozat Indokolás II. 9. 
Az Alkotmánybiróság megállapította a válaszadási jog alkotmányellenességét a PtkM. 1. §ának szabályozási módja tekintetében. ${ }^{404}$ A vonatkozó határozat értelmében a PtkM. 1. §-a által meghatározott válaszadási jog tágabb fogalom a 79. §-ban eredetileg szabályozott sajtó-helyreigazítás jogintézményénél, hiszen az új rendelkezés a tényközlések mellett megengedi a saját vélemény vagy értékelés közzétételét is. Az új rendelkezés tehát kiegészíti a sajtó-helyreigazításra vonatkozó szabályokat, további sajátosságként pedig a véleménnyel szemben is lehetővé teszi a korlátozás nélküli (tartalmában akár sértő, a sérelmet szenvedettek számától független, terjedelmében az alapközlésen túlterjeszkedő) válaszadást. Mindezek alapján a bevezetni kívánt válaszadási jog egyrészt nem teremt arányosságot az emberi méltóság és a jóhírnév alapvető jogának védelmére biztosított válaszadásról szóló szabály által elérhető eredmény, másrészt a sajtó és a véleménynyilvánítás szabadsága alapvető jogának korlátozásával előidézett hátrány között. A válaszjog korlátlan gyakorlását lehetővé tevő rendelkezés továbbá, amely még bírság kiszabását is elöírja, olyan mértékben korlátozza a sajtót, valamint közvetetten a véleménynyilvánítás szabadságát, amelyet nem indokol az emberi méltóság és a jóhírnév védelme. A NAMS és a $J K$ terminológiája - mindezek ellenére - mégis ezt a terminus technicust használta a sajtó-helyreigazításhoz hasonló jogintézménnyel kapcsolatos elvi tételek meghatározásánál. Sem $N A M S$, sem pedig a $J K$ nem határozta meg a válaszadás jogának tartalmát, és a sajtó-helyreigazítástól való elnevezésbeli megkülönböztetés sokkal inkább az audiovizuális média írott sajtótól való elkülönült szabályozására utalt, mint sem az Alkotmánybíróság által is elvetett vélemény-helyreigazítás szabályozási módjára. Hangsúlyozni szükséges itt is, hogy a $N A M S$ stratégiai kérdések, szabályozási célok és tételek meghatározását és nem jogintézmények konkrét szabályozási modelljeit tartalmazza. Álláspontja szerint továbbá a magyar jogrendszer a közösségi jogi szabályozással összhangban megfelelő polgári- és büntetőjogi személyiségi jogvédelmi eszközöket biztosít és jogkövetkezményeket rendel azokra az esetekre, amikor valamely természetes vagy jogi személy személyhez füződő jogát/személyiségi jogát a sajtóban megsértették. ${ }^{405}$ A Koncepció a lineáris és a lekérhető tartalomszolgáltatás „sajtószerü” tevékenységére vonatkozóan pedig elegendőnek tartotta a sajtó-helyreigazitás jogintézményének fenntartását az Stv. értelmező rendelkezéseinek megváltoztatásával,

${ }^{404}$ Az Országgyülés 2001. május 29-i ülésnapján elfogadott Ptk. módosítás.
${ }^{405}$ NAMS 42. 
illetőleg a Ptk. és a Pp. ${ }^{406}$ helyreigazításra vonatkozó szabályainak megfelelő módosításával. A NAMS - ebből következően - a sajtó-helyreigazitás jogintézményének „megreformálására” nem tett javaslatot, már csak azért sem, mert a Stratégia tárgyát nem egyes jogintézmények, hanem a médiaszabályozás átfogó kérdéseinek vizsgálata képezték, továbbá az írott sajtó nem is képezte a Stratégiaalkotás tárgyát. Mindezeken túl pedig az volt a szakmai álláspont, hogy az elektronikus, majd online médiával kapcsolatos szabályozási elvek kialakítását követően szükséges megvizsgálni a kapcsolódó jogintézmények „korszerüségét.” Az is meghatározó tényező volt, hogy - amint az már fentebb említésre került -, időközben folytak az új Polgári Törvénykönyv elökészítő munkálatai is és a megelőző két évtizedben a sajtó-helyreigazítással kapcsolatban kijegecesedett bírói gyakorlat ${ }^{407}$ is megfelelőnek tünt a jogintézménnyel kapcsolatos kérdések végleges rendezéséig.

A 2010. évi médiaszabályozás az Alkotmánybiróság fentiekben elemzett határozata alapján nem élt a tág értelemben vett válaszadás jogának médiatörvényi megfogalmazásával, hanem a sajtó-helyreigazitás jogintézményének korábban a Ptk.-ban fellelhető és lényeges módosuláson átesett szabályait - az 1914. évi sajtótörvényhez ${ }^{408}$ hasonlóan - a közjogi szabályozásba, az Smtv. rendelkezései ${ }^{409}$ közé helyezte. Annak érdekében, hogy nyilvánvaló legyen: a sajtó-helyreigazítás továbbra is személyiségvédelmi eszköz, ${ }^{410}$ a korábbi Ptk. utaló szabályt ${ }^{411}$ tartalmazott és a régi Pp. vonatkozó rendelkezései is módosultak. ${ }^{412}$ A sajtó-helyreigazítás jogintézményének a magánjogi szabályozásból való kikerülése, és az új Ptk. „tehermentesítése” e jogintézmény szabályozása alól, a szabályozás olyan alaki újdonsága, amely a jogintézmény közjogi elemeinek vélt felerősödésének, illetőleg annak a szemléletmód-változásnak köszönhető, miszerint ,,[...]

\footnotetext{
406 1952. évi III. törvény a polgári perrendtartásról (régi Pp.) Negyedik Rész Különleges eljárások XXI. fejezet a sajtó-helyreigazítási eljárás 342-346. §, 2016. évi CXXX. törvény a polgári perrendtartásról (új Pp.) Elfogadva az Országgyülés 2016. november 27-i ülésnapján. Hetedik Rész Különleges eljárások XXXVIII. fejezet Egyes személyiségi jogok érvényesítése iránt indított perek 134. Sajtó-helyreigazítás iránt indított per 495-501. §

${ }^{407}$ A Legfelsőbb Bíróság Polgári Kollégiumának állásfoglalásai (PK 12-15.), valamint az eseti döntések.

${ }^{408}$ 1914. évi XIV. törvénycikk a sajtóról. Második Fejezet Sajtórendészet 4. A helyreigazítási jogról 20-23. §

${ }^{409}$ Smtv. V. Cím Sajtó-helyreigazítási jog.

410 A válaszadás jogát mint személyiségvédelmi eszközt vizsgálja: POLYÁK Gábor: Haladék a sajtószabadságnak, Fundamentum, 2002/1. (POLYÁK V.) 100., TÉNYI Géza - UDVARY Sándor: A vélemény és a válasz: új Szkülla és Kharübdisz? Jogtudományi Közlöny 2001. november 469-478.

${ }^{411}$ A régi Ptk., az 1959. évi IV. törvény a Polgári Törvénykönyvről 79. §. Az új 2013. évi V. törvény a Polgári Törvénykönyvről [új Ptk.] már utaló szabályt sem tartalmaz, és egyáltalán nem rendelkezik a sajtóhelyreigazítás jogintézményéröl.

${ }^{412}$ Régi Pp. 342-346. §
} 
sokkal inkább a közönség megfelelő tájékoztatáshoz való joga került előtérbe" ${ }^{413}$ Ezzel ellentétes álláspontot képviselnek azok a nézetek, amelyek a sajtó-helyreigazításra kizárólag magánjogi szempontból úgy tekintenek, mint amely a személyiség védelmének egyik legfontosabb polgári jogi eszköze. ${ }^{414}$ Petrik magánjogi érvrendszert erősítő álláspontja szerint: „[...] a személyiség meghatározott életminőséget jelent, nevezetesen azt, hogy - az ember, szabadon rendelkezik önmaga felöl, továbbá - megilletik az emberhez méltó életfeltételek.” „[...] Vannak értékek, amelyeket a jog nevesítetten is véd, így az emberi test épsége és egészséges müködése, az ember által kialakított személyes élettér (beleértve a fizikai környezetet jelentő magánlakást), az ember külső megjelenése, mind fizikai valóságában (a képmás, a hang), mind a társadalomban róla kialakult kép minősége, az ember egyenlősége, a mindenkit azonos mértékben és módon megillető emberi személyiség." ${ }^{\not 15}$ Kisbán is e magánjogi szempontú megközelítést helyezi előtérbe, amikor a jogintézmény új szabályozását mind alaki, mind pedig anyagi jogi szempontból vitathatónak ítéli. ${ }^{416}$ Magánjogi szempontból a sajtó-helyreigazítás mindenképpen a polgári jogi szabályozás tárgya. A ,right of reply”, ${ }^{417}$ a tágabb értelemben vett sajtó-helyreigazítás ugyanakkor - médiajogi megközelítésben - egyben közjogi kategória is. A Price és Barendt ${ }^{418}$ által megkülönböztetett közvetlen, illetőleg közvetett sajtóhoz való hozzáférési jog közül Koltay a sajtó-helyreigazítást a közvetlen hozzáférés olyan formájának tekinti, amely - a szerkesztési szabadságot korlátozva - közvetlenül jogosítja a közösség valamely tagját a sajtóban való megjelenésre. A jogintézmény ilyen, közérdek szempontú megközelítése - álláspontom szerint is - megalapozza a sajtó-helyreigazítás közjogi aspektusainak előtérbe kerülését és közjogi szabályozását. Meg kell jegyezni, hogy a szabályozás „elhelyezkedésétől” függetlenül is a sajtó-helyreigazítási eljárások lefolytatása továbbra is a polgári bíróságok hatáskörébe tartoznak. Szükséges rámutatni arra is, hogy a Ptk. 2:54. $§(5)$ bekezdésében szabályozott, közösséghez tartozással összefüggő

\footnotetext{
${ }^{413}$ KOLTAY András: Sajtó-helyreigazitás és válaszjog: a sajtószabadság korlátja vagy kiterjesztése. Iustum Aequum Salutare, 2008/4. (KOLTAY III.) 148-150.

${ }^{414}$ PETRIK Ferenc: A Polgári Törvénykönyv „A személyek” címü könyvének szabályozási koncepciója (Vitaindító tézisek). A Polgári Jogi Kodifikáció, 2001/4-5.20. (PETRIK III.)

${ }^{415}$ PETRIK Ferenc: A személyiség jogi védelme, a sajtó-helyreigazítás HVG-ORAC 2001. (PETRIK I.) 4143.

${ }^{416}$ KISBÁN Tamás: A sajtó-helyreigazitás 'újrakodifikálásának' kritikája 2014. In Medias Res III. évfolyam 2. sz. 374-383.

${ }^{417}$ KOLTAY III. 147.

${ }^{418}$ MONROE E. PRICE: An access taxonomy. In SAJÓ ANDRÁS - MONROE E. PRICE (szerk.): Rights of access to the media. Boston: Kluwer Law International, 1996. 5-22.; ERIC BARENDT: Access to the media in Western Europe. In SAJÓ ANDRÁS - MONROE E. PRICE (szerk.): Rights of access to the media. Boston: Kluwer Law International, 1996. 112-116. In: KOLTAY III. 147.
} 
személyiségi jogi perek eljárási szabályait az új Pp. az egyes személyiségi jogok érvényesítése iránt indított perek körében a sajtó-helyreigazítási perekkel, valamint a képmáshoz és a hangfelvételhez való jog érvényesítése iránt indított perekkel egy fejezetben, de önálló pertípusként szabályozza. ${ }^{419}$

A médiaszabályozás a sajtó-helyreigazítás intézményét ${ }^{420}$ tehát először egy utaló szabály beépítése mellett kivette a Ptk. személyiségvédelmi eszközrendszeréből és azt önállósítva, az Smtv. rendelkezései közé illesztette. Az új Ptk. pedig - ahogy azt már jeleztem -, ilyen utaló rendelkezést sem tartalmaz. A sajtó-helyreigazítás a hatályos rendelkezések értelmében bármely médiatartalomban közzétett, illetőleg megjelenő jogsértő közlés orvoslására szolgál. Az új szabályozás a kibővült szolgáltatási eszközrendszerre és sajátosságaira figyelemmel módosítja a közlésre irányadó határidőket. A helyreigazító közleményt napilap, internetes sajtótermék és hírügynökség tekintetében az erre irányuló igény kézhezvételét követő öt napon belül, lekérhető médiaszolgáltatás esetén pedig nyolc napot követően a legközelebbi lapszámban kell megjelentetni. A helyreigazító közlemény közzétételének módja, terjedelme tekintetében a törvényi szabályozás átveszi a kialakult bírói joggyakorlatot: „a közlemény sérelmezett részéhez hasonló módot, és terjedelmet” a szabályozás körébe emeli. Itt szükséges utalnom a régi Pp. azon módosítására, ${ }^{421}$ valamint az új Pp. vonatkozó rendelkezésére, ${ }^{422}$ amelyek a sajtó-helyreigazítás szabályaihoz hasonló „statáriális” eljárási rendszert vezetnek be a képmáshoz és a hangfelvételhez való jog megsértése esetén indított bírósági perekben is.

\section{3. Általános érvényü, tartalomra vonatkozó szabályozás}

\subsubsection{Alkotmányos értékek}

Az új audiovizuális médiaszabályozás szempontjából a Koncepció továbbra is elsődleges tényezőnek tekintette az alkotmányos értékek védelmét, így különösen az emberi méltóság és a gyermekek védelmét, továbbá a faji vagy nemzetiségi hovatartozáson, nemen, valláson alapuló gyülöletkeltés és negatív diszkrimináció tilalmának érvényesítését, valamint a vélemény-nyilvánítás szabadságát. A vélemény-nyilvánitás szabadságának kitüntetett

\footnotetext{
${ }^{419}$ Új Pp. 136. A közösséghez tartozással összefüggő személyiségi jog érvényesítése iránti per 505-507. §

${ }^{420}$ Smtv. V. Cím Sajtó-helyreigazítási jog.

${ }^{421}$ A régi Pp. 2015. évi XI. törvény 2. §-ával megállapított szövege, hatályos: 2015. IV.2-töl. Pp. XXI/A. fejezet 346/A.-F. § A képmáshoz és a hangfelvételhez való jog érvényesítése iránt indított per.

${ }^{422}$ Új Pp. 500. § (1), 504. § (1)
} 
szerepét emelte ki az Alkotmánybiróság a 30/1992. (V. 26.) AB határozatában és megállapította, hogy a véleményszabadság ,anyajoga” többféle szabadságjognak. Az „anyajog”- ból eredő külön nevesített jogok a szólás- és a sajtószabadság, amely utóbbi felöleli valamennyi médium szabadságát, továbbá az informáltsághoz való jogot, az információk megszerzésének szabadságát. A Koncepció - ennek megfelelően deklarálta, hogy a tartalomra vonatkozó szabályozás során érvényre kell juttatni a véleménynyilvánítás szabadságának, a tájékoztatás függetlenségének és a tájékozódás szabadságának, továbbá a vélemények és a kultúra sokszínűségének alapelvét. ${ }^{423}$

Az Alkotmánybiróság több határozatában foglalkozik az emberi méltóság alkotmányos jogának ${ }^{424}$ elemzésével és megállapítja, hogy az emberi méltóság minden tárgyi jog megalkotásánál és alkalmazásánál a legfőbb alkotmányos vezérlő elv, az alkotmányos alapjogok, értékek és kötelezettségek rendszerének a tényleges alapja." ${ }^{425} \mathrm{Az}$ emberi méltóságot a Testület olyan szubszidiárius alapjognak tekinti, amelyet mind az Alkotmánybiróság, mind a bíróságok minden esetben felhívhatnak az egyén autonómiájának védelmére, ha az adott tényállásra a konkrét, nevesített alapjogok egyike sem alkalmazható. ${ }^{426}$ Anélkül, hogy az emberi méltóság alapjogának további részletes elemzésébe bocsátkoznék, a médiaszabályozás és a média jogalkalmazás szempontjából itt most azt tartom szükségesnek kiemelni, hogy „[...] az emberi méltóság védelme érdekében történő, az állam intézményvédelmi kötelezettségét érvényre juttató médiahatósági fellépés alkotmányosan indokolható, amennyiben az világosan elválik a jogrendszer egyéb területein biztosított jogvédelmi eszközöktől."

A jogintézmény polgári jogi megközelítését illetően meg kell említeni az Alkotmánybíróság legutóbbi vonatkozó határozatát, amely az új Ptk. közéleti szereplőkre irányadó 2:44. §-ának „méltányolható közérdekböl,” szövegrészét alaptörvény-ellenesnek nyilvánította. A közéleti szereplők alapjogának korlátozhatósága tárgyában - utólagos normakontroll keretében - hozott 7/2014. (III. 7.) AB határozat leszögezte, hogy az emberi méltóság védelméhez való jog csak az emberi státusz jogi meghatározójaként korlátozhatatlan, „mint általános személyiségi jog és a belőle fakadó részjogok korlátozhatók."

\footnotetext{
${ }^{423}$ NAMS JK 23.

${ }^{424} \mathrm{Az}$ emberi méltóság alapjog jogfejlődésének föbb állomásai, továbbá polgári jogi és médiajogi megközelítésének különbözőségei részletes kifejtésre kerültek a 6.2.4. alfejezetben.

${ }^{425}$ 37/2011. (V. 10.) AB határozat.

${ }^{426}$ 8/1990. (IV. 23.) AB határozat.
} 
A másik fontos védelmi kör, a gyermekek jogainak védelmével kapcsolatban a NAMS JK megállapította, hogy a korábban kialakult stabil jogszabályi környezet és következetes hatósági jogalkalmazás a digitális technológiára, illetve az ön- és társszabályozási kezdeményezésekre alapozva még hatékonyabbá tehető. A gyermekek védelmét szolgáló lehetőségek és szempontrendszer kialakításába szükségesnek látta bevonni a szülőket, ${ }^{427} \mathrm{az}$ oktatási intézményeket, a müsorterjesztőket és az eszközgyártókat, valamint az érintett iparági és fogyasztói szervezeteket. A digitális müsorszolgáltatás a tartalomkínálat egyénivé alakítása mellett számos eszközt biztosít a nem kívánatos tartalmak elkerüléséhez. A $J K$ ilyen eszköznek jelölte meg az elektronikus programkalauzt (EPG), illetőleg az egyes müsorszámok meta adatokkal való ellátását, és a „gyerekzár” alkalmazását is. Az egységes korhatári besorolás és a szülők megfelelő tájékoztatása érdekében a NAMS JK differenciáltabb korhatári besorolási rendszer alkalmazását javasolta, amely - hasonlóan az online játékokra bevezetett európai rendszerhez $(P E G I)^{428}$ - többféle korcsoportot határoz meg. A müsorszolgáltatásra vonatkozó új korhatárbesorolás jogalkotói elfogadásával - a Koncepció szándékai szerint -, lehetőség nyílik a filmek és az egyéb, pl. online játékok korhatári besorolásának egységesitésére is, a felhasználók tájékozódásának megkönnyítése érdekében.

A hatályos médiaszabályozás - mind az Smtv., mind pedig az Mttv. értelemszerúen kiemelt szerepet tulajdonít az alkotmányos alapjogok védelmének. E jogokat mindkét törvény megfogalmazza preambulumában, több rendelkezésében, ${ }^{429}$ illetőleg mindkét törvényt áthatja e jogok védelmének szellemisége. Az Mttv. gyermekek és a kiskorúak védelme érdekében hozott szabályai kellően differenciált rendszert vezetnek be a müsorszámok korhatár kategóriákba sorolásánál. ${ }^{430}$ A szabályozás bővíti a korhatár kategóriák számát a „hat éven aluliak számára nem ajánlott” kategóriával. Ez a bővítés figyelembe vette a gyermekek szellemi fejlődésében meghatározó, „iskoláskorúvá válás” idejét, a 6-7 éves kort, amelyben lényeges változások állnak be a gyermekek életében. ${ }^{431} \mathrm{~A}$ NAMS JK összességében a hatósági beavatkozást olyan kivételes, végső eszköznek

\footnotetext{
${ }^{427}$ A Médiatanács 551/2015. (V. 5.) számú döntése: A Médiatanács jóváhagyja, hogy „A szülők szerint káros az Éjjel-nappal Budapest!" c. elemzést a nyilvánosság számára elérhetővé tegye.

${ }^{428}$ PEGI - Egységes Európai Játékinformációs Rendszer.

${ }^{429}$ Smtv. III. Cím A sajtó szabadsága, Mttv. Első Rész II. Fejezet A Törvény alapelvei, Második Rész I. Fejezet A Médiaszolgáltatások tartalmára vonatkozó elöírások stb.

${ }^{430}$ A Médiatanács 591/2015. (V. 19.) számú döntése: A Magyar RTL Televízió Zrt. által üzemeltetett RTL Klub csatornán 2015. január 2-án 11 óra 18 perctől sugárzott Könnyü nőcske címủ müsorszám korhatárbesorolása [az Mttv. 9. § (5) bekezdésének és a 10. § (1) bekezdés c) és f) pontjának megsértése] ${ }^{431}$ Mttv. 9. § (3), valamint a Médiatanács klasszifikációs ajánlása a médiatartalmak korhatár-besorolásánál irányadó szempontokra. Klasszifikációs jelzések, piktogramok, gyermekbarát piktogram. mediatanacs.hu.
} 
tekintette, amely csak az egyéb módon nem kezelhető problémák, súlyos jogsértések esetén lép müködésbe.

A hatályos szabályozás érvényesítette a gyermekek védelme érdekében a kellően differenciált korhatár-besorolást, a kategóriák számának növelését, a Koncepcióban szándékolt besorolási egységesítés azonban még várat magára. Az NMHH nem hatósági jogkörében eljárva ajánlást tett közzé a kiskorúak védelme érdekében elöírt klasszifikációval összefüggő kérdésekben, valamint a hatékony müszaki megoldás követelményeire vonatkozóan, ${ }^{432}$ továbbá számos gyermekeket védő intézkedést tett, vizsgálatot végzett és tájékoztató anyagot helyezett el a honlapján, - többek között - a gyermekeket védő műszaki berendezések alkalmazásáról, a filmek kategória-besorolásáról, a gyermekvédő zárakról, valamint a gyermekek egészsége érdekében az élelmiszerhirdetési önkorlátozás tárgyában. ${ }^{433}$ A gyermekek védelme érdekében - a szabályozásban teljes mértékben érvényesülnek az AVMS irányelvben foglaltakon túl a $N A M S J K$ célzott elöírásai nem csak a müszaki megoldások tekintetében, hanem a jogalkalmazás során is. Különösen a preventív intézkedések meghozatalában tapasztalható a lehető legszélesebb körü társadalmi összefogás. A 9-16 éves korosztály számára médiaértés és oktató központ alakult, amelyben a fiatalok élményalapú tanulás formájában, személyes tapasztalatszerzés során sajátíthatják el a média értelmezését és használatát elősegítő új készségeket. A „Büvösvölgy” lehetőséget nyújt átfogó ismeretek közvetítésére a média müködéséről, elönyös és hátrányos befolyásoló erejéröl. ${ }^{434}$

\footnotetext{
${ }^{432}$ Mttv. 183. § a) b)

${ }^{433}$ Összefoglaló jelentés a digitális műsorterjesztés során a gyermekek és a kiskorúak védelme érdekében alkalmazott hatékony müszaki megoldások ellenőrzésének tapasztalatairól. http://nmhh.hu/dokumentum/155438/hatekony_musz_megoldasok_osszefoglalo_komplett.pdf

A tévékészülékek kiskorúak védelmét szolgáló műszaki képességeit vizsgálta az NMHH. http://nmhh.hu/cikk/156404/A_tevekeszulekek_kiskoruak_vedelmet_szolgalo_muszaki_kepessegeit_vizsgalt a_az_NMHH\#sthash.IIvWdge5.dpuf Eljárási tájékoztató - Filmbesorolás a kiskorúak védelme érdekében (korhatár-besorolás) Segítünk a tájékozódásban! Amit érdemes tudni a gyermekvédő zárakról. http://nmhh.hu/dokumentum/156110/0202805_fogyasztoi_tajekoztato_gyerekzar_01_vegleges.pdf

Élelmiszer-hirdetési önkorlátozás a védelmében. http://nmhh.hu/cikk/155043/Elelmiszerhirdetesi_onkorlatozas_a_gyermekek_vedelmeben\#sthash.kM14asRl. dpuf NMHH gyermekeket védő intézkedései.

${ }^{434}$ http://nmhh.hu/cikk/163153/Megnyilt_Buvosvolgy_Magyarorszag_elso_mediaertesoktato_kozpontja 'Büvösvölgy' projekt.
} 


\subsubsection{Müsorelözetesek és ajánlók}

A NAMS JK a müsorelözetesek és ajánlók besorolását is kötelezővé kívánta tenni. Figyelemmel arra, hogy a müsorelőzetes az általa beharangozott film vagy más müsor jeleneteit eredeti összefüggésükből kiemelve és más összefüggésrendszerbe helyezve mutatja be, a $J K$ szerinti besorolás eltérhet az előzetesen jelzett müsorszám besorolásától. A műsorelőzetes ennek megfelelően csak akkor osztotta volna automatikusan az általa bemutatott müsor minősítését, ha besorolása nem annál magasabb korhatárhoz kötődik.

Ez a szabályozási szándék nem érvényesül az új médiaszabályozásban, hiszen a műsorelőzetes $^{435}$ nem tartozhat magasabb besorolási kategóriába, mint a népszerüsíteni kívánt műsorszám. Az Mttv. - ennél fogva -, mások mellett ki is emeli a lineáris médiaszolgáltató műsorszámok besorolási kötelezettsége alá tartozó műsorszámok köréből a müsorelözetest. ${ }^{436}$

\subsubsection{Reklámszabályozás}

\section{Differenciált „reklámszabályozás”}

$\mathrm{Az}$ audiovizuális médiaszolgáltatásokban megjelenő kereskedelmi kommunikáció szabályainak NAMS JK által szándékolt törvényi elhelyezéséről, a dogmatikai átláthatóság és a differenciált szabályozás igényéröl a szabályozási tárgyak bemutatása során már volt szó. Most annyit szükséges kiemelni, hogy a differenciált szabályozás szükségessége az $A V M S$ irányelv rendelkezéseiben is több szinten megjelenik. Egyfelől látható a tartalmak különbözőségében ${ }^{437}$ (lineáris, lekérhető és kereskedelmi kommunikációra vonatkozó tartalmak), másfelől pedig tetten érhető a hagyományos, valamint a digitalizációval összefüggő korszerű médiafogyasztási szokások eltérésében. ${ }^{438} \mathrm{Az}$ AVMS fokozott jelentőséget tulajdonít a fogyasztók védelmének is a kereskedelmi kommunikációra vonatkozó rendelkezések megfogalmazása során. Azt minden esetre le kell szögezni, hogy

\footnotetext{
${ }^{435}$ Mttv. 203. § 45.

${ }^{436}$ Mttv. 9. § (1) A lineáris médiaszolgáltatást nyújtó médiaszolgáltató - a hírműsorszám, a politikai tájékoztató műsorszám, a sportműsorszám, a műsorelőzetes, valamint a reklám, a politikai reklám, a televíziós vásárlás, a társadalmi célú reklám és a közérdekü közlemény kivételével -a valamennyi, általa közzétenni kívánt műsorszámot a közzétételt megelőzően a (2)-(7) bekezdés szerinti kategóriák valamelyikébe sorolja.

${ }^{437}$ AVMS (11)

${ }^{438}$ AVMS (4)
} 
az AVMS a „reklámszabályozás” terén minimum követelményeket ír elő, amelyeknél a tagállami szabályozás lehet szigorúbb.

A differenciált irányelvi szabályozási rendszer elvét a Stratégia is átvette. A $J K$ szerint a közszolgálati, a kereskedelmi és a közösségi müsorszolgáltatók, illetve az általuk nyújtott lineáris és lekérhető szolgáltatások közötti szabályozási különbségen túl differenciált szabályozásnak kell érvényesülnie a reklámok tekintetében is. ${ }^{439}$ Az átmeneti időszakban azonban, amíg a lineáris médiafogyasztás és a lekérhető tartalom együttesen van jelen az audiovizuális médiában, a kereskedelmi kommunikációra vonatkozó szabályozásban is érvényesülnie kell az eltérő igényeket kielégítő differenciált előírásoknak. A szabályozásban a kereskedelmi kommunikáció korlátait - ennek megfelelően - a $J K$ úgy jelölte ki, hogy azokat nem csak a médiafogyasztási „simulcast” együttes, egyben eltérő igényeihez kell mérni, hanem a médiaszolgáltatások különböző formáihoz, az egyes médiatípusokhoz is igazítani szükséges.

A hatályos médiaszabályozás - megvalósítva az AVMS irányelv kétszintü szabályozását -, valamennyi médiaszolgáltatásban közzétett kereskedelmi közleményre az Smtv. általános rendelkezéseit rendeli alkalmazni, ${ }^{440}$ a médiaszolgáltatásban megjelenő kereskedelmi közlemény speciális szabályait pedig az Mttv. tartalmazza. ${ }^{441}$ A hazai médiaszabályozás összefoglaló néven a kereskedelmi közlemény formáinak tekinti - többek között - a reklámot, a támogatást nyújtó nevének, védjegyének, arculatának vagy termékének megjelenítését, a televíziós vásárlást és a termékmegjelenítést. A törvény értelmében a kereskedelmi közlemény olyan médiatartalom, amelynek „[...] célja gazdasági tevékenységet folytató természetes vagy jogi személy árujának, szolgáltatásának vagy arculatának közvetlen vagy közvetett népszerüsítése. Az ilyen tartalmak fizetés vagy hasonló ellenszolgáltatás ellenében, vagy önreklámozás céljából kísérik a médiatartalmakat, vagy szerepelnek abban."442

Az Mttv-ben a több szempontú differenciált szabályozás egyik példájaként jelenik meg a közszolgálati médiaszolgáltatás kiemelt szerepe (az Mttv. önálló részében ${ }^{443}$ kap helyet), illetőleg a közszolgálati és a közösségi médiaszolgáltatásban közzétett reklámra, valamint a közérdekü közleményre irányadó speciális szabályozás. ${ }^{44}$ Sajátos rendelkezés

\footnotetext{
${ }^{439}$ NAMS JK 24.

${ }^{440}$ Smtv. 20. § (1)-(7)

${ }^{441}$ Mttv. 23-37.

${ }^{442}$ Smtv. 1. § 9., Mttv. 203. § 20., a 2013. évi CCLII. törvény 125. § (3) bc) pontjával módosított szöveg.

${ }^{443}$ Mttv. Harmadik Rész.

${ }^{444}$ Mttv. 36. §
} 
érvényesül a rádiós médiaszolgáltatásban megjelenő műsorszám támogatására az Mttv. szponzorációs szabályai között is. ${ }^{445}$

2. Nemzeti mozgástér a reklámszabályozásban

Az Európai Unió médiaszabályozásában a $T V W F$ irányelv és annak módosításai fektették le az akkor még hagyományos értelemben használt „televíziós reklámozás” alapvető elveit, a televíziós reklám szabályait, rendelkeztek a támogatásról, a televíziós vásárlásról, tiltották a tisztességtelen reklámot, különleges szabályokat írtak elö az egyes iparági termékek, a dohány-, az alkohol- és a gyógyszerreklámokra, valamint a kiskorúak védelmére. ${ }^{446} \mathrm{~A}$ több esetben említett technológiai fejlődés az új reklámtechnikák megjelenését is ösztönözte. Az AVMS már rögzítette az audiovizuális szolgáltatások kettős természetét, ${ }^{447}$ egyfelől az audiovizuális tartalom széles közvéleményt befolyásoló és az alkotmányos értékeket óvó kulturális tulajdonságait, másfelől pedig a szolgáltatások gazdasági természetét, amely szükségessé és indokolttá tett bizonyos szabályozási beavatkozásokat. A szabályozási igények között a tulajdoni korlátok eltörlése, a piacra lépés szabályainak liberalizálása, valamint a versenysemlegesség biztosításának szükségessége megjelentek a $N A M S$ és a $D A ́ S$ stratégiai célkitüzései között, a piacra lépést elősegítő rendelkezések pedig a Dtv-ben jogszabályi megfogalmazást is nyertek. A NAMS $J K$ végleges szövegezése során látszott, hogy az $A V M S$ irányelv az audiovizuális médiaszolgáltatásokban megjelenő reklámok szabályozására vonatkozóan megfelelő mozgásteret biztosít a nemzeti szabályozás számára: a tagállamoknak továbbra is jogukban áll előírni, hogy a joghatóságuk alatt lévő médiaszolgáltatók az irányelv hatálya alá tartozó szabályozási területeken az irányelvben szabályozotthoz képest részletesebb vagy akár szigorúbb szabályokat vezessenek be. „Ugyan az irányelv lehetővé teszi az európai, a hazai müsorok védelme, a hazai médiaszereplök és egyéb piaci érdekeltségek (pl. reklámozók) versenyképessége érdekében, (..) mégsem célszerü rendelkezéseinél szigorúbb megoldásokat alkalmazni. Komoly problémát jelent a médiaszolgáltatók „elvándorlása”, ami kedvezőbb médiaszabályozást alkalmazó ország fennhatósága alá kerülését jelenti a joghatósági szabályok kijátszásának céljából." ${ }^{\text {} 48} \mathrm{Az} A V M S$ irányelv alapján a médiaszolgáltatók viszonylag minden nehézség nélkül választhatnak joghatóságot, tehát az

\footnotetext{
${ }^{445}$ A nemzeti ünnepek hivatalos eseményeiről tudósító müsorszám támogatásának tilalma Mttv. 28. § (2)

${ }^{446}$ Ld.: GELLÉN Klára: A kereskedelmi kommunikáció szabályozása 419-451 In: KOLTAY-NYAKAS I. (GELLÉN II.) 427.

${ }^{447}$ AVMS (5)

${ }^{448}$ GELLÉN I. 38.
} 
elvándorlás megakadályozása elsősorban gazdasági ösztönzőkkel, illetőleg kedvezőbb médiaszabályozási eszközökkel érhető el. ${ }^{449}$

$\mathrm{Az}$ irányelv rendelkezéseinél részletesebb szabályozás kialakítása a túlzó szabályozás veszélyét rejti magában, ezért a hazai jogalkotás csak feltétlenül indokolt esetekben tartalmaz részletesebb elöírásokat az AVMS irányelv rendelkezéseinél. ${ }^{450}$ Egyes, a kereskedelmi kommunikáció körében az AVMS irányelv által nem szabályozott jogintézmények, így a politikai reklám vagy a társadalmi célú reklám a korábbiakhoz hasonlóan az audiovizuális médiaszabályozás körében maradtak. ${ }^{451}$

3.Új reklámozási technikák és a termékmegjelenítés ${ }^{452}$

Az AVMS irányelv lehetőséget teremtett újfajta reklámozási formák bevezetésére. A NAMS $J K$ szerint a médiaszabályozás feladata a digitalizáció eredményeként a klasszikus reklám helyébe lépö új reklámtechnikákra - interaktív reklám, az osztott képernyös (split screen) reklám, illetve a virtuális reklám - vonatkozó tartalmi és müsorszerkezeti korlátozások megalkotása az AVMS rendelkezéseivel összhangban, figyelembe véve a médiapiac pénzügyi stabilitásának, illetve a fogyasztói érdekek érvényesülésének a szempontjait is.

A hatályos szabályozás az új reklámozási technikákat nevesíti, fogalmát meghatározza, ${ }^{453}$ és az új reklámtechnikára vonatkozó rendelkezéseket a szabályozásba - többek között - a lineáris médiaszolgáltatásban közzétett reklám időtartamára vonatkozó rendelkezésekbe, ${ }^{454}$ valamint a közszolgálati és a közösségi médiaszolgáltatásban megjelenő reklámokra és közérdekű közleményekre vonatkozó szabályok közé beépítette. ${ }^{455}$

A termékelhelyezés, a „product placement” jogintézménye ismert volt a hazai médiajoggyakorlatban a NAMS kidolgozása előtt is, az burkolt reklámnak minősült; ,„[...] mivel termékmegjelenítést természeténél fogva igen nehéz megkülönböztetni és elkülöníteni a műsorszámtól, a fogyasztó megtévesztésének komoly veszélyét rejti magában."456

A termékmegjelenítés intézménye és egyben a müsorszám támogatása egymást kizárták, így a műsorszám támogatójának terméke még dramaturgiailag indokolható módon sem

\footnotetext{
${ }^{449}$ Részletes kifejtésre került: A származási ország elve és annak szükséges áttörése c. 6.2.8. alfejezetben.

${ }^{450}$ A hazai szabályozás részletesebb rendelkezéseket tartalmaz az AVMS irányelvnél - többek között - a termékelhelyezés Mttv. 30. § (3) b) esetében.

${ }^{451}$ Mttv. 32. §

${ }^{452}$ A dolgozat a termékelhelyezést és a termékmegjelenítést szinonim fogalomként használja.

${ }^{453}$ Osztott képernyős reklám Mttv. 203. § 53., Virtuális reklám Mttv. 203. § 72.

${ }^{454}$ Mttv. 35. § (1)

${ }^{455}$ Mttv. 36. § (5)

${ }^{456}$ GELLÉN Klára: A kereskedelmi közleményekkel szemben támasztott müsorszerkezeti követelmények 105121. In Medias Res 2012/1. (GELLÉN III.) 109.
} 
volt elhelyezhető a müsorban. ${ }^{457}$ Idővel az ORTT a fikciós müfajokban a dramaturgiailag müsorba illő, az életszerüséget nem meghaladóan oda szerkesztett, ellenszolgáltatás nélküli termékelhelyezéssel szemben „megengedőbb” álláspontot képviselt, ${ }^{458}$ illetőleg az igénybevételre nem felhívó kulturális kiadványokban szereplő, honlapokon közzétett termékmegjelenítés felett is "szemet hunyt." 459

A 2007 -es Külügyminiszteri Jelentés ${ }^{460}$ is szükségesnek tartotta a termékmegjelenítés szabályozását, és támogatta az erre irányuló uniós kezdeményezést. A termékelhelyezés főszabály szerinti tilalmának áttörésére vonatkozó szabályozás átvétele körültekintést igényelt, mivel sem túlszabályozni, sem kevésbé szabályozni nem lett volna célszerü a termékmegjelenítést a többi tagállamhoz képest. A $N A M S J K$ ezért - a többi tagállam szabályozási megoldásának megismerését követő -, késleltetett hatályba léptetést tartott szükségesnek a jogintézmény vonatkozásában. A közszolgálati müsorszolgáltatóknál a termékelhelyezést csak igen szük körben, kizárólag független műsorszerkesztő által készített, külső forrásból származó műsorszámok esetében tartotta elképzelhetőnek. A gyermekek védelme érdekében a Koncepció az AVMS irányelv elöírásainál szigorúbb szabályozás bevezetését javasolta: a támogatói logó megjelenítését, illetve a gyermekmüsorok reklámokkal való megszakíthatóságát - ez utóbbit a Külügyminiszteri Jelentéssel összhangban - teljes mértékben tiltani tervezte. ${ }^{461}$ Az AVMS a termékmegjelenítés intézményét eléggé ambivalens módon, de lényegében a korábbi konvencionális elvárásokat ${ }^{462}$ megvalósítva szabályozta.

A hazai médiaszabályozás termékmegjelenítésnek tekinti a kereskedelmi közlemény bármely formáját, amely „terméket, szolgáltatást, ezek védjegyét vagy ezekre való utalást tartalmaz oly módon, hogy az - fizetés vagy hasonló ellenszolgáltatás ellenében - egy müsorszámban jelenik meg." ${ }^{463}$ A jogintézmény a többi kereskedelmi közlemény-

\footnotetext{
${ }^{457}$ Rttv. 18. § (2) és (4) HARGITAI Lilla: Gondolatok a médiatörvény reklámszabályainak lehetséges módositásáról Médiakutató 2001. nyár.

${ }^{458}$ 258/1997. (XI. 5.), valamint 523/2001. (IV. 11.) ORTT határozatok.

${ }^{459}$ 243/2002. (I. 31.) ORTT határozat.

${ }^{460}$ Ld.: 173. lbj.

${ }^{461}$ A Külügyminiszteri Jelentés a reklámokra vonatkozó szabályozás kapcsán szintén kiemelt jelentőségünek tartotta a gyermekmúsorok reklámokkal való megszakításának általános tilalmát. Az Mttv. ezzel szemben engedi a 30 percnél hosszabb 14 éves kiskorúaknak szóló müsorszám megszakítását 33. § (3) b).

${ }^{462}$ GELLÉN Klára: Kereskedelmi közlemények összehasonlitó elemzése az egyes európai államokban (GELLÉN IV.) 69. In: KOLTAY-NYAKAS III. 63-99.

${ }^{463}$ Mttv. 203. § 68.
} 
formával $^{464}$ egyidejűleg lett a hazai szabályozás része. A mintegy három évvel a NAMS JK közzététele után hatályba lépett szabályozásból már nem lehetett kihagyni a termékelhelyezést és nem volt szükség az e jogintézményre vonatkozó implementáció késleltetésére sem. A közszolgálati médiaszolgáltatásban megjelenő termékelhelyezés esetén a jogalkotó nem látta szükségesnek az általánostól eltérő, további korlátozások elöírását. Az NMHH Médiatanácsa 2011-ben a termékmegjelenítés szabályainak alkalmazásáról szóló ajánlását ${ }^{465}$ a médiaszolgáltatók szakmai álláspontjának figyelembevételével alakította ki. Az ajánlás meghatározza a termékmegjelenítés formáit, leszögezi, hogy a termékelhelyezés ellenszolgáltatás nélküli változatban nem létezik. A szolgáltatás - ellenszolgáltatás kapcsán kifejti, hogy a termékmegjelenítés nem 'barter' ügylet, amikor is a szolgáltatás és az ellenszolgáltatás egyenértékűek; a termékelhelyezés esetén az ellenszolgáltatás akkor is hasonlónak minősül, ha annak nagysága nem éri el a termékmegjelenítés, mint kereskedelmi közlemény értékét. A termékmegjelenítés alkalmazási területeit illetően az ajánlás felsorolja azokat az érintett müsortípusokat, amelyekben a termékmegjelenítés megengedett. ${ }^{466}$ Az Mttv.-ben meg nem határozott szórakoztató müsorszámnak a termékmegjelenés körében a Médiatanács azon nem fikciós programokat, müsorszámokat tekinti, amelyek elsődleges célja a közönség szórakoztatása. Ilyenek a talkshow, zenei show-müsor, valóságműsor, kabaré, bohózat, rádiókabaré, vetélkedőműsor, magazinműsor, valamint a sportközvetítésnek nem minősülő, sporttal foglalkozó műsorszám a sporthírek kivételével. Az ajánlás megadja a szórakoztató műsorszám és a sportmüsorszám fogalmának elhatárolása körében irányadó szempontokat, továbbá a termékmegjelenítésből kizárt müsorszám-típusokat (hír, és politikai tájékoztató műsorszám, kifejezetten tizennégy év alatti kiskorúnak szóló műsorszám meghatározott feltétellel, nemzeti ünnepek hivatalos eseményeiről tudósító müsorszám, illetve vallási, egyházi tartalmú műsorszám) is. Mivel a termékmegjelenítés kereskedelmi közleménynek minősül, meg kell felelnie az Smtv. és az Mttv. tartalmi követelményeinek, a termékmegjelenítést tartalmazó műsorszámoknak pedig követniük kell az ajánlásban megfogalmazott tartalmi elöírásokat. Az ajánlás mindezeken felül iránymutatást ad még a termékmegjelenítésről való tájékoztatás módját, valamint a jogintézmény támogatáshoz

464 A szaknyelv a kereskedelmi kommunikációval szinonim fogalomként használja a kereskedelmi közlemény meghatározását, a dolgozat is ezt teszi.

${ }^{465}$ Elfogadva a Médiatanács 10048/2011. (VII. 19.) számú határozatával, módosítva: 2011. szeptember 1-jén a Médiatanács 1151/2011. (IX. 1.) számú határozatával.

466 A termékmegjelenítés megengedett a következő müsortípusokban: a) a filmszínházban történő bemutatásra szánt filmalkotások b) a médiaszolgáltatásban való közzététel céljából készült filmalkotások és filmsorozatok c) a sportműsorok, valamint a szórakoztató müsorszámok. 
való viszonyát illetően. Az Mttv. a 14 év alatti kiskorúakhoz szóló, harminc percnél nem hosszabb műsor - egy müsorszám - reklámmal és televíziós vásárlással történő megszakítását tiltja, ${ }^{467}$ de nem tartalmazza a gyermekeknek szóló műsorszámokban a támogatói logó megjelenítésének korlátozását, amit Magyarország az AVMS irányelv uniós bizottsági tárgyalásai során képviselt.

4. Reklámidő-számítás ${ }^{468}$ és támogatott műsorszámok

A NAMS JK a jogalkotás további feladataként fogalmazta meg a reklámidő számítási módjának az Rttv-től eltérő meghatározását (given clock hour). A Koncepció szerint a megfelelő számítási mód az, amely egy adott „természetes” - a müsorkezdéstől vagy egész órától kezdődő - órára számítja a reklámidőt, ezzel egyszerüsítve a piaci szereplők számára a felhasználható reklámidő számítását, a müsorszerkesztést és a jogkövetést. A müsorszámok szponzorálhatóságára vonatkozó Rttv. által meghatározott korlátozásokat a hírmüsorok kivételével - a NAMS JK enyhíteni javasolta.

Az Mttv. az AVMS irányelvnek megfelelően, a Koncepció irányadó tételei szerint állapítja meg a reklámok időtartamának számítási módját, amikor rögzíti, hogy a lineáris médiaszolgáltatásokban közzétett reklámok időtartama egyetlen, egész órától egész óráig tartó időszakon belül sem haladhatja meg a tizenkét percet, beleértve az osztott képernyős reklámot, a virtuális reklámot és a más médiaszolgáltatás müsorszámainak népszerüsítését. ${ }^{469}$ A közszolgálati médiaszolgáltatásban közzétett reklám és televíziós vásárlás időtartama egyetlen egész órától egész óráig tartó időszakon belül sem haladhatja meg a nyolc percet, közösségi médiaszolgáltatásban pedig a hat percet.

$\mathrm{Az}$ Rttv. támogatott müsorszámokra ${ }^{470}$ vonatkozó korlátozó rendelkezései az AVMS irányelvben foglaltaknak megfelelően enyhültek. Az Mttv. mind az audiovizuális, mind pedig a rádiós médiaszolgáltatásban taxatíve felsorolja a nem támogatható müsorszámokat, így a nemzeti ünnepek hivatalos eseményeiről tudósító müsorszámokat, valamint a politikai tájékoztatókat és hírmüsorszámokat. ${ }^{471}$

„[...] a tájékozódásban és a demokratikus társadalmi vita lefolytatásában fontos szerepet játszó hírszolgáltatást és politikai magazinműsorokat védi az audiovizuális

\footnotetext{
${ }^{467}$ Mttv. 33. § (3) b)

${ }^{468}$ Ld.: GELLÉN II. 447.

${ }^{469}$ Mttv. 35. § (1), a törvény megjelöli az időbeli korlátok alóli kivételeket is: 35 . § (2)

${ }^{470}$ Rttv. 18-19. $\$$

${ }^{471}$ Mttv. 28. § (1)-(2)
} 
médiaszolgáltatásban." ${ }^{472}$ A rádiós és a tematikus médiaszolgáltatásban ez a tiltás nem érvényesül. A Médiatanács a 2011-ban felállított adatbázisa alapján 96 szempont szerint elemzi a rádiós és televíziós müsorokban megjelenő reklámszpotok Mttv-nek való megfelelőségét. ${ }^{473}$

\subsubsection{Médiatudatosság}

A NAMS JK az új technológiák, szolgáltatások igénybe vételéhez elkerülhetetlenül szükségesnek tartotta a fogyasztók tájékoztatását, oktatását. A véleménynyilvánítás szabadságának gyakorlásához fontos, hogy a fogyasztók képesek legyenek eligazodni a digitális médiatérben. A médiatudatosság fejlesztése ezért a Koncepció szerint kiemelt médiapolitikai jelentőséggel bír mind a médiapiac felügyeletéért felelős hatóság, mind pedig a fogyasztóvédelmi hatóság tevékenységében. A „média írástudás” (media literacy) céljainak a Nemzeti Alaptantervben való szerepeltetése szintén ezt a célt támogatja.

Az AVMS irányelv megfogalmazásában a médiatudatosság ${ }^{474}$ olyan készségeket, ismereteket és értelmezési képességeket jelent, amelyek alapján a fogyasztók hatékonyan és biztonságosan tudják használni a médiát. A médiatudatos emberek tájékozottan tudnak választani, megértik a tartalom és a szolgáltatás jellegét, hasznosítják az új kommunikációs technológiák által nyújtott lehetőségek teljes körét, ezáltal jobban meg tudják védeni magukat és családjukat a káros vagy sértő tartalmaktól. A médiatudatosság hazai elterjesztésében felelősségteljes szerepet vállaltak az $N M H H^{475}$ mellett a civilszervezetek $^{476}$ is. Az ombudsman 2016. februárban készült vizsgálatának gyakorlati tapasztalatokat összegzö ${ }^{477}$ megállapítása is leszögezi:

„Az állami és civil szakmai szereplők is egyetértenek abban, hogy a médiamüveltség növelése jelentős mértékben hozzájárul egy versenyképesebb tudásgazdaság, egyúttal egy befogadóbb információs társadalom megteremtéséhez.” [...] „A médiamüveltség

\footnotetext{
${ }^{472}$ KOLTAY-LAPSÁNSZKY Kommentár 99.

${ }^{473}$ A Médiatanács 595/2015. (V. 19.) számú döntése: A Médiatanács elfogadja „A televíziókban és a rádiókban közzétett új reklámszpotok (2014. július-december)" címü anyagot, és elrendeli annak közzétételét a Médiatanács honlapján. POLYÁK Gábor: Politikai célú társadalmi reklám Jogi Fórum 2016.02.17. (POLYÁK III.)

${ }^{474}$ AVMS irányelv (47)

${ }^{475}, \ldots$...Az NMHH kiemelt célja a tudatos médiahasználattal és a biztonságos internetezéssel kapcsolatos ismeretek átadása." Médiatudatosságra nevelne a Médiatanács Forrás: Kossuth Rádió/180 perc | 2013. szeptember 26. csütörtök 07:50 | (NMHH sajtóközleménye 2012. május 13.)

${ }^{476} \mathrm{http}: / /$ www.mediatudor.hu/ Médiatudor program.

${ }^{477} \mathrm{Az}$ alapvető jogok biztosának Jelentése az AJB-479/2016. számú ügyben.
} 
szintjének felmérésére ugyanakkor nem állnak rendelkezésre egyeztetett kritériumok vagy normák, amely alapján egy teljes körü és reprezentatív kutatással gyorsan felmérhetőek lennének a jelenlegi rendszer müködésének tapasztalatai, annak erösségei, illetve gyengeségei, lehetőségei és mindezek alapján kijelölhetőek lennének a jövőbeli célok, a fejlesztések irányai. A médiaismeret stúdiumok kapcsán sajnos nincsenek jelenleg ismereteink arról, hogy az iskolákban pontosan milyen digitális eszközök állnak rendelkezésre, milyen tanári kompetenciával rendelkeznek a pedagógusok, a kerettantervekből továbbá milyen tartalmi elemek kerülnek át a helyi tantervbe, és azokból ténylegesen milyen tartalmi elemek valósulnak meg, milyen időkeretben. Ezek nélkül nem lehet egyértelmü az sem, hogy hol vannak a hiányosságok és melyek azok az elemek a médiaoktatásban, amelyeken változtatni kell a hatékonyság és az elérhetőség növelése érdekében."

A hazai médiaműveltséget a 2012-ben készült Nemzeti Alaptantervet kompetencia alapon megközelítő ombudsmani Jelentés egyértelmű kétségét fejezi ki a médiatudatosság jelenlegi helyzetét illetően. Nagy megállapítása még inkább egyértelmü: „A vizsgálódás örvendetes, annak eredménye azonban lesújtó. [...] a rögzített ismeret és készségfejlesztési célok igencsak példaértékünek tekinthetők. Kevés olyan nemzeti curriculum létezik Európában, amely ilyen kidolgozottan, minden korosztályt érintően jelenik meg a médiaértés-fejlesztés, mint nálunk. Az ombudsmani jelentésböl azonban kiderül, hogy mindez csak a szavak szintjén létezik, és valójában alig valósul meg valami a napi iskolai gyakorlatban mindabból, ami papíron olyan szépen mutat."

A kedvezőtlen tapasztalatok enyhítése, a médiatudatosság elterjesztése érdekében és azért, hogy „a világháló ne fenyegesse gyermekeink biztonságát”, a Kormány 2016 szeptemberében fogadta el a Digitális Jólét Program keretében Magyarország Digitális Gyermekvédelmi Stratégiáját, ${ }^{479}$ amely stratégia nagy hangsúlyt helyez a tudatos médiahasználatra, a médiamüveltségre és mindezek oktatására.

\footnotetext{
${ }^{478}$ NAGY Krisztina: „A jelenlegi helyzet ugyanis (...) alkalmas arra, hogy a jogsérelem közvetlen veszélyét idézze elö. ”2016.02.26. Mérték blog Jogi Fórum.

479 Digitális Jólét Program, Magyarország Digitális Gyermekvédelmi Stratégiája http://www.kormany.hu/download/6/0e/c0000/Magyarorsz\%C3\%A1g\%20Digit\%C3\%A1lis\%20Gyermekv\% C3\%A9delmi\%20Strat\%C3\%A9gi\%C3\%A1ja.pdf
} 


\subsection{A müsordíj jogi „természete" ${ }^{480}$ és helye a médiaszabályozásban}

A müsordíj, más néven programdíj ${ }^{481}$ nem szerepelt a $N A M S$ szabályozási palettáján. Ennek elsődlegesen az volt az oka, hogy ez a díj-fajta nem tartozik közvetlenül a médiaszabályozás tárgykörébe, és az a hazai médiaszabályozásban - bár létjogosultságát az Rttv. is elismerte, valamint a jogintézményt a Dtv. is szabályozta -, nem játszott különösebben jelentős szerepet az új szabályozási rezsim kialakulása előtt. Az Mttv. első, 2010-ben elfogadott változata a müsordíj érvényesítését a televíziós digitális átállás Dtvben meghatározott céldátumához ${ }^{482}$ és ahhoz a feltételhez kötötte, hogy a lakosság legalább 94 százalékát elérje a digitális televízió müsorszórási szolgáltatáson keresztül a közszolgálati müsorszolgáltatás, és ehhez rendelkezésre álljon a digitális vételre alkalmas készülék. Az Mttv. eredeti szövegezése az analóg földi terjesztésű, országos audiovizuális médiaszolgáltatás médiaszolgáltatóit az akkor hatályos Dtv-ben meghatározott, ${ }^{483}$ a digitális átállás megvalósulásának időpontjáig eltiltotta a müsordíj érvényesítésétől. ${ }^{484} \mathrm{~A}$ Dtv. későbbi, 2011. évi módosítása ${ }^{485}$ a digitális átállás céldátumát 2014. december 31 . napjában úgy határozta meg, hogy addigra a közszolgálati médiaszolgáltatásnak a lakosság legalább 94 százalékát országosan el kell érnie, és a digitális müsorszórás vételi eszközeinek a kiskereskedelmi forgalomban elérhetőeknek kell lennie a lakosság számára. A Dtv.-ben meghatározott időponthoz és feltételekhez kötött, Mttv.-ben szabályozott müsordíj érvényesítésének lehetősége is - ennél fogva - tovább tolódott. Az Mttv. 2014 őszi módosítása ${ }^{486}$ (MódMttv.) - már a digitális átállás céldátumától függetlenül ${ }^{487}$ - a müsordíjra vonatkozó rendelkezéseket ismételten megváltoztatta úgy, hogy a $J B E^{488}$ lineáris audiovizuális médiaszolgáltató a programdíj fizetésének szabályait megállapító kormányrendelet hatályba lépéséig müsordíjat nem kérhet. A Mód.Mttv. hatályba

\footnotetext{
${ }^{480}$ A dolgozat e fejezete az NMHH Médiatanács MTMI felkérésére 2014-ben „A műsordíj jogi természete” címmel készült tanulmány aktualizált és tovább fejlesztett változata.

${ }^{481}$ A müsordíj, valamint a programdíj elnevezéseket a dolgozat - a hatályos szabályozással egyezően szinonim fogalomként használja. [Mttv. 207. § (6)]

482 2011. december 31.

${ }^{483}$ Dtv. 38. § (1)

${ }^{484}$ Itt ismételten utalok arra, hogy a digitális átállásnak - a Magyarország által is vállalt nemzetközi kötelezettségnek megfelelően -, 2011. december 31-ig meg kellett volna valósulnia.

${ }^{485}$ 2011. évi CCI. törvény 303. § (1) hatályos: 2012. I.1-től.

${ }^{486}$ 2014. évi XXXIX. törvény Egyes törvényeknek a költségvetési tervezéssel, valamint a pénzpiaci és a közüzemi szolgáltatások hatékonyabb nyújtásával összefüggő módosításáról. Elfogadva: 2014. IX. 29., hatályos: 2014. IX. 30. (az értekezés müsordíjjal kapcsolatos vizsgálata során: Mód.Mttv., a Médiatörvény 2014. évi módosítása, törvénymódosítás)

${ }^{487}$ A televíziós digitális átállás országos szinten 2013. október 31-vel megtörtént.

${ }^{488}$ JBE médiaszolgáltató: jelentős befolyásoló erejü médiaszolgáltató. (Mttv. 69. §)
} 
lépésekor televíziós JBE szolgáltatónak a TV2 Médiacsoport Kft. ${ }^{489}$ és a Magyar RTL Televízió Zrt. minősült.

A műsordíjat a kereskedelmi televíziózás hazai megjelenése óta a két országos kereskedelmi televízión kívül minden más televíziós médiaszolgáltató érvényesíti ${ }^{490}$ a müsorterjesztők felé, és azt a terjesztők többnyire az előfizetési díjban továbbhárítják a médiafogyasztókra. Hangsúlyozni szükséges, hogy a műsordíj nem azonos az előfizetési vagy „készülék-használati” díjjal, illetve a Magyarországon az állam által 2003-tól átvállalt, a közszolgálati műsorok terjesztéséért fizetendő üzemben-tartási díjnak ${ }^{491}$ nevezett ellenértékkel.

A programdíj jogintézménye az Mttv. 2014 őszi módosítása kapcsán került ismét előtérbe, jogi természetének elemzése a következő előzetes megállapítások alapján történik.

1) Mivel a müsordíjra vonatkozó kifejezett médiajogi szabályozás 2014 előtt nem volt, elsődlegesen a műsordíj tartalmára vonatkozó kérdéseket, nevezetesen azt kell vizsgálni, hogy a müsordíj milyen teljesítmények, tevékenységek, és szolgáltatások ellenértékét foglalhatja magában, illetőleg milyen díjelemeket összesít;

2) a müsordíj az elmúlt 60-70 évben az előfizetési díj mellett a közmédia finanszírozásához járult hozzá. Ezzel szemben a kereskedelmi televíziózás alapvető modellje szerint a meghatározó bevételi forrás a reklámbevétel, amit a műsordíj kiegészít/kiegészíthet. A müsordíj tehát a kereskedelmi média üzleti modelljének természetes eleme, a piaci alapon müködő médiaszolgáltatók müsorának ellenértéke;

3) maga a müsor piaci termék, továbbá - szerzői jogi értelemben vett - szomszédos (kapcsolódó) szerzői jogi teljesítmény is egyben, amelynek ellenértékére a televíziószervezet a nemzetközi és a hazai szerzői jogi szabályzás, illetve a polgári jog alapján jogosult;

4) a müsor piaci termék-jellege miatt egy esetleges hatósági ár/dijj ${ }^{492}$ megállapítás, hatósági díjkorlát bevezetése egyben a piaci szabadság korlátozását is jelenti. A hatósági díjkorlát elveit (alapvetően versenypolitikai és ágazatpolitikai elveit) törvényi szinten kell

\footnotetext{
${ }^{489}$ Az MTM-SBS Televízió Zrt. tulajdonos váltást követő (2014. 06. 30) új elnevezése: TV2 Médiacsoport Kft.

${ }^{490}$ Elfogadhatatlan a Viasat3 jelentös müsordíj emelése 2009. 01. 12. http://hirek.prim.hu/cikk/71017/

${ }^{491}$ Újra eltörlik az üzembentartási díjat, Népszava 2010. júl. 17. Televíziós müsordíj, fogyasztókra terhelt költségnövekedés - Törvény fogja szabályozni a kábelszolgáltatók és a csatornák viszonyát (jogiforum.hu/hirek/23917 2010. 10. 15.)

${ }^{492}$ A hatósági ár/díj fogalma azonos, így azokat azonos tartalommal használom a dolgozatban.
} 
meghatározni ${ }^{493}$ E törvényi szabályozás lehet az alapja a kormányrendeleti szintű részletes szabályozásnak.

\subsubsection{Elözmények}

A két országos kereskedelmi médiaszolgáltató már 2009-ben megkezdte a müsordíj bevezetésének háttérmunkálatait, így - többek között - a díjképzés kidolgozását, a konkrét díj meghatározását és a terjesztőkkel való egyezkedés folyamatát. A díj jogi érvényesítésének hivatalos bejelentésére azonban - a megjelent sajtóírások tanúsága szerint - csak 2010-ben került sor. A programdíj bevezetésének híre és megalapozatlanul ténynek tekintett mértéke több helyen, elsősorban a müsorterjesztők körében „kiverte a biztosítékot" és lényegében a médiapiac müködésének kényszerü üzleti modellváltásáról, az addigi médiapiaci modell felborulásáról, valamint az értékláncban szereplő média és hírközlési szolgáltatók jelentőségének, médiapiaci súlyának megváltozásáról szóltak. A sajtóban megjelent hírek nem csak a müsordíj létjogosultságát, hanem érvényesítésének lehetőségét is megkérdőjelezték.

\subsubsection{A müsordij bevezetésének lehetséges indokai}

A két országos kereskedelmi médiaszolgáltató finanszírozási alapját jelenleg teljes egészében a reklám és szponzorációs bevételek képezik. A gazdasági és hitelválság következtében e bevételek jelentős elmaradását a két médiaszolgáltató kezdetben költségcsökkentö $^{494}$ intézkedésekkel, föként a létszám racionalizálásával próbálta kompenzálni. Ezek mellett, - élve az új médiaszabályozási környezet adta lehetőségekkel mindkét médiaszolgáltató új stratégiát dolgozott ki a tematikus csatorna-portfoliójuk kialakítására, továbbfejlesztésére, illetve új tematikus csatornák indítására (RTL II, Supertv2, stb.). Az új tematikus, illetőleg újra pozícionált csatornák tartalma után a

\footnotetext{
${ }^{493}$ A Mód.Mttv. nyomán felmerült a műsordíj hatósági ár/díjmegállapításának lehetősége. Ebben az esetben a müsordíjjal kapcsolatos hatósági ár/dijképzés elveinek meghatározása további Mttv. módosítást igényelt volna.

494, „[...] a két országos adó listaáras bevétele rekordokat ért el, és az ezredfordulót követő években a vizsgált televíziók reklámbevételeinek többsége hozzájuk folyt be. Arányuk a teljes hirdetési piachoz képest is óriásinak számított, a reklámpiacon forgó hatalmas pénzmennyiség jelentős része őket illette. Ugyanakkor ez a részesedés... az utóbbi időben erős csökkenő tendenciát mutat, ami azt jelzi, hogy a kisebb csatornák megjelenése kezdetben még nem érintette a két kereskedelmi televízió monopol helyzetét, megsokasodásuk azonban már érezhetően zsugorítja a „két óriás” játékterét." A televíziós reklámpiac alakulása az ezredforduló után NMHH Médiatanács Budapest, 2011. november.
} 
műsorterjesztők már fizetnek programdíjat a két médiaszolgáltató részére, illetve e csatornák reklámideje is értékesítésre került. Mivel a tematikus csatornák által generált bevételek így sem kompenzálták teljes egészében a „föcsatornák“ reklámbevétel-kiesését, további bevételekre, bevétel-növelésre volt szükségük, egyes költségeik további csökkentése révén (pl. médiaszolgáltatási díj, müsorterjesztési költségek), illetőleg a „föcsatornák“ tartalmáért járó programdíj érvényesítésével. A reklámpiaci bevételek jelentős zsugorodását a két médiaszolgáltató „normál üzleti kockázatának“ tekinthetjük. A programdíj bevezetését természetesen ez a piaci változás is indokolhatja, de oka nem kizárólag erre a tényezőre vezethető vissza. A programdíj érvényesítésének másik célja, hogy a két médiaszolgáltató a Magyarországon mintegy két évtizede működő üzleti modellváltást ösztönözze azzal, hogy az előfizetők által a szolgáltatás után megfizetett díjak egyfajta újraelosztását, újrafelosztását kezdeményezze. Az üzleti modellváltás alapja a digitális műsorterjesztés elterjedésével megjelent, az eddigiekhez képest új, hozzáadott értékű szolgáltatások (EPG, PPV, VOD, NVOD, Catch up TV, Time Shifting stb.).
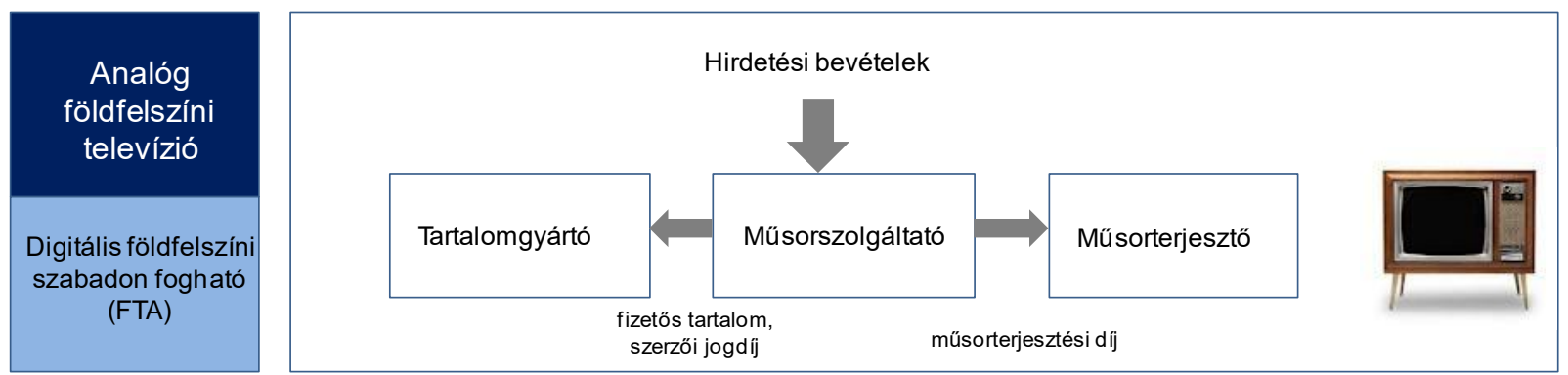

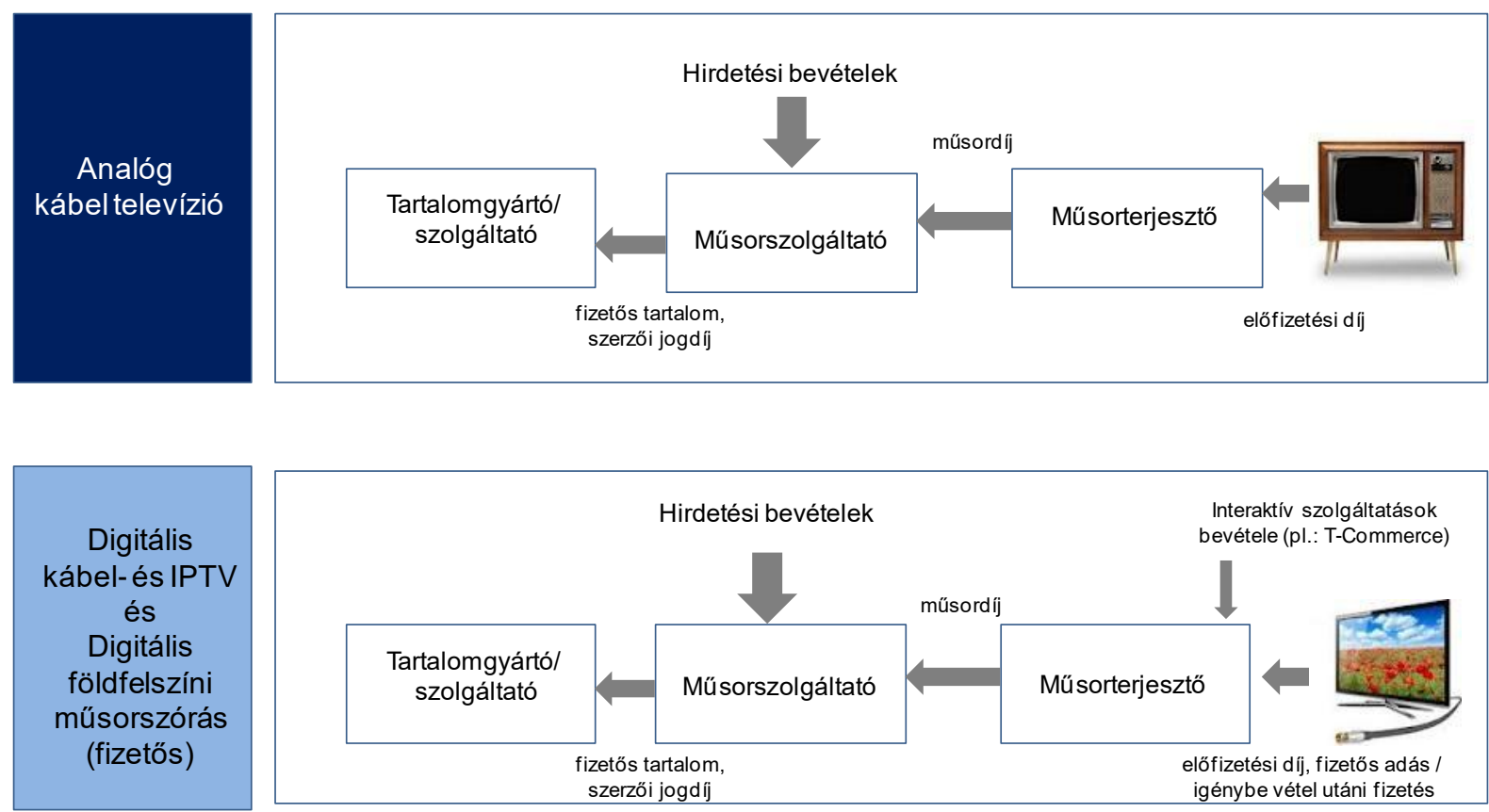

Forrás: Booz Allen analysis

\section{5. ábra A különböző platformok eltérô bevételi modelljei}

A ábrák a földfelszíni és az egyéb (CATV, IPTV, DTH) müsorterjesztő platformok „bevételi modelljei” közötti markáns különbségeket mutatják. Az értékláncok közötti eltérések jól azonosíthatóak a különböző terjesztési platformokon, illetve terjesztési módoknál. Míg a földfelszíni sugárzás esetén a médiaszolgáltató egy meghatározott díjat fizet a müsorszóró vállalkozás részére, addig a többi terjesztési platform esetén ilyen díj megfizetésére nem kerül sor. A terjesztési módok megválasztása a médiaszolgáltató diszkrecionális joga, üzleti döntése annak függvényében, hogy milyen módon és a lakosság mekkora hányadát kívánja elérni, illetve, hogy milyen módon tudja leginkább a programdíj-, és reklámbevételeit optimalizálni. A médiaszolgáltatók müsordíj bevételének tömegét/nagyságát két fontos tényezö határozza meg, egyrészt az elöfizetök száma, másrészt pedig az egyedi (előfizetőnként és havonként megállapított) programdíj mértéke. A magyarországi müsorterjesztők által továbbított televíziós csatornák átlagos, előfizetőnkénti programdíjai jellemzően kb. 0,10 - 1 euro közötti értéket képviselnek. 
Az elmúlt években a terjesztőknek - a csökkenő árbevételeik mellett -, egyre növekvő müsordíj tömeget kellett fizetniük a médiaszolgáltatók részére. A médiaszolgáltatóknak átadott díj mértéke 2013-ben átlagosan meghaladta a müsorterjesztési bevétel harmadát. ${ }^{495}$ A mennyiségi kedvezmények rendszerének müködésére utal az, hogy az egy előfizetőre jutó programdíj átlagos nagysága a „nagyobb” műsorterjesztőknél kevesebb, a „kisebb” müsorterjesztőknél pedig több. Mindehhez kapcsolódóan tényként kell megállapítani azt is, hogy a vezetékes müsorterjesztők (CATV, IPTV) egyazon hálózatukon jellemzően nem csak müsorterjesztési szolgáltatást nyújtanak, hanem bevételük jelentős részét generálják többek között - internet és telefonszolgáltatásból. Az ugyanazon a hálózaton nyújtott különböző szolgáltatások és azok kombinációi - a transzparencia feltételeinek való megfelelés céljából - olyan szabályozói törekvéseket is megjeleníthetnek, amelyek egy egységes hálózati hozzáférési díj kötelező előírása mellett, a különböző szolgáltatások díjainak differenciált, egyedi meghatározását követeli meg. Mindez azért is aktuális lehet, mert más szolgáltatók (MUX, OTT) is hozzáférést kezdeményezhetnek, illetőleg hozzájuthatnak a vezetékes infrastruktúrához, valamint az előfizetőkhöz.

\subsubsection{A Müsordíj rövid története és kis nemzetközi kitekintés}

A programdíj/müsordíj elnevezés alatt a nemzetközi használatban nem értelmezhető egységes fogalom. Leginkább az a szerzői jogi megközelítés állja meg a helyét, miszerint a müsordíj a rádió- és televízió-szervezetek ${ }^{496}$ által nyilvánossághoz közvetített médiatartalom, a műsor, valamint a nyilvánossághoz közvetítéssel együtt járó tevékenységek (szerkesztés, infrastrukturális és személyi feltételek értéke, terjesztés stb.) ellenértéke. A legtöbb államban receiver fee, broadcast fee, ${ }^{497}$ licence fee ${ }^{498}$ TV Tax, program fee neveken illetik és ezen többnyire a terjesztett tartalom ellenértékét is magában

\footnotetext{
${ }^{495}$ Itt azt is meg kell említeni, hogy ezen időszakban a műsorterjesztők egyéb hírközlési szolgáltatásokból származó bevétele jelentösen növekedett. Statisztikai Tükör, Távközlés, internet, kábeltelevízió 2013. 09. 13. ${ }^{496}$ A médiaszolgáltatók szerzői jogi terminológiával élve lényegében a rádió- és televízió szervezetek, illetőleg e szervezetek médiajogi értelemben médiaszolgáltatók. A dolgozat a televízió-szervezet/ek, műsorsugárzó szervezetek, illetőleg a médiaszolgáltató/k kifejezést is használja.

497 Broadcast Fees in Germany http://www.internations.org/germany-expats/guide/16032-mediacommunication/the-german-radio-and-tv-landscape-16007/broadcast-fees-in-germany-2

498 „Licence Fee” Encyclopedia of Television (1st Edition). Chicago: Museum of Broadcast Commuications 1997. Retrieved 21 November 2006. In: Television licence (Television licence) http://en.wikipedia.org/wiki/Television_licence 2014. 05. 20.
} 
foglaló, leginkább a közszolgálati műsorokért járó előfizetési díjat értik. ${ }^{499}$ Az előfizetési díj néven ismert ellenérték a müsordíj-elemen felül - amint arra rámutattam - még több díjelemet is magában foglal: a hálózat kiépítési költségek arányos ellenértékét, a csatlakozási/hozzáférési díj-elemet, a hozzáférés (technikai díj-elem) egyszeri belépési díjelemet, illetőleg a marketing és egyéb díj-elemeket. Mivel a nemzetközi gyakorlatban a programdíj a médiafogyasztóra áthárított, többnyire a közszolgálati müsorokért fizetett előfizetési díj felől közelíthető meg, a különböző tartalmak elérését lehetővé tevő vételi, illetőleg sugárzási engedély, valamint az ennek fejében fizetendő előfizetési díj rövid történetét és kialakult nemzetközi modelljeit is szükséges - a teljesség igénye nélkül ismertetni.

A müsorsugárzás, a rádiózás kezdeti időszakában kérdéses volt, hogy a szolgáltatók milyen forrásból tudják megteremteni a szolgáltatásuk pénzügyi finanszírozását. Egyes országok a kizárólagos reklám modellt alkalmazták, azaz a reklámbevételekből fedezték a műsorszolgáltatás költségeit. Az államok többsége azonban a kötelező elöfizetéses modellt vezette be, amely modell szerint a saját rádió-, később pedig televízió készülékkel rendelkező háztartásokat terhelte fizetési kötelezettség. A díj viselője egyértelműen a közvetlen felhasználó, a médiafogyasztó volt. Az Egyesült Királyság 1927-ben elsőként alkalmazta az előfizetéses rendszert. A Royal Charter alapján a „rádió-vételi engedély”500 fejében beszedett díj megteremtette a $B B C$ kormánytól való teljes függetlenségének feltételeit, mind a programok előállítása, mind pedig a finanszírozás terén.

A televíziózás megjelenésével több ország önálló televízió-engedélyt és ennek megfelelően külön televíziós díjat vezetett be, néhány államban pedig a rádió engedélyt kiterjesztették a televíziós müsorok vételére és a díjat megemelték. Az elnevezés is ennek megfelelően változott: rádió engedélyből, TV engedély, illetve vételi engedély ${ }^{501}$ és díj lett. Jelenleg a világon az engedélyeknek és díjaknak - többek között - a vételi eszközök fajtájától, a készülékek számától függően, illetőleg a használattól függetlenül is rendkívül sok formája létezik. A médiaszolgáltatás, ezen belül is elsősorban a közszolgálati médiaszolgáltatás finanszírozási modellje is nagyon változatos képet mutat. Létezik a kizárólagos előfizetéses, továbbá a vegyes, azaz előfizetéses és reklámbevételekből finanszírozott modell, valamint az előfizetés, a reklámbevételek és a kormány általi támogatás együttes

\footnotetext{
${ }^{499} \mathrm{BBC}$ wants you to pay TV licence fee even if you don't own a set, as shows go on iPlayer for longer Telegraph http://www.telegraph.co.uk/culture/tvandradio/bbc/10746109/BBC-wants-you-to-pay-TV-licencefee-even-if-you-dont-own-a-set-as-shows-go-on-iPlayer-for-longer.html (Telegraf) ${ }^{500}$ wireless licence

${ }^{501}$ receiver licence
} 
rendszere is. Azon államokban, ahol nincs TV elöfizetés, a kormány támogatása és a reklámbevételek, továbbá a kizárólagos kereskedelmi finanszírozás, valamint a kizárólagos kormány-támogatás modelljei érvényesülnek.

A televízió felhasználási engedélyt és az ennek fejében fizetendő díjat a világ sok országában olyan költségvetési bevételnek, azaz „,adó”-nak tekintik, amely a reklámbevételekkel együtt biztosítja a médiaszolgáltatás pénzügyi fedezetét. Míg a TV előfizetési díj rendszere ritka Amerikában, addig az ázsiai és afrikai országok felében, valamint az európai államok kétharmadában ez a díj teremti meg a közszolgálati televíziózás finanszírozási alapját. ${ }^{502}$ Példaként érdemes megemlíteni, hogy Franciaországban a közszolgálati programokért fizetendő, a helyi adók részeként beszedett előfizetési díjat kiegészítik a reklámbevételek, amelyek mértéke jelentősen csökkent az elmúlt években. Mivel a 2009-es francia törvénymódosítás célja az volt, hogy a közszolgálati csatornák ne legyenek kitéve versengésnek a reklámpiacon, a törvény megtiltotta a 20 óra utáni reklámozást a közszolgálati csatornákon.

Németországban 2013-tól egységes előfizetési rendszer müködik: a háztartások tekintet nélkül a rádió és televíziókészülékek használatára, havonta 17.98 eurót fizetnek. A vállalkozások által fizetendő díj összege függ a foglalkoztatottak létszámától és a forgalomtól, a szállodák esetén pedig az ágyak számától. A szabályozás differenciáltan kezeli a munkanélkülieket, illetőleg a minimál béren élőket; ők mentesülnek az előfizetési díj alól. A német modell a közszolgálati média finanszírozása terén a leginkább megvalósítja az előfizetéses rendszert: míg az előfizetési díjakból évente átlagosan 7.6 milliárd euró, addig a reklámbevételekből 500 millió euró származik. A közszolgálati médiaszolgáltatók (ARD és ZDF) 2007-ben pert indítottak a német kormánnyal szemben, mert az beavatkozott a költségvetési eljárásukba. A német szövetségi Legfelsőbb Bíróság, a Bundesgerichtshof helyt adott a keresetnek és ettől fogva a német közszolgálati média kormánytól való függetlensége és önrendelkezési joga teljes mértékben érvényesül. ${ }^{503}$

502 Soha nem érvényesítettek előfizetési díjat Lichtensteinben, Luxemburgban, Monacoban és Spanyolországban, az Egyesült Államokban és Kanadában, továbbá Kínában, Hong-Kongban, Iránban, és Vietnamban. Eltörölték az előfizetési díjat - többek között - Belgium flamand részén, Cipruson, Finnországban, Hollandiában, Máltán, Portugáliában, továbbá Ausztráliában, Izlandon, Új-Zélandon és Indiában. Európa legtöbb államában működik az előfizetéses modell, így érvényesítenek „készülék díjat” Albániában, Belgium vallon és brüsszeli részén, Bosznia-Hercegovinában, Csehországban, Dániában, az Egyesült Királyságban, Franciaországban, Görögországban, Horvátországban, Írországban, Lengyelországban, Németországban, Norvégiában, Olaszországban, Romániában, Svájcban, Svédországban, Szlovákiában, Szlovéniában, valamint Törökországban. (Television licence) ld.: 498. lbj.

503 A német közszolgálati televíziók megszüntetésének szándékáról ld: Anreize für effiziente Produktion Rundfunkbeitrag abschaffen! Gutachter fordert Privatisierung von ARD und ZDF 25. 05. 2015. 
Olaszországban a közszolgálati $R A I$ elsődleges bevételeit jelentő, a készülék-használattól független előfizetési díj 2014-ben háztartásonként 113.50 euró volt. A RAI bevételei kiegészülnek a reklámbevételekkel is. A szálláshelyek és a vendéglátó ipari egységek szintén a készülékek használatától függetlenül, speciális díjat fizetnek. A díj meg nem fizetése esetén járó büntetés csak mintegy fele az előfizetési díj mértékének, így a beszedési hatékonyság rendkívül alacsony (átlagosan a nézők 40 százaléka nem fizet díjat). Az Egyesült Királyságban - ezzel szemben - mintegy 1300 euró a büntetés. Lengyelországban 2012-ben a készülékenkénti éves TV előfizetési díj 45.33 euró, a csak rádiókészülékkel rendelkezők díja pedig 13,48 euró volt, amelyet havonként, negyedévenként, félévente vagy évente is lehet fizetni. Az egész évi díj elöre történő megfizetése 10 százalékos kedvezményt von maga után. A díjat a lengyel posta szedi be, a díjnak kb. 60 százaléka a lengyel televíziót illeti, a többi pedig a lengyel rádióhoz kerül.

\subsubsection{A müsordíj lényegi tartalma, konvergenciája}

A müsordíj fogalmát, tartalmát, valamint „összetételét” illetően a hazai jogi szabályozás egyrészt hiányos, másrészt pedig a közelítő szabályozások igen változatos képet mutatnak. Ennél fogva a már említett elnevezések, úgymint a tartalomért, a műsorért járó díj vagy a terjesztés ellenértéke, terjesztési díj kifejezések is használatosak a szakmai „,közbeszéd”ben. Amint arra a következőkben részletesen is kitérek, az egyes érintett jogterületek szabályozási megközelítése teljesen eltérö. Ebből következően a müsordíj eredete, tényleges tartalma, valamint más díjakhoz való viszonya tekintetében csak a nemzetközi és uniós szerzői jogi dokumentumok, továbbá valamennyi vonatkozó hazai jogszabályi rendelkezés és kialakult gyakorlat elemzése révén kapunk egyfajta „összképet.”

\subsubsection{Hírközlésjogi megközelítés}

A hírközlésjogi szabályozásnak - értelemszerüen - nem közvetlen tárgya a médiaszolgáltató által szerkesztett és nyilvánossághoz közvetített tartalom értéke és ellenértéke. A müsordíj jogi természetének meghatározásához azonban, ha közvetve is, a vonatkozó hírközlésjogi szabályozás nyújt némi támpontot. 
Az Eht. meghatározásában az elektronikus hírközlési szolgáltatás ${ }^{504}$ egyrészt - általában, de nem feltétlenül - ellenérték fejében végzett szolgáltatás, másrészt pedig - egyebek mellett - nem foglalja magában a tartalomszolgáltatást vagy a tartalom felett szerkesztői ellenőrzést gyakorló szolgáltatásokat, azaz a médiaszolgáltatásokat. A programdíj jogi természetének bemutatása szempontjából azért indokolt rámutatni az elektronikus hírközlési szolgáltatás definíciójára, mert a hírközlési szabályozás egyértelműen kiveszi a programdíj alapját képező médiaszolgáltatásokat az elektronikus hírközlési szolgáltatások fogalomköréből, ezáltal expressis verbis kimondja a médiaszolgáltatás önállóságát. Itt utalok ismételten a médiaszolgáltatás az Mttv.-beli fogalmára, amely szerint a szolgáltatás az önálló, üzletszerủen, rendszeresen, nyereség elérése érdekében, gazdasági kockázatvállalás mellett végzett gazdasági szolgáltatás, ${ }^{505}$ amelynek - e kivonatosan idézett definíció értelmében is - értéke van.

1. Müsordíj, mint díjelem a digitális törvényben

A Dtv. Mttv. által módosított, ${ }^{506}$ hatályos rendelkezései közelebb visznek a müsordíj lényegéhez; a Dtv. a versenyt biztosító szabályai között külön is rendelkezik a müsordíjról. ${ }^{507}$ Ennek értelmében a műsordíj a müsor ellenértéke, amelyet a müsorterjesztő a médiaszolgáltatóval kötött megállapodás alapján, kizárólag az előfizetőtől szedhet. A törvényi megfogalmazásból az következik, hogy a müsordíjat

i) a szerzői jogi jogosultak érdekeinek védelmében, azaz a szerzői jogi teljesítményt előállító jogosult televízió szervezet védelme miatt ii) a műsorért (nem a terjesztésért), iii) a müsorterjesztő szedheti, iv) a médiaszolgáltató javára, a vele kötött megállapodás alapján, v) a terjesztési szolgáltatás előfizetőitől.

A díj szedése tehát nem kötelezettség, hanem megállapodásban rögzített jogosultság. Szükséges megemlíteni, hogy a müsordíjra vonatkozó Dtv. rendelkezések módosítása tárgyában benyújtott T/4787. számú törvényjavaslat (Javaslat), ${ }^{508}$ illetöleg az elfogadott

\footnotetext{
${ }^{504}$ Eht. 188. § 13. „Elektronikus hírközlési szolgáltatás: olyan, más részére általában ellenszolgáltatásért végzett szolgáltatás, amely teljesen vagy nagyrészt jeleknek elektronikus hírközlő hálózatokon történő átviteléből, és ahol ez értelmezhető, irányításából áll, de nem foglalja magában az elektronikus hírközlő hálózatok és elektronikus hírközlési szolgáltatások felhasználásával továbbított tartalmat szolgáltató vagy ilyen tartalom felett szerkesztöi ellenőrzést gyakorló szolgáltatásokat, valamint nem foglalja magában az információs társadalommal összefüggő, más jogszabályokban meghatározott szolgáltatásokat, amelyek nem elsősorban az elektronikus hírközlő hálózatokon történő jeltovábbításból állnak.”

${ }^{505}$ Mttv. 203. § 40.

${ }^{506}$ Mttv. 220. § (16)

${ }^{507}$ Dtv. V. fejezet A versenyt biztosító rendelkezések 37. §

${ }^{508} 2015$. május.
} 
Dtv. módosítás ${ }^{509}$ nem változtat a műsordíj érdemi tulajdonságain és érvényesítésének feltételein, azokat kiegészíti és megteremti a kompatibilitást az Mttv. vonatkozó, már hatályba lépett rendelkezéseivel. A módosítás a közönségarányuk alapján véleménybefolyásoló képességük miatt jelentős befolyásoló erővel rendelkező - jelenleg két országos kereskedelmi médiaszolgáltató számára, továbbá azon médiaszolgáltatók vonatkozásában tartja fenn a müsordíj érvényesítésének tilalmát, amelyek ugyan nem minősülnek $J B E$ szolgáltatónak, de ha az Mttv. hatálya alá tartoznának, eleget tennének a törvényi feltételeknek. ${ }^{510}$

A médiaszolgáltatók jogos szerzői jogi érdekeit sértette az az általános gyakorlat, miszerint a kábeles vagy müholdas müsorterjesztő a médiaszolgáltatóval úgy köt szerződést a müsorterjesztés tárgyában, hogy amennyiben a médiaszolgáltató más műsorterjesztőnél ellenérték nélkül, vagy kódolatlanul teszi elérhetővé a médiaszolgáltatását a felhasználók számára, tehát free to air is sugározza a műsorát, a műsorterjesztő mentesül a díjfizetés alól, vagy a médiaszolgáltató hátrányára más feltétel lép életbe. A Módosítás ezt a jogsértő szerződéskötési gyakorlatot szünteti meg azzal, hogy az ilyen jellegü szerződések semmisségét mondja ki: „(6) Semmis a müsorterjesztő és a médiaszolgáltató közötti megállapodás olyan kikötése,

a) amelynek következtében a müsorterjesztő mentesül a müsordíj megfizetése alól, vagy

b) amely a médiaszolgáltató számára más hátrányos feltételt állapít meg abban az esetben, ha a médiaszolgáltató más műsorterjesztő útján ellenérték nélkül vagy kódolatlanul teszi elérhetővé médiaszolgáltatását a felhasználók számára."

A semmisség deklarálásával a médiaszolgáltatóknak lehetősége van új szabadon fogható csatornák indítására anélkül, hogy a törvény korlátozná a felek szerződéskötési szabadságát a müsordíj mértéke tekintetében. ${ }^{511}$ Mivel a Dtv. értelmében a müsordíj az előfizetési díjban kerül beszedésre, annak egyik „díjelemét” képezi. A Dtv. rendelkezései alapján, ahogy azt a következő ábra is mutatja, az előfizetési díj magában foglalja ${ }^{512}$

i) a médiaszolgáltató szolgáltatásáért beszedett műsordíjat,

ii) a médiaszolgáltatótól a műsor előfizetőkkel való megismertetésért, illetve elérhetővé tételéért beszedett marketing vagy más hasonló díjat, valamint

\footnotetext{
${ }^{509}$ 2015. évi CXVIII. törvény, hatályos: 2015. VII. 23 -tól.

${ }^{510}$ Dtv. módosított 37. § (1), (1a), (1b)

${ }^{511}$ Dtv. módosított 37. § (6)

${ }^{512}$ Dtv. 37. § (4)
} 
iii) az átviteli rendszer, illetve az előfizetői szolgáltatás működtetése ellenértékeként beszedett díjakat. A müsordíjat - ebböl következően is -, a müsorterjesztő az előfizetési díjban foglalva szedi be és - szintén a szerzői jogi jogosultak érdekei védelmében - az előfizetési díj valamennyi említett elemét elkülönítetten, átlátható és ellenőrizhető formában tartja nyilván. A „müsordíj-elem” előfizetési díjban való, Dtv. szerinti megjelenését a következő ábra érzékelteti:

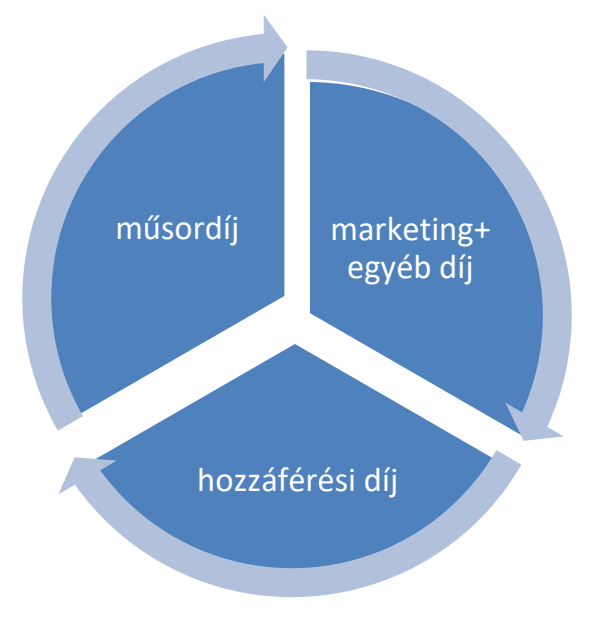

\section{6. ábra Músordíj-elem az előfizetési díjban ${ }^{513}$}

A szabályozás szerint a müsorterjesztő a müsordíjat is magában foglaló előfizetési díjak összegére tekintettel eltérő műsorcsomagokat állíthat össze. A müsorterjesztő az egyes müsorokhoz való hozzáférésért is szedhet dijjat az elöfizetőktől, ha a médiaszolgáltató az átvitelt is magában foglaló elektronikus hírközlési szolgáltatásért nem fizet külön díjat a müsorterjesztőnek. Amennyiben a médiaszolgáltató ilyen külön díjat fizet, a müsordíj összegének - nyilvánvalóan - alacsonyabbnak kell lennie az átvitelért és más elektronikus szolgáltatásért is fizetendő komplex ellenértéknél.

Mivel a Dtv. sem tartalmaz külön értelmező rendelkezést a müsordíj fogalmára, 'összetételére', illetőleg azt a müsorért fizetendő ellenértékként jelöli meg, a vonatkozó rendelkezésekből arra következtethetünk, hogy az ott szabályozott müsordíj a médiaszolgáltató - szerzői jogi terminológiával élve a rádió- és televízió-szervezet - által

\footnotetext{
${ }^{513}$ Az ábra az előfizetési díj „összetételét”, a műsordíj előfizetési díjon belüli elhelyezését, és az egyes díjelemek egymáshoz való viszonyát mutatja be, de nem fejezi ki az egyes díjelemek közti arányokat, ezek ugyanis eltéröek lehetnek.
} 
szerkesztett tartalom, a szerzői jogilag értékelhető szomszédos jogi teljesítmény ellenértéke.

\section{Hatósági „Útmutató”}

A Dtv. rendelkezéseivel nem teljesen kompatibilis megközelítésben, az NMHH 2013 júliusában nyilvánosságra hozott „Kitöltési útmutató az elöfizetéses müsorterjesztés kérdöivhez" elnevezésü dokumentuma (Útmutató) a müsordíj fogalmát a müsor terjesztéséért fizetendő nettó ellenértékként határozza meg. Ennek értelmében a müsordíj (programdíj) a műsorterjesztő által a médiaszolgáltatónak, annak müsora terjesztéséért fizetett nettó díj. E meghatározásból úgy tünik, mintha a müsordij a müsor terjesztéséért, nem pedig tartalmáért járó ellenérték lenne; a definíció második mondata azonban már - a pontosítás kedvéért - utal a programdíj szerzői jogi eredetére, illetőleg díjelemére is: „Megjegyzés: Felhívjuk a figyelmet, hogy azon müsorok esetében, amelyeknél a műsordíjat is az Artisjus szedi be, a müsordíjat az 1999. évi LXXVI. tv. („Szjt.”) ${ }^{514} 80$. §ra hivatkozó jogdíjfizetési értesítő tartalmazza."

A jogszabálynak nem minősülő Útmutató hírközlésjogi jellegű műsordíj meghatározása nem tekinthető a programdíj jogi eredete szempontjából döntő jelentőségünek. Ezt a meghatározást vélhetően az indokolta, hogy a díjat a terjesztő fizeti a médiaszolgáltatónak. A müsordíj terjesztési díjjal való azonosítása a médiaszolgáltatók nyilatkozataiban is elhangzik. $^{516}$ A „terjesztésért kért díj”, illetőleg a „terjesztési díj” elnevezés és kommunikációja a médiaszolgáltatók számára - a műsordíjjal ellentétben azért merülhetett fel, mert a médiaszolgáltatók a „saját müsoruk,"517 illetőleg a nyilvánossághoz közvetített médiatartalom létrehozatalában részt vevő alkotók (forgatókönyvíró, rendező, operatőr, szerkesztő stb.) részére a legritkább esetben fizetnek külön, nevesített szerzői jogdíjat. Ez a jogdíj a médiaszolgáltatóval munkaviszonyban, illetőleg jogviszonyban álló alkotók javadalmazásában jelenik meg, vagy a jogdíjat - külső gyártás esetén - a produkciók

\footnotetext{
514 1999. évi LXXX. törvény a szerzői jogról (Szjt.). A dolgozat az Szjt. 2016. évi XCIII. törvénnyel történő módosításáig hatályos szövegét veszi alapul. [2016. évi XCIII. törvény a szerzői jogok és a szerzői joghoz kapcsolódó jogok közös kezeléséről. Elfogadva: az Országgyülés 2016. június 13-i ülésnapján) Az Szjt. ettől eltérő hivatkozásait a dolgozat a megfelelő helyeken jelöli.

${ }^{515} \mathrm{http}: / / \mathrm{nmhh} . \mathrm{hu} /$ dokumentum/159723/31979_1_2013_elofizeteses_musorterjesztes_kitoltesi_utmutato.pdf

${ }^{516}$ Terjesztési dij a reklámadó kompenzálására? 2014-09-16 Médiainfó mediapiac.com

517 „A „saját müsor” alatt szerzői jogi értelemben a nyilvánossághoz közvetítést végző szervezet által előállított - az oltalom feltételeinek megfelelő - müsort vagy müsorszámokat kellett/kell érteni. „A saját gyártású müsorszám médiajogi lényege a médiaszolgáltató által szerkesztett tartalomban van, függetlenül attól, hogy a szerkesztett müsor egyes elemeit, adott esetben a védett müveket ki állította elö. (Ezt a fogalmat az Mttv. már nem használja)" SARKADY-GRAD-GYENGE 119.
} 
többnyire egységes ,vállalkozási” díja foglalja magában. ${ }^{518}$ Az előfizetési Útmutató a szerzői jogdíj fogalmát külön is meghatározza és azt a müsorterjesztő által a terjesztett müsorban szereplö müvek szerzői - közös jogkezelője - részére a müvek nyilvánossághoz történő egyidejü, változatlan és csonkítatlan továbbközvetítése engedélyezéséért fizetett díjjal azonosítja. A hírközlési megközelítésben a televízió-szervezetek által létrehozott és szerkesztett médiatartalom, maga a müsor, mint szomszédos szerzői jogi teljesítmény, illetőleg annak értéke és ellenértéke nem kerül külön megemlítésre. ${ }^{519}$ Abból az egyébként nem vitatott tényből kiindulva, hogy a müsordíj az előfizetői díj részeként mindenképpen egyfajta szerzői jogi teljesítmény elismerésére szolgál -, tartalmát illetően a következő változatok lehetségesek. A müsordíj 1) kizárólag a médiaszolgáltató által szerkesztett és a nyilvánossághoz közvetített tartalom/müsor felhasználásáért járó ellenérték, a televíziószervezet szerzői szomszédos jogi teljesítménye után járó homogén díj vagy 2) olyan összetett jellegü ellenérték, amely - más díjelemek mellett - a müsor tartalmáért, illetőleg felhasználásáért járó díjat is magában foglalja. A müsordíj jogi természetének vizsgálata során a gyakorlatban kialakult, a müsorterjesztők által a médiaszolgáltatóknak fizetett összetett dijj-modellt tekintem az elemzés szempontjából kiinduló változatnak.

\subsubsection{A müsordíj szerzöi jogi eredete}

\section{Szomszédos jogi teljesítmény}

A müsordíj fogalmát - amint azt már említettem -, szerzői jogi törvényünk nem határozza meg, sőt a rádió- és televízió-szervezetek szerzői jogilag értékelhető teljesítményét, a müsort sem nevesíti. Megjegyzem, a müsor egésze nem is áll felétlenül szerzői jogi védelem alatt. A műsor médiajogi fogalmát az Mttv. értelmező rendelkezései ${ }^{520}$ rögzítik: „Müsor a rádiós, illetve audiovizuális müsorszámok megszerkesztett és nyilvánosan, folyamatosan közzétett sorozata". 521

A müsordíj szerzői jogi eredetét tekintve, - ahogy azt az elnevezések is kifejezik -, alapvetően a rádió- és televízió szervezetek által szerkesztett műsornak, programnak, az ún. szomszédos szerzői jogi teljesítménynek a felhasználásáért járó, azok értékét kifejező

\footnotetext{
${ }^{518}$ BDT 2006. 1468., BDT 2008. 1862.

${ }^{519}$ Arról még a későbbiekben szó lesz, hogy a nemzetközi szerzői jogi dokumentumokban és a hazai szerzői jogi szabályozásban is a rádió- és televízió-szervezetek által létrehozott szomszédos szerzői jogi teljesítmény ellenértéke díj, de nem feltétlenül jogdíj. Ld.: 6.4.6. alfejezet 7-8. pontjait.

${ }^{520}$ Mttv. 203. § 44.

${ }^{521}$ A bírói gyakorlat a műsor (műsorfolyam) védelmét kiterjeszti a müsorszámokra is. BH 2005. 56.
} 
szerzői jogi természetü ellenérték. A szerzői jogban a szomszédos jogok olyan teljesítményeket védenek, amelyek anélkül, hogy befolyásolnák a létrejöttük során felhasznált irodalmi, tudományos és művészeti alkotásokon fennálló szerzői jogok védelmét, ${ }^{522}$ önmagukban is értéket képviselő produktumok: maga a müsor is (ha nem is minden elemében) szerzői jogilag értékelhető eredmény. A szerzői jogi „teljesítmény” kifejezés egyértelműen utal arra, hogy e jogosultak tevékenysége következtében önálló, az adott tevékenység jellegéhez igazodó, szerzői jogilag értékelhető eredmény jön létre. E teljesítmények azonban nem tekinthetők a hagyományos értelemben vett szerzői münek, alkotásnak, hanem „,...] e teljesítmények szellemi, számos esetben alkotó értékü, továbbá müszaki jellegű rutin vagy azt meghaladó tevékenységek ötvözetének eredményei."523

A szomszédos jogok összefoglaló elnevezése az Szjt-ben önálló fejezetbe foglalt és taxatíve felsorolt, az előadómüvészek, a hangfelvétel előállítók, a film előállítók, valamint a rádió- és televízió szervezetek védelem alatt álló teljesítményének. E teljesítmények egyrészt a szerzői művek közönséghez való eljutását segítik elö, másrészt pedig valamennyi ilyen jellegü teljesítmény a szerzői alkotásokhoz hasonló védelmet élvez. ${ }^{524} \mathrm{~A}$ szomszédos jogi védelem nem az egyes müsorszámok, hanem a teljes program létrehozását, a konkrét müsorok kiválogatását, szerkesztését, a programmal kapcsolatos finanszírozási feladatok stb. ellátását értékeli.

2. A szomszédos jogok önállósulása a nemzetközi szerzői jogi dokumentumokban

A szomszédos jogok önállósulását a hanglemez, illetőleg a rádiósugárzás megjelenése indította el. ${ }^{525}$ A szerzői művek közönséghez való eljuttatásának folyamatában idővel jelentőssé vált a szerzők mellett más jogosultak - így a rádió- és televízió-szervezetek egyes további tevékenységeinek a szerzői jogi védelemhez hasonló, önálló védelmének elismerése, nevezetesen e saját teljesítmények felhasználásának kontroll alatt tartása: a felhasználás engedélyezése és - ennek fejében - díjfizetési kötelezettség megállapítása. A szomszédos jogi teljesítmények mögött ugyanis olyan üzleti, gazdasági, műszaki, szervezési stb. érdekviszonyok húzódnak meg, amelyek önálló jogi védelme - több okból is - szükségessé vált. Az önálló védelem kialakulását, a rádió- és televízió szervezetek

\footnotetext{
${ }^{522}$ Szjt. 83. § (1)

${ }^{523}$ SARKADY-GRAD-GYENGE 72.

${ }^{524}$ A szomszédos jogok szerzöi joghoz való közeliségére az idegen nyelvü elnevezések is utalnak: "neighbouring rights”, „droits voisin”, „verwandte Schutzrechte”. A vonatkozó irányelvek a „related rights,” kapcsolódó jogok kifejezést használják.

${ }^{525}$ SARKADY-GRAD-GYENGE 41.
} 
védelmét az egymással versengő szereplők, az ilyen jellegű szolgáltató társaságok, mint jogosultak piaci megjelenése, illetőleg az általuk létrehozott „termék”, a müsorok előállításába befektetett, már említett szellemi, gazdasági, műszaki, szervezési tevékenység érték-jellege segítette elő. A $B U E$ folyamatosan aktualizált 1928-as római felülvizsgálati szövege elsőként ismerte el nemzetközi dokumentumban a rádiósugárzást, mint a technikai fejlödés eredményét és rögzítette a sugárzásra vonatkozó rendelkezéseket, valamint deklarálta a rádió-szervezetek sugárzásra vonatkozó kizárólagos jogát. ${ }^{526} \mathrm{Az}$ előadóművészek, a hangfelvétel-előállítók és a műsorsugárzó szervezetek szomszédos jogi jogosultak védelméről 1961-ben Rómában létrejött nemzetközi egyezmény (Római Egyezmény, $R E$ ) első ízben fogalmazta meg a müsorsugárzó szervezeteket megillető engedélyezési jogokat. A $R E$ 13. cikke ${ }^{527}$ a müsorsugárzó szervezetek korlátozhatatlan minimumjogairól rendelkezik, amely jogok kizárólag a műsorsugárzó szervezeteket illetik meg, a müsort ténylegesen a nyilvánossághoz közvetítő szervezetek e jogosultságokkal nem rendelkeznek. A $R E$ értelmében valamennyi szerződő állam nemzeti elbánásban köteles részesíteni a müsorsugárzó szervezeteket, ha azok székhelye valamely másik szerződő államban van, vagy a sugárzott müsort valamely másik szerződő államban lévő adóállomásról vették át. ${ }^{528}$ Bármelyik szerződő állam nyilatkozhat azonban úgy, hogy csak abban az esetben nyújt védelmet a sugárzott műsoroknak, ha a műsorsugárzó szervezet székhelye valamely másik szerződő államban található, és a sugárzás átvitele ugyanazon szerződő államban lévő adóállomásról történt. ${ }^{529} \mathrm{~A}$ szerzői és szomszédos jogok összehangolása tárgyában született 2001. évi INFOSOC irányelv ${ }^{530}$ a szerzői jogok mellett a szomszédos jogok tekintetében is - többek között - a belső piac zavartalan müködését akadályozó és az információs társadalom megfelelő európai fejlődését hátráltató, jogbizonytalanságot eredményező tagállami rendelkezések, illetőleg a müszaki fejlődésre

\footnotetext{
${ }^{526}$ SARKADY-GRAD-GYENGE 35-36.

527 „A müsorsugárzó szervezetek joga, hogy engedélyezzék vagy megtiltsák a) sugárzott müsoraik továbbsugárzását; b) sugárzott müsoraik rögzítését; c) (i) a sugárzott müsoraikról engedélyük nélkül készített rögzítések többszörözését; (ii) a sugárzott műsoraikról a 15. cikk rendelkezéseivel összhangban eszközölt rögzítéseknek az e rendelkezésekben említettektől eltérö célokra történő többszörözését; d) televíziós sugárzott müsoraiknak a nyilvánossághoz való közvetítését, ha az olyan helyen történik, amely a nyilvánosság számára belépődij megfizetése ellenében áll nyitva; e jog gyakorlása feltételeinek meghatározása annak a Szerződő Államnak a nemzeti jogalkotására tartozik, amelyben a védelmét igénylik." ${ }^{528}$ Az előadómüvészek, hangfelvétel-elöállítók és müsorsugárzó szervezetek védelméről szóló, 1961-ben, Rómában aláírt egyezmény, kihirdette az 1998. évi XLIV. törvény (Római Egyezmény) 6. cikk 1.

${ }^{529}$ Római Egyezmény 6. cikk 2.

${ }^{530} \mathrm{Az}$ információs társadalomban a szerzői és szomszédos jogok egyes vonatkozásainak összehangolásáról szóló 2001. május 22-i 2001/29ányelv/EK európai parlamenti és tanácsi Irányelv (INFOSOC irányelv)
} 
adott különböző nemzeti válaszok közötti ellentmondások kiküszöbölését ${ }^{531}$ irányozta elő. A 2006-os Bérlet irányelv ${ }^{532}$ kiemelte, hogy ,[...] a szomszédos jogi teljesítmények számára a rögzítés, a terjesztés, a sugárzás és a nyilvánossághoz közvetítés joga által biztosított megfelelő védelem alapvető jelentőségü a Közösség gazdasági és kulturális fejlődése szempontjából.” Ez az irányelv hangsúlyozza továbbá, hogy a szerzői jog és a szomszédos jogok által biztosított védelemnek alkalmazkodnia kell az új gazdasági fejleményekhez, így különösen az új felhasználási módokhoz.

\section{Nyilvánossághoz közvetítés és felhasználási módok}

A média-értéklánc folyamatában és szereplői közül a programdíj szempontjából a két meghatározó szereplő a médiaszolgáltató és a műsorterjesztő, illetőleg e két „láncszem” közötti kapcsolat: a médiaszolgáltató által előállított médiatartalom a műsorterjesztő ${ }^{533}$ révén jut el a médiafogyasztóhoz, a televízió-szervezetek programja a nyilvánossághoz közvetítő terjesztők által válik érzékelhetővé. ${ }^{534} \mathrm{~A}$ médiajogi értelemben vett müsorterjesztés ${ }^{535}$ fogalmának a szerzői jogban leginkább a nyilvánossághoz közvetítés cselekménye felel meg, amely a szerzői mü, jelen esetben a müsor hozzáférhetővé tételét teremti meg a médiaszolgáltatótól távollévő közönség, a médiafogyasztó számára. A médiajog és a szerzői jog eltérő terminológiai rendszerének bővebb taglalása ${ }^{536}$ nélkül hangsúlyozni kell, hogy a médiajogi értelemben vett müsorterjesztés és a fizikai müpéldányok szerzői jog szerinti terjesztése között tartalmi összefüggés lényegében nincs. A müsorterjesztés médiajogi fogalma - azon túl, hogy technológia-semleges és elsősorban müszaki-, hírközlési szempontú meghatározás, - magában foglalja az ellenérték fejében és anélküli jeltovábbítást, illetőleg a csomagban értékesített szolgáltatásokat is.

\footnotetext{
${ }^{531}$ INFOSOC irányelv (7)

${ }^{532}$ A bérleti jogról és a haszonkölcsönzési jogról, valamint a szellemi tulajdon területén a szerzői joggal szomszédos bizonyos jogokról szóló 2006. december 12-i 2006/115/EK európai parlamenti és tanácsi irányelv [Bérlet irányelv] (3)

${ }^{533} \mathrm{Az}$ értekezés elsősorban a kábeles, illetőleg vezetékes közvetítést veszi alapul és nem tér ki a jelenleg ismert valamennyi müsorterjesztési átviteli platform által nyújtott szolgáltatásokra. (Mttv. 203. § 51a.)

${ }^{534}$ Megjegyzem, hogy a programdíj jogi természete kapcsán, - jelen esetben - nem indokolt ismertetni a „reklámozás” (kereskedelmi közlemények) szervezeti kereteinek - értékláncban elfoglalt helyét és szerepét. A NAMS-ban összefoglaló néven említett „reklámozás”, illetőleg az e tevékenységekből származó bevételek - a már ismertetett modellek szerint - az egyik legfontosabb finanszírozási alapját képezik a médiaszolgáltató szervezetek müködésének, de a médiatartalom fogyasztóhoz való eljuttatásának, a müsorjel továbbításának folyamatában a műsordíj jogi természetének elemzését illetően nem bírnak elsődleges relevanciával. Az audiovizuális médiaszolgáltatásokban felhasznált reklámok szerzői jogi megítéléséről ld.: SARKADYGRAD-GYENGE 67. 168. lbj.

${ }_{535}^{53}$ Mttv. § 50.

${ }^{536}$ Ld.: SARKADY-GRAD-GYENGE 103-129.
} 
A szerzői jogi nyilvánossághoz közvetités ${ }^{537}$ különböző módjai, megvalósulási formái ugyanakkor, - ha más és más megközelítésben ugyan, de - lényegében lefedik a médiajogi értelemben vett terjesztési platformok (földi müsorszórás, kábeles, müholdas terjesztés, IPTV és mobil applikáció) által végzett müsorterjesztési tevékenységeket. A nyilvánossághoz közvetítés szerzői jogi lényege, hogy a felhasználás a müpéldány átadása nélkül valósul meg a helyszínen nem lévő személyi kör, a nyilvánosság részére. Ennek során a néző, a médiafogyasztó az elektromágneses vagy a más jelekként továbbított müvet a vevőkészülékkel visszaalakítva, mint képeket, hangokat, írásjeleket stb. érzékeli. A közvetítés módja szerzői jogi értelemben a sugárzás, vezeték vagy bármilyen más testetlen (nem anyagi) átvitel lehet. ${ }^{538} \mathrm{~A}$ nyilvánossághoz közvetítés szerzői jogi formái, így az analóg és digitális földfelszíni, ${ }^{539}$ valamint müholdas sugárzás, továbbá a vezeték útján (kábeles) vagy más módon megvalósuló (számítógépes, IPTV vagy más elektronikus hírközlési hálózat, mobil felhasználás) nyilvánossághoz közvetítés - az átfedések mellett lényegében - mind megfeleltethetők egy-egy müsorterjesztési átviteli platformnak. ${ }^{540} \mathrm{~A}$ nyilvánossághoz közvetítés jogát „,[...] olyan tágan kell, értelmezni, hogy lefedjen minden olyan nyilvánossághoz közvetítést, amikor a nyilvánosság nincs jelen a közvetítés kiindulópontjául szolgáló helyszínen. Ez a jog magában kell, hogy foglalja a művek bármilyen vezetékes, vagy vezeték nélküli közvetítését, illetve továbbközvetítését, ideértve a sugárzást is. E jog más cselekményekre nem vonatkozik."541

A szerzői jog a nyilvánossághoz közvetítés különböző, egymásnak mellérendelt formái közül a sugárzást tekinti alapesetnek és ebböl vezeti le a többi közvetítési módot. Szükséges hangsúlyozni, hogy a nem anyagi formában való műfelhasználás, a nyilvánossághoz közvetítés különböző esetei, felhasználási cselekményei a nemzetközi szerzői jogi okmányokban, (WCT, $\left.{ }^{542} B U E\right)$ valamint egyes nemzeti jogokban a magyar szabályozástól eltérő „fogalmi csoportositásban, gondolati hierarchiában” jelennek meg. ${ }^{543}$ A $B U E$, mint a sugárzást első nemzetközi okmányként deklaráló dokumentum, annak fogalmát külön kezeli, a WCT viszont a sugárzás mellett a bármilyen műszaki

\footnotetext{
${ }^{537}$ Nyilvánossághoz közvetítéssel kapcsolatos európai uniós szabályozás: INFOSOC irányelv 3. cikk, 5. cikk (2) bekezdés, d) pont, Mühold-Kábel irányelv 1. cikk (2) bekezdés d) pont.

${ }^{538}$ GYERTYÁNFY Nagykommentár 208.

${ }^{539}$ Szerzői jogi szempontból irreleváns, hogy a jel analóg vagy digitális, a digitális jeltovábbítás nem minősül önálló felhasználási módnak SARKADY-GRAD-GYENGE 106.

${ }^{540}$ Müsorterjesztő átviteli platform: azonos technológiájú jelátvitelt biztosító, jellemzően analóg vagy digitális átviteli rendszer Mttv. 203. § 51a.

${ }^{541}$ INFOSOC irányelv (23)

${ }^{542}$ WIPO Copyright Treaty adopted in Geneva on December 20, 1996) [WCT]

${ }^{543}$ GYERTYÁNFY Nagykommentár 207.
} 
módon történő vezetékkel való közönséghez közvetítésről is rendelkezik. Mindazonáltal hangsúlyozni szükséges, hogy sem a vonatkozó uniós irányelvek, sem a nemzetközi szerzői jogi egyezmények, sem pedig a hazai szerzői jogi szabályozás nem tartott lépést a rádió- és televízió-szervezeteket érintő technikai-műszaki fejlődéssel. A jogi szabályozás továbbra is jelentősen elmaradt az új technikai vívmányok szerzői jogi regulációs megoldásaival. A televízió-szervezetek szomszédos joginak átfogó védelmére nemzetközi szinten még mindig az 1961-es RE az irányadó, amelynek rendelkezéseit a TRIPS Megállapodás ${ }^{54}$ is lényegében változatlanul átvette. Az irányelvek és nemzetközi jogi dokumentumok nem tükrözik a média és hírközlés világában az elmúlt több mint fél évszázadban bekövetkezett müszaki változásokat, így az analógról a digitális technológiára való áttérést, a műsorsugárzásban alkalmazott új szabványokat, a digitális hozzáférési rendszerek korszerü jogi szabályozását. ${ }^{545}$ Ugyanakkor rá kell mutatni arra is, hogy az Európai Unió jogrendszerének átfogó felülvizsgálata során az 'Európa 2020' Stratégia először 2010-ben, majd 2015-ben a Digitális Menetrend keretében többek között az audiovizuális média szempontjából jelentős INFOSOC, valamint Média-Kábel irányelvek felülvizsgálatát és digitális környezethez való közelítését rendelték el. ${ }^{546}$

\section{A rádió- és televízió-szervezetek védelme a magyar szerzői jogi szabályozásban}

A hazai szerzői jogi szabályozásba a régi Szjt., azaz az 1969. évi III. törvény 1994. évi novelláris módosítása ${ }^{547}$ kapcsán kerültek be a szerzői joggal szomszédos jogok, ${ }^{548}$ az előadóművészek, a hangfelvétel előállítók, valamint a rádió- és televízió-szervezetek védelme. ${ }^{549}$ A régi Szjt. eredeti szövege még nem ismerte el a rádió- és televíziószervezetek müsoraiban megtestesülő szerzői jogi teljesítményt; a müsorok szerzői joggal szomszédos jogainak védelmét a kialakult gyakorlat a szerkesztői feladatokkal

\footnotetext{
${ }^{544} \mathrm{Az}$ Általános Vám és Kereskedelmi Egyezmény (GATT) keretében kialakított, a Kereskedelmi Világszervezetet (WTO) megalapító Marakeshi Egyezmény 1/C mellékletét képező, a szellemi tulajdonjogok kereskedelmi vonatkozásairól szóló megállapodás amelyet, Magyarországon az 1998. évi IX. törvény hirdetett ki. (TRIPS)

${ }^{545}$ A műsordíj elemzése szempontjából ki kell emelni, hogy különösen jelentős a nemzetközi, az uniós - és ennél fogva a hazai - szabályozás elmaradása a vezetékes (kábeles) és más módon (műholdas digitális platformon keresztül vagy IP alapú távközlési rendszerek útján stb.) megvalósuló nyilvánossághoz közvetítés, illetőleg a müsorok továbbközvetítésének szerzői jogi szabályozása terén.

${ }^{546}$ A Bizottság „Európai digitális egységes piaci stratégia” című közleménye (COM (2015) 0192)

${ }^{547}$ 1994. évi LXXII. törvény a szerzői jogról szóló 1969. évi III. törvény módosításáról

${ }^{548}$ Megjegyzem, hogy az Szjt. 2001. évi módosítása - az INFOSOC irányelvnek megfelelően - a törvény Harmadik Részének címét „A szerzői joghoz kapcsolódó jogok” elnevezésre változtatta [8. § (1)] és tartalmát a (2) bekezdés szerint kiegészítette az adatbázisok elóállítóinak védelme XI/A fejezettel.

${ }^{549}$ Az Szjt. módosítása tárgyában megjelent 2001. évi LXXVII. törvény.
} 
azonosította. ${ }^{550} \mathrm{~A}$ régi Szjt., illetőleg a törvény indokolása a $B U E 11$ bis cikkére alapítva már megfogalmazta a műsorok összeállításának ellenérték fejében végzett szolgáltatásjellegét, amikor rögzítette, hogy a rádiónak és televíziónak [...] díjazás ellenében összeállított müsorát csak hozzájárulásával vehesse át más rádió és televízió, valamint hogy forgalomba hozatal vagy nyilvános előadás céljára azt hozzájárulásával rögzíthessék. ${ }^{551}$

A régi törvényt és végrehajtási rendeletét ${ }^{552}$ 1982-ben kiegészítő jogi szabályozás ${ }^{553}$ elöírta, hogy a rádió- és televízió-szervezet müsorában sugárzott müveknek az eredetihez képest más szervezet közbeiktatásával, vezeték útján vagy egyéb módon való egyidejü nyilvános átvételéhez a szerző, valamint a rádió- és televízió-szervezet hozzájárulását megadottnak kell tekinteni, ha az átvitelt végző szervezet a Szerzői Jogvédő Hivatalnak a díjat befizette. A régi szerzői jogi szabályozás tehát az egységes törvényi engedély és a díjfizetési kötelezettség talaján állt. Szükséges megjegyezni, hogy ugyan a hivatkozott BUE rendelkezés csak a szerzőkre és szerzői jogosultakra vonatkoztatható, a korábbi magyar szabályozás mégis - a szerzőkkel azonos módon - a müsorsugárzó szervezetekre is kiterjesztette a törvényi engedélyezés rendszerét. A rádió- és televízió-szervezetek tekintetében ez a rendszer a Mühold-Kábel irányelv szabályozásának eredményeképpen formailag 1994-től, majd az Rttv. alapján 1997-től ténylegesen is megszünt. Az Rttv. az Szjt. szerzőkre és a müsorsugárzó szervezetekre vonatkozó, kötelező közös jogkezelést és díjigényt elöíró rendelkezéseit úgy módosította, hogy azokat továbbra is kötelező közös jogkezelés keretében, a szerzőkre korlátozta, így az egyidejü, vezetékes, változatlan és csonkítatlan továbbközvetítés jogát csak a szerzői jogosultak tekintetében, a szerzői jogi részben, a nyilvánossághoz közvetítés szabályai körében szabályozta és rendezi a hatályos Szjt-ben is. A rádió- és televízió-szervezetek kizárólagos szomszédos jogaikat - a jogosítást és a díjigényt -, egyénileg gyakorolhatják az Szjt. IX. fejezete alapján. Az Szjt. hatályos rendelkezései a nemzetközi egyezmények alapján kizárólagos felhasználási jogot engednek e szervezetek részére a müsorukkal való rendelkezést illetően az Szjt-ben meghatározott felhasználásokra. Ennek megfelelően a jogosult rádió- és televíziószervezetek müsorának hozzájárulást igénylő felhasználása: a müsorok sugárzása, rögzítése, nyilvánossághoz közvetítése, többszörözése, illetőleg vezeték útján történő

\footnotetext{
${ }^{550}$ PETRIK Ferenc (szerk.) A szerzői jog KJK 1990. (PETRIK II.) 104.

${ }^{551}$ Régi Szjt. 23. § (2)

552 9/1969. (XII. 29.) MM rendelet.

${ }^{553}$ 15/1982. (IX. 20.) MM rendelet.
} 
hozzáférhetővé tétele. ${ }^{554}$ E jogok - amint azt már említettem -, csak a „műsorsugárzó” szervezeteket, a médiaszolgáltatókat illetik meg, a müsort ténylegesen a nyilvánossághoz közvetítő műsorterjesztők e jogosultságokkal nem rendelkeznek.

5. Hiátus a szerzői jogi szabályozásban, a vezetékes továbbközvetítés szabályozásának szerzői és médiajogi problematikája

Amint az a nemzetközi, illetőleg uniós irányelvi szerzői jogi szabályozásból is kitűnik, a rádió- és televízió-szervezeteket megilletö önálló szomszédos jogi védelem tényleges tárgya az Szjt-ben sincs meghatározva, illetőleg hiányzik a szerzői jogi szabályozás az elmúlt évtizedekben általánossá vált kódolt „eredeztetésü” sugárzás, a nyilvánosság számára nem közvetlenül hozzáférhetően sugárzott müsorok védelme tekintetében. Ezekben az esetekben - a hatályos szabályozáson kívüli, - olyan müszaki megoldásokról van szó, amikor a digitálisan kódolt müholdas müsorjelet nem teszik közvetlenül foghatóvá, a müsor vételéhez szükséges dekóder sem kapható a kereskedelmi forgalomban; a müsorjelhez a médiaszolgáltatóval kötött megállapodás alapján csak a kábeles műsorterjesztő férhet. Szerzői jogi értelemben - ezekben az esetekben - nem valósul meg a müsorok nyilvános vételre szánt sugárzása. A hazai szerzői jogi szabályozásban a kötelezően közös jogkezelésbe tartozó egyidejü, vezetékes továbbközvetités esetében nem kell a közvetítőnek külön engedélyt kérnie a felhasználáshoz, de díjfizetési kötelezettsége van. ${ }^{555}$ „A szerzőnek az is kizárólagos joga, hogy a rádió- vagy televízió-szervezet, illetve a saját műsort a nyilvánossághoz vezeték útján vagy másként közvetítő müsorában sugárzott, illetve közvetített müvének sugárzással, vezeték útján vagy egyéb módon - az eredetihez képest más szervezet közbeiktatásával - a nyilvánossághoz történő egyidejü, változatlan és csonkítatlan továbbközvetítésére engedélyt adjon.”A jogosultak e jogaikat csak közös jogkezelés útján gyakorolhatják. A WIPO a Broadcasting Treaty tervezetben ugyan kísérletet tett a müsorsugárzó szervezetek szomszédos jogi védelmének korszerüsítésére, de átfogó nemzetközi egyezmény kidolgozására a mai napig nem került sor, így a rádió- és televízió szervezetek müsorának kábel, illetőleg más technikai eljárás útján való továbbközvetítésére, valamint a digitálisan kódolt és közvetlen nyilvános vételre nem alkalmas műsorok szomszédos jogi védelmére vonatkozó szabályozás a nemzetközi jogi

${ }^{554}$ Szjt. 80. § és 81 . §. A 80. § (1) bekezdés d) pontját beiktatta a 2003. évi CII. törvény 71. §. Hatályos Magyarországnak az Európai Unióhoz történő csatlakozásáról szóló nemzetközi szerződést kihirdető törvény hatálybalépésének napjától.

${ }^{555}$ Szjt. 28. § (2) 
dokumentációkból is hiányzik. Az eredeti Bérlet irányelv ${ }^{556}$ vonatkozó rendelkezéseit a 2006-os kodifikált változat lényegében változatlanul hagyta, a rádió- és televíziószervezetek szomszédos jogi védelmére irányuló rendelkezéseket nem vonatkoztatja a müsorok vezetékes továbbközvetítésére. A Mühold-Kábel irányelv ugyan lehetővé teszi az irányelvi szabályozásnál kedvezőbb, a rádió- és televízió-szervezetek szélesebb körü jogvédelmét elöíró tagállami szabályozást, de nem rendezi e szervezetek védelmében a szerzői jogilag legfontosabb kérdést: a rádió- és televízió szervezetek müsoruk kábeles továbbközvetítéssel kapcsolatos jogait. E jogok ugyanis saját önálló szomszédos jogi teljesitményeknek minösülnek vagy a müsorukba foglalt szerzői és egyéb szomszédos jogi teljesítmények jogosultjaitól eredő származékos jogok. ${ }^{557}$ Az 1993-as Mühold-Kábel irányelv még nem számolhatott a müsorterjesztési platformok későbbi jelentős bővülésével, valamint a műsorterjesztést végző szervezeteket is érintő technikai fejlődéssel. Az irányelv a vezetékes és az ún. mikrohullámú jelátvitel elismerésével bár szélesebb körü védelmet biztosít a televíziós szervezeteknek, azonban nem határozza meg a jogvédelem jellegét és pontos tartalmát. A „szélesebb körü jogvédelem” tekintetében az Európai Bizottság 2002. évi Jelentése ${ }^{558}$ szük értelmezést támogat: a kábeles továbbközvetítés fogalmába nem tartozik bele a digitális mikrohullámú, az IPTV rendszereken müködtetett, illetőleg a müholdas müsorcsomagok keretében végzett továbbközvetítés. ${ }^{559}$

Az elmúlt évtizedekben elterjedt és mára általánossá vált kódolt „eredeztetésü” digitális sugárzás szerzői jogi kérdéseinek uniós, nemzetközi és hazai szabályozási hiátusa abból származik, hogy az RE a sugárzás fogalmát kizárólag a nyilvános vételre szánt vezeték nélküli jelátvitelre vonatkoztatja. Az ilyen szándék nélküli, kódolt, tehát a közönség által közvetlenül nem fogható müholdas vagy egyéb módon továbbított adások után a rádió- és

\footnotetext{
${ }^{556}$ A bérleti jogról és a haszonkölcsönzési jogról, valamint a szellemi tulajdon területén a szerzői joggal szomszédos bizonyos jogokról szóló, 1992. november 19-i 92/100/EGK tanácsi irányelv. [Eredeti Bérlet irányelv]

${ }^{557}$ Mühold-Kábel Irányelv 10. cikk.

${ }^{558}$ Brussels, 26. 07. 2002 COM (2002) 430 final, Report from the Commission on the application of Council Directive 93/83/EEC on the coordination of certain rules concerning copyright and rights related to copyright applicable to satellite broadcasting and cable retransmission In: SÁR Csaba - HORVÁTH Katalin: A rádióés televizió-szervezetek müsor-továbbközvetítési joga a nemzetközi és a magyar szerzöi jogi szabályozás Emlékkönyv Ficsor Mihály 70. születésnapja alkalmából barátaitól. Szent István Társulat, Budapest, 2009. (SÁR-HORVÁTH) 3.

559 A Mühold-Kábel irányelv alapján csak a nyilvános vételre szánt müholdas sugárzás, illetőleg a müsorsugárzó szervezet által vagy hozzájárulásával a nyilvánosság számára hozzáférhetővé tett dekóderrel ellátott kódolt műholdas sugárzás tekinthető műholdas sugárzásnak. [Irányelv 1. cikk 2. bekezdés a) és c) pontok]
} 
televízió-szervezeteket szomszédos jogi védelem nem illeti meg. ${ }^{560}$ A hatályos Szjt. megfogalmazása, ${ }^{561}$ amely rögzíti a rádió- és televízió-szervezetek védelmének szabályait, szintén nem egyértelmü a védelem személyi hatálya tekintetében, nevezetesen abban, hogy a védelem kiterjed-e e szervezetek müsorának más - nem televíziós szervezetnek tekinthető (pld. IPTV) - szervezet által akár kábeles, akár egyéb műszaki eljárással történő továbbközvetítésére. A szabályozás alapján - összhangban az uniós és a nemzetközi jogi dokumentumokban foglaltakkal - csak következtetni lehet arra, hogy az Szjt. 80. § (1) bekezdés a) pontja kizárólag a nyilvános vételre szánt, azaz free to air adások kódolatlan kábeles, illetőleg mikrohullámú rendszerrel müködtetett továbbközvetítésére vonatkozik és a szomszédos jogi védelem nem terjed ki a más szervezetnek minősülö üzemeletetők, így a müsorterjesztők általi továbbközvetítésre. Mivel az Szjt. szerzői jogi részében meghatározott sugárzás és nyilvánossághoz közvetítés fogalmait a szomszédos jogi fejezetben is alkalmazni kell, a televízió-szervezetek szomszédos jogainak minősülnek az Szjt. 26. § (1)-(5) bekezdésekben megfogalmazott földi sugárzás és müholdas sugárzás, a kódolt sugárzás mindkét esete, valamint az Szjt. 28. § (2) bekezdésében meghatározott vezetékes továbbközvetítés is. Az Szjt. 80. § (1) bekezdés a) pontja azonban a szerzői jogi részben meghatározottaknál szükebb körben engedi érvényesülni a nyilvánossághoz közvetítési jogosultságokat, ugyanis a televíziós szervezeteket más televíziós szervezet általi továbbközvetítésen túl csak a müsor vezeték útján történő nyilvánossághoz közvetítése tekintetében illeti meg kizárólagos jog. (Ebben az esetben a szerzőknek fizetendő díj mellett a televíziós szervezet engedélyét is be kell szerezni). Ugyanakkor kétséges a mühold útján megvalósuló továbbközvetítés, illetőleg az IPTV vagy a GSM hálózatok igénybevételével folytatott átvitel szerzői jogi „besorolása”.A vezetékes továbbközvetítés egyes müszaki megoldásainak szerzői jogi megítélésénél ugyanis figyelemmel kell lenni az Európai Bizottság már hivatkozott 2002. évi Jelentésében foglalt korlátozó értelmezésre, miszerint a mikrohullámú rendszerek útján megvalósuló, azaz a kábeles továbbközvetítés definíciója nem vonatkoztatható e három, említett rendszerre.

A továbbközvetítés „változatlan és csonkitatlan” jellegének szerzői jogi megítélése szempontjából azonban a - Jelentéssel szemben - a magyar szabályozásnak olyan értelmezése is létezik, amelynek alapján a rádió- és televízió-szervezeteket nemcsak az

${ }^{560} \mathrm{Az}$ uniós és a nemzetközi szerzői jogi szabályozás az elmúlt évtizedekben - az ilyen jellegű felhasználásokat túlértékelve - az internet alapú felhasználásokra koncentrált és elhanyagolta a hagyományos televíziózás új müszaki vívmányainak szerzői jogi megoldásait, illetőleg azok kidolgozását.

${ }^{561}$ Szjt. 80. § (1) 
egyidejű, hanem a késleltetett, illetőleg a megváltoztatott módon való továbbközvetítés esetén is megilletik a szomszédos védelmi jogosultságok. Ennek az értelmezésnek az alapját egyrészt a már említett Mühold-Kábel irányelv minimum jogoknál bővebb védelmi tagállami szabályozást engedő rendelkezése képezi, másrészt pedig az, hogy az Szjt. 80. § (1) bekezdés a) pontjának megfogalmazásából hiányoznak az Szjt. 28. § (2) bekezdésében törvényi tényállási elemként a szerzőkre és más jogosultakra vonatkozó „változatlan” és „csonkítatlan” kifejezések, illetőleg az ilyen jellegü átvitelre való utalás. Az Európai Unió Bíróságának a következö pontban ismertetésre kerülö, a jövőbeni jogi szabályozás szükségességét is elöre vetítő eseti döntései azonban kezdik felülírni a nem kellően rugalmas és a technológiai fejlődést sem követő jelenlegi szerzői szabályozást. A digitális technológia szerzői jogi kérdéseinek szabályozására, illetőleg a műsorszolgáltató szervezetek egyes online közvetítéseire, valamint televíziós és rádiós müsorok továbbközvetítésére csak a közelmúltban kerültek kidolgozásra uniós szerzői jogi javaslatok. ${ }^{562}$ Várhatóan e jogi dokumentumok, valamint az ezek nyomán kialakuló nemzet állami szabályozások megfelelően rendezik az audiovizuális médiában és a sajtóban megjelenő alkotások jelenleg még bizonytalan szerzői jogi kérdéseit.

\section{A kódolt „eredeztetés” szerzői jogi vonatkozásai}

A vezetékes továbbközvetítés tartalmának és terjedelmének meghatározásához szükséges foglalkozni a kódolás kérdéseivel is. A kódolt sugárzásra vonatkozó rendelkezéseket az Szjt. a mű nyilvánossághoz közvetítésének joga címszó alatt a szerzőkre és más jogosultakra irányadó rendelkezések közt tárgyalja és - amint arra már utaltam -, a nyilvánossághoz közvetítés e módját is a sugárzásból vezeti le. „Kódolt a sugárzás, ha a müsort hordozó jeleket bármilyen módon átalakítják, annak érdekében, hogy a hozzáférést a nyilvánosság valamely szükebb körére korlátozzák. ${ }^{563}$ Ez médiajogi megközelítésben -

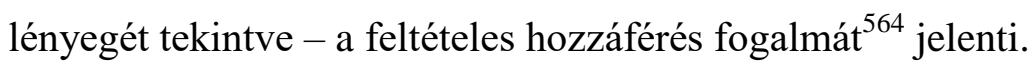

\footnotetext{
${ }^{562}$ A dolgozat kéziratának lezárását követően jelent meg az Európai Parlament és a Tanács Irányelvére vonatkozó Javaslat a digitális egységes piacon a szerzői jogról. COM/2016/0593 final - 2016/0280 (COD) 2016. 9. 14. [DEP SZJ irányelvi Javaslat], valamint az Európai Parlament és a Tanács rendeletére vonatkozó Javaslat a műsorszolgáltató szervezetek egyes online közvetítéseire, valamint televíziós és rádiós müsorok továbbközvetítésére alkalmazandó szerzői jogok és szerzői joggal szomszédos jogok gyakorlására vonatkozó szabályok megállapításáról.COM/2016/0594 final - 2016/0284 (COD) 2016. 9. 14. [SZJ Rendeleti Javaslat] Ld.: 826. és 981 . lbj.

${ }^{563}$ Szjt. 26. § (5)

${ }^{564}$ Keretirányelv [ld.: 172. lbj.] 2. cikk f) „feltételes hozzáférésű rendszer” minden olyan müszaki intézkedés vagy rendszer, amely által a védett rádióműsor vagy televízióműsor-terjesztő szolgáltatáshoz értelmezhető formában történő hozzáférés előfizetéshez vagy más formában megjelenő előzetes engedélyhez kötött."
} 
Az Szjt. szerint „sugárzásnak minősül a kódolt sugárzás is, amely a nyilvánosság körében csak azt követően fogható közvetlenül, hogy a müsort hordozó jeleket - az eredeti rádió- és televízió-szervezettel kötött megállapodás alapján, a tőle vagy a hozzájárulásával mástól beszerzett eszközzel (kódolóval) - arra alkalmassá tették." ${ }^{\text {"565 }}$ A szabályozás értelmében a mű sugárzásának minősül az is, ha a sugárzott müsor jeleit a nyilvánossághoz közvetítő szervezet kódolja és a mủ zavartalan érzékelése a nyilvánosság tagjai számára csak az $e$ szervezettel kötött külön megállapodás alapján, a tőle vagy a hozzájárulásával mástól beszerzett kódolóval lehetséges." ${ }^{566}$ Ez utóbbi, az Szjt. 2011. évi, a Mühold-Kábel irányelvvel kompatibilis szabályozást megteremtő módosítása ${ }^{567}$ továbbra is sugárzásnak tekinti a kódolt sugárzást, de a módosított szabályozás értelmében a dekódolást nem kizárólag a nyilvánossághoz közvetítő szervezet végezheti el; nem szükséges, hogy a müsort hordozó jeleket a nyilvánossághoz közvetítő szervezet tegye közvetlenül foghatóvá a nyilvánosság körében. ${ }^{568} \mathrm{~A}$ módosítás a könnyebb jogérvényesítés érdekében fenntartotta az egyetemleges felelősséget az eredeti rádió- vagy televízió szervezet, valamint a kódolót alkalmazó, nyilvánossághoz közvetítő szervezet között.

A kódolt eredeztetésü müsorok vezetékes közvetitésének szerzői jogi minősítése kapacsán indokolt felidézni az SZJSZT 38/2000 ügyszámú szakvéleményét. A Szakértő Testület a Magyar Kábelteleviziós Hálózatok Szövetségének (MKHSZ) kezdeményezésére a kódoltan sugárzott programok kábeltelevíziós hozzáférhetővé tételének szerzői jogi megítélése érdekében elemezte az Szjt. kódolt sugárzásra vonatkozó rendelkezéseit, és az MKHSZ arra a kérdésére válaszolva, hogy a nyilvánossághoz közvetítésnek a 26. § (3) bekezdésében szabályozott folyamatában a sugárzáson kívül megvalósul-e valamely más önálló felhasználási cselekmény is? - az SZJSZT eljáró tanácsa leszögezte: „a sugárzáson kívül nem valósul meg valamely más önálló felhasználási cselekmény; egyetlen felhasználási folyamatról van szó, amely az eredeti rádió- vagy televízió-szervezet uralma alatt áll, e szervezet szerzői jogilag releváns aktusának a technikailag szükséges része. A kábeltelevíziós szervezet technikai közremüködése - a dekódolás, valamint a kábel rendelkezésre bocsátása és müködtetése - épp úgy nem minősül új felhasználási tevékenységnek, mint ahogy a sugárzás megelőző szakaszaiban sem minősül annak sem a kódolás technikai művelete (még akkor sem, ha azt a rádió- vagy televízió-szervezet

\footnotetext{
${ }^{565}$ Szjt. 26. § (3)

${ }^{566}$ Szjt. 26. § (4)

567 2011. évi CLXXIII. törvény 29. §, hatályos 2012. 01. 01-töl.

${ }^{568}$ 2011. évi CLXXIII. törvény 29. §-ához füzött indokolás. A módosítás összhangba hozza az Szjt. 26. § (3) bekezdését a Mühold-Kábel irányelv 1. cikk (2) bekezdésének c) pontjával.
} 
megbízásából más végzi), sem pedig a sugárzás céljára müszaki eszközök (antennák, erősítők, kábelek, müholdas berendezések) más szervezetek általi rendelkezésre bocsátása és az eredeti rádió- és televízió-szervezettel való megállapodás alapján a sugárzás céljából való müködtetése. Mindezek ugyancsak az egyetlen felhasználási folyamatnak - a sugárzásnak - a sugárzást végző rádió- vagy televízió-szervezet uralma alatt álló, technikailag szükséges, de külön felhasználásnak nem minősülő részei.”

Az idézett szakvélemény még szintén nem tükrözhette a médiában, illetőleg a hírközlésben bekövetkezett technikai és technológiai robbanást, a digitális fejlődést, a kódolt sugárzás nagymértékü, mára szinte kizárólagos elterjedését, illetőleg a terjesztési platformok további müszaki és gazdasági önállósulását. Az ARTISJUS Jogvédő Iroda Egyesület (AJ) közös jogkezelő szervezet az évente megjelenő „Kábel” jogdíjközleményében az írók és zeneszerzők, továbbá szövegírók, azaz az általuk képviselt szerzői jogi műfaj alkotóinak már nyilvánosságra hozott müvei tekintetében elismeri a vezetékes továbbközvetités viszonylagos önálló cselekmény voltát és alkalmazza a "másodlagos nyilvánossághoz közvetítés" fogalmát a vezetékes közvetítésre. Az említett művek nyilvánossághoz közvetítését végző szervezethez kódoltan érkező rádió- vagy televízió-műsorok kódolás után vagy (át)kódoltan történő bármely módon, így különösen vezeték, mühold, vagy $I P$ platform útján megvalósított nyilvánossághoz közvetítése engedélyezésének feltételeit és az ennek fejében fizetendő szerzői jogdíjakat az $A J$ - az Szjt-ben meghatározott eljárási rend szerint - megállapítja, azaz elismeri e nyilvánossághoz közvetítés viszonylagos önálló felhasználási jellegét és azt a jogdíjban is kifejezésre juttatja. ${ }^{569}$

A vezetékes továbbközvetítést médiajogi szempontból is közelítő álláspont jelenik meg abban a felvetésben, amikor az eredeti televízió-szervezet, illetőleg a kódoló, nyilvánossághoz közvetítést, a müsorterjesztést végző kábelszervezet különböző országokban vannak. ${ }^{570} \mathrm{~A}$ kódolt eredeztetésű vezetékes továbbközvetítés önállósulása kapcsán rá kell mutatni az Európai Bíróság (EUB) azon eseti döntésére, ${ }^{571}$ mely szerint amennyiben a kódot a közönség tagja oldja, úgy a közvetítő szervezet, azaz a műsorterjesztő tevékenysége önálló felhasználási cselekménynek minősül és ezt külön kell megítélni.

\footnotetext{
${ }^{569}$ ARTISJUS (Kábel 16) jogdíjközleménye.

${ }^{570}$ Részletesen ld.: SARKADY-GRAD-GYENGE 103-120.

${ }^{571}$ Az Európai Bíróságnak az Airfield NV és Canal Digital BV kontra Belgische Vereniging van Auteurs, Componisten en Uitgevers CVBA (Sabam) C-431/09. számú és Airfield NV kontra Agicoa Belgium BVBA C-432/09. számú egyesített ügyekben 2011. október 13-án hozott ítélete (Airfield ügy) 2011.
} 
A döntés kapcsán az Európai Unió Bírósága értelmezte a Mühold-Kábel irányelv sugárzási jogra vonatkozó 2 . cikkét és bevezette az 'új nyilvánosság', az 'új közönség' fogalmát; ${ }^{572}$ az értelmezés az audiovizuális médiában való nyilvánossághoz közvetítésnél is irányadó.

A szerzői jogi szabályozásban a müsorsugárzó szervezeteket érintő nyilvánossághoz közvetítési módok legnagyobb problematikája az, hogy azok nem e szervezetek jogosultságaiként (vagy úgy is) kerültek szabályozásra, hanem csak a szerzői jogosultakat illetően. Ebböl következően vitatott kérdés, hogy a kódolt adás továbbközvetítése a televíziós szervezet szempontjából egyáltalán sugárzásnak, nyilvánossághoz közvetítésnek minősül-e, azaz a müsorterjesztő kábeles szervezet az eredeti televíziós médiaszolgáltató hozzájárulásához kötött tevékenységet végez-e?

Amint azt már jeleztem, a WIPO - eddig sikertelenül - megkísérelte a megoldást a műsorjel védelmének bevezetésével. A kódolt adásokkal kapcsolatos szerzői jogi hiátus azonban nem vezet oda, hogy a rádió- és televízió-szervezetek, valamint müsoraik teljesen védtelenül maradnak. Azon túl, hogy az EUB jelzett szerzői jogi esetei is kezdik áttörni a szabályozás hiányából eredő korlátokat, a polgári jog kötelmi szabályai is lehetőséget biztosítanak a müsorsugárzó szervezetek részére, hogy az általuk előállított programot, mint szolgáltatást értékesítsék, meghatározzák, hogy kinek, milyen feltételekkel adnak hozzáférést a műsorukhoz és azért milyen díjazást (egyelőre nem jogdíjat) kérnek. Ki kell emelni az EUB legutóbbi, e tárgykörben 2015. november 19-én az ún. SABAM ügyben hozott döntését, ${ }^{573}$ amelyben az EUB kimondta, hogy a müsorszolgáltató szervezetek nem végeznek nyilvánossághoz közvetítést, azt ténylegesen a müsorterjesztő szervezetek valósítják meg. A Mühold-Kábel irányelv 3. cikkének (1) bekezdését tehát úgy kell értelmezni, hogy nem végez nyilvánossághoz közvetítést az a müsorsugárzó szervezet, amely a müsorhordozó jeleket kizárólag a jelek elosztóihoz közvetíti anélkül, hogy e jelek e közvetítés során vagy alkalmával nyilvánosan hozzáférhetők lennének. Az elosztók majd

\footnotetext{
572 „A műholdas programcsomag-szolgáltató, azaz a műsorterjesztő köteles az érintett jogok jogosultjainak engedélyét beszerezni a televíziós műsoroknak az alapügyekben szereplöhöz hasonló közvetett és közvetlen közvetítése során való közremüködése céljából, hacsak e jogosultak nem állapodtak meg az érintett műsorsugárzó szervezettel, hogy a szerzői jogi védelemben részesülő műveket e szolgáltató közremüködésével is továbbítják a nyilvánosság számára, azzal a feltétellel, hogy ez utóbbi esetben az említett szolgáltató közremüködése nem teszi új nyilvánosság számára hozzáférhetővé az említett müveket.” Az új közönség, illetöleg új nyilvánosság fogalmának értelmezésére ld. még a 2014. február 13-i Svensson és társai ítéletét (C-466/12), valamint a GS Média BV (C-160/15.) ügyben 2016. szeptember 8-án hozott ítéletet. 573 „Elözetes döntéshozatal iránti kérelem - 2001/29/EK irányelv - a 3. cikk (1) bekezdése Nyilvánossághoz közvetítés - A »közvetítés« és a »nyilvánosság« fogalma - Televíziómüsorok terjesztése Úgynevezett direktbetáplálásos módszer" a C-325/14. sz. SBS Belgium NV c/c Belgische Vereniging van Auteurs, Componisten en Uitgevers (SABAM) ügyben.
} 
az említett jeleket előfizetőikhez közvetítik, hogy azok megnézhessék e műsorokat, feltéve, hogy a szóban forgó elosztók eljárása nem minősül egyszerü technikai megoldásnak. A technikai megoldás vizsgálata a kérdést előterjesztő bíróság feladata.

7. A müsordíj, mint a szomszédos jogi teljesítmény ellenértéke

A müsordíj ellenértékként való meghatározásánál abból indulunk ki, hogy a médiaszolgáltató által - a terjesztők közremüködésével - a nyilvánossághoz közvetített teljes müsora olyan, alapvetően gazdasági szolgáltatás, ${ }^{574}$ amelynek értéke van, és amelyért a visszterhesség vélelme alapján a polgári jog általános szabályai szerint ellenérték jár. ${ }^{575}$ A szerzői jogi törvény értelmében a müsor felhasználásáért - ha a törvény (t. i. az Szjt.) eltérően nem rendelkezik -, szintén díjazás jár. ${ }^{576} \mathrm{~A}$,ha a törvény eltéröen nem rendelkezik" megfogalmazás - logikai és nyelvtani értelmezés alapján is - magára az Szjtre vonatkozik. Mivel a szerzői jogi szabályozás - amint azt a fentiekben részletesen is kimutattam -, jelenleg még nem képezi le teljes körűen a rádió- és televízió-szervezetek müsorának különböző műszaki megoldások útján való továbbközvetítésének szerzői jogi lépéseit, ennek megfelelően nincs is szabályozási distinctio az eltérő müszaki megoldások útján továbbközvetített müsor ellenérték-fajtái között. Utalok itt a rádió- és televíziószervezetek szomszédos jogi teljesítményének nem egyértelmű szabályozására, illetőleg a kódolatlanul vagy kódoltan sugárzott müsorainak díjára, nevezetesen arra, hogy ez utóbbi esetben a müsorhoz való hozzáférés és továbbközvetítés kérdéseiben, valamint az ellenértékben való megegyezés a polgári jog szabályai alapján történhet. Mivel mind polgári jogi, mind pedig szerzői jogi megközelitésben a müsor értéket képvisel, amelyért ellenérték jár, annak más jogterület szabályozása nyomán való kizárása nem lehetséges és nem is jogszerü.

A médiaszabályozás mégis - álláspontom szerint vitathatóan -, ilyen, a díj-igény érvényesítését korlátozó törvénynek tekintette az Mttv-t és erre a kitételre alapozta a müsordij érvényesítését tiltó rendelkezés médiatörvényi bevezetését, majd a tiltás átmeneti fenntartását. Hangsúlyozni szükséges, hogy bármely, a rádió- és televízió-szervezetek díjigényét korlátozó, tiltó jogszabályi elöírás ellentétben áll a Mühold-Kábel irányelv rendelkezéseivel is: „,[...] a jogosultak annak a veszélynek vannak kitéve, hogy müveiket díjfizetés nélkül felhasználják, vagy hogy a kizárólagos jogok egyéni jogosultjai a

\footnotetext{
${ }^{574}$ Mttv. 203. § 40.

575 „A szerződéssel kikötött szolgáltatásért - ha a szerződésből vagy a körülményekből más nem következik ellenszolgáltatás jár.” új Ptk. 6:61. §.

${ }^{576}$ Szjt. 80. § (3)
} 
különböző tagállamokban megakadályozzák müveik felhasználását; mivel különösen a jogbizonytalanság képez közvetlen akadályt a müsorok Közösségen belüli szabad mozgása elött;[...]." ${ }^{, 577}$

A programdíj bevezetésének médiatörvényi korábbi tiltása egyrészt tehát az uniós jogba ütközött, ellentétes volt a Mühold - Kábel irányelvvel, másrészt pedig nem szüntette/szünteti meg a médiaszolgáltatók szomszédos jogi teljesítményének egyéni jogosításra vonatkozó, illetőleg a felhasználás után járó díjigény érvényesítésének kizárólagos jogát. A kódolt adások önálló szomszédos jogi teljesítményként való szerzői jogi elismerésének szabályozása még jelenleg is folyamatban van a nemzetközi szerzői jogi szervezetek előtt, de a müsornak, mint szomszédos jogi teljesítménynek a ténye, valamint értéke és az ellenérték iránti igény jogossága - az EUB gyakorlata szerint is vitathatatlan.

8. A müsordíj szerzői jogi elemmel kapcsolatos mértéke

A szerzői jogi szabályozás, illetőleg a szomszédos szerzői jogi védelem elsődleges célja a szerző és más jogosult, illetőleg az alkotás védelme. Ennek megfelelően az Szjt. védelemben részesíti a rádió- és televízió szervezeteket, illetőleg müsoraikat. Az Szjt. 80. § (1) bekezdése meghatározza a már említett azon felhasználási módokat, amelyek megvalósításához e szervezetek hozzájárulása szükséges, és amely felhasználásokért a felhasználással arányos ${ }^{578}$ díjazás jár. Az Szjt. a szerzői jog és a szomszédos jogok viszonya körében deklarálja, hogy amennyiben a szomszédos jogi jogosultnak - jelen esetben a rádió-, illetőleg a televízió szervezetnek - a felhasználás fejében díjazás jár, úgy azt a szerzőket megillető arányos dijazáshoz hasonlóan kell megállapítani. Az Szjt. a felhasználással arányos díjazás elvét - ennek megfelelően - átveszi a szerzőket megillető díjazás szabályaiból. A szabályozás a kizárólagos jog nélküli, díjigénnyel elismert felhasználások eseteiben pedig a szomszédos jogi jogosultak javára is érvényesíti a megfelelö dijazás elvét. Ezen elvek alkalmazására - analógia alapján - a közös jogkezelö szervezetek jogdíjközleményeiből következtethetünk. A felhasználással arányos díjazás megállapításánál - többek között - figyelembe veszik az adott műsor nyilvánossághoz közvetítésének módját, ${ }^{579}$ a médiaszolgáltatás jellegét, ${ }^{580}$ összetettségét, a műsorok és a csatlakozott háztartások számát, ${ }^{581}$ illetőleg az ismétlési lehetőségek gyakoriságát.

\footnotetext{
${ }^{577}$ Mủhold-Kábel irányelv (5)

${ }^{578}$ Szjt. 16. § (4)-(5) alapján a 83. § (2) második mondat.

${ }^{579}$ Az ARTISJUS (R-TV15), illetőleg (Kábel 15) Jogdíjközleménye.
} 
A müsordíj szerzői jogi díjelemén, a szomszédos jogi teljesítmény értékét kifejező díjon túl a már említett más díjelemek - értelemszerüen - növelik a müsordíj összegét. Azt a tényt mindenképpen ki kell emelni, hogy a programdij mértékének megállapitása a szerzői jogi elvek figyelembevételével - tekintettel a müsorok felhasználásának egyedi jogosítására is a médiaszolgáltató és a müsorterjesztő szabad megállapodásának tárgya.

A fentiekben bemutatott analógián túl nincs összefüggés a közös jogkezelö szervezetek jogdíjközleményeiben meghatározott és a szerzői jogi törvényben elöírt eljárási rend szerint jóváhagyott, a müsorokban megjelenő szerzői művek után járó szerzői jogdíjak, illetőleg a szomszédos jogi teljesítmény, a müsor díjának polgári jogi szerződésben a felek által megállapított mértéke között. ${ }^{52}$ A műsordíj szerzői jogi kérdéseit illetően hangsúlyozni szükséges, hogy annak létjogosultságát a már említett nemzetközi és uniós jogi dokumentumok, illetőleg a hazai szerzői jog elismeri és azt még az első, 1996-os médiatörvényünk hatályba lépése elött, 1994. július 1-től jogrendjébe iktatta. A fentiekben ismertetett szerzői jogi rendelkezések megerősítik azt a tényállást, miszerint a programdíj jogi tartalma alapvetően szerzői jogi természetü, a müsorok szerzői jogilag védett szomszédos, a szerzői joghoz kapcsolódó jogi teljesítmények, amelyeket az Szjt. védelemben részesít, és amely szolgáltatásért a szerzői jog szabályai szerint díj jár.

\subsubsection{A müsordíj médiajogi szabályozása}

\section{Elözmények}

A két országos kereskedelmi televízió az analóg földi terjesztésű országos audiovizuális médiaszolgáltatása tekintetében még 1997-ben, ${ }^{583}$ a müsorszolgáltatási jogosultság feltételeinek meghatározása tárgyában az ORTT-vel kötött müsorszolgáltatási (koncessziós) szerződésekben vállalta, hogy az általuk készített analóg müsorokért nem kérnek müsordíjat. Ez az önként vállalt kötelezettség a müsorszolgáltatási szerződések NMHH Médiatanácsával 2011 decemberében kötött hatósági szerződésekké ${ }^{584}$ való átalakításáig állt fenn. A két országos kereskedelmi médiaszolgáltató a hatósági

\footnotetext{
${ }^{580}$ A FilmJus 2016. Jogdíjközleménye.

${ }^{581}$ ARTISJUS Kábel 16 Jogdíjközlemény.

${ }^{582}$ A programdíj megállapítására vonatkozó médiajogi elvekre és rendelkezésekre a 6.4.6. alfejezetben térek ki.

${ }^{583}$ Mindkét médiaszolgáltató müsorszolgáltatási (koncessziós) szerződésének létrejötte: 1997. július 9.

${ }^{584}$ MTM-SBS Televízió Zrt. (2014.06.30-tól: TV2 Médiacsoport Kft.): 2011. december 27., Magyar RTL Televízió Zrt.: 2011. december 12.; a hatósági szerződések mindkét médiaszolgáltató esetében 2012. július 9én szüntek meg.
} 
szerződések, majd az ideiglenes hatósági szerződések ${ }^{585}$ hatálya alatt sem tért el a programdíj müsorterjesztők felé történő érvényesítéséről való lemondás gyakorlatától, bár a 2009-2010 évek folyamán kísérletet tettek annak bevezetésére. Ez irányú szándékaiknak az új médiaszabályozás vetett gátat azzal, hogy az Mttv. már a törvény hatályba lépésétől, azaz 2011. január 1-től tiltotta a programdíj érvényesítését. A törvényi tiltás a Dtv. 38. § (1) bekezdésének többszöri módosításával a digitális átállás megvalósulásáig, illetőleg legkésőbb 2014. december 31-ig tartott, majd az Mttv. 2014. szeptember 30-i módosításával ${ }^{586}$ (Mód.Mttv.) átmenetileg ,újjáéledt”.

2. Müsordíj a 2014. szeptember 30-ig hatályos Mttv. rendelkezések alapján

Az Mttv. a müsorszolgáltatási szerződésekre vonatkozó átmeneti szabályok között5 587 rendelkezett a két országos kereskedelmi médiaszolgáltató programdíj igényre vonatkozó átmeneti tilalmáról. „Az analóg földi terjesztésü, országos audiovizuális médiaszolgáltatás médiaszolgáltatója a Dtv. 38. $\quad$ \& (1) bekezdésében meghatározott időpontig médiaszolgáltatásáért programdíjat (müsordíjat) nem kérhet.” E jogszabályhely értelmében ez az időpont a digitális átállás megvalósulásának időpontja, legkésőbb 2014. december 31. volt, a helyi és körzeti vételkörzetü müsorszórás esetén pedig 2017. december 31.

Mivel Magyarországon az ,,analóg televíziózás” országos szinten 2013. október 31-vel befejeződött, a két országos kereskedelmi médiaszolgáltató ezt követően - a korábbi szabályozás értelmében -, jogosulttá vált a programdij/műsordíj érvényesítésére a müsorterjesztőkkel szemben. Meg kell jegyezni, hogy van olyan vélekedés is, mely szerint a programdíj-igény érvényesítése tekintetében nem volt egyértelmü a szabályozás, ${ }^{588}$ ugyanis az átállás már 2013. október végével megvalósult, de a Dtv. 2014. december 31. utánra teszi a programdíj bevezetésének végső dátumát. E vélekedéssel ellentétben a Dtv. 38. § (1) bekezdésének megfogalmazása, nevezetesen a programdíj érvényesítésének a digitális átállás céldátumához való kötése egyértelmű: „A digitális átállásnak legkésőbb 2014. december 31-ig kell megvalósulnia.” Ez a megfogalmazás azt jelenti, hogy mivel a digitális átállás korábban bekövetkezett, mint 2014. december 31., úgy a programdíj érvényesítésének nem lett volna elvi és médiajogi akadálya akár már 2013. november 1-

\footnotetext{
${ }^{585}$ Az ideiglenes hatósági szerződések megkötésének időpontja: 2012. július 10. A két médiaszolgáltató vélelmezhetően - az ideiglenes hatósági szerződésekben is lemondott a müsordíj érvényesítéséről.

${ }^{586}$ Mód.Mttv. Ld.: 486. lbj.

${ }^{587}$ Mttv. 207. § (6)

588 „A szabályozás ezzel kapcsolatban sem egyértelmű: a digitális átállás ugyan már megvalósult, a törvényben dátumként azonban a jövő év vége szerepel." Digitális sikertörténet szépséghibákkal Jogi Fórum, Mérték blog 2013. 11. 04.
} 
étől sem. Vélelmezhetően azonban, ahogy arra már utaltam, az ideiglenes hatósági szerződésekben a két médiaszolgáltató 2015. január 1-ig lemondott a programdíj érvényesítéséről, emiatt a programdíj 2014. december 31-ét megelőző bevezetésére önkéntes lemondás, nyilvánvaló üzleti és egyéb megfontolások ${ }^{589}$ miatt sem került sor.

A jogalkotói akarat - kezdetben - a programdíjat a digitális médiaszolgáltatásokkal együtt járó többletszolgáltatásokhoz kötötte és bevezetésének tiltását a digitális átállást követően már nem kívánta fenntartani; később pedig érvényesítését a Mód.Mttv. szerint bizonytalan időre elhalasztotta. Ismételten hangsúlyozom, hogy a médiajogi tiltást a szerzői jogi alapú dij-elem, illetőleg e jogcím tekintetében a médiaszabályozás nem írhatta volna elö.

A programdíj tekintetében az $N M H H$ és a két médiaszolgáltató közötti tárgyalások során

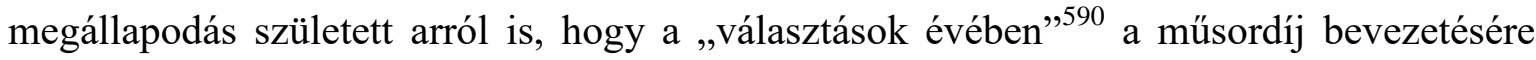
nem kerül sor. A 2014. szeptemberi törvénymódosítással nem érintett „médiaszolgáltatások felajánlásának kötelezettségére” vonatkozó rendelkezések alapján hangsúlyozni szükséges, hogy a müsordíj 2015. január 1-vel szándékolt bevezetése esetén sem indulhatott volna el a hivatalos eljárás, ${ }^{591}$ míg az érintett $J B E$ médiaszolgáltatók a médiaszolgáltatásuk terjesztésével összefüggő általános szerződési keretfeltételeiket (ÁSZF) nem alakítják ki és azt a nem hozzák nyilvánosságra.

3. A médiatörvény programdíjjal kapcsolatos módosított rendelkezéseinek elemzése

\section{Törvényi szabályozás}

Az alábbiakban kivonatosan, egységes szerkezetben idézem a Mód.Mttv. programdíj szempontjából releváns szövegét:

„206. § (3a) Felhatalmazást kap a Kormány, hogy a JBE lineáris audiovizuális médiaszolgáltató legnagyobb éves átlagos közönségarányú lineáris audiovizuális médiaszolgáltatásáért járó programdíj fizetésének szabályait rendeletben állapítsa meg.

\footnotetext{
589, „...] a jövő év elején az ilyenkor szokásos procedúra keretében kezdjük el a tárgyalásokat az érintettekkel. Vélhetően 2015. január előtt lezárulhatnak a megbeszélések, és onnantól fogunk pénzt kérni az RTL Klubért, amely - mint Magyarország első számú televíziós csatornája - 17 évig ingyenesen fogható volt. Azt hiszem, eljött az idő, hogy a sikeres tartalmainkból most már bevételt is generáljunk." Erre készül az RTL Klub http://www.mmonline.hu/cikk/erre_keszul_az_rtl_klub_interju (mmonline 2013-09-24).

Megjegyzem a médiaszolgáltató nem számolt a müsordíj esetleges fogyasztóra történő áthárításával felmerülő idő tartamával. A műsorterjesztők az Általános Szerződési Feltételeiket ugyanis 60 napos előzetes bejelentés mellett módosíthatják. Ez a felek közötti megegyezést követően még több hónappal késleltetheti a programdíj bevezetése miatt megváltozott előfizetési díjak fogyasztók felé történő érvényesítését.

${ }^{590}$ Ezen a 2014. évi országgyülési és önkormányzati, illetőleg EU választásokat kell érteni.

${ }^{591}$ Mttv. 78-79. §
} 
207. § (6) A JBE lineáris audiovizuális médiaszolgáltató a 206. § (3a) bekezdése alapján kiadott jogszabály hatálybalépéséig a legnagyobb éves átlagos közönségarányú lineáris audiovizuális médiaszolgáltatásáért programdíjat (müsordíjat) nem kérhet.

(6a) A (6) bekezdésben foglalt rendelkezés azon JBE lineáris audiovizuális médiaszolgáltató legnagyobb éves átlagos közönségarányú lineáris audiovizuális médiaszolgáltatására is vonatkozik, mely az egyes törvényeknek a költségvetési tervezéssel, valamint a pénzpiaci és a közüzemi szolgáltatások hatékonyabb nyújtásával összefüggő módosításáról szóló 2014. évi XXXIX. törvény hatálybalépésekor a Médiatanács hatósági határozata vagy hatósági szerződés alapján JBE lineáris audiovizuális médiaszolgáltató legnagyobb éves átlagos közönségarányú lineáris audiovizuális médiaszolgáltatásának minősül.”

A törvénymódosítás indokolása szerint a programdíj érvényesítése a médiaszolgáltatók piacára, a műsorterjesztők piacára, valamint az előfizetői díjakra is kedvezőtlen hatással lehet. Emiatt a jogalkotó a jelenlegi állapotot fenntartva - az előfizetői érdekekre is figyelemmel - a programdíj bevezetését bizonytalan időre elhalasztotta. A törvényszöveg elemzésénél abból kell kiindulni, hogy a jogalkotói akarat a két $J B E$ szolgáltatónak minősített televíziós társaság legnagyobb éves közönségarányú csatornái tekintetében a programdíj bevezetését átmenetileg, bizonytalan időre - a fizetés részletes szabályainak kormányrendeleti szintű megjelentetéséig - halasztotta el. A szabályozás egyrészt a ( $3 a)$ bekezdés alapján általános, időleges tiltást fogalmaz meg a programdíj érvényesítésére a $J B E$ szolgáltatók legnagyobb éves átlagos közönségarányú lineáris audiovizuális médiaszolgáltatása tekintetében, másrészt pedig a $(6 a)$ bekezdés alapján a tiltást kiterjeszti a Médiatanács által a Mód.Mttv. hatályba lépésének napján $J B E$ minősítést kapott médiaszolgáltatók legnagyobb nézettségü csatornájára. A szabályozás - ennek megfelelően - lehetőséget nyújtott a két $J B E$ szolgáltató - programdíj bevezetése szempontjából való esetleges differenciált kezelésére. A törvénymódosítással kapcsolatban a következő megállapításokat teszem:

1. A módosított törvény - általános jelleggel - tiltotta a programdij bevezetését a JBE lineáris audiovizuális médiaszolgáltatók részére a legnagyobb éves átlagos közönségarányú lineáris audiovizuális médiaszolgáltatások tekintetében. ${ }^{592}$

2. A Médiatanács a JBE meghatározásra irányuló eljárást minden év szeptember 30. napjáig folytatja le. ${ }^{593}$

${ }^{592}$ Mód.Mttv. 207. § (6) 
3. A Mód.Mttv. 2014. szeptember 30. napjától lépett hatályba.

4. A Mód.Mttv. a már JBE lineáris audiovizuális médiaszolgáltatónak nyilvánított TV2 Médiacsoport Kft. TV2 és a Magyar RTL Televizió Zrt. RTL Klub csatornái tekintetében a továbbiakban akkor tudta volna fenntartani a müsordíj érvényesítésének tilalmát a programdíj fizetésének szabályait megállapító kormányrendelet hatálybalépéséig, ${ }^{594}$ amennyiben a Médiatanács legkésőbb a törvénymódosítás hatályba lépésének napján, ${ }^{595}$ azaz 2014. szeptember 30-án (az Mttv. 70. (11) bekezdése szerint minden év - szintén - szeptember 30. napjáig lefolytatott $J B E$ meghatározására irányuló eljárásban) a $J B E$ minősitést továbbra is megállapitja (quasi folytatólagosan fenntartja) e két médiaszolgáltatóra nézve. ${ }^{596}$

5. A korlátozás - az általános átmeneti tilalmazás miatt - azokra a JBE lineáris audiovizuális médiaszolgáltatók legnagyobb éves átlagos közönségarányú lineáris médiaszolgáltatására is vonatkozhat, amelyeket hatósági határozat vagy a vele kötött hatósági szerződés alapján a Médiatanács újonnan JBE szolgáltatónak minösit minden év szeptember 30. napjáig. A Médiatanács új JBE minősítést 2014ben nem állapított meg további médiaszolgáltatók médiaszolgáltatása tárgyában.

Az Mttv. 207. § (6a) bekezdésében foglaltak törvényi megfogalmazására - vélhetően - egy dátum „egybeesés” miatt került sor. A tárgyi Mttv. módosítás hatályba lépésének napja, azaz 2014. szeptember 30, valamint a módosítással nem érintett Mttv. 70. § (11) bekezdésében a JBE médiaszolgáltatók meghatározására irányuló eljárás lezárásának határnapja ugyanaz a nap: (2014., illetöleg minden év) szeptember hó 30. napja. Ebből elviekben az következik, hogy - amennyiben - a Médiatanács 2014. év szeptember 30. napjáig lezárt $J B E$ minősítési eljárásokban bármelyik korábbi $J B E$ szolgáltatót nem minősítette volna $J B E$-nek, úgy az a $J B E$ feloldástól kezdődően (legkésőbb 2014. október 1-től) kérhetett volna programdíjat, illetőleg érvényesíthettek volna akkor programdíjat e médiaszolgáltatók, ha már egyikőjük sem minősül JBE-nek. A módosítás elviekben tehát a Médiatanács döntésétől is függővé tehette a programdíj bevezetését az „ez év szeptember

\footnotetext{
${ }^{593}$ Mttv. 70. § (11)

${ }^{594}$ Mód.Mttv. 207. § (6a)

${ }^{595}$ Mód.Mttv. hatályba lépése: 2014 . szeptember 30.

${ }^{596}$ A Médiatanács 2014. szeptember 30-i ülésének napirendi javaslatában szerepelt a két médiaszolgáltató JBE minősítése a két médiaszolgáltató tekintetében a Médiatanács a következő, 2015. szeptember 30-ig terjedő időszakra is megállapította a két médiaszolgáltató legnagyobb éves átlagos közönségarányú médiaszolgáltatása tekintetében a JBE minősítést. (Médiatanács vonatkozó határozatai) http://mediatanacs.hu/cikk/164528/A_Mediatanacs_9472014_IX_30_szamu_dontese\#sthash.VFXv8d5N.dpu $\mathrm{f}$
} 
30-ig lezáruló JBE minősítéssel", illetőleg feloldással (a törvénybe foglalt objektív kritériumok figyelembevételével) a két országos kereskedelmi médiaszolgáltató tekintetében. Hangsúlyozom, a Médiatanács a JBE minősítés kérdésében nem változtatott korábbi álláspontján.

A módosított törvényi szabályozás továbbá azt is lehetővé teszi a (6a) bekezdés alapján, hogy a Médiatanács által újonnan, minden év szeptember 30-áig JBE-nek minősített médiaszolgáltató legnagyobb éves átlagos közönségarányú médiaszolgáltatása számára is korlátozza a programdíj érvényesítését. Ilyen médiatanácsi döntés szintén nem született.

\section{Kormányrendeleti szintü szabályozás}

A törvénymódosítás a Kormányt a szabályozás elveinek meghatározása nélkül hatalmazta fel a fizetés rendeletben történő szabályozására. Hangsúlyozni szükséges, hogy a már jelzett Dtv. módosítás sem tartalmazta a versenypiaci korlátozás törvényi feltételeit.

A Kormány részletes szabályozásra történő felhatalmazása kezdetben vélhetően az érintett szolgáltatók piaci müködésének bizonyos korlátozására irányult. A korlátozás, nevezetesen a programdíj-fizetés szabályozási elveinek meghatározása törvényi szintű szabályozást, így további médiatörvényi módosítást igényelt volna.

A 2016. április 25-én megjelent 86/2016. (IV. 25.) Korm. rendelet (kormányrendelet) mondhatni kihúzta a programdíj részletes szabályainak meghatározására vonatkozó szabályozás „méregfogát.” A kormányrendelet értelmében a $J B E$ lineáris audiovizuális médiaszolgáltató a legnagyobb éves átlagos közönségarányú lineáris audiovizuális médiaszolgáltatása után, azaz a TV2 és az RTL Klub csatornák tekintetében is szedhet programdíjat, a jogszabály Magyar Közlönyben való megjelenését követő naptól, ${ }^{597}$ a müsorterjesztővel kötött megállapodása alapján. A megállapodás tartalmát a JBE szolgáltató és a müsorterjesztő szabadon állapítják meg. Ezzel a „szabályozással” a Kormány lényegében kiszállt a programdíj érvényesítés részletes elveinek, módjának, esetlegesen hatósági árának, vagy tól-ig mértékének meghatározásából, nyilvánvalóan felmérve a kormányrendeleti szabályozás és a médiatörvény módosításának bonyodalmait és - meglátásom szerint bölcsen - a piaci szereplőkre bízta a programdíj-érvényesítés feltételeinek megállapítását. A kormányrendelet a $J B E$ szolgáltató, valamint a műsorterjesztő fogalmának meghatározását egy-egy utaló szabállyal ${ }^{598}$ vette át, mindezzel is kiegészítve és megerősítve a már működő programdíj-érvényesítési modelleket. A

\footnotetext{
${ }^{597}$ 2016. április 26-tól.

${ }^{598}$ Mttv. 69. § (1) és Dtv. 5. § (1) 35.
} 
kormányrendelet - természetszerüleg - nem érinti az Mttv. médiaszolgáltatások felajánlásának kötelezettségére vonatkozó, fentiekben részletesen kifejtett rendelkezéseit.

4. A JBE azonosítás törvényi meghatározása

A JBE azonosítás médiatörvényi szabályozása szorosan összefügg a programdíj érvényesítésének törvényi lehetőségével, emiatt az azonosításra vonatkozó elemzés a müsordíj jogintézményéhez kapcsolódóan kerül elvégzésre.

\section{JBE azonositás törvényi feltételei}

A JBE minősítés a médiaszolgáltatóra ${ }^{599}$ és nem a médiaszolgáltatásokra, a csatornákra vonatkozik. „JBE médiaszolgáltatónak minősül a legalább 15\%-os éves átlagos közönségaránnyal rendelkező lineáris audiovizuális médiaszolgáltató, feltéve, hogy legalább egy médiaszolgáltatásának éves átlagos közönségaránya eléri a 3\%-ot.”

A jogszabály szövegéből az következik, hogy a médiaszolgáltatónak elég egyetlen médiaszolgáltatással rendelkeznie ahhoz, hogy $J B E$ státuszt kapjon, amennyiben az eléri a 15 százalékos közönségarányt. A $J B E$ státuszt elrendelő határozatok alapján a két médiaszolgáltató nyilatkozata és az $A G B$ Nielsen által is alátámasztott adatok szerint a médiaszolgáltatók legnézettebb médiaszolgáltatása (TV2: 19,1 százalék RTL Klub 21,7 százalék) is meghaladta a törvényi 15 százalékos küszöböt az előző, azaz 2010. évben. ${ }^{600}$ A Médiatanács vizsgálta a két médiaszolgáltató más csatornáinak, egyéb médiaszolgáltatásainak közönségarányát, ${ }^{601}$ illetőleg a legnézettebb csatorna közönségarányához hozzászámítandó további „tételeket” is:

1. a két médiaszolgáltató valamennyi, a Magyar Köztársaság területén terjesztett lineáris médiaszolgáltatásának,

2. befolyásoló részesedésük mellett működő médiaszolgáltatók Magyarország területén terjesztett lineáris médiaszolgáltatásainak, valamint

3. a médiaszolgáltatók bármely tulajdonosának, vagy tulajdonosa tulajdonosának befolyásoló részesedése mellett müködő médiaszolgáltató Magyarország területén terjesztett lineáris médiaszolgáltatásainak közönségarányát.

\footnotetext{
${ }^{599}$ Mttv. 69. § (1)

${ }^{600}$ Mttv. 70. $§(11)$

${ }^{601}$ Mttv. 70. $§(4)$
} 
A JBE minősítést elrendelő határozatok mindegyike a hozzáadott közönségarányt ${ }^{602}$ üzleti titoknak minösitette, így azokat a vonatkozó, nyilvánosan elérhető határozatok nem tartalmazzák. A két médiaszolgáltató egyéb médiaszolgáltatásai tekintetében - további adatok hiányában - mindezek alapján azt lehet vélelmezni, hogy a $J B E$ minősítéshez szükséges második feltétel teljesítésére - tekintettel a médiaszolgáltatók, mint vállalkozások által meghaladott 15 százalékos közönségarányra - már nem volt szükség, azaz a $J B E$ státuszt a médiaszolgáltatók egyetlen médiaszolgáltatásukkal is teljesítették.

\section{JBE azonositási eljárás}

A JBE azonosítási eljárást az Mttv. a médiapiaci koncentráció megelőzése érdekében hozott rendelkezések között szabályozza. A médiapiaci koncentráció megelözésére kialakított $J B E$ azonosítási eljárást ${ }^{603}$ az Mttv. a hírközlési ágazatból vett piacelemzés és jelentős piaci erő (JPE) meghatározására irányuló eljárás szempontjai alapján, de attól két alapvető eltéréssel veszi át. Egyrészt mind a $J B E$ minősítés feltételeit, mind pedig a kötelezettségek megállapításának körét, tartalmát maga a törvény határozza meg, másrészt pedig a Médiatanácsnak a $J B E$ minősítés során - éppen a törvényi feltételek miatt -, szükebb mérlegelési jogköre van, mint az $N M H H$ elnökének a hírközlési $J P E$ státusz megállapítása során. A médiajogi kategória, a „,befolyásolási képesség”604 ugyanis olyan szubjektív elem, amely a versenyjogban szokásos közgazdasági módszertan alapján nem kezelhető, továbbá az ún. társadalmi jólét nem pénzben, hanem a vélemények sokszínűségében mérhető. Emiatt a szabályozás a $J B E$ azonosítás során az egyetlen mérhető piaci feltételből, a közönségarányból indult ki. A $J B E$ azonosítási eljárás során - a már kifejtettek szerint - a médiaszolgáltató médiaszolgáltatásainak közönségarányát össze kell számítani. Az $A G B$ Nielsen által mért adatok alapján a hazai televíziós piacon a földfelszíni médiaszolgáltatók együttes közönségaránya tartósan meghaladja a 15 százalékot, ezért a magyar médiaszabályozás a NAMS Jogalkotási Koncepcióban meghatározott értékeket is figyelembe véve, a nemzetközi tapasztalatok szerinti legalsó küszöbértéket, a 15 százalékot határozta meg a $J B E$ minősítés feltételeként. ${ }^{605}$ A jogalkotó a 3 százalékos médiaszolgáltatási küszöböt a tematikus csatornákra figyelemmel jelölte ki.

\footnotetext{
${ }^{602}$ Mttv. 70. § (4)

${ }^{603}$ NAMS JK 4.2 84. Meghatározó Véleménybefolyásoló Képességű (MVK) médiaszolgáltató, illetőleg a Jelentős Véleménybefolyásoló Képességủ (JVK) médiaszolgáltató.

${ }^{604}$ Véleménybefolyásoló képességröl: KOLTAY-LAPSÁNSZKY Kommentár 172-179. SARKADYGRAD-GYENGE 49-51. Részletes kifejtését ld.: 6.2.4. és 8. 2.1. alfejezetek, 353. lbj., 717. lbj. és 742. lbj. ${ }^{605}$ NAMS JK (90) szerint az MVK státusz 20\%-os, a JVK minősítés 10\%-os éves átlagos nézettséghez volt kötve. 2010-re e különbségtétel a két kategória között már nem volt indokolt.
} 
E szabályozásból is az következik, hogy egy médiaszolgáltató (vállalkozás) egyetlen médiaszolgáltatásának közönségaránya alapján is lehet $J B E$ státuszú, (mint a vélelmezett esetben a két országos kereskedelmi médiaszolgáltató) és az is elöfordulhat, hogy egy médiaszolgáltató több tematikus csatornájának összeszámított közönségaránya alapján is elérheti a JBE minősítést, amennyiben legalább egy médiaszolgáltatásának közönségaránya eléri a 3 százalékos küszöböt.

\section{JBE kötelezettségek megállapítása}

Az Mttv. utaló szabályban rögzíti a $J B E$ minősítéshez kapcsolódó kötelezettségeket, melyeket a Médiatanács rendszeres ellenőrzése alá von. ${ }^{606}$ Ilyen kötelezettségek:

i) a hivatásos katasztrófavédelmi szerv közérdekü közleményének közzétételi kötelezettsége, ${ }^{607}$

ii) a JBE médiaszolgáltatók közérdekü kötelezettségei körében az önálló hírmüsorszám vagy általános tájékoztató müsorszám szolgáltatása a törvényben meghatározott feltételek szerint, ${ }^{608}$ továbbá

iii) a hallássérültek számára hozzáférhetővé tett müsorszámok tekintetében. ${ }^{609}$

E három rendelkezésben meghatározott kötelezettséget a $J B E$ szolgáltató a legnagyobb éves átlagos közönségaránnyal rendelkező médiaszolgáltatásában, - a TV2 és az RTL Klub állandó megnevezésű csatornák tekintetében - köteles teljesíteni. A JBE szolgáltató ugyanakkor valamennyi digitális müsorterjesztéssel terjesztett médiaszolgáltatásában köteles biztosítani a törvényben meghatározott időtartamban közzétett, eredetileg nem magyar nyelven készített filmalkotások és filmsorozatok legalább egynegyedének eredeti nyelven, magyar felirattal való elérhetőségét. ${ }^{610}$ A $J B E$ státusz alapján kirótt $J B E$ kötelezettségeket ${ }^{611}$ - a fentieknek megfelelően - a médiaszolgáltatás által, i) az Mttv. szerint csak a legnagyobb éves átlagos közönségaránnyal bíró médiaszolgáltatásban, illetőleg ii) a nem magyar nyelven készített filmalkotások és filmsorozatok feliratozási és elérhetőségi kötelezettségét ${ }^{612}$ valamennyi digitális szolgáltatásban lehet és kell teljesíteni. A határozatok szintén az Mttv. rendelkezései szerint határozzák meg az eredetileg nem magyar nyelven készített filmalkotások és filmsorozatok legalább egynegyedének eredeti

\footnotetext{
${ }^{606}$ Mttv. 69. § (2)

${ }^{607}$ Mttv. 32. § (6)

${ }^{608}$ Mttv. 38. § (1)

${ }^{609}$ Mttv. 39. §

${ }^{610}$ Mttv. 38. § (3)

${ }^{611}$ Mttv. 32. § (6), 38. § (1) 39. §

${ }^{612}$ Mttv. 38. § (3)
} 
nyelven, magyar felirattal való elérhetőségének teljesítését a két országos kereskedelmi médiaszolgáltató valamennyi médiaszolgáltatásában. Hangsúlyozni szükséges, hogy a JBE kötelezettségeket megállapító utaló szabályoktól eltérően, a törvény a lineáris audiovizuális médiaszolgáltatást nyújtó, JBE médiaszolgáltatóra állapít meg kötelezettséget, mikor az éves reklámbevételének két és fél százalékát új, magyar filmalkotás támogatására rendeli. ${ }^{613}$ Ennek nyilvánvaló alapja az, hogy míg a média pluralitása, sokszínüsége a $J B E$ szolgáltatók esetében a csatornákra kirótt kötelezettségekkel biztosítható, a médiaszolgáltatás finanszírozási alapjával, így a reklámbevételekkel csak a jogi személy médiaszolgáltató rendelkezik. Ennek megfelelően e kötelezettséget - jellegüknél fogva is - csak a médiaszolgáltató tudja teljesíteni.

Mivel a $J B E$ minősítést a két jogi személy médiaszolgáltató nyerte el, így az éves reklámbevétel mértékének megállapításánál a TV2 Médiacsoport Kft., illetve a Magyar RTL Televizió Zrt. által működtetett összes televíziós csatorna reklámbevétele az irányadó. A fenti törvényi rendelkezések alapján a $J B E$ minősités a médiaszolgáltatóra, mint nyilvántartásba vett jogi személyre vonatkozik, és megállapítása a médiaszolgáltató médiaszolgáltatásai által elért közönségarány alapján történik. E jogszabályi rendelkezés nyilvánvalóan az erre irányuló jogalkotói akarat hiányában és racionális megfontolások miatt - nem teszi lehetővé az egyes médiaszolgáltatások, szatellit-csatornák önálló $J B E$ minősítését. A JBE státusz médiatanácsi meghatározásánál az érintett médiaszolgáltatók legnagyobb közönségarányú csatornái mellett az összeszámított, egyes csatornák által elért közönségarányt is figyelembe veszik. ${ }^{614}$ A JBE státuszhoz rendelt kötelezettségek megállapításánál a médiatanácsi határozatok - a hivatkozott jogszabályhelyek szerint - azt is meghatározzák, hogy a kirótt egyes kötelezettségeket a médiaszolgáltatónak mely médiaszolgáltatásában kell teljesítenie. Az egyes kötelezettségek médiaszolgáltatáshoz rendelése az Mttv. szerint történik, a szabályozás racionális alapját elsősorban az képezi, hogy az adott kötelezettséget a médiaszolgáltató mely csatornája képes teljesíteni és a kötelezettséget - annak jellege, illetőleg a médiaszabályozás alapvető célrendszere miatt is - mely médiaszolgáltatásban érdemes elöírni.

\footnotetext{
${ }^{613}$ Mttv. 136. § (8)

${ }^{614}$ Mttv. 70. $§(4)$
} 
5. A médiaszolgáltatások felajánlásának kötelezettsége, a médiaszolgáltatói díjképzés

\section{Törvényi menetrend}

A „tisztességes és ésszerü szerződéses ajánlat” fogalmának tartalmi ismertetése előtt szükséges vázolni a médiaszolgáltatások felajánlási „must offer” kötelezettségével kapcsolatos eljárás menetét. A kötelezett médiaszolgáltatót a müsorterjesztő tisztességes és ésszerű szerződéses ajánlatára valamennyi lineáris médiaszolgáltatása tekintetében, médiaszolgáltatásonként külön-külön szerződéskötési kötelezettség terheli. ${ }^{615} \mathrm{~A}$ médiaszolgáltatások felajánlásának kötelezettsége körében az Mttv. alapján a programdíj bevezetésével kapcsolatos eljárás „menetrendje” a következő:

1) A kötelezett médiaszolgáltató először kialakítja az ÁSZF keretfeltételeit, illetőleg a már meglévő ÁSZF-et kiegészíti a programdíjra irányadó feltételekkel (ÁSZF Kiegészités) úgy, hogy azok megfeleljenek az ésszerüség követelményének, indokoltak, átláthatók és ellenőrizhetők legyenek. ${ }^{616}$ A programdíjra vonatkozó ÁSZF keretfeltételeknek ki kell terjednie ${ }^{617}$ i) a müsordíjjal kapcsolatos díjképzési politika alapelveinek, a díjképzés módszerének és a díjazás időszakának, továbbá a díjfizetés módjának és idejének meghatározására ii) a szerződéskötési eljárásra, a szolgáltatás módjának és feltételeinek megállapítására, esetleges müszaki, gazdasági vagy egyéb korlátaira iii) a szerződés módosításának, megszünésének eseteire és feltételeire iv) a szolgáltatás szünetelésének eseteire, végül pedig v) a szerződésszegésre és jogkövetkezményeire. A feltételek nem tehetik lehetővé az árukapcsolást.

2) A programdíj bevezetésével kiegészített $A ́ S Z F$-et a médiaszolgáltató közzéteszi a honlapján. $^{618}$

3) A müsorterjesztő a közzétett kiegészítő feltételekre tisztességes és ésszerü ajánlatot tesz. ${ }^{619}$ Az ajánlat visszautasitható, amennyiben a teljesítés objektív müszaki vagy gazdasági ok miatt lehetetlen és e feltételekben a felek nem tudnak megállapodni a tárgyalások során (kétség esetén a médiaszolgáltató bizonyítási kötelezettsége áll fenn). ${ }^{620}$

\footnotetext{
${ }^{615}$ Mttv. 78. § (2)

${ }^{616}$ Mttv. 79. § (1)

${ }^{617}$ Mttv. 79. § (3)

${ }^{618}$ Mttv. 79. § (1)

${ }^{619}$ Mttv. 78. § (2)

${ }^{620}$ Mttv. 78. § (6)-(7)
} 
4) Ezt követően a felek a szerzödés tartalmát - különösen a díjat - a polgári jog szabályai és az egyenlő elbánás elvének megfelelően, ${ }^{621}$ megfizethető árszinten, a technológiasemlegesség és a méretgazdaságosság elvének figyelembevételével alakítják ki. A médiaszolgáltató nem tehet indokolatlan különbséget a müsorterjesztők szerződéses ajánlatai között és a szerződésbe az ÁSZF kiegészítésébe a müsordíjjal kapcsolatos feltételeket ${ }^{622}$ be kell építenie. A szerződést a felek a díj tekintetében - a szerződéskötéstől számítva - évente egyszer módosíthatják ${ }^{623}$ a szerződéses feltételek módosítása esetén az új feltételek hatályba lépése előtt 30 nappal köteles a kötelezett szolgáltató az új szerződéses feltételeket hozzáférhetővé tenni. A müsordijat, illetöleg annak konkrét összegét az ÁSZF keretfeltételeiben, ill. a kiegészitö ÁSZF rendelkezésekben nem feltétlenül kell megjelölnie a kötelezett médiaszolgáltatónak, csak az árképzés feltételeit, stb. A konkrét müsordijat pedig kötelezöen, mint lényeges szerzödési feltételt az egyedi szerzödésnek kell tartalmaznia.

5) Megegyezés a felek között vagy jogvitás eljárás kezdeményezése. ${ }^{624}$

\section{A programdij kialakitásának egyes médiatörvényi feltételei}

Az Mttv. ${ }^{625}$ meghatározza a médiaszolgáltatók és a műsorterjesztők közötti szerződéses viszonyok alapvető szabályait, rögzíti az árukapcsolás tilalmát, továbbá a díjmegállapítás egyéb feltételeit, ${ }^{626}$ így az egyenlő elbánás, a technológiasemlegesség és méretgazdaságosság elvét, valamint a megfizethető árszint követelményét. A kötelezett médiaszolgáltató nem tehet indokolatlan különbséget a müsorterjesztők szerződéses ajánlatai között. A törvény nem tartalmaz további korlátozást vagy tiltást a megfizethető árszint, a technológiasemlegesség és a méretgazdaságosság fogalmára. E fogalmak tartalmának csak jogvitás eljárásokban lehet jelentősége. Ugyanez a törvényhely továbbá expressis verbis nem korlátozza a müsorterjesztők közötti különbségtételt sem, hiszen csak az indokolatlan különbségtételt tiltja a müsorterjesztők ajánlatai között. Az indokoltság ismérveinek médiatanácsi megállapítására csak kellő számú szerződés ismeretében kerülhet sor.

\footnotetext{
${ }^{621}$ Mttv. 78. § (4)-(5)

${ }^{622}$ Mttv. 79. § (3)

${ }^{623}$ Mttv. 78. § (4)

${ }^{624}$ Mttv. 172. §, 80. § (1)

${ }^{625}$ Mttv. 78. § (3)-(5)

${ }^{626}$ Mttv. 78. § (4)
} 
A programdíj kialakításánál kulcskérdés az egyenlő elbánás kötelezettségébe ütköző magatartás értelmezése, nevezetesen annak elemzése, hogy a médiaszolgáltató által alkalmazott díjképzési feltételek (árdiszkrimináció) eredményeként, illetőleg a forgalom után számított kedvezmény alapján ne álljon elő olyan helyzet, amelyben a legkedvezőbb feltételek csak néhány müsorterjesztő számára válnak elérhetővé. Az Mttv. külön is rendelkezik az egyenlő elbánás elvének egyes részleteiről, nevezetesen kiemel egyes körülményeket, melyeket nevesítve tilt, ezzel a szerződéses megállapodás kereteit is értelemszerűen szükíti, elsősorban a müsorterjesztő védelme céljából. ${ }^{627}$ A törvény alapján i) az árdiszkrimináció nem tilos;

ii) árdiszkriminációval csak a médiaszolgáltató élhet, ezért a törvény e tekintetben csak a médiaszolgáltatót korlátozza;

iii) a két médiaszolgáltató kiegészített $A S Z F$-je alapján tett eltérő müsorterjesztői ajánlatokra vonatkozó rendelkezést a törvény külön nem ír elő, hiszen a terjesztő is köteles úgymond „tisztességes és ésszerü” ajánlatot tenni a médiaszolgáltató felé.

A müsorterjesztők ajánlatai jogszerüen több okból is eltérhetnek egymástól a vállalkozás mérete, forgalma, költségeik stb. különbségei miatt és lényegében csak e ténybeli különbségeknek megfelelően értelmezhető esetükben a tisztességes és ésszerü ajánlat követelménye. Az ismerten eltérő feltételű terjesztők ajánlatai amennyiben ugyanis azonosak lennének, az versenyjogi szempontból kartellgyanút vethet fel.

A törvény szövegéből az következik továbbá, hogy a médiaszolgáltató kizárólag azon gyakorlata minősül jogellenesnek, amikor az árkedvezményt olyan mértékben köti például a műsorterjesztő méretéhez, előfizetőinek számához, hogy ez által a legkedvezőbb díjak csak a legnagyobb terjesztők számára lesznek elérhetők. Ezzel kapcsolatban megjegyezni szükséges: amennyiben a leghatékonyabb cégek egyben a legnagyobbak lennének, akkor a csak nekik járó legalacsonyabb díjak objektíve a hatékonysági különbségeket tükröznék, és jogszerü árdiszkriminációnak minősülnének. Álláspontom szerint ezért, az Mttv. 78. § (5) b) pontjának szövegezése ellentmondásban van a versenyjogi elvekkel és gyakorlattal.

627 „E törvény alkalmazásában az egyenlő elbánás kötelezettségébe ütköző magatartásnak minősül, különösen, ha a kötelezett médiaszolgáltató:

a) a müsor terjesztését indokolatlanul olyan müszaki feltételhez köti, amelynek teljesítésére a müsorterjesztési szolgáltatást nyújtók nagy hányada nem képes, vagy

b) a müsorterjesztő által fizetendő díj megállapítása során olyan árazási, díjképzési feltételt - ideértve a forgalom után számított árkedvezményt - állapít meg, amelyek alkalmazásával a legkedvezőbb feltételek csak néhány műsorterjesztő számára válnak elérhetővé.” Mttv. 78. § (5) 
A Médiatanács szerződést létrehozó, díjat megállapító jogkörével, ${ }^{628}$ a Kommentár által „árszabályozó hatáskörnek” ${ }^{629}$ nevezett feladatával kapcsolatban a következőkre kell rámutatni.

Abból a megállapításból indulok ki, hogy a Médiatanács Mttv.-ben biztosított azon jogköre, amely szerint vitás esetekben létrehozhatja a felek között a szerződést - és értelemszerüen benne a díjról is rendelkezhet -, nem teszi árhatósággá a Médiatanácsot. Ezt a megállapítást egyfelől a vonatkozó médiajogi rendelkezések hiányával, másfelől pedig az ártörvény rendelkezéseivel igazolom.

a) Az Mttv. sem általában, sem pedig a médiaszolgáltatások felajánlására vonatkozó rendelkezések között nem deklarálja, hogy a Médiatanács árszabályozó hatóság lenne; továbbá a törvény nem rendelkezik a Médiatanács árszabályozói jogosítványairól sem.

b) A Médiatanács árhatósági létének cáfolatát az Ártörvény ${ }^{630}$ is erősíti. Az Ártörvény hatálya, amely az árszabályozó hatóságról is rendelkezik, nem terjed ki a külön törvény felhatalmazása alapján szabályozott szolgáltatási díjakra. ${ }^{631}$

A müsordíj álláspontom szerint ilyen díjnak minősül. Ebből következően téves a Kommentár azon megállapítása, miszerint a Médiatanács árszabályozó hatáskörrel rendelkezik. Egy árszabályozó hatóságnak (árhatóságnak) alapvető funkciója ugyanis, hogy az ár/díj kialakításának minden érdemi eleme fölött meghatározási és döntési kompetenciával rendelkezzen; az árhatóság nem mérlegelési jogkörben, hanem objektív, vitathatatlan és konkrét, törvényi kritériumok alapján jogosult dönteni akár a költségek bármely eleméről, akár a nyereség szükséges és kívánatos mértékéről vagy akár bármely más árelv érvényesítéséröl. A Médiatanács ilyen jogkörrel nem rendelkezik, sem a müsordíj megállapítása tekintetében, sem pedig általában. A Médiatanács vélelmezett árhatósági jogköre a müsordíjjal kapcsolatban - megítélésem szerint - mind a

\footnotetext{
${ }^{628}$ Mttv. 74. § (1) A Médiatanács jogvitás eljárásban jogosult a médiaigazgatásra vonatkozó szabály alapján fennálló szerződéskötési kötelezettség esetén a feleknek a szerződés tartalmára vonatkozó megegyezése hiányában - a 172. § (3) bekezdésben foglaltaknak megfelelő kérelem esetén - a szerződés létrehozására, módosítására, illetve a szerződés tartalmának megállapítására.

(2) Amennyiben az e törvény szerint a müsorterjesztés, valamint a médiaszolgáltatás ellenértékére kiterjedően is indítható jogvitás eljárás, a Médiatanács megtilthatja az ellenérték további alkalmazását, egyidejüleg e törvény keretei között megállapíthatja a jogszerü árat és kötelezheti a médiaszolgáltatót vagy a műsorterjesztőt a jogszerü ár alkalmazására.

${ }^{629}$ „Fontos kiemelni, hogy a Médiatanács árszabályozó hatáskörrel rendelkezik, tehát amennyiben a felek akár az ellenértékben, akár a szerződés más lényeges elemeiben nem tudnak megállapodni, akkor a Médiatanácstól jogvitás eljárásban kérhető a szerződés létrehozatala és a díj megállapítása.” KOLTAY LAPSÁNSZKY Kommentár 199.

${ }^{630}$ 1990. évi LXXXVII. törvény az árak megállapításáról. (Ártörvény) 2016. XII.15-től hatályos szöveg.

${ }^{631}$ Ártörvény 1. § (2) b)
} 
médiaszolgáltató, mind pedig a műsorterjesztő szempontjából vitatható. A terjesztő oldaláról a jogvitás eljárásokban a tisztességes és ésszerü műsorterjesztői ajánlat megítéléséhez a törvény semmilyen elvi szempontot nem rögzít, a médiaszolgáltató oldaláról pedig az egyenlő elbánás, a megfizethető árszint, a technológiasemlegesség, vagy a méretgazdaságosság elveinek hiányzó szempontrendszere aggályos. E fogalmak az áralakító tényezők jelentős részét nem fedik le, így - többek között - a költségelemek, a nyereségszint kontrollja vagy akár az említett árdiszkrimináció „elbírálása” is vitássá tehető.

A programdíj kialakításának áralkalmazási elveit szintén nem rögzíti az Mttv. A müsordíj díjképzési elveinek meghatározását az Mttv. a médiaszolgáltatóra bízza. Ez a körülmény további aggályokat vethet fel egy „árhatósági” díjmegállapítás során. A müsordíj ugyanis teljesen más megítélés alá esik, ha azt a kereslet-kínálat viszonyai befolyásolják, vagy ha azt költség- vagy megtérülés-alapú, illetve bármilyen más elvnek vetik alá. Az áralkalmazási feltételeknek és azok szabályozottságának mindenképpen összhangban kell lennie a díjképzés jellegével.

A fentiekben ismertetettek alapján a müsordíjra vonatkozóan olyan médiatörvényi szabályozás született, amelynek konkrét esetekre való alkalmazása a hagyományos szabályozási vagy árhatósági konvenciók szerint nem ítélhető meg. Mindezeken túl az Mttv. 78. §. (5) b) pontja szerinti tiltáshoz rendelt fogalmak értelmezéséhez elvi értelemben nem is szükséges árhatósági hatáskör, de - ahogy arra már utaltam -, az egyes fogalmak tartalma még a tiltás körében sem egyértelmü.

\section{Tisztességes és ésszerü müsorterjesztői ajánlat}

\section{a) Polgári jogi és médiajogi megközelítés}

A tisztességes és ésszerű műsorterjesztői ajánlat médiajogi követelménye visszavezethető a polgári jog általános alapelveire, a polgári jogi viszonyokban elvárt, jóhiszemü és tisztességes eljárásra, amelynek követelményét az új Ptk. is tartalmazza a bevezető rendelkezések között. ${ }^{632} \mathrm{Az}$ ésszerüség követelménye expressis verbis nem jelenik meg a hazai polgári jogi alapelvek között, e követelmény kapcsán a média-jogalkotó nyilvánvalóan - az üzleti ésszerűség, a saját gazdasági érdekekkel összhangban álló, azzal

${ }^{632}$ Új Ptk. 1:3. § (1) A jogok gyakorlása és a kötelezettségek teljesítése során a felek a jóhiszemüség és tisztesség követelményének megfelelően kötelesek eljárni.

(2) A jóhiszeműség és tisztesség követelményét sérti az is, akinek joggyakorlása szemben áll olyan korábbi magatartásával, amelyben a másik fél okkal bízhatott." 
nem ellentétes müsorterjesztői ajánlat lényegi elemét kívánta megfogalmazni. A polgári jogi alapelvek a polgári jogviszonyban álló felek részére jelentenek kötelezettséget és a jogalkalmazó bíróságok részére adnak iránymutatást egy adott jogi norma, - jelen esetben - egy szerződéses ajánlat minősítése céljából. A tisztesség és az ésszerüség követelménye a média jogban pedig olyan elvek, amelyek megítélésének szempontjait a jogalkotó - ha a kritériumait jogszabályban, azaz sem törvényben, sem alacsonyabb szintü jogi normában nem határozza meg -, a joggyakorlatra bízza.

A tisztesség követelményének, a tisztességes eljárás elve értelmezésének kiterjedt polgári jogi szakirodalmi és bírói gyakorlata van, ${ }^{633}$ de az Mttv-ben megfogalmazott elvek, „a tisztességes és ésszerü ajánlat” együttes alapelvek kritériumainak joggyakorlati megfogalmazása még nem látott napvilágot. Ennek hiányában más jogterületeken, különösen a polgári jogi bírói joggyakorlatban kialakult megfogalmazások és konkrét esetekben kialakított értelmezés lehet iránymutató a műsorterjesztői ajánlat e követelményeknek való megfelelés megítélése során.

\section{b) Must offer}

A müsorterjesztői ajánlatra vonatkozó tisztesség és ésszerüség tartalmának körülírásához szükséges a médiaszolgáltatások felajánlásának kötelezettsége, a „must offer” elveinek rövid bemutatása. A must offer szabályozás mintegy a must carry szabályozás kiegészítőjeként jelent meg a médiaszabályozásban, a tartalomszolgáltatók és a müsorterjesztők közötti kereslet-kínálati viszony eltolódásának egyensúlyozására. ${ }^{634} \mathrm{~A}$ „must offer” a 2010-ben bevezetett médiaszabályozási rezsim új jogintézménye.

Korábban a Gazdasági Versenyhivatal gyakorlatában, a vállalkozások összefonódásának engedélyezése kapcsán találkozunk a verseny torzítását megakadályozó, a műsorszolgáltató számára „must offer” jellegü többlet feltétel teljesítését előíró esetekkel. ${ }^{635}$ A jogalkotó a „must offer” intézményét a véleményszabadság biztosítása, a médiapluralizmus, valamint a kiegyensúlyozott médiapiaci viszonyok szempontjából tartotta fontosnak az Mttv-ben is megjeleníteni.

A kötelezett médiaszolgáltató az általános szerződéses keretfeltételeit az ésszerüség követelményének megfelelően úgy köteles kialakítani, hogy azok indokoltak, átláthatóak és

${ }^{633}$ WELLMANN György: A szerzödések általános szabályai az új Ptk.-ban - II. Rész, 12/2013. sz. PED (12/2013. PED)

${ }^{634}$ BARTÓKI-GÖNCZY Balázs: Must-carry és must-offer szabályozás az Európai Unióban 9-61. (BARTÓKI - GÖNCZY) In: KOLTAY-NYAKAS III. 48.

${ }^{635}$ Chellomedia-Sport1 - Vj-61/2006/26., Chellomedia-Spektrum - Vj-61/2008/24. 
ellenőrizhetőek legyenek. ${ }^{636}$ Médiatanácsi gyakorlat és más értelmezés hiányában e törvényi megfogalmazásból - analógia útján - következtethetünk arra, hogy a műsorterjesztő ajánlatával szemben megfogalmazott ésszerüségi követelmény is ezen elveken nyugszik, azaz a müsorterjesztö ajánlata akkor felel meg az ésszerüség elvének, ha az indokolt, átlátható és ellenőrizhető. Megjegyezni szükséges, hogy a közösségi médiaszolgáltatók és a müsorterjesztők közötti jogvitás eljárásokban ${ }^{637}$ a Médiatanács nem vizsgálta a közösségi médiaszolgáltató ajánlatának tisztességes és ésszerü voltát, ugyanis az Mttv. közösségi médiaszolgáltatásra vonatkozó rendelkezései ${ }^{638}$ nem írják elő az e követelményeknek való megfelelést.

A programdíj bevezetése kapcsán annak ellenére, hogy a jogszabályok értelmezése a bíróságok hatáskörébe tartozik, a Médiatanácsra vár a feladat, hogy a tisztességes és ésszerű ajánlat kritériumai tekintetében iránymutatást ${ }^{639}$ adjon, ajánlást dolgozzon ki. Ennek hiányában a Médiatanács a 172. § szerinti jogvitás eljárásban egyedi jelleggel bírálja el, hogy az adott ajánlat megfelelt-e a tisztesség és ésszerüség követelményeinek.

6. A tisztesség és ésszerüség követelményének versenyjogi vizsgálata

A követelmények a versenyjogi gyakorlatban is megfogalmazódtak erőfölényes esetek kapcsán. ${ }^{640}$ Ez az ügycsoport a visszaélésszerü, azaz a "kizsákmányoló", illetőleg a versenyellenes magatartásokat elemzi. A kábelszolgáltató szervezetek versenyjogi vizsgálata korábban nem irányult versenykorlátozó magatartás feltárására, ugyanakkor több esetben volt a vizsgálatok tárgya a túlárazás. A GVH Versenytanácsa a kábelszolgáltatók átlagos infláció mértékét meghaladó ${ }^{641}$ díjemeléseinek jogszerüségét vizsgálva általános követelményként vette figyelembe a díjemelés gazdasági érvekkel való indokoltságát. Az üzleti, gazdasági érvekkel részleteiben is alátámasztott díjemelést a

\footnotetext{
${ }^{636}$ Mttv.79. § (2)

637 Így például a Domino TV Szolgáltató Zrt. által a UPC Magyarország Telekommunikációs Kft.-vel szemben a közösségi médiaszolgáltatás terjesztése tárgyában indított jogvita MJ-367-21/2013.

${ }^{638}$ Mttv. 66. §

${ }^{639}$ Mttv. 132. § A Médiatanács a 182-184. §-okkal összhangban g) állásfoglalásokat, javaslatokat dolgoz ki a magyar médiaszolgáltatási rendszer fejlődésének elvi kérdéseire vonatkozóan.

${ }^{640} \mathrm{Vj} / 151 / 2009$. A kábelszolgáltatók áremeléseinek GVH vizsgálata, versenykorlátozó hatás, valamint a szövetségen kívüli müsorterjesztőkkel szemben alkalmazott árak, kedvezmények.

${ }^{641}$ Amennyiben egy kábelszolgáltató díjemelése adott esetben nem haladta meg az inflációs mértéket, azt a Versenytanács általában jogszerűnek tekintette, ha pedig a terjesztő tervezett éves, átlagos díjszint-emelése meghaladta az átlagos inflációs mértéket, részletes költség-alátámasztásra volt köteles. (Vj-182/1998)
} 
Versenytanács tisztességesnek minősítette. ${ }^{642}$ A Versenytanács a tisztességes díjemelés megítélésénél - többek között - költségszerkezeti indokolást ${ }^{643}$ írt elö, illetőleg a következő költségelemeket vette figyelembe a jogszerüség kritériumaként:

a) az előfizetői díjak növekedésének müsorterjesztők által indokolt magyarázatát, elfogadva azt, ha a müsorterjesztő oldalán emelkedett a müsorszolgáltatók által érvényesített programdíj,

b) hálózatfejlesztés eredményeként az eszköz aktiválása miatt az amortizáció növekedését, ${ }^{644}$

c) a kamatot, mint elismert költségtényezöt,

d) a bérek és egyéb forgóeszközök terén az átlagos növekedést, ${ }^{645}$ végül pedig

e) a nyereség vagy profit esetén az adott ágazatban elfogadott, szokásos mértéket.

Az Európai Unió 2009-es iránymutatása ${ }^{646}$ az erőfölénnyel való visszaélés megítélésénél új szempontokat is megjelenített a visszaélések differenciáltabb minősítése érdekében. A jogfejlesztés eredményeképpen - többek között - arra is lett lehetőség, hogy az eljárás alá vontak bizonyos esetekben un. hatékonysági igazolással, mint például 'jóléti többletnövekedés’ kimutatásával bizonyítsák állításukat. Amennyiben ugyanis a vizsgált magatartás több hatékonyságot, azaz jóléti többlet-növekedést eredményez, mint amekkora az esetleges versenyellenes magatartás következményeként elöállott kár nagysága, nem állapítható meg jogsértés. Mindez a tisztességesség versenyjogi definícióját illetően az erőfölény esetében a fogalom „,bővülését” jelenti: adott esetben egy túlárazási vagy egy versenykorlátozó tényállás is lehet tisztességes, ha azzal jóléti többletek keletkeznek és a fogyasztónál kár nem merül fel.

\footnotetext{
${ }^{642}$ A több programcsomagos rendszerre történő áttérés esetén - amikor az egyes programcsomagok ára jelentősen eltér egymástól - a díjkalkuláció alapja nem lehet valamilyen elképzelt ("tervezett") előfizetői arány. (Vj-99/1998)

${ }^{643}$ Az egyes programcsomagokban megvalósított müsorszámnövelés azonban - a külön már figyelembe vett müsordíj növekedésen túlmenően - nem növeli arányosan a vállalkozás egészének költségeit. (Vj-17/1998) $(\mathrm{Vj}-36 / 2002)$

${ }^{644}$ Adott évi áremelésben nem érvényesíthető az előző évi összes beruházás teljes összege, hanem csak a beruházásra fordított összeg adott évre eső amortizációját indokolt szerepeltetni a költségek között. (Vj31/2002)

${ }^{645}$ A költségarányos nyereség nem alkalmas mérce a díjak versenyjogi megítéléséhez, ahhoz a befektetés arányos nyereség a megfelelö mutató. Emellett a tulajdonosnak (mint befektetőnek) - a vállalkozás müködtetésében való aktív részvétele esetén a nyereség - munkájának (bérköltségként el nem számolt) ellenértékét is magában foglalhatja. ( Vj-44/2002)

${ }^{646}$ A Bizottság közleménye - Iránymutatás az EK-Szerződés 82.cikkének az erőfölényben lévő vállalkozások versenykorlátozó visszaélő magatartására történő alkalmazásával kapcsolatos bizottsági jogérvényesítési prioritásokról 2009/C 45/02.
} 
7. Hatósági hatáskörök a médiaszolgáltatások felajánlása körében

A médiaszolgáltatások felajánlásának kötelezettsége körében az NMHH Hivatala hatósági hatáskörében ${ }^{647}$ ellenőrzi az általános szerződési keretfeltételekre vonatkozó előírások érvényesülését. Az NMHH Médiatanácsa hatósági jogköreiben eljárva hatósági felügyeletet gyakorol a müsorterjesztők továbbítási kötelezettségére vonatkozó előírások, ${ }^{648}$ valamint a médiaszolgáltatások felajánlásával kapcsolatos kötelezettségek tekintetében. ${ }^{649}$ Jogvitás eljárás ${ }^{650}$ kezdeményezése esetén szintén a Médiatanács jár el.

Ennek megfelelően az ÁSZF programdíjjal kapcsolatos kiegészítése tekintetében a hatósági ellenőrzési jogkört a Ket. ${ }^{651}$ 87-94. §-ai alapján az Mttv.-ben foglalt eltérésekkel a Hivatal gyakorolja, a hatósági felügyeleti jogkört ${ }^{652}$ pedig a Médiatanács.

\section{NAMS SZERINTI „KÖZSZOLGÁLATISÁG”}

A Stratégia-alkotás időszakában egyes szakmai körökben ugyan felmerült az önálló közszolgálati törvény megalkotásának szükségessége, azonban a NAMS kidolgozói a médiaszolgáltatások egységes szabályozási elvét követve a közszolgálatiság szabályozási céljaira, elveire vonatkozó javaslataikat nem különállóan fogalmazták meg, hanem azokat a Stratégia integráns részévé tették és a közszolgálati törvény esetleges jövőbeni önállóságát csupán jogtechnikai kérdésként kezelték.

A közszolgálati média 'ethosa' - a korábbiakhoz hasonlóan - igényelte a megkülönböztetett szabályozás szándékát, de a technológiai váltáshoz igazodó, megváltozott tartalommal. Így a NAMS a $D A ́ S$-sal egyezően olyan feltételrendszer kialakítását célozta, amelyben a közszolgálati média a digitális átállásban vezető szerepet vállalhat. ${ }^{653}$ A nemzetközi tapasztalatok ugyanis azt mutatták, hogy a digitális átállás kellő állami támogatás és ösztönző feltételrendszer hiányában vesztese lehet az új technológia térhódításának. ${ }^{654}$

\footnotetext{
${ }^{647}$ Mttv. 184. § (1) g) és Mttv. 79. §

$\left.{ }^{648} \mathrm{Mttv} .182 . \S \mathrm{bj}\right)$

${ }^{649}$ Mttv. 182. § bk)

${ }^{650} \mathrm{Mttv} .172 . \S$

${ }^{651}$ 2004. évi CXL. törvény a közigazgatási hatósági eljárás és szolgáltatás általános szabályairól (Ket.)

${ }^{652}$ Ket. 115. §, Mttv. 167. §

${ }^{653}$ DÁS 24. 90., NAMS 65.

${ }^{654}$ A brit OFCOM 2004. szeptember 30-án tette közzé a közszolgálati müsorszolgáltatás felülvizsgálatának második fázisára vonatkozó jelentését, (Második Jelentés) amely szerint „a közszolgálati műsorszolgáltatás analóg modellje [...] nem lesz képes a digitális technológiára való átmenetet átvészelni, és még 2012 elött tönkre megy.” A Második Jelentés a BBC tönkremenetelének megelőzése érdekében gyors és hatékony
} 
A NAMS és a Jogalkotási Koncepció közszolgálati müsorszolgáltatással kapcsolatos legfőbb célkitüzése a közszolgálati médiaszolgáltatás további preferált szabályozása, ezen belül is a müsorszolgáltatói szerepek tiszta elválasztása, a közszolgálati feladatok többszintű meghatározása, a közszolgálati müsorszolgáltatók piaci szegmensként történő integrációja, a közszolgálati felügyelet egyszerüsítése, a közszolgálati müsorszolgáltatás fokozatos „reklámtalanítása”, valamint a kontroll tekintetében az Állami Számvevőszék szerepének erősítése voltak.

\subsection{A közszolgálati müsorszolgáltatás rendszere}

\subsubsection{A közszolgálati müsorszolgáltatás kitüntetett jelentősége}

A NAMS Jogalkotási Koncepció a közszolgálati müsorszolgáltatást mind társadalmi, mind gazdasági szempontból kitüntetett jelentőségűnek minősítette. Álláspontja szerint a közszolgálati müsorszolgáltatás társadalmi szempontból a véleményszabadság különösen fontos garanciája; a közszolgálati müsorszolgáltatók állampolgári jogon biztosítják a tájékozódás lehetőségét, valamint alternatívát jelentenek a kereskedelmi műsorszolgáltatás mellett. A közszolgálati müsorszolgáltatás gazdasági jelentőségét a Koncepció abban látta, hogy a közszolgálati műsorszolgáltatók müködtetése egyben a médiapiac működésébe történő magas fokú állami beavatkozás is. A NAMS a közszolgálati müsorszolgáltatásnak szánt kitüntetett szerepet eredetileg azzal is erősíteni kívánta, hogy a médiaszabályozásban a közszolgálati müsorszolgáltatás számára önálló törvényt kívánt alkotni. E témakörben a NAMS szakmai vitaanyaghoz olyan vélemények érkeztek, amelyek szerint ,[...] nem is az a fő kérdés, hogy a közszolgálatiság külön jogszabályban kerül szabályozásra vagy sem, hanem az, hogy amennyiben két jogszabály születik, akkor a két jogszabály egyszerre készüljön el, hiszen a finanszírozási kérdéseket is csak a teljes rendszer összefüggésében érdemes kezelni.” Egy másik hozzászólás arra hívja fel a figyelmet, hogy „a közszolgálat szabályozásának időbeli eltolása jogbizonytalanságot okozhat." ${ }^{655}$ A Jogalkotási Koncepcióban - elfogadva a médiaszabályozás egységére tett javaslatokat - az önálló közszolgálati törvény gondolata már nem fogalmazódik meg.

reformokat sürgetett. Hivatkozza: NYAKAS Levente: A BBC Alapitó Okiratának felülvizsgálata. AKTI,

$\begin{array}{llllll}\text { Budapest, } & 2006 . & \text { október, } & 3 . & \text { szám. } & 10 .\end{array}$ (NYAKAS http://mediatanacs.hu/dokumentum/109073/a_bbc_alapito_okiratanak_felulvizsgalata.pdf ${ }^{655}$ NAMS Vélemények Összefoglalója 6. 
A hatályos médiarezsimben a közszolgálati médiaszolgáltatás szabályozása - a korábbi Rttv-beli szabályozással és a $N A M S J K$ közszolgálatiságra irányadó szabályozási elvei alapján - az Mttv. integráns részét képezi és kitüntetett figyelmű szabályozását élvezi. A médiaszolgáltatások egységének elve nem indokolta a közszolgálati médiaszolgáltatás önálló törvényi szabályozását, quasi kiszakítását a médiaszolgáltatások köréből.

\subsubsection{Intézmény-centrikus szabályozás kontra feladatközpontú, funkcionális szemlélet}

A közszolgálati müsorszolgáltatás kérdéseit a '96-os médiatörvény a müsorszolgáltatói intézmények alapján rendezte. A Koncepció - az Alkotmány és az uniós közösségi jog szerint - a szabályozás orientációjában is paradigmaváltást sürgetett és az institucionális szemlélet helyett a jövő legfőbb szabályozási módszerét a közszolgálati feladatok meghatározásában, a feladatközpontú funkcionális szemléletben látta. A közszolgálati feladatok törvényi szintü rögzítése azonban csak keretjellegü lehet, a feladatok lebontását a NAMS három, egymásra épülő szinten javasolta meghatározni. ${ }^{656}$

\subsubsection{A müsorszolgáltatói szerepek tiszta elválasztása}

A funkcionális szemlélet elsődleges tényezőjének a NAMS JK a közszolgálati médiumok és a kereskedelmi szektor viszonyának meghatározását tartotta. Az Rttv. szerint az országos kereskedelmi müsorszolgáltatók még széles terjedelemben meghatározott közszolgálati feladatok ellátására voltak kötelesek. ${ }^{657}$

A kereskedelmi médiumok által végzett közszolgálati müsorszolgáltatáshoz kapcsolt várakozásokat azonban az Rttv. alapján kialakult gyakorlat nem igazolta, ugyanis a kereskedelmi müsorszolgáltatók által az ORTT-hez rendszeresen benyújtott beszámolóikban „közszolgálatiként” megjelölt müsorszámok tényleges közszolgálati szerepe és jelentősége sok esetben megkérdőjelezhető volt; a közszolgálatiság jelentéstartalmának továbbá a kereskedelmi müsorszolgáltatás oldaláról történő ilyen

${ }^{656}$ NAMS 65. Ld.: részletesen: közszolgálati feladatok 7.2.

${ }^{657}$ Rttv. „8. § (1) bekezdés Az országos és a körzeti müsorszolgáltató - a szakosított műsorszolgáltató kivételével - napi műsoridejének tíz százalékában köteles közszolgálati müsorszámokat szolgáltatni.

(2) Közszolgálati müsorszámokat a főmüsor-időben legalább huszonöt percben kell szolgáltatni. Ha a müsorszolgáltató a föműsor-időben nem ad müsort, 7.00 és 18.30 óra közt kell közszolgálati műsorszámokat szolgáltatnia legalább huszonöt percnyi müsoridőben.

(3) Az országos televízió föműsor-időben legalább húsz perc, országos rádió legalább tizenöt perc önálló hírműsort köteles egybefüggően szolgáltatni. A más magyarországi műsorszolgáltatótól átvett híranyag a hírmüsor húsz százalékát nem haladhatja meg." 
„felhígítása” a közszolgálati müsorszolgáltatók szerepfelfogását is negatív irányba befolyásolta. E tények alapján a Koncepció olyan médiarendszer kialakítását tartotta kívánatosnak, amelyben a müsorszolgáltatói szerepek tiszta elválasztása valósul meg: a közszolgálati médiumok számára elvárás, hogy müködésükben a közszolgálati feladatokat a lehető legtisztább formában valósítsák meg, a kereskedelmi műsorszolgáltatók pedig közszolgálati feladatok ellátására ne legyenek kötelesek. A kereskedelmi müsorszolgáltatók által tett közszolgálati vállalások a NAMS JK értelmében - a koncessziós szerződések fennállásáig a közérdek és a verseny sérelme nélkül -, ,[...] csak megfelelő ellentételezés (például a közszolgálatiság fenntartásához, illetve a minőségi tartalmak fejlesztéséhez történő pénzügyi hozzájárulás) mellett szüntethetők meg."658

A Koncepció szerint - amint az már részletesen kifejtésre került -, a közösségi médiumok szerepe további szabályozói figyelmet kívánt. A közösségi müsorszolgáltatók nem kereskedelmi „logikában” müködő, de többnyire magántulajdonú médiumok, amelyek saját közönségük tekintetében lényeges közszolgálati feladatokat látnak el. A közösségi médiumok szerepének erősödése azt eredményezte, hogy már a $J K$ megalkotása idejére a korábbi duális jelleg helyett a hazai médiát háromosztatú rendszer jellemezte. ${ }^{659}$

A hatályos szabályozás kifejezetten nem rendelkezik a kereskedelmi médiaszolgáltatók közszolgálati feladatok alóli mentesítéséről, hiszen 2010-re még inkább igazzá vált: „,...] jelenleg olyan nagyszámú tartalomszolgáltató van jelen mind a műsorszolgáltatás, mind az internet területén, hogy feleslegesnek tűnhet a közszolgálati tartalom nyújtása, [mármint a kereskedelmi müsorszolgáltatók részéről (szerzői betoldás)] mert a pluralizmus e nélkül is érvényesül." ${ }^{660}$ Az Mttv. ugyanakkor a JBE kereskedelmi médiaszolgáltatók részére mégis szükségesnek látta bizonyos közszolgálati jellegü, közérdekủ kötelezettségek előírását. ${ }^{661}$

\footnotetext{
${ }^{658}$ NAMS JK 104.

${ }^{659}$ A háromosztatú hazai médiarendszer közösségi médiaszolgáltatásának szabályozási kérdéseiröl ld.: a 6.2.1. alfejezetet.

${ }^{660}$ BAYER I.

${ }^{661}$ Mttv. 38. § Ld.: 664. lbj.
} 


\subsection{A közszolgálati feladatok}

\subsubsection{A közszolgálati feladatok meghatározása}

A közszolgálati müsorszolgáltatással összefüggő, a Koncepció szerinti általános elvek alapján a vonatkozó szabályozás kulcseleme a közszolgálati feladatok meghatározása volt. Valamely müsorszolgáltató állami finanszírozása - a közösségi szabályok alapján ${ }^{662}$ kizárólag abban az esetben indokolt, amennyiben a müsorszolgáltató közszolgálati feladatait kifejezetten és hivatalos formában meghatározták, tartalmát pedig a lehető legvilágosabban rögzitették. A meghatározás nem hagyhat kétséget a tekintetben, hogy az adott tagállam szándéka szerint a megbízott szolgáltató egy adott tevékenysége a közszolgálatiság körébe tartozik-e vagy sem; a közszolgálati feladatok meghatározása a tagállamok hatáskörébe tartozik, amelyek saját jogrendszerük alapján nemzeti, regionális vagy helyi szinten hozhatnak döntést.

A közszolgálati feladatok meghatározásának rendjét a $N A M S J K$ a hazai jogban is ezeknek az elveknek a figyelembevételével javasolta kialakítani. A közszolgálati feladatmeghatározás három, egymásra épülő rendszerében i) törvényi szintet igényelt a normatív alapkövetelmények, alapelvek rögzítése, ii) a második szint a közszolgálati müsorszolgáltató által készített, társadalmi konszenzuson alapuló, hosszú távú megállapodás volt, a harmadik szintet pedig iii) a tulajdonosi szerv által elfogadott éves, esetleg kétéves operatív megvalósítási terv képezte.

A NAMS konzultációja során egyes hozzászólásokban felvetődött, hogy a szabályozás tegye lehetővé a nem közszolgálati célra létesített intézményeknek/lineáris tartalomszolgáltatóknak is, hogy a hatósággal „közszolgálati szerződést” köthessenek meghatározott müsorsáv közszolgálati müsorokkal való „feltöltésére”, megfelelö finanszírozás mellett. Ezt a megoldást a $N A M S J K$ ellentétesnek minősítette a közszolgálati és a kereskedelmi müsorszolgáltatás tiszta elválasztásának elvével, emellett - amint arra már utaltam - müködőképessége a kereskedelmi szegmensben sugárzott közszolgálati tartalommal kapcsolatos addigi tapasztalatok alapján alapvetően megkérdőjelezhető volt.

A hatályos szabályozás sem tartotta indokoltnak ilyen jellegü szerződés megkötését a médiaszolgáltatók és a Médiatanács között. Az Mttv. ugyanakkor a NAMS JK elveivel

${ }^{662}$ Elsődlegesen a Transzparencia irányelv [a Bizottság irányelve (1980. június 25.) a tagállamok és a közvállalkozások közötti pénzügyi kapcsolatok átláthatóságáról 80/723/EGK], valamint az állami támogatás szabályainak a közszolgálati műsorszolgáltatásra történő alkalmazásáról szóló 2001. évi bizottsági közlemény HL C 320., 2001. 11. 15. Módosította: 2009/C 257/01. [Közszolgálati Közlemény 2001.] Ld.: 805., 812. és $935 . \mathrm{lbj}$. 
szemben a közszolgálati médiát annak fő elvei és céljai felől közelíti, illetőleg e célokhoz rendeli az azokat megvalósító állami intézményeket. A Koncepcióban közszolgálati feladatként megfogalmazott tételek megjelennek az Mttv. közszolgálati médiaszolgáltatásra vonatkozó alapvető elveiben és céljaiban. ${ }^{663} \mathrm{Az}$ Mttv. ugyan nem mondja ki expressis verbis a közszolgálati, illetve kereskedelmi médiaszolgáltatók, illetőleg a kétféle szolgáltatás elválasztásának elvét, de a közszolgálati médiaszolgáltatók mellett lényegében csak a $J B E$ médiaszolgáltatókat kötelezi bizonyos közérdekü, elsősorban hírműsorszám vagy általános tájékoztató müsorszám szolgáltatására, illetőleg filmalkotások és filmsorozatok magyar nyelvü feliratozására vagy eredeti nyelven való elérhetővé tételére. ${ }^{664}$ A közmédia önállóságának elve az Mttv. keretein belül érvényesül.

\subsubsection{A közszolgálati feladatok jellege és meghatározásuk szabályozási szintje}

A Koncepció értelmében a közszolgálati feladatok meghatározása összetett jellegü, ezért a NAMS JK a közszolgálati feladatok rögzítését a fentiek alapján - a nemzetközi tapasztalatoknak megfelelően - három szabályozási szinten tartotta szükségesnek. i) Törvényi szinten alapelvi jelleggel, hosszú távra kell rögzíteni a közszolgálati müsorszolgáltatóknak a társadalomban betöltendő szerepét. A közszolgálati feladatok normatív erejü, törvényi szintű meghatározásának - a közösségi jog követelményéből fakadóan - a közszolgálati müsorszolgáltatók feladatainak kulcselemeit, illetve a közszolgálati műsorszolgáltatás leglényegesebb, ún. alapszolgáltatásait, azok jellemzőit, valamint szolgáltatási kötelezettségét kell tartalmaznia. ii) A közszolgálati intézményeknek koherens, saját szerepfelfogásukat tükröző, négy-öt évre szóló stratégiával kell rendelkezniük. E stratégiák lehetnek a konkrét közszolgálati feladatok meghatározásának alapjai és második szintje. Mivel a Stratégia ilyen módon túlmutat a műsorszolgáltató belső működésén, a NAMS JK szükségesnek tartotta, hogy a közszolgálati müsorszolgáltatók által indított tematikus csatornákra, illetve szolgáltatásokra vonatkozó követelményeket iii) tényleges kötelmet keletkeztető jogi formában, ún. „közszolgálati szerződésben” fogalmazza meg és azt az állam, mint tulajdonos képviseletében eljáró szereplő is jóváhagyja, ezzel a maga számára is igazodási pontként ismerje el. A közszolgálati feladatok konkrét, az uniós jog követelményeit is kielégítő módon való meghatározása - a Koncepció szerinti harmadik szinten - rövid, egy, legfeljebb két éves

\footnotetext{
${ }^{663}$ Mttv. 82-83. §

${ }^{664}$ Mttv. 69. § (2) utaló szabálya alapján: Mttv. 32. § (6), valamint 38. § (1)-(2), 39. §
} 
időszakra szóló formában történhet. Ezen a szinten a feladatokat - úgyszintén tényleges kötelmet keletkeztető jogi formában (szerződés) - már olyan részletességgel kell megfogalmazni, hogy az a finanszírozási döntések alapjául is szolgálhasson.

A létrejött médiaszabályozás nem deklarálja a közszolgálati feladatok meghatározásának szükségességét, sőt az Mttv. közszolgálati médiaszolgáltatásra vonatkozó rendelkezései még ha intézményi struktúrájában jelentősen el is térnek a korábbi Rttv. szabályozástól inkább követik annak intézményi, institucionális jellegét. A szabályozás a közszolgálati intézményekhez rendeli a közszolgálati feladatokat (A Közszolgálati Közalapítvány, a Közszolgálati Kódex és a Közszolgálati Testület, a Közszolgálati Médiaszolgáltatók). ${ }^{665} \mathrm{Az}$ Mttv. a közszolgálati médiaszolgáltatás elveit és célkitűzéseit csokorba szedi, ${ }^{666}$ ezeket a Közszolgálati Kódex részletezi, ${ }^{667}$ de nem vállalja fel a közszolgálati médiaszolgáltatás és a közszolgálati műsorszám fogalmának meghatározását, „mert úgy véli, azok nem szoríthatóak be egyetlen, néhány soros meghatározás szük kereteibe."668

\subsubsection{A közszolgálatiság alapvetö rendeltetése}

Az Európa Tanács megfogalmazásában a közszolgálatiság „,az egész társadalom számára nyújt tájékoztatást, kultúrát, oktatást és szórakozást; erősíti a társadalmi, politikai és

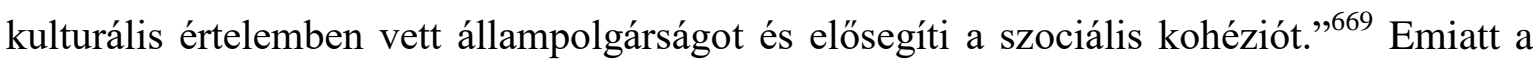
közszolgálati média mind tartalmát, mind a hozzáférést tekintve univerzális.

A NAMS a közszolgálatiságot - többek között - a médiapluralizmus letéteményesének tartotta, amely biztosítja a véleményformáláshoz nélkülözhetetlen közügyekben való eligazodást és tájékozódást, hozzásegíti a társadalom tagjait a szabad véleménynyilvánítás jogának gyakorlásához. A Jogalkotási Koncepció a közszolgálatiság alapvető rendeltetését abban látta, hogy az a társadalom valamennyi tagja számára alanyi jogon biztosítsa az egyetemes és a nemzeti kultúra értékeit, továbbá az egyén társadalmi életben való tényleges szerepvállalásához, a mindennapi élethez szükséges információkat. Ebböl következően a NAMS JK a közszolgálati feladatok tartalmának lényegi elemét annak ellenére az univerzalitásban ${ }^{670}$ fogalmazta meg (a közszolgálati média mindenki számára

\footnotetext{
${ }^{665}$ Mttv. Harmadik Rész II., III., és IV. Fejezet., Mttv. 85. § (2), Mttv. 90-91. § és $96 . \S$

${ }^{666}$ Mttv. 82-83. §

${ }^{667}$ Mttv. 95-96. §

${ }^{668}$ KOLTAY-LAPSÁNSZKY Kommentár 206.

${ }^{669}$ Recommendation 1641 (2004) Public service broadcasting - Service public de radiodiffusion, második bekezdés Ld.: NAMS 59. 19. lbj.

${ }^{670}$ Thomas GIBBONS: Regulating the media London: Sweet \& Maxwell. 1998. 56. In: KOLTAY V.
} 
szolgáltasson), hogy a Közszolgálati Tanulmány a digitális korszak közszolgálatiságának credóját éppen az univerzalitás elvének feladásában látta. A Tanulmány szerint „A közszolgálati feladatok olyan módon is meghatározhatók, hogy a közszolgálatiság egyéb módon média-megjelenéshez nem jutó társadalmi csoportok és kulturális értékek bemutatását vállalja fel ahelyett, hogy versenybe szállna a kereskedelmi szolgáltatókkal. Ez a jelenleginél kisebb szervezeti kereteket és kevesebb ráfordítást igényel, ugyanakkor a közszolgálatiságnak a szükebben értett közszolgálati feladatokon túl le kell mondania az univerzalizmusról., ${ }^{671}$

A Közszolgálati Tanulmány megállapításával ellentétben a NAMS hangsúlyozta az univerzalitás alapelvkénti alkalmazását a közszolgálatiság médiaszabályozásában és konkrét megjelenítését - többek között - a különböző korosztályoknak szóló, valamint gyermekműsorokban, továbbá a hátrányos helyzetü csoportokat, a vallásokat, egyházakat bemutató műsorszámokban. ${ }^{672} \mathrm{Az}$ univerzalitás elve ugyanis ,,a lehető legtöbb különböző nézői réteg igényeinek és érdeklődési körének megfelelő szolgáltatások nyújtását"673 jelenti, amely ugyanakkor magában foglalja a kisebbségek integrációjának előmozdítását és az esélyegyenlőségi (így a fogyatékkal élők médiahasználatának elősegítéséből fakadó) szempontok megjelenítését is.

A szakirodalomban a közszolgálat rendeltetése, credója is megfogalmazódik, megjegyzem, ehhez a NAMS JK is közel állt. ${ }^{674}$ Koltay ,a közszolgálati médiának számos [egyéb], ${ }^{675}$ jól beazonosítható jellegzetességét emeli ki. Ilyenek - többek között - a nemzeti, közösségi, európai identitás, a nyelv és a kultúra ápolása, gazdagítása; a nemzeti, etnikai, vallási kisebbségek különös igényeinek kielégítése; az államtól és a gazdasági szférától való függetlenséggel együtt a belső autonómia biztosítása a műsorkészítők számára, amely az intézményen belüli önállóságot is garantálja. A közszolgálati média sajátossága továbbá az elszámoltathatóság, a felelősségre vonás lehetősége, azaz a társadalmi felügyelet valamely formája; a kiegyensúlyozott, pontos, alapos, tárgyilagos, felelős hírszolgáltatás és tájékoztatás; valamint a sokszínü, gazdag választékú müsorok. A közszolgálati médiaszolgáltatás müködése bizonyos részben közpénzekből történik, a müsorfolyam

671 Közszolgálati Tanulmány: Döntési Mozgástér a közszolgálatiság jövőbeni szabályozásában, 4. közszolgálati feladatok.

${ }^{672}$ NAMS 60-61.

${ }^{673} \mathrm{Az}$ univerzalitás elvének Egyesült Királyságban használt megfogalmazása [the needs and satisfy the interests of as many different audiences as practicable] NAMS 60. 20. lbj.

${ }^{674}$ KOLTAY András: A közszolgálati média fogalma Médiakutató 2007 nyár (KOLTAY V.)

${ }^{675} \mathrm{Az}$ angol tájékoztatás, oktatás és szórakoztatás elvein túli közszolgálati feladatok. 
minden elemében kiemelt figyelmet kap a „minőség”; és a müsorszolgáltatás nem irányul elsősorban nyereségszerzésre.

A megvalósult szabályozás - ebböl kifolyólag - az univerzalitás elve alapján a közszolgálati médiaszolgáltatást a magyar társadalom egyik összetartó tényezőjének tekinti. ${ }^{676}$ A közszolgálati médiaszolgáltatás céljainak ${ }^{677}$ és törekvéseinek ${ }^{678}$ meghatározása során a jogalkotó a NAMS-ban javasolt szabályozási elveket ${ }^{679}$ is figyelembe vette a közszolgálati médiaszolgáltatással szemben támasztott elvárásokat illetően.

\subsubsection{Nemzeti nyelv és nemzeti kultúra}

A Koncepcióban hangsúlyos közszolgálati feladatként jelenik meg a nemzeti nyelv és a nemzeti kultúra megőrzése, ápolása, valamint e körben a közszolgálati tartalom magas minöségének követelménye. A $N A M S J K$ szerint a kulturális szerepkörrel kapcsolatban állapíthatók meg a közszolgálati müsorszolgáltatók számára a tartalom-elöállítással összefüggő kötelezettségek. ${ }^{680}$

\subsubsection{Kiemelt közszolgálati célcsoportok}

Lényeges közszolgálati feladatként jelent meg a $N A M S J K$-ban a gyermekek igényeinek megfelelö, magas színvonalú tartalmak elérhetővé tétele, valamint a határon túl élő magyarság igényeinek megfelelő szolgáltatás nyújtása és - ez utóbbi körben külön követelményként - a kárpát-medencei és a világ más részein élő magyarság igényeinek megfelelő, differenciált igények figyelembevétele. ${ }^{681}$ Ezek a feladatok a közszolgálati médiaszolgáltatás céljai között jelennek meg az Mttv. rendelkezései ${ }^{682}$ között.

\footnotetext{
${ }^{676}$ Mttv. 83. $\left.§(1) \mathrm{c}\right)$

${ }^{677}$ Mttv. 83. $§(1)$

${ }^{678}$ Mttv. 83. $§(2)$

${ }^{679}$ NAMS 65.

${ }^{680}$ NAMS JK 110. 34.

${ }^{681}$ NAMS JK 112. 113

${ }^{682}$ Mttv. 83. § (1) g) h)
} 


\subsubsection{Tájékozódáshoz és a tájékoztatáshoz való jog}

A Koncepció hangsúlyozta, hogy a közszolgálati feladatok tartalmának meghatározása során különösen figyelembe kell venni a tájékozódáshoz való jogot, amely a véleményszabadság anyajogának része. Az Alkotmánybíróság gyakorlatából ${ }^{683}$ következően a közszolgálati müsorszolgáltatással szemben feltétlen követelményként jelenik meg a belső pluralizmus, azaz annak igénye, hogy a müsorszolgáltató a tájékoztatás során az adott kérdéssel összefüggésben valamennyi, a társadalomban meglévő releváns álláspontot megfelelő súllyal megjelenítse. A magyar nemzet tagjainak tájékozódáshoz és tájékoztatáshoz füződő joga az Mttv. Alapelveiben fogalmazódik meg. ${ }^{64}$

A NAMS JK-ban új elemként azonosítható a közszolgálati feladatok között a tudatos médiahasználat előmozdítása, amely médiatudatosság, médiamüveltség elnevezéssel a médiaszabályozásban a közszolgálati médiaszolgáltatás törekvései ${ }^{685}$ mellett a Médiatanács feladatai ${ }^{686}$ között is szerepel. Mindezeket a Koncepcióban közszolgálati feladatként megfogalmazott tételeket az Mttv. bevezető rendelkezései, valamint a közszolgálati médiaszolgáltatás már említett alapvető elvei, céljai és törekvései tartalmazzák.

\subsubsection{Kettős teszt}

A közszolgálati müsorszolgáltató feladatainak meghatározása során a NAMS JK szükségesnek látta kizárni annak a lehetőségét, hogy az állam olyan feladatokat finanszírozzon, amelyeket piaci szereplők hatékonyabban képesek ellátni. ${ }^{687}$ A konkrét közszolgálati szolgáltatások meghatározása tekintetében ezért kettős teszt alkalmazását látta indokoltnak. A kettős teszt célja annak megállapítása volt, hogy az adott szolgáltatásra valós társadalmi igény van-e, és hogy az adott szolgáltatás ingyenes vagy csaknem ingyenes nyújtásával az állam ne számolja fel az adott igény piaci szereplők általi hatékony kielégítésének lehetőségét.

A kettős teszt az új szabályozásban nem jelenik meg. Az időközben kiforrt uniós és hazai rendelkezések nem indokolták a médiaszolgáltatás feladatainak ilyen jellegü megszürését.

\footnotetext{
683 1/2007. (I. 18.) AB határozat.

${ }^{684}$ Mttv. 5. $\S$

$\left.{ }^{685} \mathrm{Mttv} .83 . \S(2) \mathrm{c}\right)$

${ }^{686}$ Mttv. 132. § f)

${ }^{687}$ A közszolgálati műsorszolgáltatás nem irányulhat elsősorban nyereségszerzésre PRICE 61-67.
} 


\subsubsection{Rugalmas müsorkínálat}

A NAMS konzultációja során kapott válaszok megerősítették, hogy a közszolgálati müsorszolgáltatókkal szemben támasztott elvárások valószínüleg nem elégíthetők ki teljes körüen az akkori közszolgálati csatorna-számmal, ${ }^{688}$ ezért a közszolgálati müsorszolgáltatás - az alapszolgáltatásokon túlmenően - a jövőben feltehetően több

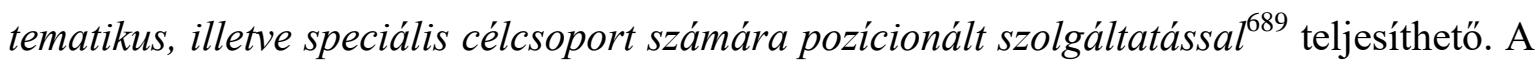
szabályozásnak ebből következően lehetőséget kell adnia a közszolgálati müsorkínálat rugalmas kialakitására, ugyanakkor - az elöbbi pontban jelzett kettős teszt következetes alkalmazásával - a piaci szereplők számára is kiszámítható piaci körülményeket kell biztosítania. ${ }^{690}$

\subsubsection{Müsorterjesztés}

A közszolgálati műsorszolgáltatók szolgáltatásainak diverzifikálásával párhuzamosan a NAMS JK szükségesnek tartotta a „,must carry” ${ }^{691}$ kötelezettségek felülvizsgálatát. Ennek során célként fogalmazta meg, hogy a szabályozás úgy biztosítsa a közszolgálati tartalmak eljuttatását a lakossághoz, hogy hosszútávon kiszámítható módon kötelezze a müsorterjesztőket. E kettős célnak megfelelően a „,must carry” kötelezettségek terjedelmét a törvényi szabályozásnak egyértelmüen rögzítenie kell a műsorterjesztő hálózatok kapacitásának maximális "must carry" terhelhetöségével. A kötelezően továbbítandó közszolgálati csatornákat az alapszolgáltatáson túlmenően nem javasolta a $J K$ nevesíteni. Az Mttv. a médiaszolgáltatások továbbításának kötelezettsége ${ }^{692}$ körében a NAMS JK elveinek megfelelően határozza meg a közszolgálati, a közösségi és a körzeti, illetve helyi médiaszolgáltatások müsorterjesztőkre háruló feladatait.

\footnotetext{
${ }^{688}$ M1, M2, Duna Televízió, Autonómia csatorna, MR1/ Kossuth Rádió, MR2/Petőfi Rádió, MR3/Bartók Rádió, valamint az MR három tematikus csatornája.

${ }^{689}$ Ld.: M3 - MTV „Retro” csatorna indulása 2013. december 20-án.

${ }^{690}$ A közszolgálati médiaszolgáltatásban 2015. 07. 0-től a következő csatornák müködnek: 1. M1, 2. M2, 3. Duna, 4. M4 Sport, 5. Duna World, 6. M6 (indulás folyamatban) 7. M3 (továbbítása nem kötelező, nem tartozik az Mttv. 74. § (1)-(1c) bekezdéseinek hatálya alá, 8. M5 (2016. 04. 22., továbbítása nem kötelezö, nem tartozik az Mttv. 74. § (1)-(1c) bekezdéseinek hatálya alá) valamint HD adások. Forrás: MTVA sajtóportál alapján, 2016. 12. 15.

${ }^{691}$ BARTÓKI-GÖNCZY 12.

${ }^{692}$ Mttv. 73-77. § Részletesebb tárgyalását ld.: müsordíj jogi természete 6.4. alfejezetben
} 


\subsubsection{Platform semleges közszolgálat}

A Koncepció deklarálta, hogy a közszolgálatiság platform semleges kategória, amely nem kapcsolódhat kizárólag egyes szolgáltatástípusokhoz. A közszolgálati tartalomszolgáltatásnak ezért az új technológiák révén nyújtott szolgáltatások - ideértve a digitális platformok szolgáltatásait is - esetében is helye van. A szabályozásnak biztosítania kell, hogy a közszolgálati feladatok konkrét tartalma lehetőséget adjon a közszolgálati müsorszolgáltatók számára szolgáltatásaik diverzifikálására, és a technikai fejlődésből fakadó lehetőségek kihasználására. A Stratégia tehát azt javasolta, hogy a közszolgálati müsorszolgáltató maga válassza ki a közszolgálati feladatokat leghatékonyabban szolgáló platformokat és tegye meg a szükséges intézkedéseket e platformok felhasználására. A $N A M S$ - ennek megfelelően - indokoltnak tartotta már tíz évvel ezelőtt is a közszolgálati müsorszolgáltatás interneten való aktív megjelenését, sőt e platformon való tartalomszolgáltatás kötelezettségként való elöírását a szabályozásban.

A létrejött szabályozásnak a $N A M S J K$ idején korszerü és akkor szükséges platform semleges közszolgálatiság elvét nem kellett kimondania, hiszen a jogalkotás időszakára a technológiai szempontból meghaladottnak minősülő elv időközben gyakorlattá, a közszolgálati médiaszolgáltatás természetes megjelenési formájává vált. Az Mttv. ugyanakkor a müsorterjesztők, médiaszolgáltatók és a kiegészítő médiaszolgáltatást nyújtók kötelezettségévé teszi, hogy szolgáltatásaikat és hálózataikat olyan egyeztetett müszaki feltételrendszerben nyújtsák és működtessék, hogy azok egységesen működő rendszert alkossanak. ${ }^{693}$

\subsection{A közszolgálati músorszolgáltatás intézményrendszere}

\subsubsection{A közszolgálati müsorszolgáltatás müködése}

A NAMS JK kidolgozása során a közszolgálati feladatokkal összefüggésben elsőként az a kérdés merült fel, hogy szükség van-e külön intézményként müködő közszolgálati műsorszolgáltatókra e feladatok megvalósításához vagy ellátásuk pusztán egy pályázati, tartalomfinanszírozási rendszer keretei között is biztosíthatók. Ezzel kapcsolatban a Koncepció megállapította, hogy az Alkotmány a közszolgálati müsorszolgáltatók müködtetését egyértelműen az állam kötelezettségeként fogalmazza meg és a hazai

${ }^{693}$ Mttv. 7. § (2) 
tapasztalatok is azt igazolták, hogy a kereskedelmi müsorszolgáltatás a közszolgálati tartalmakat akár tartalmi, akár müsorszerkezeti megoldásokkal szükségszerüen a saját értékrendjéhez igazítja. Európai példák sem erősítették meg, és a NAMS konzultációja során sem merültek fel olyan szempontok, amelyek a közszolgálati müsorszolgáltatás tekintetében radikális szemléletváltást indokoltak volna. Így a későbbiekben sem vált szükségessé olyan változtatás, amelynek eredményeként a közszolgálati műsorszolgáltatás tartalomfinanszírozási rendszerben müködött volna tovább. Mindezek alapján a $N A M S J K$ a közszolgálati feladatok ellátásának legföbb letéteményeseit továbbra is a közszolgálati müsorszolgáltatókban látta.

\subsubsection{Attátható közszolgálati gazdálkodás}

A Jogalkotási Koncepció a közszolgálati müsorszolgáltatás szervezeti rendszerével szemben a költséghatékony müködést, a közpénzekkel való hatékony és átlátható gazdálkodás követelményét állította fel. Egyértelmü volt, hogy a közszolgálati médiumok finanszírozása nem pusztán pénzügyi kérdés. Mivel a finanszírozás forrásai, módja és mértéke alapvetően meghatározza az adott médiumok működését, a müsorok típusait és tartalmát, a finanszírozás forrásai, mértéke és kiszámíthatósága közvetlen hatással van a közmédium műsorpolitikájára. „Minél nagyobb mértékben van rászorulva a közszolgálati média központi költségvetési forrásokra, annál nagyobb a lehetősége annak, hogy a mindenkori kormány részéről politikai nyomásnak lehet kitéve." ${ }^{694}$ A közszolgálati műsorszolgáltatók politikai, hír- és közéleti műsorai emiatt politikailag egyoldalúvá válhatnak, ennél fogva sérülhet a pártatlanság, a sokoldalú tájékoztatás vagy akár egyes kisebbségek érdekképviseletének a szinte minden európai médiatörvényben meghatározott, a közmédiumokra fokozott hangsúllyal vonatkozó követelménye.

Az Rttv. alapján létrejött három müsorszolgáltatóból és három felügyeleti rendszerből, illetve önálló közszolgálati hírügynökségből álló struktúra helyett a NAMS JK egy részben integrált, kevésbé tagolt szervezetben látta a források optimális felhasználásának garanciáját. Az integráció fokának meghatározásakor a NAMS JK figyelembe vette az integrált szervezet működéséből származó szinergiák kihasználásának szempontjait, továbbá azt is, hogy a költségigényesebb, és rendszerint több érdeklődést kiváltó televíziózás mellett a rádiózás és az online médiaszolgáltatás se szoruljon háttérbe.

${ }^{694}$ CSEH Gabriella: A közszolgálati müsorszolgáltatás finanszirozása Médiakutató 2008 nyár (CSEH II.) 


\subsubsection{Racionális intézményi struktúra}

A fenti szempontok alapján a Koncepció a közszolgálati müsorszolgáltatók piaci szegmensenként történő integrációját tüzte ki célul. A szabályozásban az MTI Zrt. és a Magyar Rádió Zrt. szervezeti önállóságának megtartása mellett, az MTV Zrt. és a Duna televízió Zrt. müködését egységes struktúrában, egy intézmény keretében javasolta. A NAMS megjegyezte, hogy az MTI intézményi szabályozása megfelelő, felülvizsgálata a közszolgálati feladatok egy kézben való egyesítése, az abból származó előnyök kihasználása miatt lehet szükséges. ${ }^{695}$

A 2010. évi jogalkotás a közszolgálati intézmények létrehozatala során a $N A M S J K$-nál sokkal radikálisabb változásokat eredményezett. A kezdeti négy médiaszolgáltatóval szemben a hatályos Mttv. szerint a Médiaszolgáltatás-támogató és Vagyonkezelö Alap ${ }^{696}$ (MTVA) ténylegesen müsorgyártást végez a Duna Médiaszolgáltató Zártkörüen müködö Nonprofit Részvénytársaság megrendelésére, amely egyben jelenleg az egyetlen közszolgálati médiaszolgáltató is. ${ }^{697}$

\subsubsection{Együttmüködés szorgalmazása}

A NASM JK a közszolgálati müsorszolgáltatók együttmüködését is szorgalmazta, különösen a finanszírozási döntések körében - ezzel elörevetítve a hatályos szabályozásban megvalósult szorosabb integráció szükségességét. A Koncepció az együttmüködés megvalósulását konkrét és kifejezett állami beavatkozás, illetőleg az együttmüködésre vonatkozó kötelezettségek jogszabályi meghatározása nélkül látta indokoltnak.

\subsubsection{Egységes közszolgálati felügyelet}

A szervezeti integráció kérdése a felügyelet szempontjából külön is felvetödött a Koncepcióban. A $J K$ megállapította, hogy a széttagolt felügyeleti struktúra a tulajdonosi jogokat gyakorló közalapítványok és kuratóriumaik megtöbbszörözésével magas tranzakciós költségeket generál, e mellett nem biztosítja a közszolgálati intézmények müködésének következetes, meghatározott stratégiai irányok mentén történő

\footnotetext{
${ }^{695}$ NAMS 71. 35. lbj.

${ }^{696}$ Mttv. 136-137. §

${ }^{697}$ Mttv. 2014. évi CVII. törvény 6. §-ával módosított 84. § (1), hatályos: 2015. VII. 1-től.
} 
müködtetésének lehetőségét. ${ }^{698}$ Erre tekintettel a $J K$ indokoltnak tartotta, hogy a három közalapítványt és az Országgyülésnek az MTI Zrt. felett gyakorolt tulajdonosi jogosítványait egy, a tulajdonosi jogosítványokat valamennyi közszolgálati intézmény felett egységesen gyakorló közjogi intézmény váltsa fel. E javaslatot valósítja meg az Országgyülés által létrehozott Közszolgálati Közalapítvány. Szintén a szervezeti struktúra egyszerüsítését, átláthatóságát célozza az Mttv. 2014. évi módosítása, amely a Közszolgálati Közalapítvány tulajdonában álló korábbi négy médiaszolgáltató zrt.-t a Duna Médiaszolgáltató Zártkörüen müködö Nonprofit Részvénytársaság alatt egyesíti és tartja meg a Közalapítvány tulajdonában. ${ }^{699}$

\subsubsection{A közszolgálati intézmények szervezeti formája}

A NAMS JK a közszolgálati müsorszolgáltatók szervezeti formájának optimális változataként továbbra is a gazdasági társaságokat látta annak alapján, hogy - álláspontja szerint - a gazdasági társaságokra vonatkozó szabályozás megfelelően biztosítja a közszolgálati müsorszolgáltatók szervezetszerü, egyszerü és átlátható müködését. A médiaszabályozás a Koncepcióval egyezően a közszolgálati médiaszolgáltatók szervezeti formáját továbbra is a (nonprofit) részvénytársaságban ${ }^{700}$ határozta meg.

\subsubsection{A tulajdonosi jogok gyakorlása és a tulajdonosi jogok gyakorlója}

A NAMS JK változások bevezetését tartotta indokoltnak a közszolgálati müsorszolgáltatók feletti tulajdonosi jogok gyakorlásának rendjében is. Az Rttv. által megállapított szervezeti rendet illetően kimutatta, hogy a kuratóriumok müködése átpolitizált, ebből fakadóan a szervezetrendszer több alkalommal olyan súlyos konfliktusok színtere volt, amelyek a müsorszolgáltatók müködésére is negatív hatást gyakoroltak. A NAMS konzultációja során is egyöntetü véleményként fogalmazódott meg, hogy a civil kurátorok részvétele a közszolgálati müsorszolgáltatók irányító testületeiben nem váltotta be a hozzá füzött reményeket, és a gyakorlatban alkalmatlannak bizonyult arra, hogy a müsorszolgáltatók irányításában értékként jelenjen meg. A NAMS a rendszer gyengeségeként jelölte meg többek között - a közszolgálati médiumok tulajdonosi jogait gyakorló közalapítványok átpolitizált müködését, azt, hogy a kinevezési rendszer nem biztosítja a kompetenciát és a

${ }^{698}$ NAMS JK 38.

${ }^{699}$ Ld.: 697. lbj.

${ }^{700}$ Mttv. 84. § (1) 
kuratórium nem rendelkezik megfelelő hatáskörökkel. Szintén gyengeségként került feltüntetve ,a társadalmi részvétel nem megfelelő 'telepítése’ („nagy kuratóriumban civil szervezetek, kompetencia és hatáskör nélkül)." ${ }^{, 701}$ Az Rttv. több helyen jogtechnikai hibákat, valamint pontatlanságokat is tartalmazott a kuratóriumok szabályozásával kapcsolatban. ${ }^{702}$ E problémák kiküszöbölésére olyan szabályozási megoldásokkal kellett reagálni, amelyek biztosítják, hogy a szakmaiság magas szintje jelenjen meg a közszolgálati műsorszolgáltatók irányító és tulajdonosi jogokat gyakorló szerveiben. A Koncepció kiemelte: „[...] a jogi eszközök ennek biztosítására önmagukban nem elégségesek: a közszolgálati müsorszolgáltatók teljes mértékben hatékony, politikai befolyástól mentes irányítása és felügyelete csak a közéleti kultúra pozitív változása mellett biztosítható."703

A Jogalkotási Koncepció kidolgozása során a koalíciós pártok részéröl felmerült, hogy a közszolgálati médiumok feletti tulajdonosi jogokat gyakorló intézmény maga az Országgyülés vagy annak valamely bizottsága legyen. Ezt az álláspontot a Koncepció több - szakmai és praktikussági - szempontból is elvetette. E szervezeti megoldás ugyanis az Alkotmány hatályos szövegével nem volt összhangban; a közszolgálati müsorszolgáltatók feletti tulajdonosi jogosítványok gyakorlása olyan, alapvetően végrehajtói természetü szerepkör, amely a törvényhozástól, mint hatalmi ágtól természetszerüen idegen. Kétséges volt továbbá az is, hogy egy ilyen struktúrában a közszolgálati müsorszolgáltatás kérdései az Országgyülés egyéb, nagy jelentőségü feladatai mellett mindenkor megfelelő figyelmet kaphatnak-e, illetőleg a megoldás hatékonyságát az akkor még ilyen struktúrában felügyelt MTI Zrt. múködése során nyert tapasztalatok is megkérdőjelezték. Az ismertetett érvrendszer alapján a Koncepció kimondta, hogy a közszolgálati intézmények feletti tulajdonosi jogosítványokat gyakorló egységes szerv olyan önálló, jogi személyiséggel felruházott intézmény legyen, amelynek összetételét és jogállását a törvény teljes körben szabályozza. ${ }^{704}$

A megvalósult médiaszabályozás - a NAMS JK szakmai indokaival egyetértve -, a közszolgálati médiaszolgáltatók tulajdonosaként nem az Országgyülést vagy annak valamelyik bizottságát határozza meg, hanem az Országgyülés által alapított Közszolgálati

\footnotetext{
${ }^{701}$ NAMS 24.

${ }^{702}$ Rttv. 66. $\left.\left.\S(1) \mathrm{c}\right), 66 . \S(2) \mathrm{c}\right), 71$. . Ld.: SARKADY Ildikó: A médiatörvény gyakorlati tapasztalatai Médiajogi írások, 171-178. Új Mandatum 2005. (SARKADY XI.)

${ }^{703}$ NAMS JK 38.

${ }^{704}$ NAMS JK 39.
} 
Közalapítványt, amelynek jogállását és hatáskörét nem külön törvény, hanem maga az Mttv. rögzíti. ${ }^{705}$

\subsubsection{Civil álláspontok, „becsatornázása”}

A közszolgálati médiumok irányításával és felügyeletével összefüggésben követelményként fogalmazta meg a Koncepció, hogy - az Rttv.-ben lefektetett kuratóriumi struktúrával ellentétben -, a civil társadalom elvárásait az új szabályozás megváltozott formában, megfelelően csatornázza be. A közvetlen társadalmi reprezentáció összeállítása során - komplex rendszer létrehozásával - a NAMS JK javasolta a közszolgálati intézményeken belül müködő, tanácsadó szerepet betöltő nézői panel müködtetését, a hallgatói/nézői panaszok kezelésére, aggregálására és orvoslására kiépített megfelelö eljárási rend intézményesítését, a hallgatói/nézői elégedettség visszacsatolását a közszolgálati feladatok teljesítésének értékelése körében, továbbá a nyilvános konzultáció lehetőségét a közszolgálati feladatokkal összefüggő lényeges döntések előkészítése során. A szabályozás a civilszféra véleményének figyelembe vételére kidolgozott NAMS javaslatokat csak részben fogadta meg; az Mttv. a társadalmi felügyeletet ellátó Közszolgálati Testületben ${ }^{706}$ a társadalmat reprezentáló szervezetek számát a korábbiakhoz képest jelentősen csökkentette. ${ }^{707}$

\subsection{A közszolgálati feladatok teljesítésének ellenőrzése, a hatékony feladatellátás értékelése}

\subsubsection{Ellenörzö mechanizmusok és az Állami Számvevőszék hatásköre}

A NAMS JK a közszolgálati feladatok kontrollja érdekében vizsgálta az európai közösségi jog elöírásait. Megállapította: a tagállamoknak megfelelö ellenörzö mechanizmusokat kell kiépiteniük, amelyek garantálják, hogy a közszolgálati müsorszolgáltatók a rájuk bízott közszolgálati feladatokat ténylegesen az adott tagállamtól kapott megbízásnak megfelelően látják el. Az Európai Bizottság a közszolgálati feladatok teljesitésének ellenőrzése ${ }^{708}$ körében hangsúlyozta az erre a célra felállított független intézmények szerepét; ezek

\footnotetext{
${ }^{705}$ Mttv. Harmadik Rész II. Fejezet.

${ }^{706}$ Mttv. 97. §

${ }^{707}$ Mttv. 1. számú melléklete, illetőleg Rttv. 56 .§

${ }^{708}$ A Bizottság közleménye az állami támogatás szabályainak a közszolgálati müsorszolgáltatásra történő alkalmazásáról [Hivatalos Lap C 257., 2009.10.27. 2009/C 257/01.]
} 
működtetése ugyanis különösen a közszolgálati müsorszolgáltató számára meghatározott minőségi követelmények teljesülésének elemzése során lehet elönyös. Az ilyen értékelés ugyanis az Európai Bizottság álláspontja szerint szükségszerüen szubjektív elemeket is tartalmaz, amelyeket egy független harmadik szereplö közremüködése nélkül kizárólag a megrendelő állam és a feladatokat végrehajtó müsorszolgáltató nem feltétlenül képes kezelni.

A NASM JK a közszolgálati intézmények által megfogalmazott finanszírozási igények mérlegelésére és a közszolgálati feladatok teljesítésének ellenőrzésére új intézmény felállítását nem tartotta indokoltnak, ugyanakkor szükségesnek látta az Állami Számvevöszék (ÁSZ) feladatkörének ilyen irányú kiterjesztését.

Az Mttv. a közszolgálati médiaszolgáltatók finanszírozásának és gazdálkodásának ellenőrzését a közszolgálati intézményrendszeren belül a Közszolgálati Közalapítvány hatáskörébe tette; ${ }^{709}$ az ÁSZ közszolgálati médiaszolgáltatók finanszírozásában és gazdálkodásában betöltött szerepét a Közszolgálati Költségvetési Tanácsban való részvétel $^{710}$ útján biztosítja. Az ÁSZ további jelenléte az NHIT ellenőrzésében is megmutatkozik. ${ }^{711}$

\subsubsection{A médiahatóság hatásköre a közszolgálati müsorszolgáltatásban}

A közszolgálati müsorszolgáltatók és a médiahatóság viszonyának meghatározásakor a $N A M S J K$ a médiaszektor kereskedelmi és a közszolgálati szegmensének elválasztásából indult ki. Ennek alapján nem tartotta megalapozottnak a médiarendszer általános felügyeletét ellátó médiahatósági hatáskörök bővítését speciális, kifejezetten a közszolgálati műsorszolgáltatók irányításában és felügyeletében megvalósuló, fokozott állami szerepvállalással. Ugyanakkor fontosnak tartotta a Koncepció a közszolgálati feladatok gazdaságos, hatékony és célszerü elvégzését, amelynek garanciáit - a teljesités ellenörzésében, a jó teljesitmény premizálásában, továbbá a közszolgálati szerzödésnek nem megfelelö teljesitmény esetén a jogkövetkezmények alkalmazásában - látta.

A NAMS JK olyan szabályrendszer kialakítását tartotta szükségesnek, amelyben a tulajdonost képviselő szervezet részére a közszolgálati intézmények vezetése a közszolgálati feladataik ellátásáról évente beszámolót készit és terjeszt elő. A beszámoló

\footnotetext{
${ }^{709}$ Mttv. 90. § (1) o)

${ }^{710}$ Mttv. 108. $\left.\S(1) \mathrm{c}\right)$

${ }^{711}$ Mttv. 121. $§(10)$
} 
lényege annak bemutatása, hogy az éves közszolgálati tervhez képest miként sikerült megvalósítani a közszolgálati feladatokat. ${ }^{712}$

\subsubsection{Elégedettségmérés}

Az ellenőrzésre és értékelésre vonatkozó kompetenciát a $N A M S J K$ kiemelt kérdésként kezelte. Ennek megvalósulását látjuk a közszolgálati médiaszolgáltatók gazdasági társasági formában történő létrehozatalában, illetőleg a felügyelőbizottság és könyvvizsgáló feladatainak meghatározásában. ${ }^{713}$ A Koncepció a közszolgálati feladatok teljesítésének értékelése során megfelelő módszertan alapján vizsgálni tartotta szükségesnek a közszolgálati müsorszolgáltatók szolgáltatásaival kapcsolatos nézői/hallgatói/felhasználói elégedettséget is.

A hatályos médiaszabályozás - a Jogalkotási Koncepció - elveinek megfelelően kiemelt szabályozási területként kezeli a közszolgálati médiaszolgáltatást és érdekei megvalósítását különös súllyal veszi figyelembe. ${ }^{714}$ A közszolgálatiság lényege, a közszolgálati médiaszolgáltatás feladatai megjelennek a közszolgálati médiaszolgáltatás alapvető elveiben és céljaiban, továbbá a közszolgálati médiaszolgáltatás szabályozott intézményrendszere megfelelő garanciát nyújt az elvek és célok megvalósításához. ${ }^{715}$

A közszolgálati média hatályos szabályozásával kapcsolatban le kell szögezni, hogy az nem ellentétes a $N A M S$-ban megfogalmazott szabályozási célokkal és tételekkel. Az új szabályozás eredményeként - amint arra már részletesebben is kitértem -, a közszolgálati média megtartotta méltó helyét a hazai média-jogalkotás rendszerében; érdekeinek különös súllyal való figyelembe vétele megjelenik az Mttv. közszolgálati médiaszolgáltatást szabályozó harmadik részében, valamint a közszolgálatot érintő egyéb rendelkezéseiben. A NAMS közszolgálatisággal kapcsolatos szabályozási szándékai közül a közszolgálati feladatok meghatározásának funkcionális szemlélete nem érvényesül az új szabályozásban. A közszolgálatiság elvei, alapvető céljai szerepelnek az új törvényben, sőt a NAMS által javasolt többszintủ feladat meghatározás is megvalósult a szabályozásban; vélhetően a korábbi médiatörvényhez való 'ragaszkodás' okán azonban ugyanazzal a közszolgálati

\footnotetext{
${ }^{712}$ Mttv. 108. § (7)

${ }^{713}$ Mttv. 106-107. §

${ }^{714}$ Mttv. 6. §

715 A közszolgálati médiaszolgáltatás kiemelt szerepét az Országgyülés a közszolgálati média- és hírszolgáltatás biztosítása, függetlenségének védelme tárgyában született 80/2010. (IX. 15.) OGY határozattal is megerösítette.
} 
intézményhez kötöttséggel, mint korábban. Ez az institucionalista modell akár lehet is megfelelő szabályozási megoldás, amennyiben a közszolgálati média be tudja tölteni küldetését.

\section{TÉTELEK A VERSENYSZABÁLYOZÁSBAN}

A Jogalkotási Koncepció versenyszabályozással kapcsolatos tételei radikális változásokat irányoztak elő a hazai médiaszektorban. A következőkben a médiapiac korábbi törvényi szabályozásától elveiben lényegesen eltérő és a jövőbeni szabályozás során alapjaiban érvényesített koncepciós célokat és megállapításokat mutatom be. ${ }^{716}$

\subsection{A piacra lépés szabályai}

\subsubsection{Engedélyezési eljárás helyett nyilvántartásba vétel}

A korábbi médiaszabályozás - amint az már ismertetésre került -, a rádiós és televíziós müsorszolgáltatók piacra lépéséhez főszabályként - az analóg müsorterjesztési, ezen belül is a földi analóg müsorszórási kapacitások korlátozott volta miatt - a pályáztatási eljárást és a müsorszolgáltatási szerződés megkötését írta elő. A kevésbé korlátos (pl. koaxiális kábeles, műholdas vagy IP-alapú) müsorterjesztési módok, platformok esetében az Rttv. egyfajta engedélyezéses bejelentési rendszert alkalmazott.

Mivel a digitális technológia alkalmazásával a piacra lépést akadályozó szükös kapacitások a korábbiakhoz képest lényegében megszüntek, a földfelszíni televíziós és rádiós müsorszórás esetében pedig jelentősen csökkentek, a NAMS JK a lineáris szolgáltatások szabályozását nem a korábbi engedélyezési rendszer alapján képzelte el, hanem egy olyan bejelentési kötelezettségen nyugvó regisztrációs eljárásban, amely szerint a szolgáltatás lényegében azonnal megkezdhető. A $N A M S$ a sokszínü, plurális tartalmak és a nemzeti kultúra terjesztése érdekében tehát az engedélyezési rendszer megszüntetésére tett javaslatával - az AVMS irányelv versenyt támogató céljaival összhangban - könnyíteni kívánta a lineáris szolgáltatók piacra lépését. A nem lineáris szolgáltatásokra a $J K$ nem irányozta elő a kötelező regisztrációt és javaslata szerint a pályázati eljárásokat is kizárólag

\footnotetext{
${ }^{716}$ A NAMS JK idején fennálló hazai médiapiaci helyzetről szóló elemzések közül ld.: INCZE Kinga: Médiapiaci körkép 2007 http://www.akti.hu/dok/fuzet31.pdf (INCZE) Hivatkozás még: 759. lbj.

MÁTH András: A magyar médiapiac kilátásai 2007 Piaci folyamatok és következményeik www.kreativ.hu/download.php?id=4176 (MÁTH)
} 
a korlátos erőforrások, a rádiófrekvencia használata indokolta. A tartalomcsomagolói piacra való belépésre a Dtv. müsorterjesztőkre irányadó szabályai szerint volt lehetőség. ${ }^{717}$

\subsubsection{Hatósági szerződés}

A korlátos erőforrás-használat esetén, amikor a piacra lépéshez a müsorszolgáltató frekvenciahasználati igénnyel lép fel, (például a digitális átállást követően is jelentős analóg rádiós müsorszórás esetében) a Jogalkotási Koncepció a müsorszolgáltatást jogosító pályáztatást követően, a jogosítást hatósági szerződésben tartotta célszerünek rendezni. A NAMS JK úgy vélte, hogy a hatósági szerződés ${ }^{718}$ alkalmazásával elkerülhetők a 2007 júniusában megjelent $\mathrm{AB}$ határozatban ${ }^{719}$ jelzett alkotmányellenes elemek. Kiemelte, hogy „[...] a pályázati eljárás során az alkotmányos alapelveknek megfelelően biztosítani kell a feltételek és értékelési elvek nyilvánosságát és átláthatóságát, valamint a pályázati döntések elleni teljes körủ és érdemi bírósági jogorvoslatot."720

Az Alkotmánybíróság a 46/2007. (VI. 27.) AB határozatban megállapította, hogy a médiatörvény akkori rendelkezései „nem intézményesítettek átlátható pályázati rendszert”. Kifogásolta többek között, hogy a műsorszolgáltatási jogosultságra vonatkozó pályázat során alkalmazandó értékelési szempontok nem szabályozottak a törvényben, a döntéshozatali eljárás a pályázók és a nyilvánosság számára nem követhető.

A megvalósult médiaszabályozás a NAMS JK elvei alapján a lineáris médiaszolgáltatás megkezdését bejelentéshez és az NMHH Hivatala általi nyilvántartásba vételhez kötötte, ${ }^{721}$ a piacra lépés bizonyos eseteinél pedig (a korlátos erőforrások igénye esetén az analóg lineáris médiaszolgáltatásban, ${ }^{722}$ a $J B E$ médiaszolgáltatók azonosítási eljárása eredményeként, illetőleg a sokszínűség növelésére irányuló intézkedések meghatározása érdekében) követte a hatósági szerződések ${ }^{723}$ bevezetésének a Koncepcióban megfogalmazott javaslatát.

\footnotetext{
717 A médiaszolgáltatások piacra lépésének javasolt új rendszere részletes kifejtésre került a 6.2.7. alfejezetben.

718 KOLLARIK Tamás: hatékony és eredményes a médiatartalmak felügyelete http://nmhh.hu/cikk/161426/Kollarik_hatekony_es_eredmenyes_a_mediatartalmak_felugyelete\#sthash.ivzru OzK.dpuf

719 46/2007. (VI. 27.) AB határozat.

${ }^{720}$ NAMS JK 27.

${ }^{721}$ Mttv. 41. $§(1)$

${ }^{722}$ Mttv. 48-63. $\S$

${ }^{723}$ Mttv. 67. § (3), 70. § (10)
} 
Az Mttv. differenciált szabályozást vezetett be a lineáris és non lineáris médiaszolgáltatási jogosultság pályázat útján történő megszerzésére. Mindemellett azonban szükséges rámutatni arra, hogy az Mttv. pályáztatási rendszerében - lényegében az Rttv. logikáját követve -, ,a hatóság továbbra is meglehetősen bonyolult és költséges eljárás keretében választja ki a nyertes médiaszolgáltatót, miközben a pályázatok gyakorlatilag csak helyi rádiókat érintenek."724

\subsubsection{A müsorszolgáltatói magatartás hatósági kontrollja}

A Koncepció a piacra lépést követő müsorszolgáltatói magatartás hatósági kontrollját a korábbinál jóval erősebb és hatékonyabb szankciórendszer mellett, piacfelügyeleti közigazgatási eljárás keretében javasolta. Az alkalmazható szankciókkal szemben - a kiegyensúlyozott piaci fejlődés érdekében - a kiszámíthatóság és változatosság követelményét támasztotta, a szankció fajtákat pedig a bírságolástól - ide értve a felelős vezetők bírságolását is -, a teljes vagy csak bizonyos tevékenységtől való eltiltásig, széles körben határozta meg. A szankciók alkalmazásával kapcsolatban fontos kiemelni, hogy a NAMS JK szoros és hatékony együttmüködés kialakitását írta elö az európai uniós - és különösen a régiós - társhatóságokkal, ${ }^{725}$ hiszen a magyarországi müsorszolgáltatók jelentős része már akkor sem volt magyarországi bejegyzésủ annak ellenére, hogy közülük több, kifejezetten a magyar nézök részére állította össze a müsorát, illetve a hazai piacon érdekelt vállalkozások számára kínálta reklámidejét. ${ }^{726}$

A megvalósult szabályozás ${ }^{727}$ értelmében, ha a más tagállamban letelepedett médiaszolgáltató Magyarország területére irányuló lineáris médiaszolgáltatása sérti a kiskorúak védelmére vagy a gyülöletbeszéd tilalmára vonatkozó szabályokat, úgy - a szolgáltatások szabad áramlásának elve ellenére - is fel lehet vele szemben lépni.

Az AVMS irányelv ${ }^{728}$ nem határozza meg a fellépés konkrét intézkedési körét, ugyanakkor az Mttv. eredeti változata tartalmazta az ilyen jogsértést megvalósító más tagállamban

\footnotetext{
${ }^{724}$ KISSNÉ AKLI Mária - VÁRI Péter: A helyi televíziós szolgáltatók szerepe a földfelszíni digitális átállásban Nemzeti Média- és Hírközlési Hatóság 2013 Helyi-körzeti pályáztatás: lezárult az igényfelmérés. http://nmhh.hu/cikk/2665/Helyikorzeti_palyaztatas_lezarult_az_igenyfelmeres\#sthash.5mrKEYo2.dpuf (KISSNÉ AKLI-VÁRI)

${ }^{725}$ NAMS JK 78.

${ }^{726} \mathrm{Az}$ 'elvándorlás' kérdéseivel részletesen a 6.2.8. alfejezet foglalkozik, ld.: 375. lbj.

${ }^{727}$ Mttv. 2011. évi XIX. törvény 7. §-ával megállapított 176. §

${ }^{728}$ AVMS 3. cikk (2)
} 
letelepedett audiovizuális médiaszolgáltató bírságolásának lehetőségét is. A bírságolás intézményét az EU nem tartotta az AVMS irányelv környezetébe illőnek.

A hazai szabályozással kapcsolatban érdemes a következőkben idézni Matthias Cornils álláspontját: ${ }^{729}$ „Az Európai Bizottság már röviddel a médiatörvények elfogadását követően magyarázatot kért a magyar kormánytól, különösen négy olyan rendelkezésre vonatkozóan, amelyek az Európai Bizottság véleménye szerint aggályosak az európai uniós joggal való összeegyeztethetőség szempontjából. Egyrészt az átfogóan, valamennyi médiaszolgáltatást érintő előzetes nyilvántartásba vételi kötelezettségről; másrészt a külföldi székhelyü médiaszolgáltatók magyar médiajogi szankciónak történő alávetéséröl (ami az Audiovizuális Médiaszolgáltatásokról szóló irányelvben (továbbiakban: AVMS irányelv) rögzített származási ország elvének (ún. Herkunftslandsprinzip) megsértése lenne); harmadrészt a valamennyi médiaszolgáltatásra egyformán kötelező, a híradás kiegyensúlyozottsága érdekében történő tartalmi elöírásról; és végül a magánszemélyek, kisebbség vagy többség megsértéséről szóló szigorú tiltó rendelkezésekről. Magyarország azonnal reagált, és már 2011. február elején a törvény bírált rendelkezéseinek módosítására irányuló javaslatot nyújtott be, amelyet a Bizottság el is fogadott. 2011 márciusában a Bizottsággal létrejött megállapodás alapján a törvényeket módosították. Ezt követően hogy a legfontosabb módosításokat is megnevezzük - a kiegyensúlyozott hírszolgáltatás törvényi követelménye már csak a lineáris médiaszolgáltatókra korlátozódott; a nemlineáris médiaszolgáltatók előzetes nyilvántartásba vételi kötelezettsége utólagos (a szolgáltatás megkezdésétől számított legkésőbb 60 napon belül történő) bejelentésre módosult. Az Európai Unión kívüli audiovizuális médiaszolgáltatókat terhelő szankciókra vonatkozó rendelkezéseket (Mttv. 187. § (3) bek. b) pont) törölték (Mttv. 176. §) és a közigazgatási - a sajtó és a rádiószolgáltatók esetében a Mttv. 178. § értelmében alapvetően büntetőjellegü - szankciókat (szolgáltatásnyújtás megtiltása, nyilvántartásból történő törlés: Mttv. 187. § (3) bek. c) és d) pontok) korlátozták az AVMS irányelv 3. cikkelyében megfogalmazott, a tagállamokat szükségállapotban felhatalmazó esetekre.”

A külföldön honos szolgáltatókkal szembeni szankció-alkalmazás tekintetében Cornils tanulmányához füzött szerkesztői megjegyzések - többek között - vitatják azt az állítást, miszerint a külföldi székhelyü médiaszolgáltatók magyar médiajogi szankciónak történő alávetése az AVMS irányelvben rögzített származási ország elvébe ütközne.

\footnotetext{
${ }^{729}$ Matthias CORNILS Az erős szabályozás iránti igény (Johannes Gutenberg Egyetem, Mainz, Médiajogi, Kulturális és Közjogi Tanszék) A magyar médiatörvényröl EPD Medien (Evangelischer Pressedienst) 2011/44. szám (CORNILS)
} 
Tény az, hogy az EU Bizottság a külföldi székhelyű médiaszolgáltatók tekintetében nem általában a szankciók elöírását tartotta az $A V M S$ irányelvébe ütközőnek, hanem csak a bírságolás jogintézményét, amelynek lehetősége a magyar Kormány és a Bizottság 2011. februári levélváltásának eredményeként kikerült az Mttv. szövegéböl. Ezáltal a külföldön honos médiaszolgáltatókkal szembeni fellépés kivételes és fokozatos volta erősödött.

A külföldi székhelyü médiaszolgáltatók szankcionálásával kapcsolatban további szerkesztői ténybeli pontosítás szerint - Cornils tanulmányi állításával ellentétben - e médiaszolgáltatókkal szemben kiszabható szankciók, nevezetesen a határozat közzétételi kötelezettsége és a médiaszolgáltatási jogosultság gyakorlásának felfüggesztése nem az Mttv. 2011. évi módosításának következménye, hiszen egyéb szankciók, mint például a nyilvántartásból való törlés, ${ }^{730}$ a Bizottság által kért módosításokat megelőzően sem voltak alkalmazhatók a külföldi honos médiaszolgáltatókkal szemben. E külföldi székhelyü médiaszolgáltatók ugyanakkor - a gyülöletbeszédet tiltó vagy a kiskorúak védelmére irányuló jogszabálysértés esetén a magyar joghatóság alá tartoznak.

A törvény mindezeken túl a szankciók differenciált rendszerét ${ }^{731}$ vezette be, és a jogkövetkezmények alkalmazásánál az egyenlő elbánás, a fokozatosság és arányosság elveinek figyelembe vételét írta elő. ${ }^{732}$

\subsubsection{Vállalkozási formák és magyar tulajdonosi kör}

A NAMS JK előirányozta a müsorszolgáltatók vállalkozási formáira és tulajdonosi összetételére vonatkozó Rttv. korlátozások jelentős enyhítését. A müsorszolgáltatók vállalkozási formáit csak annyiban tartotta indokoltnak korlátozni, amennyiben a túlzott piaci koncentráció megakadályozása céljából, a tulajdonosi vagy irányítói kör megismerése érdekében az szükséges. Ennek megfelelően a tulajdonosi kör követhetetlen változásait lehetővé tévő nyilvános részvénytársaságon kívül a NAMS JK - szemben az akkori Rttv. szabályozással, amely kizárólag a részvénytársasági formát tette lehetővé a müsorszolgáltatók számára - valamennyi gazdasági társasági formát elfogadhatónak tartotta.

Az Mttv. a nyilvántartásba vételt kezdeményező médiaszolgáltatóra és sajtóterméket kiadó bejelentőre vonatkozó szabályozás alanyi hatályát mind a természetes, mind pedig a jogi

\footnotetext{
${ }^{730}$ Az AVMS irányelv származási ország elvébe ütközne a külföldi székhelyü médiaszolgáltató magyar hatósági regisztrációja (33) - (37)

${ }^{731}$ Mttv. 185-189. §

${ }^{732}$ Mttv. 185. § (2)
} 
személyekre kiterjesztette, ${ }^{733}$ tehát a Koncepcióhoz hasonlóan nem korlátozta a szolgáltatók vállalkozási formáit.

A NAMS JK a müsorszolgáltatók számára nem tartotta indokoltnak a magyar tulajdonosi körre vonatkozó korlátozás előírását. A Koncepció értelmében bármely, az Európai Gazdasági Térségben bejegyzett vállalkozás vagy természetes személy szabadon alapíthat magyarországi műsorszolgáltató vállalkozást. A NAMS JK javasolta ugyanakkor, hogy a földfelszíni digitális müsorszórási platformon csak magyarországi székhelyü gazdasági társaságok végezhessenek ingyenes müsorszolgáltatást, mivel a magyar állam tulajdonában álló frekvenciák közvetett használatával megvalósuló, túlnyomórészt ingyenesen hozzáférhető szolgáltatás esetén indokolt és a közösségi jognak megfelelő lehet az ilyen kívánalom. Az alapítványi, párt és állami tulajdonosi korlátozások fenntartását a rendelkezések új médiaszabályozáshoz való hozzáigazításával továbbra is szükségesnek tartotta a $J K$. Ennek külön törvényi kimondása később már nem volt indokolt és a hazai szabályozás a tagállami hovatartozást illetően nem tartalmaz semmilyen korlátozást; de párt és a párt által létrehozott vállalkozás továbbra sem lehet lineáris médiaszolgáltató. ${ }^{734}$

\subsection{Médiapluralizmus, média- és sajtópiaci koncentráció}

\subsubsection{Koncentráció tilalma és a médiapluralizmus}

A NAMS JK a túlzott piaci koncentráció megakadályozását és a médiapluralizmus biztositását egymásra tekintettel és továbbra is kiemelt szabályozási területként ${ }^{735}$ kezelte. Deklarálta, hogy a korábban a médiaszabályozás egyik alkotmányjogi alapjának tekintett frekvenciaszükösség - a digitalizációval és az új technológiák térnyerésével - egyre kevésbé indokolja a véleménynyilvánítás szabadságának, mint alkotmányos alapjognak a korlátozását. Az Alkotmánybiróság a kiegyensúlyozott műsorszolgáltatás vizsgálata kapcsán megállapította, hogy a külső pluralizmus a rádió és a televízió programok teljes kínálatát figyelembe véve, a sokszereplős piac létrejöttével megvalósult. Ez a sokszínű müsorkínálat azonban önmagában nem teszi szükségtelenné a kiegyensúlyozottsági követelmény (belső pluralizmus) előírását. ${ }^{736}$

\footnotetext{
${ }^{733}$ Mttv. 41. § (3), 203. § 41.

${ }^{734}$ Mttv. 43. § (3) a)

735 NAMS JK 79.

736 1/2007. (I. 18.) AB határozat.
} 
A müszaki-technológiai folyamatok felgyorsulásával a frekvenciaszükösség - a NAMS JK várakozása szerint - még abban az évtizedben [t.i: 2010 végére] teljességgel megszünhet, emiatt a média- és sajtópiaci koncentráció szabályozása már nem alapozható a megszerezető engedélyek, frekvenciák számának, illetve a tulajdonosi körök korlátozására. A digitalizáció tehát lényegében ellehetetlenítette a médiapluralizmus tulajdoni alapú fenntartását; a felszabadult, illetőleg a digitális technológia eredményeként keletkezett frekvencia-helyek feltöltése pedig nem (volt) lehetséges olyan szabályozási környezetben, amelyben egy tulajdonosnak csak egyetlen országos csatornája lehetett.

A Koncepció - ennek alapján megfogalmazta azt a szükségszerüséget -, miszerint az Rttv. tulajdonra vonatkozó és médiapluralizmust érintő szabályai helyett új jogi alapokon nyugvó, teljesen új szabályozási rendszert kell létrehozni. A médiafogyasztás tömegessé válásával, a tömegmédia kialakulásával ugyanis erősödött a média véleményalakító és magatartásbefolyásoló szerepe, így - a NAMS JK megállapítása szerint - a televiziós és rádiós médiumok nem csak közvetett, hanem azonnali és közvetlen véleménybefolyásoló hatással is birnak. „A hatásmechanizmus érve [...] nemcsak azt értékeli, hogy a televízió és a rádió - egyéb médiumok, különösen az internet növekvő jelentősége mellett továbbra is a legelterjedtebb, a társadalom legszélesebb köréhez eljutó tömegkommunikációs szolgáltatás, hanem azt is, hogy az audiovizuális médiatartalmak eleve másképp befolyásolják közönségüket.",737

A médiaszabályozás alkotmányos jogalapja - ennek megfelelően - a tömegmédia azonnali és közvetlen véleményalakító, véleménybefolyásoló hatása lehet. A VBK egyfelől tehát a szólásszabadságot érintő alapjogi kategória, a médiapluralizmus érvényesülésének tényezője, másfelől pedig a médiapiac védelmét szolgáló versenypolitikai eszköz.

A Koncepció ezért kimondta, hogy „a frekvenciaszükösségi érv megszünésével a médiaszabályozást a meghatározó véleménybefolyásoló képességre (MVK) kell alapozni.",738

A túlzott piaci koncentráció megakadályozása érdekében $N A M S J K$ több szabályozási eszköz alkalmazását javasolta. A szolgáltatók számára a müsorszolgáltatás bejelentésével egyidejüleg nyilatkozattételi és a tények igazolására vonatkozó kötelezettséget írt elő a koncentrációt érintő tények, pl. tulajdonosi szerkezet, média- és sajtópiaci érdekeltségek, vertikális integráció, valamint az új jogszabályoknak való megfelelés tekintetében. A tervezett szabályozás értelmében a piaci koncentráció tilalmába ütköző magatartás esetén a

\footnotetext{
737 165/2011. (XII. 20.) AB határozat.

${ }^{738}$ NAMS JK 84.
} 
nyilvántartásba vételt a hatóságnak meg kellett tagadnia. A médiapiacra való belépés általános feltétele a müsorszolgáltató már említett nyilvántartásba vétele volt; a korlátos erőforrást, frekvenciát igénylő rádiós analóg müsorszolgáltatás pedig - ahogy az a szabályozásban is megvalósult -, a pályáztatás eredményeként kiválasztott szolgáltatóval kötött hatósági szerződés alapján indul. A Koncepció a szolgáltatók piaci magatartásának ellenőrzését a médiahatóság hatáskörébe rendelte, a müsorszolgáltatások vállalkozási formáira és tulajdonosi összetételére vonatkozó korábbi korlátozásokat a pedig számottevően enyhíteni, illetőleg az Rttv. kereszttulajdonlási szabályait eltörölni javasolta. A médiapluralizmus garanciáit a Koncepció az $M V K$ szolgáltatóhoz telepítette. Mivel az $M V K$ szolgáltatás alapvető alkotmányos célja a külső pluralizmus biztosítása, azaz a sokszínű műsortartalmak szolgáltatása, az $M V K$ státusz kizárólag olyan kötelezettségeket és olyan jogkövetkezményeket eredményezhet, amelyek hozzájárulnak a médiapluralizmus megvalósulásához és összhangban vannak a médiaszabályozásban megjelenített más szabályozási célokkal is. ${ }^{739} \mathrm{Az} M V K$ státusz - a NAMS JK szerint - ugyanakkor önmagában nem alapozza meg a reklámpiaci vagy médiapiaci koncentrációval szembeni korlátozások bevezetését; e problémák kezelését az ágazati versenyszabályozás eszközeivel, a médiaszabályozás keretében látta megoldhatónak.

Az Mttv. lineáris médiaszolgáltató piaci koncentrációjának megelőzése érdekében hozott szabályai a sokszínű médiapiac fenntartása, illetőleg a tájékoztatási monopólium létrejöttének megakadályozása céljából a törvény keretei között lehetővé teszi a korlátozást. ${ }^{740}$ A korlátozás - a törvényi feltételek fennállása esetén - új szolgáltatás indításának, és médiaszolgáltatást végző vállalkozásban való részesedés szerzésének tiltásában, illetőleg a médiapiac sokszínűségének növelése érdekében teendő intézkedések előírásában fogalmazódik meg. ${ }^{741}$

\subsubsection{Meghatározó véleménybefolyásoló képesség ${ }^{742}$ versus jelentős befolyásoló erö}

A NAMS JK szakított az Rttv. szerinti korlátos erőforráshoz való hozzáférésen nyugvó szabályozással és annak helyébe a véleménybefolyásoló képességen (VBK) alapuló

\footnotetext{
${ }^{739}$ NAMS JK 85.

${ }^{740}$ Mttv. 67. §

${ }^{741}$ Mttv. 68. (1) a)-b) A Médiatanács médiapiaci koncentrációval kapcsolatos hatáskörét a 68. § (2)-(10) bekezdések határozzák meg. A JBE szolgáltatóra vonatkozó speciális szabályokról ld.: 6.4.7. alfejezetet.

${ }^{742}$ A véleménybefolyásoló képesség elméleti, alkotmányjogi alapjairól, a német modellröl, stb. ld.: Szenzitív lekérhető szolgáltatások és sajtójogi tartalmak 6.2.4. 2. alfejezetet, 353. lbj., a 6.4.7. alfejezet JBE azonosítási eljárásra vonatkozó részét, valamint a 604. 1bj. és 717. lbj.
} 
szabályozást ültette. A $V B K$ a tartalomszolgáltató vállalkozás olyan jellemzőjét, képességét emeli ki, amely a tartalomkínálat sokszínüségét leginkább befolyásolhatja és e jellemző képesség alapján meghatározza azt a vélelmezett beavatkozási küszöböt, amely fölött a szolgáltató tevékenysége veszélyezteti a médiapluralizmus megvalósulását. ${ }^{743} A$ VBK $a$ szolgáltatónak nem a piaci jelentőségét, gazdasági súlyát, a vállalkozás nagyságát jelzi, hanem a tartalmak piacára, a vélemények befolyására, a médiapluralizmusra gyakorolt hatását fejezi ki.

A Koncepció kifejezetten nem az elektronikus hírközlési terminológia szerinti ,jelentős piaci erő" kifejezést kívánta a szabályozás során használni. Ennek legföbb szakmai indoka az volt, hogy a médiapiaci sajátosságok miatt egy médiaszolgáltató jelentősége, súlya nem feltétlenül piaci erejében, hanem befolyásolási képességében rejlik. Egy, a nettó árbevétele alapján viszonylag kis gazdasági súlyú médiaszolgáltató is gyakorolhat meghatározó befolyást a véleményekre az általa szolgáltatott müsorok (föleg hír-, politikai és közéleti müsorok) alapján a tartalmak piacán.

Annak ellenére, hogy a befolyásolási képesség sajátos voltát a Kommentár ${ }^{74}$ is kiemeli, az Mttv. szövege mégis átveszi a hírközlési piaci „erő” fogalmát és a „Jelentős befolyásoló erővel rendelkező médiaszolgáltatók” (JBE) kifejezést alkalmazza. A befolyásolási képesség „erényeit” a hatályos médiajogi szabályozás azáltal ismeri el, hogy a $J B E$ azonosítást ugyan a hírközlési ágazat elemzéseiből és a hírközlési szabályozásból ismert jelentős piaci erő azonosítására ${ }^{745}$ vonatkozó eljárás alapján végzi, de az azonosítási szempontokat és a $J B E$ státuszhoz kapcsolódó kötelezettségeket nem az $N M H H$ elnöke mérlegelési jogkörben állapítja meg, hanem - szintén garanciális okokból - maga a törvény rögzíti.

A NAMS a szabályozás gyakorlati megvalósítására két alternatívát vázolt és mindkét változat esetében a szolgáltatóhoz sorolható tartalomszolgáltatások által éves átlagban elért közönségarányt vette alapul. Az első változat szerint törvényi szinten kerülnek rögzítésre a meghatározó és a jelentős $V B K$ szolgáltatók azonosítási szempontjai, valamint az e szolgáltatókkal szemben alkalmazható intézkedések köre. Ez a változat kellően kiszámítható szabályozási környezetet biztosít az érintett szolgáltatók számára, a hatóságot pedig mentesíti a mérlegelés felelőssége alól. A szabályozás másik irányát a NAMS éppen

\footnotetext{
743 NAMS 97.

${ }^{744}$ KOLTAY - LAPSÁNSZKY Kommentár 178.

745 Eht. VI. Fejezet Piacszabályozási eljárások Piacmeghatározás, jelentős piaci erővel rendelkező szolgáltatók azonosítása és kötelezettségek elöírása.
} 
a hatóság széles mérlegelési jogkörének biztosításában látta, megemlítve ennek jogbizonytalanságban jelentkező kockázatát.

\subsubsection{VBK kategóriák, valamint az MVK és JVK kötelezettségek küszöbértéke}

A $J K$ javaslat szerint a beavatkozási küszöb meghatározását a müsorszerkesztői tevékenységben való szolgáltatói jelenlét, ezen belül is a lineáris tartalmak szerkesztése alapozná meg. Ennek okát a NAMS abban látta, hogy a klasszikus lineáris szerkesztői tevékenység $^{746}$ - a tömeges egyidejü tájékoztató jellege miatt - a $V B K$-t leginkább képes megalapozni, és a nem lineáris tartalmak objektív közönségarány mérése nemigen látszott megvalósíthatónak.

A javaslat két kategóriát látott indokoltnak bevezetni: a meghatározó és a jelentős $V B K$-t. A meghatározó véleménybefolyásoló képességgel $(M V K)$ rendelkező műsorszolgáltatót kizárólag a médiapluralizmust erősítő, illetőleg a véleménybefolyásoló képességet enyhítő kötelezettségekkel terhelte; a minősítés küszöbértéke 20 százalékos, a jelentős véleménybefolyásoló képességű müsorszolgáltatók $(J V K)$ esetében pedig 10 százalékos közönségarány volt.

A NAMS JK a televíziók esetében az MVK küszöb meghatározását a lineáris általános tematikájú és lineáris tematikus hírmüsor müsorszolgáltatására vonatkoztatta, és az adott szolgáltató érdekkörébe tartozó további tematikus müsorszolgáltatásokat az $M V K$ nézettségi/hallgatottsági vizsgálatnál eltérítő tényezőként vette számításba. A Koncepció szándéka szerint egy alacsonyabb nézettséggel rendelkező, de kiterjedt tematikus csatornahálózatot is üzemeltető általános tematikájú müsorszolgáltató vezető csatornája alacsonyabb nézettsége esetén is a szabályozás hatálya alá kerülhetett. A NAMS JK a lineáris általános tematikájú és a lineáris tematikus hírmüsor müsorszolgáltatás esetében eltérő szorzókat tartott indokoltnak alkalmazni, figyelemmel az utóbbi kategória erőteljesebb véleménybefolyásoló képességére. ${ }^{747}$

A szabályozási időtávot a Koncepció minimálisan két évben jelölte meg, mivel a hírközlési piaci tapasztalatok alapján a szabályozás alanyának megállapítása és a kötelezettségek piaci bevezetése legalább fél-háromnegyed évet vesz igénybe. Amennyiben a fenti

\footnotetext{
${ }^{746}$ Olyan elképzelés is megfogalmazódott, amelynek révén csak az általános, illetve hírcsatornák képeznék a felmérés alapját, vagy pedig e csatornák súlya nagyobb, legalább háromszoros értékben esne latba az egyéb müsorok nézettségéhez képest.

747 A médiaszabályozásban megvalósult véleménybefolyásoló képességen alapuló kategóriák részletes elemzését a dolgozat a műsordíj médiajogi szabályozásánál (6.4.7.) tartalmazza.
} 
küszöbértékektől a szabályozási időszakon belül valamely szolgáltatónál jelentős legalább 5 százalékos - tartós és bizonyított eltérés mutatkozik, a NAMS JK szándékai szerint az érintett szolgáltató átminősíthető, vagy mentesíthető.

\subsubsection{MVK és JVK kötelezettségek}

A NAMS JK a tulajdonosi koncentrációk, illetőleg tájékoztatási monopóliumok kialakulását a következő kötelezettségek megfogalmazásával szándékozta megakadályozni: az $M V K$, illetve $J V K$ státuszú szolgáltatókat elvi szinten kötelezte az európai művek, a nemzeti kultúra kiemelt támogatására, a hír- és/vagy közéleti műsort is készítő $M V K$ szolgáltatót pedig - ezen felül - a kiegyensúlyozott médiaszolgáltatásra is.

A NAMS JK szerint az $M V K$ szolgáltatót, szolgáltatói csoportot egyéb piaci koncentrációs szabályoknak is korlátozniuk kell, azonban kizárólag akkor, ha a piaci helyzetét erősítő feltételek is teljesülnek. Így nem indíthatna további csatornákat/müsorszolgáltatásokat, illetve nem szerezhetne további tulajdonosi vagy irányítási jogokat más müsorszolgáltatókban, amennyiben a következő, a piaci helyzetét erősítő feltételek is teljesülnek: (a) vertikális integráció tartalomgyártókkal vagy műsorterjesztőkkel, (b) meghatározott árbevételi szint, (c) meghatározott médiapiaci súly a nézettség alapján, (d) meghatározott reklámpiaci súly árbevételi és reklámidő alapján. A vertikálisan integrált, illetve meghatározott reklámpiaci súlyt elérő (árbevétel és reklámidő alapján) szolgáltató, vagy szolgáltatói csoportba tartozó reklámidő értékesítő vállalkozás („,sales-house”) csak átlátható és az egyenlő elbánás elvének megfelelő feltételek mellett értékesíthetné más műsorszolgáltatók reklámidejét. Az $M V K$ szolgáltató „,must offer” kötelezettségek alanya piacelemzés eredményeként, ex ante piacszabályozási jelleggel - abban az esetben lesz, amennyiben az adott szolgáltatónál vertikális integráció áll fenn valamely meghatározó tartalomgyártóval vagy müsorterjesztővel.

Az Mttv. a médiapiaci koncentráció megelőzésének szabályozása, illetőleg a must offer ${ }^{748}$ rendelkezések kialakítása során figyelembe vette a Koncepció által meghatározott tételeket. ${ }^{749} \mathrm{~A}$ hatályos szabályozás a $J B E$ médiaszolgáltatóra 15 százalékos küszöbértéket

\footnotetext{
${ }^{748}$ Mttv. 78-81. §

749 JBE kötelezettségekről részletesen ld.: 6.4.7. alfejezetet.
} 
határoz meg; ${ }^{750}$ a JBE médiaszolgáltató számára előírt kötelezettségek teljesítését a Médiatanács rendszeresen ellenőrzi, ${ }^{751}$ a $J B E$ minősítéseken eddig nem változtatott.

\subsubsection{Tulajdonlási korlátok enyhítése}

A Koncepció sürgetőnek tartotta - az országos kereskedelmi csatornák számára az új tematikus csatornák indításának lehetővé tétele érdekében - az akkor hatályos Rttv. kereszt-tulajdonlási szabályainak az eltörlését a televiziós piacon, valamint a teljes médiapiacra vonatkozó tulajdonosi korlátozások jelentős enyhitését úgy, hogy a fenntartott tulajdonosi korlátozások ne eredményezzék gazdaságtalan, fejlődésképtelen piaci struktúrák kialakulását. A $V B K$ szolgáltatók és napilapok, illetve más sajtótermékek kiadói közötti kereszt-tulajdonlási korlátozások jelentős enyhítését a $N A M S J K$ - többek között a nyomtatott sajtó folyamatos és jelentős piacvesztésével indokolta, a rádiós piac esetében pedig a körzeti és helyi rádiók közötti tulajdonosi korlátozásokat differenciált formában, az $M V K$ státuszhoz kapcsolódóan tartotta volna fenn. Az internetes oldalak piaci jelentőségét a tulajdonosi korlátozások szempontjából is szükségesnek látta vizsgálni.

A hatályos médiaszabályozás tulajdonosi koncentrációt szabályozó rendelkezései szemben az Mttv. szakhatósági eljárásra ${ }^{752}$ vonatkozó teljes médiapiacra vonatkozó szabályozásával - csak a lineáris médiaszolgáltatások tekintetében érvényesülnek. A szabályozás alapját - a NAMS JK elveivel és az AVMS irányelv rendelkezéseivel egyezően - az képezi, hogy a médiapiaci viszonyokba történő, fúziókontrollon kívüli állami beavatkozás csak és kizárólag akkor szükséges, amennyiben az a sokszínűség fenntartása érdekében indokolt és az adott médiaszolgáltató véleménybefolyásoló ereje jelentős.

Az Mttv. - az AVMS irányelv preambulumának megfelelően - a médiapiaci viszonyok torzításmentes müködését és a verseny élénkítését támogató rendelkezéseket vezetett be. Az erőfölény kialakulásának megakadályozása és a médiapiaci pluralizmus biztosítása érdekében a médiapiaci koncentráció megelőzését célzó kötelezettségeket állapít meg, illetőleg a - NAMS JK elveivel egyezően - a JBE médiaszolgáltatók számára további korlátozó rendelkezéseket írt elö. ${ }^{753}$

\footnotetext{
${ }^{750}$ Mttv. 69. § (1)

${ }^{751}$ Mttv. 69. § (2)

${ }^{752}$ A Médiahatóság Mttv. 171. §-a szerinti szakhatósági közremüködése a JK megalkotásának időszakában nem merült fel, ugyanakkor a NAMS társadalmi vitája során körvonalazódtak olyan elképzelések, amelyek szerint a szabályozás egy későbbi időszakában a Gazdasági Versenyhivatal médiapiaccal kapcsolatos felügyeleti jogköre integrálódik a média és hírközlési konvergens hatósághoz.

${ }^{753}$ Mttv. 32. §, 38-39. §, 78-81. §. Részletesen ld.: 6.4. fejezetet.
} 
A véleménybefolyásoló képességet illetően meg kell állapítani, hogy a médiaszolgáltatás rendkívül gyors tematizálódásának következményeként: „[...] ma már egyetlen médiumnak sincs általánosságban különleges befolyásoló ereje, legfeljebb egyes tartalomszolgáltatásokkal kapcsolatban tehető ilyen megállapítás." ${ }^{\text {754 }}$ Ilyen a tartalmak elsősorban a hírszolgáltatások, és a politikai háttér-elemző müsorok. „A közszolgálati médiaszolgáltató tendenciózusan elfogult tájékoztatási gyakorlata [...] elvileg egyéni jogsérelem nélkül is, a tájékoztatáshoz való alkotmányos jog alapján kifogásolható.”,755

A véleménybefolyásoló képességre épített szabályozás alapja a lehetséges véleménybefolyásolás, vagyis az adott médiumnak a vélemények befolyásolására való képessége, nem pedig a médiaszolgáltató múltbeli magatartása, vagy törekvései. ${ }^{756}$ Így a médium - a NAMS JK alapján - abban az esetben is az $M V K$ szabályozás alanya, ha médiapolitikai elvei vagy saját maga által felállított céljai között nem szerepel a véleménybefolyásolás.

A $V B K$ természetesen nem csak választási időszakban áll fenn, a legnézettebb müsorok ugyanakkor a választási vagy más politikailag kiemelt időszakban - akár közvetlenül, akár közvetve, pl. a reklámidő értékesítésén keresztül - a véleménybefolyásolás kiemelt eszközévé válhatnak. A tervezett szabályozás nem a nyomtatott sajtó piacára, hanem elsősorban a televiziós és rádiós piacra irányult, mivel a véleménybefolyásolás közvetlensége és azonnalisága ebben a szegmensben ezt fokozottan megkívánta. ${ }^{757} \mathrm{~A}$ szabályozásnak ugyanakkor a teljes média- és sajtópiacot kellett alapul vennie, ahol a televíziós vagy rádiós $M V K$ küszöb eltérítésre kerül egyéb média- és sajtópiaci részesedések alapján.

A NAMS JK a médiaszolgáltatók státusz-besorolását az általuk nyújtott adatszolgáltatáson nyugvó elemzés alapján a médiahatóság hatáskörébe utalta és törvényi szintre emelte: a minősítési küszöböt, a vizsgálati szempontokat, valamint a hatóság által alkalmazható ex ante piacszabályozási eszközöket, intézkedéseket - garanciális okokból - az új médiatörvényben írta elő meghatározni. Megállapítása értelmében „a törvény így egy rögzített kötelezettség-katalógust ad meg, amely alapján az egyes indokolt és arányos

\footnotetext{
${ }^{754}$ KOLTAY András - POLYÁK Gábor: Az Alkotmánybiróság határozata a médiaszabályozás egyes kérdéseiről 11-48. Jogesetek Magyarázata 2012/1 (KOLTAY-POLYÁK) 47-48.

${ }^{755}$ KOLTAY-POLYÁK 47.

${ }^{756}$ NAMS JK 86. 29.

${ }^{757}$ Itt ismételten utalunk a 1270/B/1997. AB határozatra, valamint a 165/2011. (XII. 20.) AB határozatra. Ld.: $353 . \mathrm{lbj}$.
} 
kötelezettségek megállapításra kerülnek." ${ }^{, 758}$ A $N A M S$ az új hatóság hatáskörének megállapításánál egyébként is törekedett - a korábbi jogi szabályozás hiátusából eredő túlzott hatósági mérlegelési jogkörök visszaszorítására és a jogbiztonság érdekében a lehető legtöbb feladat törvényi rögzítésére.

A véleménybefolyásoló kategóriák meghatározásánál az is fontos tényező volt, hogy a NAMS JK megalkotása idején, 2007-ben, a gazdasági világválság bekövetkezte előtt, a hazai médiapiac tulajdonosi szerkezetét illetően némileg differenciáltabb volt. ${ }^{759}$ Emiatt a Koncepció a televíziós piacon indokoltnak látta - a külső pluralizmus megvalósítása érdekében - egy alacsonyabb küszöbérték alapján meghatározott, kevesebb kötelezettséget tartalmazó kategória, a $J V K$ státusz bevezetését is. A rádiós piacon ilyen kategória meghatározására már akkor sem volt szükség. A megvalósult szabályozás már csak egyetlen kategóriát, a $J B E$ státuszt emeli ki a médiaszolgáltatásban.

\subsubsection{Nézettség, hallgatottság és közönségarány; verseny a nézettség 'piacán'}

Mivel a Koncepció a véleménybefolyásoló képességből, nem pedig a tényleges véleménybefolyásolásból, vagy „,véleménymonopóliumból” indul ki, a televíziós és rádiós $M V K$, illetőleg a televíziós $J V K$ küszöb meghatározásának alapját az egy adott időszakban mért (éves) átlagos nézettség, hallgatottság, a közönségarány képezte. A NAMS a VBK-t megalapozó közönségarány mérésére is több változatot dolgozott ki; ${ }^{760}$ ezek közül a hatósági mérési rendszer kiépítése indokolatlan és aránytalan költségeket jelentett volna, ezért a javaslat a nyílt kiválasztási eljárást, illetőleg a módszertani kritériumok meghirdetése melletti akkreditációs eljárást támogatta.

Az Mttv. - a NAMS JK javaslatával egyezően - a lineáris médiaszolgáltatók tekintetében nem a korábbi Rttv. szerinti tulajdonosi részarányok alapján határozza meg a piaci koncentráció kialakulását megelőző szabályokat, hanem - álláspontom szerinti is helyesen - a közönségarány ${ }^{761}$ alapján.

\footnotetext{
${ }^{758}$ NAMS JK 91.

${ }^{759}$ INCZE ld.: 716. lbj.

${ }^{760}$ NAMS 100-101.

761 „Közönségarány: egy adott időszakban a vizsgált lineáris audiovizuális médiaszolgáltatás müsorszámainak nézésére, illetve lineáris rádiós médiaszolgáltatás müsorszámainak hallgatására fordított összes időtartam százalékosan kifejezett aránya valamennyi lineáris audiovizuális médiaszolgáltatás nézésére, illetve valamennyi lineáris rádiós médiaszolgáltatás hallgatására fordított összes időtartamhoz viszonyítva. A közönségarány meghatározásánál a lineáris audiovizuális, és a lineáris rádiós médiaszolgáltatás piacát Magyarország területén külön-külön kell vizsgálni.” Mttv. 203. § 28.
} 
„A közönségarány egzaktabb mérőszám a médiaszolgáltatók tényleges véleménybefolyásoló, sokszínű tájékoztató képességének meghatározása során, tekintettel arra, hogy ezen mérőszám alapján viszonylag objektíven megítélhető, hogy az adott országos médiaszolgáltatást ténylegesen a lakosság hány százaléka nézi, azaz, hogy mekkora a médiaszolgáltató tényleges befolyásolási képessége."762

A reklámpiaci értékesítési rendszerek jelentős mértékben támaszkodnak a nézettségmérésre, megbízható nézettségmérési adatokra pedig szabályozási célból (előfizetői igényeken alapuló csomagképzés ellenőrzése, $V B K$ mértékének megítélése stb.) is szükség van. Mivel az $M V K$ szabályozás alapja és legitimációja a nézettség/hallgatottság volt, a szabályozói beavatkozáshoz megbízható információk kellettek. Ennek érdekében a NAMS JK az új médiahatóság hatáskörében piaci alapú, de meghatározott módszertani elöirásoknak és szakmai követelményeknek megfelelö nézettségi/hallgatottsági adatok beszerzését nyílt közbeszerzési eljárás keretében tartotta indokoltnak. A Koncepció megfogalmazta azt az igényt, miszerint a módszertani elöírásoknak lehetővé kell tenniük, hogy a közbeszerzés során verseny alakulhasson ki, ugyanakkor az $M V K$ szabályozáshoz elegendő és megbízható adat álljon rendelkezésre.

A GVH Ágazati Jelentése ${ }^{763}$ nem zárta ki, hogy a kisebb csatornákra és a szükebb célcsoportokra vonatkozó megbízható nézettségmérési adatok hiánya nehezíti a tematikus csatornák reklámpiaci érvényesülését. Az Ágazati Jelentés a nézettségmérés kapcsán arra a következtetésre jutott, a NAMS $J K$ által is javasolt rendszeres pályáztatással kell kiválasztani az adott időszakokra a mérést végző vállalkozást. A $G V H$ azért támogatta a pályáztatási rendszert, mert megállapítása szerint ez a megoldás biztosíthatja leginkább az erőfölényes helyzetek kialakulásának megakadályozását, ráadásul - a $V B K-\mathrm{n}$ alapuló médiaszabályozás esetén - a szolgáltatás felhasználójává váló állam így juthat a legkedvezőbb feltételekkel e mérési szolgáltatáshoz.

Az Mttv. a közönségarány módszertanának kidolgozásához lehetővé teszi külső vállalkozóval való szerződés kötését. ${ }^{764}$ Ennek indokául a még jelenleg is egyetlen

\footnotetext{
${ }^{762}$ KOLTAY-LAPSÁNSZKY Kommentár 175.

${ }^{763}$ A GVH elnöke - a médiaszabályozási fötanácsadó kezdeményezésére - 2007. július 24-en ágazati vizsgálatot indított az elektronikus média gazdasági ágazatba tartozó televíziós müsorszolgáltatás (müsortartalom szerkesztés és csomagolás) nagy- és kiskereskedelmi, valamint televíziós hirdetési piacán a televíziós reklámok értékesítésével, a sport- és filmjogokhoz való hozzáféréssel, a televíziós müsorcsatornák továbbításának feltételeivel kapcsolatos piaci folyamatok megismerése és értékelése céljából.

Az Ágazati vizsgálat eredményeit a Gazdasági Versenyhivatal ÁV-2/2009. számú Jelentése foglalta össze. (2009. április) Ld.: 980. lbj.

${ }^{764}$ Mttv. 69. § (3)
} 
közönségmérő cég létét hozza fel a Kommentár. ${ }^{765}$ A hatályos szabályozás - a NAMS JK elképzeléseivel szemben - nem valósította meg a közönségmérés tekintetében a közbeszerzési eljárást és - ezáltal - a versenyeztetést.

A véleménybefolyásoló képesség és hatásmechanizmusa egyfelől, mint a tartalompiacot védő és a médiapluralizmust biztosító „mérési módszer”, másfelől pedig a piaci koncentrációkat megakadályozó eszközrendszer, a NAMS egyik leglényegesebb újdonsága volt. A szabályozás átvette a tartalompiac mérésére bevezetett, az Alkotmánybíróság által is elfogadott és megerősített hatásmechanizmust, a véleménybefolyásoló képesség elvét. A jogi szabályozás idején azonban már nem volt szükség elkülöníteni a médiaszolgáltatók $M V K$ és JVK státuszát, elegendő volt a véleménybefolyásoló képesség elvének aktualizálása és a szabályozásban való megjelenítése.

A Koncepció piacra lépéssel, a koncentrációk megakadályozásával, illetőleg a versenyszabályozással kapcsolatos elvei és tételei- a médiapiac időközben bekövetkezett szerkezeti változásai, valamint a 2008 kora őszén kezdődött gazdasági válság miatt aktualizálva, de lényegüket tekintve megjelennek. A média piacszemléletü és versenyt támogató megközelítése - az AVMS irányelv preambulumával összhangban -, a szabályozási célok megfogalmazása során szintén újdonságnak számított. Az Mttv. médiapiac szabályozásával kapcsolatos területén az alapjaiban megváltozott szemlélet jelentős változásokat eredményezett. Az új szabályozásban a médiapiac új megközelítését látjuk - többek között - a piacra lépést megkönnyítő, az aktualizált $V B K$ mechanizmust alkalmazó, illetőleg a Médiatanács médiapiacot érintő szakhatósági közremüködését előíró rendelkezésekben.

\section{INTÉZMÉNYRENDSZER}

A Jogalkotási Koncepció a felügyeleti intézményi szabályozás legfőbb célját egy, az Országos Rádió és Televízió Testület megszünését követően „tiszta lappal induló,” autonóm, a médiapiac fejlődését támogatni képes és szakmailag is elismert médiahatóság létrehozatalában és müködésében látta. Az új médiafelügyelet kapcsán az egyik legfontosabb kérdés az intézményi konvergencia kérdése volt, nevezetesen: megérett-e a helyzet a média- és hírközlési hatóság feladatainak egyetlen szervezet keretében való

765 KOLTAY-LAPSÁNSZKY Kommentár 179. (AGB Nielsen Médiakutató Kft.) Ezzel kapcsolatban szükséges megjegyezni, hogy más közönségmérő vállalkozás (GFK Hungary Kft., IPSOS Zrt.) is jelen van a magyar médiapiacon, azonban a mérés módszertanának szinte változatlan tartalommal történő kiírása eddig lényegében kizárta más közönségmérő vállalkozás eredményes pályázását a közönségmérésre. 
egyesítésére, azaz a jövőben a szabályozási feladatokat hatékonyabban látná el egy integrált, a média és a hírközlés piacának egységes felügyeletét megvalósító szervezet? ${ }^{766}$ A nemzetközi minták, az addigi intézményi tapasztalatok, valamint a piaci és szakmai szervezetek véleménye alapján a NAMS JK megfogalmazta a médiaágazat leendő felügyeleti intézményrendszerével kapcsolatos legfontosabb általános elvárásokat. A politikai függetlenség biztosítása, a szakmaiság erősítése, az egyértelmü hatósági jogkörök meghatározása, a jogalkalmazói feladatok magas színvonalú ellátása, a jogszabályban definiált szervezeti és müködési rend kialakítása, egyértelmü összeférhetetlenségi szabályok léte, átlátható, az ad hoc elemektől mentes finanszírozási struktúra, valamint az ellenőrizhetőség és elszámoltathatóság a rendszeres beszámolás kötelezettségével voltak azok a követelmények, amelyeket a NAMS JK nevesített a felügyeleti intézményrendszerrel szemben.

\subsection{Az új médiahatóság fó feladatai}

A Koncepció elképzelései szerint az új médiahatóság legfontosabb feladatai a közszolgálati és a kereskedelmi médiaszolgáltatás felügyeletére terjedtek ki, természetüket tekintve pedig elsősorban jogalkalmazási funkciókat fedtek le. A hatóság stratégiai és a támogatási feladatainak súlyát a $N A M S J K$ jelentősen csökkenteni kívánta, és elképzelései között teret engedett a szabályozó hatósági szerepkör mellett a „governance” típusú hatósági modell kialakításának is, azaz az érintettekkel való kapcsolattartásnak, konzultációnak, valamint az ön- és társszabályozásnak. ${ }^{767}$

A $J K$ az új médiahatóság fő feladatait ${ }^{768}$ egységesen a következőkben határozta meg:

a) kezeli az audiovizuális szolgáltatások bejelentését és nyilvántartását,

b) kiszabja és beszedi a piacfelügyeleti díjat,

c) felügyeli és ellenőrzi az audiovizuális média területével összefüggő jogszabályok betartását,

d) bejelentésre vagy hivatalból eljárást indít a törvényi alapelvek megsértése esetén (a pártatlanság megsértésére vonatkozó hivatalos észleléseket továbbítja a kiegyensúlyozottság felett őrködő bizottságnak),

\footnotetext{
766 POLYÁK Gábor: Konvergens piac, konvergens hatóság? Médiakutató 2008 nyár (POLYÁK IV.)

${ }^{767}$ Jan KOOIMAN: Governing as Governance London, Sage, 2003. In: POLYÁK IV. (KOOIMAN)

${ }^{768}$ NAMS JK 41.
} 
e) azonosítja a törvény alapján meghatározó és jelentős véleménybefolyásoló képességgel rendelkező szolgáltatókat és ellenőrzi törvényi kötelezettségeik betartását,

f) a törvényben meghatározott körben vizsgálatot folytat az $M V K$ kritériumaira és fennállására vonatkozóan,

g) bírságot szab ki, illetve más szankciókat alkalmaz az audiovizuális médiaszolgáltatókkal szemben a vonatkozó jogszabályok megsértése miatt,

h) a média területén a hatósági jogértelmezési gyakorlatot összefoglaló dokumentumokat (közleményeket) tesz közzé, beleértve a klasszifikációs minősítésre vonatkozó állásfoglalását és a közérdeklődésre számot tartó események listáját,

i) elfogadja a közösségi szolgáltatók tartalomszerkesztési szabályzatát és kérelemre műsorszolgáltatót helyi, jellemzően közfeladatot ellátó műsorszolgáltatónak nyilváníthat, valamint ellenőrzi a szabályzatban foglaltak betartását,

j) müsorfigyelő- és elemző szolgálatot müködtet, és közzéteszi az ilyen szolgálat vizsgálatának és értékelésének eredményeit,

k) tájékoztatókat készít, kiadványokat és közérdekü közleményeket jelentet meg, valamint más aktív szerepvállaláson keresztül elősegíti a tudatos, választani képes fogyasztói magatartás kialakulását,

1) kutatásokat, felméréseket végez vagy végeztet a piaci folyamatok és fogyasztói igények figyelemmel kísérése érdekében és ezek eredményeit nyilvánosságra hozza,

m) fórumot biztosít az érdekképviseleti szervek és az érintettek véleményének kifejezésre juttatásához nyilvános meghallgatások és az érdekeltekkel való egyeztetés és más formákban,

n) a médiahatóság hivatala eljár a média területén különleges szakértelmet megkövetelő fogyasztói panaszok esetén,

o) részt vesz az audiovizuális ágazattal kapcsolatos döntések elökészítésében, véleményt nyilvánít minden, az audiovizuális médiaszolgáltatásokat érintő jogszabályok tervezetéről, beleértve a frekvenciagazdálkodással és hírközléssel kapcsolatos tervezeteket is,

p) együttmüködik a hírközlési hatósággal a digitális átállás előkészítésében, és a müsorterjesztést érintő szabályozási feladatok ellátásában (többek között a médiapiacokat érintő frekvenciagazdálkodási, piacelemzési ügyek) és megvalósításában,

q) kezdeményezi a hírközlési, fogyasztóvédelmi és versenyhatóság eljárását,

r) más európai hatóságokkal és az Európai Bizottsággal együttmüködik és kapcsolatot tart,

s) széles körben delegálhat tagokat és vehet részt a média, vagy azzal összefüggö területeken tevékenykedő szervezetekben. 
Ezek a feladatok megjelennek az új médiahatóság vezető szervei közötti hatáskör- és feladatmegosztásban, az $N M H H$ vezető tisztségviselőinek, ${ }^{769}$ illetőleg a Médiatanács ${ }^{770}$ és a Hivatal ${ }^{771}$ hatásköre és feladatai között a hatályos szabályozásban. Az új Hatóság önálló szabályozói szervi státusza, különösen a frekvenciagazdálkodás és a hírközlés területén, ${ }^{772}$ kidomborodott. Az intézményi konvergencia sajátosságai elsősorban az $N M H H$ speciális feladat- és hatáskörében fogalmazódnak meg, ennek garanciáját pedig a Testület államiszervezeti és financiális autonómiája, valamint a szabályozottaktól való függetlensége jelenti. Az Mttv. élesen elhatárolja az NMHH feladat- és hatáskörét egyrészt hírközlési és médiajogi szempontból, másrészt a hatósági és nem hatósági tevékenységek megközelítésében, harmadrészt pedig az $N M H H$ önálló hatáskörrel rendelkező szervei által gyakorolt hatáskörök alapján (Elnök, Médiatanács, Hivatal). ${ }^{773}$

A Hatóság autonóm központi közigazgatási szerv, amelynek egyszemélyes vezetője az Elnök. Az elnöki hatáskör szabályozásának sajátossága, hogy nincs a médiaigazgatásban hatósági jogköre, de az Mttv. és az elektronikus hírközlésről szóló törvény szerint önálló hírközlési igazgatási jogkörrel rendelkezik; hírközlési hatósági ügyekben másodfokú szervként jár el a Hivatal törvény szerinti ügyeiben. ${ }^{774}$ A Médiatanács szervezeti függetlensége érvényesül azáltal, hogy az $N M H H$ intézményén belül ugyan, de a sajtószabadság garanciájaként teljes önállósággal rendelkezik. Elnökét és tagjait az Országgyülés egyidejü, listás szavazással, ${ }^{775}$ azaz együttesen és egyszerre választja, ebből következően az egyes tagok megválasztása külön - külön nem történhet meg. Így elkerülhető az a korábbi helyzet, miszerint az ORTT egyes tagjai mandátumának lejárta és az új tagok megválasztásának hiánya ellehetetlenítette a médiatestület müködését. ${ }^{776}$

Az önálló hatáskörrel rendelkező szervek törvényi szabályai mindenre kiterjedően körül írják a választás elveit, a tagokkal szembeni szakmai és egyéb elvárásokat, összeférhetetlenségi feltételeket. A szabályozás ugyanakkor nem teremt kellő garanciát a

\footnotetext{
${ }^{769}$ Mttv. 111. §, 114. §, 116. §

${ }^{770}$ Mttv. 132. $\S$

${ }^{771}$ Mttv. 114. $\S(2), 110 . \S$

${ }^{772}$ Mttv. 109. $\S(2),(5)$ és (7)

${ }^{773}$ Mttv. Negyedik Rész 109. § (3)

${ }^{774}$ Mttv. 111. § (2) n), valamint Eht. 10. § (2)

${ }^{775}$ Mttv. 2014. évi XIV. törvénnyel megállapított 124. § (1) hatályos: 2014. V. 6-tól.

${ }^{776}$ Rttv. 33. § „,ORTT: éjféltöl lejár a testület mandátuma” http://www.origo.hu/itthon/20040229ortt.html
} 
megfogalmazott elvek gyakorlati megvalósításához, a szervek és tagjaik tényleges önállóságának és függetlenségének, valamint a demokratikus részvétel biztosításához. ${ }^{777}$

\subsection{Kiegyensúlyozottság felett őrködő bizottság}

A közszolgálati müsorszolgáltatók és a hírmüsorokat is szolgáltató $M V K$ müsorszolgáltatók esetében a tájékoztatás kiegyensúlyozottságának biztosítása egy, a kiegyensúlyozottság felett őrködő szervezeti egység (bizottság) feladata lett volna. A Koncepció szerint e bizottság tagjainak kinevezésére és a tagok összeférhetetlenségére vonatkozó szabályoknak biztosítania kell a médiahatóságtól, a politikától és a piactól való függetlenséget, valamint a széles társadalmi reprezentációt.

A megvalósult szabályozás a tájékoztatás kiegyensúlyozottságának általános tartalmi követelményét a belső pluralizmus jellemzőjeként, - a műsorszámok jellegétől függően az egyes müsorszámokon belül, illetve a rendszeresen jelentkező müsorszámok sorozatában írja elő. ${ }^{778}$ A kiegyensúlyozott, pontos, alapos, tárgyilagos és felelős hírszolgáltatás, valamint tájékoztatás ${ }^{779}$ követelményét pedig a közszolgálatiság credojával összhangban, annak céljaként fogalmazza meg és ellenőrzését nem önálló szervezethez, hanem a közszolgálati intézményrendszer keretein belül, a közszolgálati média- és hírközlés függetlensége felett őrködő Közszolgálati Közalapítvány Kuratóriumához telepíti. ${ }^{780} \mathrm{Az}$ intézményi megoldás erősíti a közszolgálat egységét, a követelmények megfogalmazásának pedig különösen azért van jelentösége, mert az új szabályozás nem határozza meg a közszolgálati médiaszolgáltatás fogalmát, hanem a célok megfogalmazásán keresztül közelít a közszolgálatiság ethoszához. Az Mttv. közszolgálati célja nem taxatívak és nem kizárólagosak; tartalmuk bővebb, részletesebb kifejtését a Közszolgálati Kódex tartalmazza a demokratikus nyilvánosságot, a kultúrát, valamint a közösségi és társadalmi kohézió erősítését szolgáló kötelezettségek csoportosításban.

\footnotetext{
${ }^{777} \mathrm{http}: / / \mathrm{nmhh} . h u / \mathrm{cikk} / 171474 / \mathrm{Het} \_$ev_utan_lejar_a_Class_FM_jogosultsaga_kibovitett_palyazatot_indithat_ a_Mediatanacs 2016. 08.01.

${ }^{778}$ Mttv. 12. § (2), 1/2007. (I. 18.) AB határozat.

${ }^{779}$ Mttv. 83. § (1) m)

${ }^{780}$ Mttv. 90. § (1) a)
} 


\subsection{Média Fogyasztási Jogok Képviselője versus Média- és Hírközlési Biztos}

Az alkotmányos alapjogok biztosításának garanciális eszközeként a $N A M S J K$ végleges változata javasolta a hatósági funkciókról leválasztott Média Fogyasztási Jogok Képviselöje (MFJK) jogintézményének létrehozását. Az MFJK az oktatási jogok biztosához hasonló jogállású, aki - többek között - bármely hatóságtól vagy audiovizuális médiaszolgáltatótól adatokat, nyilatkozatot, felvilágosítást vagy véleményt kérhet, továbbá elősegíti a média területén a következetes és egységes jogalkalmazást. Az alkotmányos jogokkal kapcsolatos visszásság esetén a biztos annak orvoslására ajánlást tehet a médiahatóság vezető testülete részére és az érintett audiovizuális médiaszolgáltatónak, továbbá indítványozhatja az Alkotmánybíróságnál a médiaszabályozást érintő jogszabály, valamint az állami irányítás egyéb jogi eszköze tekintetében utólagos normakontroll elvégzését vagy nemzetközi szerződésbe ütközésének vizsgálatát.

Az eredeti elképzelések szerint a média ombudsman jogintézménye az országgyülési biztosokéhoz hasonló jogi státusszal jött volna létre, különös tekintettel a véleményszabadság alkotmányos alapjoga feletti őrködés társadalmi igényére. Ez a szakmai elképzelés már a koalíciós egyeztetések során elvérzett. A Koncepció - emiatt már egy jelentősen alacsonyabb szintü jogi státuszú és hatáskörü, de magától a hatóságtól független miniszteri biztosi jogintézmény létrehozását szorgalmazta.

Az Mttv. eredeti szövege szerint a Média- és Hirközlési Biztos (Biztos, Ombudsman) a jogköre a médiaszolgáltatók, a sajtóterméket kiadók, valamint az elektronikus hírközlési szolgáltatók jogszabályt nem sértő, a Médiatanács, annak elnöke vagy az NMHH Hivatala hatáskörébe nem tartozó magatartására terjedt ki, amennyiben a szolgáltató tevékenysége az azt igénybe vevő felhasználók, előfizetők, fogyasztók, nézők, hallgatók, olvasók méltányolható érdekének sérelmét okozza vagy okozhatja. ${ }^{781}$ A Biztoshoz panasszal lehetett fordulni érdeksérelem vagy ennek közvetlen veszélye esetén, illetőleg a fogyasztói érdekek képviseletét ellátó társadalmi szervezet akkor élhetett panasszal, ha az érdeksérelem a fogyasztók jelentős számát érinti, vagy érintheti. ${ }^{782}$

A Biztos hatáskörét illetően a 2011-es Kommentár a „kizárásos” alapú értelmezést javasolja, miszerint: minden olyan média- és hírközlési igazgatási sérelem, amely nem a

\footnotetext{
${ }^{781}$ Mttv. 139. $\S(1), 140 . \S(1)$

${ }^{782}$ Mttv. 140. $\S(1)$ a)-b)
} 
Médiatanács, az Elnök vagy a Hivatal hatósági hatásköre, az a Biztos eljárásának terrénumába tartozik, ${ }^{783}$ ugyanis hatósági jogkört az Ombudsman nem gyakorolhat. ${ }^{784}$

A Biztos egy, a hivatali szervezetbe illeszkedő, az $N M H H$ elnöke által kinevezett, főosztályvezetői státuszban álló köztisztviselö, amely jogintézmény csak nevében hasonló az Országgyülés által választott biztosokhoz. A Média- és Hirközlési Biztos a szabályozás szerint ugyan sajátos médiaigazgatási és közigazgatási feladatokat lát el, azonban a jogintézményről maga a Kommentár állapítja meg, hogy az ,[...] sem szervezetét, sem müködését, sem feladatait tekintve nem éri el az alkotmányjogi jogérvényesülés, illetve államhatalmi ágak szintjét."785

Az új médiaszabályozási rezsim alapjogi kérdéseit átfogóan vizsgáló alkotmánybírósági határozatok $^{786}$ a Biztosra vonatkozó médiaszabályzást több szempontból is kritika tárgyává tették. A 165/2011. (XII.20.) AB határozat (2011-es ABH) a jogintézmény hatáskörét illetően leszögezi, hogy ,[...] a Biztos akár a szerkesztői szabadság körébe tartozó kérdéseket is vizsgálhat, [..] ami önmagában véve is a sajtó müködésébe való beavatkozás.” A biztosi jogintézményt az ABH abból a szempontból is górcső alá vette, hogy létrehozására legitim jogalkotói cél érdekében került-e sor, vagyis hogy a sajtószabadság kitüntetett társadalmi jelentősége indokolta-e a média tevékenységébe való állami beavatkozást a Biztos jogintézményén keresztül. Ennek kapcsán az Alkotmánybíróság megállapította, hogy nincs alkotmányos indoka a Biztos pontosan meg nem határozott „méltányolandó érdekek” sérelme, vagy annak veszélye esetén történő fellépésének. A jogintézmény létrehozását az $A B$ a véleményszabadság szükségtelen korlátozásának minősítette a médiaszolgáltatók és kiadók tekintetében, és különösen a szerkesztői szabadságot érintő körben állapította meg a szabályozás alkotmányellenességét. A Testület megsemmisítette a Biztosra vonatkozó teljes Mttv. szabályozást. $^{787}$

A közigazgatási és igazságügyi miniszter az Alaptörvény értelmezése tárgyában a sajtótermékek felügyeleti szervére, valamint a Média- és Hírközlési Biztos intézményére vonatkozó indítványát az Alkotmánybíróság a 21/2012. (IV. 21.) AB határozatában elutasította. A biztosi jogintézménnyel kapcsolatos miniszteri indítvány - a 2011-es ABH

\footnotetext{
${ }^{783}$ KOLTAY - LAPSÁNSZKY Kommentár 279. (A vonatkozó AB határozatok elött jelent meg.)

${ }^{784}$ Mttv. 141. § (1)

${ }^{785}$ KOLTAY - LAPSÁNSZKY Kommentár 276.

${ }^{786}$ A Média- és Hírközlési Biztos hatásköréröl ld.: 165/2011. (XII.20.) AB határozatot, valamint a 21/2012. (IV. 21.) AB határozatot.

${ }^{787}$ Mttv. Negyedik Rész III. Fejezet. 2012. V. 31-töl semmis.
} 
alapján - arra irányult, hogy a jogintézmény i) önmagában sérti-e a sajtószabadságot vagy ii) „csak” hatáskörének és jogosítványainak Mttv.-beli konkrét szabályozása nem felel meg az Alaptörvény IX. cikk (2) bekezdésben elismert és védett sajtószabadságnak.

Az első esetben az indítvány szerint a médiatartalom-szolgáltatók tekintetében a jogintézmény nem szabályozható újra, míg a második esetben a Biztos jogosítványainak szükebb, korlátozott tartalmú szabályozása a megfelelhet az Alaptörvény sajtószabadságra vonatkozó, hivatkozott rendelkezésének. Az Alkotmánybíróság megállapította, hogy az indítvány - a biztosi jogintézményt illetően - tartalmilag a 2011-es ABH értelmezésére irányul. A indítványt azon az alapon utasította el, hogy az Alaptörvény nem tartalmaz közvetlen rendelkezést a Biztost illetően, emiatt annak eldöntése, hogy az intézmény újra szabályozható-e, nem az Alkotmánybíróságra, hanem a törvényhozóra tartozik. Amennyiben a törvényhozó úgy dönt, hogy a jogintézményt fenntartja, és újra szabályozza, akkor az új szabályozás alapján, a konkrét hatáskörök ismeretében ítélhető meg a szabályozás összhangja az Alaptörvénnyel.

A jogalkotó a Biztos korlátozott, szükebb hatáskörü jogosítványainak megfogalmazásával a jogintézmény megsemmisítését követő alig egy hónappal az újra szabályozás mellett döntött. ${ }^{788} \mathrm{Az}$ új szabályozás a jogintézmény korábbi szabályozásának szerkezetét megtartotta. A 2011-es ABH megállapításainak megfelelően a Biztos nem médiaszolgáltatásra, hanem - mások mellett - a médiaigazgatásra vonatkozó szabály megsértése esetén jogosult eljárni, és a szolgáltatást igénybe vevők köre kibővült az olvasókkal. ${ }^{789}$ A fogyasztói érdekképviselet kiegészült az előfizetői, felhasználói, vagy nézői, hallgatói, olvasói érdekek képviseletét ellátó egyesületekkel ${ }^{790}$ és kikerült a Biztos ex officio eljárásának jogköre a panaszok vizsgálatából, továbbá a szabályozás differenciálta a Biztos eljárására irányadó szabályokat a közös eljárási szabályok, az elektronikus hírközlési szolgáltatásokra, továbbá a médiaszolgáltatásokra, illetve sajtótermékekre vonatkozó panaszok esetén.

Az új szabályozással kapcsolatban nem érkezett indítvány az Alkotmánybírósághoz, így az új rendelkezések Alaptörvénynek való megfelelése nem került terítékre. Vélhetően az új szabályozás, ha összhangban is van a sajtószabadság alaptörvényi rendelkezésével, a jogintézmény már eredetileg is olyan kiüresített jogosítványokkal rendelkezett, hogy

\footnotetext{
${ }^{788}$ 2012. évi LXVI. törvény, hatályos: 2012. VI. 19-töl, valamint az Mttv. ezt követő módosításai.

789 2012. évi LXVI. törvénnyel módosított Mttv. 140. § (1)

${ }^{790}$ 2012. évi LXVI. törvénnyel módosított Mttv. 140. § (1) b)
} 
azokon az Mttv. jelzett módosítása sem sokat segített. A jogintézmény - a média- és hírközlési biztos ajánlásai ellenére -, ténylegesen felveti létének szükségességét. ${ }^{791}$

\subsection{Hatósági modell}

A konvergens piacfelügyeleti intézményrendszer kialakításának kérdésében a kiindulópont az volt, miszerint, ,a konvergencia folyamatok tekintetében jelenleg még nem a napi problémák hatékonyabb felügyeleti kezelésének igénye az elsődleges, hanem a médiaszabályozási, illetve hírközlési hatáskörök világos elhatárolása, az egyértelmü hatósági kompetencia és munkamegosztás megvalósítása, valamint a költségtakarékos és független hatósági szolgáltatás feltételeinek biztosítása."792

A nemzetközi tapasztalatok is azt jelezték, hogy a megfogalmazott elvárások teljesen önálló, illetve különböző mértékben konvergens hatósági modellekben egyaránt megvalósíthatóak. Az is látható volt, hogy egy minden funkciójában (ügyfélkapcsolat, szervezet, irányítás) konvergens, $O F C O M$ típusú hatósági struktúra kialakítása több éves átgondolt elökészítést igényel. A Koncepció mindezek alapján a konvergens hatósági intézményrendszerrel kapcsolatban a fokozatosság elvét képviselte, nevezetesen azt, hogy az önálló médiahatóságot és hírközlési hatóságot rövid és középtávon fenn kell tartani, ugyanakkor az intézményi struktúrát hosszabb távon a konvergencia kihívásoknak megfelelően fejleszteni szükséges, ami indokolttá teszi a két hatóság fokozatos integrációját. A két hatóság egymáshoz való közelítésére kidolgozott forgatókönyv alapján 2010. év végéig „szükséges az $N H H$ ” (Nemzeti Hírközlési Hatóság) és az új médiahatóság jogállásának, szervezeti felépítésének harmonizációja."793

A NAMS Jogalkotási Koncepció rövid és középtávon egy új, önálló médiahatóság felállítását javasolta, és egyúttal felvázolta egy szervezetileg is integrált szabályozóhatóság szükségességét és fokozatos létrehozásának menetrendjét. „Ez a megoldás - amennyiben a szakmai szempontokat más megfontolások nem írják felül - alkalmas lehet arra, hogy a

\footnotetext{
791 A Média- és Hírközlési Biztos ajánlásai: Ajánlás méltányossági szempontok figyelembevételére a határozott idejü, úgynevezett hüségidős hírközlési előfizetői szerződésekkel kapcsolatos előfizetői panaszok és kérelmek kezelése körében (2016. 03. 30.), Ismerjük-e a gyermekek online világát? (2015. 04.13.), Megállapodás az öngyilkosságokra vonatkozó médiatudósításokról (2015. 03. 17.), A média- és hírközlési biztos ajánlása az emberkereskedelemről és a kapcsolati erőszakról szóló tudósításokhoz (2015. 03. 31.), A média- és hírközlési biztos ajánlása az öngyilkosságokról szóló tudósításokhoz (2012. 03.)

792 NAMS JK 44.

${ }^{793}$ NAMS JK 45.
} 
majdani „konvergens” hatóság kihasználja az integráció előnyeit, és elkerülje annak lehetséges hátrányait."794

A Jogalkotási Koncepció által előre vetített időpontra, 2010 végére, a médiaszabályozás megszületésének idejére egyértelművé vált az új konvergens média- és hírközlési hatóság létrehozatala, mégpedig a Koncepcióban megfogalmazott független, az Országgyülés alá rendelt intézmény formájában. ${ }^{795}$

\subsection{Szabályozási elvárások az új médiahatósággal szemben}

Az új médiahatóság vonatkozásában a NAMS JK fontosnak tartotta a politikai elfogadottságot, továbbá, hogy a hatóság megfelelő szakmai, személyi és pénzügyi autonómiával rendelkezzen. Ennek érdekében megfogalmazta azokat a szabályozási elveket, amelyekben ezen elvárások garanciáját látta.

A $J K$ ilyen elveknek tekintette i) a médiahatóság irányító szervezetének létrehozását és elnökének kinevezését az országgyülési választási ciklusnál hosszabb, öt éves időtartamra; ii) a testületi tagok mandátumának rotációs, eltérő időpontokban megszünő rendszerét; iii) az irányító testület létszámának a parlamenti frakciók létszámától eltérő, páratlan számban való meghatározását; iv) a szervezeti müködés kollektív irányítási modellen alapuló kialakítását; v) a tagok és az elnök meghívásos (jelölőlistás), szakmai kritériumok szerinti jelölését az alkotmánybírák mintájára; valamint vi) az elnök és a tagok Országgyülés által minősített szavazati többséggel történő kinevezését.

A létrejött szabályozás értelmében az elnököt a miniszterelnök javaslatára a köztársasági elnök nevezi ki kilenc évre, ${ }^{796}$ a Médiatanács elnökét és négy tagját az Országgyülés - a jelen lévő országgyülési képviselők kétharmadának szavazatával - szintén kilenc évre választja. $^{797}$

\subsection{A Hatóság Médiatanácsa és Hivatala}

A NAMS JK fontos intézményi követelményként rögzítette, hogy a médiahatóság szervezetén belül a napi közigazgatási eljárási ügyek vitele, a hivatali szint, valamint a stratégiai hatású és az intézmény vezetésével összefüggő döntések meghozatala (vezetői

\footnotetext{
${ }^{794}$ POLYÁK IV.

${ }^{795}$ NAMS JK 12., Mttv.109-110. §

${ }^{796}$ Mttv. 111/A. § (1) megállapította a 2013. évi XXXIII. törvény 2. §, hatályos: 2013. IV. 5-től.

${ }^{797}$ Mttv. 124. § (1)
} 
szint) szervezetileg is különüljön el. Ennek az elvnek az érvényesülését tapasztaljuk a Nemzeti Média- és Hirközlési Hatóság Hivatalának ${ }^{798}$ és a Nemzeti Média- és Hírközlési Hatóság Médiatanácsának ${ }^{799}$ szervezeti és hatásköri elválásában. Az Rttv. vonatkozó rendelkezéseihez képest az újdonság csak annyi, hogy korábban az Iroda (jelenleg Hivatal) nem rendelkezett nevesített hatósági hatáskörökkel.

\subsection{Tartalomtámogatás intézményi formája}

A tartalom-előállítás támogatását illetően igényként fogalmazta meg a $N A M S J K$, hogy az normatív módon, pályázati formában valósuljon meg a Müsorszolgáltatási Alap helyett létrehozandó Tartalom-támogatási Alapból. A hazai tartalomgyártás támogatási szabályrendszerének kialakítása során a Koncepció kiemelt jelentőséget kívánt tulajdonítani a közszolgálati és egyéb értékteremtő tartalom-fejlesztés pályázati alapú támogatásának, a helyi tartalmak ösztönzésének, a magyar kulturális örökség gyarapításának; a magyarországi audiovizuális szektor versenyképessége fokozásának, valamint a közszolgálati archívumok digitalizálásának. A szabályozás a Médiaszolgáltatástámogató és Vagyonkezelö Alapot, ${ }^{800}$ az MTVA-t a törvényben kifejezetten meghatározott célok megvalósítása érdekében - többek között - a közszolgálati és a közösségi médiaszolgáltatások, a közszolgálati célú műsorszámok gyártása és támogatása, az elsőként filmszínházban bemutatásra szánt filmalkotások és kortárs zeneművek támogatása, illetőleg az Archívum gondos kezelése céljából hozta létre.

A szabályozás figyelembe vette a Jogalkotási Koncepció intézményi rendszerre vonatkozó elképzeléseit, de a tényleges intézményi struktúra - nyilvánvalóan - a NAMS JK-ban lefektetett elveknél és szándékoknál differenciáltabb formában valósult meg.

\section{MÉDIAFINANSZÍROZÁS}

A Jogalkotási Koncepció a médiafinanszírozási kérdéskört együttesen kezelte, a rendszert három területen azonosította, és e területeken tartotta fontosnak források biztosítását: felügyelet müködése, közszolgálati intézményrendszer, és a pályázati alapú tartalomtámogatás. Mindhárom esetben fontos elvárásként fogalmazódott meg a finanszírozási források felhasználási céloknak való egyértelmű megfeleltethetősége,

\footnotetext{
${ }^{798}$ Mttv. 114-116. §

${ }^{799}$ Mttv. 123. §

${ }^{800}$ Mttv. 136. § (1)
} 
amelynek révén biztosítható az átláthatóság és a normativitás, továbbá csökken az ad hoc politikai és állami beavatkozás lehetősége. A médiafinanszírozás területein megoldásra várt az adott terület forrásigényének meghatározása, a forrásfelhasználás hatékonyságának növelése, illetőleg a hatékonyság-növelés módozatainak kidolgozása, valamint a finanszírozás szerkezetének, jogcímeinek és feltételrendszerének megállapítása. A forrásokat a NAMS $J K$ a háztartások célzott befizetéseiből, a médiaszektor érintett vállalkozásait terhelö elvonásokból, valamint közvetlen költségvetési juttatások formájában, továbbá - kiegészítő jelleggel - a támogatandó területeken képződő bevételekből javasolta biztosítani. Ilyen forrásokat határozott meg a Koncepció - elvi szinten - a felügyelet terén (bírságok, díjak, stb.), a közszolgálatban (reklám- és egyéb kereskedelmi bevételek, közszolgálati díj), továbbá a tartalomtámogatás során (pályázati díjak). A hatályos médiaszabályozás a Koncepció tételeinek megfelelően az MTVA bevételeiként - nem taxatív jelleggel - felsorolja a közszolgálati média finanszírozási forrásait. $^{801}$

\subsection{A felügyeleti rendszer finanszírozása}

A felügyeleti rendszerben a finanszírozás jogcímét a $N A M S J K$ - a hírközlési ágazatból vett megoldáshoz hasonlóan - a piacfelügyeleti tevékenység hatálya alá tartozó müsorszolgáltatókat terhelő piacfelügyeletért, illetve egyéb adminisztratív hatósági szolgáltatásokért járó ellenszolgáltatásban jelölte meg. A nem magyarországi bejegyzésü műsorszolgáltatók esetében a piacfelügyeleti díjat a Koncepció a müsorterjesztő szolgáltatást végző szervezetektől szándékozta beszedni és mértékét pedig a nettó árbevétel százalékában úgy kívánta meghatározni, hogy az a 2007. évi árszinten biztosítsa a hatósági müködés pénzügyi feltételeit.

A normaszöveg alapján a Hatóság és a Médiatanács a költségvetési szervek gazdálkodására vonatkozó jogszabályi rendelkezések szerint gazdálkodik és az állami vagyonkezelését is a központi költségvetési szervekre vonatkozó jogszabályok alapján

\footnotetext{
801 2011. évi CXCV. törvény 112. § (13) szerint megállapított Mttv. 136. § (3) alapján ilyen bevételek különösen: a médiaszolgáltatási díj, a pályázati díj, a müsorszolgáltatási szerződésszegési kötbér és kártérítés, a bírság, a közszolgálati hozzájárulás, a frekvenciadíjakból az Alaphoz utalt összeg, a lineáris audiovizuális médiaszolgáltatást nyújtó médiaszolgáltatók által befizetett támogatás, a központi költségvetési céltámogatások, a vagyonhasznosításból, illetve a vállalkozási tevékenységből származó bevételek, a kamatbevételek, továbbá az önkéntes befizetések.
} 
végzi. A Hatóság egységes költségvetését az Országgyülés önálló törvényben hagyja jóvá. $^{802}$

\subsection{Közszolgálati müsorszolgáltatás finanszírozása}

\subsubsection{Finanszírozási modellek}

A közszolgálat finanszírozása tekintetében a Jogalkotási Koncepció kiemelte, hogy az európai közösségi jog a közszolgálati feladatok ellentételezésének módját a tagállamok szabad választására bízza. ${ }^{803}$ Ennek megfelelően a közszolgálati müsorszolgáltatás jogszerűen megvalósulhat tisztán állami forrásokból, költségvetési támogatásból, üzemben tartási díj-bevételből stb., illetőleg a kereskedelmi bevételeket is biztosító ún. „vegyes” finanszírozási rendszer (reklámbevételek) alapján is. ${ }^{804}$

Az uniós jog közszolgálati médiafinanszírozással kapcsolatos egyik legfontosabb tétele a transzparencia, az átláthatóság követelménye, ${ }^{805}$ valamint annak elöírása, hogy a finanszírozás meghatározása a közszolgálati feladatok ellátására adott megbízáshoz kapcsolódjon. Ennek alapján javasolta a NAMS JK, hogy a közszolgálati müsorszolgáltatók finanszírozásának mértékét a feladat-meghatározás legkonkrétabb szintjén, az állam és a műsorszolgáltató közötti szerződésben rögzítsék. A NAMS JK a közszolgálat finanszírozásának kérdéskörét megvizsgálta az Alkotmánybíróság határozatainak való megfelelés szempontjából is. ${ }^{806}$ Megállapította, hogy az alkotmányossági vizsgálat alapját nem elsősorban a finanszírozási források, hanem azok felosztási módja, illetőleg az ezzel kapcsolatos döntési kompetenciák képezik; egyebekben az alkotmánybírósági gyakorlat szintén tág teret enged a szabályozás számára. ${ }^{807}$

\footnotetext{
${ }^{802}$ Mttv. 134. § (1)-(2)

803 „Az EU jogi dokumentumain túl az EBU 2007 februárjában közzétett, a közmédiumok finanszírozására is kitérő mintaszabályozása szerint a közszolgálati műsorszolgáltatási díjra vonatkozóan tanácsolt megoldásokat a nemzeti sajátosságokhoz kell igazítani.” CSEH II.

${ }^{804}$ Ld.: Müsordíj jogintézménye 6.4. alfejezet.

${ }^{805}$ Az átláthatóság követelményei a Bizottság „Transzparencia” irányelvében kerültek megfogalmazásra; az átláthatósági követelmények a közszolgálati műsorszolgáltatóknak nyújtott állami finanszírozásra is irányadók. [Közszolgálati Közlemény 2001, 2009.) Ld.: 662. lbj., 812. lbj. és 935. lbj.

${ }^{806}$ Nem teljes körü felsorolás: 37/1992. (VI. 10.) AB határozat, 22/1999. (VI. 30.) AB határozat, 47/1994. (X. 21.) $\mathrm{AB}$ határozat, 16/2004. (V. 14.) $\mathrm{AB}$ határozat, 1/2005. (II. 4.) $\mathrm{AB}$ határozat, 766/B/2002. $\mathrm{AB}$ határozat.

${ }^{807}$ UDVARY I. 136-146.
} 


\subsubsection{Közszolgálati finanszírozási elvek}

A közszolgálati médiarendszer esetében a Jogalkotási Koncepció az elsődleges finanszírozási elvnek a közszolgálati müsorokhoz való ingyenes lakossági hozzáférést tekintette. Az Mttv. a közszolgálati médiaszolgáltatás alapvető elveként határozza meg az államtól és a gazdasági szereplőktől független finanszírozási rendszert, amely biztosítja az elszámoltathatóságot és a társadalmi felügyelet megvalósulását. Az Mttv. deklarálja, hogy a közszolgálati médiaszolgáltatás müködésének biztosítása elsősorban a Magyarországon élők közös áldozatvállalásával, állami finanszírozás mellett történik. ${ }^{808}$

A Koncepció megjegyezte, hogy értékelése szerint az úgynevezett üzemben tartási díj ${ }^{809}$ központi költségvetés általi teljes körü átvállalása összességében több elönnyel jár, mint a háztartások által külön megfizetendö üzemben tartási díj visszaállítása. Az átvállalás indokaként a NAMS JK - többek között - a beszedési szervezet felállításával járó költségeket, a korábban tapasztalt alacsony fizetési hajlandóságot, valamint a közszolgálati müsorszolgáltatók és a médiafogyasztók közötti szorosabb kapcsolat bizonyíthatóságának hiányát emelte ki. A közszolgálati müsorszolgáltatás költségvetés általi finanszírozásának elszámolási alapját a $N A M S J K$ továbbra is a háztartásonként számolt „,közszolgálati díjban" jelölte meg.

A médiaszabályozás lényegében átvette a közszolgálati médiaszolgáltatás finanszírozására vonatkozó NAMS JK javaslatokat. Ennek megfelelően a magyar állam évente, a lineáris audiovizuális médiaszolgáltatások vételére alkalmas készüléket használó háztartások számát alapul véve közszolgálati hozzájárulást fizet ${ }^{810}$ az $M T V A$ részére, melynek mértékét az Mttv. 4. számú melléklete határoz meg.

\subsubsection{A közszolgálati média fokozatos mentesítése a reklámoktól}

Amint az már fentebb is kifejtésre került, a Jogalkotási Koncepció szorgalmazta a kereskedelmi/közösségi, valamint a közszolgálati müsorszolgáltatás határozott elválasztását. Ezt az elvet a Koncepció a finanszírozási rendszer felépítése során is

\footnotetext{
${ }^{808}$ Mttv. 82. § c)

${ }^{809}$ 1110/2002. (VI. 20.) Korm. határozat. Az üzemben tartási díjat 2002-ig a magyar háztartások fizették, majd figyelemmel a fizetési hajlandóságra, a háztartásonkénti összeget a költségvetés - 2002. évi árszinten, reálértéken tartva - átvállalta. A közszolgálati müsorszolgáltatás finanszírozása tárgyában ld.: CSEH II.

${ }^{810}$ Mttv. 136. § (4)
} 
fontosnak tartotta érvényesíteni, ezért szabályozási célként fogalmazta meg a lineáris közszolgálati média reklámoktól való fokozatos mentesítését.

A NAMS JK szerint a közszolgálat „reklámtalanítása” és a kereskedelmi müsorszolgáltatók közszolgálati feladatoktól való mentesítése együttesen képezi az alapját a bevezetni javasolt, a kereskedelmi müsorszolgáltatók által fizetendő közszolgálati járuléknak, amely dedikáltan a közszolgálat finanszírozására fordítódik. ${ }^{811}$ A reklámbevételekkel kapcsolatban a NAMS JK hangsúlyozta, hogy azok a közszolgálati müsorszolgáltatók esetében is jelentős bevételi források, amelyek azonnali hatállyal történő megszüntetése az intézmények gazdálkodását veszélyeztetné. A közszolgálat „reklámtalanítása” - a $J K$ értelmezésében - nem jelentette volna azt, hogy a közszolgálati intézményeknek minden kereskedelmi jellegű tevékenységükkel fel kellett volna hagyniuk. E kereskedelmi tevékenységet ugyanakkor világosan el kell választani a közszolgálati müködéstől.

A szabályozásnak e körben biztosítania kell, hogy a közszolgálati müsorszolgáltatók ne használhassanak fel kereskedelmi célokra olyan forrásokat, amelyeket eredetileg közszolgálati feladataik ellátására kaptak. A közszolgálati müsorszolgáltatónál a $J K$ az Európai Bizottság közszolgálati közleménye ${ }^{812}$ alapján javaslatba vette az állam által juttatott pénzeszközök közszolgálati feladatok érdekében történő felhasználásának számviteli szinten történő elkülönítését is a kereskedelmi tevékenységtől.

Mivel a közszolgálati müsorszolgáltatók lineáris szolgáltatásainak fokozatos kivonása a reklámpiacról a kereskedelmi müsorszolgáltatók reklámpiaci részesedését növelö tényezöként hat, a NAMS JK indokoltnak látta olyan, a kereskedelmi müsorszolgáltatókat terhelő további díj bevezetését, amely a közszolgálat reklámmentesítéséből fakadó piacbővülés méltányos részét - közszolgálati feladataik ellátásához nyújtott forrásként visszajuttatja a közszolgálati müsorszolgáltatóknak. E díj bevezetésének szándékát az is indokolta, hogy a Koncepció értelmében a kereskedelmi müsorszolgáltatók mentesülnek a közszolgálati kötelezettségek alól. E két jogcímen a kereskedelmi müsorszolgáltatókat terhelő, a nettó árbevétel százalékában meghatározott elvonást a NAMS JK 'közszolgálati járuléknak nevezte.

\footnotetext{
${ }^{811}$ NAMS JK 13.

812 Az állami támogatás szabályainak a közszolgálati müsorszolgáltatásra történő alkalmazásáról szóló bizottsági közlemény (EGT-vonatkozású szöveg) 2009/C 257/01. [Közszolgálati Közlemény 2009.] Preambulum 4. „Az állami támogatás szabályainak a közszolgálati müsorszolgáltatásra történő alkalmazásáról szóló 2001. évi bizottság közlemény volt az első, amely meghatározta a közszolgálati müsorszolgáltatás finanszírozását szabályozó keretet.” 2001. 11. 15. Ld.: 662., 805. és 935. lbj.
} 
A közszolgálati média fokozatos reklám-mentesítésével összefüggésben rá kell mutatni arra, hogy a Jogalkotási Koncepció megalkotása és nyilvánosságra hozatala idején még nem voltak láthatóak a későbbi, 2008 őszén bekövetkezett gazdasági világválság jelei, amelyek a későbbiekben a hazai reklámpiac összezsugorodását is eredményezték. Ennek következtében a jogalkotás idején a közszolgálat fokozatos „reklámtalanítása” már nem merülhetett fel reális alternatívaként.

\subsubsection{Finanszírozási megoldások egységesítése}

A NAMS JK megfontolandónak tartotta a különböző költségvetési finanszírozási megoldások egységesítését, a közszolgálati rádiós és televíziós finanszírozási arányok rögzítését, a díjak felülvizsgálatának és indexálásának szempontjait, valamint ütemezését is. 813

\subsection{Tartalom-finanszírozás}

\subsubsection{Pályáztatás}

A tartalom-előállítás támogatását a $N A M S J K$ normatív módon, pályázati formában képzelte el. A hazai tartalomgyártás támogatási szabályrendszerének kialakításához megfogalmazott célokat, úgymint a közszolgálati és egyéb értékteremtő tartalom-fejlesztés pályázati alapú támogatását, a magyar kulturális örökség gyarapítását, a helyi tartalmak támogatását a magyarországi audiovizuális szektor versenyképességének fokozását, valamint a közszolgálati archívumok digitalizálását, kiemelten kezelte. A minőségi tartalmak támogatásához a finanszírozási hátteret a Koncepció szerint az MVK, JVK státuszú szolgáltatók tartalomfejlesztési hozzájárulásai, (kötelezettség pénzbeli kiváltása) a reklámbevételekhez, előfizetői díjbevételekhez, illetve az elektronikus audiovizuális eszközök értékesítéséhez kapcsolt kulturális járulék képezték volna. A médiafinanszírozási rendszer részleteinek kidolgozása során az új kötelezettségek bevezetésének ütemezésénél és mértékének megállapításánál a NAMS JK szükségesnek tartotta pénzügyi hatásvizsgálatok végzését, illetőleg az analóg műsorszolgáltatói szerződésekből még fennálló kötelezettségek figyelembe vételét.

${ }^{813}$ Megjegyzem, a vendéglátó ipari egységek és szállodák által fizetett üzemben tartási díj beszedési hatékonyságának növelését igen, de költségvetés általi átvállalását a Koncepció sem tartotta indokoltnak. 


\subsection{2. Összhang más célrendszerekkel}

A szabályozásban a Koncepció a tartalomtámogatásnak olyan kiszámítható finanszírozási rendszerét kívánta megvalósítani, amely az egyéb támogatásokkal együtt (többek között mozgókép iparági támogatások) elősegítik a NAMS-ban vázolt célok megvalósulását. Alapvető követelményként fogalmazódott meg, hogy az audiovizuális tartalmak támogatási rendszerében egységes alapfeltételek érvényesüljenek, és hogy az audiovizuális tartalomtámogatás összhangban legyen más támogatások célrendszerével és támogatottjainak körével - mások mellett - Magyar Mozgókép Közalapítvány, Nemzeti Kulturális Alap Mozgókép Kollégiuma. A szabályozásnak a magyar tartalom-előállítás támogatása mellett hozzá kell járulnia a sokszínü tartalomkínálat kialakulásához, az európai és hazai tartalomgyártás gazdasági esélyeinek javításához, valamint a magyar nyelv és kultúra védelmének szolgálatához is. A hazai tartalomgyártás támogatásának legfontosabb eszközét a Koncepció a nyelvi kvóta elöírásában és a tartalom-előállítás pénzügyi támogatásában határozta meg. Tényként állapította meg, hogy ,[...] a magyarországi audiovizuális tartalom-elöállítás piaca nemzetközi összevetésben erőtlen, ezért a gyártási költségek piaci alapon nem vagy csak részben tudnak megtérülni, emiatt bizonyos esetekben indokolt a piaci viszonyok támogatási, illetve redisztribúciós eszközök útján történő korrekciója." ${ }^{814}$

A különböző támogatási rendszerek összhangja, illetőleg a magyar nyelv támogatása jelenik meg - többek között - a $J B E$ szolgáltató kötelezettségeként megfogalmazott új magyar filmalkotás támogatásában. ${ }^{815}$

\subsection{3. Összehangolt, stratégiai célokhoz kötött tartalom-támogatási rendszer}

A tartalom-támogatási mechanizmusok és célok újragondolásával párhuzamosan a NAMS $J K$ szükségesnek látta a Müsorszolgáltatási Alap, illetve addigi pályázati rendszerének átalakitását is. Az átalakítás elsődleges célja az volt, hogy összehangolt és a stratégiai célokhoz kötött tartalom-támogatási rendszer alakuljon ki. Kritikaként szükséges megjegyezni, hogy a Jogalkotási Koncepció legkevésbé kidolgozott rendszere a médiafinanszírozás volt. Mindenesetre a NAMS JK-ban vázolt elvek megjelennek a

\footnotetext{
${ }^{814}$ NAMS JK 49.

${ }^{815}$ Mttv. 136. § (8)
} 
hatályos médiaszabályozásban, nyilvánvalóan részletesen kibontva és koherens rendszert alkotva.

Az értekezés 6., 7., 8., 9. és 10. fejezetében kifejtett, a $N A M S J K$-BAN lefektetett általános szabályozási céloknak, valamint az egyes szabályozási területekhez kötött elveinek médiaszabályozásban való megvalósulását a függelék megvalósulási táblázata foglalja össze. $^{816}$

\section{HATÁROS JOGTERÜLETEK}

\subsection{Médiaszabályozás és a határos jogterületek általános elvi összefüggései}

Az audiovizuális média technológiai fejlődés által indukált kérdései csak a határos jogterületek bevonásával, az egyes jogterületek sajátos logikájának együttes értelmezésével válaszolhatók meg. A médiajog mint szabályozási terület elválaszthatatlanul kapcsolódik a médiapolitika fogalmához, amely minden esetben hatalmi célok elérését, eszmék érvényre juttatását jelenti a közérdek megvalósulása érdekében. ${ }^{817} \mathrm{Az}$ audiovizuális média szabályozása szempontjából a hatályos joganyagot maga a médiajog (tartalomszabályozás), továbbá leginkább a hírközlési jog, a versenyjog és - nem utolsó sorban - a szerzői jog szolgáltatja. A tartalmát, összetételét tekintve igen heterogén szerkezetű médiajog önálló jogági létének hiányát erősítik azok az álláspontok, amelyek szerint a médiajog „nem a magánjog, a büntetőjog és a közjog mellett áll, hanem a média látószögéből egyesíti e klasszikus joganyagok egyes vonatkozásait." ${ }^{818}$ Más megközelítésben a „médiajog” kifejezés önmagában is félrevezető, hiszen azt sugallja, mintha létezne olyan egységesnek mondható jogterület, amely a kommunikáció valamennyi médiumára vonatkozó jogi szabályozást tartalmaz; „márpedig ez a média esetében nem mutatható ki.",819

A digitális korszakban a szabályozás tekintetében egyrészt a kapcsolódó jogterületek egymásra utaltságát, konvergenciáját erősíti, ugyanakkor pedig az egyes jogterületekre jellemző sajátos szemléletet, megközelítési módokat is hangsúlyozza, biztosítva ez által az adott jogterület integritását. A jogi szabályozásban zajló konvergencia-folyamatok hatása abban nyilvánul meg, hogy a korábban egyetlen jogterület keretein belül is kezelhető

\footnotetext{
${ }^{816}$ Függelék Megvalósulási Táblázat.

${ }^{817}$ A médiapolitika, a közérdek fogalmáról részletesen ld.: GÁLIK - POLYÁK 23.

${ }^{818}$ Jens PETERSEN: Medienrecht, 1.Verlag C.H. Beck, München 2003.

${ }^{819}$ UDVARY Sándor I. Phd. Értekezés Tézisek 8.
} 
életviszonyok mára több önálló, de mégis összefüggő, egymással kapcsolatban álló jogi rezsim szabályozásának érdeklődési körébe kerültek. A határos jogterületek konvergenciájának sikerét, azaz a szabályozási konvergencia problémamentes modelljének kialakítását elsősorban a jogterületek célrendszerének egymáshoz való viszonya adja, nevezetesen az, hogy az adott célrendszerek mennyire hozhatók összhangba egymással. ${ }^{820}$ A médiaszabályozás és a határos jogterületek célrendszerében - az adott esetben közös vonások mellett -, az egyes határos jogterületek szemlélete, az adott jogintézmény megközelítési módja, terminológiai rendszere között lényegi különbségek vannak, amelyeket az adott terület jogalkotási folyamatában a jövőben is fenn kell tartani.

Sem a médiaszabályozásnak, sem pedig a joggyakorlatnak nem lehet célja, hogy közvetlenül az említett jogterületek szabályozási körébe tartozó kérdéseket kezeljen, ${ }^{821}$ illetőleg a médiaszabályozás körébe tartozó jogszabályok is csak rendkívüli helyzetekben terjedhetnek ki e határos jogterületek szabályozási tárgykörébe tartozó problémák rendezésére. ${ }^{822}$ A média szabályozásának, illetőleg a médiapolitikának - amint azt már részletesen kifejtettem -, a médiajog természetesen nem az egyetlen eszköze.

Egy jogszabályi rendelkezés médiajogi relevanciáját - általában a jogrendszeren belüli elhelyezkedésétől függetlenül - az adja, hogy mennyiben járul hozzá a médiaszabályozás alkotmányos célkitűzéseinek megvalósulásához és a közérdek érvényesüléséhez. A médiaértéklánc „láncszemeinek” bővülése, az előállított tartalom médiafogyasztóhoz való eljutásának egyre bonyolultabbá váló folyamata jelentős mértékben összefügg a médiapiaci koncentráció jelenségeivel is. A szabályozási konvergencia folyamata nyilvánvalóan kihat az egyes - médiával kapcsolatban álló - jogterületek önálló fejlődésére, így előtérbe kerülnek - többek között - a már említett koncentrációval kapcsolatos ágazati versenyjog, az átviteltechnika új eszközeivel összefüggő hírközlési- és szerzői jogi szabályozási kérdések, valamint e jogterületek mellett felértékelődik a különböző terjesztési platformok által eljuttatott tartalom és az ezt gyakran kitöltő szerzői alkotások védelmének szabályozási szerepe.

\footnotetext{
${ }^{820}$ SARKADY II. 280-292.

${ }^{821}$ Ilyen például az Mttv. által rendezett szerzői jogi rendelkezések között a közszolgálati média vagyon és a közszolgálati médiaszolgáltatók archívumára vonatkozó rendelkezések [Mttv. 100. §]

${ }^{822}$ Müsordíj (programdíj) kérdései [Mttv. 207. § (6)]
} 


\subsection{Médiaszabályozás és a szerzői jog}

A 2006-os médiaszabályozási reform indulásakor az egyik leglényegesebb újdonság volt a különbözö jogterületeket integráló átfogó, horizontális szemlélet megjelenése és tényleges megfogalmazása a szabályozást megalapozó Stratégiákban. A DÁS és a NAMS is egyfajta interdiszciplináris szemlélettel közelített a médiaszabályozási reform tárgyát jelentő digitális átálláshoz, illetőleg a médiapiac szabályozásához. Mindkét Stratégia szabályozási eszközrendszere kitért a szerzői jogra, így többek között a közös jogkezeléssel összefüggő állami feladatok ellátására. A tartalomszabályozással összefüggő szerzői jogi kérdésekre, különösen az audiovizuális szektort érintö jogdíjrendszerek bemutatására és hatásuk elemzésére külön szerzői jogi tanulmány ${ }^{823}$ is készült.

Az egymással határos jogterületek szabályozási konvergenciának optimális modellje a médiajog és a szerzői jog vonatkozásában az, hogy a közös célrendszer elemeit a nemzeti és az egyetemes kultúra értékeinek megőrzése, valamint újabb kulturális értékek létrehozatalának ösztönzése adja. A szerzői jogi törvény preambulumában rögzített célrendszer elemei, úgymint a nemzeti és egyetemes kultúra megóvása, a szellemi alkotások ösztönzése, a különböző érdekek közötti egyensúly fenntartása, illetőleg a szabad információhoz jutása igénye megjelenik a médiatörvények célrendszerében is.

A szerzői jog célkitűzései ugyan elsősorban nem a közérdek, hanem szerzők és más szerzői jogosultak, valamint alkotásaik védelme jegyében születtek, de a szellemi alkotások ösztönzése, valamint ezzel összefüggésben a nemzeti és egyetemes kultúra értékeinek megóvása, a magánjog keretein túlmutatva megfogalmaznak közösségi érdekeket is.

A szerzői jog célrendszerével szemben a médiajogi szabályozás elsősorban a közérdekű célkitüzéseken alapszik. Az első médiatörvény megalkotására - preambuluma szerint - a szabad és független rádiózás és televíziózás, a véleménynyilvánítás szabadsága, a tájékoztatás függetlensége, kiegyensúlyozottsága és tárgyilagossága, a tájékozódás szabadsága, valamint az egyetemes és a nemzeti kultúra támogatása, a vélemények és a kultúra sokszínűségének érvényre juttatása, továbbá a tájékoztatási monopóliumok kialakulásának megakadályozása érdekében került sor.

${ }^{823} \mathrm{Ld}: 9 . \mathrm{lbj}$ 


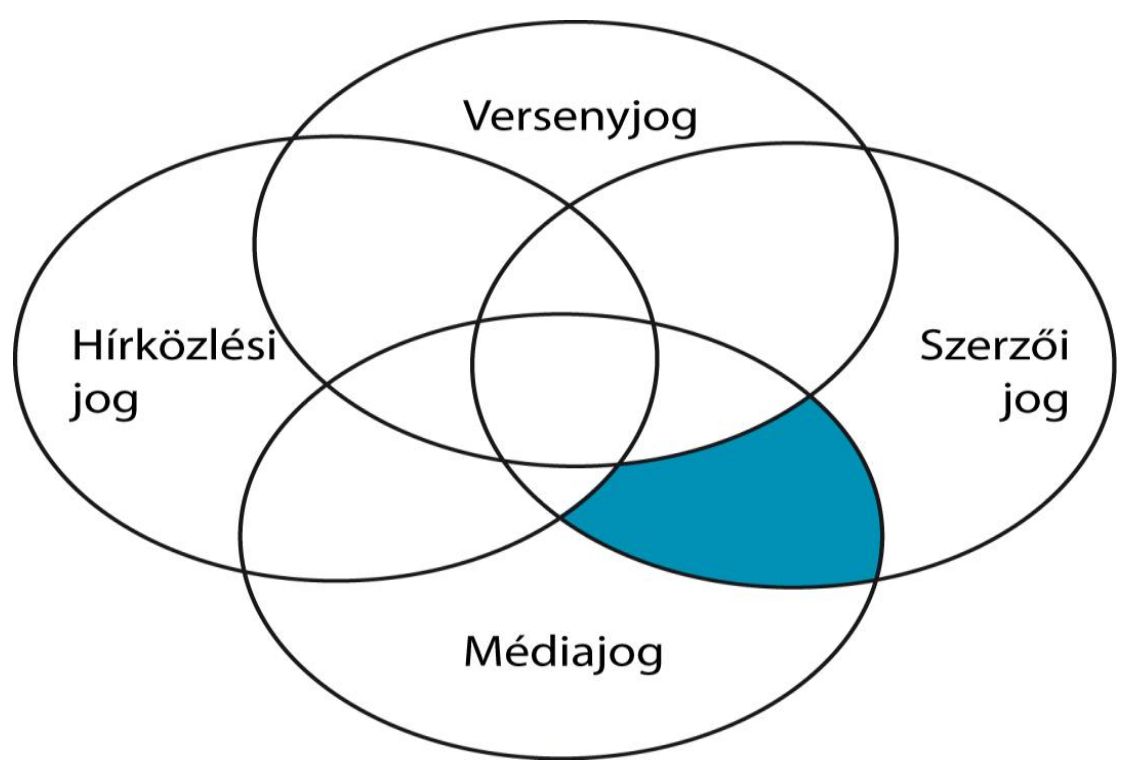

17. ábra A médiajoggal határos jogterületek és a szerzői joggal való átfedések ${ }^{824}$

A NAMS müsorszolgáltatói szegmensben megfogalmazott célkitüzései a következők:

a) a médiapluralizmus biztosítása az erős közszolgálatiság, illetőleg a kereskedelmi müsorszolgáltatók sokszínü csatornaválasztéka által;

b) diverzifikált, minőségi, a sokszínű vélemények megjelenését biztosító országos és helyi médiaszolgáltatás létrejöttének elösegítése;

c) a kulturális és nyelvi sokszínüség érvényesítése, a magyar és európai tartalmak előállításának ösztönzése és a médiafogyasztókhoz való eljuttatása - különösen a közszolgálati müsorszolgáltatásban;

d) az emberi méltóság és a közrend védelme, a gyermekek, a személyhez füződő jogok és a kisebbségek védelme.

Az Smtv. preambuluma szerint az Országgyülés ,„...] a véleménynyilvánítás és a szólás, valamint a sajtó szabadságát, a médiaszolgáltatások kiemelkedő kulturális, társadalmi és gazdasági jelentőségét és a médiapiaci verseny biztosításának fontosságát figyelembe véve" alkotta meg a törvényt.

Az Mttv. bevezetőjében a közösség és az egyén érdekeinek felismerése, a társadalom integritásának előmozdítása, a demokratikus berendezkedés megfelelő müködésének és a

${ }^{824}$ A szerző előadásanyaga: A sajtó- és médiajog aktuális kérdései, Infokommunikációs Szakjogász képzés 1996-2014, valamint Szegedi Tudományegyetem ÁJK: A média-értéklánc szerzői jogi vonatkozásai 2013. 04.09. 
nemzeti, valamint kulturális identitás megerősítése, továbbá a véleménynyilvánítás és a szólás, valamint a sajtószabadság megóvása fogalmazódik meg a célok között. A Preambulum hangsúlyozza a médiaszolgáltatások kiemelkedő kulturális, társadalmi és gazdasági jelentőségét, valamint a médiapiaci verseny biztosításának fontosságát is.

A szerzői jog és a médiajog célrendszerének átfedései az új médiaszabályozásban tételes rendelkezések formájában is jelentkeznek, és várhatóan a jövőben - a folyamatos technológiai megújulás következtében - egyre jelentősebbé is válnak.

Már az első médiatörvényünk is tartalmazott szerzői jogi vonatkozású rendelkezéseket. Az Rttv. így elöírta, hogy a müsorszolgáltató nem mutathat be filmalkotást a szerzői vagy szomszédos jogi jogosulttal kötött megállapodásban meghatározott időszakon kívül; a müsorszámok reklámmal történő megszakítása során kifejezetten utalt a szerzői jogi jogosultak jogainak és jogos érdekeinek védelmére; szankciórendszerét az Szjt. esetére is alkalmazhatóvá tette; továbbá a müsorterjesztőknek a hatósági nyilvántartásba vétel során igazolniuk kellett a szerzői jogok és a szerzői jogokhoz kapcsolódó jogok védelméhez a szükséges intézkedések megtételét. ${ }^{825}$

\subsection{A NAMS-hoz kapcsolódó és azon túli szerzői jogi intézmények}

A NAMS az új médiaszabályozáshoz kapcsolódó szerzői jogi kérdéseket a digitális átállással összefüggésben, ${ }^{826}$ de azokat kiegészítve vizsgálta. Mivel a digitalizáció eredményeképpen jelentősen bővült átviteli kapacitás szükségszerűen megnövelte a már digitális formátumban készült audiovizuális tartalom iránti igényt, a korábban analóg tartalmak csak akkor őrizhetik meg értékállóságukat, ezáltal hasznosítási lehetőségüket, ha technológiai digitalizálásuk is megtörténik. E célból már a $D A S^{827}$ rögzítette, hogy a digitális archiválás érdekében a digitális átírást a közszolgálati műsorszolgáltatók esetében támogatni kell, továbbá javasolta a jogdíjak olyan rendszerének kialakítását is, amely lehetővé teszi az archívumok gazdaságos hasznosítását. A DÁS szükségesnek látta a magántulajdonban lévő archívumok felmérését és digitalizálásuk állami támogatásokkal

\footnotetext{
${ }^{825}$ Rttv. 4/A. §, Rttv. 17. § (2) és (6), Rttv.1 2. §. valamint az Rttv. 116. § (2) b) [átkerült a Dtv. 6. § (4) bekezdésébe]

${ }^{826}$ Itt is szükséges utalni arra, hogy a szerzői jog digitális technológia által felvetett, új szabályozási kérdéseinek rendezésére az EU intézményei igen későn, csak 2016. szeptember 14-én megjelent dokumentumokban tettek javaslatot. Ld.: 546 . lbj., 562. lbj. és $981 . \mathrm{lbj}$.

${ }^{827}$ DÁS 91. 25.
} 
való megoldását is, valamint a Nemzeti Audiovizuális Archívum (NAVA) e folyamatokban való szerepvállalását, illetőleg egy egységes állami archívum létrehozatalát. ${ }^{828}$

A Digitális Stratégia a szerzői jogi vonatkozásokkal a szabályozás kapcsán is foglalkozott. ${ }^{829}$ Azon túl, hogy a szerzői jog audiovizuális médiában növekvő jelentőségét mindkét Stratégia hangsúlyozza, a szakmai - társadalmi vitára bocsátott Stratégiák szerzői jogi kérdéseivel kapcsolatban a média-értéklánc szereplői saját pozíciójukból kiindulva javasolták a szerzői jog releváns intézményeinek vizsgálatát.

A műsorszolgáltatók kezdeményezték például a közös jogkezelő szervezetek díjszabásának átfogó és részletes elemzését, valamint a müsorszolgáltatói kettős, felhasználói és szomszédos szerzői jogi teljesítményt nyújtó szerepkörének figyelembevételét. Mivel a digitalizációval a tartalmak és az azokban felhasznált szerzői müvek mennyisége is jelentősen megnő, a közös jogkezelés körébe tartozó díjak szabályozó jellege elsősorban a piaci szereplők szerkesztői tevékenységére van hatással.

A Szerzői Jogi Tanulmányhoz összeállított kérdőív kitöltése során a megkérdezett műsorszolgáltatók, valamint közös jogkezelő szervezetek eltérően ítélték meg a jogdíjak hatását a müsorokba szerkesztett tartalmakat illetően. Az MTV álláspontja szerint a müsorszolgáltató a magas magyar jogdíjak miatt kénytelen előnyben részesíteni a külföldi alkotásokat a hazaival szemben, ez utóbbiak pedig versenyhátrányba kerülnek a belföldi piacon. Az M-RTL jogdíjakkal kapcsolatos felhasználói válasza szerint a jogdíj, mint költségtényező a kalkuláció szerves részét képezi a szerkesztői döntések meghozatala során és komoly súllyal esik latba a jogdíj mértéke, valamint kiszámíthatósága, kalkulálhatósága is. A TV2 hasonlóan ítélte meg a jogdíjak szerepét a szerkesztői döntésekre; válaszában jelezte, hogy például azért sugároz csak elenyésző számban videoklipeket a müsorában, mert a videoklipek filmcsíkjának sugárzása után a jogkezelő jelentős mértékü díjat számít fel. A TMSZ kiemelte a jogdíjak magyar gyártású alkotások piaci versenyére gyakorolt negatív hatását. A műsorszolgáltatók ugyanis - gazdaságossági megfontolások miatt - a külföldi alkotásokat részesítik előnyben a magasabb hazai jogdíjas magyar alkotásokkal szemben. A magyar gyártású nagyjátékfilm, televíziós filmsorozat és dokumentumfilm kategóriák sugárzási jogdíjai ugyanis 4,5-5 x kerültek többe, mint a külföldröl beszerzett ilyen jellegü alkotások. A T-Online a hazai közös jogkezelők által

\footnotetext{
${ }^{828}$ GYENGE Anikó: A média-konvergencia hatása a szerzői jogban: az ismeretlen felhasználási módra vonatkozó szerződési kikötések érvénytelenségének problémája (1. rész) Infokommunikáció és Jog 2006/1. $17-22$.

${ }^{829}$ DÁS 156-160, 38-39.
} 
alkalmazott jogdíjak mértékét összességében tartotta túlzónak, azt mintegy 20 százalékkal értékelte magasabbnak az európai átlagnál. A müsorszolgáltatók egyöntetű véleménye szerint a jogdíjak mértéke ${ }^{830}$ egyértelmüen negatív hatást gyakorol az audiovizuális szektorra, az egyes müsorszolgáltatók müsorösszetételére és a magyar alkotások versenyképességére a hazai piacon. Ezzel szemben a közös jogkezelő szervezetek álláspontja szerint a jogdíjaknak azért nincs jelentős hatása az audiovizuális iparágra, annak versenyképességére, mivel a jogdíjak versenysemlegesek és alkalmazásuk során az egyenlő elbánás elve érvényesül. ${ }^{831}$

A $D A ́ S$ a díjszabási eljárásban - az akkori müvelődési, illetőleg az igazságügyért felelős miniszteri döntési mechanizmus és kontroll során - szükségesnek tartotta a digitális átállás szempontjainak figyelembevételét is. A $D A ́ S$ szorgalmazta az új technológia következtében előálló „tartaloméhség” enyhítése érdekében olyan általános jogdíjszint kialakítását, amely a hazai müvek megalkotását és müsorokban való felhasználását a lehető legkedvezőbb feltételekkel biztosítja, ugyanakkor a szerzők, alkotók számára is megfelelő bevételt biztosít. Szintén a jogdíjakkal kapcsolatos elvárásként fogalmazódott meg a digitálisan terjesztett csatornák részére a kedvezményes díjmérték megállapítása.

A NAMS a $D A ́ S$ által tárgyalt szerzői jogi szabályozási elveket továbbfejlesztette és kiegészítette. Rámutatott a filmarchívumok szerzői jogi helyzetére, illetőleg feltárásuk és szerzői jogi szabályozással történő támogatásuk szükségességére, a digitális felhasználási módok szerzői jogi leképezésének, valamint a digitális jogvédelmi rendszer kialakításának indokoltságára.

\subsubsection{A közös jogkezelés kérdésköre a NAMS alapján}

1. Közös jogkezelés lényege a digitális korban ${ }^{832}$

A digitális technológia elterjedése, különösen az internet megjelenése nemcsak a hagyományos rádiózás és televíziózás számára teremtett olyan technikai és technológiai „riválisokat”, amelyek eszközrendszereik révén időben és térben korlátlan teret nyitottak az emberi kommunikáció számára, hanem a szerzői müvek létrejöttének és felhasználásának is új módozatait teremtették meg. Az eredeti, egyéni jelleget tükrözö, ex

\footnotetext{
${ }^{830}$ A Szerzői Jogi Tanulmány megállapítása szerint különösen az MSZSZ-EJI, valamint az ARTISJUS jogdíjai kirívóan magasak.

${ }^{831}$ Szerzői Jogi Tanulmány 170-174.

${ }^{832}$ GRAD-GYENGE-SARKADY 15-20.
} 
lege védett szerzői alkotásoknak nemcsak terjesztése, többszörözése, hanem létrehozatala is korlátlanná vált. A tömeges müfelhasználás több mint két évszázados intézményrendszere, ${ }^{833}$ a közös jogkezelés is csak újra értelmezett szerepkörben képes kezelni a digitális formában létrehozott müvek, a szerzők és más jogosultak jogait és ellátni védelmét. A szerzői közös jogkezelés, a szerzői művek és kapcsolódó jogi teljesítmények tömeges felhasználásának professzionális kezelése, a felhasználás engedélyezése, a jogdíjak megállapítása és beszedése, valamint a szerzők és más jogosultak jogainak érvényesítése a digitális tartalmak megjelenésének világában, a 20. század végétől a digitális jogkezelés - a digital right management (DRM) - segítségével volt értelmezhetö. A NAMS-hoz készített Szerzői Jogi Tanulmány is - ennek megfelelően - nagy teret szentelt a szerzői jogi védelem szempontjából jelentős védelmi rendszer bemutatásának. ${ }^{834}$ A DRM kifejezetten informatikai védelmi rendszerként jelent meg az 1970-es évek közepén. A különböző számítógépes platformokra kidolgozott müszaki megoldások többnyire szoftveres és hardveres másolásvédelmi rendszerek voltak, így a $D R M$ e jelentése nem is kötődött a szerzői joghoz. A kezdetben informatikai másolásvédelmi rendszerek továbbfejlesztett és kiterjesztett változatai lettek képesek a szerzői jogi védelem alatt álló művek illegális másolása és többszörözése elleni küzdelemre is.

A szerzői művek védelmére alkalmas $D R M$ müszaki megoldások többsége valamennyi szerzői jogi müfajra használható, de egyes alkalmazások kifejezetten csak egyes müfajok védelmére irányulnak. ${ }^{835} \mathrm{~A} D R M$ összetett, a nemzetközi szakirodalomban sem egységes fogalom, ${ }^{836}$ amely egyfelől a digitális formában előállított és megjelenített tartalmakhoz kapcsolódó, az azokhoz való hozzáférést az alkotó, illetőleg a jogosult döntésétől függővé tevő műszaki megoldásokat foglalja magában, másfelől pedig - szükebb értelemben „hatásos müszaki intézkedés”, a „technological protection measure”, a TPM fogalmát fedi le.

A DRM azonban nem feltétlenül csak a jogosítást és a másolásvédelmet jelenti, hanem egy következő meghatározásában a jogkezelési adatok fogalmával is megegyezhet. (rights management information). „Jogkezelési adat a jogosultaktól származó minden olyan adat, amely a mủvet, a szerzőt vagy a müre vonatkozó jogok más jogosultját azonosítja, vagy a

\footnotetext{
${ }^{833}$ GRAD-GYENGE-SARKADY 15-27., részletesen ld.: GERA Eleonóra Erzsébet - CSATÁRI Bence: A zeneszerzök szövetkezetétöl az Artisjus Egyesületig 1907-2007. Budapest, Artisjus, 2007. (GERACSATÁRI)

${ }^{834}$ Szerzői Jogi Tanulmány 13-29. 33-40.

${ }^{835}$ Szerzöi Jogi Tanulmány 34-36.

${ }^{836}$ MEZEI Péter: A DRM rendszer szerzöi jogi aspektusai arsboni jogi folyóirat 2013.11. 21. (MEZEI II.)
} 
felhasználás feltételeiről tájékoztat, ideértve az ilyen adatokat megjelenítő számokat vagy jelzéseket is, feltéve, hogy az adatokat a mü példányához kapcsolják, illetve a münyilvánossághoz történő közvetítésével összefüggésben jelenik meg." ${ }^{837}$

A DRM továbbá azonosítható a micro payment (elektronikus fizetés) rendszer fogalmával is, de legtágabb értelemben a digitális tartalmakhoz kapcsolódó azon technológiákat, eljárásokat foglalja magában, amelyek lehetővé teszik a digitális művek azonosítását, a hozzájuk füződő jogok kezelését, a tartalom felhasználásának szabályozását, a felhasználói magatartások kontrollját, és a jogdíjak megfizetését. ${ }^{838}$ Legegyszerübb és egyben a legtalálóbb meghatározása szerint „a $D R M$ nem más, mint digitális adattartalmakra vonatkozó jogok kezelése." ${ }^{, 39}$

Az Szjt. meghatározásában müszaki intézkedés minden olyan eszköz, alkatrész vagy technológiai eljárás, illetve módszer, amely arra szolgál, hogy a szerzői jog jogosultja által nem engedélyezett cselekményeket - rendeltetésszerü müködése révén - megelőzze, illetőleg megakadályozza. A müszaki intézkedés akkor hatásos, ha a mü felhasználását a jogosultak a hozzáférést ellenőrző vagy védelmet nyújtó olyan eljárás útján ellenőrzik, amely alkalmas a védelem céljának elérésére. Ilyen eljárásnak számít különösen a kódolás vagy a mü egyéb átalakítása, illetve a másolatkészítést ellenőrző mechanizmus. ${ }^{840}$

A jogosultak és a felhasználók közötti küzdelemben mindkét fél ,,az általa jogosnak vélt előjogok megtartására, esetleg kiszélesítésére törekszik, ${ }^{, 841}$ a $D R M$ feladata mégis egyfajta egyensúlyi helyzet biztosítása az egymással szemben álló felek számára, egyfelől a felhasználók részére a különböző tartalmak korlátlan megismerési lehetőségének megteremtésével, másfelől pedig a müvek, a szerzők és más jogosultak védelmével a kifejlesztett technológiai rendszerek által.

2. Jogkezelési modellek, a közös jogkezelés szervezeti formái és más tulajdonságai, nemzetközi összehasonlításban

\footnotetext{
${ }^{837}$ Szjt. 96. § (2)

${ }^{838}$ Current Developments in the Field of Digital Rights Management, Standing Committee on Copyright and Related Rights, Tenth Session Geneva, November 3 to 5, WIPO, SCCR/10/2 Rev. May 4 2004. 4-22. ${ }^{839}$ MEZEI II.

${ }^{840}$ A DRMS szerzői jogi szabályozásának jogi alapjairól a WCT 12. és a WPPT 19. cikke alapján az INFOSOC irányelv 7. cikke rendelkezik. Szjt. 95. § (4)

${ }^{841}$ MEZEI Péter: A digitális technológia kihivásai a szerzői müvek szabad felhasználására Doktori Értekezés Tézisek Szeged, 2009 (MEZEI III.)
} 
A szerzői művekkel kapcsolatos jogkezelés történeti fejlődésében az egyéni felhasználásengedélyezése és jogdíj-érvényesítése a tömeges felhasználás lehetőségével a csoportos és professzionális jogkezelés irányába tolódott.

\section{1) Egyedi jogkezelés}

Az egyedi jogkezelés esetében a szerzők és más jogosultak közvetlenül adnak engedélyt müveik felhasználására; egyedi polgári jogi szerződés keretében állapítják meg a felhasználás feltételeit, díját és a felhasználókkal szemben - közbeiktatott szervezet nélkül - közvetlenül érvényesítik a müvel kapcsolatos jogaikat. Ilyen egyedi a felhasználás érvényesül az audiovizuális médiaszolgáltatók által előállított szomszédos jogi teljesítmény, a műsortartalom felhasználása tekintetében. Mivel a médiaszolgáltató müsorában szerzői alkotások, pl. filmek közvetítésére is sor kerül, a filmek jogszerü átengedése más médiaszolgáltató részére csak akkor lehetséges, ha erre a film terjesztőjével kötött jogátruházási szerződés is lehetőséget ad. ${ }^{842}$

\section{2) Csoportos joggyakorlási modellek}

A nem közvetlenül a jogosult által végzett engedélyezési, díj megállapítási és beszedési, valamint a szerzők jog- és érdekérvényesítő tevékenységének, a csoportos joggyakorlásnak történetileg többféle módja, szervezeti formája alakult ki.

a) Ügynökségi modell

A valamilyen közvetítő személy/közvetítő szervezet által végzett csoportos jogkezelés egyik módja az ügynökségi modell, amelyben a profitorientált ügynökség a hagyományos értelemben vett engedélyezési, jogdíjkezelési tevékenységen túl a jogosult helyett, annak nevében vagy a saját nevében, de a jogosult javára, a vele kötött egyedi polgári jogi (többnyire megbízási) szerződés alapján ellátja a jogosult teljes körü képviseletét a szerzői mü minél hatékonyabb kereskedelmi hasznosítása érdekében és teljes folyamatában. Ilyen jellegű egyedi jogviszony jön létre például a filmstúdiók és a felhasználók, továbbá a filmelöállítók és/vagy a színész-, forgatókönyvíró ügynökségek között.

${ }^{842}$ FALUDI Gábor: A felhasználási szerződés KJK 1999. (FALUDI I.) 26. 


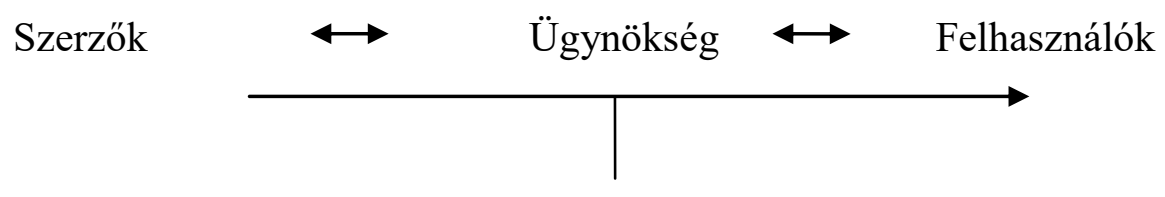

„közvetítői” pozíció

atipikus ügynöki megbízás, a szerzők nevében eljárva, teljes körü képviselet a hatékony müértékesítés érdekében

\section{8. ábra A csoportos joggyakorlás ügynöki modellje}

b) Közös jogkezelési konstrukció

A közös jogkezelés intézményesített rendszere a csoportos jogkezelés ügynökségi modelljénél fejlettebb jogi-szervezeti forma, amelyben a szerző és más jogosult jogkezeléssel kapcsolatos döntési jogkörét, valamint a jogkezelés részletes feltételeit és elöírásait speciális jogszabályok rendezik.

A közös jogkezelés intézményének egyes európai államokban létrejött szervezeti formáit, a jogintézmény monopolhelyzetének sajátosságait, valamint az alapítás, a müködés és a gazdálkodás jellemzőit a NAMS célrendszere szempontjából a nemzetközi jogdíjrendszerekkel összefüggésben volt célszerü vizsgálni. A vizsgálat alapját a szerzői közös jogkezelés intézményének - a különböző tarifarendszerekkel összefüggő közgazdasági megközelítése adta. A közös jogkezelő szervezetek eljárása egy sajátos bizományosi jogálláshoz közelitő konstrukció keretében zajlik, mivel a jogkezelők ugyan a képviselt szerzők és más jogosultak érdekében és javára, de mindig a saját nevükben járnak el; intézkedéseikben és vagyonkezelési tevékenységükben - a törvény keretei között nagyfokú önállósággal rendelkeznek. A Legfelsöbb Bíróság egy döntésében elvi éllel kimondta, hogy az Szjt. alapján a szerzői jogok közös jogkezelését végző szervezet jogállására a Ptk. megbízásra vonatkozó szabályai közvetlenül nem alkalmazhatók. A közös jogkezelő - ennél fogva - csak abban a körben és olyan adatok szolgáltatására köteles a szerző felé, amely adatok a közös jogkezelő tevékenység eredményeként az Szjt. alapján szükségképpen a rendelkezésére állnak. ${ }^{843}$

${ }^{843}$ Pfv. IV.20.273/2008/7. Az új Pp. bizonyítási szükséghelyzet szabálya ezt a kérdést megoldja. 220. § (1) 
Szerzők

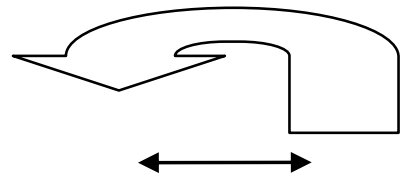

Közös jogkezelő

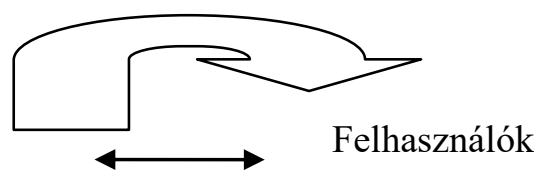

szervezet

Szerzői jogosultak

jogkezelési szolgáltatások jogérvényesítés

felhasználás engedélyezése jogdíjak beszedése

Jogszabályban rendezett jogi-szervezeti forma, quasi bizományosi jogállás, a közös jogkezelő saját nevében jár el, nagyfokú önállóság a vagyonkezelés, döntési, intézkedési jogkörökben a jogszabály keretei között

\section{9. ábra A közös jogkezelés általános modellje}

A digitális környezetben a szerzői jogok kezelése újabb és újabb kihívások elé állítja a közös jogkezelő szervezeteket, és már a NAMS megalkotásának idején versenyhelyzet alakult ki a hagyományos jogkezelés, illetve az új megoldási módok, így például a digitális jogkezelés rendszer, a DRMS között. ${ }^{844}$

A közös jogkezelés intézménye a NAMS készítése idején, uniós szinten nem volt szabályozva. Az igen változatos nemzeti szabályozások lényegi elemeinek összehangolására, illetőleg a zeneművek online felhasználására időközben európai uniós jogforrás született. ${ }^{845} \mathrm{Az}$ irányelv részletes elemzése nélkül, ${ }^{846}$ a 2006 és 2011 közötti nemzetállami gyakorlat bemutatása előtt célszerü az irányelv legfőbb céljait, a nem online zenefelhasználást végző, valamennyi közös jogkezelő szervezetre vonatkozó rendelkezéseit ${ }^{847}$ röviden ismertetni.

E rendelkezések elsősorban a közös jogkezelő szervezetek müködésére, a működés és gazdálkodás átláthatóságára, valamint a tagjaik és jogosultak általi elszámoltathatóságára vonatkozóan állapítanak meg a nemzeti szabályozásban is követendő előírásokat. Az

\footnotetext{
${ }^{844}$ Szerzői Jogi Tanulmány 13.

${ }^{845}$ Az Európai Parlament és a Tanács 2014/26/EU Irányelve (2014. február 26.) a szerzői és szomszédos jogokra vonatkozó közös jogkezelésröl és a zenemüvek belsőpiacon történő online felhasználásának több területre kiterjedő hatályú engedélyezéséről (KJK irányelv)

${ }^{846}$ A KJK irányelv-tervezet részletes elemzését ld.: GRAD-GYENGE-SARKADY 156-168.

${ }^{847} \mathrm{KJK}$ irányelv (1)-(36)
} 
irányelv a szerzői és szomszédos jogok kezelése körébe vonja a müvek felhasználók számára való engedélyezését, a felhasználók ellenőrzését, a jogok gyakorlásának figyelemmel kísérését, a szerzői és szomszédos jogok érvényesítését, a jogok gyakorlásából származó jogdíjbevételek beszedését és a jogosultakat megillető összegek felosztását. $^{848}$

Itt szükséges megjegyezni, hogy a KJK irányelvet átültető 2016-os szerzői jogi törvényt, ${ }^{849}$ illetőleg annak végrehajtása tárgyában megjelent kormányrendeletet ${ }^{850}$ megelőzően a hazai szerzői jogi szabályozásban a közös jogkezelő szervezeteket az Szjt. 2011. évi módosítása $\left(\right.$ MódSzjt.) ${ }^{851}$ érintette leginkább. E törvénymódosítás főbb rendelkezéseinek ismertetésére azért is szükséges majd kitérni, mert a MódSzjt. közös jogkezelőkre vonatkozó szabályairól a Nagykommentár már 2014-ben kijelentette, hogy azok a közös jogkezelési irányelvnek túlnyomórészt már ma is megfelelnek. ${ }^{852}$

Visszatérve a KJK irányelvhez, az a szerzői és szomszédos jogok kezelésén túl a közös jogkezelő szervezet fogalmát is meghatározza. ${ }^{853}$ A valamennyi közös jogkezelő szervezetre irányadó rendelkezések célja, hogy az irányítás, a pénzügyi gazdálkodás, az átláthatóság és a beszámolás magas szintü biztosítása érdekében meghatározza a közös jogkezelő szervezetekre vonatkozó követelményeket. Az irányelv deklarálta a közös jogkezelő szervezetek szabad szervezeti-jogi formaválasztását, továbbá - mások mellett az audiovizuális művek előállítói, a müsorsugárzó szervezetek, valamint lapkiadók számára a saját jogosultságaikkal való szabad rendelkezés jogát és más közös jogkezelő szervezetekkel a képviseleti szerződéskötés lehetőségét. Mivel - többek között - az audiovizuális művek előállítói és a műsorsugárzó szervezetek a saját jogaikon túlmenően például az előadóművészi jogokkal is rendelkeznek, továbbá a lapkiadók az egyedi megállapodások révén a rájuk testált jogokkal is bírnak és saját érdekeik szem előtt tartásával járnak el, sem az audiovizuális médiaszolgáltatók, sem a müsorsugárzó

\footnotetext{
${ }^{848}$ KJK irányelv Preambulum (2)

${ }^{849}$ 2016. évi XCIII. törvény a szerzői jogok és a szerzői joghoz kapcsolódó jogok közös kezeléséröl. Az Országgyülés 2016. június 13-i ülésnapján elfogadva. (Kjkt.)

${ }^{850}$ 216/2016. (VII. 30.) Korm. rendelet a közös jogkezelő szervezetek és a független jogkezelő szervezetek müködésének és a jogkezeléssel kapcsolatos eljárások részletes szabályairól.

${ }^{851}$ 2011. évi CLXXIII. törvény a szellemi tulajdonra vonatkozó egyes törvények módosításáról Megjegyzés: 2011. évben az Szjt-t módosító másik törvény a 2011. évi CCI. törvény, az egyes törvények Alaptörvénnyel összefüggő módositásáról. A dolgozat az Szjt. 2011. évi módosításáról szóló törvényt a közös jogkezelésre vonatkozó rendelkezések megváltozása szempontjából nevezi az „Szjt. 2011. évi módosítása”-nak, vagy MódSzjt-nek.

${ }^{852}$ GYERTYÁNFY Péter (szerk.) Nagykommentár a szerzöi jogi törvényhez Wolters Kluver Complex 2014. (GYERTYÁNFY II.) [GYERTYÁNFY Nagykommentár] 499.

${ }^{853} \mathrm{KJK}$ irányelv 3. cikk a)
} 
szervezetek, sem pedig a kiadók nem minősülnek „független jogkezelő szervezetnek” az irányelv alapján. ${ }^{854}$

A KJK irányelv rögzítette, hogy a rádió- és televízió-szervezetek műsorának online sugárzásához a zeneműveken fennálló önálló jogok külön engedélyezésére van szükség, ${ }^{855}$ illetőleg a sugárzáshoz kötődő online felhasználásokat, pl. a müsorarchívumok on-demand hozzáférhetővé tételét a helyi közös jogkezelö engedélyezheti.

A közös jogkezelés nemzetállami gyakorlatában kialakult további jellemzők összehasonlító elemzését a következőkben végzem el. ${ }^{856}$

3. A közös jogkezelés más tulajdonságai

\section{1) Jogi-szervezeti forma}

Európában a közös jogkezelők különböző jogi-szervezeti keretek között, profit és nonprofit szervezeti formában müködnek. Portugáliában, Spanyolországban és Szlovéniában; törvényi rendelkezés alapján nem lehet a közös jogkezelő nyereségérdekeltségü szervezet (not for profit legal entities) például Lengyelországban és Szlovákiában. Kifejezett nemzeti törvényi előírás határozza meg a közös jogkezelő jogi szervezetét egyesületi formában (cseh, észt, francia, lett, litván és magyar törvényhozás). A többi európai államban, így például Belgiumban, Dániában, Máltán, Hollandiában, Írországban és az Egyesült Királyságban a közös jogkezelők - jogszabályi rendelkezés hiányában - lehetnek profitorientált kereskedelmi, gazdasági vagy más jellegü jogi személyek is.

A német szabályozás ${ }^{857}$ nem nevezi meg konkrétan a közös jogkezelés kötelező jogiszervezeti formáját, nem írja elő az egyesületi formát a közös jogkezelők számára, hanem lehetővé teszi, hogy a jogkezelési tevékenységet jogi személyként vagy egyéni közösségek formájában végezzék, sőt azt magánszemélyek is elláthatják. A gyakorlatban a közös jogkezelők a számukra legmegfelelőbb, optimális szervezeti keretek között gazdasági célú egyesületek (GEMA) vagy korlátolt felelősségü társaságok (GLV) szervezeteként működnek. Bár van olyan német szakmai álláspont is, miszerint a közös jogkezelők minél

\footnotetext{
${ }^{854}$ KJK irányelv Preambulum (16)

${ }^{855}$ KJK irányelv Preambulum (48)

${ }^{856}$ A Szerzöi Jogi Tanulmány a KEA Vizsgálata (2007) alapján készült, az EU akkori 25 tagállamának gyakorlata szerint. Az értekezés ezen túlmenően $\mathrm{SE}, \mathrm{AT}, \mathrm{DE}, \mathrm{EE}, \mathrm{FR}$ és UK vonatkozásában, egyes kérdésekben figyelembe veszi a 2011. május 1-ig fellelt tagállami szabályozásokat is. (KEA European Affairs, July 2006. The Collective Management of Right sin Europe. The Quest of Efficiency)

${ }^{857}$ Ulrich HIMMEMLMANN: Verwertungsgesellschaften und Staatsicht - Vergleichende Anmerkungen aus deutscher Sicht In: Schriften zum Europäischen Urheberrcht, Karl RIESENHUBER (Hrsg.) Wahrnehmungsrecht in Polen, Deutschland und Europa Band 1, INTEGRU-Tagung 2005. 34-58.
} 
inkább formakényszer nélküli szervezetben müködnek, annál inkább a saját belátásuk szerint járnak el. ${ }^{858}$ A jogi-szervezeti formára vonatkozó jogszabályi előírás nélkül nonprofit szervezetként, egyesületi formában müködtek a közös jogkezelök Ausztriában. A 2006-os osztrák törvény többféle jogi személy keretei közt is lehetővé tette a közös jogkezelő szervezetek müködését, de a 2008. évi módosítás szerint - annak gazdasági jelentősége miatt - a közös jogkezelők nem müködhetnek egyesületi formában. ${ }^{859}$

A magyar szerzői jogi szabályozás kitartott az eredeti, 1999-ben bevezetett egyesületi formánál. A 2012-ben hatályba lépett Szjt. módosítás sem látta indokoltnak az akkor új civiltörvény ${ }^{860}$ szerinti nonprofit szervezeti forma ${ }^{861}$ megváltoztatását, sőt nem merült fel a német szabályozáshoz hasonló sui generis jogi személy létrehozása sem, nyilvánvalóan azért, mert a Civiltörvény maga biztosította az egyesülési jog alapján létrejött szervezetek külön törvény (ilyen az Szjt.) szerinti alapítását és működését. Az Szjt. módosítás Indokolása szerint ,[...] indokolt megmaradni egy olyan magánjogi forma elő́rásánál, amely lehetővé teszi a szerzői és kapcsolódó jogok kollektív gyakorlását.

Az egyesület sajátosságai közé tartozik, hogy azt az érintett jogosultak önkéntesen hozták létre, valamint, hogy tagsággal és önkormányzattal rendelkezik, továbbá a tevékenységét nonprofit jelleggel folytatja."

A KJK irányelv nem írja elő, hogy a közös jogkezelő szervezetek egy meghatározott jogi formában müködjenek, így a közös jogkezelői tevékenység a későbbiekben is végezhető profit és nonprofit tevékenységként. A tagsággal nem rendelkező alapítványokra is vonatkozik az irányelv személyi hatálya, sőt a KJK irányelv létrehozza az üzleti jellegü „független jogkezelő szervezet” atipikus jogi-szervezeti formát, amelyekre az jellemző, hogy a közös jogkezelő szervezetekkel ellentétben felettük az ellenőrzést és a tulajdonosi jogokat nem a jogosultak gyakorolják. ${ }^{863}$

\footnotetext{
${ }^{858}$ Gabrielle SCHULZ: Keine normalen Unternehmen, Politik und Kultur November - Dezember 2007. 6.

859 Bundesgesetz über Verwertungsgesellschaften /Verwertungsgesellschaftengesetz (VerwGesG) 2006/ (zuletzt geändert durch das Bundesgesetz BGB1. I. Nr. 50/2010)

${ }^{860}$ 2011. évi CLXXV. törvény az egyesülési jogról, a közhasznú jogállásról, valamint a civil szervezetek müködéséről és támogatásáról, (Civiltv.) Kihirdetve: 2011. XII. 14.

${ }^{861}$ Civiltörvény „4. § (1) Az egyesület az egyesülési jog alapján létrehozott szervezet, amelynek különös formáira: a szövetségre, a pártra, a szakszervezetre, továbbá a külön törvény hatálya alá tartozó tevékenységet végzö egyesületekre törvény az egyesületre vonatkozó rendelkezésektöl eltérő szabályokat állapíthat meg."

${ }^{862}$ Az egyesületi tagok egyenértékủ szavazati jogáról, valamint az egyesületi formára vonatkozó kérdésekről részletesen 1: GRAD-GYENGE-SARKADY 117-119.

${ }^{863}$ KJK irányelv Preambulum (15)
} 


\section{2) Alapitás}

A közös jogkezelő szervezetek alapítása jogszabály alapján engedélyhez kötött Ausztriában és Németországban, továbbá jellemzően engedélyezési rendszer érvényesül többek között - Belgiumban, Luxemburgban, Spanyolországban, Lengyelországban, Szlovéniában és Lettországban. Csak a reprográfia és a vezetékes továbbközvetítés esetén szükséges engedély a közös jogkezelő szervezet létrehozásához Franciaországban. Nincs szükség engedélyre az alapításhoz Svédországban, Észtországban és az Egyesült Királyságban. Magyarországon a közös jogkezelö szervezetek egyesületi formában való müködése a Szellemi Tulajdon Nemzeti Hivatalánál vezetett nyilvántartásba vételhez kötött tevékenység. ${ }^{864}$

A magyar szerzői jogban a közös jogkezelésnek jelenleg három típusa létezik. ${ }^{865}$ i) A kötelező közös jogkezelés ex lege létező típus, független a jogosultak elhatározásától, a képviseleti jog kizárólagos és nem vonható vissza, azaz a jogosultak nem léphetnek ki az adott közös jogkezelő szervezetből. Kötelező közös jogkezelésben müködnek például a sugárzott vagy vezetékes saját müsor egyidejü, változatlan és csonkítatlan továbbközvetítése miatti szerzői engedélyezési jogok, a kábeltévék jogdíjai, ${ }^{866}$ amelyeket az adott alkotói müfajtól függően az ARTISJUS, a FILMJUS, a HUNGART, az EJI vagy a MAHASZ kezel. ii) A törvény által elöirt/ajánlott kiterjesztett hatályú közös jogkezelés esetében a jogtulajdonosok által önkéntesen létrehozott közös jogkezelési rendszer hatályát - meghatározott feltételekkel - utóbb kiterjesztik a kívülálló jogtulajdonosokra is. A közös jogkezelő szervezetből való kilépést a törvény biztosítja. iii) A harmadik típus, a „tisztán” önkéntes közös jogkezelő szervezet olyan vagyoni jogok kezelésére jön létre, amelyekre a szerzői jogi törvény nem írja elö és nem is ajánlja a közös jogkezelési rendszer létrehozatalát, az teljes egészében a jogtulajdonosok elhatározásán múlik.

A közös jogkezelővel való jogviszony megbízási vagy tagsági alapon keletkezik, a szervezetbe való be- és kilépés a jogosult döntésétől függ. Az alapítás, illetőleg nyilvántartásba vétel szigorú elöírásait ebben az esetben is be kell tartani. A kilépést engedő közös jogkezelési rendszer érvényesül a „Másként, mint sugárzással vagy saját müsor vezetékes nyilvánossághoz közvetítésével, így különösen nyilvánosság számára

\footnotetext{
${ }^{864}$ Szjt. 90-92/D. §

${ }^{865}$ GYERTYÁNFY Nagykommentár 506.

${ }^{866}$ Szjt. 28. §, Szjt. 73. § (3), Szjt.77. § (3)
} 
lehívással hozzáférhetővé tételre (online felhasználás) vonatkozó előadó-müvészi és nem dramatikus zenemüvek" engedélyezésére. ${ }^{867}$

\section{3) Versenyhelyzet - monopolhelyzet szabályozása vagy a szabályozás hiánya}

A közös jogkezelő szervezetek piaci súlyát, jelentőségét és versenypiaci pozícióját alapvetően meghatározza az a tény, hogy van-e nemzeti szabályozás az egyes vagy többes jogkezelés lehetőségét illetően, illetőleg az, hogy vonatkozó jogszabályi rendelkezés hiányában miként alakul az adott közös jogkezelő szervezet helyzete az adott államban. Szükséges leszögezni, hogy a szerzők személyéhez kötődő, a 19. században kialakult kizárólagos jogok (nyilvánosságra hozatal, név feltüntetés, müintegritás) intézménye, az ún. „szerzői monopólium” nem azonos a közös jogkezelés intézményének történetileg létrejött monopolhelyzetével. ${ }^{868}$

Versenyjogi értelemben a közös jogkezelő szervezetek a felhasználókkal szemben lényegében piacuralmi helyzetben vannak, hiszen tagjaik, más közös jogkezelökkel kötött képviseleti szerződéseik és az ún. kiterjesztett közös jogkezelés következtében a teljes világrepertoárral rendelkeznek. Versenypolitikai-versenyjogi aspektusból ugyanakkor a monopolhelyzet önmagában nem releváns, hiszen a versenyjog csak a monopolhelyzettel, az erőfölénnyel való visszaélést minősíti.

A közös jogkezelés jogintézményének versenyjogi szerepe mellett e szervezetek vitathatatlanul jelentős kultúrpolitikai tényezők is. Az a szerzői joggal kapcsolatos ismeretés tudásanyag, valamint vagyoni jogok, amelyekkel a közös jogkezelők rendelkeznek, továbbá a reprezentativitás, a nemzetközi szervezetekben betöltött tagságuk és tisztségek mind hozzájárulnak egy adott nemzetállam kulturális image-jának megítéléséhez.

E szervezetek pedig szinte valamennyi államban szociális és kultúratámogatási feladatokat is ellátnak, emiatt e szervezetek adottságaiknál fogva kialakult monopolhelyzetének vizsgálata nem egyszerűen csak versenypolitikai és versenyjogi kérdés.

A közös jogkezelő szervezetek tevékenységét vizsgáló magyar Alkotmánybiróság a szerző vagyoni jogait, illetőleg a díj feletti rendelkezési jogot részben korlátozó szabályozást a közös jogkezelésből eredően szükségszerünek és a tulajdonhoz való jog nem aránytalan és nem alkotmányellenes korlátozásának minősítette. ${ }^{869}$

\footnotetext{
${ }^{867}$ Szjt. 27. § (3), Szjt. 74. § (2)

${ }^{868}$ GRAD-GYENGE Anikó - SARKADY Ildikó: Közös jogkezelés az audiovizuális médiában (KOLTAYNYAKAS szerk.) MTMI 2014. 28-29,123-128. (GRAD-GYENGE-SARKADY)

${ }^{869}$ 382/B/1995.AB határozat, megerősítette: 482/B/2002. AB határozat In: GYERTÁNYFY: Nagykommentár 500 .
} 
A közös jogkezelés nemzetközi jogi szabályozását illetően rá kell mutatni Faludi azon megállapítására, mely szerint „A közös jogkezelési szabályoknak nem létezik nemzetközi szerzői jogi egyezményes legkisebb közös többszöröse"; ${ }^{870}$ a közös jogkezelés kérdésköre - elsősorban az angolszász és a kontinentális jogrendszerek eltérő megközelítései miatt - a nemzetközi jogban nincs átfogóan szabályozva. A Berni Uniós Egyezmény 1928. évi római revíziója $^{871}$ tartalmaz ugyan a vagyoni jogok egyedi engedélyezéstől eltérő gyakorlásának módjára vonatkozó rendelkezéseket, valamint a $B U E$ adminisztrációját végző WIPO szerkesztő bizottságokban is történtek kísérletek a közös jogkezelés egyes aspektusainak egyezményes szabályozására, de ezek a kísérletek nem vezettek eredményre. Az Európai Unió ugyanakkor már az első közös jogkezeléssel kapcsolatos versenyjogi eljárás megindítása, ${ }^{872}$ azaz 1971 óta behatóan foglalkozik az intézménnyel.

A közös jogkezelő szervezetek monopolhelyzetét és annak megítélését az Európai Unió kezdetektől fogva a belső piac versenyjogi kérdésének tekintette. ${ }^{873}$ A Bizottság az egyedi ügyeiben hozott döntéseire és kialakult gyakorlatára vonatkozóan általában megfogalmazható, hogy az kevésbé volt tekintettel a szerzői jog, valamint a jogkezelést végző szervezetek fent említett kulturális „küldetésére” és más - szintén már vázolt szervezeti-eljárási sajátosságaira. A Bizottság gyakorlata - az EU Bíróságával szemben azt a tényt sem vette figyelembe, hogy a szerzői jog territoriális jellege miatt a jogkezelök nemzetállami keretek között alakultak és müködnek, emiatt saját nemzeti piacukon belül domináns pozícióba kerültek. ${ }^{874}$

Az online felhasználás kivételével a jogkezelők a saját műfaji területükön a világrepertoárt képviselik és a kölcsönös képviseleti szerződések által intézményi hálózatot alkotnak. Itt röviden utalni szükséges az ún. CISAC ügyre, amelyben az Európai Bizottság a vezetékes továbbközvetítés, a müholdas sugárzás és a lehívásra hozzáférhetővé tétel felhasználási módokra vonatkozóan egyeztetett formában létrejött kölcsönös képviseleti megállapodásokat tiltott összehangolt magatartásnak minősítette. ${ }^{875}$ Az Európai Bíróság a

\footnotetext{
${ }^{870}$ FALUDI Gábor: Első oldal Infokommunikáció és Jog 2011. december (FALUDI II.)

${ }^{871}$ BUE 11 bis cikk.

${ }^{872}$ A Bizottság által a német GEMA egyes szabályzatainak erőfölénnyel való visszaélést vizsgáló eljárása az EK szerződés 86. cikke alapján [71/224/EGK határozat (IV/26.760- „GEMA”]

${ }^{873}$ Már a német GEMA közös jogkezelővel szembeni eljárásában vizsgálta a Bizottság a szerzői jogi szabályok belső piacra gyakorolt hatását. Ld.: előző lbj., valamint 877 . lbj.

${ }^{874}$ Jonathan D.C. TURNER: Intellectual Property and EU Competition Law. Oxford University Press, 2010. 232-240.

${ }^{875}$ Az Európai Bizottság döntéséről részletesen ld.: FALUDI Gábor: A szerzői jogi közös jogkezelés mint szabályozott monopólium. Infokommunikáció és Jog 2009. augusztus (FALUDI III.) 126-135.
} 
Bizottság döntését több ponton is felülbírálta, és összességében a területiség elve alapján megerősítette a közös jogkezelés történetileg kialakult monopolhelyzeti formáját. ${ }^{876}$

A közös jogkezelő szervezetek müködését és ez által versenyjogi helyzetét illetően alapvetően két modell érvényesül: a közös jogkezelő szervezetek de facto, illetőleg de jure monopóliuma. Az Európai Bizottság versenyjogi gyakorlata a közös jogkezelők monopolhelyzete vonatkozásában e két müködési típus jogszerüségét sarkalatos döntésekben ismerte el. ${ }^{877} \mathrm{Az}$ Unió területén a monopolhelyzettel való visszaélésnek egyfelől a speciális állami engedélyezési szabályok, másfelől pedig az általános versenyjogi kontroll szabnak gátat. ${ }^{878} \mathrm{~A}$ de jure monopóliumok a szakirodalom szerint egyben ún. természetes monopóliumok is, ${ }^{879}$ amelyekben a költség- és keresleti viszonyok - hosszú távon - egyetlen szolgáltató piacon maradását indokolják. Megjegyezni szükséges ugyanakkor, hogy egy irányelvi szabályozás ${ }^{880}$ kifejezetten lehetővé teszi, hogy egy adott felhasználási területen akár több közös jogkezelő szervezet is müködjön.

A gyakorlatban az előadóművészek és a hangfelvétel-elöállítók közös jogkezelő szervezetei körében találkozunk a többes jogkezelés intézményével Franciaországban, Hollandiában, Lengyelországban és Szlovákiában. Az audiovizuális média szerzőinek pedig két jogkezelő szervezete is müködik Spanyolországban (SGAE és a DAMA).

A közös jogkezelő szervezetek monopolhelyzetét illetően nincs német, francia, svéd, finn, luxemburgi és portugál jogszabályi előírás és ezekben az államokban a jogi szabályozás hiányában de facto monopolhelyzetet élveznek az egyes jogkezelők. Észtországban jogszabály teszi lehetővé a többes jogkezelést és a common law országaiban - a már említett amerikai rendszerhez hasonlóan - általában szintén versenyhelyzeten alapul a jogkezelők müködése. Európában jogszabály alapozza meg a jogkezelők monopolhelyzetét az adott felhasználási területekre Ausztriában, Belgiumban, Csehországban, Dániában,

\footnotetext{
${ }^{876}$ CISAC ügy Európai Bírósági döntésének részletes elemzését ld.: GRAD-GYENGE-SARKADY 142-146. 877 71/224/EGK bizottsági határozat (IV/26.760 - „GEMA”) Amtsblatt Nr. L 134 vom 20/06/1971. 15-29. Belgische Radio en Televisie (BRT) v. SV. SABAM, (127/73. számú eset, [1974] E.C.R. 313; [1974] 2. C.M.L.R. 199), Ministére Public v. Jean-Louis Tournier (395/87. számú eset, [1989] E.C.R. 2521; [1991] 4 C.M.L.R. 248.). Szjt. 86. §-hoz füzött indokolása.

${ }^{878}$ Ezzel a megközelítéssel szemben az USA szabályozása - a rendkívül fejlett kartelljog miatt - lehetővé teszi több társaságnak (ASCAP, BMI, SESAC) is, hogy egymással versenyezve kezeljék a nyilvános előadási és sugárzási jogokat, sőt a felhasználók a jogokat - a jogkezelő társaságok megkerülésével - közvetlenül a szerzőktől vagy a kiadóktól is megszerezhetik.

${ }^{879}$ Maria Mercedes FRABBONI: The Current Discussion on Collective Management of Right sin the EU. In: Szerzői Jogi Tanulmány) 148. 297. lbj.

${ }^{880}$ Mühold-Kábel Irányelv 9. cikkének (2) bekezdése szerint: „Ha több jogkezelő szervezet foglalkozik ilyen [azonos fajtájú] jogok érvényesítésével, a jogosult szabadon választhat, hogy közülük melyiket kell a jogainak érvényesítésére megbízottnak tekinteni.”
} 
Olaszországban, valamint Lettországban és de jure monopólium érvényesült a hazai szabályozásban is a 2011. évi Szjt. módosításának hatályba lépéséig. ${ }^{881}$

A NAMS Szerzői Jogi Tanulmányhoz készült hatásvizsgálati kérdőívre adott válaszában a Gazdasági Versenyhivatal a hazai médiapiacot - versenyjogi értelemben - még mindig legfeljebb nemzeti kiterjedésünek minősítette a fennálló nyelvi, kulturális és szabályozási környezetek különbözőségei miatt. A GVH által a FilmJus közös jogkezelő „,vállalkozás” ellen gazdasági erőfölénnyel való visszaélés miatt indult eljárásban ${ }^{882}$ a Versenytanács az eljárás alá vont közös jogkezelő szervezet piaci magatartását illetően és ez által a közös jogkezelés versenyjogi megítélésével kapcsolatban kardinális megállapításokat tett. A GVH valószínűsítette, hogy az eljárás alá vont a Tpvt. ${ }^{883}$ szerint az 1987. évet megelőzően gyártott magyar filmek után fizetendő jogdíjak megállapításakor visszaél gazdasági erőfölényével azáltal, hogy $a$ ) a jogdíjak aránytalanul túlzóak és nem veszik figyelembe a piaci realitásokat [Tpvt. 21.§ a) pont], b) korlátozhatják a magyar gyártású filmalkotásoknak az előfizetőkhöz való eljuttatását [Tpvt. 21. § b) pont], c) a jogdíjak az egyes jogdíjfizetésre kötelezettek irányában indokolatlanul eltérő mértéküek [Tpvt.21.§g) pont]. A Versenytanács megállapításai a következők:

a) a Tpvt. alanyi hatálya egyértelmúen kiterjed a FilmJusra mint jogi személyre; a vizsgálat tárgyát képező tevékenysége, a szerzői jogdíjak megállapítása és beszedése piaci magatartásnak minősül,

b) a Tpvt. szerinti gazdasági erőfölénnyel való visszaélés tilalmát szabályozó rendelkezések alkalmazásának a közös jogkezelő szervezetek esetében is helye van,

c) a jogdíjközlemény jóváhagyási rendjét, nevezetesen annak miniszteri jóváhagyását a Versenytanács külön is értékelte és - a vonatkozó gyakorlata ${ }^{884}$ alapján - megállapította, hogy a jogdíjközlemény szerinti díjak vizsgálatára a Tpvt. hatálya szintén kiterjed,

d) a túlzottan magas árak megállapításához alkalmazott szokásos közgazdasági módszer (gazdaságilag indokolt költség, befektetés arányos nyereség) a szerzői jogdíjak esetében nem értelmezhető. A szokásos módszer alkalmazhatatlansága miatt és más módszer híján a szerzői jogdíjak esetében nem a díj mértéke, hanem megállapításának módja alapján vizsgálható az esetleges tisztességtelenség,

\footnotetext{
881 2012. január 1.

${ }^{882}$ A Vj-97/2004/37 az eddig egyetlen lezárt és nyilvánosan elérhető versenytanácsi határozat, amely egy közös jogkezelö piacuralmi, erőfölényes helyzetét versenyjogi szempontból vizsgálta.

883 1996. évi LVII. törvény a tisztességtelen piaci magatartás és a versenykorlátozás tilalmáról.

${ }^{884} \mathrm{Vj}-100 / 2003$.
} 
e) a díjmegállapítás módja tekintetében meghatározó jelentőségü a felhasználók szempontjainak figyelembevétele. Mivel az Szjt. szerinti díjszabás-véleményezési eljárásban a jelentős felhasználók és érdekképviseleti szerveik díjmegállapítással kapcsolatos álláspontjának kikérése a FilmJus kötelezettségein kívül esik, (az az akkori Nemzeti Kulturális Örökség miniszterének hatáskörébe tartozott, ez pedig nem minősül piaci magatartásnak), a Versenytanács szükségtelennek ítélte a véleménykérési folyamat Tpvt. szerinti vizsgálatát,

f) A díjmegállapítás módjával kapcsolatban a Versenytanács vizsgálta a „,Ft/perc/elöfizető szám” alapú díjmeghatározás tisztességtelenségét is. Az Szjt. felhasználással arányos díjmegállapítás elvét ${ }^{885}$ a Versenytanács versenyjogi szempontból is elfogadhatónak értékelte. Az „előfizető szám” alapon megállapított díjat a müsordíj tekintetében közvetlenül bevételarányosnak minősítette, a reklámbevétel vonatkozásában pedig „,igen szoros összefüggésben” állónak értékelte. A sugárzott film hossza, azaz a „perc” alapú díjazás is összefüggésben áll a müsorszolgáltató bevételeivel.

Fentiek alapján a Versenytanács álláspontja szerint nem volt megállapítható sem az aránytalanul túlzó jogdíjak alkalmazása, sem pedig a termelést, a forgalmazást a fogyasztók kárára korlátozó magatartás a FilmJus részéröl. A Versenytanács a különböző felhasználókkal szemben érvényesített jogdíjak tekintetében azt is kimondta, hogy azonos jogdíj összeg mellett nem minősül megkülönböztetésnek, ha a jogdíjközlemény alapján a müsorszolgáltató által fizetett jogdíjnak a müsorszolgáltató általa a filmforgalmazónak fizetett díjhoz viszonyított aránya akár lényegesen is eltér. A megkülönböztetés csak akkor ütközik a Tpvt. 21. § g) pontjába, ha az „egyes üzletfeleknek hátrányt okoz a gazdasági versenyben.” Ez pedig csak akkor valósul meg, ha az adott vállalkozás a tevékenységéhez szükséges valamely inputhoz a versenytársainál magasabb áron jut hozzá. Ilyen tényállás pedig nem volt megállapítható. A Versenytanács az eljárást jogsértés hiányában megszüntette, illetőleg visszaélés hiányában, érdemben nem vizsgálta a gazdasági erőfölény meglétét.

A Bizottság 2007-ben, a médiaszabályozási reform időszakában, a magyar szerzői jogi szabályozás szerinti jogi monopóliumot az EK-szerződés szolgáltatások szabad mozgására és a letelepedés szabadságára vonatkozó szabályaiba ütközőnek találta. A de jure

${ }^{885}$ Szjt. 16. § (1) 
monopolhelyzet miatt Magyarország ellen indított kötelezettségszegési eljárásban ${ }^{886} \mathrm{az}$ Európai Bizottság 2007. március 23-án küldött felszólítására (infringement notice) adott válaszában hazánk készségét fejezte ki a jogi monopolszituáció megszüntetésére. A de jure monopólium megszüntetésére először 2009-ben történt kísérlet a jogalkotó részéről; a szerzői jogi szabályozás megváltozását e téren végül az Szjt. 2011. évi módosítása érte el. A módosítás indokolása szerint a törvényi monopólium fenntartása addigra már több okból sem volt szükséges, ,az átmenetet követően a Szerzői Jogvédő Hivatal helyett létrejött a jogosultak önszerveződésén alapuló stabil közös jogkezelői intézményi rendszer.”

A 2011. évi törvénymódosítás ugyan jogilag megszüntette a közös jogkezelő szervezetek monopóliumát, de a gyakorlatban fennmaradt a de facto monopólium intézménye. Ezt igazolja az a tény is, hogy a törvénymódosítás egyelöre nem járt egyetlen müfaji területen sem a többes jogkezelés gyakorlati megvalósulásával. ${ }^{887}$ A többes/párhuzamos jogkezelés jelenlegi hiánya mindenekelőtt arra a gazdasági okra vezethető vissza, hogy - a nemzetközi tapasztalatok szerint is - a viszonylag kisebb piacokon (mint amilyen a magyar piac is), létrejött közös jogkezelö szervezetek a saját müfaji területükön ténylegesen természetes monopóliumokként müködnek, és e szervezetek mellett - azonos felhasználási területen -, hosszabb távon nem jövedelmező a többi jogkezelő működése. ${ }^{888}$

A MódSzjt. a fentieken túl a „közös jogkezelői piacra” újonnan belépni szándékozó közös jogkezelő számára rendkívül szigorú adminisztratív és érdemi feltételek teljesítését írja elő; tényleges versenyt a jogkezelők között pedig igazán csak a kezelési költségek csökkentésével lehet előidézni. A többes jogkezelés - a szerzői jogi törvényben meghatározott feltételek megléte esetén - ugyanazon jogosulti csoport ugyanazon vagyoni jogainak kezelésére nyújt lehetőséget két vagy több közös jogkezelő szervezet keretében. A többes jogkezelés nem jelenti azt, hogy egy jogosult ugyanazon joga tekintetében több

\footnotetext{
${ }^{886}$ A kötelezettségszegési eljárás még nem fejeződött be. A Bizottság az olasz és osztrák jogi monopólium létét nem vitatta, és az uniós jogforrások, így a KJK irányelv is kerülik a közös jogkelezők monopolhelyzetének szabályozását GYERTYÁNFY: Nagykommentár 525.

${ }^{887}$ 2015. 08. 04-én kezdeményezte nyilvántartásba vételét az SZTNH előtt a Digitalfilm Közös Jogkezelő Egyesület. A kódolt, illetve müsorterjesztő rendszerekbe közvetlenül betáplált lineáris médiaszolgáltatásokban foglalt filmalkotások müsorterjesztő rendszerek által történő nyilvánossághoz közvetítésének hivatali nyilvántartásba vétele esetén sem többes jogkezelés valósulna meg a film és más audiovizuális alkotások tekintetében, hanem önálló, önkéntes kiterjesztett hatályú közös jogkezelés jönne létre a nyilvántartási eljárást kezdeményező szervezet részére.

${ }^{888}$ A többes jogkezelés gazdasági rentabilitását illetően megjegyzem, hogy azokban az államokban, ahol nincs jogi szabályozás a közös jogkezelés versenyjogi helyzetére, (Spanyolország kivételével) lényegében valamennyi európai államban de facto monopólium alakult ki.
} 
szervezet is eljárhatna, mivel ez a joggyakorlás és az engedélyezés ellehetetlenüléséhez vezetne." $" 889$

\section{4) Szociális és/vagy kulturális juttatások}

A közös jogkezelő szervezetek önszerveződő és önkormányzati jellegükből adódóan a jogi szabályozás keretei között vagy e nélkül is, de a gyakorlatban szinte a kezdetektől fogva, különböző juttatásokkal támogatták a rászoruló szerzőket, illetőleg segítették kulturális tevékenységüket. ${ }^{890}$ Jogszabályi ajánlás biztosítja a szociális és/vagy kulturális juttatások nyújtását Észtországban, Lettországban és Máltán. Kötelező a szociális és/vagy kulturális juttatás Franciaországban, ahol a jogszabály azt is meghatározza, hogy a magáncélú másolásból származó jogdíj 25 százalékát kell kulturális célra fordítani. A jogdíjfajtától függően kötelező a juttatás Ausztriában és Németországban, utóbbiban csak alapos okból mellőzhető a juttatás. Szintén kötelező a juttatás Belgiumban, Csehországban, Portugáliában, Spanyolországban, Dániában és Szlovákiában. A közös jogkezelő szervezetek - a ciprusiak kivételével - jogszabályi elöírás, illetőleg ajánlás nélkül is élnek az ilyen jellegü juttatások nyújtásának lehetőségével lényegében az összes többi államban. Magyarországon az Szjt. 2011. évi módosításáig a közös jogkezelő szervezetek különböző módokon, de a gyakorlatban szinte kivétel nélkül alkalmazták a szociális és/vagy kulturális támogatások intézményét. A juttatások konkrét formái a pályázati támogatások, egyedi díjazások, ösztöndíj-szerü juttatások, célzott és szabad felhasználású kölcsönök, eszközvásárlási támogatások, kiállításokon való megjelenést támogató juttatások voltak. Az 2011. évi módosítás hatályba lépéséig az ilyen juttatások nyújtása többnyire nem közvetlenül a közös jogkezelő szervezeteken keresztül történt, hanem kontrollálhatatlanul, sokszor szubjektív döntések alapján, több esetben e célra létrehozott ún. „szatelit” szervezetek útján valósult meg.

$\mathrm{Az}$ újonnan bevezetett rendelkezések törvényi szintre emelték, egységesítették és átláthatóvá tették a juttatások nyújtásának és levonásának rendjét. ${ }^{891}$ A MódSzjt. a jogosultak érdekében a juttatások négy forrását határozta meg: tagdíj, gazdasági tevékenységből származó bevétel, az ún. fel nem osztható jogdíj 25 százaléka, valamint a felosztható jogdíj 10 százaléka. A szociális és/vagy kulturális juttatások nyújtásának belső szabályozási alapját a közös jogkezelők felosztási szabályzata, az ehhez kapcsolódó ún. támogatási politika és az egyedi döntések képezik. Az Szjt. szociális/kulturális támogatási

\footnotetext{
${ }^{889}$ Szjt. 2011. évi módosítás 87 . §-hoz füzött indokolásának részlete.

${ }^{890}$ FICSOR Mihály: Collective Management of Copyright and Related Rights, Genf, WIPO, 2002. 149-153.

${ }^{891}$ Szjt. 89. § (8)-(11/a)
} 
rendszerére vonatkozó szabályozás 2013 októberétől ismét módosult. ${ }^{892}$ A módosított rendelkezések értelmében a támogatásra elkülönített összeg 70 százalékát kulturális célra át kell adni a Nemzeti Kulturális Alap (NKA) részére. A közös jogkezelö szervezet támogatási politikájának eleve összhangban kell állnia az $N K A$-ra irányadó törvény szerinti kulturális célokkal, mert az NKA saját hatáskörében - lényegében az érintett közös jogkezelők nélkül - hoz egyedi támogatási döntéseket. A közös jogkezelőkre előírt 2013-as Szjt. módosítás szerinti kulturális támogatási rendszerhez hasonló „modell”-t sem az Európai Unió nem ismer, és ilyen irányú szabályozást a KJK irányelv nem tartalmaz. Az utóbbi uniós jogforrás kifejezetten elöírja: ,[...] fontos, hogy a kezelési díj címén történő levonáson kívüli bármely egyéb - például szociális, kulturális vagy oktatási célú levonáshoz - a közös jogkezelő szervezet tagjainak döntése legyen szükséges." ${ }^{893}$

A támogatási rendszer alaptörvényi aggályokat is felvet. A támogatási politika $N K A$ törvényhez rendelése, a támogatásra elkülönített bevétel meghatározott százalékos mértékének $N K A$ részére történő törvényi „elvonása”, a jogtulajdonosok képviselőinek kizárása a konkrét támogatási döntésekből, valamint a közös jogkezelő szervezet támogatási céljainak figyelmen kívül hagyása az NKA konkrét kulturális döntései során, nem egyeztethetők össze az Alaptörvény tulajdonhoz való alapjogával sem. A teljesség kedvéért meg kell jegyezni, hogy a közös jogkezelő a már említett forrásokból támogatásra elkülönített összeg 30 százalékát fordíthatja szociális célokra; erröl saját hatáskörben, legfőbb szerve útján dönt vagy az általa e célra létrehozott jogi személy határoz.

A 2013. évi módosítás az üres hordozó és a reprográfiai jogdíjak felhasználása tekintetében is változást eredményezett. A magánmásolási díjak egy részének kulturális célra történő fordítása nem ismeretlen a nemzeti szabályozásokban. Ausztriában, Franciaországban és Spanyolországban azonban e díjak felhasználásáról - a magyar szabályozással szemben maguk a jogkezelők döntenek. A 2013-asmódosítás az üres hordozó és a reprográfiai jogdíjak 25 százalékának $N K A$ részére való törvényi átadási kötelezettsége szintén aggályos alkotmányjogi szempontból és ellentétben áll az EUB Amazon ${ }^{894}$ ügyben hozott döntésével is. A döntés értelmében a szerzők méltányos díjazásához való joga nem korlátozható, illetőleg az ennek fedezetét jelentő magáncélú másolat után fizetendő díj nem zárható ki azért, mert a díjat nem közvetlenül a jogosultak részére, hanem a jogosultak

\footnotetext{
892 2013. évi CLIX. törvény hatálybalépés: 2013. október 25.

${ }^{893}$ KJK irányelv Preambulum (28)

${ }^{894}$ C-521/11. Amazon.com International Sales Inc. és társai kontra Austro-Mechana Gesellschaft zur Wahrnehmung mechanisch-musikalischer Urheberrechte Gesellschaft mbH. (Amazon ügy)
} 
javára alapított szociális és kulturális intézményeknek folyósítják, amennyiben ezen intézmények ténylegesen a jogosultakat támogatják, és müködésük nem hátrányosan megkülönböztető.

\section{5) Jogdij-felosztás}

A közös jogkezelő szervezetek által alkalmazott díjazások fajtáit, a díjak felhasználók által fizetendő mértékét és a fizetés feltételeit a nemzetközi gyakorlatban jogszabály vagy e szervezetek belső szabályzata, a felosztási szabályzat határozza meg. Jogszabály állapítja meg a jogdíjak felosztási rendjét Belgiumban, Csehországban, Görögországban, Olaszországban és Luxemburgban. Szintén jogszabályi alapon müködik a felosztás rendje bizonyos felhasználási módokra Franciaországban (hangfelvételek sugárzása). Nincs jogszabályi rendelkezés a jogdíjak felosztásának rendjére például Svédországban, és szintén a közös jogkezelő maga határozza meg a felosztás rendjét - alapszabályban és/vagy közgyülés által - Ausztriában, Németországban, Dániában, Észtországban, Finnországban és Cipruson. A jogdíjak felosztása tekintetében külső, felügyeleti szerv jóváhagyása érvényesül a hollandoknál.

A KJK irányelv nagy hangsúlyt fektet a jogdíjak méltányos elosztásának elvére. Hivatkozik a 2005/737/EK bizottsági ajánlásban ${ }^{895}$ foglaltakra, nevezetesen arra, hogy a közös jogkezelő szervezetek egymással folytatott tárgyalásaik során adjanak kellö tájékoztatást a díjszabásokról és a repertoárról. Az irányelv továbbá döntési lehetőséget is ad a közös jogkezelök számára, hogy bizonyos tevékenységeiket, így például a jogosultakat megillető összegek felosztását, leányvállalataikon vagy más, ellenőrzésük alatt álló szervezeteken keresztül lássák el, ${ }^{896}$ amely szervezetekre is kiterjeszti az irányelv hatályát.

A jogdíjak rendszeréről a közös jogkezelő a honlapján keresztül köteles tájékoztatást adni. Az irányelv értelmében a jogosultak által rájuk bízott jogok gyakorlásából származó, a jogosultakat megillető bevételeket a közös jogkezelő szervezetek szedik be, kezelik és osztják fel. ${ }^{897}$ E tevékenység végzése során a lehető legnagyobb gondossággal kell eljárni, pontos nyilvántartást kell vezetni a tagokról, a felhasználási engedélyekről, valamint a művek és egyéb teljesítmények felhasználásáról. A jogosultakat megillető, beszedett összegeket a könyvelésben elkülönítetten kell kezelni, a befektetések kockázati kitettségét a minimálisra kell csökkenteni. A kezelési költségeket illetően az irányelv elöírja az

\footnotetext{
${ }^{895}$ KJK irányelv Preambulum (6) Az irányelv megállapítja az ajánlás nem kiegyenlített követését.

${ }^{896}$ KJK irányelv Preambulum (17)

${ }^{897}$ KJK irányelv Preambulum (26)
} 
„indokoltság” szempontját, valamint azt, hogy a levonáshoz a - a szociális, kulturális és oktatási célú levonásokhoz hasonlóan - a közös jogkezelő szervezet tagjainak legyen döntési kompetenciája, továbbá a jogosultaknak megkülönböztetés nélküli hozzáférése. ${ }^{898}$ A jogdíjak felosztását és kifizetését az irányelv a közös jogkezelő szervezet erre vonatkozó általános politikájának megfelelően rendeli végezni. A jogdíjak felosztását illetően hangsúlyozni szükséges, hogy a 2012-től bevezetett magyar szabályozás alapvetően megfelelt az irányelv fentiekben ismertetett rendelkezéseinek.

6) Felügyelet

A felügyelet fogalma kifejezetten a közös jogkezelök feletti szakmai felügyeletet jelenti és értelmezése szerint nem tartozik ide az általános versenyhatósági felügyelet vagy a kérelemre indult eljárásokban a bírósági kontroll. A közös jogkezelő szervezetek feletti felügyelet nem általános Európa államaiban. Az európai országok többségében ugyan létezik a jogintézmény, de nincs felügyeleti hatóság Észtországban és Svédországban, az Egyesült Királyságban pedig a Copyright Tribunal csak kérelemre járhat el.

A KJK irányelv elöírja, hogy a tagállamok kötelesek olyan megfelelő eljárásokat bevezetni, amelyek révén kontrollálható, hogy a közös jogkezelő szervezetek megfelelneke az irányelv szabályainak, ${ }^{899}$ különösen, ami az auditált adatokat tartalmazó átláthatósági jelentést, valamint a szociális, kulturális és oktatási szolgáltatásokra szánt összegek felhasználását részletező külön jelentést illeti. ${ }^{900}$ A tagállamok nem kötelesek új felügyeleti „illetékes” hatóság létrehozására, azonban - jogsértés esetén valamennyi érdekelt számára - biztosítani szükséges a hatóság értesítési lehetőségét, továbbá az irányelvet átültető nemzeti jogszabályok be nem tartása esetén visszatartó erejü szankciók (helyszíni ellenőrzések, vezetők menesztése, engedély visszavonása stb.) alkalmazását és különböző intézkedések meghozatalát. Az irányelv „felügyeleti feladatkör” alatt a közös jogkezelő szervezetek belső hierarchikus viszonyait rendezi. ${ }^{901}$

\subsubsection{A hazai közös jogkezelést érintő legföbb szabályozási változások}

A magyar közös jogkezelés szabályozási tulajdonságai a 2011. évi szerzői jogi törvénymódosítás kapcsán változtak a legjelentősebben. Itt most nem kívánok kitérni a

\footnotetext{
${ }^{898}$ KJK irányelv Preambulum (28)

${ }^{899}$ KJK irányelv Preambulum (50)

${ }^{900}$ KJK irányelv Preambulum (36)

${ }^{901}$ KJK irányelv 9. cikk.
} 
közös jogkezelés szabályozásának hazai jogtörténeti előzményeire, ${ }^{902}$ hanem csak a NAMS idején hatályos rendelkezésekhez képest bekövetkezett 2011. évi Szjt. módosítás összefoglaló ismertetésére szorítkozom.

A hazai közös jogkezelés szerzői jogi szabályainak áttekintésére és felülvizsgálatára elsődlegesen egy felügyeleti-hatásköri változás ${ }^{903}$ szolgáltatott okot: a közös jogkezelő szervezetek feletti felügyelet jogköre a mindenkori kulturális tárcától átkerült a Szellemi Tulajdon Nemzeti Hivatalához (SZTNH, korábban Magyar Szabadalmi Hivatal). A hazai szabályozás revízióját az is indokolta, hogy az Európai Unió Bizottsága folytatta aktivitását a közös jogkezelés irányelvi szintü szabályozásának előkészítését illetően. A szerzői és szomszédos jogok gyakorlásáról a belső piacon ${ }^{904}$ címmel kibocsátott 2004. évi bizottsági közleményt követően a Bizottság 2005 októberében hatástanulmányt készíttetett a szerzői jogok határokon átnyúló engedélyezésének vizsgálatáról, ${ }^{905}$ majd a közlemény alapján ajánlást fogalmazott meg a jogszerü online zeneszolgáltatás érdekében a szerzői és szomszédos jogok közös, határokon átnyúló kezeléséröl. ${ }^{906}$ A közös jogkezelési irányelvet 2010-től több stratégiai dokumentum is előkészítette. ${ }^{907}$ Minden esetre a hazai jogi felülvizsgálat idején, 2011-ben már körvonalazódtak a 2014-es közös jogkezelési direktíva tervezetének irányai, amelyek szempontokat határoztak meg a közös jogkezelés hazai szabályozásának újragondolásához.

A MódSzjt. rendelkezéseinek megalkotását a jelentős közös jogkezelői piac ${ }^{908}$ felmérése, a szervezetek jogi és közgazdasági szempontú átvilágítása előzte meg. A felmérés és átvilágítás módszertanának alapját a hazai közös jogkezelő szervezetek által nyújtott adatszolgáltatás, a felügyeleti szerv közös jogkezelö szervezeteknél végzett személyes vizsgálatai és egyeztetései, valamint a nyilvános forrásokból hozzáférhető dokumentumok

\footnotetext{
${ }^{902}$ Ld.: GRAD-GYENGE-SARKADY 15-28.

${ }^{903}$ Szjt. 2010. évi CXLVIII. törvény a Magyar Köztársaság minisztériumainak felsorolásáról szóló 2010. évi XLII. törvénnyel összefüggésben szükséges törvénymódosításokról és egyes iparjogvédelmi tárgyú törvények módosításáról.

904 Commission Staff Working Document on the Study a Community Initiative on the Cross-border Collective Management of Copyright. Brussels, 7 July 2005 (Bizottsági Közlemény 2005) COM (2004) 261 final 2004. április 16.

${ }^{905}$ CMO Tanulmány.

${ }^{906}$ 2005/737/EK Európai bizottsági ajánlás 2005. május 18.

907 A közös jogkezelés a nemzetközi és az uniós jogban, részletesen ld.: GRAD-GYENGE-SARKADY 6193.

${ }^{908}$ A teljes szerzői jogi szektort felölelő kreatív ágazatok súlya a GDP több mint 7\%-át tette ki 2011-ben, és a 2008. évi világgazdasági válság korlátozó hatásáig a nemzetgazdasági átlagnál mintegy másfélszer gyorsabb ütemű éves növekedést produkált. 21-26 (Szerzői jogi ágazatok súlya Magyarországon SZTNH 2012.) Megjegyzés: A szektor GDP-ben mutatott súlya 2014-re 0,25 százalékponttal csökkent, majd 2016-ra összesen 8,23\%-ra emelkedett. (Szerzői jogi ágazatok gazdasági súlya Magyarországon SZTNH 2016.)
} 
szolgáltatták. Az átvilágítás és felmérés célja a közös jogkezelő szervezetek szakmai, szervezeti és gazdálkodási viszonyainak feltárása, a hatékonyságot és eredményességet befolyásoló tényezők azonosítása volt. A vizsgálat tényként rögzítette, hogy a nemzetgazdaság egyre nagyobb jelentőséggel bíró kreatív iparon belül a hazai közös jogkezelés a nemzeti és közösségi kultúrpolitika fejlesztésének és szabályzásának fókuszában áll, és ennek megfelelő jelentős gazdasági és kultúrpolitikai befolyással bír.

A vizsgálat eredményeként általánosságban megállapítható volt, hogy a hazai közös jogkezelő szervezeti „háló”909 nagy értékű szerzői vagyoni jogokkal rendelkezik, továbbá heterogén felhasználói és jogosulti körrel, sokszereplős piaci léttel, szoros szervezeti kooperációval, valamint kiterjedt nemzetközi kapcsolatokkal jellemezhetö. A közös jogkezelöi piac átvilágítása - többek között - rámutatott a regisztrált nyolc közös jogkezelő rendkívül heterogén strukturális-szervezeti formáira, a közös jogkezelő tevékenység szervezetenkénti különböző funkcionális megvalósulására, valamint a jelentős eltéréseket mutató gazdálkodási, pénzügyi-számviteli gyakorlat folytatására. A közös jogkezelők 1996-tól önszerveződésen alapuló egyesületi, szövetségi, szövetkezeti szervezeti formában müködtek, és érdekeltségüket számos más egyesület, alapítvány, nyugdíjpénztár, klub, gazdasági társaság és ügynökség által alkotott intézményi hálózat alkotta.

Az Szjt. a közös jogkezelés hiányos definícióján túl ${ }^{910}$ nem tartalmazott részletes szabályozást a közös jogkezelés tartalmi követelményeit illetően. A jogintézmény érdemi lényegét - ebből kifolyólag - a gyakorlat töltötte ki. A közös jogkezelőket illető nem kellő jogi szabályozás heterogén funkciók sokaságának gyakorlását tette lehetővé. A közös jogkezelők egyszerre voltak a szerzők és más szerzői jogosultak érdekvédő szervezetei, szociális és kulturális funkciókat is gyakorló nonprofit alakulatok, valamint a közös jogkezelés alapvető tevékenységét megvalósító jogosító és a jogdíjakat kezelő szervezetek. A közös jogkezelők működésüket csak részben illesztették a digitális kor kihívásaihoz; a $D A ́ S$ már említett kívánalma, miszerint a szerzői jogi szabályozás során figyelembe kell venni a digitális átállás szempontjait is, akkor még nemcsak a szabályozásban, de a közös jogkezelök gyakorlatában sem érvényesült.

\footnotetext{
909 A közös jogkezelő szervezetek 2011. évi átvilágítása idején nyolc közös jogkelező szervezet alkotta a hazai jogkezelés szervezeti rendszerét: ARTISJUS, MAHASZ, MSZSZ-EJI, FILMJUS, HUNGART, MASZRE, REPROPRESS, MRSZ. Megjegyzem, a törvénymódosítás eredményeként egyes jogkezelők (MAHASZ, EJI) elnevezése változott.

910, „[...] a szerzői és szomszédos, illetve adatbázis-elöállítói jogok érvényesítése a jogosultak által erre létrehozott szervezet útján, függetlenül attól, hogy azt a törvény írja elő vagy az a jogosultak elhatározásán alapul”Szjt. 85. § (1) 2011. évi módosítást megelőző rendelkezés.
} 
A piacfelmérés és átvilágítás eredményeként megszülettek azok a szabályozási intézkedések, amelyek - korábban a NAMS elvei között is, - többnyire az akkor formálódó KJK irányelv célkitűzéseiként is megjelentek. A 2012. január 1-vel hatályba lépett módosítás ${ }^{911}$ részletesen meghatározta a közös jogkezelés fogalmát, közös jogkezelési tevékenység minimum-tartalmát, ${ }^{912}$ továbbá szigorította a nyilvántartásba vétel, a müködés és a gazdálkodás szabályait (kettős könyvelés elöírása, díjszabási eljárás törvényi rendelkezései, stb.), valamint átláthatóvá tette a díjmegállapítás és jogdíjfelosztás hatásköri szabályait. Előírta azt is, hogy közös jogkezelő csak másik közös jogkezelő szervezet részére adhatja át a jogdíjat felosztás céljára. A módosított rendelkezések értelmében megerősödött a közös jogkezelés de facto monopóliuma, de jogilag lehetővé vált az azonos szerzői műfajokban a többes jogkezelés. A 2011. évi törvénymódosítás nem jelentette a hazai szerzői jogi törvény átfogó reformját, de a közös jogkezelő szervezeteket érintő jogi szabályozást és a kialakult gyakorlatot jelentősen átformálta.

A módosítás a közös jogkezelő szervezetekre bevezetett több rendelkezésével, így különösen a müködési és gazdálkodási átláthatóságot, kontrollt szolgáló elöírásaival több esetben részletesebb szabályozást vezetett be a későbbi KJK irányelvben lefektetett, a fentiekben már bemutatott hasonló elvekhez képest.

A KJK irányelv hazai átültetését társadalmi egyeztetés keretében előkészítő jogi dokumentum $^{913}$ a Szerzői Jogi Szakértő Testület (SZJSZT) által összeállított észrevételek és javaslatok (együtt: Észrevételek) - többek között - hiányolják a szubszidiaritás és arányosság, továbbá a hatáskör-átruházás elvének megfogalmazását az irányelv rendelkezéseivel szemben, valamint a kulturális és nyelvi sokszínüség védelmének igényét. Az SZTNH a KJK Irányelv (IRE) átültetését célzó, 2015 júliusában nyilvánosságra bocsátott Részletes Koncepciója ${ }^{914}$ (Átültetési Koncepció, ÁK) több szabályozási

\footnotetext{
${ }^{911}$ Szjt. 85. § - 92/P. §

${ }^{912}$ Szjt. 89. § (1) „A közös jogkezelő szervezetnek legalább kétfajta tevékenységet kell közvetlenül ellátnia: egyrészt a jogdíjak és a felhasználás egyéb feltételeinek megállapítását (vagy az abban való részvételt), másrészt a jogdíjak felosztását (vagy - ehelyett - a jogdíjak beszedését és felosztás céljára más közös jogkezelő szervezetnek történő átadását."

${ }^{913}$ Javaslat a KJK irányelv átültetésére Szellemi Tulajdon Nemzeti Hivatala 2014. november.

${ }^{914}$ Részletes koncepció a szerzői és szomszédos jogokra vonatkozó közös jogkezelésről és a zeneművek belső piacon történő online felhasználásának több területre kiterjedő hatályú engedélyezéséről szóló 2014/26/EU irányelv átültetéséhez megalkotandó magyar jogi szabályozás főbb tartalmi kérdéseivel kapcsolatban 2015. július. http://www.sztnh.gov.hu/sites/default/files/20150710_kjk_ire_reszletes_atultetesi_koncepcio_konzultaciora_ 0.pdf
} 
tárgykörben implementációs javaslatokat dolgozott ki; ezekből az alábbiakban csak a legjelentősebbek ismertetésére szorítkozom.

1. A Közös jogkezelési rendszer körében az átültető jogszabály alanyi és tárgyi hatályát illetően az $A K$ az IRE közös jogkezelés fogalmának átvételét javasolja azzal, hogy a rendszer kulcsfontosságú területein a jogszabály megtartaná a hatályos garanciális követelményeket (reprezentativitás, párhuzamos jogkezelői tevékenység korlátozottságának elve).

2. A magyar szerzői jogban egyelöre ismeretlen „független jogkezelő szervezet” témakörében a film- és hangfelvétel-elöállítók, a müsorsugárzó szervezetek, valamint a különböző kiadói szervezetek, mivel egyedi szerződésekkel rájuk ruházott jogokkal rendelkeznek, és sokkal inkább a felhasználói oldal sajátosságait hordozzák magukon, nem tartoznak az IRE szerinti „,független jogkezelö szervezet” kategóriájába. A jogosultakat képviselö, a jogosultak érdekében fellépö közvetitök, menedzserek, ügynökök, ugyanakkor amennyiben felhasználást engedélyeznek, díjakat kezelnek, tehát megvalósítják a közös jogkezelés minimumtartalmát, megfelelnek a független jogkezelő szervezet IRE fogalmának. Az intézmény integrálását a hazai szerzői jogrendszerbe az $A K$ csak jelentős garanciális szabályok bevezetése mellett tartotta elképzelhetőnek (pl. kiterjesztett hatályú jogkezelés végzésének tiltása ilyen jogkezelési formában).

3. A más tagállamban letelepedett közös jogkezelők határon átnyúló, Magyarország területén végzett tevékenysége megkezdésének elözetes nyilvántartásba vételhez indokolt. 4. A díjszabások jóváhagyási rendje segítené az előzetes kontroll bevezetését. Cél a belföldi jogosítási rendszer integritásának megörzése és hatékonyságának biztosítása. Az átültető jogszabálynak rögzítenie kell, hogy a Magyarország területét érintő felhasználás engedélyezésére irányadó közös jogkezelői tevékenység főszabály szerint a magyar jogi szabályozás alá tartozik, továbbá, hogy a Magyarország területére irányuló, letelepedés nélkül nyújtott közös jogkezelési tevékenységre is a Magyarországon letelepedett közös jogkezelésre irányadó szabályok vonatkoznak.

A jelenleg alkalmazott díjszabás jóváhagyási rend megtartását és annak a más tagállamban letelepedett, de Magyarországon jogkezelői tevékenységet folytató szervezetekre való kiterjesztését, továbbá a jóváhagyási rendbe a $G V H$ bevonását is javasolta az $A K$.

5. A szervezeti forma kérdéseit tekintve - a ,független jogkezelö szervezetek” kivételével - az $A K$ indokoltnak tartotta megtartani az egyesületi formakényszert.

6. A közös jogkezelői tevékenység megkezdésének feltételeit, illetőleg a nyilvántartásba vétel szabályait illetően az $A K$ - a társadalmi egyeztetés során érkezett vélemények alapján 
- a hatósági nyilvántartás jelenlegi rendszerét megtartani javasolja, továbbá azt is, hogy a nyilvántartásba vételhez kötöttség elvét a más tagállamban letelepedett, de Magyarországon közös jogkezelő tevékenységet végző szervezetekre is alkalmazni kelljen. A javaslat elképzelhetőnek tartja, hogy bizonyos körben a regisztrációs kötelezettséget egy egyszerü adatszolgáltatásból álló bejelentési kötelezettséggel való váltsa fel. (pld. önkéntes közös jogkezelő szervezetek, „függetlenek”stb.)

7. Az IRE a tágabb jogosulti kör fogalmának való megfelelés érdekében az $A K$ utaló szabállyal rendezné a jelenlegi Szjt. szerinti jogosulti kör pontosítását, az adott vagyoni jog tekintetében már kizárólagos felhasználási engedéllyel rendelkező személyek a közös jogkezelés vonatkozásában szintén a jogosulti kör részei lennének.

8. A felhasználó nem fogyasztói minőségben eljáró személyekre, szervezetekre szükített fogalmán az $A K$ az átültetés során sem kívánt változtatni.

9. A nem kereskedelmi célú felhasználás fogalmának pontos meghatározását és a felhasználás lehetőségének eseti jelleggel való előírását szorgalmazta az $A K$.

10. A kereskedelmi forgalomban nem kapható, („out of commerce”) müvek speciális kezelését az $A K$ - a német modell alapján - önálló közös jogkezelési esetként való bevezetésére tett javaslatot. ${ }^{915}$

11. A hatósági felügyelet megtartása mellett az ÁK a felügyeleti rendszer ,független közös jogkezelök”-re, valamint a más tagállamban letelepedett, de Magyarországon jogkezelői tevékenységet végző szervezetekre való kiterjesztését javasolta.

A társadalmi egyeztetés eredményeként kidolgozott Átültetési Koncepció szabályozási javaslatai egyfelöl jól illeszkedtek a közös jogkezelés hazai szerzői jogi rendszerébe, másfelől kiegészítették a vonatkozó szabályozást. ${ }^{916}$ A javaslatok igazolják, hogy a hazai szerzői jogi jogfejlődés kellően alkalmazkodott a közös jogkezelés rendszere elé a technológiai fejlődés által állított újabb és újabb kihívásokhoz, a szabályozás pedig több esetben meg is előzte az uniós irányelvi rendelkezésben foglaltakat. Szjt. szükség szerinti módosításai biztosították, hogy a magyar közös jogkezelői rendszer alapjaiban megfeleljen a digitális környezet által előhívott új feladatoknak.

\footnotetext{
915 Átültetési Koncepció 34-36.

916 Az Átültetési Koncepció alapján elkészített törvényjavaslat az értekezés kéziratának lezárásakor az Igazságügyi Minisztérium véleményezése alatt állt. Az Átültetési Koncepció hazai jogrendszerbe ültetéséről a 2016. évi XCIII. törvény a szerzői jogok és a szerzői joghoz kapcsolódó jogok közös kezeléséről jelent meg. A törvényt az Országgyülés 2016. június 13-i ülésnapján fogadta el.
} 


\subsubsection{Az audiovizuális médiával kapcsolatos jogdíjrendszerek nemzetközi és hazai összefüggései}

\section{Nemzetközi jogdíj-rendszerek}

A NAMS JK az audiovizuális médiát érintő szerzői joggal kapcsolatos megállapításai körében elsődlegesen a közös jogkezelés során érvényesített jogdíjak hatását vizsgálta. Az audiovizuális iparágban felhasznált tartalmakra vonatkozó jogdíjrendszerek nemzetközi gyakorlatában ${ }^{917}$ kialakult alapvetően kétféle modell, - a bevételarányos jogdíj-, illetőleg a felhasználással összefüggésben megállapított jogdíjrendszer (pld. a vételkörzet nagysága szerint kialakított jogdíj vagy a percdíj) - a konkrét felhasználások eltérése, valamint a tarifaszámítás adott módozatának különbözősége miatt nem vethetők össze a hazai jogdíjakkal. Az eltérések okát az országonként eltérő hagyományokban, sajátos helyi árviszonyokban, fogyasztói szokásokban és más körülményekben lehet keresni. Általánosan érvényesül azonban a „10 százalékos szabály”, azaz a felhasználók a mü hasznosítása révén szerzett összes bevétel egy tizedéről lemondanak a szerzők és más jogosultak javára. A megállapított külföldi jogdíjak differenciáltabbak, sokkal inkább alkalmazkodnak a müfelhasználás mennyiségéhez és a felhasználás módjához; a tarifák a ténylegesen felhasznált audiovizuális tartalom arányához igazodnak, és például különkülön jogdíjakat határoznak meg a kereskedelmi televíziók, valamint a kereskedelmi rádiók müsoraiban felhasznált müvek tekintetében. A bevételarányos rendszerben a jogdíjak alapját a nettó bevételek képezik, azaz az összbevétel csökkenthető a müfelhasználástól független tételekkel vagy százalékos arányban, illetve egyes bevételeknek csak meghatározott része vehető figyelembe.

A nemzetközi tarifarendszerek jellemzően többféle alapon alkalmaznak jogdíjkedvezményeket is. A jelentősebb felhasználók részére egyedi szerződések alapján nyújtanak kedvezményt például Németországban, ahol 20 százalékos kedvezményt kapnak azon felhasználók, amelyek egyesületei a közös jogkezelővel szerződnek a tagszervezeteik nevében. ${ }^{918}$ Kedvezmény érvényesül továbbá bizonyos felhasználási területekre (internet útján történő nyilvánossághoz közvetítés esetére a német és spanyol jogkezelők a szolgáltatások piaci bevezetésének időszakában az átlagostól kedvezőbb jogdíjakat állapítanak meg). A kedvezmények új típusú szolgáltatások alkalmazását, a legális

\footnotetext{
917 Szerzői Jogi Tanulmány 150-174.

918 Daniel J. GERVAIS: Collective Management of Copyright and Neighbouring Rights in Canada: An International Perspective 2001 August Canadian Heritage (GERVAIS) 60.
} 
nyilvánossághoz közvetítési módok elterjedését segítik elő a például az interneten történő zene- és filmletöltések esetében.

\section{Hazai szerzői jogdíjak}

A szerzői jogdíj a szerzőt a mű felhasználása fejében megillető ellenérték. A jogdíjak sajátosságai miatt egzakt, más termékekre és szolgáltatásokra érvényes árképzési modell a jogdíjak vonatkozásában nem értelmezhető és ez által nem is alkalmazható. ${ }^{919}$ A közös jogkezelők által érvényesített szerzői jogdíjaknak a műsorszolgáltatás és a műsorterjesztés általános feltételei körében van jelentősége. Össztársadalmi érdek füződik ahhoz, hogy e jogdíjak esetében a szerzői és szomszédos jogi jogosultak, valamint a felhasználók érdekei megfelelően és egymással egyensúlyban érvényesüljenek. A NAMS konzultációja során elsősorban a felhasználói - hozzászólásokból világossá vált, hogy a jogdíjak megállapításával összefüggő utólagos kontroll lehetőségei jelentős mértékben korlátozottak. A beérkezett észrevételek alapján megállapítható volt, hogy a magyarországi audiovizuális piacon döntően az MSZSZ-EJI és a FilmJus ún. „ismételt sugárzási” jogdíjközleményeinek jogalapjával és díjmértékeivel kapcsolatban van (jog) vita az érintettek között. Az SZJSZT szakvéleménye ${ }^{920}$ értelmében az előadóművész díjigénye akkor is fennáll, ha az előadómüvész hozzájárul előadásának filmalkotásban való rögzítéséhez és nem köti ki külön, hogy a díjigény a rögzítéshez való hozzájárulással nem száll át a rögzítést végzőre vagy másra. A jogdíjközlemények jóváhagyási rendjét vitató műsorszolgáltatói megkeresésre a szakvélemény megállapította, hogy a felhasználók az Szjt. alapján véleményezési jogukat gyakorolhatják az eljárás során. Az igazságügyi miniszter a véleményeket ugyan mérlegelés tárgyává teheti, de azokat nem köteles elfogadni; a díjszabást jóváhagyja vagy sem. Az adott ügyben vizsgálat tárgyává tett díjszabások sem a díjtételek, sem egyéb feltételek tekintetében nem tettek indokolatlan különbséget a felhasználók között.

A Szerzői Jogi Tanulmány szerint a jogdíjközlemények más díjtételeit, így a sugárzási díjat, szinkrondíjat, illetőleg az „on demand” hozzáférési jogdíjat is érte kritika, ,[...] a többi audiovizuális jogdíjközleményt a müsorszolgáltatók elfogadták, azokkal kapcsolatban kifogással nem éltek." ${ }^{921}$

\footnotetext{
${ }^{919}$ A szerzői közös jogkezelés közgazdasági alapjai és versenyjogi megközelítéséről ld.: GRAD-GYENGESARKADY 28-48.

${ }^{920}$ SZJSZT 27/2006.

${ }^{921}$ NAMS JK 25.
} 
A hazai közös jogkezelök közül az ARTISJUS, a MAHASZ, az EJI, a HUNGART és a FilmJus jogdíjközleményei ${ }^{922}$ érintik az audiovizuális szektort. A rádió- és televíziószervezetek a bevételarányos rendszerben, a költségvetési támogatás, az előfizetői díjbevételek, valamint a reklám- és szponzorációs bevételek százalékában megállapított jogdíjakat fizetik, amelyek megfelelnek a nemzetközi ajánlásoknak. A rádió- és televíziómüsorok egyidejű változatlan átvitelét végző kábelszervezetek által fizetett jogdíjak a pedig a legalacsonyabbak közé tartoznak Európában és a kis kábelszervezetek még ennél is alacsonyabb díjakat fizetnek. Amint azt a fentebb részletezett eljárásban a Versenytanács is megállapította, a jogdíjak megállapítására nincsenek általánosan elfogadott, más területen érvényesülő közgazdasági elvek, szabályok. A túlzóan magas ár kapcsán a versenytanácsi határozat megállapította, hogy ,_...] tisztességtelenül (túlzóan) magas az ár akkor, ha az meghaladja a gazdaságilag indokolt költségek és a befektetés adott szakmát jellemző kockázatával arányban álló hozam alapján adódó nyereség összegét, a szerzői jogdíjak esetében nem értelmezhető, és más módszer sem alkalmas azok megítéléséhez.” A szerzői jogdíjak esetében - ennél fogva - nem a díj mértéke, hanem megállapításuk módja [...] esetén vizsgálható a tisztességtelenség."923

A hazai előírások a jogdíjak mértékének megállapításánál az arányos díjazás elvét ${ }^{924}$ követik, más esetekben pedig a megfelelő díjazás ${ }^{925}$ elve érvényesül. A már említett bevételarányos modell ${ }^{926}$ alkalmazásánál meghatározó jelentőségü, hogy a jogkezelő a jogdíj megállapításához milyen, a mü felhasználásához kapcsolódó bevételeket ismer el. Mivel az audiovizuális médiaszolgáltatóknál a müvek felhasználásához közvetlen bevétel többnyire nem mutatható ki, a jogdíjszámítás alapjául szolgáló bevételeket közelítő módszerekkel határozzák meg, ami miatt nemcsak a magyar, hanem az EU tagországokat is - közgazdasági szempontú - kritika éri e modell alkalmazása során. A bevételarányos modellel szembeni egyik érv az, hogy a médiaszolgáltató üzleti sikere és összbevételének növekedése független annak a közös jogkezelőnek a kockázatvállalásától, (az ugyanis nem vesz részt a felhasználásban) amelynek a sikeres felhasználás eredményeként megnőtt bevétel miatt magasabb összegü jogdíjat kell fizetnie. ${ }^{927}$ A másik ellenérv a bevételarányos

\footnotetext{
${ }^{922}$ Szerzői Jogi Tanulmány 90.

${ }^{923} \mathrm{Vj}-97 / 2004 / 37$.

${ }^{924}$ Szjt. 16. § (4)

${ }^{925}$ Szjt. 16. § (5) első mondat.

${ }^{926}$ Ilyen modellt alkalmaz például az ARTISJUS R-TV 15 jogdíjközleménye (költségvetési támogatás, előfizetői díjak, egyéb, reklám és szponzorációs bevételek)

${ }^{927}$ Az Európai Bíróság előtti Kanal 5 Limited TV 4 Aktiebolag kontra Föreningen Svenska Tonsättares Internationella Musikbyra (Stim) C-52/07. sz. ügy Szerzői Jogi Tanulmány 306. lbj. (Stim C-52/07. sz. ügy)
} 
rendszerrel szemben az, hogy azok nem a közös jogkezelő által nyújtott szolgáltatáshoz, hanem a felhasználó összbevételéhez kötődnek, így előfordul, hogy az egyes felhasználók ugyanazon alkotás felhasználásáért nagyon különböző jogdíjakat fizetnek, ezzel versenyhátrányba kerülhet a több jogdíjat fizető felhasználó. A tiszta bevételarányos modell többnyire ötvöződik a jogdíjminimum megállapítási módszerrel, amely minimumot a felhasználás valamely jellemzőjéhez, a nézettséghez, hallgatottsághoz, csatornaszámhoz stb. kötnek. ${ }^{928}$ A jogdíjak fizetésének másik modellje többnyire a müfelhasználás nagyságrendjéhez igazodó fix dijj, amelyet a jelentős felhasználókkal kötött egyedi átalánydíj szerződések tartalmaznak.

A nemzetközi gyakorlatban a jogdíjminimum általában kis összegü, tól-ig számított havi díjat jelent. ${ }^{929}$ A közszolgálati és kereskedelmi médiaszolgáltatók közötti különbségtétel a jogdíjösszegek nagyságában, megállapításuk módjában is megmutatkozik. Az a nemzetközileg folytatott gyakorlat, miszerint a kereskedelmi médiaszolgáltatók a díjszabások díjtételei alapján fizetik a jogdíjat, a közszolgálati médiaszolgáltatókkal pedig a közös jogkezelő szervezetek egyedi szerződéseket kötnek, a magyar gyakorlatban úgy alakult, hogy a közszolgálati médiaszolgáltató mellett a hazai két $J B E$ médiaszolgáltató is több évre előre megköti az egyedi felhasználói (keret) szerződéseit az adott jogkezelő szervezetekkel. A közszolgálati rádió- és televízió-szervezetek általánostól kedvezőbb díjtételeit és szerződési feltételeit ${ }^{930}$ ugyanis korábban a jelentős felhasználók sérelmezték és a felek e sérelmeket egyedi kedvezményekkel, külön megállapodások megkötésével orvosolták.

\subsubsection{Magyar díjszabási eljárás az Szjt. alapján}

A hazai müsorszolgáltatóknak és szervezeteiknek a jogdíjak aránytalan, túlzó, ezáltal nem versenyképes mértékére vonatkozó álláspontján túl a legtöbb kritika az Szjt-ben hiányosan szabályozott és a gyakorlatban sem kellően érvényesülő díjszabási eljárást érte.

A NAMS JK lényeges szabályozói célkitüzésnek tekintette a közös jogkezelők jogdíjközleményeinek elfogadása során az átlátható, az érintett felek érdekeinek

\footnotetext{
${ }^{928}$ ARTISJUS RTV 2015 jogdíjközlemény: költségvetési támogatás 1\%-a, előfizetői díjbevételek 2\%-a, egyéb, a müsorszolgáltatással összefüggő (pl. reklám- és szponzorációs) bevételek 4\%-a; de legalább csatornánként 12500 Ft havonta.

929 A GEMA esetében a jogdíjminimum havi 30-900 Euro között mozgott 2007-ben, ez akkor cca7500225000-, Ft-nak felelt meg, Szerzői Jogi Tanulmány 168.

${ }^{330}$ A közszolgálati média kedvezőbb díjtételeit a médiaszabályozás közszolgálati médiára vonatkozó szigorúbb elöírásai (reklám, közszolgálati müsorok jellege, archívum stb.) indokolják.
} 
harmonikus megjelenítését biztosító rend kialakítását. Ennek megteremtését a $J K-$ természetszerüleg - nem a médiaszabályozás, hanem a szerzői jog keretei között tartotta megvalósíthatónak.

A határos jogterületek integritásának megőrzése érdekében a magyar jogrendszer az audiovizuális média szerzői joggal kapcsolatos kérdéseit - a NAMS JK vonatkozó tételének megfelelően - továbbra is a szerzői jog keretei között szabályozza. Az Mttv. alapvetően a közszolgálati médiavagyonba tartozó szerzői művek és szomszédos szerzői jogi teljesítmények, illetőleg a műsordíj tekintetében tartalmaz speciális rendelkezéseket. ${ }^{931}$

A közös jogkezelő szervezetek jogdíjközleményeinek véleményezési és miniszteri jóváhagyási rendjét az Szjt. 2011. évi módosítása - összhangban a NAMS szabályozási szándékaival - lényeges elemek tekintetében megváltoztatta. A díjszabások véleményezési eljárása és jóváhagyási rendje is a felügyeleti jogkört 2011-től gyakorló SZTNH-hoz került. A díjszabástervezetek Hivatalhoz történő benyújtásának időpontját a módosítás törvényi szintre emelte és minden év szeptember hó 1. napjában határozta meg; az igazságügyért felelős miniszter által jóváhagyott díjszabások alkalmazásának időpontját pedig a következő év első napjában jelölte meg. A díjszabások felhasználókkal való tényleges egyeztetése érdekében szükségessé vált a véleményezési és jóváhagyási rend határidőkhöz kötése is, mivel az egyes közös jogkezelő egyesületek díjszabásai és az azokhoz füzött indokolások több ponton is kapcsolódnak egymáshoz. A díjszabások előterjesztésére törvényileg meghatározott határidő és az ez által kiszámítható menetrend a felhasználók és a jogosultak jobb tájékozódását is szolgálja, továbbá a díjszabások azonos időben való összehasonlítási lehetősége a MódSzjt. alapján valamennyi eljárásban résztvevő számára előnyösebbé vált. ${ }^{932}$

A törvénymódosítás a korábbiaknál szélesebb körben teszi lehetővé a jelentős felhasználók és a felhasználói érdekképviseleti szervezetek bevonását a díjszabások véleményezési eljárásába azáltal, hogy a befizetett éves jogdíjak arányához kötött ,jelentős” felhasználó meghatározását a korábbi 10 százalékról 5 százalékra, az érdekképviseleti szervek vonatkozásában pedig 25 százalékról 10 százalékra szállította le. Az egyes díjszabásokban meghatározott felhasználási feltételek, mint például a jogok és kötelezettségek rögzítése, az egyes mütípusok és a felhasználás egyediségei szerint különböznek. Az egyes felhasználási módok tekintetében a közös jogkezelő szabadon dönthet új felhasználási mód bevezetéséről; az új applikációk bevezetése előtt azonban tanácsos a műszaki - szakmai

${ }^{931}$ Mttv. 100. §, 207. § (6)

${ }^{932}$ MódSzjt. Indokolás alapján. 
körökkel való egyeztetés. A közös jogkezelők díjszabással kapcsolatos önállóságának az egyenlő elbánás elve, a felhasználók közötti diszkrimináció mentesség, valamint a szerzői jogi törvényben előírt jóváhagyási eljárás képezi ésszerủ és arányos korlátját. ${ }^{933}$

A szerzői jogi szabályozás közös jogkezelőket érintő módosításai és a bevezetés óta kialakított gyakorlata nem csak a KJK irányelv akkor körvonalazódó rendelkezéseinek való megfelelést célozta, hanem a NAMS Szerzői Jogi Tanulmány által megállapított irányainak normaszöveg keretében való deklarálását is rögzítette.

\subsection{Közszolgálati médiavagyon és az archívumok szerzői jogi kérdései}

\subsubsection{A közszolgálati médiavagyon}

A közszolgálati müsorszolgáltatást érintő szerzői jogi kérdések elemzése előtt feltétlenül szükséges rávilágítani a közszolgálati tartalom finanszírozásával összefüggő médiavagyon kérdéseire. $^{934}$

A közszolgálat finanszírozásának új alapokra helyezése, a közszolgálati feladatokhoz igazodó, átlátható, ${ }^{935}$ gazdaságos és hatékony müködést biztosító rendszer kialakítása a $N A M S$ egyik legfontosabb célkitüzése volt. A NAMS a médiafinanszírozás elveit és tételeit önálló fejezetben, három fő terület, a felügyelet müködése, a közszolgálati intézményrendszer, valamint a pályázati alapú tartalomtámogatás vonatkozásában tárgyalta. A NAMS alapvető általános elvként fogalmazta meg az átláthatóság és normativitás növelése érdekében, hogy a finanszírozási források egyértelmüen megfeleltethetök legyenek a felhasználási céloknak, elöírta továbbá, hogy a tartalomelőállítás támogatásának egy kiszámítható, más támogatásokkal ${ }^{936}$ harmonizált finanszírozási rendszerben, pályázati formában, normatív módon kell megvalósulnia. A hazai támogatási szabályrendszer kialakítása során a Stratégia - többek között - kiemelt jelentőséget tulajdonított a közszolgálati és az egyéb értékteremtő tartalom-fejlesztés

933 A díjszabások belső elveiről: GYERTÁNFY Péter: A szerzői és a szomszédos jogok közös kezelése II. Magyar Jog, 1997/5. sz. (GYERTÁNFY III.) 258. In: GYERTÁNFY Nagykommentár 544.

934 Megjegyzem, hogy a finanszírozási rendszer nem vonatkoztatható el a NAMS által javasolt új közszolgálati intézményi struktúrától, amelyre a dolgozat 7. „közszolgálatiság” fejezete tér ki.

${ }^{935}$ Az átláthatóság követelményei a közösségi jog „Transzparencia” irányelvében (a Bizottság 80/723/EGK irányelve a tagállamok és az állami vállalkozások közötti pénzügyi kapcsolatok átláthatóságáról) a tagállamok által a közvállalkozásoknak nyújtott pénzügyi támogatásokkal összefüggésben kerültek megfogalmazásra. Az átláthatósági követelmények a közszolgálati müsorszolgáltatóknak nyújtott állami finanszírozásra is irányadók. Ld.: 662., 805. és 812. lbj.

936 Akkor még a Magyar Mozgókép Közalapítvány, valamint a Nemzeti Kulturális Alap Mozgókép kollégiumának támogatási rendszereivel. 
pályázati alapú támogatásának, valamint a közszolgálati archívumok digitalizálásának. ${ }^{937}$ Az új tartalom-pályázati rendszer kialakítása a közszolgálati müsorszolgáltatók tartalomelőállító tevékenységének pályáztatását, a közszolgálati és közösségi szolgáltatók számára kvóták biztosítását, illetőleg a pályázatok során a projektszemlélet erősítését szolgálták. A $J K$ a támogatási intézményrendszerben az addigi Müsorszolgáltatási Alap helyett új elnevezéssel a Tartalom-támogatási Alap létrejöttét szorgalmazta.

Az új médiaszabályozási rezsim a korábban a közszolgálati rádiók és televíziók, ${ }^{938}$ valamint a Magyar Távirati Iroda Zrt. és a Közszolgálati Közalapitvány vagyona meghatározott körének a Médiaszolgáltatás-támogató és Vagyonkezelö Alap ${ }^{939}$ (Alap) részére történő átadásáról Országgyülési határozatban ${ }^{940}$ (Ogy. határozat) rendelkezett. Az Ogy. határozat értelmében a közszolgálati részvénytársaságok és a jogelődeik fennállása során, az általuk készített, sugárzott, illetve egyéb módon közreadott hang-, mozgókép-, valamint fényképfelvételek, továbbá a müsor- és hírszolgáltatás kapcsán keletkezett egyéb dokumentumok és a közszolgálati részvénytársaságok tulajdonában álló jelmez-, díszlet, valamint kottatár térítésmentesen került állami tulajdonba. E vagyon vonatkozásában a tulajdonosi jogok és kötelezettségek összességét az Alap, mint sajátos vagyon- és pénzkezeléssel foglalkozó szerv ${ }^{941}$ gyakorolja. A szabályozás az Alap számára a közszolgálati médiavagyon tekintetében - egészben és részben - elidegenítési, terhelési és átruházási tilalmat ír elő azzal, hogy a tilalom nem akadályozza a közszolgálati médiavagyon egyes elemein fennálló szerzői, illetve felhasználási jogok hasznosítását. ${ }^{942}$

\subsubsection{Archívumok}

A NAMS JK tényként állapította meg, hogy az archiválás hazai intézményrendszere széttagolt. A benne részt vevő állami szervezetek, a Nemzeti Audiovizuális Archívum (NAVA), a Filmintézet, az ORTT Müsorfigyelö- és Elemzö Szolgálata, az MTV, a Magyar Rádió, stb. sok esetben párhuzamos struktúrákat müködtetnek. Ennek alapján szükséges az archívumok felügyeletét ellátó intézményrendszer müködésének összehangolása, az

\footnotetext{
${ }^{937}$ NAMS 49.

${ }^{938}$ Magyar Rádió Zrt., Magyar Televízió Zrt., Duna Televízió Zrt.

939 2010. december 31-ig Müsorszolgáltatás Támogató és Vagyonkezelő Alap.

${ }^{940}$ 109/2010.(X.28.) OGY határozat 4. pont.

${ }^{941}$ GRAD-GYENGE Anikó: Az audiovizuális archívumok szabályozási kerete - különös tekintettel a médiajogi és szerzői jogi rendelkezésekre KOLTAY-NYAKAS (szerk.) MTMI 2015. (GRAD-GYENGE I.) 16.

${ }^{942}$ Mttv. 100. § (1)-(2)
} 
indokolatlan párhuzamosságok felszámolása. Ugyancsak szükségesnek látta a $N A M S J K$ az archiválást végző intézmények közös szakmai szabályok alá vonását annak érdekében, hogy az állami részvétellel végzett archiválás ne csak az állagmegóvást, hanem a multiplatform felhasználást is szolgálja. A $J K$ kívánatosnak tartotta egy egyszerüsitett jogszerzést lehetővé tévő rezsim kialakítását a szerzői jog keretein belül.

Az új médiaszabályozás az Archívumra vonatkozó rendelkezéseket az Mttv. a közszolgálati médiavagyon jogintézményének megalkotásával, annak szabályai körében helyezi el. Az Alap feladata kettős: egyrészt az állami tulajdonban álló közszolgálati médiavagyon tekintetében gyakorolja a tulajdonosi jogok és kötelezettségek összességét, másrészt pedig a közszolgálati médiavagyon egyes elemein fennálló, illetőleg az Alap által megszerzett szerzői, szomszédos, illetve felhasználói jogokat - külön engedély és díjfizetési kötelezettség nélkül - jogosult átadni a közszolgálati médiaszolgáltató ${ }^{943}$ részére. A közszolgálati médiaszolgáltató a közszolgálati médiavagyon részét képező vagy oda nem tartozó szerzői müveket és más szellemi alkotásokat a jogosultakkal kötött megállapodás keretei között használhatja fel. Az Mttv. szerint szintén az Alap gondoskodik a közszolgálati médiavagyon, valamint a médiaszolgáltató és az Alap tulajdonába került, a közszolgálati médiavagyon körébe nem eső, az Szjt. hatálya alá tartozó müveket és más teljesítményeket tartalmazó fizikai hordozók - vagyis az Archívum - tárolásáról, megőrzéséről és felhasználásáról. ${ }^{944}$ Az Mttv. 2014-es módosítása ${ }^{945}$ az Alap tulajdonosi jogait és kötelezettségeit a közszolgálati médiavagyon tekintetében pontosította, lehetővé téve, hogy az külön engedély- és díjfizetési kötelezettség nélkül a közszolgálati feladatai ellátásához szükséges felhasználás - így különösen a nyilvánossághoz közvetítés - céljára átadja a közszolgálati médiaszolgáltató részére a közszolgálati médiavagyonba tartozó szerzői műveket, valamint azon szellemi alkotásokat, amelyek nem tartoznak a közszolgálati médiavagyonba, de amelyekre nézve az Alap felhasználási joggal rendelkezik. A közszolgálati médiaszolgáltató a közszolgálati médiavagyon általa felhasznált elemeire ingyenes felhasználási jogot szerez.

Az Mttv. szerint a szerzői művek és más szellemi alkotások az Szjt., illetőleg a szerzői jogi és szomszédos jogi jogosultakkal kötött megállapodás alapján és keretei között használhatók fel. A jelenlegi médiaszabályozás - eltérő megállapodás hiányában - tiltja a munkaviszonyban vagy más hasonló jogviszonyban létrehozott mű vagyoni jogainak más

\footnotetext{
${ }^{943}$ Mttv. 2014. évi CVII. törvénnyel módosított 100. § (5)

${ }^{944}$ Mttv. 100. § (3)

${ }^{945} 2014$. évi CVII. törvény 14. §-ával módosított Mttv. 100. § (5)-(6)
} 
részére történő engedélyezése esetén a szerzőt megillető díjazást. ${ }^{946} \mathrm{E}$ rendelkezésre is tekintettel rendkívül fontos, hogy a munkavállaló-szerző a médiaszolgáltatónál munkaviszony vagy más jogviszony keretében létrehozott szerzői müvének felhasználása tekintetében külön megállapodást kössön a munkáltatóval. Az egyedi megállapodás ugyanis a létrejött szerzői mü vagyoni jogainak munkáltatóra való automatikus átszállását kizárhatják vagy terjedelemben, időben korlátozhatják. A munkáltató Szjt. szerinti általános szerzői jogi jogszerzésének - ezekben az esetekben - elsődleges feltétele a szerzői mủ tényleges átadása a munkáltató részére, amely átadás csak munkajogi alapon, a munkaszerződés alapján követelhető.

A teljesség igényli, hogy rámutassak az Archívummal kapcsolatos azon hatályon kívül helyezett szerzői jogi rendelkezésekre, amelyek 2014. december 31-ig lehetővé tették az Archívumba tartozást illetően „kétséges”, már bemutatott mü tekintetében -azok közszolgálati médiában történő felhasználása esetén - a szerző vagy a szomszédos jogosult fellépését müvének védelme, valamint díjigény érvényesítése érdekében a médiaszolgáltató felé. ${ }^{947}$ E médiatörvényi rendelkezés hatályon kívül helyezése, a szerzőket és a szomszédos jogi jogosultakat megillető védelem és díjigény érvényesítési lehetőségének kizárása, jogszerütlen beavatkozás a szerzői jog területébe; sérti a szerzők és más jogosultak vagyoni jogait. Grad-Gyenge álláspontjával egyetértve, a módosítás célja a közszolgálati médiaszolgáltató helyzetének könnyítése, ${ }^{948}$ és kötelezettségének díjfizetésre szorítása volt. Az Archívum országos gyüjtőkörü közgyüjteménnyé való minősítésének ${ }^{949}$ - azon túl, hogy a közgyüjteményi jogállás állami támogatások és pályázati források lehetőségét is megnyitja, - elsősorban szerzői jogilag van jelentősége. A kép- és hangarchívumok részét képező müvek ugyanis - mások mellett - a mü nyilvánossághoz közvetítésével rokon felhasználási mód útján, a nyilvánosság Szjt-ben meghatározott köréhez, az Archívum intézményében ilyen célból üzembe állított számítógépes terminál képernyőjén tudományos kutatás vagy egyéni tanulás céljára nonprofit jelleggel szabadon megjeleníthetők és szabadon közvetíthetők. ${ }^{950}$

\footnotetext{
${ }^{946}$ Szjt. 30. § (3) „A szerzőt megfelelö díjazás illeti meg, ha a munkáltató a felhasználásra másnak engedélyt ad vagy a müvel kapcsolatos vagyoni jogokat másra átruházza."

${ }^{947}$ Mttv. 100. § (8)

${ }^{948}$ GRAD-GYENGE I. 29.

${ }^{949}$ Mttv. 100. § (3) utolsó mondata.

${ }^{950}$ Szjt. 38. § (5)
} 
A hatályos médiaszabályozás az eredetileg a $N A V A^{951}$ kezelésének, fenntartásának és müködtetésének feladatát 2011. március 31. után a Hatóság hatáskörébe utalta. ${ }^{952}$ Ezzel az egységes nemzeti archívum megteremtésének folyamata elkezdődött, de a filmarchívum a Magyar Nemzeti Digitális Archívum és Filmintézet (MaNDA) keretében továbbra is megtartotta önállóságát. ${ }^{953}$ A $N A M S J K$ által a szerzői jog keretein belül szükségesnek tartott egyszerüsitett jogszerzést lehetôvé tévő rezsim kialakítása uniós szinten, a közös jogkezelő szervezetekről szóló irányelv elfogadásával megvalósult és a $K J K$ irányelv hazai implementálásával a magyar szerzői jog részévé is válik. ${ }^{954}$

\subsection{A mű integritásának védelme}

A NAMS Szerzői Jogi Tanulmánya és az ennek nyomán létrejött Jogalkotási Koncepció nem foglalkozott külön az audiovizuális müsorszolgáltatásban megjelenő szerzői művek egységével és az egység védelmével. Ennek nyilvánvaló egyik oka a szerzői jog e területének tartalmi, minden részletre kiterjedő szabályozása és kialakult gyakorlata volt, másrészt pedig a Tanulmány e jogintézménytől távol eső tárgya, a közös jogkezelők által alkalmazott jogdíjak szerepe az audiovizuális szektorban. Ennek ellenére, a hatályos médiaszabályozásban megjelenő műintegritást érintő szerzői jogi rendelkezések miatt az audiovizuális média szerzői jogi kérdései körében szót kell ejteni a médiaszolgáltatásban megjelenő szerzői müvek egységének speciális védelméről, ${ }^{955}$ illetőleg e védelem média- és szerzői jogi szabályozási különbözőségéről.

\footnotetext{
951 2004. évi CXXXVII. törvény a Nemzeti Audiovizuális Archívumról.

${ }^{952}$ Mttv. 218. §

${ }^{953}$ A MaNDA 2011-ben az ország egyetlen filmes közgyüjteményeként alakult meg. Célja digitalizálni, online elérhetővé tenni és újra hasznosítani a teljes magyar kulturális örökséget. A MaNDA az Országos Széchényi Könyvtárba történő beolvadással 2017. 01. 01.-vel megszünik azzal, hogy a Filmintézet és Filmarchívum feladatait (beleértve a korábban a Magyar Nemzeti Filmarchívum által örzött filmekkel kapcsolatos digitalizálási feladatokat, valamint a Filmintézeti Szakkönyvtár és Médiatár feladatait) - a Nemzeti Filmtörténeti Élménypark kivételével - a Magyar Nemzeti Filmalap Közhasznú Nonprofit Zártkörủen Müködő Részvénytársaság látja el. A 1853/2016. (XII. 27.) Korm. határozattal módosított 1312/2016. (VI. 13.) Korm. határozat 1. melléklet 1. e) ea) pont.

${ }^{954}$ GRAD-GYENGE-SARKADY 146-156. Az Igazságügyi Minisztérium Versenyjogi, Fogyasztóvédelmi és Szellemi Tulajdonjogi Főosztálya által „A szerzői jogok és a szerzői joghoz kapcsolódó jogok közös kezeléséröl" szóló -, a Kormány által még meg nem tárgyalt - törvénytervezet társadalmi egyeztetése a dolgozat kéziratának leadásakor folyamatban van. A kézirat lezárását követően, 2016. június 13-i ülésnapján fogadta el az Országgyülés a 2016. évi XCIII. törvényt a szerzői jogok és a szerzői joghoz kapcsolódó jogok közös kezeléséröl Ld.: 849. lbj. és 850. lbj.

${ }^{955}$ SARKADY-GRAD-GYENGE 87.
} 
A mü integritásának védelme alapvetően a szerzői jog tárgykörébe tartozó jogintézmény. Ennek megfelelően a mű sérthetetlenségéről az Szjt. a szerző személyhez füződő jogai körében rendelkezik. A médiaszabályozás a szerzői művek sérthetetlenségére vonatkozó rendelkezést az 1996-os médiatörvényben a reklámszabályok között, nevezetesen a müsorszám reklámmal történő megszakítása ${ }^{956}$ körében helyezte el. Az akkori szabályozás alapján a szerző mindkét törvény, azaz az Szjt. ${ }^{957}$ és az Rttv. alapján is felléphetett jogai védelmében az elektronikus médiában megjelenő, a jogát vagy jogos érdekét sértő reklám miatt. Az Rttv. emellett részletesen szabályozta a filmalkotások reklámmal történő megszakításának feltételeit és időbeli korlátait is. ${ }^{958}$

Az Mttv. a mü integritását védő rendelkezését - szintén a lineáris médiaszolgáltatásban megjelenő reklámszabályok között -, hozzáigazította a médiapiac müködése által diktált feltételekhez: „A lineáris médiaszolgáltatásban a müsorszám megszakításával közzétett reklám és televíziós vásárlás - figyelembe véve a müsorszámon belüli természetes szüneteket, a müsorszám időtartamát és jellegét - nem sértheti indokolatlan mértékben a műsorszám egységét, valamint a műsorszám szerzői vagy szomszédos jogi jogosultjának jogát vagy jogos érdekét." 959

Az új médiaszabályozás - a fentiekből következően - lehetővé teszi a müsorszám „, indokolt mértéku”" megszakítását reklámmal és televíziós vásárlással, nyilvánvalóan abból a megfontolásból, hogy a kereskedelmi közlemény e két formája az audiovizuális médiaszolgáltatás természetes velejárói és a médiaszolgáltatás finanszírozásának egyik alapját képezik. Ez a médiatörvényi lehetőség azonban továbbra is sajátos problémaként jelentkezik a szerzői jogban, illetőleg a müintegritás szerzői jogi védelmében.

A régi Szjt. ${ }^{960}$ a mü sérthetetlenségének tekintett minden jogosulatlan felhasználást, megváltoztatást. Az Szjt. 13. §-ának eredeti ${ }^{961}$ szövege szerint „A szerző személyhez

\footnotetext{
${ }^{956}$ Rttv. eredeti, az Országgyülés 1995. december 21. ülésnapján elfogadott 17. § (2) szerint: „A (3)-(6) bekezdésben meghatározott feltételek szerint müsorszámon belül is közzétehető reklám úgy, hogy az ne sértse a müsorszám értékét, egységét, valamint a müsorszám szerzői vagy szomszédos jogi jogosultjának jogát és jogos érdekét.” Az Rttv. Mttv-vel hatályon kívül helyezett utolsó változatának 17. § (2) bekezdése tartalmazta a figyelembe véve a müsorszám idötartamát, a müsorszámon belüli természetes szüneteket és a müsorszám jellegét tényállási elemeket is. Rttv. utolsó változat 17. § (2) „A (3)-(6) bekezdésben meghatározott feltételek szerint müsorszámon belül is közzétehető reklám úgy, hogy az ne sértse a müsorszám értékét, egységét - figyelembe véve a müsorszám időtartamát, a műsorszámon belüli természetes szüneteket és a müsorszám jellegét -, valamint a müsorszám szerzői vagy szomszédos jogi jogosultjának jogát és jogos érdekét."

${ }^{957}$ Szjt.13. §

${ }^{958}$ Rttv. 17. § (3)-(6)

${ }^{959}$ Mttv. 33. § (2)

${ }^{960}$ 1969. évi III. törvény a szerzői jogról. 10. §
} 
füződő jogát sérti művének mindenfajta eltorzítása, megcsonkítása vagy más olyan megváltoztatása vagy megcsorbítása, amely a szerző becsületére vagy hírnevére sérelmes." E szerzői jogi törvényi megfogalmazás egyik értelmezése alapján az eltorzítás, megcsonkítás, megváltoztatás vagy megcsorbítás csak akkor tiltott, ha az a szerző becsületére vagy hírnevére sérelmes. A másik magyarázat alapján a törvényszöveg egyrészt általában tiltja a mü bármilyen eltorzítását vagy megcsonkítását, - függetlenül attól, hogy az sérti-e a szerző becsületét vagy hírnevét -, másrészt pedig jogsértő a mü olyan megváltoztatása vagy csorbítása, amely sérelmes a szerző becsületére vagy hírnevére. ${ }^{962} \mathrm{~A}$ mü torzítása alatt a szakirodalom a mü lényeges vonását érintő megváltoztatását érti, a mű megcsonkítása pedig a mű lényeges vonásait érintő elhagyásokat jelenti. ${ }^{963}$ A korábbi szöveg kétfajta értelmezést is lehetővé tevő rendelkezését az Szjt. 2013. évi módosítása pontosította. ${ }^{964}$ A hatályos Szjt. 13. §-a értelmében ${ }^{965},[\ldots]$ a szerző személyhez füződő jogát sérti művének mindenfajta eltorzítása, megcsonkítása, vagy a mü más olyan megváltoztatása vagy a művel kapcsolatos más olyan visszaélés, amely a szerző becsületére vagy hírnevére sérelmes."

A módosított szöveg - „a müvel kapcsolatos más olyan visszaélés” beiktatásával egyértelmüen a második értelmezés mellett foglal állást. A mű egységébe történő beavatkozás esetei több szempont, - így a jogsértés módja, a vagyoni jogokkal való összefüggés, illetőleg a beavatkozás oka - szerint csoportosíthatók. A jogsértés módja szerinti beavatkozásnak minősül egy szerzői mü méltatlan környezetbe, például reklámfilmbe helyezése, a vagyoni jogokkal való kapcsolat alapján a felhasználás jogszerűsége a döntő momentum, a beavatkozás oka szerinti tényező pedig lehet művészi beavatkozás vagy a müpéldányra vonatkozó tulajdonosi joggyakorlás, ez utóbbi leginkább az építészeti alkotásoknál fordul elő. ${ }^{966} \mathrm{~A}$ módosított Szjt. megfogalmazása ellenére, az audiovizuális médiaszolgáltatásban felhasznált szerzői müvek integritásának ,indokolt

\footnotetext{
${ }^{961}$ Szjt. 2013. március 31-ig hatályos szövege.

${ }^{962}$ Az elöbbi értelmezést erősítette az Szjt. indokolása, az utóbbi talaján állt: GYERTYÁNFY Péter (szerk.): A szerzői jogi törvény magyarázata KJK-KERSZÖV 2000 (GYERTYÁNFY I.) 86.

${ }^{963}$ SZJSZT 30/2003, 20/2005, In: A szerzői joggyakorlat kérdései. Válogatás a Szerzői Jogi Szakértö Testület szakvéleményeiböl (2010-2013) fennállásának 130. évfordulója alkalmából SZTNH 2014. (SZJSZT 2014) 327., valamint GYERTYÁNFY Péter (szerk.): A szerzöi jogi törvény magyarázata Complex 2006. (GYERTYÁNFY IV.) 89.

$964 \mathrm{Az}$ értelmezés összhangját az alkotmányos alapjogokkal és a BUE 1948-as szövegével ld.: GYERTYÁNFY Nagykommentár 139.

${ }^{965}$ 2013. évi XVI. törvény 35. §-ával módosított Szjt. Hatályos: 2013. IV. 1-töl.

966 GYERTYÁNFY Péter: A szerzői jog birói gyakorlata 2006-tól: A védelem tárgya és a mü egysége Iparjogvédelmi és Szerzői Jogi Szemle 7.(117.) évfolyam 4. szám, 2012. augusztus, SZTNH (GYERTYÁNFY V.) 45, 51.
} 
mértéku" médiajogi megsértési lehetősége továbbra is felveti a kollízió problémáját a két jogterület vonatkozó szabályozása között.

„A mü egységének védelmére vonatkozó általános szerzői jogi rendelkezések és a müsorszám megszakítására irányadó speciális médiajogi előírások egymás viszonylatában, mint lex generális és a lex speciális értelmezhetők." ${ }^{967}$ Ennek megfelelően a szerző részéről adott engedély sem teszi lehetővé a müsorszám megszakítására vonatkozó médiatörvényi rendelkezések megsértését. A mü sérthetetlenségének megítélése müfajoktól, illetőleg a sérelem jellegétől (eltorzítás, megcsonkítás, megváltoztatás, illetőleg más visszaélés) függ. A régi Szjt. alapján például a mü integritásának sérelmét állapította meg a bíróság, amikor kicserélték egy televíziós filmsorozat zenéjét egy másik föcím zenére, ${ }^{968}$ de jogsértő megváltoztatásnak értékelte a bíróság a dokumentum hangjáték hangfelvételröl való törlését is. ${ }^{969}$

A mü - az Szjt. és az Mttv. szerint is - reklámmal történő megszakítására adott szerzői engedély nyilvánvalóan kizárja a jogsértő felhasználást. Ennek hiányában azonban - az indokoltság mértékének életszerü birói értelmezése ${ }^{970}$ - a konkrét jogvitás ügyekben az $A V M S$ irányelv vonatkozó rendelkezései alapján - megteremtheti a szerzői- és médiajogi szabályozás közti látszólagos kollízió feloldását. ${ }^{971}$

\section{ÖSSZEGZÉS ÉS KÖVETKEZTETÉSEK}

A dolgozatban elvégzett kutatás eredményei és következtetései - a föbb témaköröknek megfelelően - 1. A vizsgált időszak stratégiákkal kapcsolatos megállapításai és a jövő média-jogalkotása szempontjából megfontolandó következtetések 2 . a modern szabályozási tendenciák szerepe a média jogi szabályozásában, valamint 3. a határos jogterületek és a médiajog szabályozási kapcsolódásai vizsgálódási területek köré csoportosíthatók.

\footnotetext{
${ }^{967}$ SARKADY-GRAD-GYENGE 91.

${ }^{968}$ Fővárosi Bíróság 8. P. 26.070/1944/41.

${ }_{969}^{96}$ BH 1991. 146.

${ }^{970}$ Ilyen bírói vagy a SZJSZT által adott szakvéleményi értelmezés eddig nem született.

${ }^{971}$ Szükségesnek tartom hangsúlyozni, hogy a már hivatkozott szerzői jogi Nagykommentár nem foglalkozik az indokoltság mértékével, a tárgyi szerzői jogi és médiajogi szabályozás közti ellentét bemutatásával és a feloldás kísérletével sem. Megjegyzem, a médiajogi kommentár sem tartalmaz e jogintézménnyel kapcsolatos iránymutatást.
} 


\section{Stratégiaalkotással kapcsolatos megállapítások}

A 2006 - 2008 közötti hazai átfogó médiaszabályozási reform alapvető célkitűzése a konvergáló hírközlési- és médiapiac korszerü müködéséhez szükséges, szabályozási stratégiákkal alátámasztott jogszabályi háttér megteremtése volt. A mintegy két éves időszakban a média-jogalkotás korábban soha nem tapasztalt stratégiai megalapozása, egyfelől a Stratégiák kidolgozása, aktualizálása, társadalmi- szakmai egyeztetése, majd véglegesítése történt. A Nemzeti Audiovizuális Média Stratégia és Jogalkotási Koncepció megalkotásának célját az Európai Unió médiaszabályozásával koherens, a digitális korszak vívmányaihoz rugalmasan alkalmazkodni képes magyarországi médiaszabályozási reform elvi megalapozása, fő irányainak kijelölése, illetőleg a kodifikációs feladatok elökészítése jelentette. A média-jogalkotás alapvető elvei, tételei és szabályozási irányai először a NAMS szakmai vitaanyagban, majd a véleményeket összegző NAMS Jogalkotási Koncepcióban fogalmazódtak meg. A média jogalkotás új módszertana, stratégiai megalapozása korábban nem volt ismert a hazai szabályozás gyakorlatában, de a digitális korszak kihívásai feltétel nélkül szükségessé tették az integrált szemléletet, mind a hírközlési piac, mind pedig a médiaszektor átfogó felmérését, az analóg rendszerek helyzetelemzését.

A dolgozat elsődleges kutatási eredményeként szükséges állapítani, hogy általában a digitális technika a médiaszolgáltatás és müsorterjesztés eszközrendszerében olyan lényegi műszaki változásokat hozott, amelyek a terület hazai szabályozását is alapvetően új kihívások elé állították. Egyértelmüvé vált, hogy az első médiatörvény nem tudja kezelni a földfelszíni digitális televíziózásra való átállás következtében előállt technológiai változásokat, - többek között -, a frekvenciaszűkösség jelentős csökkenését, a fogyasztói szokások interaktívvá válását, a terjesztői piac versenyét és a közszolgálati műsorszolgáltatás előtt álló feladatok megoldását. A médiaszabályozás tekintetében a dolgozat egyik lényegi megállapítása, hogy a technológiai robbanás, a földi analóg rendszerek digitális átállása, az egymással konvergáló hírközlési- és médiapiaci folyamatok Magyarországon átfogó és radikális, szemléletében újszerü, és alapjaiban is korszerüsödött törvényi szintü szabályozási váltást indokoltak; már nem volt elegendő a korábbi törvényi környezet folytonos módosítása. ${ }^{972}$

\footnotetext{
972 A hazai szabályozással szemben Finnországban és Svédországban a digitális átállást nem jogalkotási feladatként, hanem olyan természetes folyamatként kezelték, amelynek elsődleges célja az átállás társadalmi hatásainak kiaknázása volt. Ld.: SZŐKE Gergely László: A digitális átállás médiajogi hatásai Észak
} 
A jövő médiaszabályozása szempontjából szükséges következő tétel szerint a technológia változásainak jelentős mértékben kitett média szabályozása - a hosszú távon is életképes jogalkotás érdekében -, nem tekinthet el piaci folyamatok átfogó vizsgálatától, az aktuális társadalmi, gazdasági, kulturális és politikai igények figyelembevételétől, a szabályozás közgazdasági, jogi irányainak és célkitűzéseinek stratégiai kijelölésétől, azaz a teljes körü média-jogalkotás rendszer-szemléletü, stratégiai megalapozásától. Ennek hiányában a jogi szabályozás csupán az előző törvényalkotás hiátusának részleges pótlására, jogalkotási és szerkesztési hibáinak eseti orvoslására szorítkozhat, de nem adhat teljes körü, rendszerszintű megoldásokat az elkövetkezendő idők médiaszabályozási kihívásaira. ${ }^{973}$

Az audiovizuális tartalom elöállitása területén a Koncepció víziójával egyezően a színvonalas, értékes tartalom szerepe az elmúlt időszakban felértékelödött, a médiaértékláncban a hangsúly a két kevésbé szabályozott „láncszemre”, a tartalomra és a fogyasztóra helyeződött át. A tartalomkínálat a müsorarchívumok digitalizálása révén még az archívumok teljes egységesülése nélkül is -, jelentősen bővült, és e bővüléshez hozzájárult a megvalósult szabályozás tartalom-előállítást támogató, átgondolt rendszere. A tematikus szegmens - a sokszereplös hazai lineáris médiaszolgáltatási piac mellett már a $N A M S J K$ létrejöttekor - is dinamikus növekedést mutatott; így látszott, hogy a szakosított csatornák várhatóan a reklámpiacból egyre nagyobb részt fognak kihasítani. A Koncepció az általános tematikájú kereskedelmi csatornák kereszttulajdonlási korlátainak eltörlésétől - utóbb a megvalósult szabályozás által is igazoltan - azt várta, hogy e médiaszolgáltatók piaci részesedésük megörzése érdekében további terjeszkedésre törekednek. A tematikus csatornaszám növekedéséhez a korábbi tiltó rendelkezések feloldásával a NAMS JK nyomán a médiaszabályozás jelentős mértékben hozzájárult.

A Koncepció a közszolgálatiság eszméjét és céljait kitüntetett figyelemmel kezelte, az általa kívánatosnak tartott célállapotban a széles körü társadalmi és piaci konszenzussal kijelölt közszolgálati feladatokat egy hatékony, innovatív, a jövő kihívásaira és változásaira gyorsan és rugalmasan reagáló szervezetrendszerben látta megvalósíthatónak. Az Mttv. közszolgálati médiaszolgáltatásra irányadó rendelkezései - kifejezetten a közszolgálati médiaszolgáltatásra irányadó alapvető elvek és célok törvényi

Európában (Finnország, Svédország, Hollandia, Észtország) 2009. január $37 . \quad$ szám, http://www.akti.hu/dok/fuzet37.pdf

973 GÁLIK Mihály - HORVÁT János - SZENTE Péter: Egy új médiatörvény alapjai (Javaslat), In: Magyarország Médiakönyve 2003 II. kötet ENAMIKÉ 943-989., GELLÉRT KISS Gábor - Dr. BALLAI Éva: A köznyilvánosság működéséről szóló törvény koncepciója In: Magyarország Médiakönyve 2003 . II. kötet ENAMIKÉ 991-1028. Ld.: 236. lbj. 
megfogalmazása mellett - megkülönböztetett szabályozási környezetbe, önálló részbe kerültek. A közszolgálati médiával szembeni társadalmi elvárások teljesítése nem a létrejött szabályozáson múlik. A kialakított közszolgálati szabályrendszer - beleértve a szervezeti, intézményi struktúrát, a törvényileg rögzített feladat- és hatásköröket, az összeférhetetlenségi előírásokat, valamint a gazdálkodásra vonatkozó rendelkezéseket -, alkalmas a korábban is megfogalmazott célkitüzések megvalósítására, de a szabályok helyes értelmezésén, végrehajtásán, gyakorlati alkalmazásán sok múlik.

$\mathrm{Az}$ átviteli rendszerek, a müsorterjesztés piacán a $N A M S J K$ tovább élénkülö versennyel számolt. A Magyarországon meghatározó, ám a müholdas müsorszórás árainak csökkenése miatt már a Koncepció idején is kihívásokkal szembesülö kábeltelevíziós társaságoknak új versenytársakkal kellett szembe nézniük a földi digitális, illetve az IP-alapú szolgáltatások megjelenésével és elterjedésével. A digitalizáció, a fejlettebb tömörítési technikák hozzájárultak a platformok versenyének további élénküléséhez, a csomagrendszer helyett a fogyasztók egyedi csatornaválasztásához, továbbá az új szolgáltatások (online tartalmak, OTT szolgáltatások VoD, PVR, timeshifting, stb.) és tartalom-formátumok (HDTV, mobilTV) elterjedéséhez. Az interaktivitás, valamint az egyénre szabhatóság nyújtotta lehetőségek mindezekkel együtt egyre népszerübbekké válnak.

A két $J B E$ lineáris audiovizuális szolgáltató legnagyobb éves átlagos közönségarányú csatornája után is szedhető műsordíj érvényesítésének lehetősége értelemszerűen átrendezi a két évtized alatt kialakult üzleti modellt a médiaszolgáltató és a terjesztő viszonylatában. A létrejött tartalomszabályozás az akkorra már végleges $A V M S$ irányelvet megfelelően implementálta a hazai médiaszabályozásba. A közszolgálati médiaszolgáltatás $N A M S J K$ ban célzott „reklámtalanításának” a 2010. évi szabályozás idején már nem volt realitása, de a kereskedelmi kommunikáció új formái már az új médiatörvény részeivé váltak.

A Koncepció által elöre vetített jövőkép olyan felügyeleti-hatósági modell létrehozását szorgalmazta, amely képes felkészülni a konvergencia-kihívásokra, és amelynek meghatározó elemei a függetlenség, a szakmaiság és a szolgáltató jelleg voltak. A 2010-es médiaszabályozás - elnevezésében is - konvergens, integrált felügyeleti hatósági intézményt hozott létre, amelynek szervezeti önállósága, függetlensége, önálló hatásköre, feladatai, illetőleg az összeférhetetlenségre vonatkozó elöírások törvényi szinten kétségtelenül biztosítottak. 
A jövő médiafogyasztási szokásait illetően a $N A M S J K$ fontos szerepet tulajdonított a tudatos választás és fogyasztás biztosításának. A médiatudatosságra ${ }^{974}$ való nevelés és a médiaismeretek oktatása az elmúlt években jelentős szerephez jutottak. ${ }^{975}$ Célja egyértelmüen pozitív: a média bonyolult műszaki világában az eligazodás segítése, a felhasználói készségek fejlesztése révén a biztonságos, célzott és tudatos fogyasztói választás lehetőségének megteremtése. A tudatos médiafogyasztás hozzájárul a különböző tartalmak értelmezéséhez, a káros tartalmak kiszüréséhez, illetőleg a tartalmak közötti felelősségteljes választáshoz. A médiaműveltség célzott társadalmi elterjesztése elősegíti a médiához való tudatos hozzáállást, a „fogyasztói döntéshozatal felelösségteljes kultúrájának” kialakulását, ezáltal a „leghatékonyabb védelmi eszköz lehet a média káros hatásaival szemben." 976

A dolgozat komparatív elemzése igazolja a NAMS Jogalkotási Koncepció elveinek és tételeinek, valamint a kész normaszöveg több esetben tapasztalható egybecsengését. A szakmai fundamentumok lerakása és a több szintü egyeztetések hozták meg az előkészítő munka eredményét, a jelenlegi médiaszabályozási rezsim kialakulását. ${ }^{977}$ A NAMS minden esetre a magyar média jogalkotás eddigi történetében az első olyan koncepcionális elemzés, amely piacfelmérésen, az akkori korszerű médiaszabályozási elveken és ismereteken nyugszik, valamint nyilvános szakmai-társadalmi vitában formálódott és megtalálta azokat a kompromisszumos szabályozási megoldásokat, amelyek a jelenlegi, többszintü médiaszabályozási rendszer létrejöttéhez vezettek.

A 2010-es médiaszabályozással szemben kezdetben megnyilvánuló kritikai hangvétel szakmai alapja több esetben vitatható volt; a bíráló megjegyzések sokkal inkább valamiféle demonstratív ellenállást céloztak az új szabályozással szemben. Minden esetre manapság a sajtó nem a médiaszabályozás elégtelenségétől hangos. A médiában tapasztalt hazai visszásságokat nem a szabályozás, illetve vélt, esetleg valós hibái indukálják, hanem az „,in fraudem legis” elve, azaz a jogszabályok kijátszására, megkerülésére irányuló törekvés, vagy éppen a szabályok sajátos értelmezése és alkalmazása.

\footnotetext{
${ }^{974}$ Médiatudatosság alatt olyan készségek, ismeretek és értelmezési képességek összegző fogalmát kell értenünk, amelyek segítségével az átlag-médiafogyasztó hatékonyan és biztonságosan képes a média használatára. AVMS irányelv (47) Preambulum.

975 A médiatudatos személy jellemzőit ld.: a Médiatudatosság Európai Kartája megfogalmazása szerint http://www.euromedialiteracy.eu/charter.php

${ }^{976}$ GELLÉN I. 124.

977 Az értekezésben több esetben hivatkozási pontként megjelölt, 2008 nyarán megjelent tanulmányokban megfogalmazott szakmai álláspontok már nem járulhattak hozzá a NAMS még teljesebbé tételéhez, ezek a tanulmányok ugyanis már jóval a nyílt társadalmi konzultációt követően láttak napvilágot.
} 


\section{A modern szabályozási tendenciák szerepe a média jogi szabályozásában}

A médiaszabályozás korszerü szemléletét, a digitális átállástól sem független, ${ }^{978}$ egyre korszerűsödő módszereit a médiareform dokumentumai magukon hordozzák. A szakmai civilszervezetek aktivitása révén a gyakorlatban is feltủntek a médiaszabályozás új, alternatív módozatai, a már müködő önszabályozó szervezetekkel való együttmüködés lehetőségei, így különösen a társszabályozás igénye, amely - összhangban az AVMS irányelv rendelkezéseivel - az új médiatörvényben is szerephez jutott. Az EU kezdeményezései és az új szabályozási módszerekkel kapcsolatos hazai médiajogi szabályozás is igazolta, hogy a hagyományos jogi szabályozás csak az alternatív szabályozási módszerekkel együtt képes megfelelni az új korszak, a digitális médiakörnyezet kihívásainak. A jövő komplex szabályozási igényének kielégítése jelentős mértékben függ majd az állami szabályozási rendszerek és az alternatív ön- és társszabályozás, valamint a „better regulation” együttes működésétől, ez utóbbiak különböző jogalkotási és döntés előkészítő folyamatokba való beépülésétől. Minden esetre az már most megállapítható, hogy a jövő jogi szabályozása egyre aktívabban igényli az önés társszabályozás alkalmazását, valamint a ,jobb szabályozás” érdekében kifejlesztett eszközöket és módszereket. Az AVMS irányelv módosítására tett javaslat ${ }^{979}$ konkrét intézkedéseket is megfogalmaz a ,jobb szabályozás” az utólagos értékelés, az érdekeltekkel való konzultációk, továbbá a hatásvizsgálat szükségességéről, illetőleg a minőségi jogalkotás érdekében az ön- és a társszabályozás eszközeinek alkalmazásáról.

A fejlődés iránya - vélhetően - az állami jogalkotó szervek és az önszabályozó szervezetek közös szabályozási gondolkodása, közös szabályozási célok meghatározása és megvalósítása, a tényleges együttes szabályozás felé tart, valamint lassan helyet követel magának a jogi oktatásban is.

\section{A határos jogterületek és a médiajog szabályozási kapcsolódásai}

A NAMS Jogalkotási Koncepció olyan, sokszereplös, versenyalapú, innovatív média szektor szabályozási alapját kívánta megteremteni, amely biztosítja az információk hatékony továbbítását, a fogyasztók sokszínű tájékoztatását és tartalmas szórakoztatását, valamint hozzájárul a kapcsolódó iparágak sikerességéhez. A Stratégia-alkotással szinte egy időben indult a Gazdasági Versenyhivatalban az analóg médiapiac teljes átvilágítása,

\footnotetext{
978 SZÖKE Ld.: 972. lbj.

${ }^{979}$ AVMS Felülvizsgálati Javaslat. 1d.: 114. lbj.
} 
hiszen a szektor nem léphetett át a digitális korszakba az analóg piaci folyamatok eredményeinek elemzése nélkül. ${ }^{980}$

A kutatás eredményeként meg kell állapítani, hogy a szabályozási konvergencia szükségessége már a média-jogalkotás első fázisában, a stratégiai megalapozásban és az ágazati vizsgálat kezdeményezésében jelentkezett, majd a 2010-es médiaszabályozásban teljesedett ki. A konvergens média-, és hírközlési piac Mttv. szerinti szektorális versenyszabályozásához a tudományos elemzések és piaci vizsgálatok, egyfelől a NAMShoz készült versenyjogi tanulmány, másfelől pedig az ágazati vizsgálat eredményei egyértelmüen hozzájárultak; a médiaszabályozásnak a jövőben is alapoznia kell a tudományos kutatás időszerű elméleti megállapításaira és gyakorlati tapasztalataira.

A dolgozat kitüntetett figyelmet szentel a médiával határos jogterületek közül a szerzői jogi kérdéseknek, ezen belül is az audiovizuális média közös jogkezelési rendszerének, valamint az archívumok és a müintegritás témakörének. Az elemzés kimutatja, hogy a határos jogterületek közelítése, adott esetben átfedése, egyetlen jogintézmény tekintetében sem vezethet odáig, hogy egymás szabályozási kompetenciájába tartozó kérdéseket rendezzenek. Az egyes jogterületek eltérő szemléletmódja, különböző szabályozási célkitüzései, terminológiai rendszere és jogi logikája - a jogterületek egymásra való hatása mellett is -, szükségszerüen igényli és meg is alapozza az adott jogterületek önállóságát, integritásuk megörzését, valamint a jogterületek egyes átfedő jogintézményei közötti összhang megteremtésének szükségességét.

A közös jogkezelési rendszerek behatóbb vizsgálatát egyfelől az audiovizuális média szerzői jogi kérdéseinek felértékelődése, ezzel együtt a már említett új közös jogkezelési irányelv létrejötte és annak hazai jogrendszerbe való implementálási kötelezettsége indokolta. A szerzői művek létrejöttét és felhasználását inspiráló új technológiák a közös jogkezelés mintegy két évszázados rendszerét is új kihívások elé állítják, a már kialakult szervezeti modellek és a szerzői művek hasznosulási folyamatának újra gondolására ösztönzik a szerzői értéklánc valamennyi szereplőjét. A 2014-ben elfogadott közös jogkezelési irányelv korábban ismert főbb irányainak megfelelő szerzői jogi szabályozás a hazai közös jogkezelő szervezetek müködésének és gazdálkodásának átláthatóságára vonatkozó rendelkezések beépítésével, a jogi monopólium megszüntetésével és a nyilvántartási szabályok korszerüsítésével már a 2011. évi Szjt. módosítással elkezdődött.

980 Ld.:763. lbj. 
A közös jogkezelés rendszerének modernizálása az irányelv implementálásával, a közös jogkezelésre vonatkozó törvény hatályba lépésével megvalósult. A 2016 szeptemberében a digitális egységes piacon a szerzői jog jövőbeni szerepéről megjelent irányelvi és rendeleti javaslat pedig még inkább közelíti egymáshoz az audiovizuális média és a kapcsolódó uniós szerzői jogi szabályozást. ${ }^{981}$

Összességében a folyamatosan megújuló médiaszabályozásnak a jövőben is meg kell küzdenie a megállíthatatlan technológiai fejlődés újabb és újabb vívmányainak médiajogi relevanciájával és azzal a kihívással, hogy a kizárólagos jogi szabályozás egyedül képtelen megfelelni az egyre bonyolultabb médiarendszer kezelésének. A hírközlés egyetemleges keretszabályozásához hasonló egyetemleges médiaszabályozási keretrendszer, az ágazatokon átívelő horizontális médiaszabályozás létrehozásának szükségességét ${ }^{982}$ többek között - a világszerte különböző nemzetállami szabályrendszerek és a többszintü, heterogén médiapolitika (nemzeti, regionális és nemzetközi) egységesítése indokolja.

A médiapolitika jövőbeni kérdéseit $M c Q U A I L$ öt témakör alapján csoportosította:

a) a médiateljesítményre koncentráló etikai, szakmai normák alapján történő elszámoltathatóság b) az egyén és a társadalom védelme az új kommunikációs rendszerek által okozott sérelmek esetén c) a nyilvános társadalmi és kulturális kommunikációval kapcsolatos pozitív célkitűzések és elvárások meghatározása d) a kommunikáció alapvető szabadságjogainak megtartása, valamint e) az állami és a politikai hatalom, illetőleg a kommunikációs uralom közötti viszonyok demokratikus elvek mentén történő kezelése. ${ }^{983}$ A keretrendszer kialakulását ugyanakkor több tényezö is késlelteti. Jelenleg nincs közös álláspont - egyebek mellett - a médiatulajdon, az internet szürése, ${ }^{984}$ valamint a cenzúra ${ }^{985}$ kérdéseiben.

A média gazdasági és kulturális jellege és e kettős természet közt feszülő ellentét a jövőben is meghatározza a jogi szabályozás irányát. ${ }^{986}$ Meggyőződésem ugyanakkor, hogy a

\footnotetext{
981 „A Javaslat elő fogja mozdítani a fogyasztók több, más tagállamból származó televízió- és rádióműsorhoz való hozzáférését, mind a müsorszolgáltató szervezetetek kiegészítő online szolgáltatásait, mind a továbbközvetítési szolgáltatásokat illetően. A javaslat közös uniós megközelítést vezet be, miközben a jogosultak részére fenntartja a magas szintủ védelmet. Ezáltal hozzájárul a belső piac belső határok nélküli területként való müködéséhez." [DEP SZJ Javaslat] Ld.: 546. lbj, 562. lbj. és 826. lbj.

982 Zöld Könyv 1997.

${ }^{983}$ Denis McQUAIL: The Current State of Media Governance in Europe. In: European Media Governance National and Regional Dimensions 2007 UK, TERZIS 17-25, 25.

984 „A szürés azt a folyamatot jelenti, amely eredményeként az internetes felhasználót megakadályozzák konkrét weboldalak meglátogatásában, például DNS módosításával, az URL vagy az IP-cím szürésével, magas szintü csomagelemzéssel, HTTP proxy szüréssel, geolokáción alapuló szüréssel, tartalomszürő szoftver, túlterheléses támadások révén.” WEBER - HEINRICH 53. lbj. 284.

${ }^{985} \mathrm{Ld} .:$ 31. és 32. lbj.
} 
globalizált világ folyamatai, a piac törvényei fokozatosan, de biztosan áttörik a hagyományos jogi szabályozási struktúrák korlátait. A jövő médiájának szabályozási sikere - mások mellett -, a jogi szabályozás belső konfliktusainak feloldásában, a határos jogterületek egymásra figyelő rendszerében és a különböző szabályozási modellek egymásra találásában rejlik.

${ }^{986}$ Ld.: részletesen: NYAKAS Levente: A média a nemzetközi kereskedelemben Magyar és európai médiajog [KOLTAY András - NYAKAS Levente (szerk.)] Wolters Kluwer Budapest, 2015. 205-214. 
Függelék

\section{MEGVALÓSULÁSI TÁBLÁZAT}

\begin{tabular}{|c|c|c|c|}
\hline \multirow[b]{2}{*}{ NAMS } & \multicolumn{3}{|c|}{ A médiaszabályozásban } \\
\hline & megvalósult & $\begin{array}{c}\text { részben } \\
\text { megvalósult }\end{array}$ & $\begin{array}{c}\text { nem valósult } \\
\text { meg }\end{array}$ \\
\hline \multicolumn{4}{|l|}{$\begin{array}{l}\text { ÁLTALÁNOS SZABÁLYOZÁSI } \\
\text { ELVEK }\end{array}$} \\
\hline $\begin{array}{l}\text { 1. Új médiaszabályozás, új } \\
\text { „médiatörvény”szükségessége } \\
(2.3 .1 .)\end{array}$ & Smtv., Mttv. & & \\
\hline $\begin{array}{l}\text { 2. Média- és hírközlési szabályozás } \\
\text { szétválasztása (5.2.) }\end{array}$ & $\begin{array}{l}\text { Eht. - Dtv. - Smtv. - } \\
\text { Mttv. }\end{array}$ & & \\
\hline $\begin{array}{l}\text { 3. AVMS átültetése (6.1.) } \\
\text { EU jogának való megfelelés }\end{array}$ & Mttv. 230. § & & \\
\hline $\begin{array}{l}\text { 4. Írott sajtó önálló szabályozása } \\
\text { (5.2.) }\end{array}$ & & & $\begin{array}{l}\text { Smtv. } 1 . \S 6 . \\
\text { Mttv. } 203 . \S \\
\quad 60 .\end{array}$ \\
\hline $\begin{array}{l}\text { 5. Rádiós médiaszolgáltatás } \\
\text { digitális átállásának szükségessége } \\
\text { (3.6.) }\end{array}$ & Dtv. 38. $\S(2)$ & & \\
\hline $\begin{array}{l}\text { 6. Rádiós médiaszolgáltatás a } \\
\text { médiaszabályozás rendszerében } \\
(3.6 ., 6.2 .1 .1 .)\end{array}$ & $\begin{array}{l}\text { Smtv. 1. } \S 3 ., \text { Mttv. } \\
\text { 203. } 1 \text { a., } 58 ., 10 . \S \\
(3), 20 . \S(3) 21 . \S \\
(1)-(2), 28 . \S(2)\end{array}$ & & \\
\hline $\begin{array}{l}\text { 7. Egységes médiatörvény - } \\
\text { egyszerü és minősített többségü } \\
\text { szabályok egy törvényben (5.1.) }\end{array}$ & Mttv. 229. § & & \\
\hline \multicolumn{4}{|l|}{$\begin{array}{l}\text { ÁLTALÁNOS NAMS } \\
\text { SZABÁLYOZÁSI ELVEK }\end{array}$} \\
\hline $\begin{array}{l}\text { 8. Új, Integrált szemléletmód a } \\
\text { szabályozásban (4.2.1.) }\end{array}$ & Dtv. - Smtv. - Mttv. & & \\
\hline $\begin{array}{l}\text { 9. Egység és kölcsönhatás a } \\
\text { szabályozási pillérek között (2.3.1.) }\end{array}$ & Dtv. - Smtv. - Mttv. & & \\
\hline $\begin{array}{l}\text { 10. NAMS szabályozási } \\
\text { célrendszerének időtávlata (2.3.1.) }\end{array}$ & $\begin{array}{l}\text { Smtv. - Mttv. } \\
\text { hatálya }\end{array}$ & & \\
\hline $\begin{array}{l}\text { 11. Szabályozási célrendszer főbb } \\
\text { elmei alapjogok, pluralizmus, } \\
\text { kulturális, nyelvi sokszínúség, } \\
\text { európai és magyar tartalom } \\
\text { támogatása, gyermekek jogai, } \\
\text { versenyképes médiapiac (4.2.3., 8.) }\end{array}$ & $\begin{array}{l}\text { Mttv. Preambulum, I. } \\
\text { Rész II. Fejezet 9- } \\
11 . \S, \text { V. fejezet, } 171 . \\
\S\end{array}$ & & \\
\hline 12. Szabályozási pillérek & & $\mathbf{X}$ & \\
\hline $\begin{array}{l}\text { TARTALOM SZABÁLYOZÁSI } \\
\text { ELVEK (6.) }\end{array}$ & & & \\
\hline
\end{tabular}




\begin{tabular}{|c|c|c|c|}
\hline $\begin{array}{l}\text { 13. Háromosztatú médiarendszer, } \\
\text { közösségi média jelentősége a } \\
\text { szabályozásban (6.2.1. 2.) }\end{array}$ & $\begin{array}{l}\text { Mttv. 203. § 15. 24. } 25 . \\
\text { 31. 52., I. Rész IV. } \\
\text { Fejezet, 36. §, 64. § (2) }\end{array}$ & & \\
\hline $\begin{array}{l}\text { 14. Jogalkotási menetrend (6.2.2.), } \\
\text { lekérhető szolgáltatások } \\
\text { késleltetett szabályozása (6.2.6.) }\end{array}$ & & & $\begin{array}{l}\text { Mttv. } 203 . \S \\
\text { 35. } 36 .\end{array}$ \\
\hline $\begin{array}{l}\text { 15. Lekérhető szolgáltatások } \\
\text { Elker. törvényben való } \\
\text { szabályozása }(6.2 .2 ., 6.2 .4 .)\end{array}$ & & & $\begin{array}{l}\text { Smtv. 4. } 5 . \\
\text { Mttv. 203. } \\
\text { 35. } 36 .\end{array}$ \\
\hline $\begin{array}{l}\text { 16. Ön- és társszabályozás } \\
\text { szorgalmazása (6.2.3.) }\end{array}$ & Mttv. 8. $\S$ & $\begin{array}{l}\text { IV. Rész VI. } \\
\text { Fejezet }\end{array}$ & \\
\hline $\begin{array}{l}\text { 17. Dogmatikai átláthatóság } \\
\text { (6.2.4.) Ld.: 14.15. sh., ker. } \\
\text { kommunikáció }\end{array}$ & & & $\begin{array}{l}\text { Pp., Fttv., } \\
\text { Grtv., } \\
\text { Tptv.Smtv.Mt } \\
\text { tv. }\end{array}$ \\
\hline $\begin{array}{l}\text { 18. Lineáris szolgáltatás kötelező } \\
\text { bejelentése és nyilvántartásba } \\
\text { vétele (6.2.7.) }\end{array}$ & $\begin{array}{l}\text { Smtv. 5. § (1) Mttv. } \\
\text { 41. § (1) 42- 43. } \S\end{array}$ & & \\
\hline $\begin{array}{l}\text { 19. Lekérhető szolgáltatás } \\
\text { önkéntes bejelentése (6.4.7.) }\end{array}$ & & & $\begin{array}{l}\text { Smtv. 5. } \S \\
(1), \text { Mttv. } 41 . \\
\S(2)\end{array}$ \\
\hline 20. Származási ország elve (6.2.8.) & $\begin{array}{l}\text { Mttv. } 1 . \S, 2 . \S 176- \\
\text { 180. } \S 183 . \S(1) \mathrm{n}) \\
182 . \S \mathrm{d})\end{array}$ & & \\
\hline 21. Kvótaszabályozás (6.2.9.) & $\begin{array}{c}\text { Mttv. } 20 . \S-22 . \S 203 . \S \\
9.12 .37 .\end{array}$ & & \\
\hline 22. Válaszadás joga (6.2.10.) & & & $\begin{array}{l}\text { régi Ptk. } 79 . \S \\
\text { Smtv. V. Cím } \\
\text { régi Pp. } 342- \\
\text { 346. } \S \\
\text { új Pp. } 495- \\
501 . \S\end{array}$ \\
\hline $\begin{array}{l}\text { 23. Alkotmányos értékek (6.3.1.) } \\
\text { véleményszabadság, emberi } \\
\text { méltóság (6.2.4.) gyermekek } \\
\text { védelme (6.2.4.) differenciáltabb } \\
\text { korhatári besorolás }\end{array}$ & $\begin{array}{l}\text { Mttv. Preambulum, I. } \\
\text { Rész II. Fejezet, II. } \\
\text { Rész I. Fejezet } \\
\text { Mttv. 9-11. } \S, 183 . \S \\
\text { a) b) }\end{array}$ & & \\
\hline $\begin{array}{l}\text { 24. Músorelőzetesek, ajánlók } \\
\text { (6.3.2.) }\end{array}$ & & $\begin{array}{l}\text { Mttv. 9. § (1) } \\
\text { 203. } \$ 45 .\end{array}$ & \\
\hline 25. Reklámszabályozás (6.3.3.) & $\begin{array}{c}\text { Kereskedelmi } \\
\text { közlemény Smtv. } 20 . \\
\S(1)-(7) \text { Mttv. 23- } \\
\text { 37.§ 32. } \S, 36 . \S, \\
\text { 203. } \S 53.72 ., 30-31 . \\
\S\end{array}$ & & \\
\hline $\begin{array}{l}\text { 26. Gyermekmüsorok reklámmal } \\
\text { történő megszakíthatóságának } \\
\text { tiltása, támogatói logó } \\
\text { megjelenítése }(6.3 .3 .3)\end{array}$ & & Mttv. 33. $\S(3)$ & $\mathbf{X}$ \\
\hline
\end{tabular}


27. Reklámidő számítása, támogatott müsorszámok (6.3.3.

4.)

28. Médiatudatosság, médiamüveltség (6.3.4.)

\section{KÖZSZOLGÁLATISÁG (7.)}

29. Közszolgálati média kiemelt jelentősége (4.2.3., 7.)

30. Közszolgálati és kereskedelmi feladatok tiszta elválasztása (7.1.)

31. Közszolgálati feladatok funkcionális, feladatközpontú meghatározása (7.2.2.)
Mttv. 35. § (1)-(2),

$36 . \S(1)-(2)$, Smtv.

20. $\S(8)-(10)$, Mttv. 26-28. $\S$

Mttv. 83. § (2) c) 132. $\S \mathrm{k})$
Mttv. 6. §. III. Rész, 203. $\S 31 ., 32$.

\section{A közszolgálatiság rendeltetése}

(7.2.3.)

33. A közszolgálatiság univerzalitása (7.2.3.)

34. Nemzeti nyelv, nemzeti kultúra (7.2.4.)

35. Kiemelt közszolgálati célcsoportok (7.2.5.) 36.Tájékozódáshoz és tájékoztatáshoz való jog (7.2.6.) 37. Kettős teszt (7.2.7.) 38. Rugalmas müsorkínálat (7.2.8.)

39. Müsorterjesztés (7.2.9.) 40. Platformsemleges közszolgálat (7.2.10.)

41. Önálló közszolgálati intézményrendszer szükségessége (7.3.1.) 42.Átlátható közszolgálati gazdálkodás (7.3.2.) 43. Racionális intézményi struktúra (7.3.2.) 44. Közszolgálati müsorszolgáltatók együttműködésének szorgalmazása (7.3.4.) 45. Egységes közszolgálati felügyelet (7.3.5.) 46. Közszolgálati intézmények nonprofit részvénytársasági szervezeti formája (7.3.6.)

Mttv. III. Rész

II., III. IV.

Fejezet, 85. §

(2), 90-91. § 96.

$\S$ 


\begin{tabular}{|c|c|c|c|}
\hline $\begin{array}{l}\text { 47. A tulajdonosi jogok gyakorlása } \\
\text { és gyakorlója (7.3.7.) }\end{array}$ & $\begin{array}{l}\text { Mttv. III. Rész II. } \\
\text { Fejezet }\end{array}$ & & \\
\hline $\begin{array}{l}\text { 48. Civil álláspontok } \\
\text { becsatornázása (7.3.8.) }\end{array}$ & & $\begin{array}{l}\text { Mttv. } 97 . \S, 1 . \\
\text { sz. melléklet }\end{array}$ & \\
\hline $\begin{array}{l}\text { 49. Ellenőrző mechanizmusok, } \\
\text { ÁSZ hatáskörének bővítése (7.4.1.) }\end{array}$ & $\begin{array}{l}\text { Mttv. } 90 . \S(1) \text { o) } 106- \\
\text { 107. } 108 . \S(1) \text { c) } 121 . \\
\S(10)\end{array}$ & & \\
\hline $\begin{array}{l}\text { 50. Médiahatósági hatáskör, } \\
\text { közszolgálati müsorszolgáltatók } \\
\text { beszámolási kötelezettsége (7.4.2.) }\end{array}$ & & $\begin{array}{l}\text { Mttv. } 98 . \S(7)-(8) \\
108 . \S(7)\end{array}$ & \\
\hline 51. Elégedettségmérés (7.4.3.) & & & $\mathbf{X}$ \\
\hline $\begin{array}{l}\text { 52. Közszolgálati média } \\
\text { 'reklámtalanítása' (10.2.3.) Ld.: } \\
\text { 72. }\end{array}$ & & & $\mathbf{X}$ \\
\hline \multicolumn{4}{|l|}{$\begin{array}{l}\text { TÉTELEK A } \\
\text { VERSENYSZABÁLYOZÁSBAN } \\
\text { (8.) }\end{array}$} \\
\hline $\begin{array}{l}\text { 53. Piacra lépés könnyítése (8.1.) } \\
\text { Engedélyezési eljárás helyett } \\
\text { nyilvántartásba vétel }(8.1 .1,6.2 .7 .) \\
\text { Ld.: 18. } 19 .\end{array}$ & $\mathbf{X}$ & & $\mathbf{X}$ \\
\hline 54. Hatósági szerződés (8.1.2.) & $\begin{array}{l}\text { Mttv. 41. § (1) } 48-63 . \S \\
\text { 67. § (3), 70. § (10) }\end{array}$ & & \\
\hline $\begin{array}{l}\text { 55. Müsorszolgáltatói magatartás } \\
\text { hatósági kontrollja (8.1.3.) } \\
\text { elvándorlás megakadályozása } \\
(6.2 .8 .)\end{array}$ & $\begin{array}{l}\text { Mttv. } 185-189 . \S \\
\quad 185 . \S(2)\end{array}$ & & \\
\hline $\begin{array}{l}\text { 56. Vállalkozási formák } \\
\text { kötetlensége, magyar tulajdonosi } \\
\text { kör (8.1.4.) }\end{array}$ & $\begin{array}{l}\text { Mttv. 41. § (3), 203. § } \\
\quad \text { 41., 43. § (3) a) }\end{array}$ & & \\
\hline $\begin{array}{l}\text { 57. Koncentráció tilalma, } \\
\text { médiapluralizmus (8.2.1.) }\end{array}$ & $\begin{array}{l}\text { Mttv. II. Rész V. VI. } \\
\text { Fejezet, 171. } \S\end{array}$ & & \\
\hline $\begin{array}{l}\text { 58. Véleménybefolyásoló képesség } \\
(8.2 .2 ., 6.2 .4 .2 ., 6.4 .7 .)\end{array}$ & & $\begin{array}{l}\text { Mttv. 69.-70. } \\
\text { 32. },, 38-39 . \S, \\
\text { 78-81. } .\end{array}$ & \\
\hline $\begin{array}{l}\text { 59. Közönségarány (8.2.6.) } \\
\text { mérésének pályáztatása }\end{array}$ & Mttv. 203. $\S 28$. & & Mttv. 69. § (3) \\
\hline \multicolumn{4}{|l|}{ INTÉZMÉNYRENDSZER (9.) } \\
\hline 60. Intézményi konvergencia (9.) & Mttv. IV. Rész & & \\
\hline 61. Governance típusú hatóság (9.) & $\begin{array}{l}\text { Mttv. IV. Rész VI. } \\
\text { Fejezet }\end{array}$ & & \\
\hline 62. A Hatóság feladatai (9.1.) & $\begin{array}{c}\text { Mttv. 111. }, 114 . \S, 116 . \\
\S 132 . \S 114 . \S(2) 110 . \S \\
\text { 109. }(2),(5) \text { és (7) } \\
\text { Mttv. Negyedik Rész } \\
\text { 109. § (3) 111. § (2) n) } \\
\text { 124. § (1) }\end{array}$ & & \\
\hline $\begin{array}{l}\text { 63. Kiegyensúlyozottság felett } \\
\text { őrködő bizottság }(9.2 .)\end{array}$ & & $\begin{array}{l}\text { Mttv. 83. § (1) m) } \\
\quad 90 . \S(1) \text { a) }\end{array}$ & \\
\hline
\end{tabular}




\begin{tabular}{|c|c|c|c|}
\hline $\begin{array}{l}\text { 64. MFJK versus Média- és } \\
\text { Hírközlési Biztos (9.3.) }\end{array}$ & & & $\begin{array}{l}\text { Mttv. IV. } \\
\text { Rész III. } \\
\text { Fejezet }\end{array}$ \\
\hline 65. Hatósági modell (9.4.) & Mttv. IV.Rész109-110. § & & \\
\hline $\begin{array}{l}\text { 66. Szabályozási elvárások a } \\
\text { Hatósággal szemben (9.5.) } \\
\text { függetlenség, szakmaiság, feladat } \\
\text { elhatárolás, vezető szervek } \\
\text { kompetenciája stb. }\end{array}$ & & $\begin{array}{l}\text { Mttv. } 111 / \mathrm{A} . \S(1) \\
\text { 124. § (1) }\end{array}$ & \\
\hline 67. Médiatanács és Hivatal (9.6.) & & $\begin{array}{l}\text { Mttv. } 114-116 . \S \\
\text { 123. }\end{array}$ & \\
\hline 68. Tartalomtámogatás (9.7.) & Mttv. 136. § (1) & & \\
\hline \multicolumn{4}{|l|}{ MÉDIA FINANSZÍROZÁS (10.) } \\
\hline $\begin{array}{l}\text { 69. A finanszírozás egységes } \\
\text { kezelése (10.2.4.) }\end{array}$ & & & $\begin{array}{l}\text { Mttv. 136. } \S \\
\text { (3) }\end{array}$ \\
\hline $\begin{array}{l}\text { 70. A felügyeleti rendszer } \\
\text { finanszírozása (10.1.) }\end{array}$ & & $\begin{array}{l}\text { Mttv. } 134 . \S(1)- \\
\text { (2) }\end{array}$ & \\
\hline $\begin{array}{l}\text { 71.Közszolgálati müsorszolgáltatás } \\
\text { finanszírozása (10.2.2.) }\end{array}$ & $\begin{array}{l}\text { Mttv. } 82 . \S \mathrm{c}) \\
136 . \S(4)\end{array}$ & & \\
\hline $\begin{array}{l}\text { 72. Közszolgálat fokozatos } \\
\text { mentesítése a reklámoktól (10.2.2.) } \\
\text { Ld.: } 52 \text {. }\end{array}$ & & & $X$ \\
\hline $\begin{array}{l}\text { 73. Tartalomfinanszírozás, } \\
\text { pályáztatás (10.3.1.) }\end{array}$ & Mttv. 136. § (8) & & \\
\hline
\end{tabular}




\section{JOGI DOKUMENTÁCIÓS JEGYZÉK}

\section{Európai uniós irányelvek}

A Tanács a tagállamok törvényi, rendeleti vagy közigazgatási intézkedésekben megállapított, a televíziós müsorszolgáltatási tevékenységre vonatkozó, a határok nélküli televíziózásról szóló, 97/36/EK irányelvvel módosított 89/552/EGK irányelve (1989.október) [Televíziós Irányelv, TWVF]

Az Európai Parlament és a Tanács 97/36/EK irányelve (1997.július 30.) a tagállamok törvényi, rendeleti vagy közigazgatási intézkedésekben megállapított, televízió müsorszolgáltató tevékenységre vonatkozó egyes rendelkezéseinek összehangolásáról szóló 89/552/EGK tanácsi irányelv módosításáról, valamint az Európai Parlament és a Tanács 2007/65/EK irányelve (2007.december 11.) a tagállamok törvényi, rendeleti vagy közigazgatási intézkedésekben megállapított, televízió müsorszolgáltató tevékenységre vonatkozó egyes rendelkezéseinek összehangolásáról szóló 89/552/EGK tanácsi irányelv módosításáról

Az Európai Parlament és a Tanács 2010/13/EU irányelve (2010. március 10.) a tagállamok audiovizuális médiaszolgáltatások nyújtására vonatkozó egyes törvényi, rendeleti vagy közigazgatási rendelkezéseinek összehangolásáról [Audiovizuális médiaszolgáltatásokról szóló irányelv, AVMS]

Javaslat az Európai Parlament és a Tanács irányelve a tagállamok audiovizuális médiaszolgáltatások nyújtására vonatkozó egyes törvényi, rendeleti vagy közigazgatási rendelkezéseinek összehangolásáról szóló 2010/13/EU irányelvnek a változó piaci körülményekre tekintettel való módosításáról. Brüsszel, 2016.5.25. $\operatorname{COM(2016)} 287$ final 2016/0151 (COD) [AVMS felülvizsgálati javaslat]

A Tanács 1990. június 28-i 90/387/EGK irányelve a távközlési szolgáltatások egységes belső piacának kialakításáról [Nyílt Hálózati Hozzáférési Irányelv]

Az Európai Parlament és a Tanács 2002. március 7-i 2002/19/EK irányelve az elektronikus hírközlő hálózatokhoz és kapcsolódó berendezésekhez való hozzáférésről és azok összekapcsolásáról [Hozzáférési Irányelv]

Az Európai Parlament és a Tanács 2006. december 2-i 2006/123/EK irányelve a belsőpiaci szolgáltatásokról [Szolgáltatási Irányelv]

Az Európai Parlament és a Tanács 2002. március 7-i 2002/20/EK irányelve az elektronikus hírközlő hálózatok és elektronikus hírközlési szolgáltatások engedélyezéséről (engedélyezési irányelv), az Európai Parlament és a Tanács 2002. március 7-i 2002/21/EK irányelve az elektronikus hírközlő hálózatok és elektronikus hírközlési szolgáltatások közös keretszabályozásáról [Keretirányelv]

Az Európai Parlament és a Tanács 2002. március 7-i 2002/22/EK irányelve az egyetemes szolgáltatásról és az elektronikus hírközlő hálózatokhoz és elektronikus hírközlési szolgáltatásokhoz kapcsolódó felhasználói jogokról [Egyetemes Szolgáltatási Irányelv]

Az Európai Bizottság 2002. szeptember 16-i 2002/77/EK irányelve az elektronikus hírközlő hálózatok és elektronikus hírközlési szolgáltatások piacának versenyéről

Az Európai Parlament és a Tanács 2000. június 8-i 2000/31/EK irányelve a belső piacon az információs társadalommal összefüggő szolgáltatások, különösen az elektronikus kereskedelem, egyes jogi vonatkozásairól [Elektronikus Kereskedelemről szóló Irányelv]

Az Európai Parlament és az Európai Bizottság 95/47/EC irányelve (1995. október 24.) a televíziójelek átvitelére szolgáló szabványok használatáról

Az Európai Parlament és a Tanács 2005/29/EK irányelve (2005.május 11.) a belső piacon az üzleti vállalkozások fogyasztókkal szemben folytatott tisztességtelen kereskedelmi gyakorlatairól, valamint a 84/450/EGK tanácsi irányelv, a 97/7/EK, a 98/27/EK és a 2002/65/EK európai parlamenti és tanácsi irányelvek módosításáról [UCP Irányelv a Tisztességtelen Kereskedelmi Gyakorlatról] 
Az Európai Parlament és a Tanács 2014/26/EK irányelve (2014. február 26.) a szerzői és szomszédos jogokra vonatkozó közös jogkezelésről és a zeneművek belső piacon történő online felhasználásának több területre kiterjedő hatású engedélyezéséről Az irányelvet 2016. április 10-ig kell átültetni a nemzeti jogrendszerekbe. (43) cikk [KJK irányelv]

A Tanács 93/83/EGK irányelve a müholdas sugárzásra és a vezetékes továbbközvetítésre alkalmazandó egyes szerzői és szomszédos jogi szabályok összehangolásáról [Mühold - Kábel Irányelv]

A Bizottság irányelve (1980. június 25.) a tagállamok és a közvállalkozások közötti pénzügyi kapcsolatok átláthatóságáról 80/723/EGK [Transzparencia Irányelv]

A Bizottság irányelve (1985. július 24.) a tagállamok és a közvállalkozások közötti pénzügyi kapcsolatok átláthatóságáról szóló 80/723/EGK irányelv módosításáról (85/413/EGK)

Az Európai Parlament és a Tanács 2001. május 22-i 2001/29/EK irányelve az információs társadalomban a szerzői és szomszédos jogok egyes vonatkozásainak összehangolásáról [INFOSOC Irányelv]

Az Európai Parlament és a Tanács 2006. december 12-i 2006/115/EK irányelve a bérleti jogról és a haszonkölcsönzési jogról, valamint a szellemi tulajdon területén a szerzői joggal szomszédos bizonyos jogokról [Bérlet Irányelv]

A Tanács 93/83/EGK irányelve (1993. szeptember 27.) a müholdas müsorsugárzásra és a vezetékes továbbközvetítésre alkalmazandó egyes szerzöi és szomszédos jogi szabályok összehangolásáról [MűholdKábel Irányelv]

Az Európai Parlament és a Tanács Irányelvére vonatkozó Javaslat a digitális egységes piacon a szerzői jogról COM/2016/0593 final - 2016/0280 (COD) 2016. 9. 14.

\section{Egyéb uniós dokumentumok}

Az Európai Unió Bizottságának Zöld Könyve „A müsorszolgáltatási közös piac létrehozásáról, különös tekintettel a kábeles és müholdas szolgáltatásra.” [COM (84) 300] [Zöld Könyv 1984]

Az állami támogatás szabályainak a közszolgálati müsorszolgáltatásra történő alkalmazásáról szóló bizottsági közlemény (EGT-vonatkozású szöveg) 2009/C 257/01. [Közszolgálati Közlemény 2009.]

Az Európai Unió Bizottságának Közleménye az Európai Parlamentnek, a Tanácsnak, az Európai Gazdasági és Szociális Bizottságnak és a Régiók Bizottságának Az általános gazdasági érdekủ szolgáltatásokra vonatkozó uniós állami támogatási szabályok reformjáról, Brüsszel, 2011.3.23. [COM (2011)]

Az Európa Tanács: Declaration by the Committee of Ministers on Internet governance principles 2011 September 21 OECD: Council Recommandation on Principles for Internet Policy Making 2011 December 11

Az Európai Unió Bizottságának Zöld Könyve: Green Paper on the convergence of the telecommunications, media and information technology sectors and the implications for regulation - Towards an approach for the information society [COM (97) 623] [Zöld Könyv 1997]

Az Európai Unió Bizottságának Fehér Könyve az európai kormányzásról, új lendület Európa fiataljai számára Brüsszel, 2001.11.21. [COM 2001]

Európa Tanács Recommendation 1641 (2004) Public service broadcasting - Service public de radiodiffusion

Az Európai Unió Bizottságának Közleménye a Tanácsnak és az Európai Parlamentnek: A jobb szabályozás a növekedés és a munkahelyteremtés területén az Európai Unióban Brüsszel, 16.3.2005 [COM (2005) 97] [Jobb szabályozásért Közlemény]

Az Európa Tanács 4064/89/EGK rendelete (1989. december 21.) a vállalkozások közötti összefonódások ellenőrzéséröl 
Az Európai Unió Bizottságának Közleménye - Iránymutatás az EK-Szerződés 82.cikkének az erőfölényben lévő vállalkozások versenykorlátozó visszaélő magatartására történő alkalmazásával kapcsolatos bizottsági jogérvényesítési prioritásokról 2009/C 45/02

Az Európai Parlament és a Tanács rendeletére vonatkozó Javaslat a müsorszolgáltató szervezetek egyes online közvetítéseire, valamint televíziós és rádiós müsorok továbbközvetítésére alkalmazandó szerzői jogok és szerzői joggal szomszédos jogok gyakorlására vonatkozó szabályok megállapításáról COM/2016/0594 final - 2016/0284 (COD) 2016. 9. 14.

Schall jelentés (1981)

Hahn jelentés (1982)

Arfé határozat (1983)

A Bizottság 1983-ban kiadott „Realitások és tendenciák az európai televíziózásban” címü jelentése.

\section{Nemzetközi jogi dokumentumok}

Az Egyesült Nemzetek Egyezménye az áruk nemzetközi adásvételi szerződéseiről Bécs, 1980.április 11.

A határokat átlépő televíziózásról szóló Európai Egyezmény [1998. évi XLIX. törvény a határokat átlépő televíziózásról szóló, Strasbourgban, 1989. május 5-én kelt európai egyezmény kihirdetéséről]

Az irodalmi és művészeti müvek védelméről szóló Berni Uniós Egyezmény 1886. szeptember 30. Hazai törvénybe iktatása: 1922. évi XIII. törvénycikk „Magyarország belépéséről az irodalmi és művészeti művek védelmére alakult berni nemzetközi unióba." 1975. évi 4. törvényerejü rendelet az irodalmi és a müvészeti müvek védelméröl szóló 1886. szeptember 9-i Berni Egyezmény Párizsban, az 1971. évi július hó 24. napján felülvizsgált szövegének kihirdetéséről [Berni Uniós Egyezmény, BUE]

A jogalkotás minőségének javításáról szóló 2003.december 16-i intézményközi megállapodás (2003/C321/01) Interinstitutional agreement on better law-making Co-regulation 18. [A jogalkotás minőségének javításáról, intézményközi megállapodás 2003]

Az előadómüvészek, hangfelvétel-elöállítók és müsorsugárzó szervezetek védelméről szóló, 1961-ben, Rómában aláírt egyezmény, kihirdette az 1998. évi XLIV. törvény [Római Egyezmény]

WIPO Copyright Treaty (adopted in Geneva on December 20, 1996) [WCT]

Az Általános Vám és Kereskedelmi Egyezmény (GATT) keretében kialakított, a Kereskedelmi Világszervezetet (WTO) megalapító Marakeshi Egyezmény 1/C mellékletét képező, a szellemi tulajdonjogok kereskedelmi vonatkozásairól szóló megállapodás amelyet, Magyarországon az 1998. évi IX. törvény hirdetett ki. [TRIPS Egyezmény]

OECD Internet Szabályozási Elvek: Council Recommendation on Principles for Internet Policy Making [OECD Szabályozási Elvek 2011]

UNESCO Jelentés 2011 Zlatev, Ognian; Lani, Remzi; Baydar, Yavuz; Mollerup, Jacob; Vilović, Gordana; Turtia, Tarja; Hulin, Adeline Professional Journalism Self-Regulation and New Media, Old Dilemmas in South East Europe and Turkey [UNESCO Jelentés 2011]

\section{Az Európai Unió Bíróságának eseti döntései}

C 155/73 1975. április 30. „Sacchi” ügy

C-521/11. "Amazon" ügy

C-52/07. „Stim” ügy

C-431/09. és C-432/09. egyesített „Airfield” ügy

C-466/12. „Svensson” és társai ítélet

C-325/14. "SABAM" ügy 


\section{Magyar jogszabályok}

1949. évi XX. törvény a Magyar Köztársaság Alkotmánya

Magyarország Alaptörvénye (Szabadság és felelösség IX. Cikk)

1914. évi XIV. törvénycikk a sajtóról

1921. évi LIV. törvénycikk a szerzői jogról

1952. évi III. törvény a polgári perrendtartásról

1959. évi IV. törvény a Polgári Törvénykönyvröl

1987. évi XI. törvény a jogalkotásról

1990. évi LXXXVII. törvény az árak megállapításáról

1994. évi LXXII. törvény a szerzői jogról szóló 1969. évi III. törvény módosításáról

1996. évi I. törvény a rádiózásról és a televíziózásról

1996. évi LVII. törvény (Tpvt.) A tisztességtelen piaci magatartás és versenykorlátozás tilalmáról.

1997. évi LVIII. törvény a gazdasági reklámtevékenységről

1998. évi IX. törvény az Általános Vám- és Kereskedelmi Egyezmény (GATT) keretében kialakított, a

Kereskedelmi Világszervezetet létrehozó Marrakesh-i Egyezmény és mellékleteinek kihirdetéséről

1999. évi LXXVI. törvény a szerzői jogról

2001. évi LXXVII. törvény a szerzői jogról szóló 1999. évi LXXVI. törvény módosításáról

2003. évi C. törvény az elektronikus hírközlésröl

2004. évi II. törvény a mozgóképröl

2004. évi CXL. törvény a közigazgatási hatósági eljárás és szolgáltatás általános szabályairól

2007. évi LXXIV. törvény a müsorterjesztés és digitális átállás szabályairól

2007. évi CLIV. törvény a müsorterjesztés és digitális átállás szabályairól szóló 2007. évi LXXIV. törvény valamint a rádiózásról és televíziózásról szóló 1996. évi I. törvény módosításáról

2008. évi XLVII. törvény a fogyasztókkal szembeni tisztességtelen kereskedelmi gyakorlat tilalmáról

2008. évi XLVIII. törvény a gazdasági reklámtevékenység alapvető feltételeiről és egyes korlátairól

2010. évi LXXXII. törvény a médiát és a hírközlést szabályozó egyes törvények módosításáról

2010. évi CIV. törvény a sajtószabadságról és a médiatartalmak alapvető szabályairól

2010. évi CXXX. törvény a jogalkotásról

2010. évi CXXXI. törvény a jogszabályok előkészítésében való társadalmi részvételről

2010. évi CLXXXV. törvény a médiaszolgáltatásokról és a tömegkommunikációról

2010. évi CXLVIII. törvény a Magyar Köztársaság minisztériumainak felsorolásáról szóló 2010. évi XLII. törvénnyel összefüggésben szükséges törvénymódosításokról és egyes iparjogvédelmi tárgyú törvények módosításáról

2011. évi CVII. törvény az egyes elektronikus hírközlési tárgyú törvények módosításáról

2011. évi CLXXIII. törvény a szellemi tulajdonra vonatkozó egyes törvények módosításáról

2011. évi CLXXV. törvény az egyesülési jogról, a közhasznú jogállásról, valamint a civil szervezetek müködéséről és támogatásáról

2011. évi CCI. törvény az Egyes törvények Alaptörvénnyel összefüggő módosításáról

2013. évi V. törvény a Polgári Törvénykönyvröl

2013. évi XVI. törvény a szellemi tulajdonra vonatkozó egyes törvények módosításáról

2013.évi XXXIII. törvény a sajtószabadságról és a médiatartalmak alapvető szabályairól szóló 2010. évi

CIV. törvény és a médiaszolgáltatásokról és a tömegkommunikációról szóló 2010. évi CLXXXV. törvény módosításáról

2013. évi CXXI. törvény a helyi és körzeti televíziók digitális átállásának biztosítása érdekében szükséges és egyes hírközléssel összefüggő törvénymódosításokról

2013. évi CLIX. törvény a szellemi tulajdonra vonatkozó törvények módosításáról

2014. évi CVII. törvény a közszolgálati médiaszolgáltatásra és a médiapiacra vonatkozó egyes törvények módosításáról

2014. évi XXXIX. törvény egyes törvényeknek a költségvetési tervezéssel, valamint a pénzpiaci és a közüzemi szolgáltatások hatékonyabb nyújtásával összefüggő módosításáról 
2015. évi CXVIII. törvény a müsorterjesztés és a digitális átállás szabályairól szóló 2007. évi LXXIV. törvény módosításáról

2016. évi CXXX. törvény a Polgári perrendtartásról

Alacsonyabb rendü jogszabályok és közjogi szervezetszabályozó eszközök

160/2006.(VII.28.) Korm. rendelet 1110/2002. (VI.20.) Korm. határozat 1014/2007.(III.13.) Korm. határozat 9/1969. (XII.29.) MM rendelet 15/1982.(IX.20.) MM rendelet 109/2010.(X.28.) OGY határozat 80/2010.(IX.15.) OGY határozat

\section{Alkotmánybírósági határozatok}

8/1990. (IV. 23.) AB határozat 64/1991. (XII.17.) AB határozat 37/1992. (VI.10.) AB határozat 47/1994.(X. 21.) AB határozat 1/1999. (II. 4.) AB határozat 22/1999.(VI. 30.) AB határozat 5/2001. (XII. 5.) AB határozat 57/2001. (XII. 5.) AB határozat $16 / 2004 \mathrm{~V}$. 14.) AB határozat 1/2005. (II. 4.) $A B$ határozat 1/2007. (I. 18.) AB határozat 46/2007. (VI. 27.) AB határozat 37/2011. (V. 10.) AB határozat 165/2011. (XII. 20.) AB határozat 382/B/1995. AB határozat 1270/B/1997. AB határozat 482/B/2002. AB határozat 766/B/2002. AB határozat

\section{Bírói gyakorlat}

12/2013. PED

PK 12.13.14.15

Pfv. IV.20.273/2008/7.

BH1991.146.

Fővárosi Bíróság 8. P. 26.070/1944/41.

BDT 2006.1468,

BDT 2008.1862.

BH 2005. 56.

\section{ORTT határozatok}

258/1997. (XI. 5.) ORTT határozat 523/2001. (IV. 11.) ORTT határozat 243/2002. (I. 31.) ORTT határozat 
A Médiatanács döntései

A Médiatanács 248/2015. (III. 17.) számú döntése A Médiatanács 551/2015. (V. 5.) számú döntése A Médiatanács 580/2015 (V. 19.) számú döntése A Médiatanács 591/2015. (V. 19.) számú döntése A Médiatanács 594/2015. (V. 19.) számú döntése A Médiatanács 595/2015. (V. 19.) számú döntése

Médiatanács előtti jogvitás eljárás

MJ-367-21/2013.

Gazdasági Versenyhivatal Versenytanácsának határozatai és Ágazati Jelentése

$\mathrm{Vj}-17 / 1998$.

$\mathrm{Vj}-99 / 1998$

$\mathrm{Vj}-182 / 1998$.

$\mathrm{Vj}-31 / 2002$.

$\mathrm{Vj}-36 / 2002$.

$\mathrm{Vj}-44 / 2002$.

$\mathrm{Vj}-100 / 2003$.

$\mathrm{Vj}-97 / 2004$.

$\mathrm{Vj}-61 / 2006$.

$\mathrm{Vj}-61 / 2008$.

$\mathrm{Vj}-151 / 2009$.

Gazdasági Versenyhivatal ÁV-2/2009. számú Ágazati Jelentése

\section{A Szerzői Jogi Szakértő Testület szakvéleményei}

38/2000. SZJSZT

30/2003. SZJSZT

20/2005. SZJSZT

27/2006. SZJSZT 


\section{IRODALOMJEGYZÉK}

\section{STRATÉGIÁK ÉS HÁTTÉRTANULMÁNYOK}

Digitális Átállás Stratégiája (A)DÁS - a konzultációs észrevételek alapján véglegesített cél-, eszköz és feltételrendszer a 2007-2012-es időszakra - Miniszterelnöki Hivatal 2007. február. Melléklet a televiziózás és a rádiózás digitális átállásának kormányzati feladatairól szóló 1014/2007. (III.13.) számú Korm. határozathoz

Nemzeti Audiovizuális Média Stratégia (NAMS) 2007. június (Réczicza White \& Case LLP KPMG)

Nemzeti Audiovizuális Média Stratégia Jogalkotási Koncepció (NAMS Jogalkotási Koncepció) 2007. december (AMK)

A közös jogkezelők által alkalmazott szerzői jogdíjak szerepe az audiovizuális szektorban MSZH szerk.: KISS Marietta szerzők: CSERBA Veronika, FICSOR Mihály, HEPP Nóra, KISS Zoltán, MUNKÁCSI Péter, PENYIGEI Krisztina. Budapest, 2007. (Szerzői Jogi Tanulmány).

A kereskedelmi músorszolgáltatás versenyjogi alapú szabályozása MTA Jogtudományi Intézet Infokommunikációs Jogi Centrum, 2007 Szerzők: TÓTH András, POLYÁK Gábor, Közremüködők: KOPPÁNYI Szabolcs, TÉNYI Géza (Versenyjogi Tanulmány).

A nemzeti tartalmak előállításával, szerkesztésével és átvitelével összefüggő tartalmi és pénzügyi feltételrendszer kialakítása - a közszolgálati müsorszolgáltatás szabályozási kérdései PTE ÁJK Informatikai és Kommunikációs Kutató Intézet, szerzők: LENGYEL Márk, POLYÁK Gábor, SZÖKE Gergely László 2007. (Közszolgálati Tanulmány)

BARTLE, Ian - VASS Péter: Self-Regulation and the Regulatory State. A Survey of Policy and Practice. The Universty of Bath Research Report 17. 2005.

CAFAGGI, Fabrizio: Constitutional Foundations of Transnational Private Regulation ix, HiiL Project, Coordinated by Fabrizio CAFAGGI European University Institute Florence, Italy 2010 Colin SCOTT University College Dublin, Ireland \& Linda SENDEN Tilburg University Tilburg, The Netherlands 2011

\section{KÖNYVEK, ÉRTEKEZÉSEK}

BENKE Gabor: Constitutional Issues of European Advertising Self-Regulation Outsourcing Chilling Effect? PHD. Értekezés Budapest, 2013.

CROTEAU, David - HOYNES, William: A média mint üzlet Nagyvállalati média és közérdek Complex Wolters Kluwer 2013.

CSINK Lóránt - MAYER Annamária: Variációk a szabályozásra Önszabályozás, társszabályozás és szabályozó hatóság a médiajogban MTMI 2012. (CSINK-MAYER)

ENYEDI NAGY Mihály - SARKADY Ildikó - POLYÁK Gábor (szerk.) Magyarország médiakönyve 2002. Enamiké

FALUDI Gábor: A felhasználási szerződés KJK 1999. (FALUDI I.)

FECHNER, Frank: Medienrecht UTB Für Wissenschaft Mohr Siebeck, 2001.

GÁLIK Mihály (szerk.): A médiakoncentráció szabályozása - szöveggyűjtemény Gondolat 2011. (GÁLIK I.)

GÁLIK Mihály (szerk.) Médiagazdaságtan, Médiaszabályozás Szöveggyüjtemény BKÁE Aula. 2002. (BKÁE Szöveggyüjtemény, GÁLIK IV.)

GÁLIK Mihály - POLYÁK Gábor: Médiaszabályozás KJK-KERSZÖV 2005. (GÁLIK-POLYÁK)

GELLÉN Klára: A kereskedelmi kommunikáció szabályozása a médiajogban (prof. dr. Homoki-Nagy Mária (szerk.) HVG-ORAC 2012. (GELLÉN I.) 
GERA Eleonóra Erzsébet - CSATÁRI Bence: A zeneszerzők szövetkezetétől az Artisjus Egyesületig 1907 2007. Artisjus, 2007.

GERVAIS, Daniel J.: Collective Management of Copyright and Neighbouring Rights in Canada: An International Perspective Candian Heritage 2001 August

GRAD-GYENGE Anikó: Az audiovizuális archívumok szabályozási kerete - különös tekintettel a médiajogi és szerzői jogi rendelkezésekre KOLTAY-NYAKAS (szerk.) MTMI 2015. (GRAD-GYENGE I.)

GRAD-GYENGE Anikó - SARKADY Ildikó: Közös jogkezelés az audiovizuális médiában KOLTAYNYAKAS (szerk.) MTMI 2014. (GRAD-GYENGE-SARKADY)

GLATZ Ferenc (szerk.) Magyarország az ezredfordulón, Stratégiai Tanulmányok a Magyar Tudományos Akadémián, Mühelytanulmányok „Az információs társadalom és a jog átalakulása” 2. Átdolgozott változat, MTA Társadalomkutató Központ 2002.

GYERTYÁNFY Péter (szerk.): A szerzői jogi törvény magyarázata KJK-KERSZÖV 2000. (GYERTYÁNFY I.)

GYERTYÁNFY Péter (szerk.): A szerzői jogi törvény magyarázata Complex 2006. (GYERTYÁNFY IV.)

GYERTYÁNFY Péter (szerk.) Nagykommentár a szerzői jogi törvényhez Complex Wolters Kluver 2014. (GYERTYÁNFY II.)

HABERMAS, Jürgen: A társadalmi nyilvánosság szerkezetváltozása: Vizsgálódások a polgári társadalom egy kategóriájával kapcsolatban Századvég Budapest, 1993. Eredeti megjelenés: 1962.(HABERMAS habilitációja)

KELLER, Perry: Európai és nemzetközi médiajog, liberális demokrácia, kereskedelem és az új média, Complex Wolters Kluwer 2014.

KOLTAY András - NYAKAS Levente (szerk.) Magyar és európai médiajog Complex 2012. (KOLTAY NYAKAS I.) Második, átdolgozott kiadás 2015.

KOLTAY András (szerk.) A médiaszabályozás két éve (2011-2012) MTMI 2013. (KOLTAY szerk.)

KOLTAY András - NYAKAS Levente (szerk.) Összehasonlító médiajogi tanulmányok A „közös európai minimum" azonosítása felé MTMI 2014. (KOLTAY-NYAKAS II.)

KOLTAY András - LAPSÁNSZKY András (szerk.) A médiaszabályozás kommentárja, Complex Wolters Kluwer 2011. (KOLTAY - LAPSÁNSZKY Kommentár)

MEZEI Péter: A digitális technológia kihívásai a szerzői művek szabad felhasználására Doktori Értekezés Tézisek Szeged, 2009. (MEZEI III.)

PAÁL Vince (szerk.) A magyarországi médiaháború története Média és politika 1989-2010, sorozatszerk.: KOLTAY András - NYAKAS Levente) Complex Wolters Kluwer Budapest, 2013.

(Magyarországi médiaháború)

PETERSEN, Jens: Medienrecht, Verlag C.H. Beck, München 2003.

PETRIK Ferenc: A személyiség jogi védelme, a sajtó-helyreigazítás HVG-ORAC 2001. (PETRIK I.)

PETRIK Ferenc (szerk.) A szerzői jog KJK 1990. (PETRIK II.)

POLYÁK Gábor: A médiarendszer kialakítása PHD Értekezés HVG - ORAC 2008 (POLYÁK I.)

PRICE, Monroe E.: A televízió, a nyilvános szféra és a nemzeti identitás Magvető 1998.

PRUZSINSZKY Sándor: Halhatatlan cenzúra MTMI 2014.

RIESENHUBER, Karl (Hrsg.) Wahrnehmungsrecht in Polen, Deutschland und Europa Band 1, INTEGRU Tagung 2005.

SAJÓ ANDRÁS - MONROE E. PRICE (szerk.): Rights of access to the media. Boston: Kluwer Law International, 1996. 112-116. In: KOLTAY III.

SARKADY Ildikó: Médiajogi írások ÚMK 2005.

SARKADY Ildikó - GRAD-GYENGE Anikó: A média-értéklánc szerzői jogi vonatkozásai MTMI 2012.

SMITH, Adam: Nemzetek gazdagsága 1776.

STÖCKEL, Heinz: Presserecht München Verlag C.H. Beck, 1994.

TÓTH András: Az elektronikus hírközlés és média gazdasági szabályozásának alapjai és versenyjogi vonatkozásai PHD Értekezés 2008. HVGORAC (TÓTH I.)

UDVARY Sándor: Alkotmányos médiajog PhD. Értekezés KRE 2008. (UDVARY I.) Tézisek 2008. (UDVARY II.) 


\section{TANULMÁNYOK, CIKKEK}

BARTÓKI-GÖNCZY Balázs: Must-carry és must-offer szabályozás az Európai Unióban In: KOLTAY NYAKAS III.

BAYER Judit: A közszolgálati televíziózás újragondolása a digitális korszakban Médiakutató 2008 nyár (BAYER I.)

BAYER Judit: Az internet tartalomszabályozása Magyarországon (Önszabályozás versus állami szabályozás) In: Magyarország médiakönyve 2002.(BAYER II.)

BOTH Vilmos - LUDÁNYI Arnold: Három kérdés a digitális átállásról Médiakutató 2012 TÉL

BÓDINÉ DR. BELIZNAY Kinga: Sajtórendészeti igazgatás a XIX. századi Európában Magyar Közigazgatás 1998/1.

CAMPBELL, Angela: Self-Regulation and the Media. Federal Communications Law Journal 711, 06/15/99 (In: (CSINK-MEYER)

CORNILS, Matthias: Az erős szabályozás iránti igény (Johannes Gutenberg Egyetem, Mainz) A magyar médiatörvényről EPD Medien (Evangelischer Pressedienst) 2011/44.

CULIENBURG, Jan van \& McQUAIL, Denis Media Policy Paradigm Shifts: Towards a New Communications Policy Paradigm. European Journal of Communication, 2003 No. 18. In: NYAKAS I.

CSEH Gabriella: A digitális müsorszolgáltatásra vonatkozó időszerű jogi kérdések Magyarországon Médiakutató 2004 ősz (CSEH I.)

CSEH Gabriella: A közszolgálati műsorszolgáltatás finanszírozása Médiakutató 2008 nyár (CSEH II.)

CSEH Gabriella - SÜKÖSD Miklós: Médiajog és médiapolitika Magyarországon I. Médiajog ÚMK 1999. In: UDVARY I.

CSERMELY Péter: A rejtett hálózatok ereje: Hogyan stabilizálják a világot a gyenge kapcsolatok? Vince 2005. In: SARKADY-GRAD-GYENGE

DEZSÉRI Kálmán: A magyar médiatörvény a médiáról szóló európai uniós vitákban Médiakutató 2011 ősz

FALKHEIMER, Jesper: Swedish Press Ethics in a Changing Media Landscape 1, Paper for the 23rd Conference and General Assembly, IAMCR, Intercultural Communication, Barcelona, 21-26. July 2002.

FALUDI Gábor: Első oldal Infokommunikáció és Jog 2011. december (FALUDI II.)

FALUDI Gábor: A szerzői jogi közös jogkezelés mint szabályozott monopólium. Infokommunikáció és Jog 2009. augusztus (FALUDI III.)

FRANKLIN, M.I.: Digital Dilemmas Power, Resistance and the Internet OXFORD University Press 2013.

GÁLIK Mihály: A hozzáférés és a médiakoncentráció túlszabályozása a digitális átállás hazai folyamatában Médiakutató 2008 nyár (GÁLIK II.)

GÁLIK Mihály: A médiapolitika két évtizede Politikai évkönyv online 2009 (GÁLIK III.)

GÁLIK Mihály - HORVÁT János - SZENTE Péter: Egy új médiatörvény alapjai (Javaslat), In: Magyarország Médiakönyve 2003 II. kötet ENAMIKÉ 943-989.

GELLÉN Klára: A kereskedelmi kommunikáció szabályozása In: KOLTAY-NYAKAS I. (GELLÉN II.)

GELLÉN Klára: A kereskedelmi közleményekkel szemben támasztott műsorszerkezeti követelmények In Medias Res 2012/1. (GELLÉN III.)

GELLÉN Klára: Kereskedelmi közlemények összehasonlító elemzése az egyes európai államokban In: KOLTAY III. (GELLÉN IV.)

GELLÉRT KISS Gábor - Dr. BALLAI Éva: A köznyilvánosság működéséről szóló törvény koncepciója In: Magyarország Médiakönyve 2003. II. kötet ENAMIKÉ 991-1028.

GIBBONS, Thomas: Regulating the media London: Sweet \& Maxwell. 1998. In: KOLTAY V.

GOSZTONYI Gergely: A közösségi médiaszolgáltatók a hatályos magyar jogi szabályozásban. Médiakutató 2011 tél (GOSZTONYI I.)

GOSZTONYI Gergely: Alternatív (?) média. A közösségi média jogi szabályozásának vetületei. ELTE Eötvös Kiadó, 2014. (GOSZTONYI II.)

GOSZTONYI Gergely: Az alternatív média helye a médiadiskurzusban. Az alternatív média története és a közösségi médiaszolgáltatók a hatályos magyar szabályozásban. MTMI Budapest, 2014. (GOSZTONYI III.) 
GYENGE Anikó: A média-konvergencia hatása a szerzői jogban: az ismeretlen felhasználási módra vonatkozó szerződési kikötések érvénytelenségének problémája (1.rész) Infokommunikáció és Jog 2006/1.

GYERTÁNFY Péter: A szerzői és a szomszédos jogok közös kezelése II. Magyar Jog, 1997/5. sz. (GYERTÁNFY III.)

GYERTYÁNFY Péter: A szerzői jog bírói gyakorlata 2006-tól: A védelem tárgya és a mü egysége Iparjogvédelmi és Szerzői Jogi Szemle 7.(117.) évfolyam 4. szám, 2012. augusztus, SZTNH (GYERTYÁNFY V.)

HARGITAI Lilla: Gondolatok a médiatörvény reklámszabályainak lehetséges módosításáról Médiakutató 2001. nyár.

HIMMEMLMANN, Ulrich: Verwertungsgesellschaften und Staatsicht - Vergleichende Anmerkungen aus deutscher Sicht In: Schriften zum Europäischen Urheberrcht In: RIESENHUBER

JAKUBOWICZ, Karol: Médiapluralizmus és koncentráció In: GÁLIK I.

KERTÉSZ Krisztina: A média szabályozása az Európai Unióban és Magyarországon. A jogharmonizáció folyamata az audiovizuális szektorban, Médiakutató 2001 tavasz

KISSNÉ AKLI Mária - VÁRI Péter: A helyi televíziós szolgáltatók szerepe a földfelszíni digitális átállásban Nemzeti Média- és Hírközlési Hatóság 2013 Helyi-körzeti pályáztatás: lezárult az igényfelmérés. NMHH honlap publikálva: 2010. 06.15.

KOLLARIK Tamás: hatékony és eredményes a médiatartalmak felügyelete Médiatanács hírek 2013.11.20.

KOVÁCS Krisztina - CSEH Gabriella: A lapalapítás és a sajtószabadság magyar és nemzetközi szabályozása COLPI 1996.

KOLTAY András: Bevezetés: a média és a médiajog In: Magyar és európai médiajog (KOLTAY I.)

KOLTAY András: A nyomtatott sajtó önszabályozása az Egyesült Királyságban: a Press Complaints Commission Infokommunikáció és Jog 2010/39. augusztus. (KOLTAY II.)

KOLTAY András: Sajtó-helyreigazítás és válaszjog: a sajtószabadság korlátja vagy kiterjesztése. Iustum Aequum Salutare, 2008/4. (KOLTAY III.)

KOLTAY András: Az emberi jogok, az emberi méltóság és az alkotmányos rend védelme a magyar médiaszabályozásban In Medias Res 2012/1 (KOLTAY IV.)

KOLTAY András: A közszolgálati média fogalma Médiakutató 2007 nyár (KOLTAY V.)

KOLTAY András: Átalakuló sajtószabadság - az állam jövőbeni feladatai a demokratikus nyilvánosság erősítése érdekében című előadása, HTE konferencia 2015. (KOLTAY VI.)

KOLTAY András - MAYER Annamária - NYAKAS Levente - POGÁCSÁS Anett: A médiaszolgáltatás és a sajtótermék fogalma az új magyar médiaszabályozásban. Iustum Aequum Salutare VII.2011/4. 71-101.

KOLTAY András: A média tartalmi szabályozásának alkotmányossága az új magyar médiaszabályozásban Médiakutató 2011 ősz (KOLTAY VII.)

KOLTAY András: A műsorterjesztés és a digitális átállás szabályairól szóló 2007. évi LXXIV. törvény 26. $\S$ (1) bekezdésének értelmezéséről Jogi Fórum 2008 nyár (KOLTAY VIII.)

KOLTAY András: Az emberi méltóság védelmének kérdései a médiaszabályozásban és a joggyakorlatban In: Személy és személyiség a jogban szerk.: MENYHÁRD Attila - GÁRDOS-OROSZ Fruzsina (Wolters Kluwer Budapest, 2016) 192-246. (KOLTAY IX.)

KOLTAY András - POLYÁK Gábor: Az Alkotmánybíróság határozata a médiaszabályozás egyes kérdéseiről 11-48. Jogesetek Magyarázata 2012/1 (KOLTAY-POLYÁK) 47-48.

KISBÁN Tamás: A sajtó-helyreigazítás 'újrakodifikálásának' kritikája 2014. In Medias Res III. évfolyam 2.

KOOIMAN, Jan: Governing as Governance London, Sage, 2003. In: POLYÁK IV.

KOVÁCS András Péter: A digitális technológiák hatása az európai médiaversenyre Jogi Fórum 2001.

LAITILA, Tiina: Journalistic codes of ethics in Europe 10; European Journal of Comunication 1995.

LAPSÁNSZKY András: Társszabályozás a médiaigazgatásban In: KOLTAY-NYAKAS I. (LAPSÁNSZKY) LIVELY, Donald E. Kommunikációs jog lényeges elvei In: UDVARY I.

MAJONE, Giandomenico - SURDEJ, Alexander: Regulatory Agencies in Economic Governance, The Polish Case in a Comperativ Perspective, KICES Working Papaers, June 2006 In: TÓTH I.

MEZEI Péter: A szerzői jog jövője (is) a tét - gondolatok a Google books könyvdigitalizálási projektről. Iparjogvédelmi és Szerzői Jogi Szemle 6. évf. 5. szám, 2011. október (MEZEI I.) 
MEZEI Péter: A DRM rendszer szerzői jogi aspektusai arsboni jogi folyóirat, 2013. november 21. (MEZEI II.)

McQUAIL, Denis: The Current State of Media Governance in Europe. In: European Media Governance National and Regional Dimensions 2007 UK, TERZIS

METCALF, Katrin Nyman: A digitalizáción túl: médiaszabadság az új valóságban In Medias Res 2014/2. 255.

NAGY Dóra: Magyarországra sugárzó, külföldi joghatóságú médiaszolgáltatók. Hová és miért mentek el Magyarországról a televíziók? In Medias Res 2012/1.

NAGY Krisztina: Közösségi médiatérkép Mérték blog 2012. 07. 19.

NAGY Krisztina: „A jelenlegi helyzet ugyanis (...) alkalmas arra, hogy a jogsérelem közvetlen veszélyét idézze elö." Mérték blog 2016. 02. 26.

NYAKAS Levente: A magyar médiaszabályozás lehetőségei az európai audiovizuális politika fényében Médiakutató 2008 nyár (NYAKAS I.)

NYAKAS Levente: Az audiovizuális és rádiós médiaszolgáltatások szabályozása In: KOLTAY-NYAKAS I. (NYAKAS II.)

NYAKAS Levente: A kvótaszabályozás az európai audiovizuális médiaszabályozásban - gazdasági és kulturális megfontolások határán Iustum Aequum Salutare X. 2014. 1. 129-147. (NYAKAS III.)

NYAKAS Levente: A BBC Alapító Okiratának felülvizsgálata. AKTI, Budapest, 2006. október, 3. szám. (NYAKAS IV.)

NYAKAS Levente: A média a nemzetközi kereskedelemben Magyar és európai médiajog [KOLTAY András - NYAKAS Levente (szerk.)] Wolters Kluwer Budapest, 2015. (NYAKAS V.)

PALZER, Carmen: Co-Regulation of the Media in Europe: European Provisions for the Establishment of CoRegulation Framework Iris Plus, No.6 In: GÁLIK-POLYÁK

PÁPAI Zoltán: Digitális átállás: utolsó pár elöre fuss 2012. Infrapont.hu

PÁZMÁNDI Kinga: A kereskedelmi kommunikáció és a médiapiac 'Tények' és normatív 'ellensúlyok' In Medias Res 2012/1

PETRIK Ferenc: A Polgári Törvénykönyv „A személyek” címü könyvének szabályozási koncepciója (Vitaindító tézisek). A Polgári Jogi Kodifikáció, 2001/4-5. (PETRIK III.)

POGÁCSÁS Anett: A nyomtatott és az internetes sajtótermékek szabályozási kérdései In: KOLTAYNYAKAS I.

POLYÁK Gábor - SZÖKE Gergely: Médiaszabályozás Németországban 2007. január AKTI

POLYÁK Gábor: Megjegyzések a digitális kor médiapolitikájához Médiakutató 2002 ősz (POLYÁK II.)

POLYÁK Gábor: Politikai célú társadalmi reklám 2016.02.17. Mérték blog (POLYÁK III.)

POLYÁK Gábor: Konvergens piac, konvergens hatóság? Médiakutató 2008 nyár (POLYÁK IV.)

POLYÁK Gábor: Haladék a sajtószabadságnak, Fundamentum, 2002/1. (POLYÁK V.)

PRICE, MONROE E.: An access taxonomy. In SAJÓ - PRICE

RÉVÉSZ T. Mihály: A duális médiarendszer jogi megalapozása Magyarországon, Jogtörténeti Szemle 2005. 2. 27-40.

ROZGONYI Krisztina: A digitális átállás folyamata és helyzete Magyarországon - régiós kitekintésben Médiakutató 2012 tél

SARKADY Ildikó: A sajtó európai szabályozása In: MTA, BKÁE Szöveggyüjtemény, Médiajogi írások (SARKADY I.)

SARKADY Ildikó: Közös jogkezelés és médiaszabályozás, In: Emlékkönyv Ficsor Mihály 70. születésnapja alkalmából barátaitól Szent István Társulat 2009. (SARKADY II.)

SARKADY Ildikó: A sajtójog aktuális kérdései 2002, Átdolgozott változat: Bírák Lapja XII. évf. 2002.1. In: Médiajogi írások (SARKADY III.)

SARKADY Ildikó: Karácsonyi meglepetés Lapkiadás és Médiapiac 2009. 1-2.sz. február (SARKADY IV.)

SARKADY Ildikó: Az önálló sajtótörvény problematikája és a kormányzati irányítás Acta Humana 2005. 1. Infokommunikáció és Jog 2004/4. Médiajogi írások. (SARKADY V.)

SARKADY Ildikó: Jogi intézményrendszer a médiában 1. Acta Humana - Emberi jogi közlemények, 30. 1998. Médiajogi írások (SARKADY VI.)

SARKADY Ildikó: Digitális átállás - Meddig? Infokommunikáció és Jog 2012/3 (SARKADY VII.) 
SARKADY Ildikó: A digitális müsorszolgáltatás jogi kérdései In: Médiajogi írások (SARKADY VIII.)

SARKADY Ildikó: Az önszabályozás szerepe a modern szabályozási struktúrákban ÖRT 2015. (SARKADY IX.) http://www.ort.hu/images/Pdf/\%C3\%96RT_Tanulm\%C3\%A1ny_FINAL_SARKADY.pdf

SARKADY Ildikó: Emberi méltóság és a reklám, az ÖRT felkérésére 2016-ban készült tanulmány, megjelenés alatt. (SARKADY X.)

SARKADY Ildikó: A médiatörvény gyakorlati tapasztalatai In: Médiajogi írások, Új Mandatum 2005. (SARKADY XI.)

SÁR Csaba - HORVÁTH Katalin: A rádió- és televízió-szervezetek müsor-továbbközvetítési joga a nemzetközi és a magyar szerzői jogi szabályozás 2008.december 31. danubia.hu online, Emlékkönyv Ficsor Mihály 70. születésnapja alkalmából barátaitól. Szent István Társulat, Budapest, 2009.

SZŐKE Gergely László: A digitális átállás médiajogi hatásai Észak Európában (Finnország, Svédország, Hollandia, Észtország) 2009. január 37. szám, http://www.akti.hu/dok/fuzet37.pdf

SELZNICK, Philip: Focusing operational research on regulation, in R. Noll, ed., Regulatory Policy and the Social Science, Berkeley California, 1985. In: TÓTH I.

SCHULZ, Gabrielle: Keine normalen Unternehmen, Politik und Kultur November-Dezember, Kulturrat 2007.

DR. SZELÉNYINÉ DR. ROSZIK Erzsébet A média lehetőségei és korlátai Bírák Lapja 2/2002.91. In: UDVARY I.

SZIKORA Tamás: Társszabályozás a médiaigazgatásban In: (KOLTAY-NYAKAS II.)

TÉNYI Géza - UDVARY Sándor: A vélemény és a válasz: új Szkülla és Kharübdisz? Jogtudományi Közlöny 2001. november.

TÓTH András: A hozzáférési kötelezettség versenyjogi és szabályozási alkalmazása a távközlésben In: A versenyjog aktuális kérdései TÓTH Tihamér (szerk.) Gazdasági Versenyhivatal 2005. (TÓTH II.)

TURNER, Jonathan D.C.: Intellectual Property and EU Competition Law. Oxford University Press, 2010.

UDVARY Sándor: Alkotmányos médiajog Phd. Értekezés Tézisek 2008. (UDVARY II.)

UDVARY Sándor: A médiaszabályozás alkotmányos alapjai, a kommunikációs alapjogok In: Magyar és európai médiajog (UDVARY III.)

VELJANOVSKI Cento: Regulators and the Market Institute of Economic Affairs, London 1991 In: TÓTH I. WEBER, Rolf H. - HEINRICH, Ulrike I. Az új médiakörnyezet szabályozási kérdései In: Medias Res III.2. WEBER, Rolf H.: International Governance in a New Media Environment In: Monroe E. PRICE - Stefan G. VERHULST - Libby MORGAN (szerk.) Routledge Handbook of Media Law. Abingdon, Routledge, 2013. WELLMANN György: A szerződések általános szabályai az új Ptk.-ban - II. Rész, 12/2013. számú PED YosHIYUKI Tamura: Rethinking Copyright Institution for the Digital Age.WIPO Journal 2009/1.In:MEZEII.

\section{INTERNETES ELÉRÉSEK, utolsó letöltés}

http://dsd.sztaki.hu/mockups/itb/dokumentumok/zold_konyv/index.htm 2016.02.10.

http://mediatorveny.hu/dokumentum/105/EU_tagallamokbol_szarmazo_peldak.pdf 2015. 11. 20.

http://www.akti.hu/dok/fuzet06.pdf 2015.11.20.

http://www.mediakutato.hu/cikk/2008_02_nyar/04_mediaszabalyozas_eu_audiovizualis_politika/ 2015.11.20.

http://www.mediakutato.hu/cikk/2008_02_nyar/01_kozszolgalati_televiziozas_digitalis 2015.11.20.

http://www.hte.hu/web/medianet2015/program 2015.10.15.

http://mtmi.hu/cikk/645/Az_EU_olasz_elnoksege_elinditotta_az_AVMS_iranyelv_felulvizsgalatat 2015.01.20.

http://www.mediakutato.hu/cikk/2002_03_osz/07_digitalis_kor 2015.02.05.

http://www.portalcomunicacion.com/bcn2002/n_eng/programme/prog_ind/papers/0_arribats_peremail/abans _07_2002/pdf/falkheimer.pdf 2014.12.10.

http://europa.eu/rapid/press-release_IP-15-4988_en.htm. 2014. 10.15.

http://ec.europa.eu/atwork/pdf/planned_commission_initiatives_2015.pdf. 2015.11. 10. 
http://www.ort.hu/images/Pdf/\%C3\%96RT_Tanulm\%C3\%A1ny_FINAL_SARKADY.pdf 2015. 12. 20 https://sierra.ceu.edu/search?/aBenke+G $\{$ u00E1 $\}$ bor/abenke+gabor/1\%2C1\%2C2\% $2 \mathrm{CB} /$ frameset\&FF=aben ke+gabor\&1\%2C\%2C2 2016. 10. 30.

http://mte.hu/az-egyesuletrol/ 2015. 02.10.

http://www.cgi.br/english/regulations/resolution2009-003.htm 2015. 07. 05.

http://www.oecd.org/internet/ieconomy/49258588.pdf 2015.06. 15.

http://www.bath.ac.uk/management/cri/pubpdf/Research_Reports/17_Bartle_Vass.pdf 2015. 06. 20.

http://www.jogiforum.hu/files/mediajog/polyak_gabor-digitalis_mediapolitika[jogi_forum].pdf 2016. 11. 11.

http://www.mediakutato.hu/cikk/2008_02_nyar/03_hozzaferes_mediakoncentracio_digitalis_atallas/ 2015. 09. 10.

http://mte.hu 2015. 09. 10.

http://www.politikaievkonyv.hu/online/mp20/1-17_galik.html 2015. 09. 10.

http://www.sat.hu/hirek/eljaras-indult-hazank-ellen-a-mediatorveny-miatt/1211.html $\quad 2014.04 .30$.

https://emasa.hu/print.php?id=2349 2014.12.10. (a kézirat leadásának idején már nem elérhető)

http://www.kulugyminiszterium.hu/NR/rdonlyres/B3F510C4-2D2A-42E7-

9EF5CBF1B1A1531D/0/OGYjel_honlapra_070404.pdf 2016. 02.15.

http://www.europarl.europa.eu/ftu/pdf/hu/FTU_4.8.2.pdf 2014.04.15. (a kézirat leadásának idején már nem elérhetö)

http://en.wikipedia.org/wiki/Digital_Video_Broadcasting 2015. 10. 20.

http://d.hdtvmagazine.info/dvb.htm, http://www.dvb.org/ 2014. 11. 15.

http://www.jogiforum.hu/publikaciok/31 2014. 09. 10.

http://www.ahrt.hu/Cegunkrol/Cegtortenet/2000-.asp 2014. 04. 15. (a kézirat leadásának idején már nem elérhetö)

http://www.mediakutato.hu/cikk/2012_04_tel/05_digitalis_atallas 2016. 03. 10.

http://www.origo.hu/techbazis/20150422-norvegiaban-elsokent-szunik-meg-a-hagyomanyos-radio.html

2015. 05. 10.

http://www.sat.hu/hirek/a-digitalis-tevek-utan-jonnek-a-digitalis-radiok/3160.html 2015.10. 20.

http://hu.euronews.com/2017/01/11/norvegia-atall-a-kristalytiszta-digitalis-radiozasra 2017. 01. 11.

http://brandtrend.hu/2014/03/04/reklamtorta-2013-2/ 2014. 04.15.

https://www.mediapiac.com/mediapiac/Reklamtorta-2014/112183/ 2015. 05. 15.

http://www.hificity.hu/cikk.php?ident=7182 2014.04.15. (a kézirat leadásának idején már nem elérhető)

http://www.telekom.hu/rolunk/sajtoszoba/sajtokozlemenyek/2011/oktober_07 2015. 10. 20.

http://nol.hu/belfold/20120119-digitalis_tili-toli-1295623 2014. 04. 15.

http://infrapont.postr.hu/ 2014. 04. 15.

http://nmhh.hu/dokumentum/151795/dig_atallas_2012_tavasz_webre_vegleges.pdf 2014. 04.15.

http://nmhh.hu/tart/index/569/Hirek_a_digitalis_atallasrol\#sthash.bM3iZgn8.dpuf 2014. 04.15. (a kézirat leadásának idején már nem elérhetö)

http://nmhh.hu/tart/index/601/Televizio_havi_gyorsjelentes 2014. 04.15. (a kézirat leadásának idején már nem elérhetö)

http://www.mediakutato.hu/cikk/2004_03_osz/02_digitalis_musor 2016.10.30.

http://nmhh.hu/tart/index/569/Hirek_a_digitalis_atallasrol\#sthash.bM3iZgn8.dpuf 2014. 04.10.

http://nmhh.hu/cikk/161427/Nezopont_Intezet_Sikertortenet_a_digitalis_atallas\#sthash.BdnNbpbU.dpuf

http://nmhh.hu/tart/index/601/Televizio_havi_gyorsjelentes 2014. 04. 10.

http://www.mediakutato.hu/cikk/2011_03_osz/05_magyar_mediatorveny 2015. 10. 25.

http://media.mandiner.hu/cikk/20120811_matthias_cornils_az_eros_szabalyozas_iranti_igeny 2014. 03. 21.

http://www.origo.hu/itthon/20040229ortt.html 2016. 11. 09.

http://mrsz.hu/cmsfiles/4d/b6/Rekametikai_Kodex_2009.pdf 2016. 02. 10.

http://ejc.sagepub.com 2015. 11. 30.

http://www.mediakutato.hu/cikk/2011_04_tel/02_kozossegi_mediaszolgaltatok 2016. 12. 10.

http://mertek.hvg.hu/2012/07/19/kozossegi-mediaterkep/ 2016. 10. 31.

http://hvg.hu/itthon/20110706_media_mediatanacs_reklam 2015.08.10.

http://atlatszo.hu/2011/11/17/mediatorveny-a-tarsszabalyozasimegallapodas-az-ordoggel-kotott-paktum/

2014. 09. 14. 
http://www.parlament.hu/irom36/3797/3797.htm 2015. 11. 30.

http://nmhh.hu/dokumentum/155438/hatekony_musz_megoldasok_osszefoglalo_komplett.pdf 2015. 02. 20.

http://hir.ma/belfold/alapjogokert-kozpont-megalapozatlanok-voltak-az-uj-mediaszabalyozast-ero-

kritikak/510234 2015. 05. 15.

http://www.jogiforum.hu/hirek/36981 2016. 12. 09.

http://nmhh.hu/cikk/156404/A_tevekeszulekek_kiskoruak_vedelmet_szolgalo_muszaki_kepessegeit_vizsgalt a_az_NMHH\#sthash.IIvWdge5.dpuf 2015.02.20. (a kézirat leadásának idején már nem elérhetö)

http://nmhh.hu/dokumentum/156110/0202805_fogyasztoi_tajekoztato_gyerekzar_01_vegleges.pdf 2015. 02. 20.

http://nmhh.hu/cikk/155043/Elelmiszerhirdetesi_onkorlatozas_a_gyermekek_vedelmeben\#sthash.kM14asR1. dpuf 2015. 02. 20.

http://nmhh.hu/cikk/163153/Megnyilt_Buvosvolgy_Magyarorszag_elso_mediaertesoktato_kozpontja 2015. 02. 20.

http://ias.jak.ppke.hu/hir/ias/20084sz/12.pdf 2014. 04. 30.

http://www.jogiforum.hu/mediajog/235 2016. 03. 01.

http://www.mediatudor.hu/ 2016. 03. 01.

https://www.ajbh.hu/documents/10180/2500969/Jelent\%C3\%A9s+a+m\%C3\%A9dia\%C3\%A9rt\%C3\%A9soktat\%C3\%A1s+helyzet\%C3\%A9r\%C5\%911+497_2016/41838d72-616e-45bf-8b51-

e744c4fa1b59?version=1.0 2016. 03. 01.

http://mediatanacs.hu/dokumentum/109073/a_bbc_alapito_okiratanak_felulvizsgalata.pdf 2016. 11. 10.

http://www.jogiforum.hu/mediajog/235 2016. 03. 01.

http://www.mediakutato.hu/cikk/2011_04_tel/02_kozossegi_mediaszolgaltatok 2016. 10. 30.

http://mtmi.hu/dokumentum/499/gosztonyi_gergely_az_alternativ_media_helye_a_mediadiskurzusban.pdf 2016. 10. 30 .

http://www.arsboni.hu/drm.html 2015. 04. 15.

http://www.wipo.int/edocs/mdocs/copyright/en/sccr_10/sccr_10_2_rev.pdf 2014. 10. 20.

http://doktori.bibl.u-szeged.hu/560/2/mezei_tezis.pdf 2014.11.20.

http://www.europarl.europa.eu/meetdocs/2004_2009/documents/dv/study-collective-management-rights-

/study-collective-management-rights-en.pdf 2014. 04. 10.

http://www.degruyter.com/viewbooktoc/product/21512 2015. 11. 20.

http://www.kulturrat.de/dossiers/verwertungsgesellschaften.pdf 2015. 11. 20.

http://www.hipo.gov.hu/sites/default/files/joggyakorlat/cjeu_osszefoglalo_2015_01.pdf 2015. 10. 20.

http://ec.europa.eu/internal_market/copyright/docs/management/study-collectivemgmt_en.pdf 2014. 02. 20.

http://www.sztnh.gov.hu/sites/default/files/20150710_kjk_ire_reszletes_atultetesi_koncepcio_konzultaciora_ 0.pdf 2015. 09. 10.

http://works.bepress.com/cgi/viewcontent.cgi?article=1028\&context=daniel_gervais 2014. 04. 10.

http://hirek.prim.hu/cikk/71017/ 2014. 10. 20.

http://nepszava.hu/cikk/324817 2014. 10. 20.

http://www.jogiforum.hu/hirek/23917 2016. 02. 10.

http://mediatanacs.hu/dokumentum/3132/1322213621a_televizios_reklampiac_alakulasa_az_ezredfordulo_ut an.pdf 2015. 10. 20.

http://www.ksh.hu/docs/hun/xftp/idoszaki/tavkint/tavkint12.pdf 2014. 10. 20.

http://www.internations.org/germany-expats/guide/16032-media-communication/the-german-radio-and-tv-

landscape-16007/broadcast-fees-in-germany-2 2014. 05. 20.

http://en.wikipedia.org/wiki/Television_licence 2014. 05. 20.

http://www.telegraph.co.uk/culture/tvandradio/bbc/10746109/BBC-wants-you-to-pay-TV-licence-fee-even-

if-you-dont-own-a-set-as-shows-go-on-iPlayer-for-longer.html 2014. 05. 20.

http://nmhh.hu/dokumentum/159723/31979_1_2013_elofizeteses_musorterjesztes_kitoltesi_utmutato.pdf

2014. 09. 10.

http://www.mediainfo.hu/hirek/article.php?id=33845 2014. 09. 20.

http://www.danubia.hu/upload/files/HK_radio_es_tv_szervezetek_jogai_081231\%20_2_.pdf 2015.05. 15 .

http://www.jogiforum.hu/mediajog/133 2014. 04. 20.

http://www.mmonline.hu/cikk/erre_keszul_az_rtl_klub_interju 2014.04. 20. 
http://mediatanacs.hu/cikk/164528/A_Mediatanacs_9472014_IX_30_szamu_dontese\#sthash.VFXv8d5N.dpu f 2014. 10. 15 .

http://www.akti.hu/dok/fuzet31.pdf 2015. 04. 30.

www.kreativ.hu/download.php?id=4176 2015. 04. 30.

http://nmhh.hu/cikk/161426/Kollarik_hatekony_es_eredmenyes_a_mediatartalmak_felugyelete\#sthash.ivzru OzK.dpuf 2015.02.10.

http://nmhh.hu/cikk/2665/Helyikorzeti_palyaztatas_lezarult_az_igenyfelmeres\#sthash.5mrKEYo2.dpuf 2014. 02.10. (a kézirat leadásának idején már nem elérhető)

http://mediatorveny.hu/dokumentum/433/MatthiasCornils_UngarischesMediengesetz_epdmedien_HU_final. pdf 2014.02.10.

http://www.mediakutato.hu/cikk/2007_02_nyar/02_kozszolgalati_media_fogalma/2016.02.10

http://mtva.hu/en/sajtoszoba-main/sajtokozlemenyek/vallalati-sajtokozlemenyek/6389-mar-indulaskorcsaknem-masfel-millio-haztartasba-jut-el-az-m3-csatorna 2014. 09. 15.

http://www.mediakutato.hu/cikk/2008_02_nyar/02_kozszolgalati_musorszolgaltatas_finanszirozasa 10. 15 .

http://www.mediakutato.hu/cikk/2008_02_nyar/05_konvergens_piac_hatosag/ 2014.09. 15.

http://press.uchicago.edu/ucp/books/book/distributed/E/bo5891195.html 2014. 09. 15.

http://nmhh.hu/cikk/171474/Het_ev_utan_lejar_a_Class_FM_jogosultsaga_kibovitett_palyazatot_indithat_a_ Mediatanacs 2016. 08. 10. 


\section{PUBLIKÁCIÓS JEGYZÉK}

\section{KÖNYVEK}

Médiajogi írások 2005. ÚMK 300 o.

A média-értéklánc szerzői jogi vonatkozásai 2012. MTMI (szerzőtárs: dr. Grad-Gyenge Anikó) 138 o. Közös jogkezelés az audiovizuális médiában 2014. MTMI (szerzőtárs: dr. Grad-Gyenge Anikó) 170 o.

\section{TANULMÁNYOK, CIKKEK}

\section{A médiatörvény gyakorlati tapasztalatai}

XI. Jogász Vándorgyülés - Országos Jogászegyleti Konferencián (1997. Gyula) elhangzott korreferátum szerkesztett változata Magyar Jogászegylet kiadványa (Máthé Gábor szerk.) 1997 117122.o. In: Médiajogi írások 2005. ÚMK 171-179.o.

Reklámtörvény az Alkotmánybíróság előtt Médiafigyelö, 1997. december 15.

Gyermekek és fiatalok a médiajogban

Gyermekek és fiatalok a média vonzásában c. tudományos konferencián elhangzott elöadás szerkesztett változata 1998. február 4. Budapest, kiadja: a Gyermek- és Ifjúsági Alapprogram Lovas György, Rab László (szerk.) 63-78.o.

Jogi intézményrendszer a médiában

Acta Humana - Emberi jogi közlemények 30. 1998. Emberi Jogok Magyar Központja Közalapítvány, Bokorné Szegő Hanna (főszerk.) 37-41.o. In: Médiajogi írások 2005. ÚMK 179186. o.

Még egyszer a reklámtörvényről

Médiafigyelö, 1998. január 12.

Gyermekek és fiatalok a médiajogban

Gyermekek és fiatalok a média vonzásában tudományos konferencián (1998. febr.4., szervezők: MeH Gyermek és Ifjúsági Koordinációs Tanács Titkársága, Magyar Médiapedagógiai Kutató Intézet, Gyermek és Ifjúsági Alapprogram) elhangzott előadás szerkesztett változata a Gyermekek és fiatalok a média vonzásában című kiadványban 1998 március 63-78. o.

A reklámtörvény alkotmányossági kérdései Magyarország Médiakönyve 1999 ENAMIKÉ (Cseh Gabriella, Enyedi Nagy Mihály, Solténszky Tibor szerk.) 681-686.o. In: Médiajogi írások 2005. ÚMK 237-245. o.

Média, jog, jogharmonizáció

A Média Hungary 1999. konferencián megtartott előadás szerkesztett változata

In: A média jövője Internet és hagyományos média az ezredfordulón Média Hungária Kiadó 1999. (Csermely Ákos, Ráduly Margit, Sükösd Miklós szerk.) Média Hungaria Könyvek I. kötet 219220.o.

\section{A sajtójog aktuális kérdései}

A Magyar Tudományos Akadémia és a Magyar Jogászegylet által Budapesten, 2000. szeptember 45-én rendezett „Információs társadalom hatása a jogrendszerre” című konferencián elhangzott előadás alapján készült tanulmány. Megjelent: Magyarország az ezredfordulón, Stratégiai tanulmányok a Magyar Tudományos Akadémián „Információs társadalom és jogrendszer” címü kiadása, Budapest 2002. Glatz Ferenc (szerk.) 105-122.o. Bírák Lapja, XII. évfolyam 2001.1. Magyar Bírói Egyesület dr. Uttó György (szerk.) In: Médiajogi írások 2005. ÚMK 11-36. o.

Jogelméleti bevezetés, a véleménynyilvánítás szabadságának alkotmányjogi szabályozása A véleménynyilvánítás szabadsága és korlátai a sajtóban és más médiumokban című szekció elődadása, elhangzott: Tizenhetedik Jogász Vándorgyülés Hajdúszoboszló 2001. október 18-19. Az előadás szerkesztett változata megjelent a Magyar Jogász Egylet kiadványában, Budapest 2001. dr. Benisné dr. Győrffy Ilona (szerk.) 275-288. o. 
A reklámtörvény módosítása

Magyarország Médiakönyve Tények és Tanok 2000-2001. II. kötet ENAMIKÉ Enyedi Nagy Mihály, Farkas Zoltán, Molnár Adél, Solténszky Tibor (szerk.) 597-608.o. In: Médiajogi írások 2005. ÚMK 245-265. o.

Szabályozási modellek az európai médiában

Magyarország Médiakönyve 2002. II. kötet. ENAMIKÉ Enyedi Nagy Mihály, Polyák Gábor, Sarkady Ildikó (szerk.) 517-534. o.

A sajtó európai szabályozása

Magyarország az ezredfordulón, Stratégiai tanulmányok a Magyar Tudományos Akadémián „Az információs társadalom és a jog átalakulása" Budapest, 2002. Glatz Ferenc (szerk.) 353-388.o. Átdolgozott változat megjelent: Médiagazdaságtan - Médiaszabályozás Szöveggyüjtemény AULA 2002. Gálik Mihály (szerk.) 91-128.o. In Médiajogi írások 2005.ÚMK 36-86. o.

A reklám nemzetközi és hazai szabályozása

Médiagazdaságtan - Médiaszabályozás Szöveggyüjtemény AULA 2002. Gálik Mihály (szerk.) 143152.0.

Sajtójogi szabályozás Európában

Az Országgyülés Kulturális és Sajtóbizottsága megbízásából készített tanulmány 2002.

A médiatörvény módosított reklámrendelkezései MRSZ tájékoztató 2002/11. In: Médiajogi írások 2005. ÚMK 265-270.o.

Média a tárgyalóteremben

Az Országos Igazságszolgáltatási Tanács Hivatala által szervezett „Igazságszolgáltatás és média” címü konferencián elhangzott bevezető előadás leírt változata 2004. december 14. MÚOSZ Székház. In: Médiajogi írások 2005. ÚMK 186-199.o.

Reklámjogi szerződések a sportban

A Pécsi Tudományegyetem Állam- és Jogtudományi Karán 2004. április 22-23-án rendezett sportjogi konferencián elhangzott előadás leírt változata In: Médiajogi írások 2005. ÚMK 288296.o.

Kereskedelmi szerződések a sportban (szerzőtárs: dr. Tamás Lajos) Gazdaság és Jog 2005/2. 13. évf. 2. HVG-ORAC

Védjegy a médiában

Magyarország Médiakönyve 2003. Tények és tanok II. kötet ENAMIKE 793-802.o. átdolgozott változat: MSZH Iparjogvédelmi és Szerzői Jogi Szemle 109.évf. 2. sz. 2004. (Bana Zsuzsa szerk.) 42-46.o. In: Médiajogi írások 2005. ÚMK 219-234.o.

Trademarks in the Media

Proceedings of the Hungarian Group, International Association for the Protection of Intellectual Property (IAPIP) Budapest 31/2004.

A személyiségvédelem jogi eszközei

Magyar Kereskedelmi és Iparkamara Jogi Tájékoztató Füzetek - elhangzott szakmai előadásokról Jogi Szekció 2004.156-159.o.

A digitális müsorszolgáltatás jogi kérdései

„Tudósítók Világtalálkozója” című konferencián elhangzott előadás (2004. Nyíregyháza) szerkesztett változata megjelent: Magyar Reklám 2004. november, In: Médiajogi írások 2005.ÚMK 200-210.o.

Az európai nemzeti médiaszabályozások áttekintése Médiafüzetek 2004/1. ENAMIKÉ 2004. 209-217.o.

A rádióreklám jogi kérdéseiről Magyar Rádió - Rádiós évkönyv 2004.

Az önálló sajtótörvény problematikája és a kormányzati irányítás Infokommunikáció és Jog 2004/4., Acta Humana 2005. 10.évf.1.sz. Bokorné Szegő Hanna (föszerk.) 33-51.o. In: Médiajogi írások 2005. ÚMK 139-168.o.

A médiatörvény múltja és jövője

Reklámvonal 2005/7. 
A reklámjogi szabályozás konstrukciója Magyarországon és az Európai Unióban

A Magyar Iparjogvédelmi és Szerzői jogi Egyesület konferenciáján (2004.október 21.) elhangzott előadás leírt változata. Nyitó előadásként elhangzott még a XI. Országos Reklámkonferencián a „Jogos kérdések” c. szekcióban (2003.november 11-12. Eger) In: Médiajogi írások 2005. ÚMK 271287. o.

A nemzeti hírügynökségről szóló 1996. évi CXXVII. törvény jogi felülvizsgálatáról

Tanulmány az Országgyülés Kulturális- és Sajtó Bizottságának felkérésére készült 2005. Acta Humana 2006.17. évf. Bokorné Szegő Hanna (főszerk.) 29-40.o.

A hírügynökségi törvény felülvizsgálata I. címmel In: Médiajogi írások 2005. ÚMK 86-108.o.

A nemzeti hírügynökségről szóló 1996. évi CXXVII. törvény jogi felülvizsgálatáról II. Tanulmány - az Országgyülés Kulturális és Sajtó Bizottságának felkérésére készült 2005.

A hírügynökségi törvény felülvizsgálata II. címmel In: Médiajogi írások 2005. ÚMK 109-125.o.

A nemzeti hírügynökségről szóló 1996. évi CXXVII. törvény jogi felülvizsgálatáról

A tanulmány rövidített változata, Infokommunikáció és a Jog 2005. december „Első oldal”

A szerzői jog aktuális kérdései - különös tekintettel a sajtóra

A Lapkiadók Egyesületének konferenciáján elhangzott előadás (2003. Balatonfüred) szerkesztett változata In: Médiajogi írások 2005. ÚMK 126-138.o.

Az ORTT gyakorlata a vitatott televíziós, rádiós jogsértések megítélésében

In: Médiajogi írások ÚMK 2005. 211-218 o.

A közszereplök személyiségvédelme a bírói gyakorlatban Médiakutató 2006 ősz 13 o.

Gyermekek a médiában

A média hatása a gyermekekre és a fiatalokra IV. c. konferencián elhangzott előadás szerkesztett változata Nemzetközi Gyermekmentő Szolgálat Magyar Egyesület KOBAK Könyvsorozat (Gabos Erika szerk.) 2007. 112-117. o.

Első oldal

Infokommunikáció és jog 10. szám 2005. december

Infokommunikáció és jog 22. szám 2007. december

Karácsonyi meglepetés - az új médiatörvény tervezetének kritikája

Lapkiadás és Médiapiac VI. évf.1-2 sz. 2009. január-február

Közös jogkezelés és médiaszabályozás

Emlékkönyv Ficsor Mihály 70. születésnapja alkalmából barátaitól Szent István Társulat Budapest, 2009 Tattay Levente (szerk.)

A médiajog szerzői jogi megközelítése

Médiajog 2011 Tanulmányok a médiajog köréből Infokommunikáció és jog könyvek HVG-ORAC (83-96) 2011. SZTE, Iparjogvédelmi és Szerzői Jogi Szemle 6.(116.) évfolyam 6. sz. 2011.63-76 o.

Reklámjogi szösszenet

Reklám vagy amit akartok Hargitai Lilla (szerk.) Akadémiai Kiadó 2012. 139-146.o.

Digitális átállás - Meddig?

Infokommunikáció és Jog 50. 2012. HVG-ORAC 128-133 o.

A Nemzeti Audiovizuális Média Stratégia Jogalkotási Koncepció elvei a hatályos médiaszabályozásban

MTMI felkérésére készült tanulmány 2014. 101 o.

A müsordíj jogi természete

MTMI felkérésére készült tanulmány 2014. 57 o.

Az önszabályozás szerepe a modern szabályozási struktúrákban

ÖRT felkérésére készült tanulmány 2015. Megjelent: www.ort. online: 51 o.

Az emberi méltóság a reklámban. Emberi méltóság az időskorúaknak szóló televíziós reklámokban és sajtóhirdetésekben

ÖRT - Médiatanács 2016. évi közös projektje keretében készült tanulmány, várható megjelenés:

2017. tavasz. 


\section{SZERKESZTŐI TEVÉKENYSÉG}

Axel Springer-Magyarország Kézikönyvek - Megyei napilapok szerkesztése és kiadása (1999.) - szerkesztőbizottsági tag

Médiakönyv Tények és tanok 2001-2002.

Enyedi Nagy Mihály, Polyák Gábor, Sarkady Ildikó (szerk.)

Médiakönyv Tények és tanok 2003.

Enyedi Nagy Mihály, Polyák Gábor, Sarkady Ildikó (szerk.)

Médiafüzetek 2004/1. szám - szerkesztőbizottsági tag

Infokommunikáció és Jog c. folyóirat - Tanácsadó Testületi tag 2003- 